UNIVERSIDADE DE SÃO PAULO

MUSEU DE ARQUEOLOGIA E ETNOLOGIA

PROGRAMA DE PÓS-GRADUAÇÃO EM ARQUEOLOGIA

LEVANTAMENTO ARQUEOLÓGICO E ETNOARQUEOLOGIA NA ALDEIA LALIMA, MIRANDA/MS: UM ESTUDO SOBRE A TRAJETÓRIA HISTÓRICA DA OCUPAÇÃO INDÍGENA REGIONAL

\title{
Eduardo Bespalez
}

São Paulo 
UNIVERSIDADE DE SÃO PAULO MUSEU DE ARQUEOLOGIA E ETNOLOGIA PROGRAMA DE PÓS-GRADUAÇÃO EM ARQUEOLOGIA

LEVANTAMENTO ARQUEOLÓGICO E ETNOARQUEOLOGIA NA ALDEIA LALIMA, MIRANDA/MS: UM ESTUDO SOBRE A TRAJETÓRIA HISTÓRICA DA OCUPAÇÃO INDÍGENA REGIONAL

Eduardo Bespalez 
UNIVERSIDADE DE SÃO PAULO

Museu de Arqueologia e Etnologia

PROGRAMA DE PÓS-GRADUAÇÃO

LEVANTAMENTO ARQUEOLÓGICO E ETNOARQUEOLOGIA NA ALDEIA LALIMA, MIRANDA/MS: UM ESTUDO SOBRE A TRAJETÓRIA HISTÓRICA DA OCUPAÇÃO INDÍGENA REGIONAL

Eduardo Bespalez

Dissertação apresentada ao Programa de PósGraduação em Arqueologia do Museu de Arqueologia e Etnologia da Universidade de São Paulo, para a obtenção do título de Mestre em Arqueologia

Orientadora: Prof. ${ }^{a}$ Dr. ${ }^{a}$ Fabíola Andréa Silva 


\title{
Resumo
}

Esta dissertação apresenta os resultados obtidos com a pesquisa de levantamento arqueológico realizado na TI Lalima, uma aldeia de índios Terena localizada no município de Miranda, Pantanal de Mato Grosso do Sul. A pesquisa foi realizada com o objetivo de contribuir com a História Cultural da ocupação indígena regional, desde o período pré-colonial até o presente. As pesquisas arqueológicas, históricas e etnográficas indicam que a região deve ser entendida como área de mosaico cultural, formado por populações distintas, originárias das áreas adjacentes, desde antes da chegada dos europeus e do início do colonialismo. Os resultados sustentam que a Aldeia Lalima pode ser compreendida como um palimpsesto da História Indígena regional, pois foram detectados sítios e ocorrências arqueológicas constituídos por correlatos materiais relativos à trajetória de ocupação Guarani, da Tradição Pantanal e do contexto etnográfico atual.

Palavras-chave: Arqueologia, História Indígena, Pantanal sul-mato-grossense, rio Miranda, Aldeia Lalima

\begin{abstract}
This account shows the results obtained with the archaeological survey developed in Lalima Indigenous Land, a Terena Indians village situated at Miranda city, Pantanal from Mato Grosso do Sul. The survey was developed with the aim to contribute with the Cultural History from regional indigenous occupation, since prehistoric times until the present. The archaeological, historical and ethnographical researches indicate that the region must be understood like a cultural mosaic area, shaped by distinct inhabitants, originary from adjacencies areas, since before of European coming and the colonialism beginning. The results support that Lalima Village can be agreed like a palimpsest from regional Indigenous History, because the archaeological sites detected are shaped by material correlates concerning to Guarani, Tradição Pantanal and ethnographical occupation trajectories.
\end{abstract}

Key-words: Archaeology, Indigenous History, Pantanal from Mato Grosso do Sul, Miranda river, Lalima Indigenous Land 
Dedicatória

À Silvana Zeni Sparrenberger Bespalez, mãe, e à Eunice Bespalez e Everton Bespalez, irmãos 
In Memorian

Antônio Bespalez Neto, pai, e Olga Lazzaris, avó paterna 


\section{Agradecimentos especiais}

À Fabíola Andréa Silva, orientadora, e Manuel de Souza Neto, principal interlocutor.

\section{Agradecimentos}

À minha família, particularmente José Bespalez Sobrinho, tio paterno, e Elvira Jesse Sparrenberger, avó materna; ao Prof. Dr. Gilson Rodolfo Martins; ao Programa de Pós-graduação do Museu de Arqueologia e Etnologia da Universidade de São Paulo (PPG/MAE/USP); à Fundação de Apoio à Pesquisa do Estado de São Paulo (FAPESP), pela Bolsa de Mestrado (Processo No 05/57404-0) e pelo Auxílio Pesquisa ao projeto "Arqueologia, Etnoarqueologia e História Indígena - um estudo sobre a trajetória da ocupação indígena em territórios do Mato Grosso e do Mato Grosso do Sul: a Terra Indígena Kaiabi e a Aldeia Lalima" (processo $\mathrm{n}^{\mathrm{o}}$ 06/60241-8); ao Instituto do Patrimônio Histórico e Artístico Nacional (IPHAN), particularmente Maria Margareth Ribas Escobar; à Fundação Nacional do Índio (FUNAI), particularmente Eliseu Lily; aos Professores Dr. Eduardo Góes Neves, Drª ${ }^{\mathrm{a}}$ Emília Mariko Kashimoto, Dr. Paulo Antônio Dantas DeBlasis, Ms. Francisco Silva Noelli, Dr. Levi Figutti, Dr. Pedro Ignácio Schmitz, Dra ${ }^{\mathrm{a}}$. Marisa Afonso Coutinho, Dr. José Luiz dos Santos Peixoto, Dr. Jorge Eremites de Oliveira; aos índios na Aldeia Lalima, particularmente Gilmar Vieira, Cacique, sua família e seu Conselho Tribal; João da Silva e família; Evair Borges, Chefe do Posto Indígena (PIN) Lalima, e Família; Deir de Souza Alves, Cacique da Campina, sua família, particularmente Atanásio Alves, Protásia de Souza e Deli de Souza Alves, e seu Conselho Tribal; a toda família de Manuel de Souza Neto, particularmente João de Souza, Luiz de Souza, Severino de Souza, José Rondon de Souza, Jandira Lipú de Souza, Romário Lipú de Souza, Josué Lipú de Souza e Elbia Lipú de Souza; aos auxiliares de pesquisa e às suas famílias: Ofnéias de Souza Alves, Aparecida de Souza Pereira, Mário Antônio Pereira, Atair Góes de Oliveira, Claudinei da Silva, Leonel da Silva, Edimara Pinheiro Paiva e Gilmar de Souza; aos Professores indígenas; aos colegas de campo, Marinho Ribeiro Martins, Francisco Forte Stuchi, Rafael dos Santos, Marcos Brito, Alexandre Hering, Frederic Caíres Pouget e Bruno Marcos Morais; à Melian Gaspar, com muita admiração; aos colegas Rafael 
Bartolomucci, Mirian Pacheco Forancelli, Gilmar Henriques Júnior, Danilo Assunção, Tânia Ferraz, Marcolina da Penha Daniel Ribeiro Martins, Francisco Antônio Pugliese Júnior, Agmar dos Santos Vieira, Sílvia Cunha Lima, Márcio Aparecido Pontes, Luiz Carlos Borges Pinto, Regivaldo Leite, José Roberto Nicácio, Renato Gomes Coelho, Rafael Brandi, Rafael Milhera, Rucirene Miguel, Mileni Fornari, Fernando Osório, André Penin, Fernando W. Costa, Márcio W. Castro, Bernardo Lacale, Vinícius Honorato, Leandro Camilo, Edward Koole, Fábio Almeida, Fábio Origuela, Raoni Vale, Morgan Schmidt, Claide de Paula Moraes, Anne Rapp Py-Daniel, Ricardo Portocarrero, Bernardete Póvoa, Letícia Martins Gomes, André Voto Alves dos Santos, José Paulo Jacob, Dária E. F. Barreto, Carlos Alberto Rizzi, Tatiane Iaconis Pitcher, Cheng Chi Cheng, Alexandre Robazzine; aos amigos de sempre, Rodrigo Giacomelli, Alex Santa Cruz, Mário Cesar Botelho Fonseca, Adriano Bueno, João Pedro Sabóia, Vinicius Mausmann, Eduardo Aguiar, Danilo Malignitas, Victor Augusto Nascinbeni, James Fafael Rosa, Gustavo Rosa e Alexandre Tata, bem como às suas famílias. 
Introdução

Capítulo 1 - Os processos de formação do registro arqueológico .....................................17

Capítulo 2 - 0 contexto geográfico regional em torno da Aldeia Lalima ..............................27

Capítulo 3 - A trajetória histórica da ocupação indígena regional........................................40

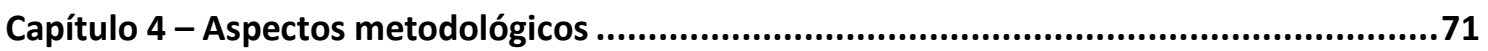

Capítulo 5 - Levantamento arqueológico na Aldeia Lalima...............................................78

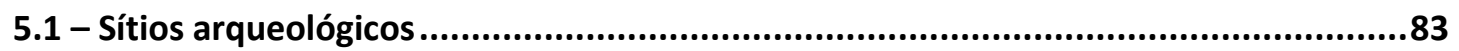

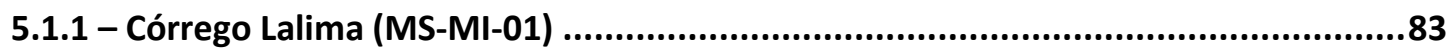

5.1.2 - José Rondon de Souza (MS-MI-02)..............................................................117

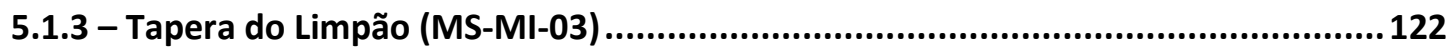

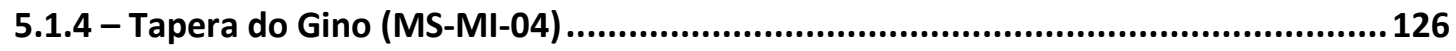

5.1.5 - Tapera da Mata do Urumbeva (MS-MI-05).........................................................131

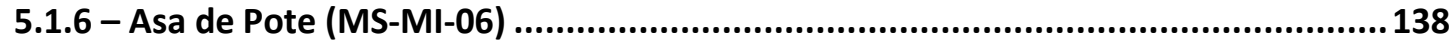

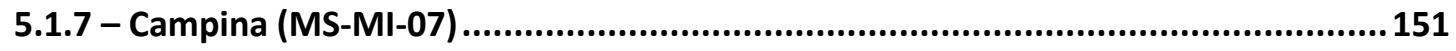

5.1.8 - Manuel de Souza Neto (MS-MI-08) ................................................................... 152

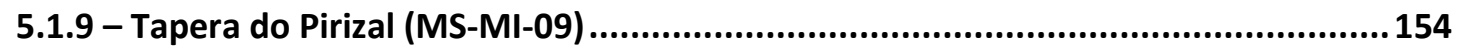

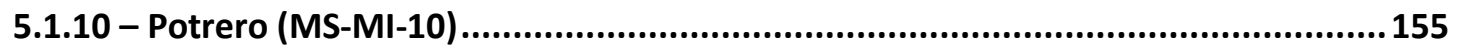

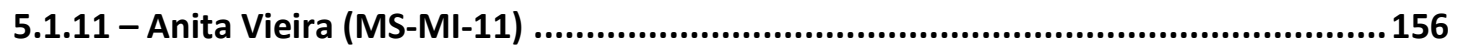

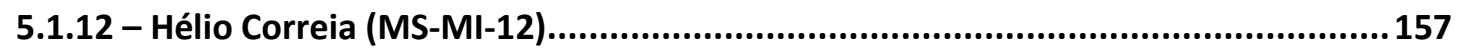

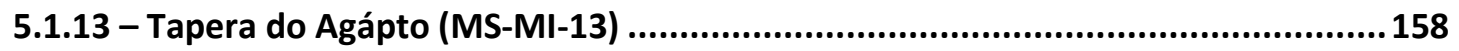

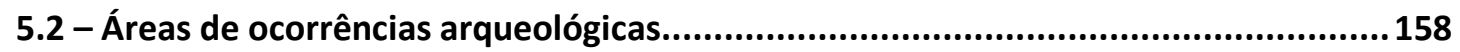

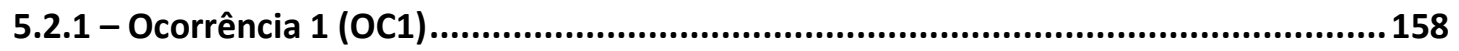

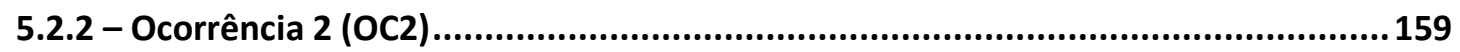

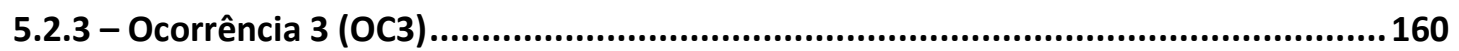

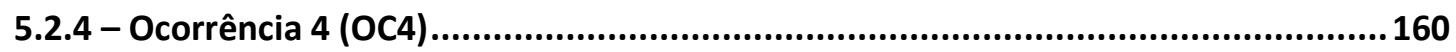

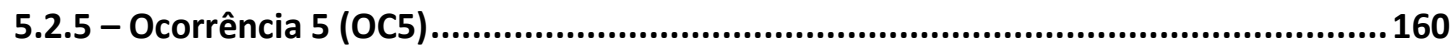

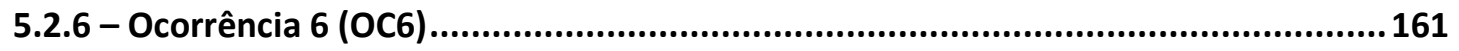

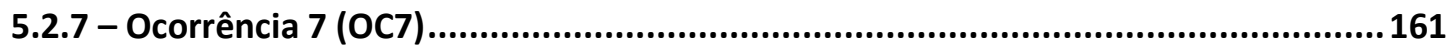

Capítulo 6 - Arqueologia na Aldeia Lalima e a História Indígena regional ...........................162

Conclusão - A participação dos Terena na pesquisa arqueológica na Aldeia Lalima ............169

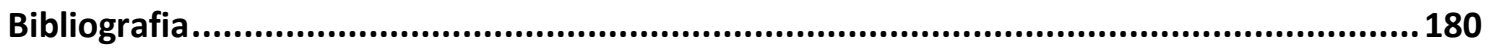

Anexos

Anexo 1

Anexo 2 


\section{Introdução}

Esta dissertação apresenta os resultados da pesquisa arqueológica realizada na Terra Indígena (TI) Lalima, uma aldeia Terena localizada no município de Miranda, Pantanal de Mato Grosso do Sul (ver Mapas 1 à 3).

Considerado território Terena, porque a maioria dos habitantes assim se autoidentifica, o contexto etnográfico atual em Lalima foi formado por grupos étnicos distintos, depois da passagem do Marechal Rondon pelo antigo sul de Mato Grosso e em função da política indigenista do início do séc. XX, que apregoava o confinamento das populações indígenas em reservas. Assim, remanescentes étnicos Kinikinao, Laiana e Terena foram convocados a ocupar o Posto Indígena (PIN) Lalima, fundado pelo Serviço de Proteção aos Índios (SPI) em 1907, juntamente com os Guaikurú, os quais, por sua vez, já estavam assentados na área ao menos desde o séc. XIX. Os Guaikurú, parcialidades étnicas falantes de línguas da família Mbayá do tronco Mbayá-Guaikurú e os Terena, Kinikinao e Laiana, conhecidos genericamente como Guaná, falantes de línguas da família Chané-Guaná do tronco Aruak, são descendentes de populações que teriam migrado do Chaco para o Pantanal mato-grossense nos séc. XVII e XVIII (Azanha 2004, Cardoso de Oliveira 1976: 75-77, Carvalho 1992, Metraux 1946: 21418, 238-41, Ribeiro 1980: 17-18).

O projeto de pesquisa foi concebido inicialmente com o objetivo de investigar a presença Guarani no médio curso do rio Miranda, tendo em vista a localização de um sítio arqueológico Guarani, na Aldeia Lalima, pelo arqueólogo Prof. Dr. Gilson Rodolfo Martins, denominado Córrego Lalima (Kashimoto \& Martins 2008: 153, 155). Com efeito, fontes históricas e etnográficas quinhentistas e seiscentistas apontam que nos primeiros séculos do colonialismo ibérico na bacia platina, o alto e o médio Miranda era ocupado, dentre outras populações, por índios falantes de línguas da família TupiGuarani, historicamente conhecidos como Guarani-Itatim. Naquela época, o que atualmente corresponde ao Estado de Mato Grosso do Sul era território do Paraguai Colonial, sendo denominado Provincia del Itati (Cortesão 1952, Esselin 2000, Gadelha 1980, Gandia 1932). Atraídos pela densidade demográfica de índios Guarani na região, os espanhóis do Paraguai buscaram integrar a antiga Província nas estruturas sócioeconômicas coloniais, explorando o trabalho dos índios, através das encomiendas, e incentivando a colonização com a fundação de cidades, a exemplo de Santiago de 
Xerez, abandonada na margem direita do rio Aquidauana em 1632 (Martins 2002a). Com a destruição das Missões Jesuítas do Guairá pelas bandeiras luso-paulistas nas primeiras décadas do séc. XVII, tanto os padres da Província Jesuítica do Paraguai quanto os portugueses de São Paulo voltaram-se para o Itatim, visando as últimas reservas de mão-de-obra Guarani disponíveis no sertão. Depois dos assaltos dos mamelucos e dos colonos de Xerez aos pueblos de índios reduzidos nas Missões do Itatim, do assédio territorial dos índios chaquenhos e de uma história permeada pelos efeitos catastróficos dos primeiros séculos do colonialismo, como, por exemplo, o genocídio provocado pelas doenças trazidas pelos europeus, tanto os Guarani quanto os espanhóis abandonaram a bacia do Miranda na segunda metade do séc. XVII, com os índios refugiando-se nas matas da Serra de Maracajú, nas proximidades de Assunção e na Mesopotâmia Argentina, nos Trinta Povos das Missões.

Além do sítio Córrego Lalima, até então eram conhecidos dezenas de sítios com cerâmica Guarani em Mato Grosso do Sul (Kashimoto 1997, Martins \& Kashimoto 1999a, Noelli 2004), inclusive nas proximidades do alto e do baixo Miranda (Martins, 2003, Peixoto 1998). Embora ainda não haja uma cronologia satisfatória em nível estadual, sabe-se que os Guarani ocuparam a margem sul-mato-grossense do rio Paraná ao menos entre os séc. VIII e XVIII (Martins, Kashimoto \& Tatumi 1999). Compreendendo o sítio em Lalima como uma "ponta de iceberg" no contexto da História Colonial, o projeto de pesquisa inicialmente elaborado visava contribuir com a Arqueologia Guarani no Pantanal de Mato Grosso do Sul, através do levantamento de sítios arqueológicos no médio Miranda.

Contudo, na medida em que fui avançando - já no âmbito institucional do Programa de Pós-Graduação do Museu de Arqueologia e Etnologia da Universidade de São Paulo (PPG/MAE/USP), sob orientação da Prof $f^{a}$. Dra ${ }^{\mathrm{a}}$. Fabíola Andréa Silva - no aprofundamento das questões arqueológicas, históricas e antropológicas, e estimulado pelo ambiente acadêmico, redefini o eixo do projeto, que passou a ser desenvolvido com outra perspectiva. Ou seja, se o projeto estava centrado na ocupação Guarani no rio Miranda, num primeiro momento, ele se amplia e passa a ter como objetivo o estudo da trajetória histórica das ocupações indígenas na região, tendo como referencial de pesquisa a Aldeia Lalima, que passou a ser entendida como palimpsesto destas ocupações (Binford 1980, 1981, 1983).

O Mato Grosso do Sul, sobretudo o Pantanal, pode ser entendido enquanto área de mosaico cultural cujas origens podem remontar a alguns milênios de anos antes do 
presente, ou, em outras palavras, palco de processos de ocupação, re-ocupação e abandono de diferentes populações (Cameron \& Tomka 1993, Carvalho 1992, Eremites de Oliveira 2003, Eremites de Oliveira \& Viana 1999-2000, Kashimoto \& Martins 2000, Nelson 1997, Schmitz et al 1998, Schiffer 1987, Zedeño 1997). As pesquisas arqueológicas realizadas até o momento indicam que a ocupação indígena se iniciou com o assentamento de grupos caçadores-coletores em áreas de refúgio ecológico, entre o fim do Pleistoceno e o início do Holoceno. No Holoceno médio, a cerca de 5 mil anos atrás, a ocupação caçador-coletor foi intensificada, espalhando-se pelas morrarias, cursos fluviais e aterros construídos nas planícies inundáveis do Pantanal. Desde uns 3 mil anos, nas mesmas áreas mencionadas acima, começou a confecção das cerâmicas da Tradição Pantanal, cuja tecnologia pode ter sido reproduzida até muito recentemente por populações diversas. Por volta do período entre o início do primeiro e do segundo milênio da era cristã, a região também começou a ser ocupada por populações indígenas provindas da Amazônia, falantes de línguas dos troncos Tupi e Arawak, as quais se estabeleceram nas áreas mais florestadas e férteis no Pantanal e no Chaco (Migliacio 2006, Pärssinen 2005).

De acordo com os dados históricos e etnográficos (Carvalho 1992, Costa 1994, Gadelha 1980, Metraux 1946, Susnik 1987) enquanto os Guarani sucumbiam perante os transtornos do colonialismo e abandonavam a região do rio Miranda, os MbayáGuaikurú, tornados cavaleiros através da apropriação dos rebanhos trazidos pelos espanhóis, ampliavam as suas áreas de correria desde o Chaco até o Pantanal. Em conjunto com os Guaná, povos agricultores e seus aliados contra os Guarani e os espanhóis, os Mbayá migraram para a margem esquerda do rio Paraguai, estabelecendose em muitas das áreas adrede ocupadas pelos Guarani, entre as quais a região do médio Miranda.

No séc. XVIII, após as descobertas auríferas e diamantíferas em Cuiabá e Mato Grosso, os aguerridos Mbayá, aliados com os Payaguá, povos canoeiros de língua Mbayá-Guaikurú, constituíram um dos maiores entraves na colonização do Mato Grosso por Portugal, sobretudo no trecho pantaneiro da ligação fluvial entre São Paulo e Cuiabá, quando a comunicação e o comércio no interior da capitania de São Vicente eram efetuados através das Monções (Holanda 2000, Taunay 1981). Depois de constantes expedições punitivas, os Mbayá firmaram um acordo com os portugueses, o que permitiu a construção da linha de fortes na fronteira dos domínios ibéricos, entre os quais o Presídio de Miranda, fundado em 1797 (Esselin, 2000). Paulatinamente, o 
colonialismo enfraqueceu o poderio dos Mbayá, os quais tiveram seus últimos dias de glória guerreira na Guerra do Paraguai (1864-1870), quando os cavaleiros, embora aliados das tropas imperiais, atacaram indiscriminadamente a quem lhes convinha, brasileiros ou paraguaios (Cardoso de Oliveira 1976, Moreira Neto 2005, Taunay 1997).

Na medida em que os Mbayá se enfraqueciam, mesmo antes do grande conflito platino, os Guaná, seus aliados desde os tempos do Chaco, se aproximavam cada vez mais dos Purutuya, o termo para português na língua dos Terena, uma das últimas parcialidades Guaná contatadas pelos europeus (Azanha 2004, Cardoso de Oliveira 1968, 1976, 2002). Com o término da Guerra do Paraguai, na qual os Guaná, entrincheirados na Serra de Aquidauana, impediram o avanço das tropas comandadas por Solano Lopez, o território antes pertencente aos Mbayá e Guaná, vindos do Chaco mais de 200 anos antes, fora, por um lado, monopolizado pela Companhia Mate Laranjeira, e, por outro, loteado entre os combatentes remanescentes da Guerra. A partir de então, com os índios drasticamente reduzidos em termos demográficos e injustamente usurpados dos seus antigos territórios, começa o período lembrado pela tradição oral dos Terena como "tempo da escravidão", quando os índios foram obrigados a trabalhar nas colônias agrícolas das fazendas instaladas na região, sendo libertos somente mais de trinta anos depois, com a passagem do Marechal Rondon, no início do séc. XX.

Em seguida, como visto acima, deu-se início à política de confinamento nas "reservas indígenas", onde, com a promessa da garantia dos seus direitos, os índios foram postos sob a tutela do antigo SPI, posteriormente transformado em Fundação Nacional do Índio (FUNAI), com a instauração da Ditadura Militar. Do interior destas reservas, os índios se resignaram com o processo de fragmentação cultural e territorial ao qual foram submetidos com a consolidação definitiva do Estado Nacional, sobretudo depois da execução de projetos desenvolvimentistas como a construção da estrada de ferro Noroeste do Brasil e a divisão do Estado do Mato Grosso.

Com o crescimento demográfico da população indígena verificado nas últimas décadas, as lacunas da política indigenista desenvolvida entre os Terena tornaram-se muito evidentes. Se por um lado falta terra para garantir o desenvolvimento sustentável das reservas, uma vez que as mesmas foram delimitadas sem o mínimo de planejamento humano e social, por outro, os órgãos oficiais não comportam as demandas dos indígenas por políticas públicas. Embora haja um sentimento crescente entre os Terena de que o presente é o momento da Retomada das suas terras, apenas os Kadiwéu, os 
únicos remanescentes étnicos de língua Mbayá-Guaikurú no Brasil, possuem uma reserva digna em termos territoriais no Estado de Mato Grosso do Sul (Martins 2002b, Instituto Socioambiental 2001/2005).

Considerando todos estes referenciais arqueológicos, históricos e etnográficos, Com efeito, pode-se perceber porque Lalima deveria deixar de ser entendida como a "ponta do iceberg" da Arqueologia Guarani no rio Miranda para se tornar o "palimpsesto" da História Indígena regional, haja vista que a Aldeia, cuja paisagem pode ser compreendida como um pergaminho antigo, escasso e caro, não só apresenta vestígios da ocupação Guarani, que por sua vez, podem ser entendidos como rasuras originadas com a raspagem das escritas anteriores para o reaproveitamento do pergaminho, como ainda é ocupada por populações descendentes dos Mbayá-Guaikurú e Guaná, as quais, finalmente, podem ser vistas como a última das escritas grafadas no pergaminho reaproveitado. $\mathrm{O}$ mais interessante nesta percepção consiste na possibilidade de descobrir, total ou parcialmente, ao olho nu ou mediante técnicas especiais, os conteúdos das escritas apagadas a partir dos debuxos detectados sob a escrita ulterior (Barton et al. 2004, Binford 1980, 1981, 1983, Panja 2003).

Dito ainda de outra maneira, pode-se afirmar que o principal objetivo da pesquisa arqueológica na Aldeia Lalima - que se constituiu basicamente de um levantamento arqueológico da área e da coleta de informações sobre a dinâmica do uso do espaço por parte dos seus ocupantes ao longo do tempo - é contribuir com a História Cultural da ocupação indígena na região. Por conta disso, a Arqueologia é aqui compreendida enquanto História Indígena de longa duração (Brochado 1984, Eremites de Oliveira 2003, Heckenberguer 2001, 2005, Hodder 1987, Neves 1998, 1999, 2006, Wüst 1990). Em termos amplos, isto significa que a Arqueologia, devido à constituição vestigial e à complexidade padronizada dos contextos arqueológicos - por sua vez decorrentes dos processos culturais e naturais de formação do registro arqueológico atua com maior propriedade no estudo dos processos históricos temporalmente extensos e diacronicamente lentos, tais como os processos de expansão, territorialização, continuidade, mudança, abandono, ruptura e migração.

A compreensão da Arqueologia enquanto História Indígena também pressupõe relações interdisciplinares com outras áreas do conhecimento. Com efeito, mais que 
benefícios teóricos e metodológicos, a inter, a multi e a transdisciplinaridade proporcionam uma compreensão diacrônica, crítica e holística do passado (Morais 1999-2000: 212). Assim, se por um lado as relações da Arqueologia com a Lingüística Histórica, a Etnografia e a Ecologia permitem a construção de hipóteses e modelos bastante abrangentes sobre as origens, as rotas de expansão e os processos históricos de longa duração (Brochado 1984, Heckenberger 2005, Heckenberger, Neves \& Petersen 1998, Noelli 1993, 1996), por outro, a Etnologia e a Etno-história demonstram criticamente que os grupos étnicos são e foram muito mais fluidos e dinâmicos culturalmente do que as percepções estáticas e monolíticas proporcionadas pelas concepções essencialistas sobre as relações entre vestígio material, etnicidade e língua (Jones 1996).

Como dito anteriormente, o levantamento arqueológico na Aldeia Lalima foi desenvolvido em conjunto com a coleta de dados etnográficos e etnoarqueológicos sobre a dinâmica do espaço em Lalima ao longo do tempo (David \& Kramer 2001, Finnegan 1992). Todavia, tendo em vista que estes dados ainda não foram tratados de modo adequado, os mesmos serão usados apenas pontualmente, sobretudo na sistematização do problema de pesquisa, na elaboração das hipóteses e na justificativa das conexões entre os contextos arqueológicos, etno-históricos e etnográficos.

Apesar da não apresentação de uma síntese sobre a Etno-história e o modo de vida tradicional dos Terena em Lalima, é importante ressaltar que tais dados são sumamente importantes para o estudo equacionado nestas páginas. Esta importância se dá não somente por conta do problema de pesquisa propriamente, mas também devido às discussões em torno do caráter colonialista da Arqueologia e os esforços pela descolonização do conhecimento arqueológico (Layton 1994, Smith \& Wobst 2006). A realização de pesquisas arqueológicas em territórios indígenas favorece o combate às origens colonialistas da Arqueologia que possibilitaram, em alguns contextos, que a mesma fosse usada como arma na legitimação situacional do poder das elites dominantes e na marginalização das populações dominadas (Condori 1994, Kojan \& Angelo 2005, Noelli \& Motta no prelo). Além da colaboração entre arqueólogos e índios em prol da construção do conhecimento, tais estudos viabilizam oportunidades para que as vozes discriminadas das populações indígenas se façam ouvidas (Sheppard 2003, Jackson \& Smith 2006) e ressaltam o papel ativo das populações frente aos processos de fragmentação territorial e cultural desencadeados pelo colonialismo (Monteiro 1992, 1994, Puntoni 2002, Rubertone 1994, Silliman 2005) 
Apesar destas questões terem sido tratadas em outro lugar (Silva et al. no prelo), é importante frisar que em Lalima a participação dos Terena se deu não só na construção do conhecimento - com a colaboração dos índios enquanto auxiliares de pesquisa nas atividades de levantamento e de interlocutores nas atividades de coleta de dados etno-históricos e etnoarqueológicos - como também foi sentida, não raro imperiosamente, nas negociações para a realização e a manutenção da autorização dos membros da comunidade para a execução do projeto e na escolha dos auxiliares e interlocutores.

É importante ressaltar que a entrada na TI Lalima foi permitida através da “Autorização para o Ingresso em TI No 24/CGEP/07”, outorgada pela FUNAI, depois de cumpridos todos os trâmites previstos na Instrução Normativa N ${ }^{0}$ 001/PRESI/94, onde constam as normas que disciplinam o ingresso em Terras Indígenas com a finalidade de desenvolver pesquisa científica. Da mesma forma, a Permissão e Autorização para a execução da pesquisa de levantamento arqueológico na Aldeia Lalima, conforme os procedimentos previstos na lei $n^{\circ} 3.924 / 61$ e estabelecidos na Portaria SPHAN N ${ }^{\circ}$ 007/88, protocolado junto à $18^{\circ}$ Superintendência Regional do Instituto do Patrimônio Histórico e Artístico Nacional (18 SR/IPHAN), foi concedido em nome da Prof $f^{a}$. Dr". Fabíola Andréa Silva, conforme "Portaria No 039/07, Seção I do Diário Oficial da União", com apoio institucional do Museu da Arqueologia da Universidade Federal de Mato Grosso do Sul (MuArq/UFMS). O apoio financeiro para a execução da pesquisa arqueológica na Aldeia Lalima foi dado pela Fundação de Apoio à Pesquisa do Estado de São Paulo (FAPESP), através do projeto de Auxílio Pesquisa "Arqueologia, Etnoarqueologia e História Indígena - um estudo sobre a trajetória da ocupação indígena em territórios do Mato Grosso e do Mato Grosso do Sul: a Terra Indígena Kaiabi e a Aldeia Lalima" (processo $n^{\circ}$ 06/60241-8), coordenado pela Prof ${ }^{a}$. Dra . Fabíola Andréa Silva (Silva et al. 2007), e da concessão de uma bolsa de mestrado FAPESP (05/57404-0). 
Isto tudo posto, cabe explicar que, além desta Introdução, a estrutura da monografia conta com duas partes. A primeira, intitulada "A Aldeia Lalima enquanto palimpsesto da trajetória histórica da ocupação indígena regional”, foi redigida com o objetivo de contextualizar o plano teórico a partir do qual foram elaboradas as hipóteses de pesquisa que, por sua vez, também estavam embasadas na bibliografia arqueológica, histórica e etnográfica sobre a História Cultural dos índios na região. Constituída por três capítulos, a Parte I apresenta: 1) uma descrição do arcabouço teórico de pesquisa; 2) um resumo acerca das características geográficas na região, com ênfase no entorno da área da Aldeia Lalima; 3) uma síntese sobre a trajetória histórica de longa duração da ocupação indígena regional, sistematizada a partir dos pressupostos teóricos apresentados no Capítulo 1.

O levantamento arqueológico propriamente dito será apresentado na Parte II, por sua vez denominada "Correlatos materiais da trajetória histórica da ocupação indígena regional na Aldeia Lalima". Igualmente constituída por três capítulos, a segunda parte apresenta: 1) as descrições dos métodos e das técnicas de pesquisa utilizadas no levantamento arqueológico; 2) a descrição dos sítios e das ocorrências arqueológicas detectadas e das atividades de coleta, bem como dos resultados das análises radiocarbônicas em amostras de carvões e das análises preliminares em amostras de fragmentos cerâmicos; 3) considerações sobre a relação entre os dados obtidos com o levantamento arqueológico em Lalima e a História Indígena regional de longa duração. $\mathrm{Na}$ Conclusão, ainda apresenta-se um relato sobre a realização da pesquisa arqueológica na Aldeia Lalima, com o objetivo de enfatizar a colaboração entre arqueólogos e indígenas em prol da construção do conhecimento. 


\section{Parte I - A Aldeia Lalima enquanto palimpsesto da trajetória histórica da ocupação indígena regional}

\section{Capítulo 1 - Os processos de formação do registro arqueológico}

A maioria dos modelos relativos à compreensão dos diversos processos culturais e naturais de formação do registro arqueológico foi concebida entre os anos 70 e 90 . No entanto, parte considerável deles resultou de pesquisas iniciadas mesmo antes dos anos 60 (Binford 1981, Schiffer 1987). Como é sabido, foi durante os anos que precederam a década de 60 que muitos dos descontentamentos em relação à Arqueologia HistóricoCultural alcançaram certo consenso entre os arqueólogos ocidentais, sobretudo os norteamericanos (Trigger 2004, Willey \& Sablof 1980). Tais insatisfações acabaram por consolidar as proposições teórico-metodológicas da Nova Arqueologia ou Arqueologia Processual (Binford 1962, 1964, Binford \& Binford 1968), uma escola de pensamento na qual os pesquisadores estavam interessados em descobrir e explicar, através de métodos comparativos, as regularidades inerentes ao comportamento humano e os processos de mudança cultural das sociedades.

Apenas à título de contextualização, cabe referenciar que, por volta desta época, a Arqueologia ainda não se encontrava nem mesmo institucionalizada nas universidades brasileiras (Barreto 1999-2000).

Postos à parte as críticas de uma escola teórica sobre a outra e os problemas históricos da Arqueologia Brasileira, pretende-se chamar a atenção para o fato de que no momento em que surgiram os estudos sobre os processos de formação do registro arqueológico, visto como o momento da "perda da inocência" da Arqueologia (Binford 1962, Trigger 2004, Willey \& Sablof 1980), os pesquisadores estavam tornando-se cada vez mais conscientes da complexidade por trás da variabilidade e da variação dos materiais arqueológicos. A Arqueologia Processual, assim, passou a dar uma grande importância à noção de contexto arqueológico a aos processos culturais e naturais responsáveis pela formação destes contextos (Binford 1981, Schiffer 1987).

A idéia de se entender os sítios arqueológicos enquanto palimpsestos igualmente data da primeira metade do século passado (Trigger 2004: 120). Tal idéia significa que, ao invés de enxergar o sítio como um livro, no qual cada capítulo corresponderia à uma camada e, por conseguinte, à um momento distinto de ocupação, sendo que quanto mais 
profundo, mais antigo - em conformidade com os princípios geológicos uniformitaristas - a compreensão dos sítios arqueológicos enquanto manuscritos antigos, utilizados diversas vezes, mediante a sobreposição de uma escrita sobre a outra previamente apagada, mas que entretanto ainda apresenta os vestígios das escritas anteriores, aproxima-se muito mais da realidade empírica observada tanto no registro arqueológico como nos relatos etnográficos (Binford 1980, 1981, 1983). Em termos mais claros, vislumbrar um sítio arqueológico como um palimpsesto implica na compreensão de que o mesmo local pode ter sido tanto ocupado por sociedades culturalmente diferenciadas através do tempo, quanto de diversas maneiras pela mesma sociedade durante um determinado período, sendo que ambas as possibilidades podem resultar em conjuntos de materiais arqueológicos sobrepostos espacialmente de modo muito complexo (Panja, 2003). Mais recentemente, alguns autores têm encarado não somente os sítios enquanto palimpsestos, mas também as paisagens, definidas, neste caso, como paisagens contingentes (Barton et al 2004).

No entanto, mesmo considerando as pesquisas embrionárias sobre sistema de assentamento de G. Willey e P. Philips no Peru - os quais sustentaram, mesmo antes do "debate do musteriense", que sítios com materiais arqueológicos diferentes podem ter resultado das diversas atividades de uma mesma sociedade, não de sociedades diferentes - ninguém havia contribuído tanto ao entendimento da variabilidade dos materiais achados nos sítios arqueológicos do que L. R. Binford. Em função do debate citado acima, travado com o arqueólogo francês F. Bordes, Binford se empenhou em pesquisas etnoarqueológicas junto aos esquimós Nunamiut, com o objetivo de demonstrar que a padronização nos conjuntos de materiais arqueológicos detectados nos mais diversos sítios é resultante das diferentes atividades associadas aos sistemas adaptativos das sociedades. Bordes acreditava que as diferenças nos conjuntos de materiais líticos correspondiam às diferenças de etnicidade de seus produtores (cf. Bordes 1968).

Com base em seu trabalho etnoarqueológico no Alasca, Binford foi capaz de construir um modelo no qual sustenta que uma mesma sociedade pode gerar, por meio das diversas atividades associadas aos subsistemas que constituem o seu sistema cultural, sobretudo os subsistemas de assentamento e subsistência, diferentes conjuntos de materiais arqueológicos. Tal variabilidade torna-se padronizada em função dos sucessivos episódios de ocupação dos sítios residenciais e de atividades específicas ao longo do tempo em uma determinada região e/ou sítio (Binford 1983). Os sítios residenciais, devido às inúmeras atividades levadas a cabo quotidianamente, apresentam 
uma variabilidade nos materiais arqueológicos muito maior que nos sítios de atividades específicas. Os sítios de atividade específica apresentam menos variabilidade em seus materiais arqueológicos, resultante da repetição das mesmas atividades nestes locais ao longo do tempo (Binford 1980).

Assim como a abordagem sistêmica de Binford, o modelo de fluxo (flow model) de M. B. Schiffer $(1972,1976,1987)$, concebido com o objetivo de possibilitar a realização de inferências comportamentais a partir do estudo do ciclo de vida dos objetos ou elementos associados aos sistemas culturais tanto das sociedades do passado como do presente, também contribui com importantes instrumentos conceituais sobre os processos de formação do registro arqueológico. Em termos gerais, o autor divide os processos responsáveis pela origem dos registros em processos culturais e não-culturais, também denominados respectivamente de $C$-transforms ou $\mathrm{N}$-transforms. Os processos não-culturais, ou naturais, são aqueles associados ao meio-ambiente do local onde o registro arqueológico foi formado, como as características geomorfológicas e climáticas, as quais podem tanto gerar a perda definitiva dos elementos, através da decomposição dos materiais orgânicos em solos muito ácidos, como a preservação dos mesmos, por meio da conservação dos materiais mais susceptíveis à decomposição em ambientes extremamente úmidos ou congelados. Os processos naturais atuam a partir do momento em que os elementos passam do contexto sistêmico, ou seja, do contexto dinâmico de produção, uso e descarte dos elementos/materiais para o contexto arqueológico, ou seja, o contexto estático que se forma a partir do descarte e abandono dos materiais.

De acordo com Schiffer (1987), os processos culturais de formação do registro, por sua vez, são iniciados desde à aquisição das matérias-prima para a confecção dos artefatos e se estendem até aos eventos pós-deposicionais, os quais podem causar muitos danos aos materiais arqueológicos, à exemplo de saques aos sítios em busca de tesouros, uso do solo em atividades agro-industriais e até mesmo das escavações e técnicas de coleta empregadas em campo pelos arqueólogos. Importante frisar que, na prática, é difícil separar os processos culturais e naturais, haja vista que tanto um quanto o outro ocorrem alternada e simultaneamente.

No caso de materiais duráveis (Schiffer 1972: 158), como os líticos e/ou cerâmicos, o ciclo de processos culturais que leva os elementos do contexto sistêmico ao arqueológico decorre das atividades e estágios associados aos processos comportamentais de busca de matéria-prima, manufatura, uso, manutenção e descarte. 
Entre tais processos, sobretudo antes do descarte, o autor ainda considera o transporte, a armazenagem, a reciclagem e o ciclo lateral, ou seja, a utilização de um elemento em atividades diversas e subseqüentes. Destarte, tais elementos tornam-se refugos arqueológicos com os processos de descarte. No entanto, o autor pondera que nem sempre os elementos duráveis das sociedades passam obrigatoriamente pelos processos aludidos acima, uma vez que os mesmos podem ser obtidos, por exemplo, através de atividades de troca ou comércio.

De maneira geral, Schiffer $(1972,1987)$ classifica os elementos em refugos e refugos de fato. Os refugos correspondem aos sub-produtos da performance de alguma atividade, à exemplo de pequenas lascas e estilhas resultantes de atividades de lascamento. Os refugos de fato são os materiais recuperados pelos arqueólogos em plenas condições de uso, como as pontas de projétil ou as vasilhas cerâmicas intactas. Todavia, reconhecendo as implicações espaciais dos processos de formação, visto que os estágios e atividades relacionadas aos diferentes processos que levam um elemento da manufatura ao descarte tem de ser performados em algum lugar, o autor ainda classifica os materiais arqueológicos em duas categorias: refugos primários e refugos secundários. Os refugos primários são os vestígios depositados nos mesmos locais em que foram usados na performance de alguma atividade, ao contrário dos refugos secundários, os quais, por sua vez, correspondem aos materiais que são transportados da área de atividade e depositados em áreas específicas de descarte, como os refugos produzidos por sociedades mais numerosas, à exemplo dos agricultores-ceramistas e da nossa própria, nas quais o lixo é amontoado em locais distintos das áreas em que foram produzidos.

Além do modelo de fluxo, Schiffer ainda proporcionou uma série de insights sobre a identificação dos processos culturais e naturais responsáveis pelo modo como os registros arqueológicos são formados. Em termos demasiado amplos, o autor (1987: 226-303) sustenta que os processos de formação podem ser identificados a partir da análise dos depósitos arqueológicos e das propriedades simples e complexas dos seus elementos. Os depósitos podem conter tanto elementos associados a uma simples atividade, como no caso das áreas de atividade específica - onde o refugo produzido pode apresentar repetição em seu conteúdo - quanto materiais relacionados a diferentes atividades, à exemplo dos assentamentos residenciais - o que ao fim e ao cabo resulta em uma diversidade de elementos e estruturas arqueológicas. O autor ainda chama a atenção para os processos naturais de formação do depósito, como a dinâmica de 
sedimentação, por exemplo. As propriedades simples dos elementos, como tamanho, densidade e forma, e complexas, como quantidade, diversidade e distribuição espacial, podem apresentar indícios dos processos naturais e culturais suportados pelos materiais desde o descarte, como o pisoteamento, o qual reduz o tamanho, modifica a forma e aumenta a quantidade dos fragmentos cerâmicos, ou então o dano causado pelos processos de decomposição de elementos orgânicos ou as pátinas ocasionadas por processos erosivos e pela ação eólica e hidrológica, a qual gera o arredondamento dos bordos dos elementos, a diminuição na quantidade e a redução da diversidade dos materiais.

Tanto Schiffer (1987) quanto Binford (1983) também deram ênfase às implicações arqueológicas ocasionadas pelas atividades de conservação (curation) dos artefatos. Em termos gerais, ambos salientaram que artefatos em condições plenas de uso podem ser deixados, ou melhor, conservados, nos diferentes assentamentos ou áreas de atividades específicas associadas ao sistema cultural para serem utilizados e/ou levados em outras ocasiões. Mais recentemente, estudos arqueológicos e etnoarqueológicos centrados em torno da noção de abandono têm sustentado que atividades de delayed curation, ou seja, curadoria a posteriori, podem resultar tanto na concentração de refugos de fato em certas áreas quanto na diminuição progressiva dos materiais deixados nos sítios arqueológicos (Brooks 1993, Joyce \& Johannessen 1993, Tomka 1993, cf. Cameron \& Tomka 1993).

Concebido principalmente a partir de pesquisas arqueológicas realizadas no sudoeste americano, o conceito de abandono foi definido tendo em vista o estudo do movimento nas sociedades intermediárias ou de nível-médio, em oposição aos termos mobilidade, usado nas pesquisas sobre sociedades de pequena-extensão, e colapso, utilizado nos estudos sobre as sociedades citadinas e estatais (Nelson 1997). Antes de tudo, cabe ressaltar que tanto a autora citada quanto os demais pesquisadores concernidos com as pesquisas sobre abandono (cf. Cameron \& Tomka 1993), enfatizam uma abordagem arqueológica menos normativa, o que efetivamente abre espaço para admitir que não há uniformidade nos processos ocorridos no passado, fato que, por sua vez, leva à uma certa flexibilização nos conceitos utilizados nas explicações sobre o passado. Assim, mais que um rótulo, o conceito de sociedades intermediárias, o qual combina as definições antropológicas de tribo, chefia e sociedades pré-estatais, deve ser entendido como um refinamento teórico, não como uma classificação neo-evolucionista, haja vista que a variabilidade dos testemunhos arqueológicos deixados por tais 
sociedades, assim como por aquelas que os arqueólogos brasileiros denominam de agricultores-ceramistas, geralmente, mas nem sempre, apresenta-se de modo latente em relação aos conjuntos formados pelos vestígios dos caçadores-coletores ou pelas estruturas das sociedades estatais. A respeito destas diferenças, os termos de Nelson (1997: 53) são bastante elucidativos:

“(...) Between states and bands, middle range societies may be characterized as having relatively firm residential focus on places and as subsisting on concentrated resources. They comprise primarily farmers who hunter and gather and live predominantly in aggregated settlements with limited institutionalized leadership (short-term and/of limited authority). All of these conditions are highly variable, however, and I list them not as a way to classify communities in the past but as a way to delimit the context I am addressing."

Ainda segundo Nelson (op. cit.), enquanto inicialmente os estudos sobre abandono lidavam apenas com os fatores causais, vendo o abandono como um efeito passivo, as pesquisas atuais são orientadas de acordo as seguintes perspectivas:

a) $\mathrm{O}$ abandono é um processo, não um mero evento, cujo movimento pode começar a ser preparado logística e até mesmo ritualisticamente muito antes de se efetivar, sendo que suas conseqüências podem perdurar por muitos anos depois de concluído, uma vez que os grupos mobilizados defrontam-se com uma série de obstáculos culturais e naturais que devem ser enfrentados e superados;

b) As causas dos processos de abandono variam de acordo com as escalas em que são estudadas, sendo que quando observado em amplitudes regionais, o abandono pode ser resultante de pressões ambientais, como grandes secas, e culturais, à exemplo de guerras e/ou epidemias, enquanto que nos contextos inter e intra sítio, pode ser ocasionado pelos próprios padrões culturais de uma determinada sociedade (cf. Binford 1980, 1983, Panja 2003);

c) $\mathrm{O}$ abandono pode ocorrer de várias maneiras, podendo ser caracterizado como temporário ou sazonal, episódico, permanente, residencial ou não, rápido, gradual e de longa ou curta duração (Tomka 1993: 14-15), planejado ou não planejado (Brooks 1993: 178-9), sendo o último tipo o que mais se aproxima do grau de integridade vislumbrado na "premissa de Pompéia" (Binford 1981);

d) Os processos de abandono transformam o uso dos lugares, pois se por um lado um local antes usado como espaço doméstico por um determinado grupo pode vir à se tornar, depois de abandonado, em uma área destinada às atividades de caça e coleta, 
por outro podem ocorrer transformações mais radicais nos padrões de uso do solo, sobretudo quando as populações são assimiladas ou substituídas por outras. Neste sentido, são interessantes as atualizações em torno das antigas noções do termo migração, entendido por Nelson (1997) como um complemento conceitual de abandono, adequado ao estudo dos processos de re-assentamento.

As implicações das perspectivas esboçadas acima sobre o conceito de abandono permitem que se considere o papel do movimento na relação entre registros materiais e a continuidade e/ou ruptura ocupacional das sociedades nas mais diversas paisagens. Da mesma forma, permite que sejam levadas em conta as conseqüências sócio-históricas dos processos de abandono, os quais podem desembocar tanto na formação de grandes comunidades originadas por grupos diferentes, quanto no inverso; o reconhecimento da variabilidade comportamental dentro das sociedades, pois os processos de abandono variam; e a natureza das relações sociais nas comunidades, uma vez que o abandono apresenta-se como um processo complexo, permeado por relações ecológicas, políticas, religiosas, etárias e de gênero.

Com isto posto, torna-se claro que os estudos sobre abandono, onde causas e conseqüências são vistas como processos ativos, fornecem uma estrutura teóricoconceitual privilegiada para a compreensão dos processos de mudança nas sociedades, pois estas mudam na medida em que se movimentam. As palavras de Nelson (1997: 545) são esclarecedoras em se tratando da relação do abandono com a mudança social:

“(...) Abandonment is a process of transformation from a way to using landscape to another, within sites, locales, and regions. (...) It is not mysterious that people change by moving residence; in fact, perceiving abandonment as part of ongoing process of transformation allow us to link the past to the present. People are constantly transforming themselves, their land, and their communities."

O modelo denominado de história de formação territorial, concebido por M. N. Zedeño (1997) a partir do estudo etnoarqueológico da formação do território dos índios pueblos Hopi no Arizona, e ampliado para o estudo arqueológico de reconstrução da história de vida dos territórios de modo geral, apresenta-se como uma síntese das propostas apresentadas acima, tendo em vista que trata dos dados sobre uma ocupação indígena regional, bem como explica esta ocupação a partir dos conceitos de abandono e migração. Com base nos laudos antropológicos encomendados ambos pelo 
Departamento de Justiça americana e pelos próprios Hopi no âmbito de processos por disputa de terras, Zedeño (op. cit.: 73) sustenta uma noção de território enquanto objetos agregados, constituídos por terra, recursos naturais e objetos feitos pelo homem, reunidos historicamente através de processos dinâmicos de interação sócio-ambiental. Devido à importância do conceito de território, vale citar textualmente a definição da própria autora:

“(...) Territories as object aggregates, in turn, follow specific trajectories that are combined result of the natural history of the land and its resources and the social history of the land and resource use. Societies establish, maintain, and transform territories through a variety of interactions and activities. These... include not only effective use of the landscape but also relationships of land and resource ownership within a society as well as between the society and its neighbors (Ingold, 1986). Through time, the material record of these interaction and activities reflects adjustments of land-use strategies to a changing environment as well as changes in the landscape owing to human modification."

Com efeito, a essência do modelo de Zedeño encontra-se subjacente ao trecho citado, uma vez que, generalizadamente, a história de formação dos territórios passa pelas trajetórias específicas aludidas acima, ou seja, o estabelecimento, a manutenção e a transformação territorial. Para a autora, cada uma dessas trajetórias está associada com inúmeros processos, atividades e correlatos materiais. Assim, os arqueólogos podem, teoricamente, reconstruir a história de vida de um território a partir da detecção dos correlatos materiais das atividades associadas aos processos contidos nas suas trajetórias de formação. Em termos gerais, os correlatos, bem como as trajetórias, processos e atividades relacionadas à formação territorial, segundo Zedeño (1997: 85-95), pode ser visto na tabela 1. É importante frisar que a trajetória esquematizada no quadro abaixo, assim como os processos, atividades e correlatos materiais, foram abstraídos e generalizados especificamente a partir do caso Hopi. Obviamente cada território deve apresentar suas interações sócio-ambientais características acumuladas ao longo da sua própria trajetória histórica de formação, sendo que o “(...) Abandonment may occur at any point in the sequence, thereby interrupting territory formation and opening the possibility for other human groups to begin their own interactions" (Zedeño 1997: 86).

Os modelos sobre os processos de formação do registro fornecem instrumentos teóricos que possibilitam o entendimento dinâmico dos contextos arqueológicos, seja em termos culturais ou naturais. Em se tratando dos fatores culturais de formação do 
registro, os modelos sintetizados demonstram que a variabilidade dos diferentes contextos arqueológicos, por mais estáticos, complexos e redundantes que possam parecer, resultam das atividades associadas aos processos realizados ao longo trajetória histórica de ocupação das sociedades, sejam estas distintas cultural e cronologicamente ou não.

\begin{tabular}{|c|c|c|c|}
\hline Trajetórias & Processos & Atividades & Correlatos materiais \\
\hline \multirow[t]{3}{*}{ Estabelecimento } & Exploração & $\begin{array}{ll}\text { Reconhecimento, uso temporário } & \mathrm{e} \\
\text { exploração restrita de recursos; } & \end{array}$ & Abrigos efêmeros, esconderijos e sinalizações; \\
\hline & Colonização & $\begin{array}{l}\text { Usos prolongados e assentamentos semi- } \\
\text { permanentes; }\end{array}$ & $\begin{array}{l}\text { Habitações permanentes e semi-permanentes, feições } \\
\text { agrícolas e facilidades rituais; }\end{array}$ \\
\hline & Assentamento & $\begin{array}{l}\text { Assentamentos permanentes e divisão } \\
\text { formalizada do espaço }\end{array}$ & $\begin{array}{l}\text { Estruturas e sítios funcionalmente diversos, facilidades } \\
\text { produtivas e interativas e marcadores de fronteiras }\end{array}$ \\
\hline \multirow[t]{3}{*}{ Manutenção } & Expansão & $\begin{array}{l}\text { Uso de terras marginais, exploração de } \\
\text { ecótonos diversos, deslocamento de } \\
\text { fronteiras, ajuste do espaço de vida e } \\
\text { expansão das redes de comunicação }\end{array}$ & $\begin{array}{l}\text { Aparecimento de aldeias satélites, aumento na produção } \\
\text { de comida e outros materiais, expansão das facilidades } \\
\text { domésticas e interativas, assim como dos caminhos e das } \\
\text { redes de comunicação }\end{array}$ \\
\hline & Consolidação & $\begin{array}{l}\text { Aumento nas atividades rituais, interativas, } \\
\text { políticas e bélicas e aumento da população e } \\
\text { no controle de recursos }\end{array}$ & $\begin{array}{l}\text { Expansão/modificação de facilidades interativas, } \\
\text { arquitetura defensiva, feições de controle do solo e da } \\
\text { água e baixo crescimento de facilidades domésticas }\end{array}$ \\
\hline & Fissão & $\begin{array}{l}\text { Fragmentação da comunidade, colonização } \\
\text { de áreas distantes e consolidação de } \\
\text { atividades em áreas fragmentadas }\end{array}$ & $\begin{array}{l}\text { Abandono parcial de facilidades domésticas e de áreas } \\
\text { periféricas, rápido crescimento de comunidades satélites } \\
\text { distantes e colonização além do território fragmentado }\end{array}$ \\
\hline \multirow[t]{3}{*}{ Transformação } & $\begin{array}{l}\text { Mudança dos } \\
\text { padrões de uso da } \\
\text { terra }\end{array}$ & $\begin{array}{l}\text { Mudanças na localização das áreas de } \\
\text { produção, aldeias dentro do território e na } \\
\text { função das estruturas }\end{array}$ & $\begin{array}{l}\text { Abandono de campos e estruturas, remodelamento } \\
\text { arquitetônico e construção de vilas e estruturas de } \\
\text { controle da água }\end{array}$ \\
\hline & Abandono & $\begin{array}{l}\text { Deslocamento permanente da população } \\
\text { fora do território, visita/uso esporádico ou } \\
\text { regular das facilidades abandonadas }\end{array}$ & Estruturas dilapidadas e locais persistentes \\
\hline & Reclamação & $\begin{array}{l}\text { Colonização de territórios antigamente } \\
\text { ocupados por populações relacionados e } \\
\text { usurpação de territórios através de guerra e } \\
\text { conquista }\end{array}$ & $\begin{array}{l}\text { Reocupação de facilidades abandonadas, mudanças } \\
\text { drásticas na cultura material, morte violenta, facilidades } \\
\text { defensivas e armamento }\end{array}$ \\
\hline
\end{tabular}

O contexto arqueológico, histórico e etnográfico da ocupação indígena regional, a história da formação do contexto etnográfico atual na Aldeia Lalima e o contexto arqueológico Guarani do sítio Córrego Lalima sugerem que a área da Aldeia pode apresentar materiais arqueológicos relacionados com populações culturalmente diversas, que teriam se estabelecido na região. Obviamente que o estudo pormenorizado dos processos de formação do palimpsesto arqueológico de Lalima foge do escopo desta dissertação, mesmo considerando que os mesmos estão parcialmente documentados nos escritos de caráter histórico e etnográfico sobre a ocupação indígena regional sobretudo em se tratando dos processos relativos ao abandono Guarani, causado pelos constrangimentos do colonialismo, e os processos de migração, transformação e fragmentação territorial e cultural enfrentados pelos Mbayá-Guaikurú e Guaná. Contudo, os modelos apresentados permitem uma compreensão da dinâmica da ocupação indígena regional de uma maneira mais sistemática, processual e holística, mesmo que o objetivo consista basicamente na localização de sítios arqueológicos, afinal, estes são constituídos por vestígios que podem ser entendidos como correlatos 
materiais das distintas atividades desenvolvidas pelas diferentes populações que ocuparam a Aldeia Lalima no contexto da dinâmica histórica da ocupação indígena regional. 


\section{Capítulo 2 - O contexto geográfico regional em torno da Aldeia Lalima}

A TI Lalima situa-se na margem direita do médio curso do rio Miranda, entre a margem esquerda do cór. do Lima, limite com a Faz. Santa Rosa, e a direta do cór. Barreiro, limite com a Faz. Vargem Grande. Em termos regionais, a Aldeia está localizada em meio ao relevo dissecado do centro do dorso da "Depressão de Miranda", no município de Miranda, no centro-oeste de Mato Grosso do Sul, em contexto peripantaneiro (SEPLAN 1990: 12-3). O território da Aldeia possui pouco mais de 3.000 há, perímetro de aproximadamente $30.150 \mathrm{~m}$ e quase 1.300 habitantes. O PIN Lalima localiza-se nas coordenadas UTM 21K 0574403/7725693, no principal núcleo habitacional da Aldeia, denominado Sede. Uma estrada precária, com cerca de $50 \mathrm{~km}$, conecta Lalima com o perímetro urbano de Miranda, situado ao norte (ver Mapas 1 á 3).

Além da localidade Sede, onde foi detectado o sítio Córrego Lalima, a Aldeia apresenta mais 5 outros núcleos populacionais. O baixadão e o morrinho podem ser considerados subdivisões da Sede, sendo o primeiro localizado entre o PIN Lalima e o rio Miranda, e o segundo entre o PIN e a Fazenda Vargem Grande. A Campina constitui a segunda localidade mais povoada de Lalima, estando situada entre a entrada da Aldeia e a Sede. Finalmente, o Potrero localiza-se em uma área desapropriada pelo INCRA da Fazenda Vargem Grande, porém retomada pelos índios. Todas estas localidades estão conectadas por ruas, estradas e trilhas diversas. Afora a sede do PIN Lalima, a Aldeia ainda conta com duas escolas, dois postos de saúde, energia elétrica e água encanada, entre outras facilidades de caráter público.

As casas dos índios, edificadas principalmente com madeiras, bambu e sapé embora também existam casas exclusivamente de madeira e alvenaria - estão construídas nas encostas das colinas suaves existentes na Aldeia, onde são formados pequenos núcleos compostos por várias casas habitadas por famílias aparentadas. Geralmente, cada família possui duas casas, uma utilizada como cozinha e quarto dos pais, e outra como quarto dos filhos. Na encosta ocupada pelo Sr. Maneco de Souza Neto, nosso principal interlocutor, foram construídas mais duas casas, uma para o seu pai, um senhor octogenário chamado João de Souza, e a outra para o seu tio, o setuagenário Luiz de Souza, um dos últimos remanescentes Guaikurú em Lalima.

As casas comumente estão dispostas em um plano irregular, sendo circundadas por quintais e roças (Ver Foto 1). Os quintais, limpos diariamente, são usados no manejo de pomares e plantas medicinais, bem como na criação de animais domésticos 


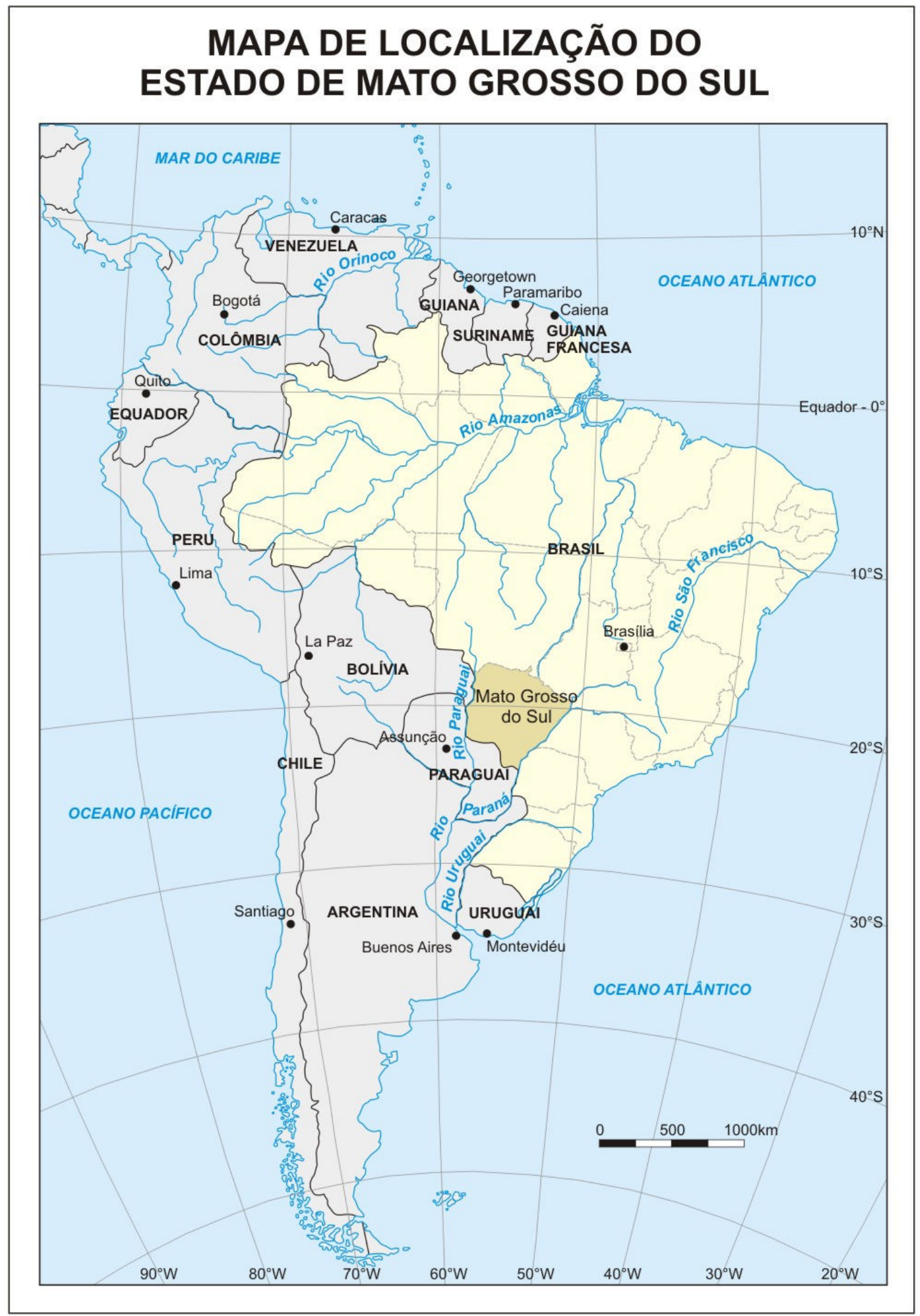




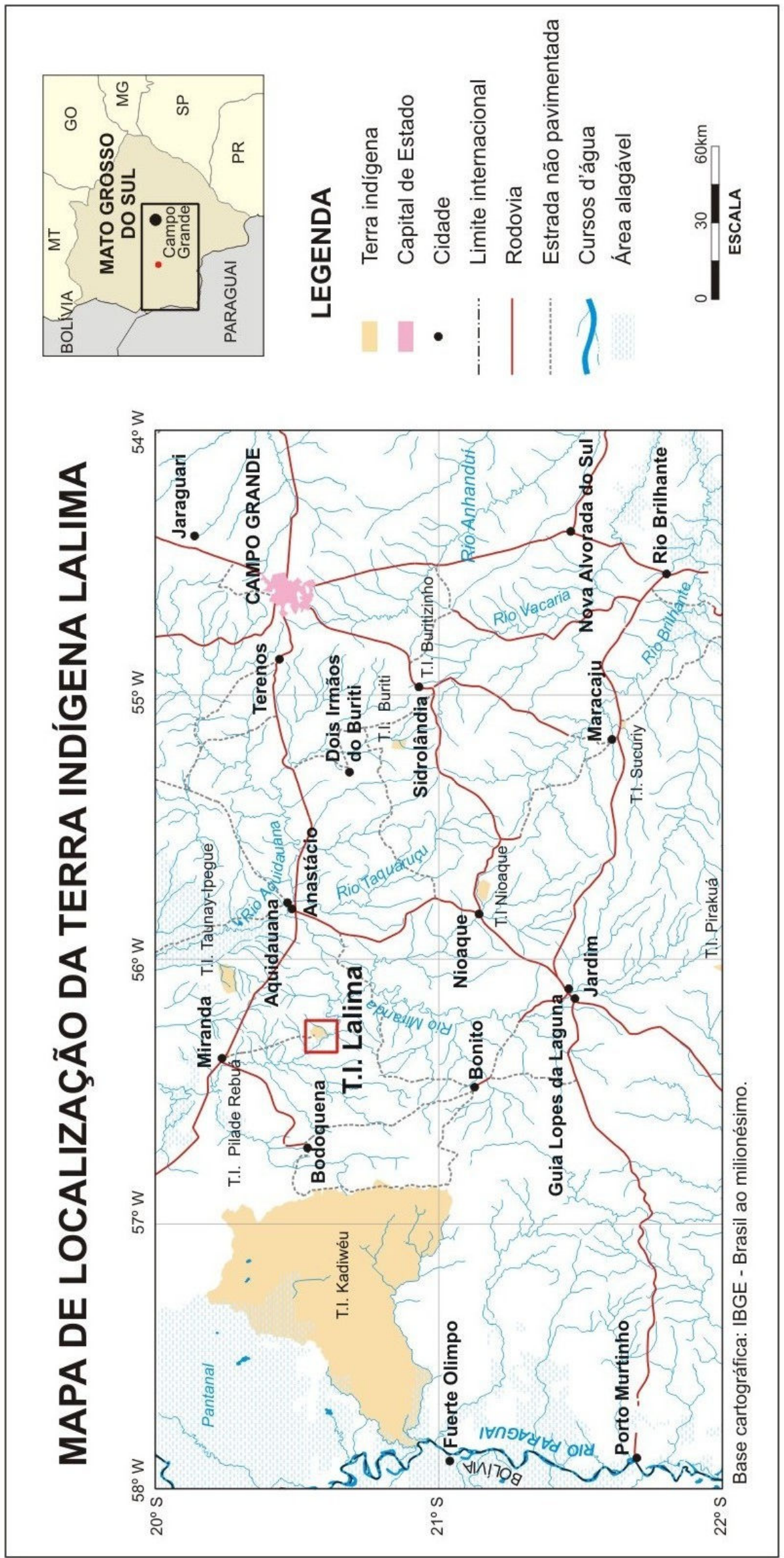




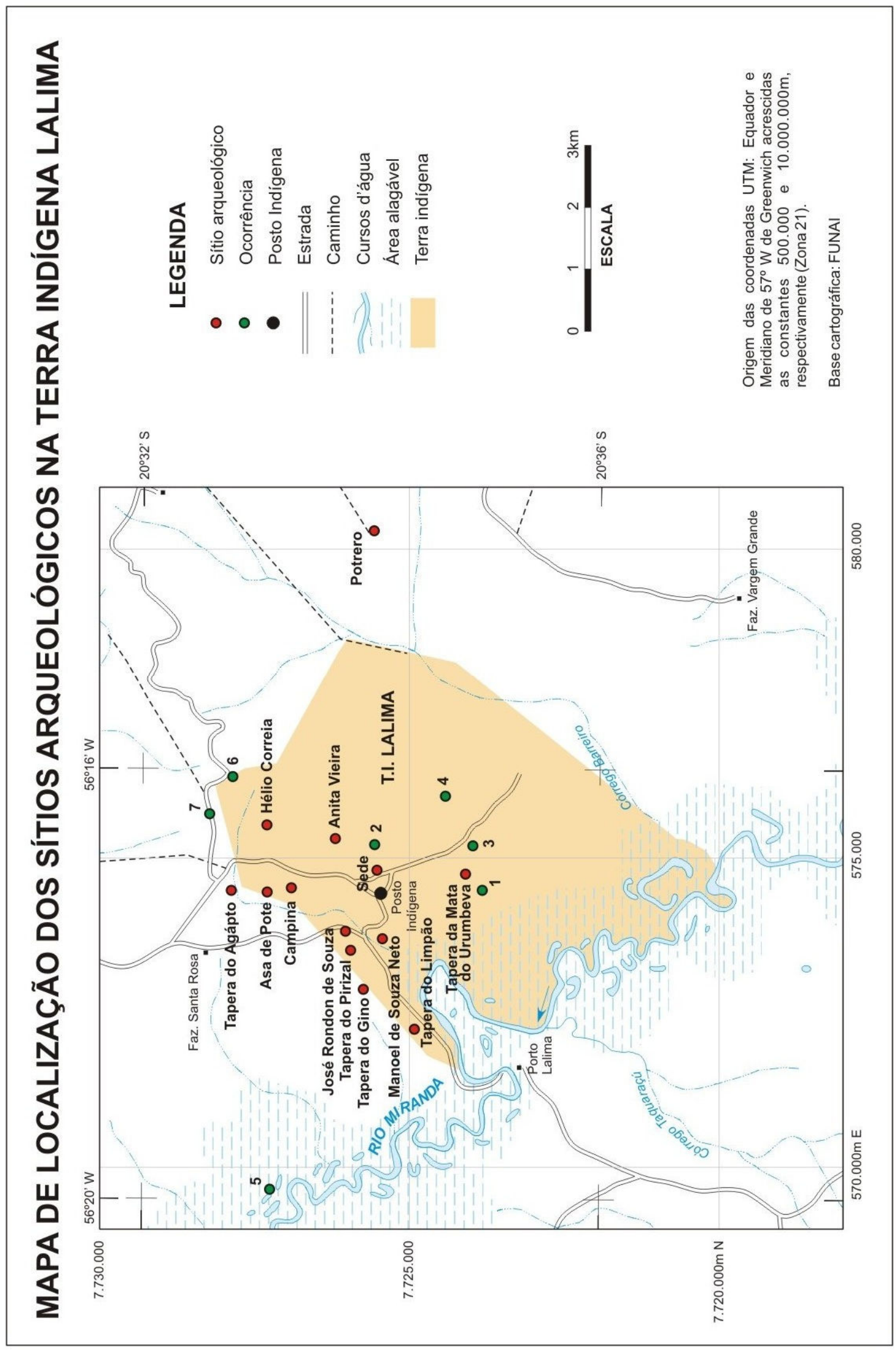


de estimação ou então destinados ao consumo, como galinhas e porcos. As roças, que também podem estar localizadas em áreas relativamente distantes das casas, são cultivadas com mandioca, milho, abóbora, batata-doce, feijão e arroz. Algumas casas ainda apresentam currais, onde são criados bovinos, eqüinos e caprinos.

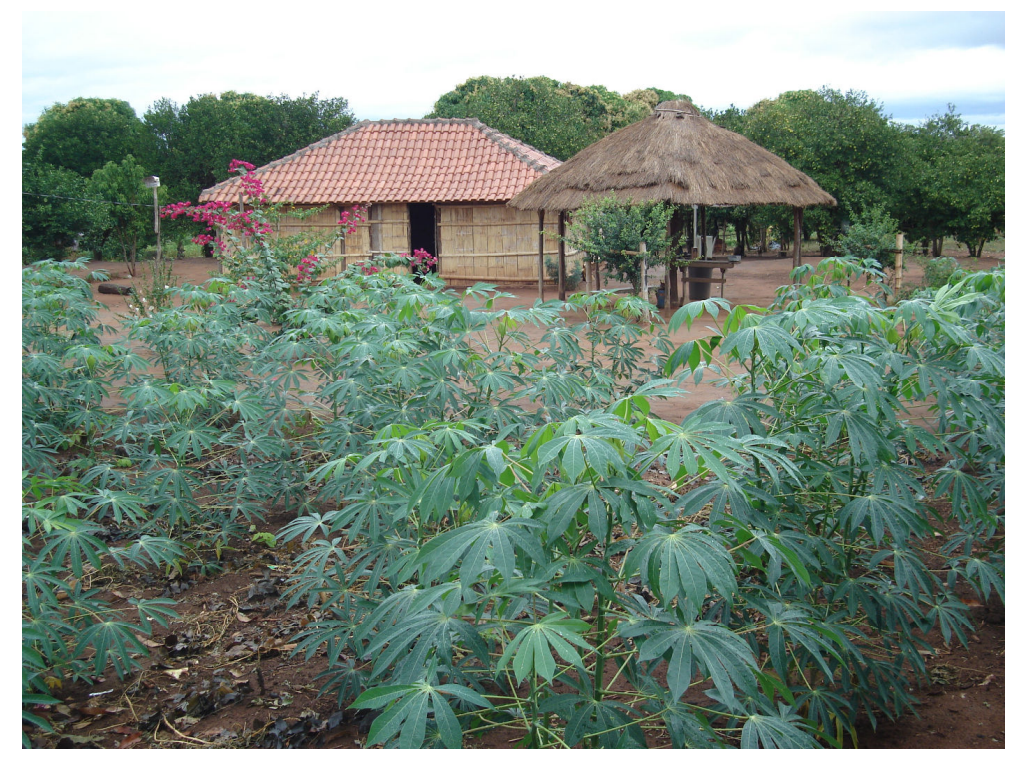

Foto 1: Aspecto geral das áreas domiciliares dos Terena na Aldeia Lalima

Apesar da identificação étnica e das reminiscências culturais dos seus antepassados, o modo de vida dos Terena em Lalima, em termos de parentesco, organização social e religião, se resume ao modelo camponês regional (Altenfelder Silva 1949, Cardoso de Oliveira 1968, 1976, 2002).

A principal fonte de renda e trabalho ainda é a changa, espécie de trabalho braçal, do tipo bóia fria, prestado nas fazendas e nas usinas sucroalcooleiras da região. Muitas famílias logram viver da agricultura, cuja produção é vendida em Miranda. Várias pessoas acabam assumindo os misteres necessários ao funcionamento da comunidade, como carpinteiros, mecânicos, borracheiros, comerciantes, enquanto outras terminam ocupando os cargos públicos oferecidos na Aldeia, como motoristas e técnicos de saúde, por exemplo, sendo que alguns conseguem preencher as vagas que exigem maior qualificação profissional, como de professor ou enfermeiro. Aposentadorias, pensões e benefício oferecidos pelo governo também constituem fonte de renda importante na comunidade. Ainda existem alguns projetos de agricultura e desenvolvimento sustentável e sócio-cultural promovidos por órgãos governamentais e privados em andamento na Aldeia. 
A organização política da comunidade é protagonizada pelo Chefe de Posto, pelo Cacique, pelo Vice-cacique e pelo Conselho Tribal. O Chefe de Posto é um funcionário público, porém sua nomeação depende do aceite do Cacique, do Vice e do Conselho. Em se tratando de Lalima, o Chefe de Posto é originário da própria Aldeia, sendo descendentes de índios Kinikinao e Terena. O Cacique e o Vice são eleitos pela comunidade, porém o Conselho é escolhido por ambos, entre membros prestigiosos e anciões. Recentemente, a Campina se dividiu politicamente do restante da Aldeia, passando a eleger um Cacique e um Vice próprio.

A despeito dos limites estabelecidos pelas cercas de arame e pelas placas de aviso, sejam do governo federal ou dos proprietários das fazendas, os índios transcendem o território diminuto da Aldeia a todo o momento, com o objetivo de desenvolver atividades de caça, pesca e coleta. Todo o entorno, ao longo de um raio de vários quilômetros, é nomeado e acessado cotidianamente por trilhas e caminhos.

A Depressão de Miranda constitui a parte sudeste de um compartimento geomorfológico maior, denominado "Depressão do Alto Paraguai” (SEPLAN 1990, Alvarenga, Brasil \& Del'Arco 1982: 145-7). Por situar-se entre as escarpas das Serras de Aquidauana e Maracajú, ao leste e sudeste, e do Planalto da Bodoquena, à oeste e sudoeste, a referida Depressão pode ser entendida como uma Superfície Intermontana, Interplanáltica e/ou Periférica - tendo em vista sua localização na periferia da borda ocidental da Bacia Sedimentar do Paraná. Ao norte, limita-se com o Pantanal MatoGrossense, especificamente os Pantanais do Miranda-Aquidauana (Magalhães 1992).

Em seu dorso, o relevo apresenta, principalmente, as seguintes formas de modelados: dissecadas, com predomínio dos tipos convexos, seguidos pelos tabulares e aguçados; erosivas, representados pelas superfícies pediplanadas, pedimentos e inselbergs; e formas de acumulação aluvial em planícies e terraços fluviais, sobretudo nas margens do rio Miranda (Foto 2). Encontra-se entre cotas altimétricas de 100 a $300 \mathrm{~m}$ acima do nível do mar, com predomínio de clima Termoxeroquimênico Atenuado, médias de $24^{\circ} \mathrm{C}$, precipitações anuais entre 1.200 e $1.400 \mathrm{~mm}$, e período seco de 3 à 5 meses (maio à agosto).

Até há pouco tempo, a vegetação era constituída por unidades fisionômicoflorísticas da Região Fitoecológica dos Cerrados (Savana Arbórea Densa), seguidas pela Região da Floresta Estacional Semi-decidual (Floresta Aluvial) e Decidual (Floresta Sub-montana), além das Áreas de Tensão Ecológica entre as mesmas. Atualmente, porém, predominam Áreas de Ação Antrópica, relacionadas às atividades de pecuária. 
Mesmo assim, tanto a Aldeia quanto as fazendas da região ainda apresentam alguns nichos ambientais mais preservados, sobretudo nas encostas dos morros mais íngremes e na mata ciliar do Miranda.

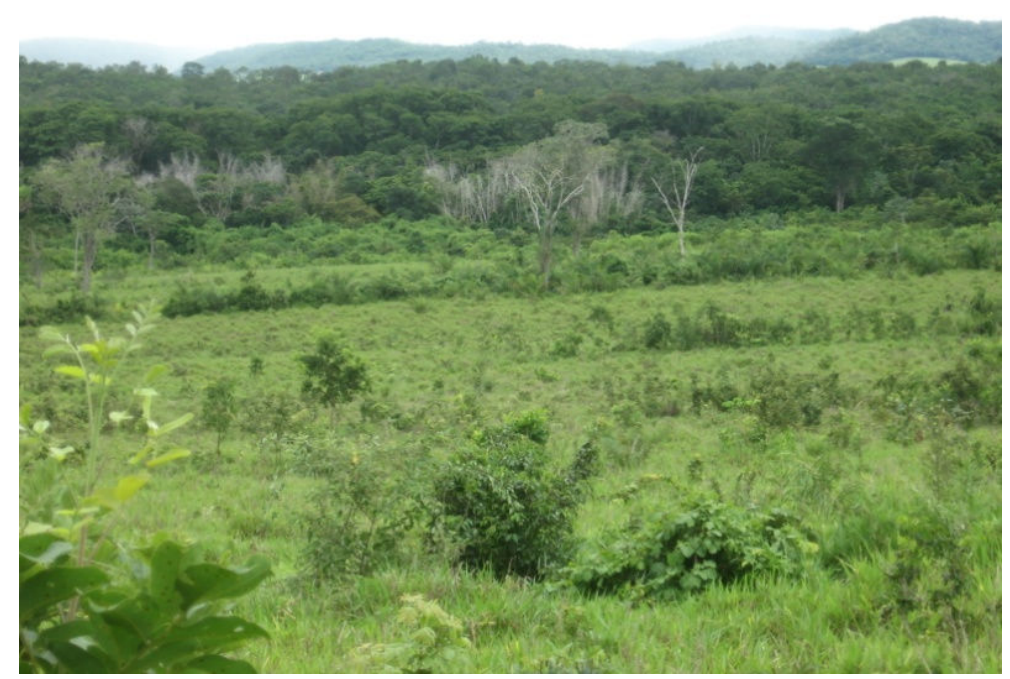

Foto 2: Relevo em torno da TI Lalima

Em meio à Depressão, predominam os afloramentos rochosos pré-cambrianos do Grupo Cuiabá, mormente representados por xistos, filitos, calcários e quartzos. Estratigraficamente, as rochas do Grupo Cuiabá constituem as camadas basais da Unidade Geotectônica denominada Cinturão Metamórfico Paraguai-Cuiabá ou Geossinclíneo Paraguai-Araguaia, sendo sotopostas pelas rochas igualmente PréCambrianas do Grupo Corumbá, classificadas na mesma Unidade. Estruturalmente, o Cinturão Metamórfico Paraguai-Araguaia encontra-se em posição intermediária entre as rochas Pré-Cambrianas que formam o cráton Amazônico e as fanerozóicas da Bacia do Paraná, sendo notáveis as estruturas de lineamentos, falhas e dobramentos, tanto no contato entre as rochas das diferentes Unidades, quanto no dorso da Superfície Interplanáltica.

A Folha SF 21 Campo Grande do Projeto RADAMBRASIL (Brasil 1982a), apresenta informações geológicas sobre as rochas do Grupo Cuiabá bastante interessantes à Arqueologia, sobretudo no tocante à oferta de matérias-prima líticas e argilosas. Na estrada entre a cidade de Miranda e a Aldeia Cachoeirinha, por exemplo, foram observados os "afloramentos mais significativos de quartzitos" (Araújo et al., 1982: 62), utilizados por inúmeras populações indígenas enquanto matéria-prima lítica 
em atividades de lascamento e polimento, bem como "ocorrências de argila... associadas à aluviões recentes" (Idem: 100), matéria-prima indispensável na confecção da utensilagem cerâmica. Os geólogos do projeto também percorreram a estrada que liga Miranda à Aldeia Lalima, onde, nas proximidades da Aldeia, “dominam amplamente os quartzo-xisto" (Idem: 62).

Acerca dos afloramentos quartzosos, matéria-prima amplamente utilizada pelas sociedades indígenas na confecção de diversos artefatos e utensílios líticos, os geólogos do RADAMBRASIL (Idem: 61) escreveram o seguinte:

“Uma característica que as rochas do Grupo Cuiabá exibem, principalmente os xistos e filitos, diz respeito à presença de numerosos veios de quartzo de espessura variando desde centímetros até $1 \mathrm{~m}$. Nos locais em que estas rochas se encontram fortemente alteradas, estes veios originam verdadeiras cascalheiras constituidas de fragmentos de quartzo. Esta propriedade permite a fácil identificação das rochas deste grupo em áreas intensamente intemperizadas."

Devido à diversidade litológica e aos vários processos de pedogênese, os solos são bastante diversificados, com ocorrência das seguintes classes: Regossolo álico e Podzólico vermelho-amarelo eutrófico, predominantes, associado às áreas dissecadas; Glei pouco úmido eutrófico, restrito às margens do Miranda e baixo curso de seus afluentes; Latossolo vermelho escuro álico, próximos aos sopés da Serra de Aquidauana; Brunizém avermelhado e Terra roxa estrutural similar eutrófica, nos pediplanos e pedimentos associados às rochas do Grupo Corumbá. Apesar de Cardoso de Oliveira (1976: 76) ter escrito que a Aldeia Lalima localiza-se em meio às terras "mais férteis da região", os solos classificados como Glei pouco úmido eutrófico, os mais férteis na área da Aldeia, segundo as escalas dos mapeamentos do Projeto RADAMBRASIL (Brasil 1982a) e do Atlas Multirreferencial (SEPLAN 1990: 18), apresentam aptidão agrícola "restrita nos níveis de manejo A e B - áreas do solo com medianas e boas reservas de nutrientes". Seja como for, é possível que os cultivares no passado tenham sido tão vistosos quanto os roçados e os pomares do presente.

Pertencente à "Bacia Hidrográfica do rio Paraguai (...) Sub-bacia do Miranda" (Idem: 6), o rio Miranda nasce no Planalto de Maracajú-Campo Grande, em um divisor entre suas cabeceiras e aquelas da Bacia do Ivinhema, por sua vez tributárias da margem direita do alto curso do rio Paraná. Ao atravessar as escarpas da Serra de Maracajú e as cidades de Jardim e Guia Lopes da Laguna, as águas piscosas do Miranda, em seu 
sentido geral sul-norte-noroeste, de padrão dendrítico, adentram em seu médio curso à jusante dos tributos das águas turísticas do rio Formoso, vindas de Bonito, pela margem esquerda. Inicialmente condicionado pela Falha de Cachoeirinha, o seu curso médio inicia a drenagem do dorso da Depressão de Miranda depois de receber as águas do rio Nioaque, pela margem direita. Tão logo à jusante da Aldeia Lalima, onde os índios dizem que existia o "antigo travessão" do Miranda, o rio começa a adquirir feições tipicamente pantaneiras, notáveis pelo crescimento da planície de inundação e das lagoas fluviais (Fotos 3 e 4). Após sua passagem pela cidade homônima, o rio Miranda chega à planície inundável do Pantanal, atingido o seu baixo curso, onde recebe, pela margem direita, as águas do rio Aquidauana, seu principal tributário, formando os Pantanais do Miranda-Aquidauana. Sua confluência com a margem esquerda do rio Paraguai ocorre defronte à Morraria da Patrulha e ao distrito corumbaense de Albuquerque, no planalto do Urucum-Amolar, situados na outra margem do Paraguai (Brasil 1982b), muito próximo da área piloto das pesquisas arqueológicas do Projeto Corumbá (Schmitz 1998, Schmitz et al., 1998).

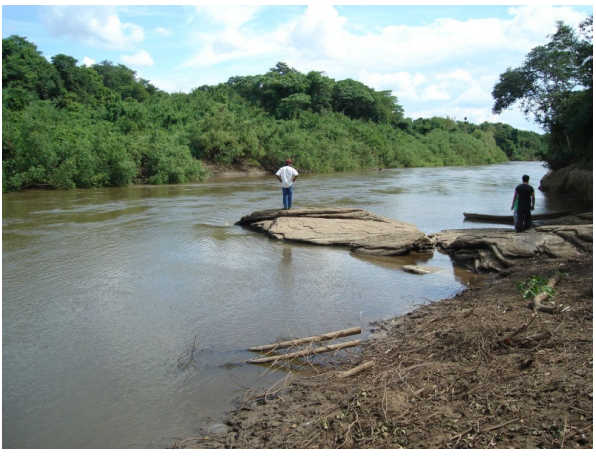

Foto 3: Travessão do médio curso do rio Miranda na Aldeia Lalima

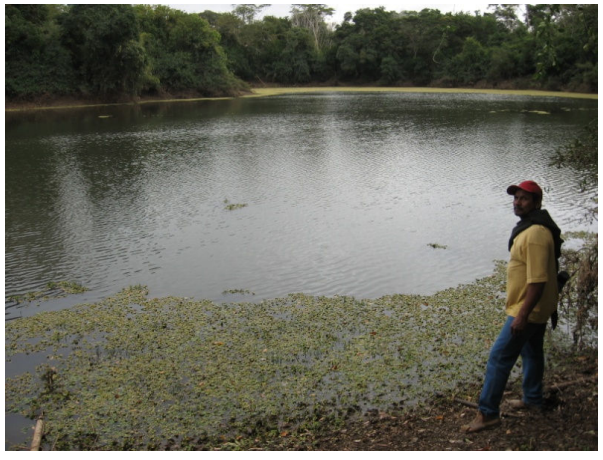

Foto 4: Planície de inundação na margem direita do rio Miranda na Aldeia Lalima

No âmbito e nos arredores da Depressão, além dos municípios citados, destacam-se as cidades de Aquidauana e Anastácio, onde as atividades econômicas mais importantes, de modo geral, são a pecuária, a pesca, a mineração de calcário e o turismo. Em Miranda, especificamente, além das atividades econômicas elencadas, sobressai-se a produção oleira, "formando uma constelação de indústrias cerâmicas, abastecedoras de grande parte do mercado consumidor de telhas e tijolos do Estado de Mato Grosso do Sul" (Araújo et al. 1982).

De modo geral, a história fisiográfica e geoecológica do Pantanal MatoGrossense proposta por Ab'Sáber (2006), concebida sob os auspícios da Teoria dos 
Refúgios e Redutos Florestais, "pode servir ao fomento das discussões que permeiam a história pré-colonial do Pantanal", tal como defendido por Eremites de Oliveira (1999: 31). Complementado com os dados específicos sobre a geografia da Depressão de Miranda contidos no Projeto RADAMBRASIL (Brasil 1982a), sobretudo em termos de história geológica e evolução do relevo, pode-se esboçar um quadro físiográfico associado ao surgimento da configuração física e ambiental da Depressão, desde a formação das rochas Pré-Cambrianas afloradas em seu dorso até o início da tropicalização associada aos assentamentos dos primeiros indígenas no Pantanal.

De acordo com Araújo et al. (1982: 95-7), as rochas do Grupo Cuiabá foram originadas através da metamorfose dos sedimentos das rochas do cráton Amazônico constituído pelas litologias pré-cambrianas polimetamórficas do Complexo rio Apa, as explosivas piroclásticas do Grupo Amoguijá e as intrusivas da Suite Alumiador - os quais foram depositados em um graben formado pelos arqueamentos, fraturas e distensões da crosta terrestre. Com o fecho da sedimentação e a conseqüente orogênese das rochas do Grupo Cuiabá, no pré-cambriano superior, forças verticais formaram as rochas do Grupo Corumbá, assim como novas bacias de sedimentação. Após reativações tectônicas associadas à origem das intrusivas do granito Taboco, já no cambro-ordoviciano, iniciaram-se os processos de deposição, a partir do siluriano, de sedimentos fanerozóicos sob as soleiras Pré-Cambrianas das bacias então formadas.

Ainda segundo os mesmos autores, tais sedimentos originaram, em ambientes marcados por transgressões e progressões marinhas, assim como pelas primeiras deposições continentais em ambientes glaciais, as camadas basais da Bacia do Paraná, à exemplo dos arenitos Paleozóicos das Formações Furnas e Aquidauana, entre outras não aflorantes ou então erodidas nas proximidades da Depressão de Miranda. No Mesozóico, novas reativações tectônicas originaram as rochas alcalinas triássicas Fecho dos Morros e as juro-cretácicas do Grupo São Bento, ou seja, os arenitos jurássicos da Formação Botucatu, originados a partir de dunas formadas em clima desértico, e os basaltos juro-cretácicos da Formação Serra Geral. Com a subsidência do eixo da Bacia do Paraná e o conseqüente empinamento das suas bordas, ocasionada pela densidade dos derrames magmáticos e por processos epirogenéticos, formaram-se os arenitos do Grupo Bauru, originados dos sedimentos da "vasta abóbada de escudo ali formada até o cretácio" (Ab’Sáber 2006: 16).

Com o advento da era cenozóica, toda a região da Bacia do Paraná passou por movimentos tectônicos epirogenéticos positivos e negativos e por processos erosivos 
denudacionais, responsáveis pela elaboração dos planaltos peripantaneiros, pela abertura da Depressão do Alto Paraguai e pelo preenchimento detrítico do Pantanal. Aos movimentos tectônicos, ocorridos entre o paleogênico e o pleistoceno, correspondem abaulamentos e afundamentos ocasionados por zonas de fraqueza, por sua vez adrede originadas com as sucessivas reativações tectônicas pré-cambrianas e paleo-mesozóicas. Os movimentos negativos foram intensificados com a epirogênese andina ocorrida no neogênico, por meio de movimentos isostáticos. Assim, "[s]oergueram-se os Andes, sorgueu-se a bacia do Paraná e abateu-se entre os dois a região onde instalou-se a atual bacia do Paraguai" (Alvarenga, Brasil \& Del'Arco 1982: 152).

Os processos erosivos foram intensificados por falhas inversas, decorrentes da movimentação tectônica, pelas oscilações climáticas, incluindo a instalação dos primeiros climas úmidos, e pela susceptibilidade dos sedimentos da Bacia do Paraná e do Grupo Cuiabá. Assim, no eo-paleoceno toda a região sofreu pediplanação, resultando na evacuação de parte dos sedimentos das camadas superiores da Bacia do Paraná e no nivelamento altimétrico dos Planaltos e Serras circundantes. No mio-eoceno, com a chegada dos climas úmidos e da consequente tropicalização do meio - ocorrida com o surgimento de bacias hidrográficas e áreas florestadas - ocorreram processos de "etchplanação" (Ab'Saber 2006: 26). Importante frisar que o surgimento das bacias hidrográficas ocorreu através de processos de captação de drenagens nas falhas inversas. Mudanças climáticas na direção da aridez ocorridas na transição do terciário ao quaternário, seguidas por intensos processos de pediplanação, provocaram o desmantelamento total da paisagem florestada constituída nos climas úmidos, ocasionando o preenchimento detrítico do Pantanal, durante o plio-pleistoceno, com a eversão das rochas da Bacia do Paraná. Atualmente, no Holoceno, o Pantanal continua recebendo os sedimentos das áreas elevadas circun-adjacentes.

Na Depressão de Miranda, segundo testemunham os inselbergs, tais processos causaram o afloramento do embasamento rochoso do Grupo Cuiabá com o recuo da cuesta das Serras de Maracajú e Aquidauana. Alvarenga, Brasil \& Del'Arco (1982: 154) resumiram a abertura da parte oriental da Depressão do Alto Paraguai, ou seja, da Depressão de Miranda, da seguinte maneira:

“A parte [oriental] da Depressão, talhada em sedimentos paleozóicos da bacia do Paraná, deu-se em função do recuo das escarpas da borda ocidental do Planalto de MaracajúCampo Grande. Trata-se de uma erosão que pode estar relacionada a processos muito 
abrangentes de circundesnudação periférica à bacia. Regionalmente, esses processos originaram cuestas desdobradas, algumas com frentes nitidas, outras já dissimuladas pela dissecação atual".

Referindo-se de modo geral à Depressão do Rio Paraguai, Ab’Sáber (2006: 15) utilizou o conceito de bouttonière para ilustrar os eventos tectônicos e os processos denudacionais relacionados à morfogênese da Depressão do Alto Paraguai e do Pantanal Mato-Grossense:

"Uma bouttonière é um tipo de relevo estrutural, que envolve uma notável inversão topográfica, a partir de uma estrutura dômica de grande extensão, comportando-se como uma depressão alongada, escavada a partir da abóbada central do domo. Via de regra, pressupõe um arqueamento em abóbada (em um setor de uma bacia sedimentar), uma superimposição hidrográfica (no eixo central do domo), e uma longa história erosiva, suficiente para ocasionar a evacuação de um grande estoque de massas rochosas, anteriormente constituintes de sua própria estrutura."

Contudo, de acordo com o mesmo autor (op. cit.: 12), "os fatos mais extraordinários e relevantes para a herança da região pantaneira aos homens e às comunidades (que a incorporaram como seu espaço de vivência e de recursos naturais) vieram a se processar nas últimas três dezenas de milhares de anos", ou seja, na transição do Pleistoceno ao Holoceno. Foi neste período, marcado pelo aumento da temperatura e da umidade, que o Pantanal adquiriu os contornos da sua configuração geoecológica atual. Até então, a região era mais fria, os pantanais e os rios não existiam, e a vegetação era composta por unidades fitoecológicas típicas da Região das Caatingas.

De acordo com as premissas da Teoria dos Refúgios, concernida com as "repercussões das mudanças climáticas quaternárias sobre o quadro distributivo de faunas e floras, em tempos determinados, ao longo de espaços fisiográficos, paisagística e ecologicamente mutantes" (Idem: 64), apenas eram florestadas as áreas que apresentavam condições ecológicas favoráveis diante do quadro semi-desértico da época, como os Planaltos e Serranias da Bouttonière do Alto Paraguai, onde as florestas puderam se refugiar em situações orográficas. Com o aumento da temperatura, subiram os níveis do mar e dos lençóis freáticos, aumentaram as chuvas e formaram-se os rios e pantanais. Conseqüentemente, criaram-se condições ecológicas que permitiram a expansão das áreas florestadas além dos seus refúgios. 
Como a planície pantaneira situa-se em torno do Planalto Central Brasileiro, da Amazônia e do Chaco, sua biodiversidade foi constituída por componentes florísticos e faunísticos do Cerrado, da Floresta Tropical e do Parque Chaquenho, além dos relictos da Caatinga. Efetivamente, a conquista fitogeográfica consolidou-se no Holoceno médio, com o Optimum Climaticum - um período de aquecimento global que tornou as condições ecológicas ainda mais favoráveis à tropicalização. Foi por volta desta época que o Pantanal tornou-se o que é atualmente. Ab’Sáber (Idem: 65) resumiu o processo da referida conquista da seguinte maneira:

“(...) No caso do Pantanal - um território deprimido situado entre os domínios dos cerrados, do Chaco e da Pré-Amazônia -, após a última crise de secura do Pleistoceno terminal, houve uma reconquista do antigo espaço seco por diferentes 'stocks' de vegetação tropical, a partir de refúgios e redutos acantonados nas chapadas, serranias e terras firmes adjacentes. $A$ invasão dos cerrados em expansão comportou uma colonização descendente pelo corpo geral do grande leque do Taquari, envolvendo, ainda, os trechos remanescentes das colinas pedimentadas do leste, sudeste e sul da depressão pantaneira. Pelo lado norte, entraram massas de vegetação periamazônica, comportando padrões de florestas tropicais decíduas e semi-decíduas, além de grandes palmares adaptados a conviver com as condições climáticas e hidrogeomorfológicas atuais dos setores setentrionais do Pantanal Mato-Grossense. Pelo extremo sudoeste e sul, a depressão pantaneira sofreu a penetração de componentes florísticos do Chaco Oriental, ela própria transicional quando comparada com a área nuclear chaquenha..."

Com efeito, antes da expansão das fronteiras agropecuárias, predominavam o Cerrado e o Cerradão em tensão com as Florestas Deciduais e Semi-Deciduais submontanas e aluviais na Depressão de Miranda. Levando-se em conta que "os principais contornos e ecossistemas - aquáticos, subaquáticos e terrestres - do Pantanal teriam sido elaborados nos últimos cinco ou seis milênios", é provável que as floras e faunas tenham iniciado o seu estabelecimento na área drenada pelo médio Miranda, no dorso da Depressão, na seqüencia da formação dos leques aluviais do Pantanal, "elaborados entre 23 e 13 mil anos antes do presente" (Idem: 41). Portanto, a despeito das oscilações climáticas ocorridas depois do Optimum Climaticum, como aquelas na direção da aridez verificadas no alto curso do rio Paraná entre 3.000 e 1.500 anos atrás (Kashimoto \& Martins 2000), pode-se inferir que, de modo geral, ao menos desde 5 mil anos que o rio Miranda apresenta condições ecológicas semelhantes às de antes do destoque da vegetação primária para fins pecuários. 


\section{Capítulo 3 - A trajetória histórica da ocupação indígena regional}

A despeito das controvérsias, as pesquisas arqueológicas indicam que a trajetória histórica da ocupação indígena regional se iniciou no final do período pleistocênico, com o estabelecimento de grupos paleoíndios nas áreas de refúgios ecológicos configuradas em torno do Pantanal (Ab'Sáber 2006, Eremites de Oliveira 1999 Eremites de Oliveira \& Viana 1999-2000, Martins 1998, 2005). Em Santa Elina, um abrigo sob rocha com arte rupestre situado no sopé da serra das Araras, município de Jangada/MT, foram obtidas datações arqueológicas com mais de 20 mil anos, em níveis estratigráficos onde os vestígios da cultura material estavam associados a restos faunísticos de animais extintos da mega-fauna (Vilhena-Vialou 2005). As pesquisas realizadas no Abrigo do Sol, localizado no alto curso do rio Guaporé, igualmente remetem a ocupação indígena no Mato Grosso ao Pleistoceno, com datas que alcançam até 19 mil AP (Miller 1983).

Na transição do Pleistoceno ao Holoceno, quer dizer, no período entre 12 e 8 mil anos atrás, as transformações ecológicas ocasionadas com a crescente tropicalização do meio favoreceram o estabelecimento de diversas populações caçadoras-coletoras na região. Além de Santa Elina, contextos arqueológicos datados deste período foram pesquisados em outras regiões em torno do Pantanal, não só no Mato Grosso, mas também em Mato Grosso do Sul. No território dos índios Bororo, no sudeste de Mato Grosso (Wüst \& Vaz 1998), e no alto curso do rio Sucuriú, no nordeste de Mato Grosso do Sul (Schimtz 1998), tais contextos, detectados em abrigos rupestres, foram atribuídos à Tradição Itaparica. Principalmente concebida por conta dos aspectos tecno-tipológicos da indústria lítica, onde se destacam artefatos plano-convexos talhados e retocados unifacialmente, os sítios Itaparica, também encontrados a céu aberto, foram associados com um horizonte bastante amplo de populações caçadoras-coletoras estabelecidas nos planaltos do centro-oeste, sudeste, nordeste e norte do Brasil (Bueno 2007, Etchevarne 1999-2000, Prous 1992, 1999, Schmitz 1999b, Silva 1992).

$\mathrm{Na}$ região centro-oeste, principalmente em Goiás, admite-se ainda outro horizonte caçador-coletor, denominado Tradição Serranópolis, datada do Holoceno inicial (Schmitz 1999b). Caracterizada a partir de conjuntos artefatuais formados por uma indústria lítica expediente, por vezes detectado nos mesmos sítios em que encontram-se vestígios atribuídos à Tradição Itaparica, a ocorrência de vestígios associados a Tradição Serranópolis ainda não encontra-se definitivamente constatada 
em Mato Grosso e Mato Grosso do Sul (Eremites de Oliveira \& Viana 1999-2000). Não obstante, contextos arqueológicos caçador-coletor datados em 7 mil anos foram estudados na bacia do rio Vermelho, no sudeste mato-grossense (Vilhena-Vialou 2006, Wüst 1999), enquanto que em Mato Groso do Sul são conhecidos sítios arqueológicos que podem ter sido formados por grupos caçadores-coletores, mas que ou não foram datados, à exemplo dos sítios registrados no município de Rio Negro por Martins (1998), ou então que o foram apenas parcialmente, como os abrigos Maracajú-1, situado no planalto Maracajú-Campo Grande, na cidade de Maracajú (Martins 2003), e Cera, localizados nas escarpas da serra de Maracaju-Aquidauana, município de Aquidauana (Póvoa 2007), nos quais, como se verá adiante, foram datados apenas os contextos estudados nos níveis superiores, associados à populações ceramistas. Cabe frisar que as pesquisas contidas nas últimas duas referências foram desenvolvidas em áreas relativamente próximas da Aldeia Lalima, sendo a primeira situada no planalto divisor de águas entre os formadores das bacias do Ivinhema, tributária da margem direita do rio Paraná, e do Miranda, tributária da margem esquerda do Paraguai; e a segunda no contexto da margem direita do médio curso do rio Aquidauana, o principal tributário do Miranda.

No Pantanal sul-mato-grossense, região de Corumbá - uma área tão próxima à Lalima quanto aquelas destacadas acima - o contexto arqueológico detectado no aterro MS-CP-22, considerado a estrutura monticular mais antiga de toda a bacia platina (Eremites de Oliveira 2004: 43), remete a ocupação indígena ao Holoceno inicial (Schmitz 1998, 1999a, Schmitz et al. 1998). Estrategicamente construído sobre um terraço fluvial na margem direita do rio Paraguai, localizado no município de Ladário/MS, entre as terras altas e as terras baixas, quer dizer, entre as encostas do planalto residual do Urucum-Amolar e a planície inundável, amostras de conchas retiradas das camadas construtivas do MS-CP-22 foram datadas entre 8.100 e 8.300 AP. Além de vestígios líticos de lascamento e polimento, constituídos por núcleos, lascas, talhadores, percutores, bigornas, mãos de pilão, boleadeiras, lâminas de machado e adornos, também foram coletados artefatos ósseos e conchíferos, tais como pontas e contas, restos faunísticos de alimentação e sepultamentos humanos. Este contexto arqueológico foi denominado Fase Corumbá I.

Os responsáveis pelas pesquisas no MS-CP-22 sugerem que o aterro teria constituído algo como um assentamento central ocupado por grupos caçadorescoletores-pescadores durante cerca de 200 anos (Schmitz et al. op. cit.: 241-2). Estas 
populações teriam explorado recursos alimentares animais e vegetais por todo o entorno, ou seja, tanto na planície inundável, já fazendo uso da canoa, quanto nas encostas do planalto do Urucum-Amolar. Todavia, como os próprios pesquisadores admitem (ibidem), o MS-CP-22 ainda é único, sendo necessário que se estudem outros contextos associados ao início da ocupação indígena no Pantanal, sejam estes mais antigos ou mais recentes que aquele, não tão somente para conhecer mais sobre os grupos do Holoceno inicial, mas também para compreender melhor o hiato arqueológico evidenciado entre as datas obtidas no MS-CP-22 e aquelas conseguidas nos aterros construídos por grupos caçadores-coletores-pescadores aceramistas na planície inundável durante o Holoceno médio, mais abundantes.

De volta ao entorno do Pantanal, foram estudados contextos arqueológicos caçadores-coletores datados desde o Holoceno médio tanto no Mato Grosso como em Mato Grosso do Sul. Em Santa Elina, a indústria lítica datada entre 6 e 2 mil anos atrás apresenta distinções tecno-tipológicas em relação as indústrias datadas do Holoceno inicial e do Pleistoceno final (Vilhena-Vialou 2005: 168, 173-4). Já no rio Vermelho, enquanto as pesquisas realizadas nos abrigos rupestres da Cidade de Pedras sustentam que não há alterações tecno-tipológicas na indústria lítica coletada nos níveis datados entre 4.600 e 2 mil AP (Vilhena-Vialou 2006: 219-21), no Território Bororo foi possível distinguir uma indústria lítica datada em até 5 mil anos, detectada em abrigos sob rocha, denominada Tradição Lítica Local, de uma outra, datada em aproximadamente 3 mil AP, chamada de Tradição Tombador (Wüst 1999: 304). Esta última, concebida a partir de conjuntos líticos formados por grandes lascas bipolares detectadas em sítios a céu aberto, pode representar uma transição do modo de vida caçador-coletor ao agricultor, antes mesmo do estabelecimento dos primeiros grupos ceramistas portadores da Tradição Una nos abrigos da região, no início da era Cristã (Wüst 1990, 1992, 1999).

As pesquisas realizadas na margem sul-mato-grossense do alto curso do rio Paraná indicam que a trajetória histórica da ocupação indígena caçador-coletor se desenvolveu entre 4 e 2 mil anos atrás, durante o último período de aridez identificado na região (Kashimoto 1997, Kashimoto \& Martins 2000, Martins, Kashimoto \& Tatumi, 1999). Embora os arqueólogos citados admitam que haja certa correlação entre as suas pesquisas e os trabalhos desenvolvidos em áreas adjacentes, sobretudo no Estado de São Paulo (Morais 1983, 1988, Pallestrini 1984, Pallestrini \& Chiara 1978, Vilhena-Vialou 1980), o horizonte caçador-coletor na margem direita do alto Paraná, constituído, entre outros materiais líticos talhados e retocados, por pontas de projétil, não foi inserido em 
nenhuma Tradição arqueológica. Contudo, é possível que se encontrem sítios líticos em Mato Grosso do Sul semelhantes aos contextos denominados de Tradição Umbu, diagnosticada principalmente pela presença de pontas de projétil, e amplamente difundida nas regiões sul, onde as datas se estendem desde 12 até cerca de 1 mil AP (Noelli 1999-2000: 231-33), e sudeste do Brasil, principalmente São Paulo, onde os contextos inseridos naquela Tradição foram datados entre 6 e 1 mil AP (Morais 19992000: 215). Os sítios a céu aberto detectados no planalto Maracajú-Campo Grande (Martins 2000, 2003, Martins \& Kashimoto 1999b), majoritariamente constituídos por vestígios líticos lascados, mas não raro com uma ou outra ocorrência cerâmica, também podem vir a apresentar datações em torno do Holoceno médio.

A despeito do contexto arqueológico detectado no MS-CP-22, as pesquisas arqueológicas indicam que o estabelecimento definitivo da ocupação indígena caçadorcoletor-pescador no Pantanal tomou corpo no médio Holoceno (Eremites de Oliveira 2003, 2004, Schmitz 1998, 1999a, Schmitz et al. 1998). Os contextos arqueológicos correlatos desta trajetória, denominados Fase Corumbá II, foram detectados em vários aterros construídos em locais estratégicos na região de Corumbá/MS, tais como as margens das lagoas Negra e Jacadigo e as áreas de tensão ecológica entre as terras altas e as terras baixas. Os conjuntos arqueológicos recolhidos nestes aterros são formados por materiais líticos, ósseos, conchíferos e restos alimentares, datados entre 5.000 e 2.500 anos atrás (Peixoto 2003). Comparativamente, cabe destacar que os materiais líticos são ainda mais expedientes e informais que aqueles definidos na Fase Corumbá I, e que não foram encontrados sepultamentos nos cortes estratigráficos empreendidos nos aterros da Fase Corumbá II. Mesmo assim, muitos destes sítios, devidos às suas dimensões e estruturas, apresentam características de assentamentos centrais, ocupados permanente e/ou sazonalmente ao longo de muitos séculos.

Nas planícies inundáveis dos pantanais do Abobral, em uma área sujeita às inundações periódicas do baixo Miranda, foram detectados dezenas de sítios em aterros na Fazenda Bodoquena (Schmitz et al. op. cit.: 125-41). Em um deles, denominado MSMA-16, constituído por um conjunto de aterros, a ocupação caçador-coletor-pescador foi datada entre 3 mil e 2.700 AP (idem: 136).

Certamente, não é à toa que o estabelecimento da ocupação caçador-coletorpescador no Pantanal coincide com o término do Optimum Climaticum, o período de estabilização das feições ambientais e geoecológicas características da biodiversidade dos distintos ecossistemas pantaneiros (Ab'Sáber 2006, Eremites de Oliveira 1999). 
Grupos indígenas distintos, originários de regiões diversas, devem ter sido atraídos pelas condições favoráveis do meio. As interações históricas entre estes grupos, permeadas por relações sociais e ecológicas, podem ter originado, em paralelo ao aumento demográfico, um sistema de ocupação peculiar, caracterizado pelo estabelecimento territorial de populações diversas em aterros construídos nas áreas mais propícias à manutenção do modo de vida caçador-coletor-pescador. Também é provável que, em conjunto à exploração dos diversos ambientes das terras baixas e altas, essas populações garantissem a sua subsistência através da realização de atividades de manejo ambiental de várias espécies vegetais, tais como a palmeira acurí e o arroz nativo do Pantanal, e até mesmo por meio de alguma agricultura incipiente (Eremites de Oliveira 2001).

Todavia, as pesquisas arqueológicas indicam que o Pantanal se tornou totalmente ocupado a partir de 3 mil anos atrás (Eremites de Oliveira 2003: 79), com o desenvolvimento de processos de expansão e consolidação territorial desencadeados pelas diversas populações indígenas construtoras de aterros. A multiplicação dos aterros nas planícies inundáveis e o surgimento da cerâmica, denominada Tradição Pantanal, datada entre 2.800 e $800 \mathrm{AP}$, são os principais correlatos destes processos (Peixoto 2003). Embora não se possa afirmar com todas as letras que as populações por trás da Tradição Pantanal descendem diretamente dos grupos estabelecidos na região desde o Holoceno médio, é possível que a incorporação da tecnologia cerâmica e a multiplicação dos aterros, transformações que devem ter ocorrido em conjunto com a intensificação das atividades agrícolas e de manejo ambiental, sejam resultantes de processos de continuidade e mudança, desencadeados através de interações entre as populações já estabelecidas na área, em pleno crescimento demográfico, e outros grupos, recém chegados ou então assentados em torno do Pantanal. Seja como for, ao mesmo tempo em que é importante ressaltar que a Tradição Pantanal disputa com a Tradição Una a posição da cerâmica mais antiga fora da Amazônia, muitos autores sugerem que a sua tecnologia pode ter sido reproduzida até recentemente, o que a configura como uma das tradições tecnológicas mais longevas entre as populações indígenas no Brasil (Eremites de Oliveira 2004, Migliacio 2000, Peixoto 2004, Peixoto \& Bezerra 2004, Schmitz 1998, 1999a, Schmitz et al 1998).

A Tradição Pantanal foi concebida a partir das análises dos materiais cerâmicos coletados na região de Corumbá/MS (Schmitz et al. op. cit.: 221-36). Em termos gerais, a Tradição Pantanal se caracteriza por vasilhas utilitárias, tais como panelas, tigelas e 
jarras, não restringidas e restringidas, não raro independentes, contornos simples e inflectido, formas esféricas, elípticas e ovais, dimensões pequenas e médias; tratamento de superfície predominantemente alisado, com presença de tratamentos cromáticos e plásticos, por vezes sobrepostos e/ou combinados; técnica de manufatura acordelada; queima incompleta; uso de antiplásticos minerais. Além de fragmentos de vasilhas, não só são encontrados outros artefatos cerâmicos nos contextos arqueológicos da Tradição Pantanal, tais como cachimbos, fusos e adornos, como também artefatos ósseos, materiais conchíferos, restos alimentares e sepultamentos humanos.

Diferenças observadas nos contextos arqueológicos ceramistas detectados em Corumbá/MS conduziram à subdivisão da Tradição Pantanal em duas Fases, por sua vez denominadas Pantanal, associada aos aterros, e Jacadigo, relacionada aos piemontes do planalto do Urucum-Amolar. Ainda foi identificado um terceiro conjunto de materiais cerâmicos da Tradição Pantanal no planalto do Urucum, em Corumbá, porém por tratarse de um achado isolado, detectado em apenas um sítio, denominado MS-CP-25, ainda não lhe foi atribuído uma denominação (Peixoto \& Bezerra 2004, Schmitz et al. 1998).

Os contextos arqueológicos da Fase Pantanal, datados entre 2.800 e 1.700 anos, estão associados tanto aos aterros até então ocupados pelos grupos aceramistas, quanto aos aterros construídos às centenas, talvez até aos milhares, pelas terras baixas da região. Aos atributos cerâmicos característicos da Tradição Pantanal, soma-se, ente outros, a presença de tratamentos cromáticos como o engobo vermelho, engobo branco, pintura de traços vermelhos e pretos; tratamentos plásticos funcionais, como corrugado, roletado, serrungulado, escovado e beliscado, bem como decorativos, como o nodulado, acanalado, aplicado, inciso e impresso com corda; predomínio de antiplásticos minerais, mas com presença de caco moído e concha triturada; bordas extrovertidas com reforço junto ao lábio, “... que podem servir de diagnóstico dessa fase” (Peixoto \& Bezerra 2004). Além dos materiais cerâmicos, ainda são encontrados materiais líticos, ósseos e conchíferos, bem como restos alimentares e sepultamentos humanos primários e secundários. No sítio MS-MA-16, quer dizer, no conjunto de aterros sujeitos às inundações do Miranda pesquisado na Fazenda Bodoquena, a ocupação ceramista foi datada em 1.700 AP (Schmitz et al. 1998: 130, 136).

Baseados nos dados arqueológicos resultantes do estudo dos contextos da Fase Pantanal, numa percepção um tanto determinista das pressões exercidas pela meioambiente pantaneiro e nas informações etnográficos sobre os diversos índios canoeiros outrora estabelecidos na região, tais como os Guató, Payaguá e Guaxarapó (Schmidt 
1942, 1949, Eremites de Oliveira 1996, 2004), foi proposto um modelo inicial sobre o sistema de assentamento e subsistência das populações ceramistas construtoras de aterros (Schmitz et al. 1998: 240). Destarte, os aterros com dimensões avantajadas e alta densidade e variedade de materiais e estruturas, geralmente implantados nas áreas mais propícias à ocupação humana, quer dizer, as margens das grandes lagoas e as áreas de tensão ecológica, foram compreendidos enquanto assentamentos centrais. Já os aterros edificados nas planícies inundáveis, por possuírem dimensões e densidades de materiais menores que aqueles, muitas vezes constituídos apenas por contextos ceramistas da Tradição Pantanal, foram entendidos como assentamentos temporários. Tendo em vista a sazonalidade do meio, marcada por uma estação seca, no inverno - quando apenas os cursos dos grandes rios e as grandes lagoas do Pantanal retêm água e outros recursos indispensáveis à sobrevivência - e outra chuvosa, no verão - momento em que as planícies permanecem inundadas durante alguns meses, ocasionando a dispersão dos recursos pelos pantanais e pelas áreas protegidas das cheias - os arqueólogo propuseram que os sítios centrais deveriam concentrar maior quantidade de pessoas no período seco, enquanto que os aterros menores, localizados nas planícies de inundação, seriam ocupados durante as cheia. Os autores citados resumiram o modelo proposto da seguinte maneira (Ibidem):

“O modelo resultante nos mostraria, então, assentamentos centrais, mais densos $e$ permanentes, para os quais a população dispersa se recolheria no tempo da vazante $e$ assentamentos periféricos e temporários, de populações dispersas durante o tempo da enchente. Apesar da necessidade de parte da população ter de dispersar durante a enchente, provavelmente os assentamentos centrais manteriam populações residentes o ano inteiro, guardando o espaço dos vivos e dos falecidos"

Não obstante, Eremites de Oliveira (2003: 80-81, 2004: 76-79), estimulado pelo modelo utilizado para entender a emergência da complexidade social entre populações construtoras de Sambaquis no Brasil e de cerritos no Uruguai, tem argumentado que os contextos arqueológicos constituídos pelos aterros devem ser entendidos como algo muito mais complexo que apenas como respostas adaptativas às condições impostas pelo meio físico e ambiental do Pantanal. O autor citado advoga que a construção dos aterros “(...) requereu o uso de conhecimentos arquitetônicos e a organização do trabalho social, além de fatores ideológicos, relações de poder e estratégias de territorialidade, ou seja, estratégias de domínio da paisagem natural e social dentro de 
uma visão cognitiva do universo" (Eremites de Oliveira 2003: 80). Com efeito, mesmo considerando que ambas as proposições ainda precisam ser testadas, a segunda lança um olhar mais social às questões relacionadas aos processos culturais de formação dos aterros, ainda mais em um quadro histórico marcado pelo crescimento populacional e pela chegada de populações distintas, o que pode ter ocasionado disputas territoriais e até mesmo diferenciações sociais a nível hierárquico, como aquelas existentes entre as populações de língua Mbayá-Guaikurú e Chané-Guaná no Pantanal e no Chaco entre os séc. XVI e XIX (Carvalho 1992, Metraux 1946).

Já os contextos arqueológicos classificados na Fase Jacadigo foram coletados em sítios a céu aberto, implantados nas encostas suaves dos piemontes do planalto residual do Urucum-Amolar (Schmitz et al. 1998: 226-8). As variações nas dimensões e nos conteúdos dos contextos dos sítios da Fase Jacadigo também sugerem a existência de assentamentos centrais e acampamentos sazonais. Ao mesmo tempo em que os materiais cerâmicos da Fase Jacadigo se inserem na Tradição Pantanal pela presença dos seus atributos característicos, se diferem da Fase homônima não só pelo padrão de implantação dos sítios, mas também por variações na forma das vasilhas, com ocorrência de fragmentos carenados, denotando contornos complexos - aos quais foi atribuída certa influência de populações de língua Tupi-Guarani; no tratamento de superfície cromático, com predomínio de engobo vermelho, e plástico, tanto em termos funcionais - com corrugado, roletado, beliscado e serrungulado - quanto decorativo com impressão de corda, inciso, ungulado, aplicado e nodulado; na presença de apêndices de suspensão, sobretudo alças; e, entre outros atributos, na ausência de caco moído e concha triturada como antiplástico (Peixoto \& Bezerra 2004). É oportuno registrar que nas reconstituições gráficas do vasilhame da Fase Jacadigo apresentada em Schmitz et al (1998: 235) deu-se ênfase à decoração labial formada por apliques de filigranas de argila em uma vasilha de contorno inflectido, porém, por mais vistosa que possa parecer, esta ocorrência não foi discutida, nem sequer citada, nas descrições dos autores. Além dos materiais cerâmicos característicos da Tradição Pantanal, como cachimbos, fusos e adornos, os contextos da Fase Jacadigo também são constituídos por restos faunísticos de alimentação, os quais, por sua vez, também são distintos daqueles estudados nos aterros, haja vista que não são encontrados remanescentes de peixes e moluscos, apenas de mamíferos, répteis e aves.

De fato, não só os restos alimentares, mas também o padrão de implantação dos sítios e as variações na cerâmica sugerem que as populações ceramistas da Fase 
Jacadigo não ocuparam a planície inundável, sendo caracterizados mais como agricultores de subsistência que como caçadores-coletores-pescadores. Os sítios da Fase Jacadigo ainda não foram datados, mesmo assim os pesquisadores responsáveis suspeitam que eles “... sejam recentes, talvez taperas dos pastores Mbayá-Guaicuru (sic) do séc. XIX” (Schmitz et al. op. cit.: 228). Nos abrigos Cera, na serra de MaracajúAquidauana, onde o conjunto cerâmico estudado por Póvoa (2007) apresenta atributos também presentes na Fase Jacadigo da Tradição Pantanal, foi obtida uma datação em torno de 500 AP. No município de Terenos, próximo à Campo Grande, um sítio com alguns fragmentos cerâmicos detectados no cór. Varadouro, um afluente do Aquidauana, foi datado em 1.135 AP (Martins \& Kashimoto 1999b: 25).

Apesar de detectados nas terras altas do Planalto do Urucum-Amolar, assim como os contextos da Fase Jacadigo, os materiais cerâmicos do MS-CP-25 variam em relação àqueles e aos da Fase Pantanal principalmente em termos decorativos, haja vista que predominam padrões geometrizados feitos com impressões de corda e policromia. Também deve se destacar as ocorrências de bordas com entalhes e incisões labiais, bem como a presença minguada de antiplásticos compostos por conchas trituradas. O MSCP-25 também não foi datado, porém, do mesmo modo como no caso da Fase Jacadigo, Schmitz et al. (Ibidem: 229) sublinharam que “(...) A muita Impressão de Corda faz lembrar novamente a cerâmica dos Mbayá-Guaicuru (sic), atualmente chamados Kadiwéu (...)".

Posteriormente, pesquisas realizadas no Pantanal de Cáceres/MT (Milgiacio 2000) e na lagoa do Castelo, em Corumbá/MS (Peixoto \& Bezerra 2004, Felicíssimo et al. 2004), conceberam outras duas Fases cerâmicas da Tradição Pantanal associadas aos aterros, respectivamente denominadas Taiamã e Castelo. A primeira, datada entre 1.200 e 1 mil AP, varia em relação às outras sobretudo pela preponderância de decorações plásticas realizadas com impressões de corda, porém estas não chegam a constituir motivos geométricos como no contexto do MS-CP-25. A Fase Taiamã também se destaca pela presença de caco moído, concha triturada e cauixi enquanto antiplásticos. No pantanal de Cáceres também foi estudado um contexto cerâmico denominado Inciso-Penteado (Migliacio 2000). Já a Fase Castelo, datada entre 2.600 e 1.300AP, também apresenta variações em relação às demais Fases da Tradição Pantanal. Em se tratando do tratamento de superfície, predominam decorações plásticas efetuadas por incisões e cromáticas realizadas com banhos de engobo branco e vermelho. Também 
ocorrem antiplásticos constituídos por conchas trituradas e cauixi na Fase Castelo, porém não foi observado caco moído.

Outros aterros ocupados por populações ceramistas no Pantanal foram registrados nas sub-regiões do Paraguai, São Lourenço e Poconé, no Mato Grosso (Eremites de Oliveira 2007, Schmidt 1940a, 1940b), e nos Pantanais do Nabileque, na região do município de Porto Murtinho/MS (Eremites de Oliveira 2004). Na região de Poconé, um sítio a céu aberto localizado nas proximidades do Morro do Cará-cará, em uma área então ocupada por dois índios Guató, embora uma coisa pode não ter nada a ver com a outra, foi datado em 800 AP (Eremites de Oliveira \& Viana 1999-2000: 171). Ainda não foram obtidas datações arqueológicas nos diferentes sítios detectados na região de Porto Murtinho, porém um contexto arqueológico implantado sobre um dique aluvial da margem esquerda do rio Paraguai, no sítio Cayman I, apresenta materiais cerâmicos “(...) cujas características lembram à cerâmica dos Kadiwéu, o que obviamente não significa que foram eles que as produziram" (Eremites de Oliveira 2004: 94). Além do mais, contextos arqueológicos semelhantes àqueles que constituem a Tradição Pantanal no Brasil foram estudados no Chaco paraguaio, boliviano e argentino, onde foram respectivamente classificados como Wettiadau-Mbayá (Susnik 1959), Guaná-Mbayá (Susnik 1984) e Complexo Cultural Alto-Paraguaiense (Perasso 1978); Tradição Chaquenha (Willey 1971); Cultura São Francisco e Tradição Ribeirinha Paranaense (Amílcar-Rodrigues 1992).

Também são conhecidos vários sitos com arte rupestre no Pantanal. Denominados Estilo Alto Paraguai, os contextos arqueológicos com arte rupestre são constituídos tanto por petróglifos, como aqueles pesquisados nos lajedos da região de Corumbá/MS e nos morros testemunhos próximos à lagoa Gaíva, quanto por pictoglifos, a exemplo das pinturas detectadas na região de Porto Murtinho/MS e no morro do Cará-cará (Girelli 1994, Schmidt 1940b, Eremites de Oliveira 2004, 2007). Mesmo considerando que esses sitos ainda não foram relacionados aos distintos contextos arqueológicos identificados na região, há certa tendência em correlacioná-los aos "... antigos grupos que construíram e/ou ocuparam aterros" (Eremites de Oliveira 2004: 59). Como aludido acima, também existem dezenas de sitos com arte rupestre nos planaltos circum-adjacentes ao Pantanal, muitos deles em abrigos sob rocha, tanto em Mato Grosso quanto no Mato Grosso do Sul (Martins 1998, 2002: 21-5, 2003, Póvoa 2007, Schmitz 1998: 216-8, Vilhena-Vialou 2005, 2006, Wüst 1999) 
Como frisado por Schmitz et al (1998: 12), as Fases Corumbá I e II, a Tradição Pantanal e o Estilo Alto Paraguai foram concebidos no ínterim de um projeto cujos objetivos consistiam em “... criar uma história contínua das populações indígenas, abrangendo o período pré-histórico e o colonial, com eventuais transgressões para o período nacional". Posteriormente, diante da descoberta da enorme variação nos conjuntos cerâmicos dos contextos arqueológicos do Pantanal, pesquisadores como Eremites de Oliveira (2004: 79) passaram a entender a Tradição Pantanal como uma macro-tecnologia, constituída “... de elementos cerâmicos relacionados a distintos estilos e etnicidades". Ao mesmo tempo, os arqueólogos passaram a admitir que a tecnologia da Tradição Pantanal pode ter sido reproduzida entre as populações indígenas até recentemente, sendo que existe “(...) possibilidades de pertencerem a grupos étnicos coloniais", como sugerido, entre outros, por Peixoto \& Bezerra (2004).

Apesar da presença de muitas populações falantes de línguas isoladas ou então inseridas em famílias lingüísticas menores, como os Chamacoco e os Yshir, cujas línguas foram agrupadas na família Zamuco, a maioria das populações indígenas que ocupavam o Chaco no séc. XVI falavam línguas do tronco Mbayá-Guaikurú (Eremites de Oliveira 2004: 80, Herberts 1998, Metraux 1946, Urban 1992: 97-8). Antes da conquista, segundo Metraux (1946: 214), os Mbayá-Guaikurú estavam estabelecidos entre o rio Paraguai e os rios Pilcomayo e Bermejo, ambos afluentes daquele pela margem direita. Contudo, é provável que já houvesse populações Mbayá-Guaikurú estabelecidas à jusante, no rio Paraná, e à montante, nos pantanais do Abobral e do Miranda-Aquidauana. Nesta última área, de acordo com a carta ânua do Pe. Diogo Ferrer sobre a geografia e a etnografia do Itatim, remetida ao provincial em 21 de agosto de 1633 - quiçá o documento mais importante acerca da ocupação indígena na região de Miranda na primeira metade do séc. XVII - viviam os Guaxarapó, grupos canoeiros possivelmente falantes de línguas Mbayá-Guaikurú (apud Cortesão 1952: 47, Eremites de Oliveira 2004). Na primeira metade do séc. XIX, os últimos canoeiros dos pantanais do Miranda-Aquidauana, registrados sob a designação étnica Guachi, foram encontrados por Castelnau (1949).

Os principais grupos Mbayá-Guaikurú eram constituídos pelos Abipon, Mocovi, Toba, Pilagá, Payaguá e Mbayá (Metraux 1946, Herberts 1998, Schimdt 1949, Weber 2002). Os Payaguá eram grupos canoeiros que ocupavam o rio Paraguai, tanto no território atual do país homônimo quanto na fronteira do Brasil com a Bolívia, no Pantanal. O próprio termo Paraguai, inclusive, deriva de uma corruptela de origem 
espanhola da expressão Guarani payaguá'y, que significa "rio do Payaguá", sendo Payaguá um dos caciques dos Evuevi, a auto-denominação étnica proferida pelos Payaguá. Os Mbayá ou Guaikurú - termo de origem Guarani, que quer dizer "gente malvada e suja", usado por aqueles para expressar alteridade em relação aos grupos chaquenhos de modo geral - ocupavam a área em torno do delta do Pilcomayo, defronte à Assunção, e se auto-definiam como Eyguayegui, que significa "habitantes dos palmeirais". Posteriormente, parcialidades Payaguá e Mbayá, tornados cavaleiros com a apropriação dos rebanhos eqüinos trazidos pelos europeus, se expandiram para o norte e se consolidaram no Pantanal, em áreas então ocupadas pelos Guarani ou ainda por outras populações, enquanto que as demais hordas Mbayá-Guaikurú se espalharam pelo Chaco, sobretudo nas direções sul, sudoeste e oeste de Assunção. De acordo com Metraux (1946: 218, cf. Azara 1809, Castelnau 1949), os Mbayá-Guaikurú que se consolidaram no rio Miranda eram os Beutuebo, também chamados de Beuaquiechos, "... who had lived near the Paraguayan border and later migrated to Miranda."

Os Mbayá eram populações extremamente móveis e aguerridas (Boggiani 1975, Metraux 1946, Herberts, 1998). Crendo que haviam sido criados para tanto, perambulavam pelos seus territórios escalpelando os inimigos e saqueando-lhes as mulheres, os filhos, os víveres e os artefatos. Infanticidas, preferiam criar crianças mais velhas e capazes de suportar as correrias e rapinagens do grupo, tomando-as dos inimigos e aliados e criando-as como se fossem suas, que se dispor ao sedentarismo e às agruras da maternidade. Inimigos irreconciliáveis dos Guarani, eram aliados de outras populações, como os Guaná, com os quais migraram para o Pantanal. Apesar da ênfase na caça e na coleta, conheciam a cerâmica e praticavam a agricultura. Suas aldeias apresentavam um plano semi-elíptico formado por choças portáteis próximas umas nas outras, com a residência do chefe ao centro.

Constituída por uma sociedade de guerreiros, a estrutura social era estratificada entre classes mais privilegiadas, menos privilegiadas e escravas. As primeiras eram formadas pelos chefes e suas famílias, geralmente integrantes de linhagens consideradas puras. As classes intermediárias eram formadas por mestiços, filhos de integrantes das famílias puras de linhagem e dos cativos. Estes, por sua vez, eram obtidos junto às populações vizinhas através do rapto, porém a relação entre tais e os seus senhores era muito mais branda do que se pode imaginar, ao ponto dos cativos serem plenamente incorporados ao ethos Mbayá, inclusive na qualidade de guerreiro destemido e impiedoso. Havia também os xamãs, chamados nidjienigi ou purungueiro, e os cudina, 
homens que viviam como mulheres depois da passagem por um rito caracterizado pelo corte do cabelo. Ribeiro (1980: 154-6) esteve com a última nidjena da Aldeia Lalima, chamada Maria Vicenza, quando realizava pesquisas junto aos Kadiwéu, na década de 40. Esta senhora era tia-avó do nosso principal interlocutor durante a realização da pesquisa arqueológica em Lalima, Manuel de Souza Neto.

Hipóteses arqueológicas e lingüísticas sobre as origens destas populações ainda não foram propostas sistematicamente, embora seja pleiteada uma provável origem pampiana antiga e uma certa relação com os contextos arqueológicos da Tradição Pantanal (Schmitz et al. 1998, Urban 1992). Com efeito, é inegável que a cerâmica dos Kadiwéu, reproduzida nos moldes atuais ao menos desde a viagem filosófica de Alexandre Rodrigues Ferreira, no final do séc. XVIII, apresenta alguns traços em comum com aquelas detectadas nos contextos arqueológicos da região (Ferreira 1791). Apesar da tecnologia cerâmica Kadiwéu ainda não ter sido abordada através de uma perspectiva etnoarqueológica, descrições relativamente detalhadas podem ser vistas em Ribeiro (1980: 287-95). As semelhanças entre esses traços foram observadas em maior profusão nos contextos da Fase Jacadigo e do sítio MS-CP-25, em Corumbá/MS (Schmitz et al,1998), e no sítio Cayman I, em Porto Murtinho/MS (Eremites de Oliveira 2004), áreas historicamente ocupadas por diversos grupos Mbayá a partir dos séc. XVI e XVII (Bastos 1972: 142-61). Contudo, também se observam alguns elementos comuns entre as cerâmicas suspeitas como mais recentes e aquelas definidas nas Fases mais antigas da Tradição Pantanal, coletadas nos aterros.

Com isto, é importante sublinhar, não se está sugerindo uma relação unilateral entre a Tradição Pantanal e as populações de matriz cultural Mbayá-Guaikurú, mesmo levando em conta que estas eram as mais populosas do Chaco e admitindo que elas possuíam certos mecanismos sociais, tais como a alta mobilidade, guerra de rapina e circulação de cativos, que poderiam criar um ambiente propício ao desencadeamento de processos de mudança cultural, como o advento da cerâmica e da agricultura. Tudo leva a crer que a Tradição Pantanal correlata um sistema de ocupação multi-étnico, elaborado não só com o desenvolvimento cultural das diversas sociedades estabelecidas na área desde o Holoceno médio, mas também com o estabelecimento de outras populações, provenientes das áreas localizadas no entorno. Nesse sentido, o que se especula aqui é que populações de matriz cultural Mbayá-Guaikurú podem ter participado da elaboração do sistema de ocupação compartilhado pelas diversas populações por trás da Tradição Pantanal desde antes da formação do mosaico cultural 
encontrado pelos europeus no séc. XVI, ao seu turno consituído com a expansão e a consolidação de populações ceramistas e agricultoras oriundas do planalto Central e da Amazônia nas áreas mais férteis da região (Brochado 2004, Eremites de Oliveira 2003, Heckenberger 2002, Wüst 1992).

Provavelmente a configuração etnográfica encontrada pelos europeus foi constituída entre o início da era cristã e o milênio subseqüente (Eremites de Oliveira (2003). As trajetórias destas populações na região foram distintas em termos cronológicos, espaciais e culturais, porém, de um modo ou de outro, todas sentiram os efeitos catastróficos ocasionadas com o colonialismo europeu, seja pelo genocídio causado com a difusão dos vetores infecto-contagiosos trazidos pelos primeiros exploradores e conquistadores, ou então pela subjugação dos grupos remanescentes.

As populações vindas do planalto Central, portadoras de matriz cultural MacroJê, talvez tenham sido as primeiras a se expandir desde suas áreas de origem e a contribuir com a formação do mosaico cultural encontrado pelos europeus. Os dados históricos e etnográficos apontam que estas populações ocuparam as porções nordeste, oeste e sudeste dos entornos do Pantanal, nas áreas sob influência dos cerrados localizadas nos patamares do planalto Central e nos pimontes entre aquele e a planície inundável, território tradicional dos índios Bororo, Umutina, Kayapó do Sul e, talvez, dos Ofayé-Xavante, e os pantanais do Poconé e Paraguai, regiões tradicionalmente ocupadas pelos Guató (Eremites de Oliveira 1996, Schmidt 1942, Viertler 1990, Wüst 1992).

No rio Vermelho, no território dos Bororo, as Tradições Una e Uru, em geral associadas às populações Macro-Jê, foram respectivamente datadas em 2.390 e 1.150 AP (Wüst 1999: 305). Na Cidade de Pedras, onde os materiais arqueológicos não foram discriminados em Tradições arqueológicas, as ocupações ceramistas foram datadas entre 1.900 e 250 AP (Vilhena-Vialou 2006). A Tradição Una, datada em até 3 mil AP na região sudeste e caracterizada por vasilhame cerâmico simples, utilitário e de pequenas proporções, geralmente é detectada em abrigos sob rocha, podendo estar relacionada com populações caçadoras-coletoras tardias, em transição para a agricultura, ou então com áreas de atividades específicas das populações portadoras da Tradição AratuSapucaí (Dias Júnior 1982, Henriques 2006, Henriques, Costa \& Koole 2004). Já a Tradição Uru, constituída por vasilhame bastante diversificado, relacionada ao tratamento da mandioca amarga, geralmente é encontrada em sítios a céu aberto associados às grandes aldeias circulares da região Centro-Oeste do Brasil, as quais 
podiam ser ocupadas por várias centenas e até mesmo por algumas milhares de pessoas (Eremites de Oliveira \& Viana 1999-2000, Robrhan-González 1996, Wüst 1992).

Contudo, a ocupação de populações de origem Macro-Jê na bacia do Miranda nos primeiros séculos do colonialismo é controversa. A carta ânua do Pe. Diogo Ferrer aponta que o rio Botetey, o qual pode ser tanto o Miranda, também chamado de Cayy, quanto o Aquidauana (Martins 2002a: 248-9), sobretudo em seu médio-baixo curso, era ocupado não apenas pelos Guarani, mas também por uma série de outros povos chamados de Gualacho, descritos como "... labradores que tienen pueblos fixos y chacaras grandes y en ellas todo lo que tienen los Guaranis, y no difieren en nada dellos sino en la lengua, aun que diz que tambien ellos entre si tienen una lengua o dos universales, y entran a contratar con estos Itatines” (apud Cortesão 1952: 47).

Como é sabido, Gualacho é um etnônimo geralmente atribuído às populações falantes de línguas da família Jê, tronco Macro-Jê, na região centro-sul do Brasil (Monteiro 1994: 70). Contextos arqueológicos associados aos ascendentes destas populações, classificados como Tradição Taquara, Itararé e Casa de Pedra, foram datados em aproximadamente 2 mil anos atrás (Noelli 1999-2000: 244-5). Com a extinção dos Otti-Xavante na primeira metade do séc. XX, os Kaingang, confinados em reservas indígenas em São Paulo e nos Estados da região Sul, e os Xokleng, presentes apenas em Santa Catarina, são os últimos remanescentes destas populações no sulsudeste.

Até o início do séc. XX, o nordeste de Mato Grosso do Sul ainda era ocupado pelos Kayapó meridionais, populações Jê amplamente distribuídas entre São Paulo, Minas Gerais, Goiás, Mato Grosso e Mato grosso do Sul - uma região até hoje referida como Kayapônia (Martins 2001). Os Kayapó do Sul podem estar relacionados às populações portadoras da Tradição Aratu, caracterizada por vasilhame cerâmico diversificado, mais adequado ao tratamento do milho, datada no Centro-Oeste em até 1.100 AP (Eremites de Oliveira \& Viana 1999-2000, Robrhan-González 1996).

Os últimos remanescentes Jê em Mato Grosso do Sul são os Ofayé-Xavante, que atualmente vivem na margem esquerda do alto Paraná, em uma área doada pela CESP (Martins 2002b). Sabe-se que um grupo Ofayé ocupou a região do rio Taboco, um afluente da margem direita do médio-baixo Aquidauana, após a Guerra do Paraguai. Depois de sofrerem violências dos fazendeiros locais, estes Ofayé se dispersaram em direção aos pantanais do rio Negro, onde desapareceram (Martins 2003). É provável que 
os Ofayé ocupassem o planalto de Maracajú-Campo Grande entre os séc. XVI e XIX, nas regiões entre os territórios dos Kayapó Meridionais e dos Guarani.

Todavia, de acordo com a interpretação de Gadelha (1980: 78), os Jesuítas parecem ter utilizado o etnônimo Gualacho às populações do Itatim diferentes dos Guarani em termos gerais, e nãos aos Jê especificamente. Assim, à exemplo da famosa dicotomia entre Tupi e Tapuia na costa atlântica do Brasil, o termo Gualacho, assim como Guaikurú, foi usado para estabelecer distinções entre os Guarani e as outras populações que ocupavam a região, por sua vez distintas culturalmente não só daqueles, mas também entre si mesmas. As palavras da historiadora citada são as seguintes:

"Divide o padre Ferrer as nações indigenas em dois grupos lingüisticos: os gualacho, que não falavam o guarani, e os guarani propriamente ditos. Dentre os gualacho cita os guaná, tunu, mbaiá, garamo, etc. São tribos chaquenhas conhecidas pelo nome de guaycuru e guaycuruti. Comerciavam com os itatim e seu domínio se estendia até o rio Bermejo (sic)."

Se a leitura da ânua de 1633 do Pe. Ferrer até justifica a interpretação da historiadora, haja vista que várias populações que definitivamente não falavam línguas Jê foram denominadas Gualacho, como os Mbayá-Guaikurú e os Chané-Guaná, também não se pode afirmar com todas as letras que não havia populações Jê no Itatim, afinal estas não só estavam estabelecidas nos pantanais do Poconé e nos planaltos em torno do Pantanal, seja em Mato Grosso ou Mato Grosso do Sul, como os jesuítas eram profundos conhecedores das questões indígenas daquele período. Seja como for, tal controvérsia não existe em se tratando das populações vindas da Amazônia, por sua vez portadoras de matrizes culturais Tupi e Aruak.

As pesquisas arqueológicas indicam que os Tupi, sobretudo as populações falantes de línguas Guarani, da família lingüística Tupi-Guarani - encontrados pelos europeus no litoral da região centro-sul do Brasil e na bacia platina, inclusive Argentina, Paraguai e Bolívia - foram os primeiros dentre os povos de origem amazônica a se consolidar na região. Em Foz do Iguaçú, no Estado do Paraná, foi obtida uma data em torno de 2 mil anos atrás (Chmyz 1983). Outras datações antigas, entre 1.800 e 1.600 AP, foram alcançadas no vales dos rios Jacuí e Uruguai, no Rio Grande do Sul (Schmitz \& Brochado 1972), na bacia do Paranapanema, em São Paulo e no Paraná (Brochado 1973, Faccio 1998), e nos piemontes das serras andinas orientais, na Bolívia (Pärssinen, 2005). Datas entre 1.400 e 1.200 são abundantes por toda a bacia platina, enquanto que 
aquelas em torno de 800 estão presentes na maioria das áreas historicamente ocupada pelos Guarani no início da colonialismo europeu (Laponte \& Acosta 2008, Martins, Kashimoto \& Tatumi 1999, Milheira 2008, Noelli 1999-2000, Mentz Ribeiro 2008, Soares 2004).

Em Mato Grosso do Sul, a ocupação Guarani foi datada entre 1.300 e 300 AP na margem esquerda do rio Paraná, no segmento entre as desembocaduras dos rios Amambaí e Invinhema, localizado defronte à foz do Paranapanema, e entre 800 e 600 AP no abrigo Maracajú-1, situado nos formadores da bacia do Ivinhema (Chmyz 1974, Kashimoto \& Martins 2008, Martins 2003, Martins, Kashimoto \& Tatumi 1999). O contexto arqueológico Guarani pesquisado por Chmyz (1974) na margem sul-matogrossense do alto Paraná foi denominado Fase Ivinhema. No Pantanal, um sítio Guarani foi datado em 500 AP na reserva dos índios Kadiwéu e outros tantos foram detectados no planalto do Urucum-Amolar, em Corumbá/MS, mas ainda não foram datados (Kashimoto \& Martins 2008, Peixoto 1998). De acordo com as fontes seiscentistas e setecentistas, inclusive a carta ânua do Pe. Ferrer, a área onde se localiza a TI Kadiwéu fazia parte do antigo Itatim, do mesmo modo como a TI Lalima, sendo então ocupada por índios Guarani, entre outros, enquanto que as terras altas em torno de Corumbá estariam ocupadas pelos Guarani-Ybytyryguara, que significa "habitantes das serras" (Cabeza de Vaca 1984, Schmiedl 1903, Cortesão 1952).

De volta à margem esquerda do rio Paraná, porém agora no segmento situado entre as confluências dos rios Pardo e Verde, em frente à desembocadura do Tietê - ou seja, ao norte do segmento entre o Amambaí e o Ivinhema - foram detectados conjuntos cerâmicos classificados como "Tupiguarani não-Guarani” (Martins \& Kashimoto 2008: 165), devido à baixa densidade de materiais em relação aos contextos classificados como Guarani, localizados mais ao sul, às variações no tratamento de superfície e às formas sub-arredondadas e sub-quadrangulares, semelhantes àquelas descritas por Brochado (1984) como pertencentes à Sub-tradição Tupinambá. Na mesma área, entendida como próxima da fronteira entre os Guarani e os Tupinambá, também foram coletados vestígios cerâmicos datados entre 2.200 e 600 AP, os quais, por sua vez, podem estar relacionados com ocupações distintas e ainda mais antigas que as Tupi.

No entorno do Pantanal, foram detectados outros conjuntos Tupi não classificados como Guarani no rio Vermelho, em Mato Grosso. Nos abrigos sob rocha da Cidade de Pedras, as cerâmicas descritas como “... fragmentos que trazem traços estilísticos característicos da Tradição Tupi-Guarani” (Berra \& DeBlasis 2006: 199) 
foram coletadas nas camadas estratigráficas mais recentes, enquanto que os sítios a céu aberto, sendo um deles datado entre 650 e 300 AP, foram ocupados por populações ceramistas portadoras das Tradições Uru e Tupi (Figuti 2006: 214). Já no Território Bororo, a cerâmica da "Tradição Tupiguarani Polícroma” (Wüst 1999: 305), foi datada em 680 AP. A propósito, as pesquisas efetuadas junto aos Bororo indicam que estes, cuja cerâmica foi datada em 230 AP, podem ter uma origem relativamente recente, resultante da fusão cultural entre os Tupi e as populações portadoras das Tradições Una e Uru (Wüst 1990, 1992, 1999).

Não obstante, considerando que os dados lingüísticos apontam que o provável centro de origem do tronco Tupi situa-se onde atualmente se encontra o Estado de Rondônia, “(...) na área próxima da bacia do Madeira-Guaporé” (Noelli 1996: 31, cf Rodrigues 1964: 103), e que a expansão dessas populações teria se desencadeado de norte a sul - inicialmente pelos grandes cursos fluviais, como o rio Paraguai, alcançado a partir do alto Guaporé, e, posteriormente, pelos afluentes de menor porte, e assim sucessivamente - é possível que se encontrem datas tão antigas em Mato Grosso e Mato Grosso do Sul, inclusive na antiga região do Itatim, quanto aquelas obtidas nas regiões adjacentes. Por outro lado, embora haja certo consenso quanto ao provável centro de origem, uma vez que a sua localização definitiva ainda não foi estabelecida arqueologicamente, também é importante frisar que a revisão dos dados disponíveis e o surgimento de novas descobertas, como aquelas efetuadas na Bolívia (Pärssinen 2005), podem sugerir outras rotas de expansão (Heckenberger, Neves \& Petersen 1998, Osório 2007, Viveiros de Castro 1996, Urban 1996).

Os contextos arqueológicos Guarani são constituídos por sítios diversos, nunca isolados, desde aqueles com grandes dimensões, não raro ocupados por vários séculos a fio - por vezes até por mais de um milênio - até aqueles de pequenas dimensões, limitados a uma ou outra ocorrência cerâmica ou lítica (Noelli 1993, 2004). Os sítios podem estar implantados tanto nos terraços fluviais nas margens dos rios de primeira e segunda ordem, quanto nos topos e encostas das colinas suaves dos tributários de menor porte. Os materiais arqueológicos são formados principalmente por fragmentos de vasilhas cerâmicas, vestígios líticos de lascamento e polimento, solos escuros antropogênicos, tembetás e enterramentos em urnas funerárias. Não só os sítios podem estar implantados sobre contextos arqueológicos distintos, pertencentes a outras tradições tecnológicas, como são encontrados materiais tecnologicamente diferenciados 
nos contextos arqueológicos Guarani e materiais Guarani em outros contextos arqueológicos.

Apesar das variações, as vasilhas cerâmicas apresentam características estilísticas típicas e peculiares, reproduzidas continuamente desde o início da ocupação Guarani até o colapso cultural causado com o colonialismo (La Salvia \& Brochado 1989, Martins \& Kashimoto 2008, Mentz Ribeiro 2008, Noelli 1999-2000). As formas diversas, constituídas por vasilhas não restringidas, restringidas e restringidas independentes, com contornos simples, inflectidos, compostos e complexos, formatos conoidais e arredondados, bem como dimensões pequenas, médias e grandes, denotam utilidades várias, associadas ao processamento, consumo e armazenamento de alimentos diversos, sejam sólidos ou líquidos. Apesar das formas serem mais adequadas ao tratamento do milho, também são conhecidos fragmentos pertencentes a vasilhas propícias ao tratamento da mandioca nos contextos Guarani, como os tostadores utilizados na fabricação de farinha e beiju (Brochado \& Monticelli 1994). A queima geralmente é incompleta, os antiplásticos são formados principalmente por minerais e cacos moídos, e o acordelado é a técnica de manufatura predominante.

Se bem que o alisamento ainda predomine nas faces das vasilhas cerâmicas, tratamentos de superfície cromáticos e plásticos geralmente estão presentes em densidades consideráveis (La Salvia \& Brochado 1989). A respeito dos tratamentos cromáticos, destacam-se as pinturas de linhas e/ou faixas vermelhas e/ou pretas sobre engobo branco, muitas vezes compondo motivos ricamente elaborados, tanto na face externa quanto interna. Entre os tratamentos plásticos funcionais, predominam as inúmeras variedades de corrugados, com presença de roletados, escovados, espatulados, beliscados e serrungulados, enquanto que entre os plásticos decorativos sobressaem-se os ungulados e os incisos, entre muitos outros, combinados ou sobrepostos.

Não raro, são encontradas vasilhas inteiras intactas e/ou fragmentadas nos contextos arqueológicos, sobretudo nas estruturas de sepultamento em urnas funerárias, nas quais não só determinadas vasilhas eram utilizadas como recipientes e tampas dos restos mortais, como também integravam a parafernália que acompanhava o morto na sepultura (Piedade \& Soares 2000). Ainda podem ser encontrados artefatos cerâmicos modelados nos contextos arqueológicos Guarani, tais como cachimbos e adornos.

Com o objetivo de estudar a relação da cerâmica Guarani com os outros aspectos da cultura, mas principalmente em relação à adaptabilidade e à subsistência, Brochado e seus associados propuseram um método de análise baseado nas classificações êmicas 
sobre a produção e a utilização de vasilhas contidas nos dicionários guarani-espanhol organizados pelo Pe. Montoya, S.J., na primeira metade do séc. XVII (cf. Brochado \& Monticelli 1994, Brochado, Monticelli \& Neumann 1990, Noelli \& Brochado 1998, La Salvia \& Brochado 1989). Comparações entre descrições sobre a funcionalidade das vasilhas extraídas dos dicionários, de um lado, e coleções constituídas por dezenas de vasilhas arqueológicas inteiras, de outro, resultaram na convenção analítica de seis grandes classes funcionais de vasilhas utilizadas pelos Guarani.

De acordo com Brochado \& Monticelli (1994: 110), tais classes são as seguintes: 1) a dos yapepó, termo Guarani traduzido como "panela", caracterizada por vasilhas restringidas e restringidas independentes, com contornos inflectidos, formas conoidais e arredondadas, bojos pronunciados, bordas côncavas e bases cônicas e arredondadas, dimensões desde grandes até miniaturas, muitas vezes com corrugações na face externa, utilizadas no processamento de alimentos sólidos e líquidos junto ao fogo, através do cozimento, ou como urnas funerárias; 2) a classe dos nãetá, traduzido como "caçarola", caracterizada por vasilhas não restringidas, contorno simples, formas conoidais e elípticas horizontais, bordas diretas e bases circulares e côncavas, igualmente corrugadas e utilizadas no processamento de alimentos junto ao fogo, ou então como tampas nos enterramentos em urnas; 3) dos ñamôpyú, ou "tostador", constituída por vasilhas não restringidas, contorno simples, formas elípticas horizontais, porém bem mais rasas que aquelas das classes dos ñaetá, bordas convexas muito baixas ou então apenas vestigiais, utilizadas para torrar farinha e assar beiju; 4) dos cambuchi, que quer dizer "talha, cântaro ou jarro", formada por vasilhas restringidas independentes, com contornos complexos, constituídos por segmentos balizados por pontos angulares salientes ou reentrantes, como carenas e ombros, não raro pintadas com motivos diversos em vermelho e/ou preto sobre engobo branco, formas conoidais, bordas cambadas, relativamente inclinadas interna, com pintura de faixa vermelha nos lábios, bases cônicas e circulares, utilizadas para preparar, servir e armazenar alimentos líquidos, inclusive as inúmeras variedades de bebidas alcoólicas fermentadas, e como urna funerária; 5) dos ñaembé, traduzida como "prato ou tigela de comer", caracterizada por vasilhas não restringidas, com contornos simples, formas elípticas horizontais, dimensões variadas, por vezes com pinturas na face interna, bordas diretas inclinadas externamente e bases arredondadas, usadas no consumo de alimentos sólidos; e, finalmente, 6) a classe dos cambuchi caguâba, entendidas como "tigelas de beber", formada por vasilhas restringidas e não restringidas, contornos simples, compostos ou 
complexos, tais como os cambuchi, porém em dimensões muito menores, muitas vezes com pinturas nas faces externa, interna e no lábio, formas elípticas ou conoidais, bordas diretas ou inclinadas internamente, utilizadas no consumo de alimentos líquidos e, secundariamente, como acompanhamento funerário.

Os pesquisadores citados também estabeleceram regras para a reconstituição gráfica das vasilhas pertencentes às classes dos yapepó, ñaetá e cambuchi caguâba a partir dos fragmentos de borda característicos das vasilhas destas classes, com base na proporcionalidade conferida entre o diâmetro da boca e a altura do vasilhame nas vasilhas arqueológicas inteiras presentes nas coleções. Assim, conforme a linha de regressão apresentada por Brochado, Monticelli \& Neumann (1990: 733), por sua vez calculada a partir de uma equação regressiva, e as descrições de yapepó de dimensões variadas e determinadas contidas nos dicionários do Pe. Montoya, bordas côncavas características da classe, com diâmetro da boca entre 12 e $16 \mathrm{~cm}$, deveriam ser representadas nas reconstituições gráficas, conforme as regras de proporcionalidade estabelecidas, com alturas entre 8 e $15 \mathrm{~cm}$, sendo correspondentes às vasilhas descritas nos dicionários como yapepó myri, ou "panela pequena"; já aquelas com diâmetro bocal entre 18 e $30 \mathrm{~cm}$ teriam altura entre 18 e $30 \mathrm{~cm}$, sendo correspondentes aos yapepó boyá, ou "panela média"; e, finalmente, as bordas de yapepó maiores que $32 \mathrm{~cm}$ corresponderiam aos yapepó guaçú, ou panela grande, sendo que as vasilhas arqueológicas analisadas nas coleções com diâmetros de boca entre 40 e $55 \mathrm{~cm}$ apresentaram alturas entre 32 e $48 \mathrm{~cm}$. Os autores ainda notaram que os yapepó myri e as miniaturas de yapepó - quer dizer, os yapepó com diâmetros de boca inferiores a $10 \mathrm{~cm}$ - apresentavam formas arredondadas, enquanto que os yapepó boyá e guaçú possuíam formas conoidais e bojo pronunciado.

Em se tratando dos nãetá e dos cambuchi caguâba, subdivididos em quatro outras classes devido às variações nas formas - sendo as mais rasas e abertas associadas aos primeiros, ou seja, aos pratos de comer, e as mais fundas e restringidas aos cambuchi caguâba, quer dizer, às tigelas de beber - foi observado que, quanto maior o diâmetro da boca, proporcionalmente mais rasa a tigela (Brochado, Monticelli \& Neumann op. cit.: 736). Assim, enquanto um ñaetá com forma elíptica horizontal, borda direta e base arredondada apresentou $8 \mathrm{~cm}$ de diâmetro de boca e $4 \mathrm{~cm}$ de altura, um outro, da mesma classe, apresentou $30 \mathrm{~cm}$ de diâmetro bocal e $12 \mathrm{~cm}$ de altura. Da mesma forma, um cambuchi caguâba com contorno complexo, forma conoidal, borda inclinada externa e base cônica apresentou $10 \mathrm{~cm}$ de diâmetro da boca e $6 \mathrm{~cm}$ de altura, 
enquanto um outro, semelhante, apresentou abertura da boca em $32 \mathrm{~cm}$ de diâmetro e altura em 12cm. Cabe frisar que Noelli (1999-2000: 259) demonstrou que muitas populações indígenas falantes de línguas da família Tupi-Guarani, inclusive aquelas que ocupam a Amazônia, distantes milhares de quilômetros dos territórios Guarani, ainda usam ou então usaram termos cognatos àqueles compilados pelo Pe. Montoya 400 anos atrás, o que, de certa forma, não só prova a validade do método proposto por Brochado e colegas, mas também demonstra o quanto as classificações êmicas utilizadas estão estruturalmente enraizadas na cultura Guarani.

A padronização dos contextos arqueológicos Guarani, mesmo levando em conta as suas variações regionais, seja na cerâmica ou nos outros materiais que o constituem, figura como algo realmente impressionante, ainda mais a se julgar pela sua amplitude espacial e temporal. No passado, do mesmo modo como em relação à semelhança lingüística e cultural, tal padronização foi explicada como conseqüência de migrações rápidas, ocorridas pouco antes da chegada dos conquistadores ibéricos, desde um centro de origem supostamente localizado entre o Paraná, o Paraguai e a Argentina. Contudo, atualmente, com o cruzamento mais sistemático e criterioso dos dados arqueológicos, lingüísticos, históricos e etnográficos, acredita-se que os contextos arqueológicos são correlatos de processos históricos de longa duração, caracterizados pela reprodução contínua de um modo de vida característico, ou melhor, de um ethos cultural (Noelli 1993).

De fato, as evidências indicam que os Guarani eram culturalmente prescritivos, o que teria levado não só à conquista de territórios pertencentes a outras populações com a expansão e a consolidação na região, mas também à incorporação dos membros dos grupos encontrados pelo caminho no ethos cultural. A evocação do ñande reko, uma expressão que significa algo como "o bom ou o verdadeiro modo de ser e de viver", sendo proferido sempre em situações de crise e em alusão nostálgica à cultura tradicional, pode ser entendida como uma manifestação do vigor das forças prescritivas subjacentes à manutenção do ethos cultural Guarani (Schaden 1974). Ainda hoje presente nas vozes resignadas e reivindicativas dos Guarani confinados em reservas, o ñande reko foi evocado freqüentemente nas insurreições contra o julgo dos colonizadores europeus nos séc. XVI e XVII, sobretudo pelos xamãs, que exortavam os índios aldeados e reduzidos a se rebelarem contra os cristãos e a voltar a viver como os seus antepassados (Monteiro, 1992). Diante da padronização e da peculiaridade dos 2 
mil anos da cultura material Guarani, não há razões para não compreende-la enquanto outra destas manifestações.

Apesar da validade das críticas sobre o uso indiscriminado das diversas formas de analogias entre os contextos culturais dos Guarani seiscentistas e setecentistas, de um lado, e os contextos etnográficos pré-coloniais correlatos nos contextos arqueológicos, de outro (Soares 1999, 2001-2002), a utilização dos dados contidos nas fontes históricas e etnográficas escritas naquele período são fundamentais ao estudo da trajetória histórica da ocupação Guarani, seja onde e quando for. Como demonstrado por muitos arqueólogos, as fontes históricas e etnográficas estão recheadas de dados ainda não completamente exauridos sobre organização e relação social, religião e mitologia, assentamento e subsistência, cultura material e tecnologia (Brochado 1984, La Salvia \& Brochado 1989, Meliá, Saul \& Muraro 1987, Monteiro 1994, 1992, Noelli 1993, Schaden 1974, Scatamachia 1990, Soares 1997).

Com base nesses dados, por exemplo, é sabido que os Guarani, ao menos nas vésperas da conquista, eram constituídos por milhares de pessoas, associadas umas às outras através de inúmeras parcialidades étnicas distintas, as quais muitas vezes se autoidentificavam etnicamente pelos nomes dos caciques ou chefes das famílias extensas, chamados tuvitxá. As parcialidades também podiam se auto-designar pelos topônimos das aldeias e dos territórios ocupados, respectivamente designados tekó e tekohá, ou ainda por designações que expressam alteridade em relação aos outros, como, por exemplo, avá-eté, que quer dizer gente de verdade.

A família extensa, por sua vez, era a unidade básica da morfologia social Guarani, sendo constituída, além do chefe, pela esposa ou esposas do chefe, pelos seus filhos solteiros, filhas casadas, genros, esposas dos genros, filhas solteiras e netos. Cada família extensa ocupava uma casa grande, chamada oga-guaçu, sendo que os tekó podiam ser constituídos por várias destas, as quais podiam estar dispostas em um plano aparentemente regular, defronte umas das outras, em torno de uma espécie de praça central, por vezes cercadas por paliçadas, ou não. Os chefes também podiam deter a função de xamãs, pajés ou médicos-feiticeiros, denominados ñanderú, paí ou karaí. Estes últimos, se bem que poderiam figurar como chefes, perambulavam de aldeia em aldeia profetizando, curando e amaldiçoando, sendo amados, temidos, odiados e, não raro, mortos, sob acusação de feitiçaria. As comunidades também hospedavam cativos de guerra, destinados à execução nas praças das aldeias durante os rituais antropofágicos. Aos xamãs, chefes ou não, cabia a interlocução com o sobrenatural, 
efetuada através de curas, cantos, sonhos e rituais religiosos; a orientação dos membros da comunidade nos estados de crise, como na couvade, nos ritos de passagem e na morte; e a guarda dos conhecimentos mitológicos, cosmológicos, filosóficos e etnohistóricos. A crença em um paraíso terreal, denominado yvy mará ey, e na pluralidade da alma, constituída pelo ayvú, a parte divina, e o atsýygua, a parte terrena ou animal, são alguns dos aspectos mais conhecidos da religiosidade Guarani.

As parcialidades podiam ser constituídas por vários tekó e tekohá, ao eu turno unidos por laços de consangüinidade, afinidade e reciprocidade, isto sem falar das redes de vias fluviais e caminhos terrestres, sendo os últimos chamados peabirú. A união entre vários tekohá, muitas vezes incentivada pela poligamia e, conseqüentemente, pela relação sogro-genro, resultava na formação dos guará. Contudo, os tekohá, formados por um ou mais tekó, eram entidades territoriais relativamente autônomas e independentes umas das outras, ao menos em termos territoriais, políticos e econômicos. A própria autoridade dos chefes, fundamentada mais no prestígio social do guerreiro antropófago, na capacidade oratória e persuasiva, na qualidade de beberrão, na quantidade de esposas, filhas e genros e no poder sobrenatural do paí ou do karaí, não implicava em quaisquer privilégios que os diferenciassem socialmente, sendo regulada e até contestada pelos conselhos integrados pelos outros membros influentes e prestigiosos da comunidade, como os chefes das outras famílias extensas, os xamãs e os outros guerreiros.

A autoridade dos chefes se fazia mais presente nas questões envolvendo a comunidade como um todo, como na organização dos trabalhos coletivos, chamados putxiran, e nas relações com outras comunidades, fossem estas pacíficas ou não. Muitas vezes, tendo em vista a realização de tarefas como derrubadas, queimadas, construções de facilidades, organização de rituais e beberagens, fortificações e mudanças de aldeia, os putxiran requeriam grande número de pessoas, as quais apenas podiam ser mobilizadas por chefes que detivessem muito prestígio, capazes de oferecer festas regadas à comida e bebida durante a realização dos trabalhos. As relações com outras comunidades, fossem estas Guarani ou não, podiam ser pacíficas, como no caso dos tekohá unidos, ou violentas, como no caso das guerras intestinas motivadas por vinganças e pela captura de cativos.

Se aos homens cabiam os papéis de chefes, xamãs, guerreiros e cativos, às mulheres recaíam grande parte das atividades de subsistência, como o cultivo dos roçados e a confecção dos utensílios cerâmicos. Como demonstrado pelo estudo 
etnoarqueológico sobre assentamento e subsistência desenvolvido por Noelli (2003), os dados contidos nas fontes históricas e etnográficas indicam que os Guarani eram consideravelmente autônomos em relação ao meio e não apresentavam restrições alimentares. A dieta era garantida pelas centenas de espécimes vegetais cultivadas e/ou manejadas por todo o tekohá, tanto trazidas da região amazônica quanto incorporadas nas áreas colonizadas, e complementada por atividades de caça, pesca e coleta, inclusive de insetos. As áreas de cultivo e de manejo, constituídas por plantas alimentícias, medicinais e utilizadas enquanto matérias-prima na confecção de artefatos diversos, estavam dispostas tanto no entorno imediato dos tekó, quanto ao longo dos caminhos abertos pela floresta. A caça e a pesca eram realizadas através do uso de diversas armadilhas, muitas delas um tanto quanto engenhosas, sendo que na pesca também eram utilizados ictiotóxicos.

Os Guarani consolidados no rio Miranda entre os séculos XVI e XVII foram etnicamente descritos como Garambaré, Ñuara, Cutaguá e Temiminós (Gadelha 1980, Monteiro 1994). Acerca desses índios, chamados Itatim em termos gerais, o Pe. Ferrer, em sua famosa carta ânua de 1633, escreveu o seguinte (apud Cortesão 1952: 30-1):

“(...) estos Itatines son de buen natural, y no difieren de los demas guaranis, sino que tienen mas trato y policia de quantos Guaranis avemos visto hasta agora, y tambien en la lengua tienen alguma diferencia de los demas Guaranis aunque poca acercandose algo al languaje Tupi, de suerte que algunos dizen que non son verdaderos Guaranis ni Tupis tampoco, sino que es una nacion entremedia entre los Guaranis y Tupis que llaman Temiminos. (...) Todos estos Itatines reconocem a un cacique que se llama Nanduabuçu como a principal de todos los Indios Guaranis que ay desde la ciudad de la Assumpcion para aca son todos sus vasallos, y aun los Indios que estan adelante de la dicha ciudad que corren cerca de ciento y cinquenta léguas. Todos viven en pueblos grandes o chicos, pero por la maior parte los pueblos son cerca de cien familias, y algunos ay de docientas y aun mas, lo que facilita mucho el reduzirles. (...)”

Depois do esgotamento da mão de obra Guarani em torno de Assunção, ainda na segunda metade do séc. XVI, parcialidades dos Itatim foram aldeadas e encomendadas pelos espanhóis nos rio Ypané e Jejuý (Gadelha 1980). Os espanhóis tentaram assegurar a posse de toda a região onde atualmente se encontra o Mato Grosso do Sul com a fundação da cidade de Santiago de Xerez, erigida inicialmente nas proximidades da confluência do Ivinhema com o Paraná, em 1.593, e transladada para a margem direita do médio Aquidauana, em 1.600 (Martins 2002a). Com o acirramento do 
bandeirantismo, no início dos seiscentos, e com a destruição do Guairá, em 1628, jesuítas e bandeirantes se voltam para o Itatim, com vistas nas últimas reservas de Guarani da região.

A despeito das experiências prévias com os Itatim aldeados anteriormente, os jesuítas começaram a catequese no Itatim em 1632, com a redução de índios Ñuara, que ocupavam o rio Miranda, na missão de San Jose de Yacaroy (Gadelha 1980, Sousa 2002). Todavia, logo depois, com o apoio dos colonos de Xerez, uma bandeira comandada por Ascenso Quadros assaltou várias aldeias na região, causando uma série de transtornos. Mesmo assim, a obra missioneira continuou e, depois de muitos reveses, logrou algum progresso, até que, em 1647, Antônio Raposo Tavares, acompanhado por André Fernandes, desestabilizou as Missões do Itatim de uma vez por todas.

Os Itatim não levados para São Paulo na condição de escravos dos portugueses acompanharam os jesuítas para Assunção e, mais tarde, para a mesopotâmia argentina (Monteiro 1994: 239). Outros ainda se refugiaram nas matas sub-montanas da serra de Maracajú, de onde assistiram a expansão dos Mbayá-Guaikurú e dos Guaná sobre os seus antigos territórios. Ainda hoje os Guarani são as populações indígenas mais numerosa em Mato Grosso do Sul, onde as parcialidades Ñandeva e Kaiowá somam quase 30 mil pessoas, dispersas em reservas indígenas localizadas na região sul do estado, principalmente na fronteira com a Paraguai (Instituto Sócio-Ambiental 20012005).

Assim como os Tupi, os Aruak, também chamados Maipure, eram populações agricultoras, viviam em grandes aldeias, estavam distribuídas em várias parcialidades étnicas, ocupavam territórios dispersos por uma área bastante ampla e se originaram na Amazônia, porém no mais se diferenciavam daqueles em quase todos os aspectos. Em termos gerais, a maior parte das populações Aruak, consolidadas em territórios formados na costa da Flórida, nas ilhas caribenhas, nas floretas da Amazônia e nas terras baixas do Pantanal e do Chaco, viviam em aldeias circulares, divididas em metades, dispostas em torno de uma praça central, apresentavam estratificação social complexa e um grau de sedentarismo elevado. O próprio termo Cacique, diga-se de passagem, aplicado aos chefes indígenas em geral, deriva da palavra Cacib, denominação dada ao chefe dos Taino, populações Aruak encontradas por Colombo na ilha de Santo Domingo, em 1492 (Fausto 2000). Além destes traços, as populações de matriz cultural Aruak também apresentam semelhanças tecnológicas entre si, inclusive 
em se tratando da cerâmica (Heckenberguer 2001, 2002, 2005, Neves 2000, Rouse 1992).

As questões sobre o centro de origem e as rotas de expansão Aruak são tão nebulosas quanto aquelas relativas aos Tupi, porém há certa inclinação da maior parte dos arqueólogos e lingüistas em atribuir a região entre o alto rio Negro e o alto rio Orinoco, na fronteira entre Venezuela e Brasil, como provável área de dispersão destas populações (Heckenberger 2005, Urban 1992). De acordo com Heckenberger (2002: 106), os Aruak teriam partido da área de origem para centros de dispersão secundários, tais como a Amazônia central e o alto Madeira, de onde teriam se espalhado, através de diversas rotas de expansão, para os locais onde foram encontrados pelos conquistadores europeus. Acerca da origem e das rotas de expansão das populações Aruak ao sul da Amazônia, o mesmo arqueólogo citado acima destacou, em um trabalho anterior (Heckenberger, 2001: 30-31), o seguinte:

"Embora também não me proponha aqui desenvolver uma discussão geral sobre a origem ou antigüidade das línguas Maipure no sul da Amazônia (bauré, mojo, piro, chané, terena [guana], pareci, e as do Alto Xingú), gostaria de destacar que é provável que todas - ou a maioria - possam ser remetidas a uma antiga migração, ou série de migrações, para a região do Alto Madeira, de onde posteriormente se expandiram para oeste (Acre e Perú), para sul (terras baixas da Bolívia) e para leste (Periferia Meridional). Os terena (guana) e os chané limitam as extensões desse processo ao sul, enquanto os pareci e os alto-xinguano limitam-nas a leste. (...)"

Os contextos arqueológicos associados à indústria cerâmica BarrancóideSaladóide detectados na Amazônia, datada em até 3 mil AP, não raro circundados por valas de caráter defensivo escavadas em torno de sítios com grandes dimensões, foram associadas com populações Aruak (Heckenberger 2005, Neves 1999a, 1999b, 2000, 2006). No alto Xingú, enquanto as primeiras ocupações Aruak datam em 1 mil AP, a construção das fortificações foram datadas entre de 600 e 400 AP, mesmo período da chegada das populações de matriz cultural Karib na área (Heckenberger 2001).

No Pantanal e no Chaco, as populações de matriz cultural Aruak foram encontradas pelos europeus na região do alto Paraguai, na área fronteiriça entre o Mato Grosso e a Bolívia, e no arco setentrional do Chaco, nas terras baixas ao longo da fronteiras entre Paraguai, Bolívia e Brasil (Metraux, 1946). No alto Paraguai, os Aruak eram constituídos pelos Orejones, Xaray e alguns grupos Chiquitanos, tais como os 
Saraveka, Koraveka e Kuruminaca. Ainda foram encontrados grupos Chané no alto Paraguai ao tempo dos primeiros contatos com os conquistadores, porém estes haviam fugido dos Chiriguano, povos Guarani consolidados nos sopés andinos que costumavam tomá-los como cativos.

$\mathrm{Na}$ região de Cáceres/MT, as populações Aruak do alto Paraguai foram associadas à Tradição Descalvados, por sua vez caracterizada por sítios de grandes dimensões, constituídos por muitos fragmentos de vasilhas cerâmicas, líticos lascados e polidos, montículos artificiais e sepultamentos humanos, datados entre 1.500 e 300 AP (Martins \& Kashimoto 2000, Migliacio 2000, 2001-2002, 2006). As vasilhas cerâmicas apresentam formas não restringidas, restringidas e restringidas independentes, contornos simples, infletidos, compostos e complexos, formas esféricas, semi-esféricas, ovais verticais, semi-ovais verticais e semi-elípticas horizontais, tais como pratos, alguns muito rasos, tigelas, panelas, jarros e silos, adequadas ao consumo, processamento e armazenagem de alimentos. Algumas vasilhas restringidas independentes com formas ovais e contornos inflectidos, compostos e complexos, impressionam pelas dimensões avantajadas, com capacidades volumétricas superiores a 160 litros. Destacam-se também a ocorrência de pinturas geometrizadas sobre engobo vermelho, constituídas por linhas, faixas, pontos, cruzes e triângulos combinados, e a presença de alças e apêndices de suspensão. Entre os antiplásticos aprecem cacos de cerâmica e conchas trituradas. Também são achados outros artefatos cerâmicos nos contextos Descalvados, entre os quais se destacam estatuetas antropomórficas e zoomórficas.

Nas terras baixas do arco setentrional do Chaco, na região fronteiriça entre Bolívia, Paraguai e Brasil, havia duas grandes populações de matriz cultural Aruak no séc. XVI, falantes de línguas Chané, de família lingüística Chané-Guaná: os Chané propriamente, que ocupavam o segmento oriental da área, e os Guaná, que estavam estabelecidos no segmento ocidental (Metraux 1946). Os Guaná, assim como os Chané, se auto-denominavam etnicamente como Chané, que significa "gente", e estavam constituídos por várias parcialidades distintas (Schuch 1995). Algumas dentre estas, sobretudo os Kinikinao e Laiana, eram aliadas dos Mbayá e migraram com estes para o Pantanal, nos séc. XVI e XVII, assentando-se inicialmente na região de Corumbá e, posteriormente, na região de Miranda. Outras, como os Terena, não eram aliadas dos Mbayá, mas, assim como estes e muitas das populações Aruak do arco ocidental do Chaco, se estabeleceram no que hoje é o Mato Grosso do Sul na época colonial, depois que o antigo Itatim foi abandonado pelos Guarani e espanhóis. 
De acordo com os estudos de Cardoso de Oliveira (1968: 17-35, 1976: 41-53), ao tempo dos primeiros contatos com os europeus, ocorridos no séc. XVIII, a cultura tradicional dos Terena, também referidos como Etelena ou Etelenoé, era caracterizada pela presença de aldeias circulares, divididas em metades e estratificadas socialmente entre classes endogâmicas. Indivíduos que adquirissem prestígio, sobretudo por meio da guerra, podiam ascender às classes superiores, deixando de ser caracterizado como whaherê e caati, ou seja, "gente comum" e "cativo", e passando a ser reconhecido como xuna-xati. Os caati, geralmente originários de outras parcialidades étnicas, nunca poderiam ascender à classe dos naati, a mais privilegiada, mas apenas à dos whaherê, o segmento intermediário. Os whaherê, por sua vez, poderiam vir a ser reconhecidos como naati. Os xamãs, também designados pelo termo purungueiro, eram chamados koixomuneti. Ainda hoje existe uma localidade bastante povoada na TI Cachoeirinha, ou Bookoti, uma das mais tradicionais dos Terena, chamada Argola, em alusão àquela que pode ser considerada como uma das últimas aldeias circulares dos Guaná em Miranda.

Entre fins dos setecentos e inícios dos oitocentos, a região de Miranda era ocupada por populações Guaikurú, como os Beuatebo, e Guaná, sobretudo Laiana e Terena. Talvez estas tenham sido as primeiras populações a se estabelecer na região depois do abandono Guarani, a qual deixou de ser referenciada como Itatim e passou e ser denomina de Lauiad, que em Mbayá quer dizer "campo belo" (Taunay 1997: 48). Até mesmo o rio Miranda, então referido como Mbotetey ou Cayy, passou a ser chamado de Mondego (Martins 2002a).

Os Mbayá e Guaná pelejaram contra espanhóis e portugueses pelo domínio territorial da região durante todo o séc. XVIII e grande parte do XIX (Costa 1999). Vencida a resistência indígena, os portugueses, consolidados nas áreas auríferas e diamantíferas de Cuiabá e Mato Grosso, se estabeleceram definitivamente nas regiões de Corumbá e Miranda na segunda metade do séc. XVIII, com a fundação do Forte Coimbra e do Presídio de Miranda (Esselin 2000). Esta última fortificação, construída de taipa e guarnecida com algumas poucas dezenas de soldados, foi destruída quando os paraguaios invadiram o então sul de Mato Grosso e deflagraram a Guerra. Suas ruínas são uma incógnita à Arqueologia Regional, haja vista que elas ainda não foram detectadas.

A princípio, a relação entre os índios e as praças que formavam o contingente do Presídio era amistosa, porém na medida em que a colonização avançou, sobretudo com a primeira frente de expansão agro-pastoril vinda de Minas Gerais, os brasileiros 
começaram a explorar o trabalho dos índios nas fazendas recém formadas (Azanha 2004, Cardoso de Oliveira 1968, 1976, 2002). O processo de fragmentação territorial e cultural aí iniciado se exacerbou depois da Guerra do Paraguai, com o loteamento dos territórios e a exploração compulsiva da mão-de-obra indígena. Posteriormente, no início do séc. XX, os remanescentes étnicos em Miranda, formados principalmente por índios Terena, foram libertos do cativeiro nas colônias de fazenda e confinados em reservas indígenas, onde começaram a ser tutelados pelo SPI.

Os contextos arqueológicos formados com a ocupação dos Aruak em Mato Grosso do Sul ainda não são conhecidos, todavia é possível que eles se confundam com os materiais inseridos na Tradição Pantanal, principalmente em se tratando das fases mais recentes, haja vista que muitas destas populações eram aliadas dos MbayáGuaikurú desde os tempos do Chaco. Por outro lado, tendo em vista as descobertas realizadas com as pesquisas nos contextos arqueológicos da Tradição Descalvados, no alto Paraguai, nada impede que populações de matriz cultural Aruak, aparentadas culturalmente dos Guaná ou não, tenham se estabelecido nas regiões de Corumbá e Miranda em período pré-colonial.

Os Terena ainda continuam confeccionando cerâmica em muitas das suas aldeias, porém apenas eventualmente em Lalima, onde eles dizem que "o barro não é bom". Assim como no que se refere aos Kadiwéu, a tecnologia cerâmica Terena, reproduzida socialmente nos moldes atuais ao menos desde o fim da Guerra do Paraguai, também não foi alvo de pesquisas etnoarqueológicas sistemáticas, porém Cardoso de Oliveira (2002: 237) oferece uma descrição sintética do fluxo de produção das vasilhas. Vale frisar que a tinta branca utilizada sobre engobo vermelho na decoração das faces e dos lábios no vasilhame Terena, obtida através da decantação de certo tipo específico de argila, por vezes apresenta-se com uma densidade tão alta que até chega à lembrar os apliques de filigranas que decoram as faces externas e os lábios das vasilhas da Tradição Pantanal, sobretudo em se tratando da Fase Jacadigo. O pupuí, uma vasilha restringida, com alça de suspensão, utilizada para armazenar e servir líquidos, ao lado das estatuetas zoomórficas inspiradas na fauna do Pantanal, vendidos às centenas entre os turistas que visitam a região, são os objetos cerâmicos mais conhecidos dos Terena.

Na região de Corumbá, foram detectados os sítios históricos oitocentistas das missões de Nossa Senhora do Bom Conselho e Nossa Senhora da Misericórdia, fundadas por padres salesianos junto aos índios Kinikinao, assentados na área em 
conjunto com os Guaikurú desde o séc. XVII (Schmitz et al:: 1998). Com a Guerra do Paraguai e os tumultos causados no sul do Mato Grosso, os Kinikinao se dispersaram em direção à região de Miranda, onde se assentaram nas margens do cór. Agaxi (Cardoso de Oliveira 1976: 64, Moreira Neto 2005). Posteriormente, em 1925, estes Kinikinao foram levados para Lalima pelo SPI, onde passaram a conviver com os Guaikurú, já estabelecidos na área, e com os Terena e Laiana, igualmente recém chegados.

De acordo com Nimuendajú (2002), aldeias Guaikurú foram registradas no rio Miranda por Antônio Pires de Campos e Francisco Rodrigues do Prado, respectivamente no início e no fim do séc. XVIII. Antes da Guerra do Paraguai, segundo informações etnográficas coletadas por Cardoso de Oliveira (1976: 70) - que esteve em Lalima uma década depois de Ribeiro (cf. 1980) e também manteve interlocução com a $\mathrm{Sr}^{\mathrm{a}}$. Maria Vicenza, última nidjienigi Guaikurú e tia-avó do nosso principal interlocutor - os Terena se referiam à Aldeia como território Guaikurú, denominando-a Sinikué. Em outro trecho da obra citada, situado entre as páginas 75 e 76 , tendo como base os registros mais antigos do SPI, o referido antropólogo sublinhou que o território de Lalima foi concedido aos Guaikurú pela monarquia. Taunay (2000) também aponta que o Miranda era ocupado por índios Guaikurú desde o séc. XIX. Já Azanha (2000), apoiado nos documentos das titulações de imóveis da região de Miranda, colheu a denominação de “...' 'aldeamento Guaicurú’ ou 'Colônia Guaicurú' (sic) $"$.

Ao que os Guaikurú nos disseram enquanto realizávamos a pesquisa arqueológica, o termo Lalima é uma corruptela da palavra lalímaga, que significa "terra do sol poente". Seja como for, a despeito da origem Guaikurú, a formação do contexto etnográfico atual, constituído por índios Terena descendentes de Guaikurú, Terena, Kinikinao e Laiana, está relacionada com a passagem do Marechal Rondon e com a atuação do SPI, no início do séc. XX. 


\section{Parte II - Correlatos materiais da trajetória histórica da ocupação indígena regional na Aldeia Lalima}

\section{Capítulo 4 - Aspectos metodológicos}

Os materiais arqueológicos foram obtidos através dos seguintes procedimentos técnico-metodológicos: a) levantamento extensivo, oportunístico e assistemático de superfície; b) coletas assistemáticas e sistemáticas em superfície; c) coletas sistemáticas em sub-superfície (Araújo 2001, Joukowsky 1980, Kashimoto 1997, Orton 2000, Plog et al. 1978, Redman 1970, Redman \& Watson 1970).

O levantamento de superfície foi desenvolvido com o objetivo de localizar, registrar e plotar sítios arqueológicos correlatos da trajetória histórica da ocupação indígena regional na TI Lalima. A localização dos sítios foi realizada através da vistoria assistemática, oportunística e extensiva, com base nos dados bibliográficos sobre o contexto de implantação dos sítios nas regiões do entorno, nas variáveis ambientais favoráveis ao assentamento indígena na Aldeia Lalima, nas informações orais dos índios e na visibilidade do solo.

No entorno do médio Miranda e da Aldeia Lalima, situados no centro-oeste de Mato Grosso do Sul, são conhecidos, principalmente, os contextos de implantação de sítios arqueológicos e os prováveis horizontes culturais nas seguintes áreas: a) os aterros e afloramentos com gravuras rupestres atribuídos às populações ceramistas da Tradição Pantanal em torno das lagoas do Castelo e Vermelha, na planície de inundação do rio Paraguai, no nordeste do Estado (Peixoto 2003); b) os aterros na planície inundável dos pantanais do Abobral e do Miranda-Aquidauana, ocupado por pescadores-caçadorescoletores e por populações da Tradição Pantanal, e os sítios implantados nos lajedos e nos patamares baixos e altos das morrarias residuais do Planalto do Urucum, ocupado tanto pelas populações supracitadas quanto pelos Guarani, no oeste do MS (Schmitz, 1998); c) os sítios da Tradição Pantanal implantados em aterros e diques fluviais no Pantanal do Nabileque, região de fronteira com o Paraguai sob forte influência ambiental chaquenha, no oeste-sudoeste do Estado (Eremites de Oliveira, 2004); d) os abrigos sob rocha e os sítios à céu aberto nas escarpas e nos topos e vertentes das colinas e terraços próximos aos cursos fluviais perenes no Planalto Maracajú-Campo Grande, ocupado por caçadores-coletores, pelos Guarani e talvez por outros povos 
ceramistas, localizados no centro e sudoeste do Estado (Martins 2003, Martins \& Kashimoto 1999); e) os abrigos sob rocha e os sítios a céu aberto nas escarpas e nas colinas e encostas próximas aos cursos d'água perenes e sazonais na Serra de Aquidauana, ocupados por populações caçadoras-coletoras e ceramistas, no centro-oeste do MS (Martins 2002b, Póvoa 2007); f) o sítio histórico da cidade espanhola de Santiago de Xerez, abandonada pelos colonos em 1632, localizado na margem direita do médio-baixo curso do rio Aquidauana, no centro-oeste do Estado (Martins 2002a); e f) os abrigos sob rocha nos patamares e escarpas da borda ocidental da bacia sedimentar do Paraná, no centro-norte de Mato Grosso do Sul, na área do município de Rio Negro, talvez ocupados tanto por grupos de caçadores-coletores quanto por povos agricultoresceramistas (Martins 1998).

Além das potencialidades sugeridas pela bibliografia, a localização dos sítios arqueológicos foi realizada tendo em vista as variáveis ambientais favoráveis ao assentamento indígena observadas na TI Lalima (cf. Kashimoto, 1997), as quais, por sua vez, foram elencadas de acordo com os dados geográficos sobre a região (SEPLAN, 1990; RADAMBRASIL (Brasil, 1982a); Ab’Sáber; 2006) e com o contexto de implantação do sítio Córrego Lalima. Assim, enquanto os dados geográficos apresentam uma região piemontana estrategicamente localizada entre o Pantanal, ao norte, a Serra da Bodoquena, ao oeste, e a Serra de Maracajú-Campo Grande/Aquidauana, ao leste, dotada de várias formas de relevos, nascentes fluviais, solos relativamente férteis, abundância florística e faunística, afloramentos de quartzo e depósitos de argila, o sítio Guarani indicou que outros assentamentos, talvez atribuídos a outros contextos arqueológicos, poderiam ser encontrados nos topos e nas encostas suaves das colinas contornadas por nascentes fluviais e calhas flúvio-pluviais existentes na Aldeia.

No mais, tendo em vista que até a pouco tempo atrás existia um travessão amplamente utilizado na travessia das margens do rio Miranda em Lalima, é bem capaz que o vale do alto e médio Miranda, dada a sua localização central entre o Pantanal e as Serras da Bodoquena e Maracajú, tenha servido como área de passagem nos deslocamentos das populações indígenas até as regiões além dos limites dos ditos compartimentos geomorfológicos. Neste sentido, é importante referenciar que, historicamente, o rio Miranda foi usado como rota de passagem não só pelos Guaikurú e os Guaná, mas, também, pelos mamelucos luso-paulistas em suas entradas e bandeiras no sertão (Abreu 2000, Bastos 1972, Holanda 1990), e que o rio Miranda, em seu curso sul-norte, constitui a via de acesso mais favorável à penetração nas florestas e terras 
férteis do sudeste do continente sul-americano, outrora dominada pelos Guarani, tendo em vista deslocamentos populacionais da Amazônia, através do interflúvio GuaporéParaguai, pelo rio Paraguai, em sentido norte-sul (Brochado 1984, Noelli 1996).

A coleta de informações etnográficas sobre a localização dos sítios foi realizada de modo formal e informal. Formalmente, tais dados foram coletados através da gravação de entrevistas pautadas nas elaborações êmicas sobre a trajetória histórica dos índios em Lalima, preferencialmente realizadas com os anciões da Aldeia. Informalmente, tais dados foram obtidos através das conversas travadas com os índios durante a realização das atividades de campo, sendo que, neste sentido, fomos privilegiados, Manoel de Souza Neto, nosso principal interlocutor, mostrou-se um profundo conhecedor das histórias contadas pelos seus avôs, tio-avôs, pais, tios e pessoas mais velhas, presenteando-nos, a todo o momento, com informações orais e com os sítios onde as histórias contidas nestas informações teriam se passado. $\mathrm{Na}$ medida em que iniciamos as atividades de levantamento e nos tornamos conhecidos na Aldeia, as pessoas também passaram a nos procurar para nos informar sobre a localização de "cacos de pote" e "pedras de raio", sendo que, posteriormente, enquanto realizávamos as atividades de coleta, tais atitudes tornaram-se corriqueiras, porém desta feita não apenas com informações sobre a localização de sítios, mas também com as mãos cheias de materiais arqueológicos. Nestas conversas, ao mesmo tempo em que se percebeu que os fragmentos cerâmicos em geral eram atribuídos aos ancestrais, já que "os antigos só tinham panelas e potes de barro", foi notado que os Terena de Lalima denominam os sítios, conectados ou não à sua Etno-história, pelo termo tapera, de origem Tupi-Guarani, que significa "aldeia antiga ou abandonada".

Além dos fatores considerados acima, ou seja, a potencialidade arqueológica regional, as variáveis ambientais favoráveis ao assentamento indígena e as informações orais sobre a localização de sítios, também foi levada em conta a visibilidade do solo. Assim, as vistorias foram executadas preferencialmente em áreas com solos expostos, como nas estradas e ruas da Aldeia, nos acessos, pomares e quintais dos domicílios dos índios, campos de futebol, atalhos, roças, aceros, sedimentos escavados na construção de cercas, moradias, lixeiras e mictórios, bem como nas voçorocas, erosões e ravinas. Afortunadamente, foram detectados sítios e ocorrências arqueológicas em quase todos os locais procurados, sendo os sítios os locais com concentrações de materiais consideráveis em termos quantitativos e qualitativos, e as ocorrências as áreas com densidade mínima de materiais. 
O registro dos sítios foi efetuado em fichas de cadastro concebidas a partir do Cadastro Nacional de Sítios Arqueológicos (CNSA/IPHAN), e a plotagem foi realizada em uma base cartográfica da TI Lalima conseguida junto à Diretoria de Assuntos Fundiários da FUNAI (DAF/FUNAI) (Mapa 3).

Uma vez que as expectativas do levantamento foram superadas, com a detecção de mais de uma dezena de sítios em apenas uma semana, com materiais da Tradição Pantanal, Guarani e etnográficos, foram selecionados alguns dentre os sítios detectados com o intuito de desenvolver as atividades de coleta. Considerando o principal objetivo da pesquisa, ou seja, estudar a dinâmica histórica da ocupação indígena no rio Miranda, os sítios foram selecionados tendo em vista os diferentes contextos culturais pretéritos correlatos nos contextos arqueológicos detectados em Lalima.

Os contextos arqueológicos, por sua vez, foram definidos principalmente a partir dos atributos diagnósticos contidos nos fragmentos das vasilhas cerâmicas e das informações etnográficas. Os dados etnográficos, formais e informais, foram utilizados na definição dos contextos arqueológicos associados às elaborações e representações etno-históricas dos índios inseridos no contexto etnográfico atual da ocupação indígena em Lalima, o qual foi formado, a despeito da origem Guaikurú, no ínterim da atuação do Marechal Rondon e do antigo SPI. Os sítios constituídos por materiais etnográfícos estritamente conectados aos dados etno-históricos obtidos no âmbito do contexto cultural da ocupação indígena atual, foram classificados como sítios Etno-históricos.

Os contextos arqueológicos mais antigos foram definidos, inicialmente, através de observações apoiadas nas descrições dos materiais cerâmicos Guarani e da Tradição Pantanal presentes na bibliografia, realizadas ainda em campo (cf. Brochado \& La Salvia 1989, Eremites de Oliveira 2004: 45-48, Noelli 1999-2000: 247-59, Peixoto \& Bezerra 2004, Schmitz et al. 1998). Posteriormente, em laboratório, as observações de campo foram complementadas com análises preliminares em amostras de materiais cerâmicos, realizadas com a quantificação dos atributos dos fragmentos considerados diagnósticos em se tratando da forma e do acabamento de superfície das vasilhas.

As atividades de coleta foram efetuadas com o intuito de obter coleções dos materiais arqueológicos e de aferir a forma, a extensão, a profundidade, a espessura, o tipo e o estado de conservação do sítio. Em superfície, as coletas assistemáticas foram realizadas simplesmente com o recolhimento dos materiais detectados em áreas previamente setorizadas, ao passo que as coletas sistemáticas foram desenvolvidas com a utilização de uma Estação Total, em conjunto com as atividades de topografia, tendo 
em vista a plotagem das peças coletadas em plantas planialtimétricas. A topografia foi realizada apenas nos sítios selecionados onde foram efetuadas atividades sistemáticas de coleta em superfície e sub-superfície.

As coletas sistemáticas de sub-superfície, por sua vez, foram efetuadas através da escavação de alinhamentos de furos de sondagem e poços-testes situados nos grids das áreas setorizadas estabelecidos com a topografia dos sítios, em níveis artificiais de $10 \mathrm{~cm}$, com peneiramento dos sedimentos escavados e preenchimento de tabelas e fichas com descrições, observações e resultados das escavações, na busca de contextos arqueológicos em bom estado de conservação e obtenção de materiais para a realização de datações arqueológicas por intermédio do método do $\mathrm{C}^{14}$. Assim, os alinhamentos de sondagem, escavados com trados articulados (cavadeira do tipo boca de lobo), cerca de $30 \mathrm{~cm}$ de diâmetro, ao menos $50 \mathrm{~cm}$ de profundidade e distantes no máximo $20 \mathrm{~m}$ um do outro, foram executados com o objetivo de descobrir áreas com materiais arqueológicos mais preservados em sub-superfície. Já os poços-teste, comumente chamados de "cabine telefônica”, com exatamente $1 \mathrm{~m}^{2}$, escavados com colheres de arqueólogo, espátulas, pincéis e pás plásticas, foram empreendidos tendo em vista a coleta tri-dimensional dos contextos sugeridos pelas sondagens.

As amostradas de materiais utilizados para a obtenção de datações arqueológicas foram enviadas ao laboratório norte-americano Beta Analytic Inc.

A análise da forma das vasilhas foi desenvolvida com base na classificação geométrica proposta por Shepard (1956), porém também foram consultados os manuais escritos por Orton, Tyers \& Vince (1993), Rice (1987) e Rye (1981). Em se tratando da análise da forma dos materiais Guarani, também foram utilizadas as classes funcionais e as regras de reconstituição gráfica estabelecidas por Brochado e associados (cf. Brochado \& Monticelli 1994, Brochado, Monticelli \& Neumann 1990, Noelli \& Brochado 1998, La Salvia \& Brochado 1989).

Assim, de acordo com Shepard (1956: 224-55), o vasilhame cerâmico apresenta, em geral, três classes simétricas distintas de vasilhas: 1) não restringidas ou abertas, caracterizadas por vasilhas que apresentam diâmetro da boca igual ou maior que o diâmetro do bojo, como pratos e tigelas, por exemplo; 2) restringidas ou fechadas, constituídas por vasilhas com diâmetro da boca menor que o diâmetro do bojo, tais como certas tigelas, panelas e jarras; e 3) restringidas independentes ou fechadas com pescoço, formadas por vasilhas que possuem prolongamentos ou pescoços acima da 
constrição do segmento superior, geralmente maiores que $1 / 4$ da altura total da vasilha, como certos jarros e moringas.

As diferentes classes de vasilhas, sempre segundo Shepard (op. cit.), podem apresentar contornos simples, inflectidos, compostos ou complexos, por sua vez identificados através de pontos característicos contidos na direção da curvatura das paredes, bases e bordas. Destarte, as vasilhas com contornos simples possuem apenas pontos finais, situados na base a na borda, ou então pontos de tangência vertical, localizados na base, na borda ou no maior diâmetro do bojo. Os contornos inflectidos apresentam pontos de inflexão, ou seja, mudança da direção da curvatura da parede da vasilha, a qual passa da convexidade, geralmente presente no segmento inferior, à concavidade, presente no segmento superior e no pescoço. Os contornos compostos são caracterizados pela presença de pontos angulares salientes ou reentrantes, tais como carenas e ombros. Já as vasilhas com contornos complexos são caracterizadas pela associação de vários destes pontos característicos.

Uma vez identificados a classe e o contorno das vasilhas, a forma deve ser definida em comparação com figuras geométricas esféricas, elípticas, ovais, cilíndricas, hiperbólicas e cônicas. As figuras geométricas ainda devem ser subdivididas em semiesféricas, elípticas e semi-elípticas verticais e horizontais, e ovais e semi-ovais verticais e invertidas, as quais podem estar combinadas com segmentos cilíndricos, hiperbólicos e cônicos, sobretudo nas vasilhas restringidas e restringidas independentes com contornos compostos e complexos.

Assim, tendo em vista a análise da forma das vasilhas a partir dos fragmentos cerâmicos coletados na Aldeia Lalima, as variantes contidas nos atributos analisadas foram divididos entre observáveis e deduzidos. Em se tratando dos atributos observáveis, foram analisados as variantes da categoria dos fragmentos, por sua vez subdivididos em parede, borda, base e apêndice, e as espessuras, sub-divididas em muito finas, finas, médias, espessas e muito espessas. Entre as variantes da borda, foram analisadas a forma e a posição em relação à vasilha, a forma do lábio, o diâmetro da boca, o ângulo do fragmento e a relação entre o diâmetro da boca e o diâmetro do bojo. Os atributos deduzidos, ao seu turno, dizem respeito às classes simétricas, contornos específicos, formas geométricas e, especificamente em se tratando das vasilhas Guarani, funcionalidades (ver, em anexo, listas dos atributos e respectivas variantes dos atributos observáveis e deduzidos, e a tabela de classificação). 
Além dos manuais e dos escritos de Brochado e colegas, citados anteriormente, a análise do acabamento de superfície, ao seu turno, foi orientada pelas análises contidas em Faccio (1998), Migliacio (2000), Peixoto (1998, 2003), Peixoto \& Bezerra (2004) Robrhan-González (1996) e Schmitz et al. (1998). Dividido entre tratamento plástico e cromático, o acabamento de superfície foi analisado nas faces externas e internas dos fragmentos selecionados como diagnósticos, e no lábio dos fragmentos de borda (ver lista dos atributos e tabela de classificação, anexos). Entre os fragmentos que apresentavam acabamentos plásticos associados, foi considerado $\mathrm{o}$ acabamento preponderante nas quantificações, enquanto que aqueles que possuíam acabamentos associados entre tratamentos plásticos e cromáticos, foram quantificados como tratamentos cromáticos. 


\section{Capítulo 5 - Levantamento arqueológico na Aldeia Lalima}

Ao todo, foram detectados 13 sítios e 7 ocorrências arqueológicas durante o desenvolvimento das atividades de campo, sendo todos cerâmicos e a céu aberto (ver Mapa 4 e Tabelas 2 e 3). Destes, 11 sítios e 4 ocorrências foram achados na TI Lalima, 1 sítio e 3 ocorrências na Faz. Santa Rosa, localizada nos limites noroeste, norte e nordeste da Aldeia, e 1 sítio no Potrero, ou seja, na área que os índios retomaram do INCRA e da Faz. Vargem Grande.

Com base nos atributos dos fragmentos cerâmicos e nas informações etnográficas, 8 entre os 11 sítios localizados na área de Lalima apresentaram contextos arqueológicos associados a apenas um contexto cultural pretérito, sendo 3 Guarani (Campina [MS-MI-07], Anita Viera [MS-MI-11] e Hélio Correia [MS-MI-12]), 3 da Tradição Pantanal (Limpão [MS-MI-02], José Rondon de Souza [MS-MI-04] e Manuel de Souza Neto [MS-MI-08]), e 2 Etno-históricos (Urumbeva [MS-MI-05] e Pirizal [MS-MI-09]). Os outros 3 sítios detectados na Aldeia apresentaram contextos arqueológicos associados a mais de um contexto cultural, sendo 2 com materiais da Tradição Pantanal e Guarani (sítio Córrego Lalima [MS-MI-01] e Asa de Pote [MS-MI06]), e 1 com materiais da Tradição Pantanal, Guarani e Etno-históricos (Tapera do Gino [MS-MI-03]). Dentre as áreas de ocorrência detectadas na Aldeia, duas apresentaram fragmentos de vasilhas cerâmicas da Tradição Pantanal (ocorrências 2 e 4) e duas apresentaram fragmentos cerâmicos desprovidos de atributos diagnósticos ou informações etnográficas que os vinculassem aos contextos arqueológicos observados em Lalima (ocorrências 1 e 3).

Na Fazenda Santa Rosa, foi detectado 1 sítio Etno-histórico (Tapera do Agápto [MS-MI-13]), 1 ocorrência Guarani (ocorrência 5), uma da Tradição Pantanal (ocorrência 7) e uma desprovida de atributos diagnósticos. O sítio achado na área retomada, denominado Potrero (MS-MI-10), foi associado à Tradição Pantanal.

Assim, entre os 13 sítios localizados, 3 apresentaram materiais Guarani, 4 da Tradição Pantanal, 3 apresentaram materiais etnográficos, 2 da Tradição Pantanal e Guarani e 1 com materiais Guarani, da Tradição Pantanal e etnográficos. Dentre as ocorrências, 1 apresentou materiais Guarani, 3 da Tradição Pantanal e 3 não estavam vinculadas com informações etnográficas e nem apresentavam fragmentos cerâmicos com atributos diagnósticos. 


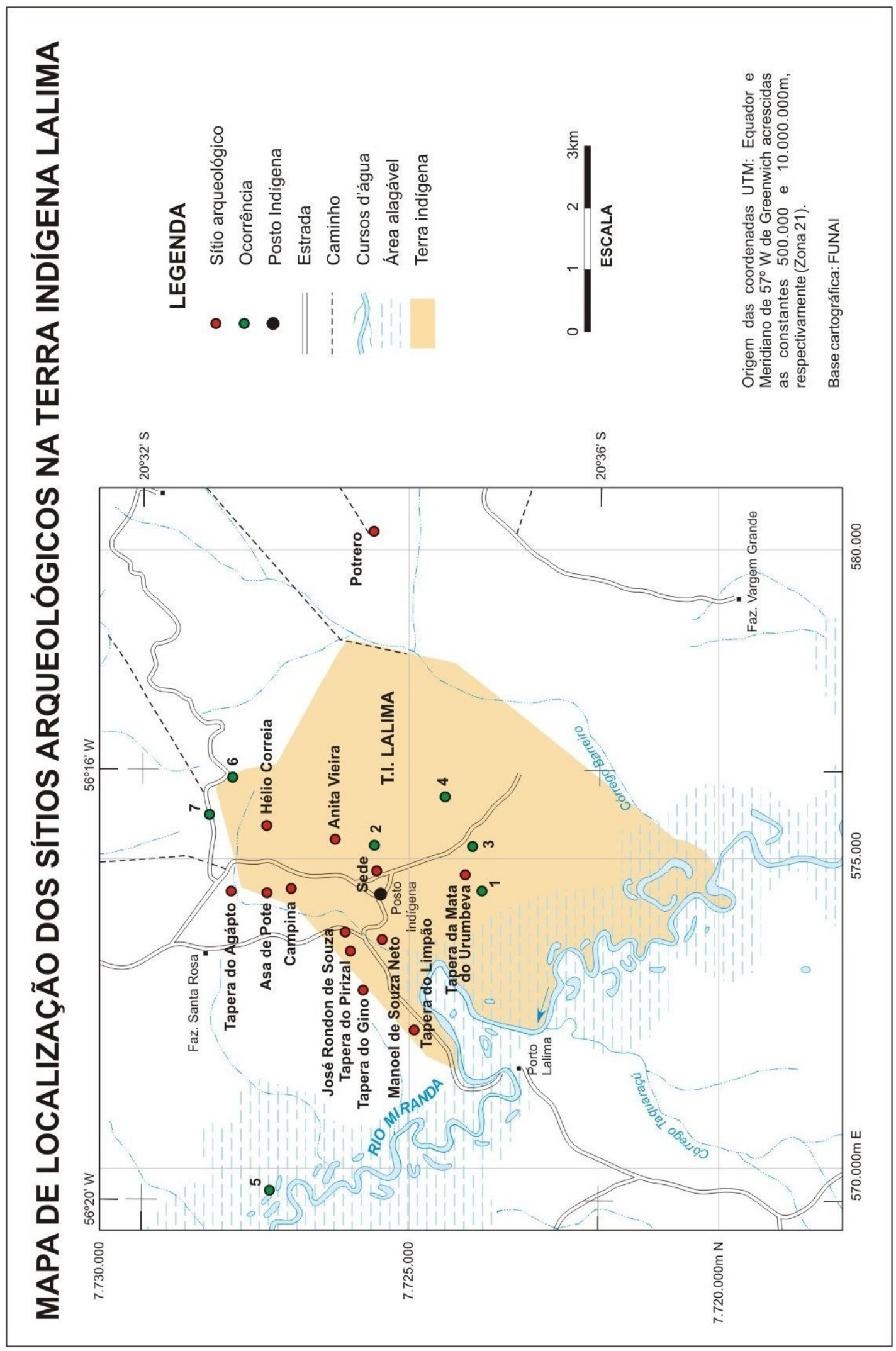




\begin{tabular}{|c|c|c|c|c|c|}
\hline Nome & Sigla & Coordenadas & Local de implantação & Tradição tecnológica & Trabalhos realizados \\
\hline $\begin{array}{l}\text { Córrego } \\
\text { Lalima }\end{array}$ & MS-MI-01 & $\begin{array}{l}21 \mathrm{~K} 0574802 / \\
7725523\end{array}$ & $\begin{array}{l}\text { Colina suave rodeada por nascentes } \\
\text { tributárias da margem direita do rio } \\
\text { Miranda, onde se situa a Sede, um dos } \\
\text { bairros da Aldeia, constituída por } \\
\text { sedimentos arenosos, argilosos e litólicos }\end{array}$ & $\begin{array}{c}\text { Guarani e Tradição } \\
\text { Pantanal }\end{array}$ & $\begin{array}{l}\text { Registro, topografia, } \\
\text { setorização, coletas de } \\
\text { superfície sistemáticas e } \\
\text { assistemáticas, escavação } \\
\text { de sondagens e poços- } \\
\text { teste } \\
\end{array}$ \\
\hline $\begin{array}{l}\text { José } \\
\text { Rondon de } \\
\text { Souza }\end{array}$ & MS-MI-02 & $\begin{array}{l}21 \mathrm{~K} 0573816 / \\
7726032\end{array}$ & $\begin{array}{l}\text { Baixa encosta de colina suave situada na } \\
\text { confluência da margem direita de uma } \\
\text { pequena nascente com a margem esquerda } \\
\text { do baixo curso do cór. do Lima, constituída } \\
\text { por sedimentos arenosos }\end{array}$ & Tradição Pantanal & $\begin{array}{l}\text { Registro, esboço de croqui, } \\
\text { coleta assistemática de } \\
\text { superfície }\end{array}$ \\
\hline $\begin{array}{l}\text { Tapera do } \\
\text { Limpão }\end{array}$ & MS-MI-03 & $\begin{array}{l}21 \mathrm{~K} 0572232 / \\
7724920\end{array}$ & $\begin{array}{l}\text { Topo de colina suave não inundável situada } \\
\text { próxima da margem direita do médio } \\
\text { Miranda, constituída por sedimentos } \\
\text { arenosos e litólicos } \\
\end{array}$ & Tradição Pantanal & $\begin{array}{l}\text { Registro e coleta } \\
\text { assistemática de superfície }\end{array}$ \\
\hline $\begin{array}{l}\text { Tapera do } \\
\text { Gino }\end{array}$ & MS-MI-04 & $\begin{array}{c}21 \mathrm{~K} 0572877 / \\
7725744\end{array}$ & $\begin{array}{l}\text { Colina suave situada na margem esquerda } \\
\text { de uma nascente tributária da margem } \\
\text { direita do rio Miranda, constituída por } \\
\text { sedimentos arenosos e litólicos, na divisa } \\
\text { entre Lalima e a Faz. Santa Rosa }\end{array}$ & $\begin{array}{l}\text { Etno-histórico, } \\
\text { Guarani e Tradição } \\
\text { Pantanal }\end{array}$ & $\begin{array}{l}\text { Registro e coleta } \\
\text { assistemática de superfície }\end{array}$ \\
\hline $\begin{array}{l}\text { Tapera da } \\
\text { Mata do } \\
\text { Urumbeva }\end{array}$ & MS-MI-05 & $\begin{array}{l}\text { 21K } 0574739 / \\
7724094\end{array}$ & $\begin{array}{l}\text { Baixa e média encosta de colina suave, } \\
\text { constituída por sedimentos litólicos e } \\
\text { arenosos, situada em torno de uma } \\
\text { nascente tributária da margem direita do rio } \\
\text { Miranda }\end{array}$ & Etno-histórico & $\begin{array}{c}\text { Registro, setorização, } \\
\text { topografia, coleta } \\
\text { sistemática de superfície, } \\
\text { escavação de sondagens e } \\
\text { de poços-teste } \\
\end{array}$ \\
\hline $\begin{array}{l}\text { Asa de } \\
\text { Pote }\end{array}$ & MS-MI-06 & $\begin{array}{l}21 \mathrm{~K} 0574450 \\
7727296\end{array}$ & $\begin{array}{l}\text { Colina suave situada entre a confluência da } \\
\text { margem direita de uma nascente com o } \\
\text { médio curso da margem esquerda do cór. } \\
\text { Guanandi, constituída por sedimentos } \\
\text { argilosos e arenosos }\end{array}$ & $\begin{array}{c}\text { Guarani e Tradição } \\
\text { Pantanal }\end{array}$ & $\begin{array}{c}\text { Registro, setorização, } \\
\text { topografia, coleta } \\
\text { sistemática de superfície, } \\
\text { escavação de sondagens e } \\
\text { poços-teste } \\
\end{array}$ \\
\hline Campina & MS-MI-07 & $\begin{array}{l}21 \mathrm{~K} 0574518 / \\
7726905\end{array}$ & $\begin{array}{l}\text { Colina suave situada entre a confluência da } \\
\text { margem esquerda de uma nascente com o } \\
\text { médio curso da margem esquerda do cór. } \\
\text { Guanandi, constituída por sedimentos } \\
\text { argilosos e arenosos }\end{array}$ & Guarani & Registro \\
\hline $\begin{array}{l}\text { Manuel de } \\
\text { Souza Neto }\end{array}$ & MS-MI-08 & $\begin{array}{l}21 \mathrm{~K} 0573695 / \\
7725436\end{array}$ & $\begin{array}{l}\text { Colina suave, constituída por sedimentos } \\
\text { arenosos, situada na confluência de ambas } \\
\text { as margens de um nascente uma nascente } \\
\text { com a margem direita do rio Miranda }\end{array}$ & Tradição Pantanal & Registro \\
\hline $\begin{array}{l}\text { Tapera do } \\
\text { Pirizal }\end{array}$ & MS-MI-09 & $\begin{array}{l}\text { 21K 0573508/ } \\
7725949\end{array}$ & $\begin{array}{c}\text { Área plana não inundável constituída por } \\
\text { sedimentos arenosos situada na planície de } \\
\text { inundação da margem direita do rio } \\
\text { Miranda }\end{array}$ & Etno-histórico & $\begin{array}{l}\text { Registro e coleta } \\
\text { assistemática de superfície }\end{array}$ \\
\hline $\begin{array}{c}\text { Sítio } \\
\text { Potrero }\end{array}$ & MS-MI-10 & $\begin{array}{l}\text { 21K } 0580296 / \\
7725567\end{array}$ & $\begin{array}{l}\text { Colina suave, constituída por sedimentos } \\
\text { argilosos e arenosos, situada entre o sopé } \\
\text { do morro do Potrero e o médio curso de um } \\
\text { cór. sazonal tributário do médio Miranda, na } \\
\text { párea retomada do INCRA e da Faz. Vargem } \\
\text { Grande pelos Terena em Lalima }\end{array}$ & Tradição Pantanal & $\begin{array}{l}\text { Registro, esboço de croqui } \\
\text { e coleta assistemática de } \\
\text { superfície }\end{array}$ \\
\hline $\begin{array}{l}\text { Anita } \\
\text { Vieira }\end{array}$ & MS-MI-11 & $\begin{array}{l}21 \mathrm{~K} 0575314 / \\
7726195\end{array}$ & $\begin{array}{l}\text { Colina suave, constituída por sedimentos } \\
\text { arenosos e argilosos, situada na margem } \\
\text { esquerda do alto curso do cór. do Lima }\end{array}$ & Guarani & Registro \\
\hline $\begin{array}{l}\text { Helio } \\
\text { Correia }\end{array}$ & MS-MI-12 & $\begin{array}{l}21 \mathrm{~K} 0575535 / \\
7727300\end{array}$ & $\begin{array}{l}\text { Colina suave, constituída por sedimentos } \\
\text { argilosos e arenosos, situadas entre o sopé } \\
\text { do morro do Inocêncio e a confluências das } \\
\text { nascentes formadoras do cór. Guanandi }\end{array}$ & Guarani & Registro \\
\hline $\begin{array}{l}\text { Tapera do } \\
\text { Agápto }\end{array}$ & MS-MI-13 & $\begin{array}{c}21 \mathrm{~K} 0574477 / \\
7727875\end{array}$ & $\begin{array}{l}\text { Baixa encosta e colina suave, constituída por } \\
\text { sedimentos arenosos e argilosos, situada na } \\
\text { margem direita do médio curso do cór. } \\
\text { Guanandi, na Faz. Santa Rosa } \\
\end{array}$ & Etno-histórico & Registro \\
\hline
\end{tabular}

O sítio e as ocorrências encontradas na Fazenda Santa Rosa, cujas terras, em parte, são reivindicadas pelos índios, foram detectadas enquanto conferíamos, a pedido e na companhia dos índios, inclusive do Cacique Gilmar, através de um GPS, se as terras ocupadas por eles atualmente correspondiam ou não com os limites demarcados pela FUNAI. Um dia antes, contudo, já havíamos sido levados, pelo Manoel de Souza 
Neto, em conjunto com o Cacique Gilmar, até a Santa Rosa, no "marco de madeira". Tal marco, um mastro talhado em aroeira, com inscrições verticais das letras $\mathrm{LH}, 1,45 \mathrm{~m}$ de altura e $20 \mathrm{~cm}$ de largura (ver Foto 5), pode ser entendido como um dos sítios Etnohistóricos mais importantes para os índios que formam o contexto etnográfico atual, tanto por conta dos seus significados, diretamente ligados à luta pela retomada das terras usurpadas pelos fazendeiros, quanto pela difusão das histórias sobre o marco, conhecidas e compartilhadas pela maioria na Aldeia, não obstante a origem multiétnica e as transformações colonialistas. O marco constitui, segundo os índios, o último dos marcos que delimitavam a área reservada aos Guaikurú, o que teria ocorrido talvez até mesmo antes da passagem de Rondon pela região. A pedido dos índios, por razões de segurança, não divulgaremos as coordenadas UTM do marco de madeira, pois todos acreditam que ele apenas não foi destruídos pelos fazendeiros, como ocorrido com os outros marcos que delimitavam o território de Lalima, por estar situado em uma área de difícil acesso.

\begin{tabular}{|c|c|c|c|}
\hline \multicolumn{4}{|r|}{ Tabela 3: Ocorrências detectadas na TI Lalima } \\
\hline $\begin{array}{l}\text { Ocorrência } \\
\mathrm{N}^{\circ}\end{array}$ & Sigla & Coordenadas & Observações \\
\hline 1 & $\mathrm{OC} 1$ & $\begin{array}{c}21 \mathrm{~K} \\
0574477 / 7723824\end{array}$ & Fragmentos cerâmicos achados na roça afastada de Manuel de Souza Neto \\
\hline 2 & $\mathrm{OC} 2$ & $\begin{array}{c}21 \mathrm{~K} \\
0575216 / 7725561 \\
\end{array}$ & Fragmentos cerâmicos da Tradição Pantanal achados no quintal da casa de Martírio Vieira \\
\hline 3 & OC3 & $\begin{array}{c}21 \mathrm{~K} \\
0575196 / 7723975\end{array}$ & Fragmentos cerâmicos achados na roça de Agripino Pires \\
\hline 4 & OC4 & $\begin{array}{c}21 \mathrm{~K} \\
0575998 / 7724418\end{array}$ & Fragmentos cerâmicos da Tradição Pantanal achados na roça de Estevão Cabrocha \\
\hline 5 & OC5 & $\begin{array}{c}21 \mathrm{~K} \\
0569646 / 7727257\end{array}$ & Fragmentos cerâmicos Guarani achados na planície inundável do rio Miranda, na Faz. Santa Rosa \\
\hline 6 & OC6 & $\begin{array}{c}21 \mathrm{~K} \\
0576316 / 7727850\end{array}$ & $\begin{array}{c}\text { Fragmentos cerâmicos achados ao lado dos mourões da cerca da divisa entre a Aldeia Lalima e a } \\
\text { Faz. Santa Rosa }\end{array}$ \\
\hline 7 & OC7 & $\begin{array}{c}21 \mathrm{~K} \\
0575715 / 7728224\end{array}$ & $\begin{array}{c}\text { Fragmento cerâmico da Tradição Pantanal achado na divisa entre a Aldeia Lalima e a Faz. Santa } \\
\text { Rosa }\end{array}$ \\
\hline
\end{tabular}

Foram selecionados 8 dentre os sítios detectados para a realização das atividades de coleta. Dos sítios selecionados, foram desenvolvidas atividades sistemáticas de coleta e de topografia em apenas 3 , sendo que nos 5 restantes foram realizadas somente coletas assistemáticas de superfície. As atividades sistemáticas foram realizadas nos sítios Córrego Lalima (MS-MI-01), Urumbeva (MS-MI-05) e Asa de Pote (MS-MI-06). Já as atividades de coleta assistemática de superfície foram efetuadas nos sítios José Rondon de Souza (MS-MI-02), Limpão (MS-MI-03), Gino (MS-MI-04), Pirizal (MSMI-09) e Potrero (MS-MI-10). Os outros 5 sítios detectados no levantamento, ou seja, Campina (MS-MI-07), Manoel de Souza Neto (MS-MI-08), Anita Vieira (MS-MI-11), Hélio Correia (MS-MI-12) e Tapera do Agápto (MS-MI-13), foram apenas registrados e plotados, assim como as áreas ocorrências. Aproximadamente, foram recolhidos 3.363 
materiais arqueológicos através das atividades de coleta (3.178 cerâmicos, 79 líticos, 66 orgânicos, 19 louças, 17 amostras de carvão, 2 metais, 1 fragmento de conta azul e 1 suposta bolota de argila), sendo 2.814 em superfície (1.972 nas coletas assistemáticas e 843 nas sistemáticas) e 539 nas sistemáticas em sub-superfície (Tabela 4).

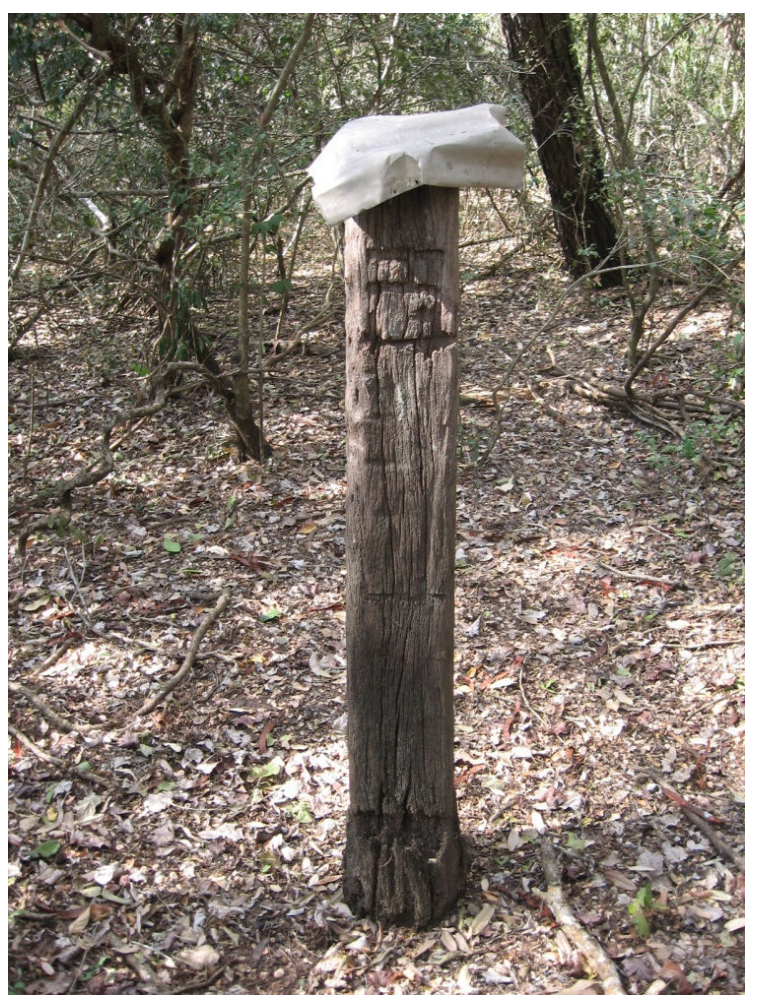

Foto 5: Marco de madeira localizado na Faz. Santa Rosa

As análises preliminares nos fragmentos cerâmicos considerados diagnósticos da forma e do acabamento de superfície foram realizadas nas coleções obtidas nos setores 1 e 2 do sítio Córrego Lalima (MS-MI-01), no sítio José Rondon de Souza (MS-MI-02), Tapera do Limpão (MS-MI-03), Tapera do Gino (MS-MI-04), Tapera da Urumbeva (MS-MI-05) e no setor 2 do Asa de Pote (MS-MI-06).

\begin{tabular}{|c|c|c|c|c|c|c|c|}
\hline \multicolumn{7}{|c|}{ Tabela 4: Materiais Arqueológicos coletados na TI Lalima } \\
\hline Sítio/Sigla & Cerâmicos & Líticos & Carvões & Orgânicos & Louças & \multicolumn{2}{c|}{ Outros } \\
\hline Córrego Lalima (MS-MI-01) & 2.357 & 49 & 2 & 42 & 11 & & 2.461 \\
\hline José Rondon de Souza (MS-MI-02) & 57 & & & & & & 57 \\
\hline Tapera do Limpão (MS-MI-03) & 117 & 4 & & & & & 121 \\
\hline Tapera do Gino (MS-MI-04) & 121 & & & & & 1 (Conta azul) & 122 \\
\hline Tapera do Urumbeva (MS-MI-05) & 57 & 6 & & 23 & 8 & 1 (Tampa de radiador) & 95 \\
\hline Asa de Pote (MS-MI-06) & 360 & 17 & 15 & 1 & & 1 (Suposta bolota de argila) & 394 \\
\hline Campina (MS-MI-07) & 3 & & & & & & 3 \\
\hline Manuel de Souza Neto (MS-MI-08) & & 2 & & & & & 2 \\
\hline Tapera do Pirizal (MS-MI-09) & 46 & & & & & 1 (Ponta de ferro batido) & 47 \\
\hline Potrero (MS-MI-10) & 54 & 1 & & & & & 55 \\
\hline Anita Vieira (MS-MI-11) & 1 & & & & & & \\
\hline Tapera do Agápto (MS-MI-13) & 5 & & & & & & \\
\hline Totais & 3.178 & 79 & 17 & 66 & 19 & & 5 \\
\hline
\end{tabular}


As amostras de carvão enviadas ao Beta Analytic Inc.,coletadas em poços-teste escavados no setor 1 do sítio Córrego Lalima e no setor 2 do sítio Asa de Pote, resultaram na obtenção de 3 datações radiocarbônicas (Tabela 5).

\begin{tabular}{|c|c|c|c|c|c|c|}
\hline \multicolumn{7}{|c|}{ Tabela 5: Datações arqueológicas obtidas na TI Lalima } \\
\hline $\begin{array}{c}\text { Data radiocarbônica } \\
\text { convencional } \\
\text { AP }\end{array}$ & $\begin{array}{c}\text { Data } \\
\text { calibrada } \\
2 \text { sigma } \\
\text { AC/DC }\end{array}$ & $\begin{array}{c}\text { Data } \\
\text { calibrada } \\
2 \text { sigma } \\
\text { AP }\end{array}$ & $\begin{array}{l}\text { Código do } \\
\text { laboratório }\end{array}$ & Sítio/Sigla & Proveniência & $\begin{array}{l}\text { Tradição } \\
\text { tecnológica }\end{array}$ \\
\hline $970+/-60$ & 980 à 1210 & 970 à 940 & Beta (238765) & $\begin{array}{l}\text { Córrego } \\
\text { Lalima } \\
\text { MS-MI-01 } \\
\end{array}$ & $\begin{array}{c}\text { Setor 1, poço-teste 1, nível } 3 \\
(\mathrm{PN}=2.184, \mathrm{X}=57 \mathrm{~cm}, \mathrm{Y}=23 \mathrm{~cm} \mathrm{e} \\
\mathrm{Z}=26 \mathrm{~cm})\end{array}$ & Guarani \\
\hline $1070+/-60$ & 870 à 1040 & 1080 à 910 & Beta (238768) & $\begin{array}{l}\text { Asa de Pote } \\
\text { MS-MI-06 }\end{array}$ & $\begin{array}{c}\text { Setor 2, poço-teste 1, nível } 3 \\
(\mathrm{PN}=348, \mathrm{X}=56 \mathrm{~cm}, \mathrm{Y}=62 \mathrm{~cm} \mathrm{e} \\
\mathrm{Z}=27,5 \mathrm{~cm})\end{array}$ & Pantanal \\
\hline $6430+/-70$ & $\begin{array}{c}5510 \text { à } \\
5300\end{array}$ & $\begin{array}{c}7460 \text { à } \\
7250\end{array}$ & Beta (238767) & $\begin{array}{l}\text { Asa de Pote } \\
\text { MS-MI-06 }\end{array}$ & $\begin{array}{c}\text { Setor 2, poço-teste 1, nível } 6 \\
(\mathrm{PN}=362, \mathrm{X}=86 \mathrm{~cm}, \mathrm{Y}=32 \mathrm{~cm} \mathrm{e} \\
\mathrm{Z}=51,5 \mathrm{~cm})\end{array}$ & \\
\hline
\end{tabular}

\section{1 - Sítios arqueológicos}

\subsection{1 - Córrego Lalima (MS-MI-01)}

Localizado nas coordenadas UTM 21K 0574802/7725523, o sítio Córrego Lalima (MS-MI-01) está implantado em uma vasta colina suave, circundada por nascentes e cursos flúvio-pluviais, onde também se situa a localidade da Sede, o centro do contexto etnográfico atual (Mapa 5). A visibilidade de entorno é muito ampla, sobretudo nas direções sul, sudeste e oeste, permitindo a visualização da baixa encosta, das planícies de inundação e da mata ciliar do rio Miranda, bem como das colinas da margem esquerda e até mesmo do lineamento da Serra da Bodoquena, situado no limite oeste da Depressão Interplanáltica de Miranda (Foto 6). Tendo em vista que todas as extensões da colina encontram-se ocupadas pelos domicílios dos índios, predominam os pomares em volta dos quintais das casas, em detrimento de quaisquer resquícios do cerrado ou cerradão, outrora predominantes, inclusive nas margens dos cursos d'água circundantes, com exceção do rio Miranda, onde ainda há mata ciliar. Os cursos d'água circundantes, por sua vez, deixaram de fluir à margem direita do Miranda de maneira permanente, e até mesmo a fluência sazonal diminuiu, por conta dos impactos ocasionados por obras de represamento das nascentes e construção de pontes e canais nos cruzamentos das estradas com os leitos dos córregos. Da mesma forma, os sedimentos, predominantemente arenosos, mas com porções argilosas e litólicas, foram intensamente perturbados e remexidos, não somente devido às construções da escola, 


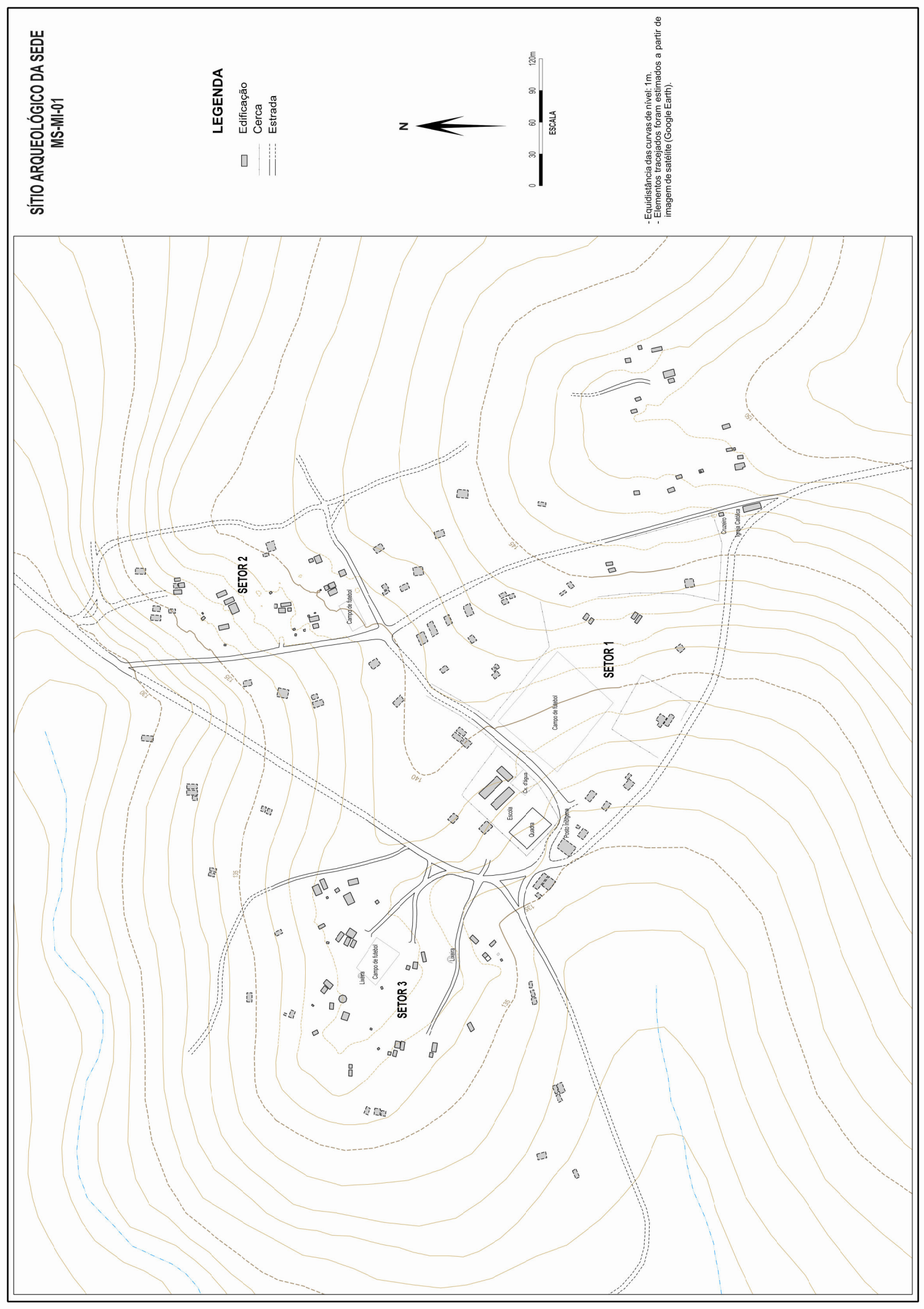


das estradas e dos postos da FUNAI e FUNASA, certamente mais impactantes, mas também pelas obras nos domicílios dos índios, o que inclui escavações, terraplanagens, aterros, contenções e acessos, assim como pelas práticas cotidianas levadas a cabo nos domicílios, como atividades de limpeza, conservação, agri-horticultura e criação de animais.

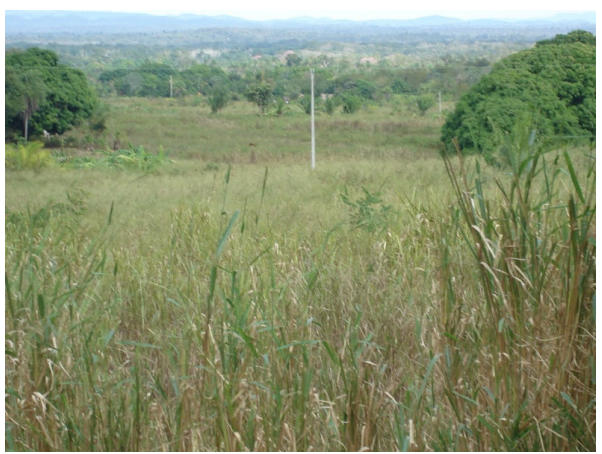

Foto 6: Visibilidade de entorno no sítio Córrego Lalima

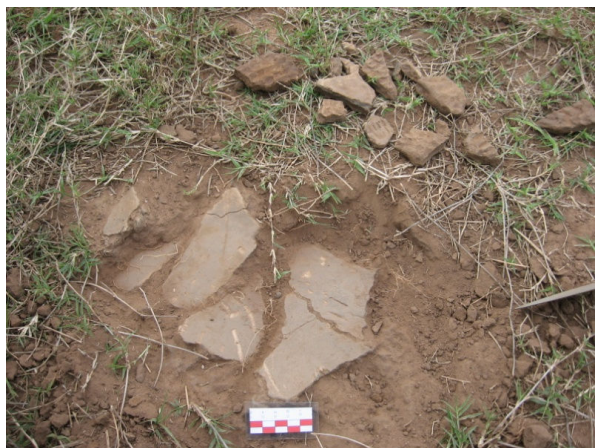

Foto 7: Fragmentos corrugados de vasilhas Guarani no setor 1 do sítio Córrego Lalima

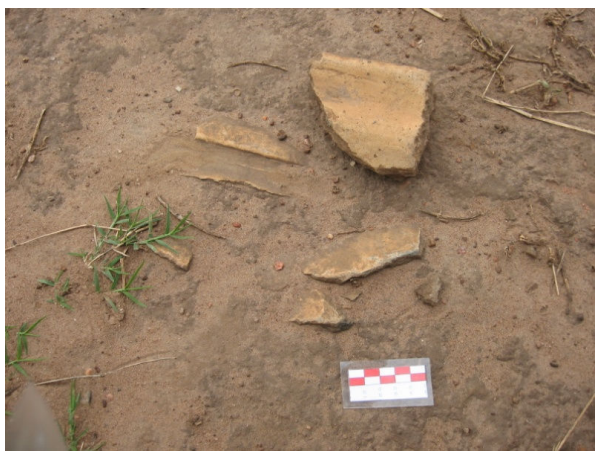

Foto 8: Fragmentos de borda de cambuchi no setor 1 do sítio Córrego Lalima

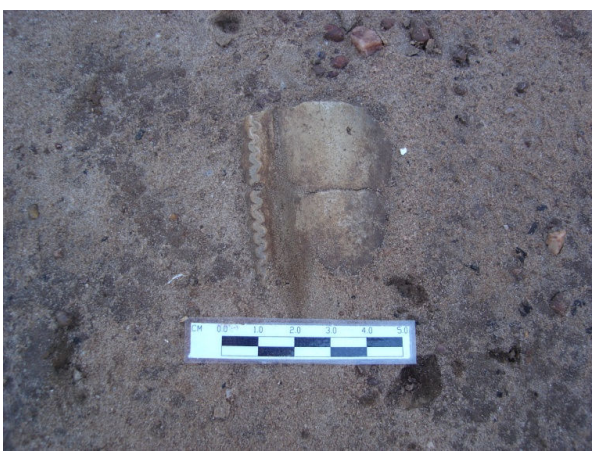

Foto 9: Fragmento de borda de vasilha da Tradição Pantanal no setor 2 do sítio Córrego Lalima

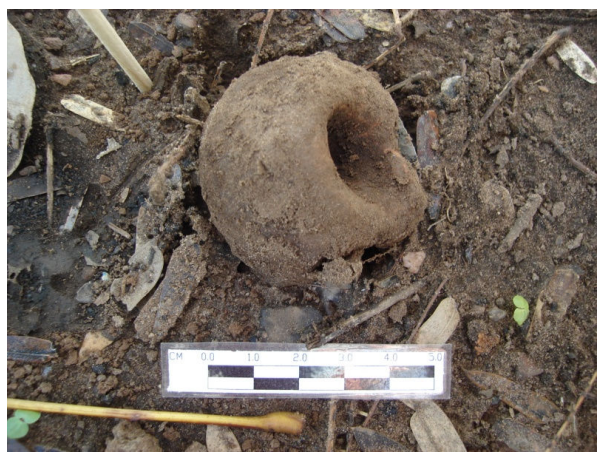

Foto 10: Apêndice de suspensão de vasilha cerâmica da Tradição Pantanal no setor 3 do sítio Córrego Lalima

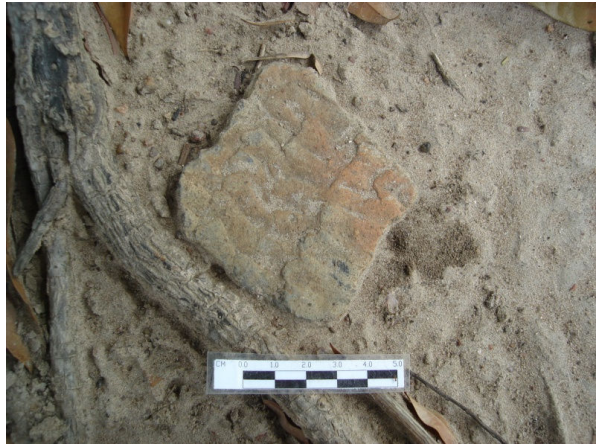

Foto 11: Fragmento corrugado de vasilha cerâmica Guarani no setor 3 do sítio Córrego Lalima

Os materiais arqueológicos, constituídos majoritariamente por fragmentos de vasilhas cerâmicas Guarani e da Tradição Pantanal, encontram-se esparsos por toda a superfície, aflorando nos quintais, canaletas de escoamento pluvial em volta das casas, nas hortas, roças, lixeiras, acessos, campos de futebol e estradas (Fotos 7 à 11). Porém, 
as maiores concentrações estão dispostas nas porções mais planas do topo e nas encostas alta e média da colina. É interessante notar que, embora as concentrações se sobreponham umas às outras, as sobreposições ocorrem apenas nos limites entre as mesmas.

Dotado com mais de $500 \mathrm{mil} \mathrm{m}^{2}$, o Sede foi segmentado em 4 setores, dos quais 3 foram pesquisados e 1 apenas registrado (Mapa 5). As atividades de coleta resultaram no recolhimento de 2.461 materiais, entre os quais 2.357 cerâmicos, 49 líticos, 42 orgânicos, 11 louças e 2 amostras de carvão (Tabela 4). No setor 1 , com 80 mil m² delimitados sobre contexto arqueológico Guarani situado nas porções centro-sudeste da colina, foram coletados 929 materiais, sendo 810 cerâmicos com as atividades de coleta assistemática de superfície e 119 nas coletas sistemáticas em sub-superfície (84 cerâmicos, 3 líticos, 31 orgânicos 1 amostra de carvão). As coletas assistemáticas foram realizadas no mesmo campo de futebol onde anteriormente o Prof. Dr. Gilson Rodolfo Martins havia coletado 50 fragmentos de vasilhas Guarani. O campo possui uma área de $7 \mathrm{mil} \mathrm{m}^{2}$ de sedimento arenoso marrom-claro, terraplanado, compacto e parcialmente gramado (Mapa 6, Tabela 6, Foto 12).

\begin{tabular}{|} 
Tabela 6: Materiais arqueológicos coletados no setor 1 do sítio Córrego Lalima (MS-MI-01) \\
\hline Atividades de coleta & Cerâmicos & Líticos & Carvões & Orgânicos & Totais \\
\hline Assistemática de superfície & 810 & & & & 810 \\
\hline Sub-superfície & 84 & 3 & 1 & 31 & 119 \\
\hline Totais & 894 & 3 & 1 & 31 & 929 \\
\hline
\end{tabular}

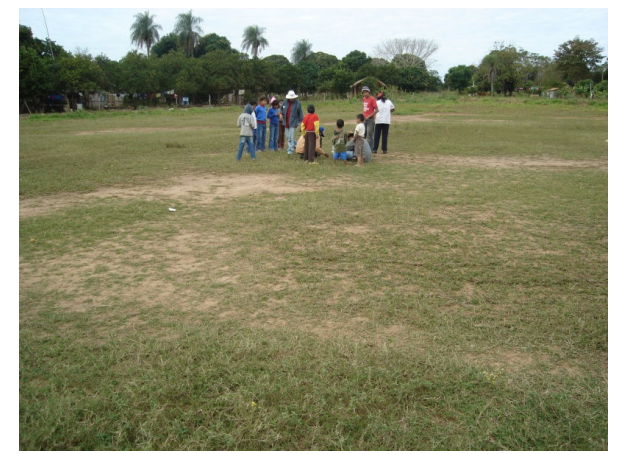

Foto 12: Coleta de superfície assistemática no setor 1 do sítio Córrego Lalima

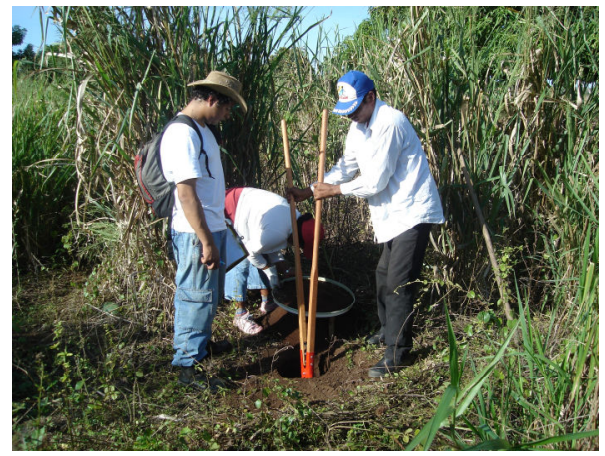

Foto 13: Escavação de sondagem no setor 1 do sítio Córrego Lalima

Entre os materiais coletados em sub-superfície no setor 1, 59 são provenientes das sondagens (28 cerâmicas, 1 lítico e 30 orgânicos) e 60 dos poços-teste (56 cerâmicos, 2 líticos, 1 orgânico e 1 amostra de carvão). As sondagens totalizaram 13 furos, escavados em um segmento de reta traçado a sudeste do campo de futebol, entre cinco domicílios, com $20 \mathrm{~m}$ de distância entre os furos e média de $55 \mathrm{~cm}$ de 


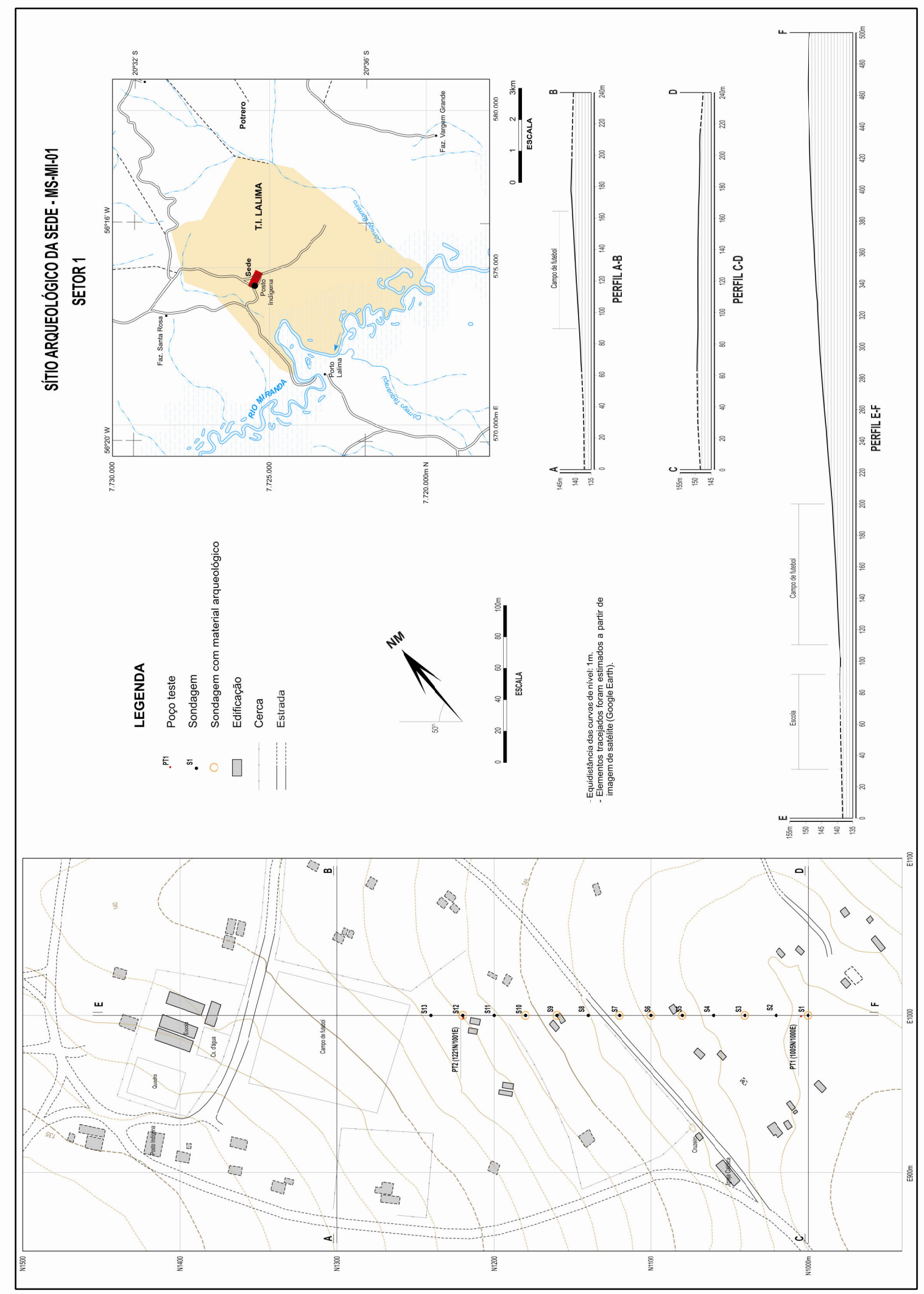


profundidade. Os materiais foram recolhidos em 8 das sondagens escavadas (S1, S3, S4, S5, S6, S7, S9, S10 e S12). Os materiais estavam concentrados entre os níveis artificiais 1 e 3, constituídos por sedimentos areno-argilosos marrom-escuros. Também foram observados sedimentos argilosos vermelhos. Na sondagem 8 , estéril arqueologicamente, foi atingido o embasamento rochoso em quartzo, à apenas $30 \mathrm{~cm}$ da superfície (Mapa 6, Tabela 7, Foto 13).

\begin{tabular}{|c|c|c|c|c|}
\hline Sondagens & Cerâmicos & Líticos & Orgânicos & Totais \\
\hline S1 & 12 & 1 & & 13 \\
\hline S3 & 1 & & & 1 \\
\hline S4 & 2 & & & 2 \\
\hline S5 & 4 & & 29 & 33 \\
\hline S6 & 2 & & 1 & 3 \\
\hline S7 & 1 & & & 1 \\
\hline S9 & 1 & & & 1 \\
\hline S10 & 3 & & & 3 \\
\hline S12 & 2 & & & 2 \\
\hline Totais & 28 & 1 & 30 & 59 \\
\hline
\end{tabular}

A estratigrafia mostrou-se muito remexida e perturbada por aterros, terraplanagens e lixeiras, fato que torna ainda mais incrível a descoberta de um pequeno tembetá confeccionado em resina de jatobá na sondagem $5(1080 \mathrm{~N} / 1000 \mathrm{E})$, escavada em solos extremamente revirados, com presença, inclusive, de resíduos de materiais industrializados, como arames, pilhas, pregos, sacolas plásticas, pedaços de tecido e cacos de vidro. Com efeito, a $\mathrm{S} 5$, perfurada a até $70 \mathrm{~cm}$ de profundidade, foi escavada em uma lixeira aterrada, sobre a qual foi construída, por sua vez, a casa da $\mathrm{D}^{\mathrm{a}}$. Dilma Pereira. Assim, muito provavelmente tanto o tembetá quanto os outros materiais arqueológicos recolhidos na $\mathrm{S} 5$, ou seja, 4 fragmentos cerâmicos e 29 materiais orgânicos - os quais precisam ser analisados adequadamente, pois podem corresponder aos restos de alimentação atuais, não obstante a descoberta de um dente de animal com marcas de uso - provavelmente foram tratados do mesmo modo como o lixo no contexto atual da ocupação indígena em Lalima, ou seja, foram aglutinados, recolhidos, jogados numa lixeira escavada nas imediações dos domicílios, queimados na medida em que a lixeira foi cheia, e cobertos com o aterramento da mesma. Muitos materiais foram escavados nestas condições, não só no setor 1, mas em todo o sítio.

A área mais preservada em sub-superfície descoberta através dos furos de sondagem no setor 1 foi o entorno da sondagem 1 (1000N/1000E), localizada entre a roça de mandioca e o pomar do domicílio do Sr. Ervírio. Escavada a até $83 \mathrm{~cm}$, foram coletados 12 fragmentos cerâmicos e 1 lítico na S1, sendo 10 dos fragmentos descobertos entre os níveis 1 e 2 , constituídos por sedimentos argilo-arenosos marrom- 
escuros, e 2 no nível 6, formado por sedimentos argilosos vermelho. O lítico, uma lasca em sílex, foi detectada no nível 5, composto pelo mesmo sedimento do nível 6 .

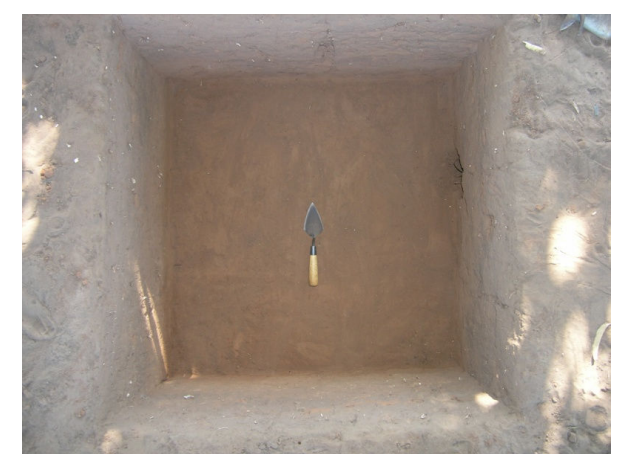

Foto 14: Escavação do poço-teste 1 no setor 1 do sítio Córrego Lalima

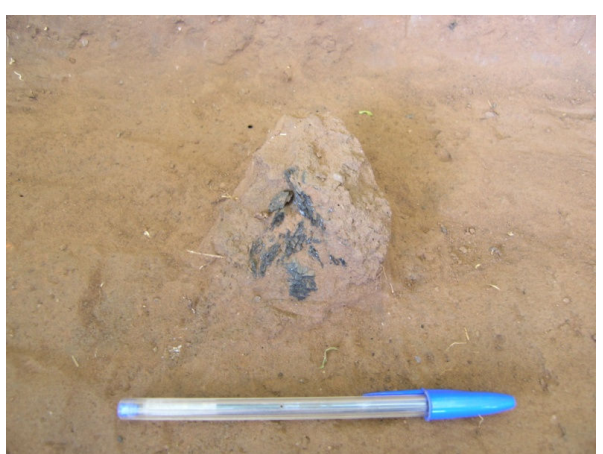

Foto 15: Amostra de carvão coletada no poçoteste 1 no sítio Córrego Lalima e datada em 970 $\pm 60 \mathrm{AP}$

No poço-teste $1(1005 \mathrm{~N} / 1000 \mathrm{E})$, delimitado ao lado da $\mathrm{S} 1$, foram escavados seis níveis artificiais, coletados 45 materiais arqueológicos (43 cerâmicos, 1 orgânico e 1 amostra de carvão) e evidenciadas 3 camadas de sedimentos, além da camada superficial (Mapa 6, Tabela 8, Foto 14, Ilustrações apresentadas no Anexo 2). Na superfície, constituída por sedimentos arenosos marrom-claros, foram recolhidos 3 fragmentos de vasilhas cerâmicas no poço-teste, coletados sistematicamente, e 15 fragmentos em torno da quadrícula, coletados assistematicamente. Na camada A, formada pelos sedimentos arenosos marrom-escuros (dark brown 10YR3/3) descobertos com a escavação dos níveis 1, 2 e porções do 3, foram obtidos 40 materiais, sendo 39 cerâmicas e um vestígio osteológico faunístico. $\mathrm{Na}$ camada $\mathrm{B}$, constituída pelo sedimento areno-argiloso marrom-escuro (dark brown 7.5YR3/4) evidenciado com a escavação dos níveis 3, 4 e porções do 5, foi coletado apenas um fragmento corrugado e uma pequena concentração de carvão. Os níveis 5 e 6 apresentaram uma camada arenoargilosa vermelha, denominada camada $\mathrm{C}$, arqueologicamente estéril.

\begin{tabular}{|c|c|c|c|c|}
\hline Níveis/Camadas & Cerâmicos & Orgânicos & Carvões & Totais \\
\hline N0/Superficial & 3 & & & 3 \\
\hline N1/Camada A & 27 & 1 & & 28 \\
\hline N2/ Camada A & 12 & & & 12 \\
\hline N3/ Camada A e B & 1 & & 1 & 2 \\
\hline \multicolumn{5}{|l|}{ N4/Camada B } \\
\hline \multicolumn{5}{|l|}{ N5/Camada C } \\
\hline N6/Camada C & & & & \\
\hline Totais & 43 & 1 & 1 & 45 \\
\hline
\end{tabular}

Aparentemente, os sedimentos escavados no poço-teste 1 foram mais remexidos pela bioturbação causada por plantas e insetos que pelo contexto etnográfico atual, não 
obstante as atividades de limpeza e passagem desenvolvidas diariamente há décadas na superfície, e a utilização do entorno da área no cultivo de árvores frutíferas, cana e mandioca. A amostra de carvão coletada no nível 3 foi datada em $970 \pm 60 \mathrm{AP}$, a qual recua a ocupação Guarani no médio Miranda ao período pré-colonial, entre o final do séc. X e início do XIII, ao menos (Foto 15, Tabela 5).

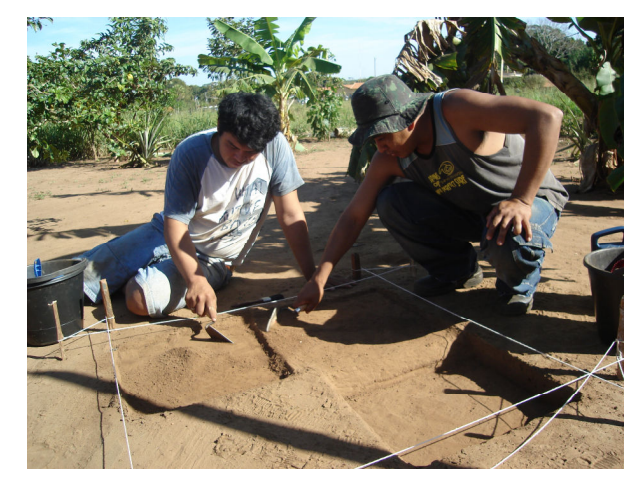

Foto 16: Escavação do poço-teste 2 no setor 1 do sítio Córrego Lalima

No poço-teste 2 (1221N/1001E), empreendido ao lado da sondagem 12 (1220N/1000E), no quintal da casa do Sr. Paulo, nas proximidades do campo de futebol da Sede, foram escavados seis níveis artificiais, coletados 15 materiais arqueológicos (13 cerâmicas e dois líticos) e evidenciadas, além da superfície, 3 camadas de sedimentos (Mapa 6, Tabela 9, Foto 16, Ilustrações no Anexo 2). Na superfície, constituída por chão batido arenoso marrom-claro, foi coletado 1 fragmento cerâmico. Na camada A, evidenciada com a escavação do nível 1 e parte do nível 2, formada por sedimento arenoso marrom-claro, foram coletados 8 materiais, 7 cerâmicos e 1 lítico. A camada B, observada através dos sedimentos areno-argilosos marrons escavados nos níveis 2, 3 e parte do 4, apresentou 6 materiais, 5 cerâmicos e 1 lítico. O restante do nível 4 e os níveis 5 e 6 revelaram a ocorrência de uma outra camada, denominada $\mathrm{C}$, constituída por sedimento areno-argiloso marrom-avermelhado, arqueologicamente estéril.

\begin{tabular}{|c|c|c|c|}
\hline \multicolumn{5}{|c|}{ Tabela 9: Materiais arqueológicos coletados no Poço-teste 2 no setor 1 do sítio Córrego Lalima (MS-MI-01) } \\
\hline Níveis/Camadas & Cerâmicos & Líticos & Totais \\
\hline N0/Superficial & 1 & & 1 \\
\hline N1/Camada A & 5 & 1 & 6 \\
\hline N2/Camadas A e B & 2 & 1 & 2 \\
\hline N3/Camada B & 5 & & \\
\hline N4/Camdas B e C & & & \\
\hline N5/Camada C & 13 & 2 & 15 \\
\hline Totais & &
\end{tabular}


Tanto a camada A quanto a B apresentaram refugos de materiais industrializados, os quais provavelmente são relacionados ao contexto etnográfico atual, sugerindo que ambas as camadas foram perturbadas e remexidas. Pode ser que o poçoteste tenha sido escavado em um aterro relacionado à construção da moradia do Sr. Paulo, sobretudo com a construção de uma casa mais antiga, derrubada para a construção das casas atuais.

Com o objetivo de realizar observações mais sistemáticas no contexto Guarani detectado no sítio Córrego Lalima, foram selecionados 428 fragmentos de vasilhas cerâmicas considerados diagnósticos da forma e do acabamento de superfície entre os materiais coletados no setor 1 . Entre os fragmentos selecionados, 376 , ou seja, 87,85\%, foram recolhidos em superfície, sobretudo no campo de futebol (ver Gráfico 1). Entre os fragmentos restantes, provenientes das atividades de coleta de sub-superfície, 32 peças, ou $7,47 \%$ da amostra total, foram coletadas no poço-teste 1 , o mesmo onde foi obtida a amostra de carvão datada.

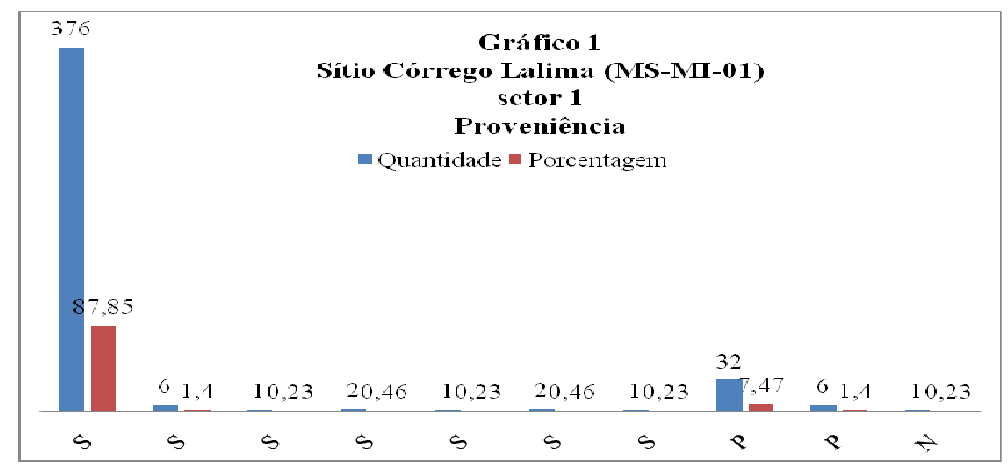

Em se tratando da análise da forma, 356 fragmentos $(83,17 \%)$ foram categorizados como paredes de vasilhas, 67 (15,65\%) como bordas e $4(0,93 \%)$ como bases (ver Gráfico 2). Entre os fragmentos de parede, 21 (5,89\%) foram classificados como paredes infletidas, por apresentarem ponto de inflexão, ou seja, mudança de direção no contorno da vasilha; $16(4,49 \%)$ como paredes carenadas, por apresentarem carenas, caracterizadas por pontos angulares salientes; $3(0,84 \%)$ como paredes complexas, por possuírem 2 pontos angulares reentrantes; 2 (0,56\%) como paredes do segmento superior do bojo de vasilhas restringidas; e $314(88,2 \%)$ não foram categorizadas (Gráfico 3, Foto 17). Entre os fragmentos de base, 3 foram classificados como circular-plano e 1 como circular convexa (Gráfico 4). 

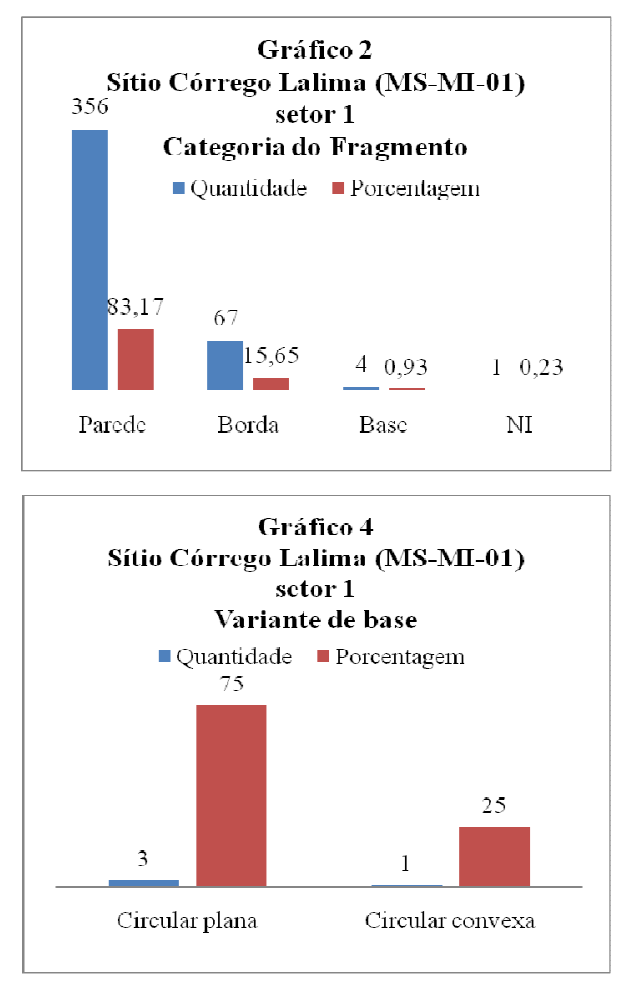
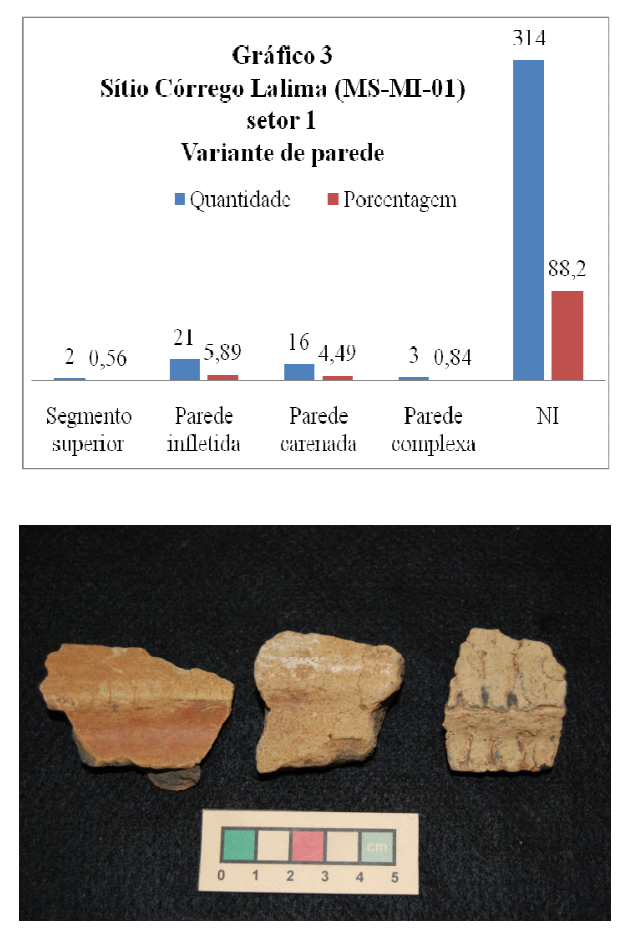

Foto 17: Fragmentos de parede carenada analisados no setor 1 do sítio Córrego Lalima

Entre os fragmentos categorizados como bordas, 13 (19,4\%) foram classificadas como direta vertical, por apresentarem ângulo entre 0 e $10^{\circ}$ positivos ou negativos; 7 $(10,44 \%)$ como direta inclinada externa, com ângulo entre 10 e $30^{\circ}$ positivos; outras 7 $(10,44 \%)$ como direta inclinada interna, com ângulo entre 10 e $30^{\circ}$ negativos; mais 7 (10,44\%) como côncavas; 6 como extrovertidas, como ângulo superior a $30^{\circ}$ positivos; $4(5,97 \%)$ como cambadas, por apresentarem pontos angulares salientes e reentrantes; 1 $(1,49 \%)$ como introvertida, com ângulo superior a $30^{\circ}$ negativos; 1 (1,49\%) como carenada; e 1 (1,49\%) como inflectida (ver Gráfico 5). Acerca da forma do lábio, 30 dentre os fragmentos de bordas (44,77\%) apresentaram-se arredondados, $11(16,41 \%)$ apontados, $9(13,43 \%)$ aplanados, $7(10,44)$ como reforçado externo, 6 (8,95\%) biselados, 2 (2,98\%) ondulados, 1 (1,49\%) como expandido e $1(1,49 \%)$ não apresentava lábio (Gráfico 6). O diâmetro da boca foi aferido em 19 (28,36\%) das bordas analisadas, sendo $3(4,22 \%)$ com $4 \mathrm{~cm}, 2(2,81 \%)$ com $30 \mathrm{~cm}$ e outras $2(2,81 \%)$ com $40 \mathrm{~cm}$. O restante das bordas apresentaram os seguintes diâmetros de boca, com 1 $(1,49 \%)$ ocorrência cada: $6 \mathrm{~cm}, 8 \mathrm{~cm}, 12 \mathrm{~cm}, 14 \mathrm{~cm}, 18 \mathrm{~cm}, 20 \mathrm{~cm}, 22 \mathrm{~cm}, 24 \mathrm{~cm}, 28 \mathrm{~cm}$, $30 \mathrm{~cm}, 32 \mathrm{~cm}, 40 \mathrm{~cm}, 42 \mathrm{~cm}$ e $58 \mathrm{~cm}$ (Gráfico 7, Ilustrações 1, 2, 3 e 4).

Novamente considerando-se todos os fragmentos selecionados no setor 1 do sítio Córrego Lalima, ou seja, as 428 peças diagnósticas, 198 (46,26\%) apresentaram espessura fina, entre 5 e 10mm; 166 (38,78\%) espessura média, entre 10 e $15 \mathrm{~mm} ; 40$ 
$(9,34 \%)$ espessura grossa, entre 15 e 20mm; 21 (4,9\%) espessura muito fina, ou seja, menor que $5 \mathrm{~mm}$; e $2(0,46 \%)$ espessura muito grossa, ou melhor, maior que $20 \mathrm{~mm}$ (ver Gráfico 8). Sobre a relação entre os diâmetros da boca e do bojo, 72 (16,28\%) dos fragmentos analisados proporcionaram diâmetro da boca menor que o diâmetro do bojo, características de vasilhas fechadas, restringidas ou restringidas independentes; 5 $(1,16 \%)$ apresentaram diâmetro da boca maior ou igual ao do bojo, específicas de vasilhas abertas, não restringidas (Gráfico 9).
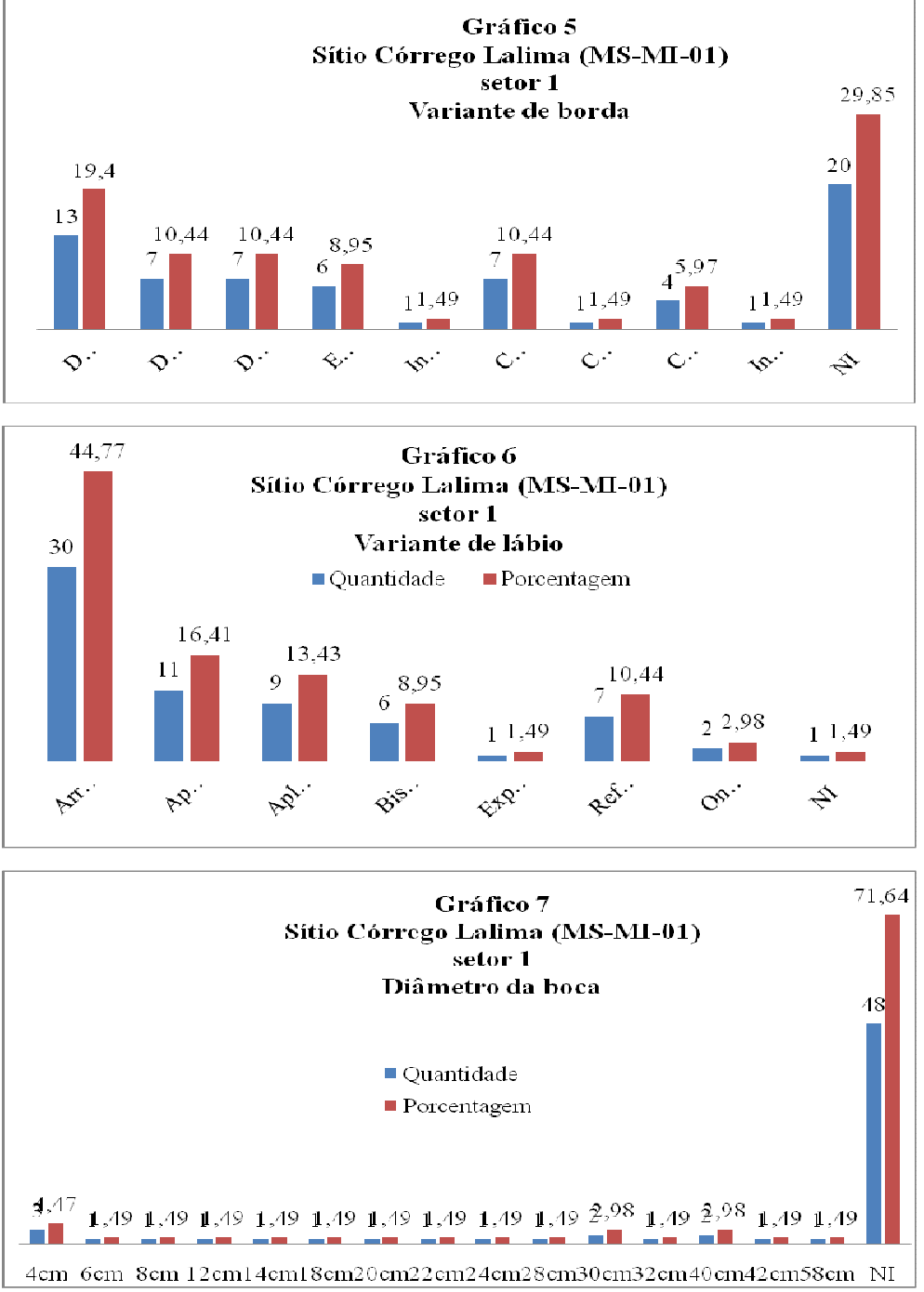

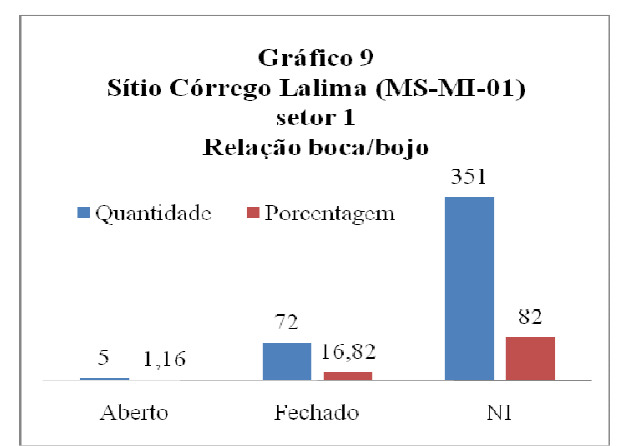


Com a análise dos atributos observáveis, foi possível inferir que 10 fragmentos $(2,33 \%)$ estavam associados com vasilhas restringidas independentes, $6(1,4 \%)$ com vasilhas restringidas e $5(1,16)$ com vasilhas não restringidas (Gráfico 10). Do mesmo modo, 7 fragmentos $(1,63 \%)$ são relativos a vasilhas com contornos complexos, 5 $(1,16 \%)$ com contornos simples, $2(0,26 \%)$ com contornos simples e outros $2(0,26 \%)$ com contornos inflectidos (Gráfico 11). Sobre a forma, $3(0,7 \%)$ foram classificadas como esféricas, 2 (0,46\%) como cônicas e 1 (0,23\%) como semi-esférica (Gráfico 12).

Com base no método de reconstituição gráfica das classes funcionais proposto por Brochado e colaboradores (cf. Brochado \& Monticelli 1994, Brochado, Monticelli \& Neumann 1990, Noelli \& Brochado 1998, La Salvia \& Brochado 1989), 14 bordas (3,27\%) foram associadas com os yapepó, 10 (2,33\%) como os cambuchi, 7 (1,63) com os cambuchi caguâba e $1(0,23 \%)$ com o ñaetá (Gráfico 13, Ilustrações 1 à 4)). Ainda segundo o método citado, foi possível deduzir, conforme a proporcionalidade entre a abertura da boca e a altura dos yapepó e cambuchi caguâba, que 2 fragmentos $(0,46 \%)$ são relativos a uma miniatura de yapepó e a um cambuchi caguâba, com até $10 \mathrm{~cm}$ de altura, $1(0,23 \%)$ a yapepó boyá, entre 10 e $20 \mathrm{~cm}$ de altura e 1 outro $(0,23 \%)$ a um yapepó guaçú, maior que $50 \mathrm{~cm}$ de altura (Gráfico 14).
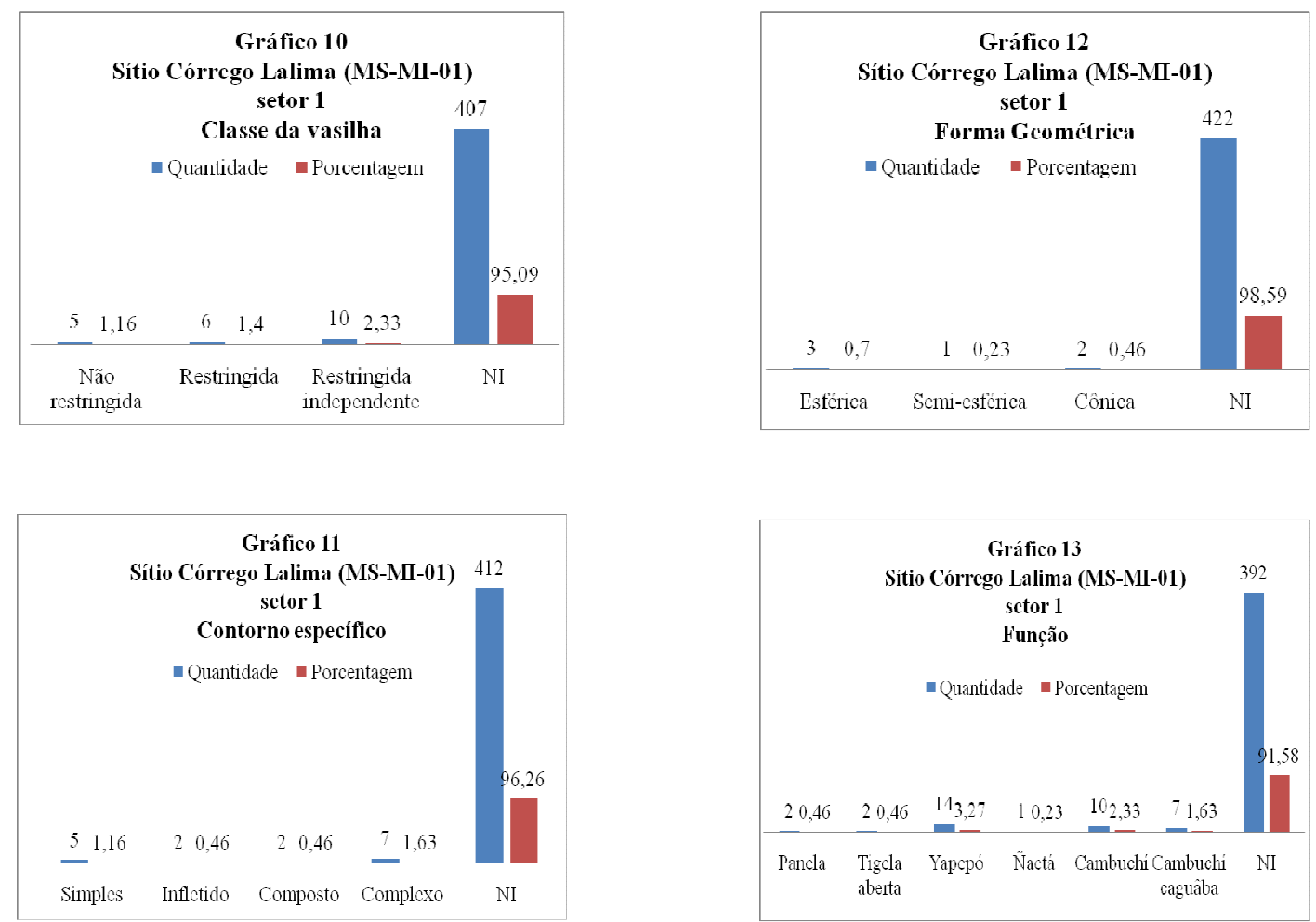


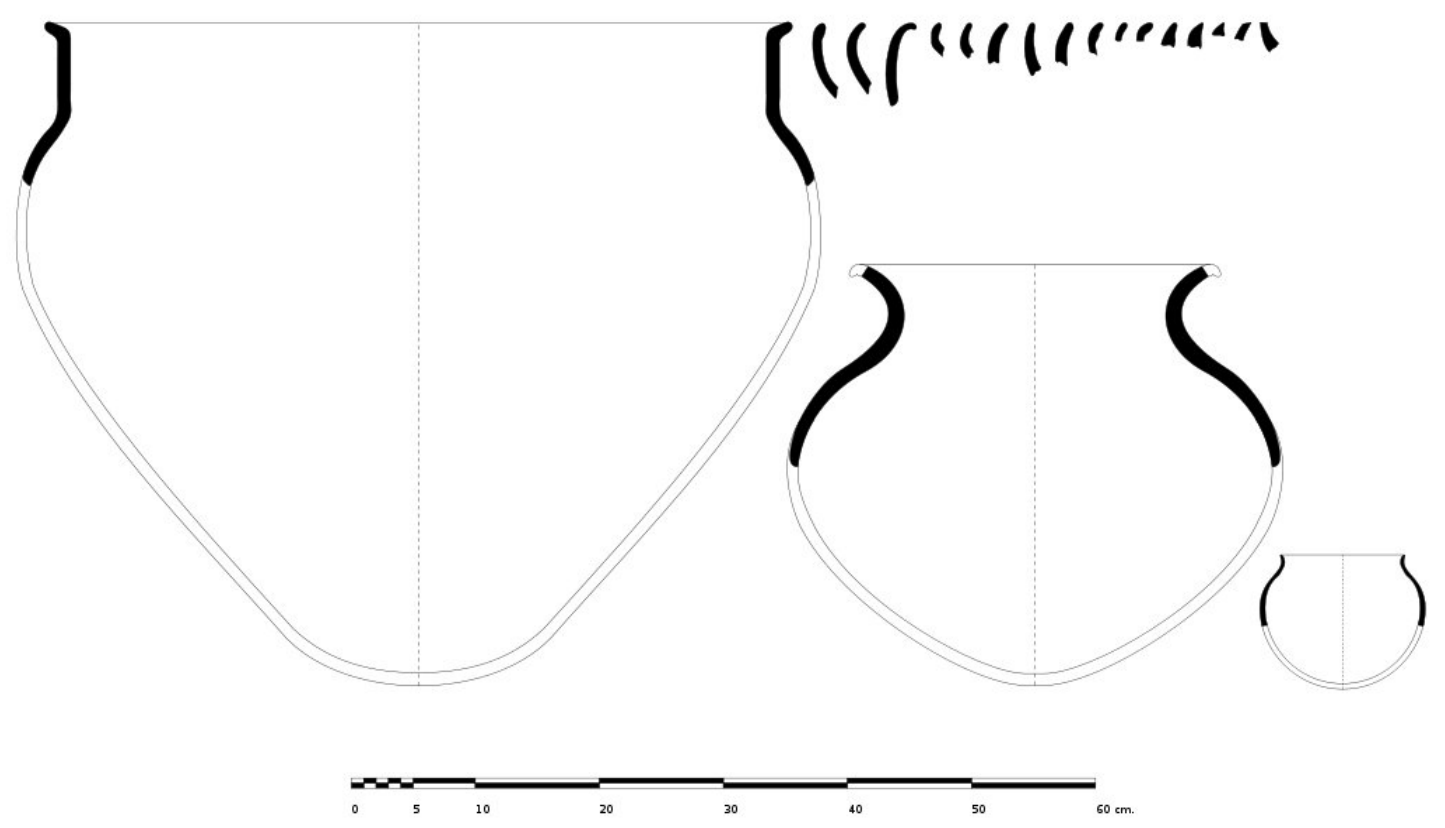

Ilustração 1: Bordas côncavas, diretas e inflectidas de yapepó analisadas no setor 1do sítio Córrego Lalima

Sitio Córrego Lalima (MS-MI-01) Setor 1 Bordas Ñaetá

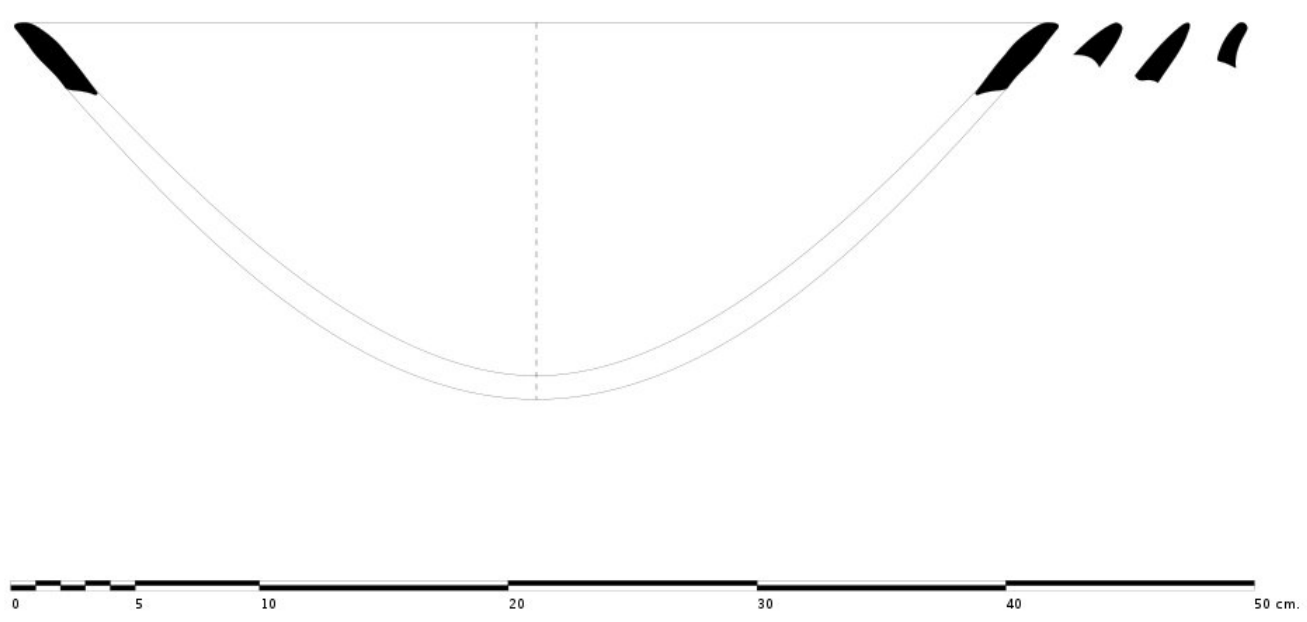

Ilustração 2: Bordas extrovertidas de ñaetá analisados no setor 1 do sítio Córrego Lalima 
Sitio Córrego Lalima (MS-MI-01) Setor I Bordas Cambuchi

\}

$11121 \cdots$

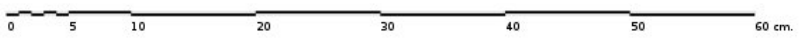

Ilustração 3: Bordas cambadas, carenadas e diretas de cambuchi analisadas no setor 1 do sítio Córrego Lalima

Sitio Córrego Lalima (MS-MI-01) Setor 1 Bordas Cambuchi Caguâba

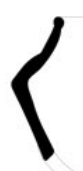

$\left.\gamma^{\prime \prime 1}\right)^{\prime}$

Sítio Córrego Lalima (MS-MI-01) Setor 1 Bordas Direta Vertical

$\| 1+1 \mid$

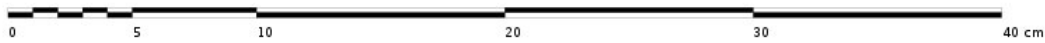

Ilustração 4: Bordas cambadas e carenadas de cambuchi caguâba e bordas direta vertical analisadas no setor 1 do sítio Córrego Lalima 
Sobre o acabamento de superfície na face externa, 375 fragmentos $(87,61 \%)$ apresentaram tratamento plástico e $47(10,98 \%)$ tratamento cromático (Gráfico 15). Entre os tratamentos plásticos, 292 (68,22\%) foram classificados como corrugados, 44 (10,28\%) como alisados, 15 (3,5\%) como polidos, 12 (2,8\%) como ungulados, 6 (1,4\%) como incisos, $2(0,46 \%)$ como nodulado, outros $2(0,46 \%)$ como impresso com corda, 1 $(0,23 \%)$ como ponteado e 1 outro $(0,23 \%)$ como roletado. Entre os tratamentos cromáticos, 29 fragmentos (6,77\%) apresentaram banho de engobo branco, 17 (3,97\%) pintura vermelha e/ou preta sobre engobo branco e $1(0,23 \%)$ apresentou engobo vermelho na face externa. Na face interna, foram observados tratamentos plásticos em 392 fragmentos (91,58\%) e cromáticos em 23 (5,37\%; Gráfico 16). Entre os plásticos, 249 fragmentos $(58,17 \%)$ apresentaram alisamento e $143(33,41 \%)$ polimento. Já entre os cromáticos, foram observados 12 fragmentos $(2,8 \%)$ como engobo branco, $6(1,4 \%)$ como engobo vermelho e $5(1,16 \%)$ com pintura vermelha e/ou preta sobre engobo branco. Entre as bordas, ou seja, 67 peças (15,65\%), foram registrados 40 fragmentos (59,7\%) com lábios alisados, 12 (17,91\%) com lábios polidos, 6 (8,95\%) com lábios pintados de vermelho, sobretudo faixas, e $3(4,47 \%)$ com lábios decorados com apliques de filigranas de argila (Gráfico 17, Fotos 18 à 23).
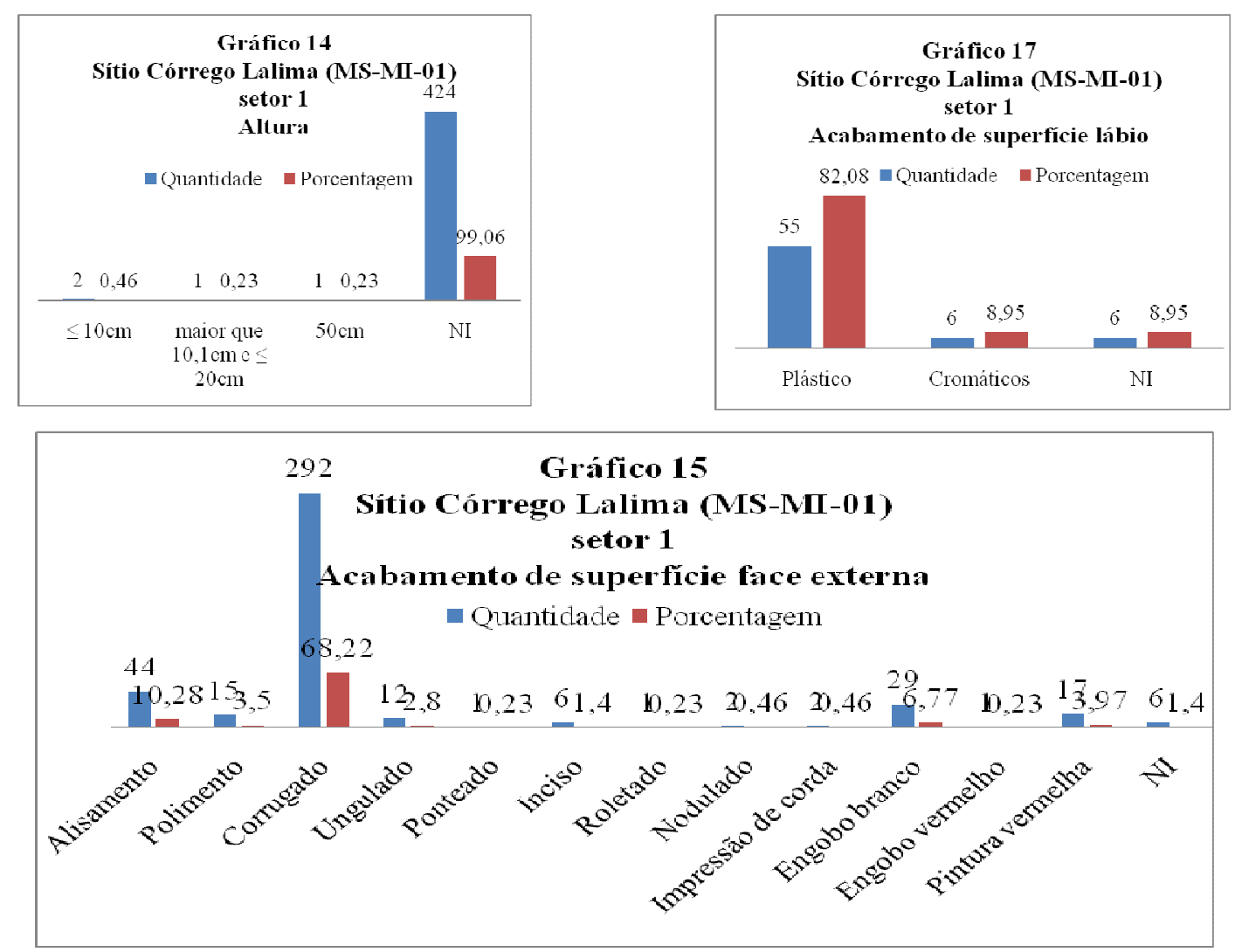


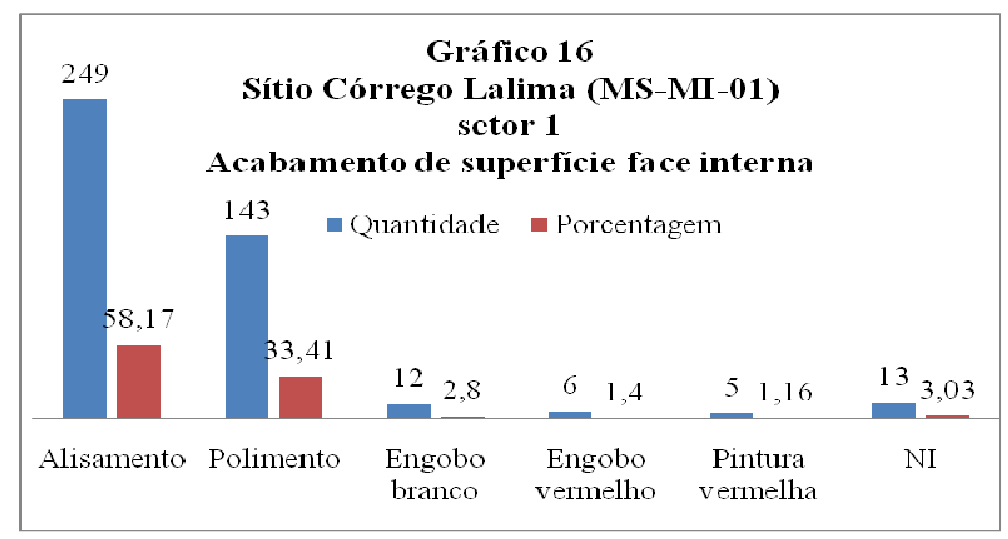

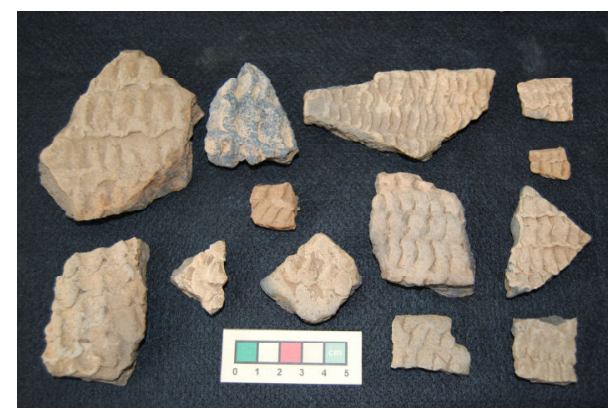

Foto 18: fragmentos corrugados de vasilhas cerâmicas Guarani analisados no setor 1 do sítio Córrego Lalima

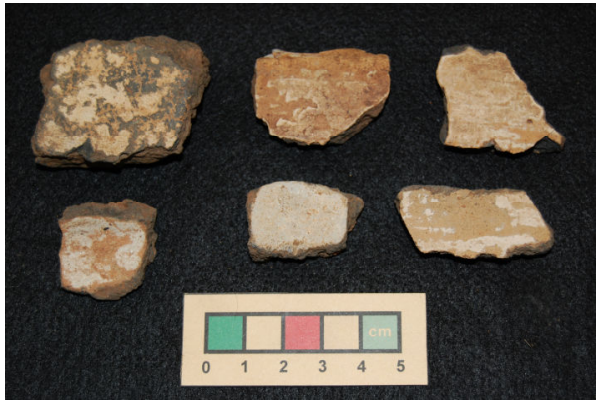

Foto 19: Fragmentos com tratamento cromático de vasilhas cerâmicas Guarani analisados no setor 1 do sítio Córrego Lalima

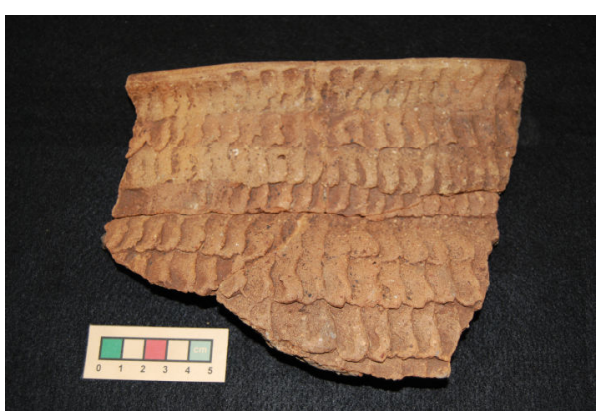

Foto 20: Fragmento de borda de yapepó guaçu analisados no setor 1 do sítio Córrego Lalima

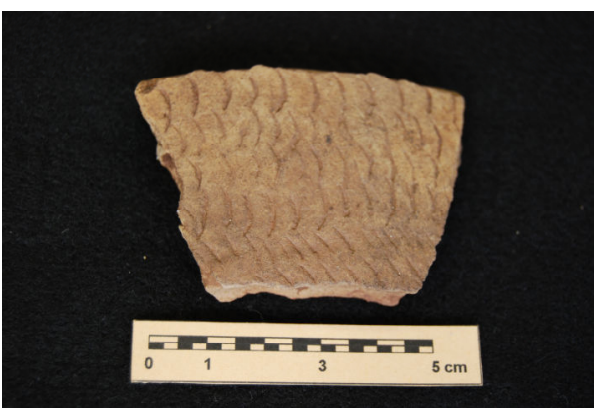

Foto 21: Fragmento ungulado de vasilha cerâmica Guarani analisados no setor 1 do sítio Córrego Lalima

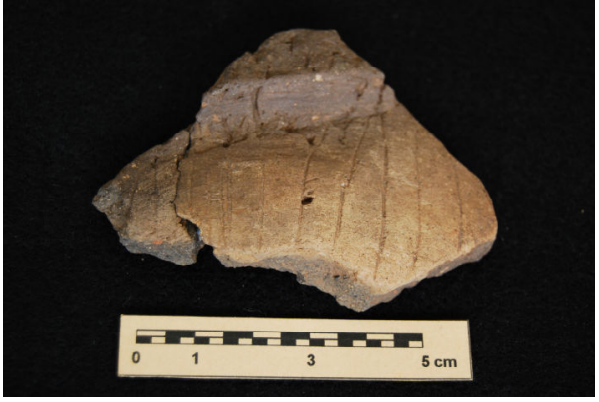

Foto 22: Fragmento carenado de vasilha cerâmica Guarani com incisões analisados no setor 1 do sítio Córrego Lalima

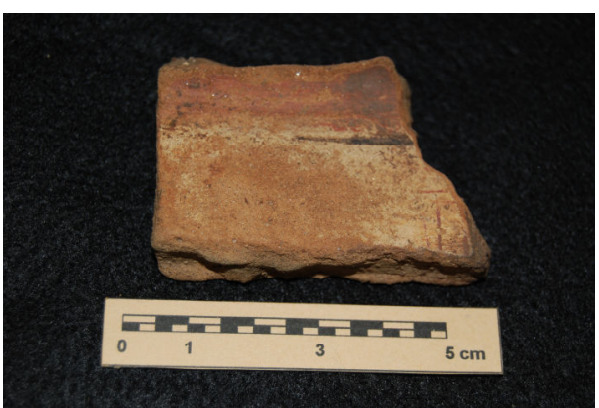

Foto 23: Fragmento de vasilha cerâmica Guarani pintado com linha preta e linhas e

faixas vermelhas sobre engobo branco analisados no setor 1 do sítio Córrego Lalima 
Assim, dentre os fragmentos selecionados no setor 1, 401 (93,69\%) foram classificados como Guarani, 15 (3,5\%) como da Tradição Pantanal e 12 (2,8\%) não foram tecnologicamente identificados (Gráfico 18). Ao que as análises preliminares da forma e do acabamento de superfície indicam, os materiais Guarani coletados em Lalima são análogos aos demais conjuntos Guarani presentes em Mato Grosso do Sul e nas regiões sul e sudeste do Brasil (Kashimoto \& Martins 2008, La Salvia \& Brochado 1989, Mentz Ribeiro 2008, Noelli 1999-2000). Com efeito, assim como naquelas regiões, os fragmentos Guarani em Lalima apresentam formas e acabamentos característicos, como a presença de ao menos 4 dentre as 6 grandes classes funcionais estabelecidas nos trabalhos de Brochado e seus colaboradores e a ocorrência de tratamentos cromáticos, como pintura vermelha e/ou preta sobre engobo branco, e plásticos, como corrugados, ungulados e incisos. Os fragmentos associados à Tradição Pantanal analisados no setor 1 apresentam atributos característicos distintos daqueles presentes nos materiais Guarani, como apliques de filigranas de argila, impressões de corda e associações entre incisos e ponteados.

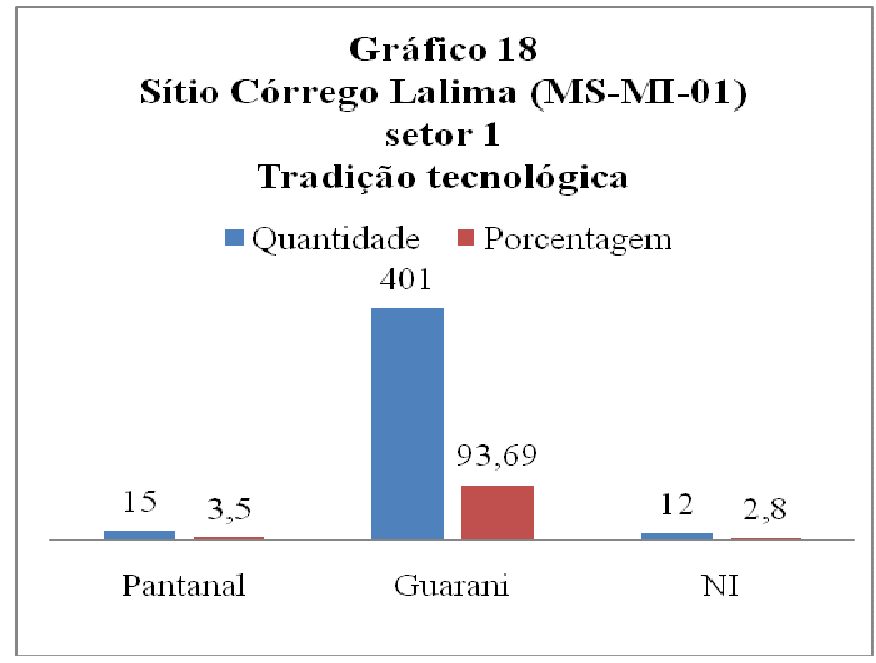

O setor 2 do sítio Córrego Lalima, com $20.000 \mathrm{~m}^{2}$, foi delimitado sobre contexto arqueológico da Tradição Pantanal, situado nas encostas alta e média no norte-nordeste da colina (Mapa 7). Encerrado nas áreas de quatro domicílios, foram coletados 868 materiais no setor, com 604 em superfície (594 cerâmicos e 10 líticos) e 266 em subsuperfície (210 cerâmicos, 42 líticos, 11 orgânicos e 11 louças, Tabela 10). Entre os materiais recolhidos em superfície, 120 fragmentos cerâmicos foram coletados assistematicamente, e 484 (474 cerâmicos e 10 líticos) sistematicamente. As coletas assistemáticas foram realizadas durante as obras relativas aos preparativos do 


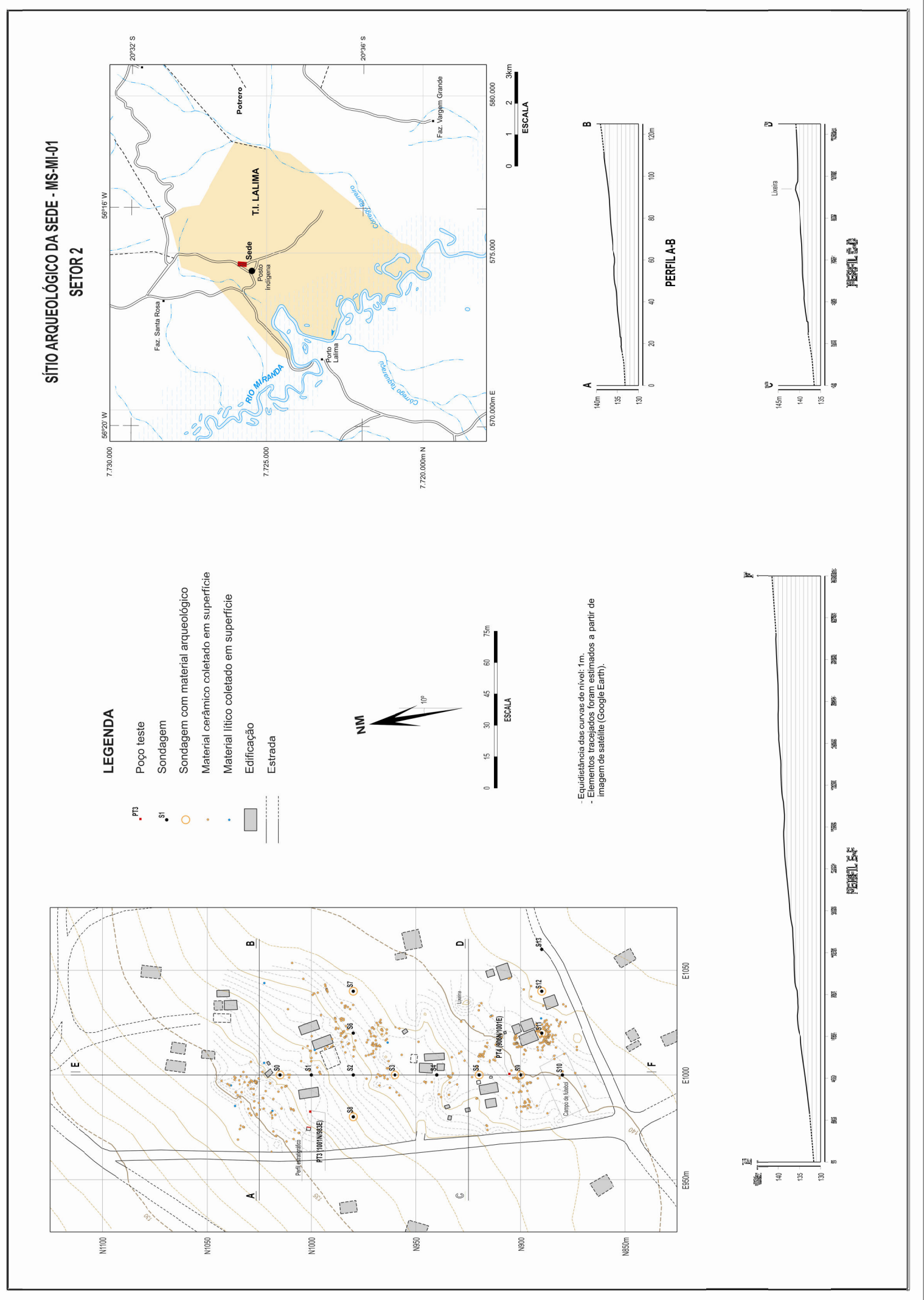


casamento de um dos filhos de Cláudio da Silva, no quintal do seu domicílio, em uma área de $375 \mathrm{~m}^{2}$. Com efeito, o setor 2 foi detectado depois que o referido senhor, membro do Conselho da Sede na categoria de ancião e sogro dos dois Caciques de Lalima, nos chamou para ver os "cacos de pote" descobertos enquanto ele e os seus filhos, entre os quais o Claudinei da Silva, nosso futuro auxiliar, melhoravam os acessos da estrada ao domicílio, aplanando-os com uma enxada, e construíam uma estrutura coberta por folhas de palmácea e suportadas por troncos de árvore, sob a qual seria realizado o casamento (Foto 25).

\begin{tabular}{|c|c|c|c|c|c|}
\hline Tabela 10: Materiais arqueo & cos coletados & setor 2 & sítio Córre & alima (1) & MI-01) \\
\hline Atividades de coleta & Cerâmicos & Líticos & Orgânicos & Louças & Totais \\
\hline Assistemática de superfície & 120 & & & & 120 \\
\hline Sistemática de superfície & 474 & 10 & & & 484 \\
\hline Sub-superfície & 210 & 32 & 11 & 11 & 264 \\
\hline Totais & 804 & 42 & 11 & 11 & 868 \\
\hline
\end{tabular}

A coleta sistemática de superfície, por sua vez, foi efetuada no interior de toda a área setorizada. Apesar da satisfação com a coleção obtida na superfície do setor 2, pois a enorme variação estilística contida nos fragmentos, sobretudo em termos decorativos e morfológicos, não foi observada em nenhum dos outros contextos da Tradição Pantanal detectados em Lalima, a camada superficial, geralmente constituída por sedimentos argilo-arenosos marrons, apresentou-se extremamente perturbada pela ocupação atual, mais até que o setor 1 (Foto 26).

Desafortunadamente, a sub-superfície apresentou o mesmo grau de impacto que a superfície, como foi possível observar desde a escavação das sondagens, as quais evidenciaram, à grosso modo, duas camadas estratigráficas de sedimentos argiloarenosos, uma marrom, situada entre os níveis artificiais 1 e 3 , e outra vermelha, geralmente situada sob a outra, com os materiais arqueológicos concentrados muito mais na primeira que na segunda, não raro em contexto com resíduos industrializados e orgânicos associados ao contexto etnográfico atual. As sondagens totalizaram 14 furos, dispostos numa malha de $20 \mathrm{~m}$, intersectados nas extremidades norte e sul de um segmento de reta estabelecido no centro do setor 2 , média de $54 \mathrm{~cm}$ de fundura e coleta de 27 fragmentos de vasilhas cerâmicas, os quais, por sua vez, foram recolhidos em 8 dos furos escavados (S0, S3, S5, S7, S8, S9, S11, S12, Mapa 7, Tabela 11, Foto 27). Os resultados mais satisfatórios foram obtidos nas sondagens 5 (920N/1000E) e 9 (980N/980E), entre as quais foi escavado o poço-teste 4 (906N/1001E). Porém, tanto o dito poço-teste quanto o poço-teste 3 (1001N/983E), empreendido nas proximidades de 
um perfil retificado na fossa de um mictório inutilizado, tornaram ainda mais clara a certeza de que a sub-superfície foi quase totalmente perturbada, embora também tenham sido coletados 248 materiais arqueológicos nestas escavações (183 cerâmicos, 32 líticos, 11 orgânicos e 11 louças).

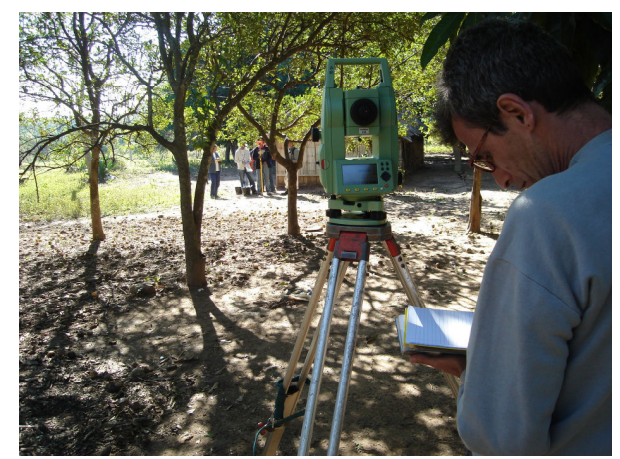

Foto 24: Topografia no setor 2 do sítio Córrego Lalima

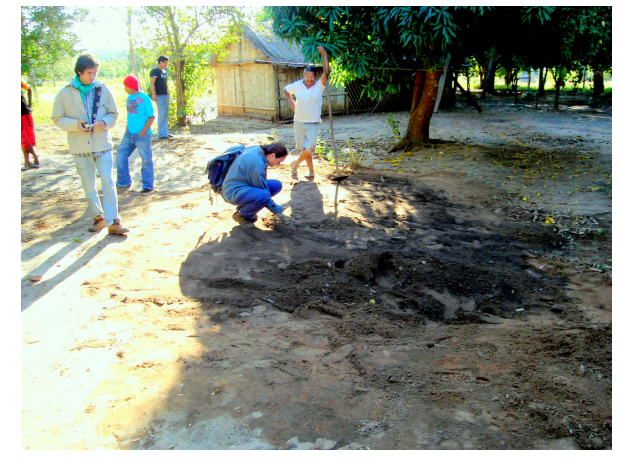

Foto 25: Coleta assistemática de superfície no setor 2 do sítio Córrego Lalima

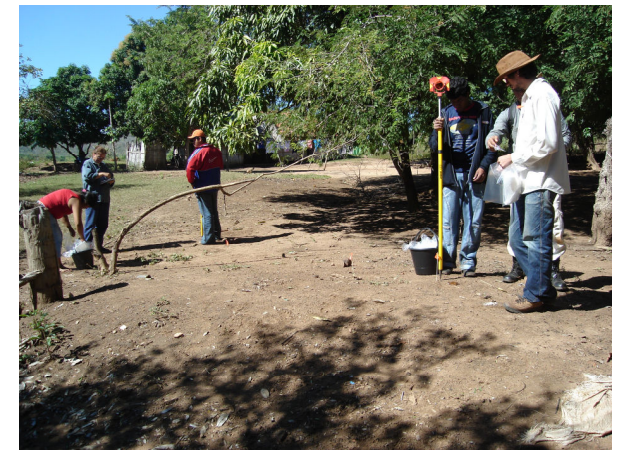

Foto 26: Coleta sistemática de superfície no setor 2 do sítio Córrego Lalima

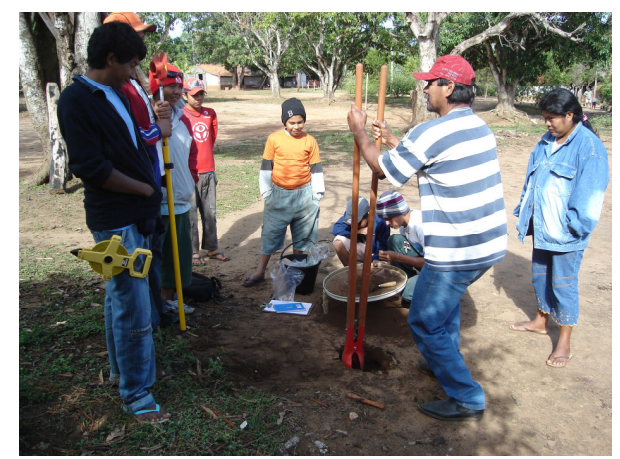

Foto 27: Escavação de sondagens no setor 2 do sítio Córrego Lalima

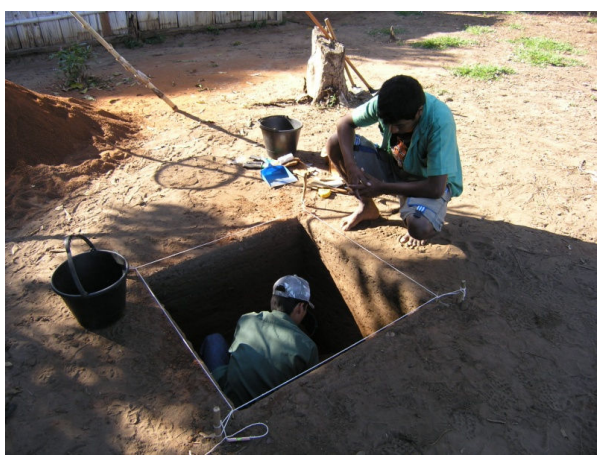

Foto 28: Escavação do poço-teste 3 no setor 2 do sítio Córrego Lalima

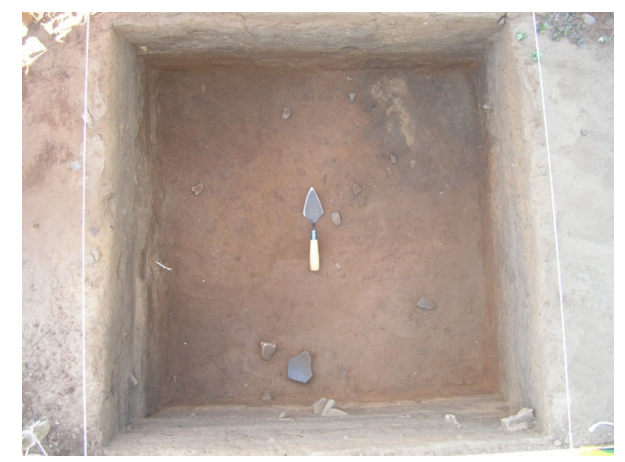

Foto 29: Escavação do poço-teste 4 no setor 2 do sítio Córrego Lalima

O poço-teste 3 foi escavado no domicílio do Sr. Cláudio da Silva, atrás da casa do seu filho, Lourenço da Silva (Mapa 7, Foto 28). Os 10 níveis artificiais escavados revelaram, além da superfície, sete camadas de sedimentos e 79 materiais arqueológicos (46 cerâmicos, 14 líticos, 9 orgânicos e 10 fragmentos de louça, Tabela 12, Ilustrações 
apresentadas no anexo 2). Na superfície, constituída por sedimento areno-argiloso marrom-claro, foram coletadas 8 cerâmicas. Na camada $\mathrm{A}$, formada por areia fina, marrom-claro (dark brown 10YR3/3), foram coletadas 3 cerâmicas. Na camada B, formada por areia fina marrom (dark grayish brown 10YR3/2) com carvões, não foram coletados materiais arqueológicos. As camadas A e B foram evidenciadas com a escavação do nível 1, assim como a camada C, observada em parte do nível 1 e em parte do nível 2, constituída por sedimento areno-argiloso marrom-escuro (dark brown 7.5YR3/2), onde coletaram-se 20 materiais arqueológicos (16 cerâmicos e 4 louças). A continuidade da escavação do nível 2 e do nível 3 evidenciaram a ocorrência da camada $\mathrm{D}$, formada por sedimento areno-argiloso marrom-escuro (very dark brown 10YR2/2), onde foram coletados 38 materiais (16 cerâmicos, 7 líticos, 9 orgânicos e 6 louças). As escavações dos níveis 4, 5, 6 e 7 evidenciaram a camada E, constituída por sedimento areno-argiloso marrom-escuro em transição para vermelho (dark reddish brown 5YR3/4), sem presença de materiais relacionados ao contexto etnográfico atual, porém com apenas 10 materiais arqueológicos coletados (6 cerâmicas e 4 líticos). Finalmente, os níveis 8 à 10 evidenciaram a camada $\mathrm{F}$, formada por sedimento argiloso vermelho (dark red 2.5YR3/6), arqueologicamente estéril.

\begin{tabular}{|c|c|c|}
\hline Sondagens & Cerâmicos & Totais \\
\hline S0 & 4 & 4 \\
\hline S3 & 1 & 1 \\
\hline S5 & 6 & 6 \\
\hline S7 & 1 & 1 \\
\hline S8 & 3 & 3 \\
\hline S9 & 9 & 9 \\
\hline S11 & 3 & 3 \\
\hline S12 & 3 & 3 \\
\hline Totais & 27 & 27 \\
\hline
\end{tabular}

As camadas evidenciadas com a escavação dos níveis 1, 2 e 3, ou seja, camadas A, B, C e D, apresentaram muitos restos de materiais industrializados, tais como metal, plástico, tecido e vidro, em conjunto com muito material arqueológico. Provavelmente, o poço-teste 3 foi escavado em uma lixeira, construída no contexto etnográfico da ocupação atual, na qual tanto os materiais descartados no passado recente quanto os refugos arqueológicos deixados por populações mais antigas foram jogados, queimados e enterrados, no bojo das atividades de limpeza e tratamento do lixo.

O poço-teste 4 foi escavado no domicílio da casa de Carlos, entre um campo de futebol (não confundir com o campo do setor 1) e a casa de um dos seus filhos, chamado Sr. Adenir, entre a S5 e a S9, tendo em vista os resultados obtidos com as 
escavações de ambas (Mapa 7, Foto 29). Além da superfície, constituída por chão batido arenoso marrom-claro, onde foram recolhidas 6 cerâmicas, os 9 níveis artificiais escavados revelaram a ocorrência de mais quatro camadas de sedimentos, denominadas A, B, C e D, e resultaram na coleta de mais 163 materiais arqueológicos (131 cerâmicas, 18 líticos, 2 orgânicos e 1 louça, Tabela 13, Ilustrações no anexo 2). A camada A, evidenciada pelo nível 1 e constituída por sedimento arenoso marrom (brown 7.5YR4/4), apresentou 36 materiais arqueológicos, sendo 29 cerâmicas, 5 líticos e 1 orgânico, além de muitos vestígios de materiais industrializados. A camada $\mathrm{B}$, formada por sedimento arenoso marrom-escuro (dark brown 7.5YR3/3) e evidenciada pelos níveis 2, 3 e 4, apresentou 119 materiais, sendo 102 cerâmicas, 13 líticos, 1 orgânico e 1 fragmento de louça, igualmente descobertos em conjunto com muitos vestígios de materiais industrializados. A camada $\mathrm{C}$, observada a partir da escavação dos níveis 5, 6 e 7, constituída por sedimento areno-argiloso marrom-avermelhado (strong brown 7.5YR4/6), apresentou 10 cerâmicas, além de manchas escuras no quadrante NE. Finalmente, as escavações dos níveis 8 e 9 revelaram a ocorrência de uma outra camada, denominada D, constituída por sedimento areno-argiloso vermelho (dark red 2.5YR3/6), porém arqueologicamente estéril. Muito possivelmente, os refugos de materiais industrializados e as manchas escuras do quadrante NE, descobertos com a escavação do nível 1 ao 6, ou seja, camadas A, B e C, estão associadas a uma lixeira escavada no solo no contexto etnográfico da ocupação indígena atual, do mesmo modo como ocorrido no poço-teste 3.

\begin{tabular}{|c|c|c|c|c|c|}
\hline \multicolumn{6}{|c|}{ Tabela 12: Materiais arqueológicos coletados no Poço-teste 3 no setor 2 do sítio Córrego Lalima (MS-MI-01) } \\
\hline Níveis/Camadas & Cerâmicos & Líticos & Orgânicos & Louças & Totais \\
\hline N0/Superficial & 8 & & & & 8 \\
\hline N1/Camadas A, B e C & 16 & 3 & & 4 & 23 \\
\hline N2/Camadas C e D & 10 & 3 & 5 & 4 & 22 \\
\hline N3/Camada D & 6 & 4 & 4 & 2 & 16 \\
\hline N4/Camada E & 4 & 4 & & & 8 \\
\hline N5/Camada E & 1 & & & & 1 \\
\hline \multicolumn{6}{|l|}{ N6/Camada E } \\
\hline N7/Camada E & 1 & & & & 1 \\
\hline \multicolumn{6}{|l|}{ N8/Camada F } \\
\hline \multicolumn{6}{|l|}{ N9/Camada F } \\
\hline \multicolumn{6}{|l|}{ N10/Camada F } \\
\hline Totais & 46 & 14 & 9 & 10 & 79 \\
\hline
\end{tabular}

No setor 2, foram selecionados 179 fragmentos cerâmicos diagnósticos da forma e do acabamento de superfície das vasilhas da Tradição Pantanal em Lalima. Destes, 130 (72,62\%) foram coletados em superfície e 49 (27,38\%) em sub-superfície (Gráfico 19). 89 fragmentos $(49,72 \%)$ foram categorizados como paredes, 80 (44,69\%) como bordas, 5 (2,79\%) como bases e 4 (2,23\%) como apêndices de suspensão (Gráfico 20). 
Entre os fragmentos de parede, $15(8,37 \%)$ foram classificados como paredes infletidas, $2(2,24 \%)$ como pertencente ao segmento superior de vasilha restringida ou não restringida e $1(1,12 \%)$ como ombro, caracterizado a partir de um ponto de tangência vertical no maior diâmetro do bojo (Gráfico 21). Todos os fragmentos de bases foram classificados como circular-convexa e todos os apêndices de suspensão como alças.

\begin{tabular}{|c|c|c|c|c|c|}
\hline \multicolumn{6}{|c|}{ Tabela 13: Materiais arqueológicos coletados no Poço-teste 4 no setor 2 do sítio Córrego Lalima (MS-MI-01) } \\
\hline Níveis/Camadas & Cerâmicos & Líticos & Orgânicos & Louças & Totais \\
\hline N0/Superficial & 6 & & & & 6 \\
\hline N1/Camada A & 29 & 5 & 1 & & 36 \\
\hline N2/Camada B & 56 & 8 & & 1 & 67 \\
\hline N3/Camada B & 36 & 4 & 1 & & 41 \\
\hline N4/Camadas B e C & 10 & 1 & & & 11 \\
\hline N5/Camada C & 2 & & & & 2 \\
\hline $\mathrm{N} 6 /$ Camada C & 6 & & & & 6 \\
\hline \multicolumn{6}{|l|}{ N7/Camada C e D } \\
\hline \multicolumn{6}{|l|}{ N8/Camada D } \\
\hline \multicolumn{6}{|l|}{ N9/Camada D } \\
\hline Totais & 137 & 18 & 2 & 1 & 169 \\
\hline
\end{tabular}

Entre os fragmentos de borda, 23 (28,75\%) foram qualificados como extrovertidas, $20(25 \%)$ como direta vertical, 4 (5\%) como direta inclinada externa, outros 4 (5\%) como direta inclinada interna, 3 (3,75\%) como côncava e 1 (1,25\%) como inflectida (Gráfico 22, Ilustrações 5 à 7). Em se tratando do lábio, 41 (51,25\%) foram classificados como reforçado externo, 12 (15\%) como rebarbado, 9 (11,25\%) como arredondado, outros $9(11,25 \%)$ como dobrado, $3(3,75 \%)$ como apontado, outros 3 $(3,75 \%)$ como aplanado e mais $3(3,75 \%)$ como biselado (Gráfico 23). Acerca do diâmetro da boca, foram observados 5 fragmentos de bordas $(6,25 \%)$ com $22 \mathrm{~cm}, 4$ (5\%) com $18 \mathrm{~cm}$, outros $4(5 \%)$ com $32 \mathrm{~cm}$ e $3(3,75 \%)$ com $26 \mathrm{~cm}$. Ainda foram registrados os seguintes diâmetros de boca, em um fragmento de borda cada: $10 \mathrm{~cm}, 12 \mathrm{~cm}, 14 \mathrm{~cm}$, $16 \mathrm{~cm}$ e $30 \mathrm{~cm}$ (Gráfico 24).

A respeito da espessura, 120 fragmentos (67,03\%) foram classificados como finos, $40(22,34 \%)$ como muito finos, $17(9,49 \%)$ como médios, $1(0,55)$ como grosso e outro $1(0,55 \%)$ como muito grosso (ver Gráfico 25$)$. Sobre a relação entre o diâmetro da boca e do bojo, 32 fragmentos $(17,87 \%)$ foram categorizados como fechados e 21 (11,73\%) como abertos (Gráfico 26).

No tocante à classe de simetria das vasilhas, 20 fragmentos $(11,17 \%)$ foram associados com vasilhas não restringidas, outros $11(6,14 \%)$ com vasilhas restringidas e $1(0,55 \%)$ com uma vasilha restringida independente (Gráfico 27). Em se tratando do contorno, 21 fragmentos $(11,73 \%)$ foram classificados como simples e 7 (3,91\%) como inflectidos (Gráfico 28). Em relação à forma geométrica, 7 fragmentos $(3,91 \%)$ foram 
relacionados com vasilhas semi-esféricas, 2 (1,11\%) com vasilhas esféricas, $1(0,55 \%)$ com uma vasilha semi-elíptica horizontal e 1 outro $(0,55 \%)$ com uma vasilha semi-oval vertical (Gráfico 29, Ilustrações 5 à 7). Em termos funcionais, 1 fragmento Guarani $(0,55 \%)$ foi associado a um yapepó.

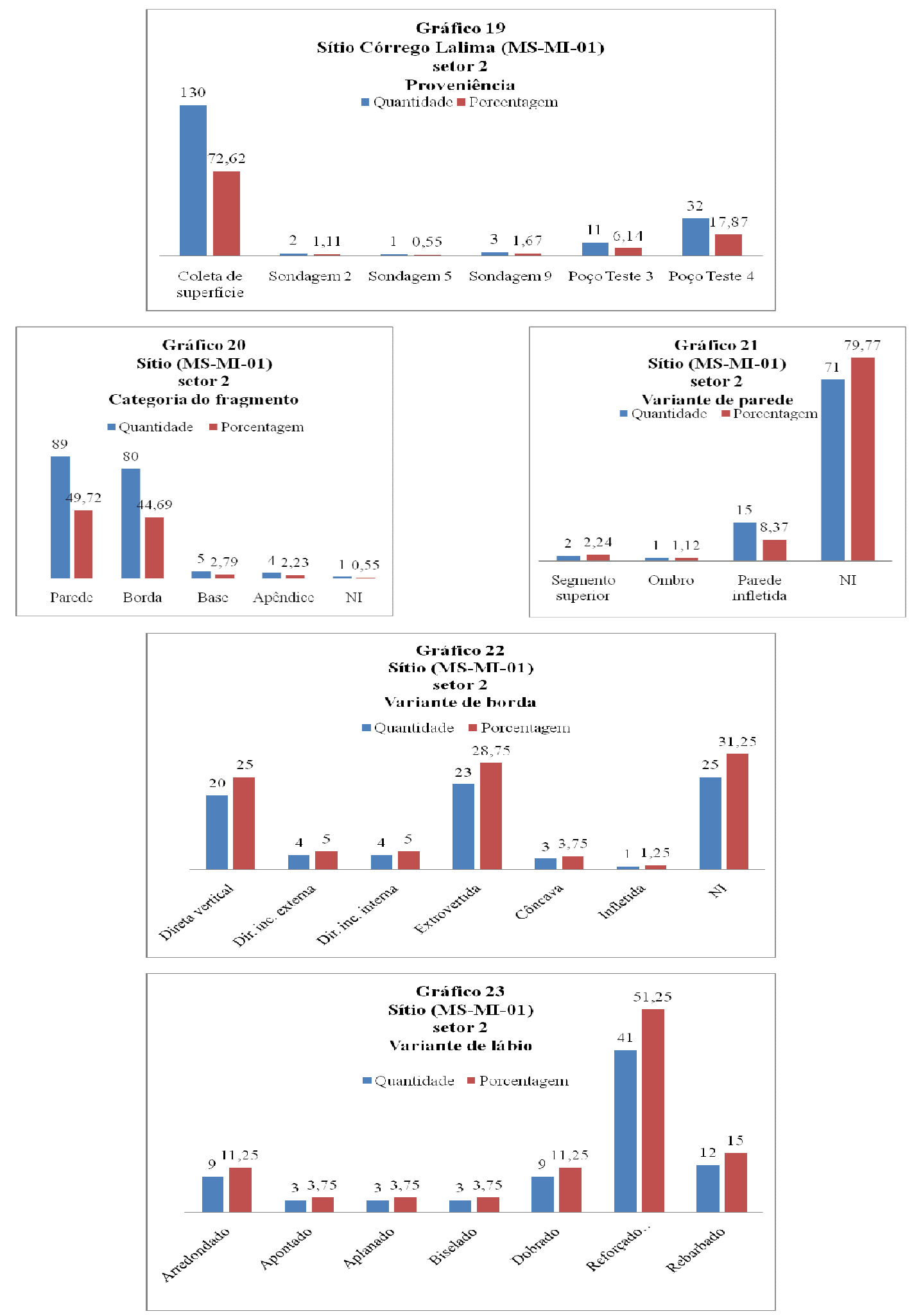




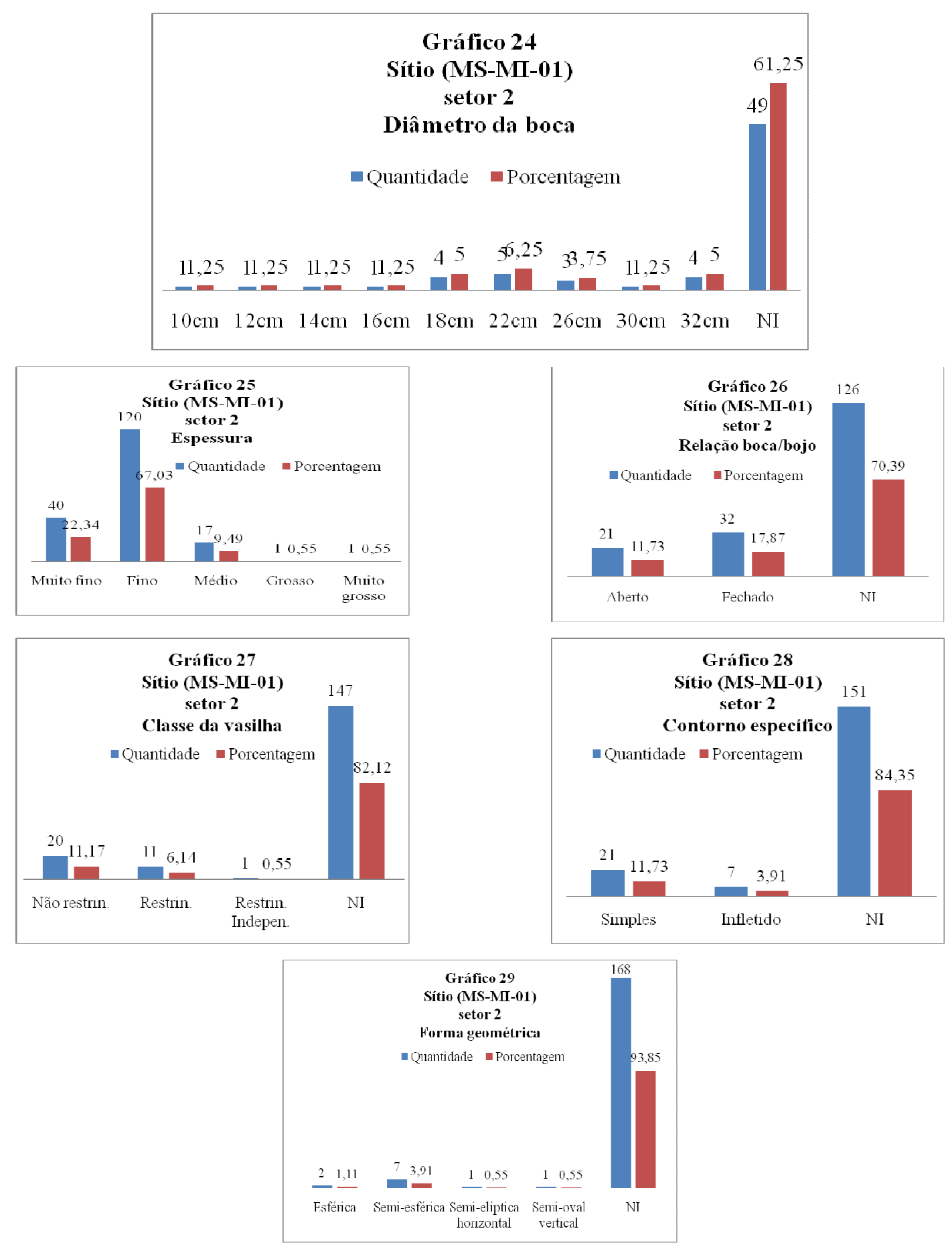

No que se refere ao acabamento de superfície na face externa, foram verificados 135 fragmentos $(75,41 \%)$ com tratamentos plásticos e $34(18,99 \%)$ com tratamentos cromáticos (Gráfico 30). Entre os tratamentos plásticos, 59 fragmentos (32,96\%) apresentaram a face externa alisada, $21(11,73 \%)$ incisa, $13(7,26 \%)$ polida, outros 13 (7,26\%) corrugada, mais $13(7,26 \%)$ acanalada, $6(3,35 \%)$ aplicada com filigranas de argila, outros $6(3,35 \%)$ impressa com cordas, $3(1,67 \%)$ ponteada e $1(0,55 \%)$ perfurada. Já entre os tratamentos cromáticos na face externa, 23 (12,84\%) 
apresentaram pintura vermelha, 10 (5,58\%) engobo vermelho e $1(0,55 \%)$ engobo branco. $\mathrm{Na}$ face interna, foram observados 158 fragmentos $(88,26 \%)$ com tratamentos plásticos e $17(9,49 \%)$ com cromáticos (Gráfico 31). Entre aqueles com tratamentos plásticos, foram contabilizados 109 (60,89\%) alisados, 46 (25,69\%) polidos, 2 (1,11\%) corrugados e $1(0,55 \%)$ aplicado. Entre os cromáticos, 9 (5,02\%) apresentaram pintura vermelha, 7 (3,91\%) engobo vermelho e 1 (0,55\%) engobo branco. É importante ressaltar que as corrugações na Tradição Pantanal, caracterizadas por roletadoscorrugados, são diferentes das corrugações Guarani, mais digitais e rugosas. No lábio dos fragmentos de bordas, foram observados 68 (85\%) tratamentos plásticos e 11 (13,75\%) cromáticos (Gráfico 32). Entre os plásticos, foram qualificados 41 (51,25\%) como alisados, $17(21,25 \%)$ aplicados com filigranas, 7 (8,75\%) polidos, 2 (2,5\%) ponteados e $1(1,25 \%)$ ungulado (Fotos 30 à 38$)$.

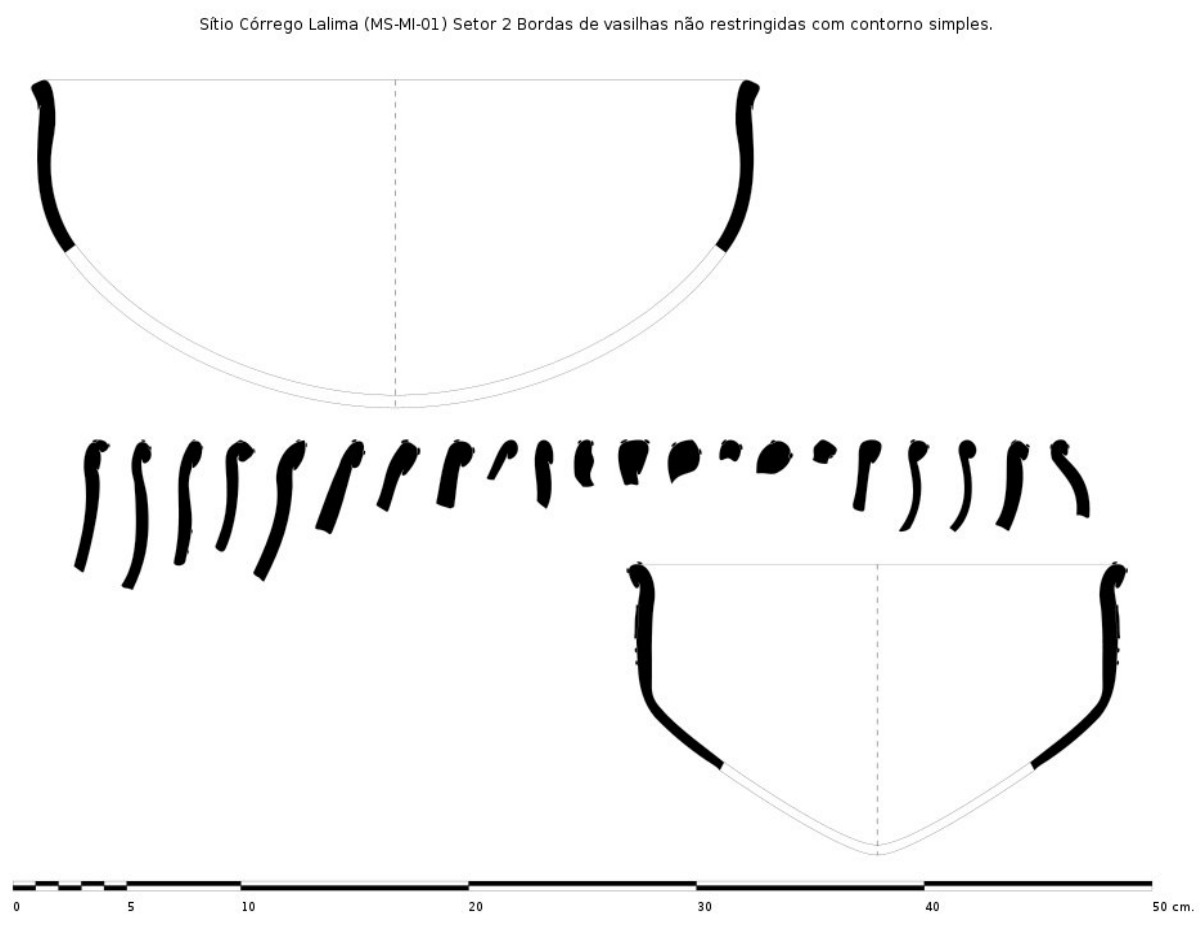

Ilustração 5: Bordas diretas com lábio reforçado analisadas no setor 2 do sítio Córrego Lalima

Em termos tecnológicos, 159 fragmentos $(88,82 \%)$ foram categorizados como Tradição Pantanal, 13 (7,26\%) como Guarani e 7 (3,91\%) como etnográficos (Gráfico 33). De acordo com as análises preliminares, os materiais cerâmicos da Tradição Pantanal detectados no setor 2 do sítio Córrego Lalima podem ser caracterizados pela presença de vasilhas não restringidas, restringidas e restringidas independentes, contornos simples e inflectidos, formas semi-esféricas, semi-elípticas, semi-ovais e 
esféricas, bordas extrovertidas e diretas, lábios reforçados externamente, não raro decorados com apliques de filigranas, presença de apêndices de suspensão, funções como tigelas, jarras e panelas, com decorações plásticas incisas, corrugadas, acanaladas, aplicadas, impressas com corda, ponteadas e perfuradas, e cromáticas como pinturas de faixas vermelhas e banhos de engobo vermelho.

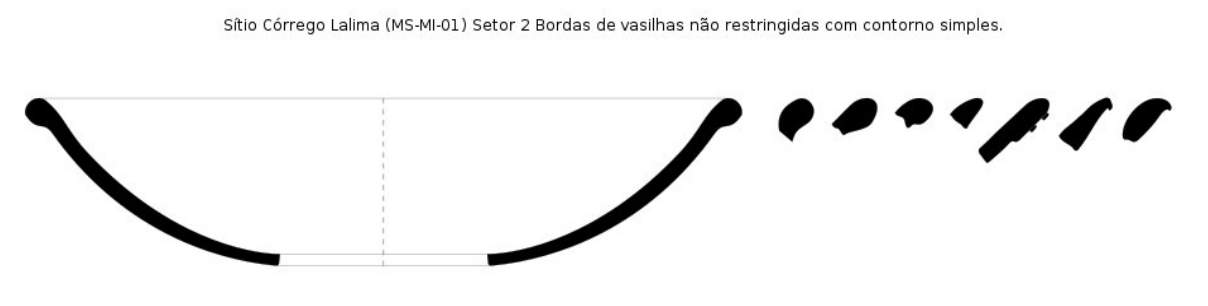

Sítio Córrego Lalima (MS-MI-01) Setor 2 Bordas Direta Vertical

\section{P(II}

Sitio Córrego Lalima (MS-MI-01) Setor 2 Borda Extrovertida
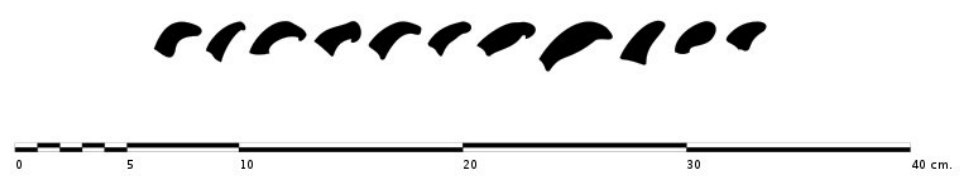

Ilustração 6: Bordas extrovertidas e diretas analisadas no setor 2 do sítio Córrego Lalima

Sítio Córrego Lalima (MS-MI-01) Setor 2 Bordas de Vasilhas Restringidas com Contornos Inflectidos

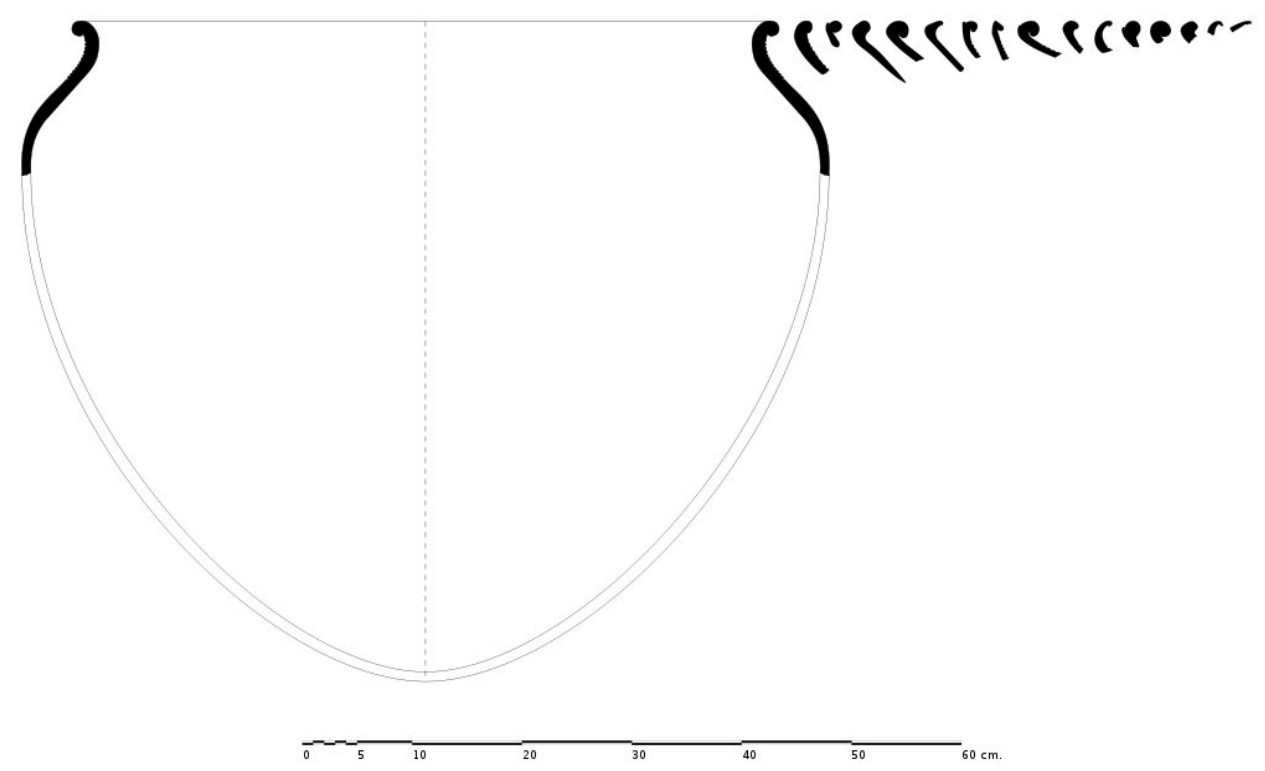

Ilustração 7: Bordas introvertidas e inclinadas internas com lábio reforçado analisadas no setor 2 do sítio Córrego Lalima 

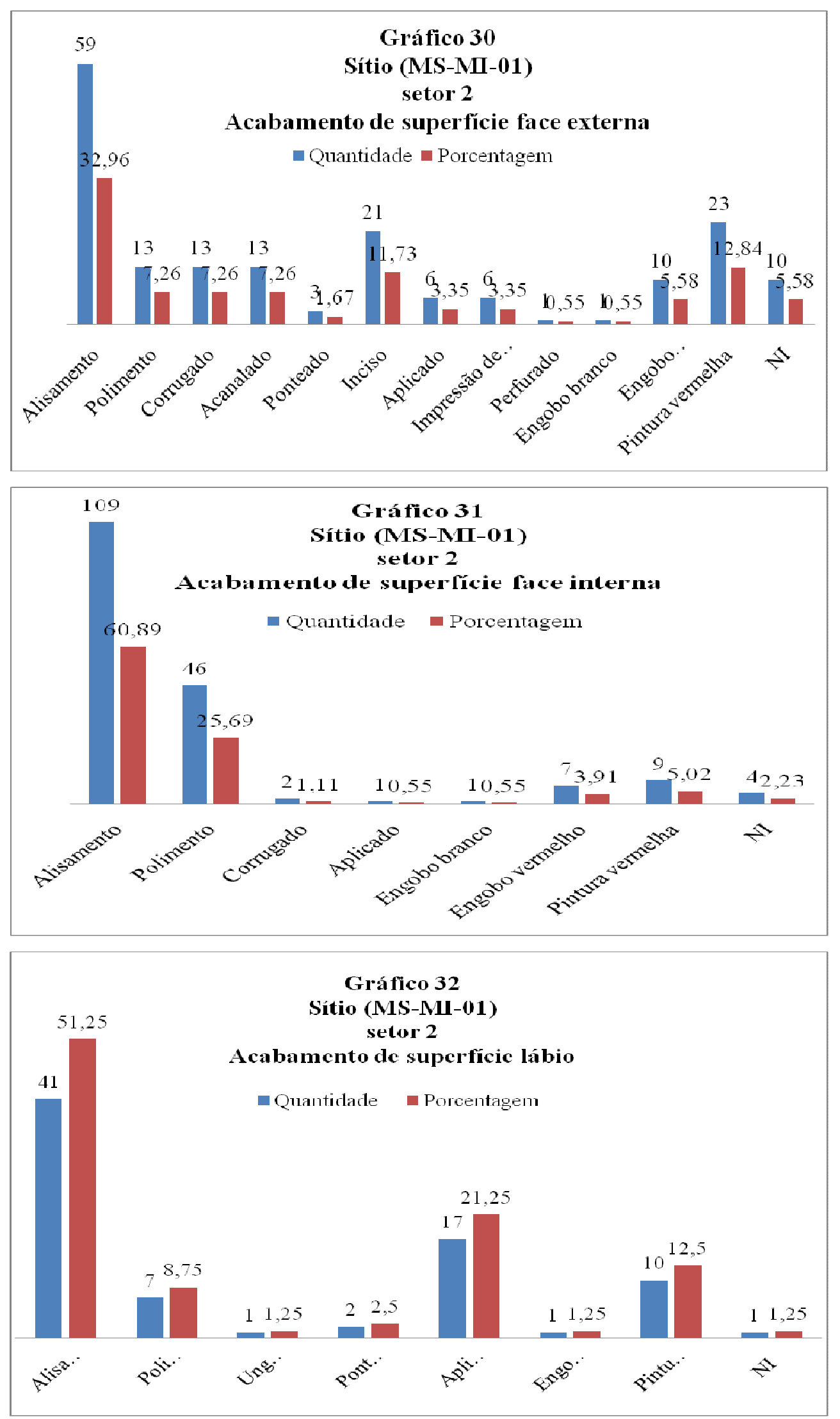

Os materiais da Tradição Pantanal no sítio Córrego Lalima apresentam muitas semelhanças com os materiais da Fase Jacadigo, concebida a partir dos fragmentos de 
vasilhas coletados em sítios a céu aberto implantados nas encostas suaves das colinas piemontanas do planalto do Urucum-Amolar (Bezerra \& Peixoto 2004, Schmitz et al. 1998). Contudo, apesar das semelhanças tecnológicas e espaciais, o conjunto detectado em Lalima varia em relação à Fase Jacadigo, principalmente pela ausência de contornos compostos e complexos, caracterizados por pontos angulares reentrantes e salientes, e pela possibilidade de tratar-se de um contexto arqueológico pré-colonial, como sugerido por uma das datas obtidas no setor 2 do sítio Asa de Pote (MS-MI-06). Não só vale lembrar que Schmitz et al. (op. cit.: 241) suspeitaram que os contextos arqueológicos da Fase Jacadigo seriam recentes, associados aos Mbayá-Guaikurú emigrados do Chaco para o Pantanal nos séc. XVII e XVIII, como também é importante frisar que eles igualmente sugeriram que a presença de carenas e ombros seria influência das populações Guarani, as quais teriam sido as primeiras dentre as sociedades agricultoras a se estabelecer na região até então desocupada do planalto do Urucum-Amolar. Seja como for, as distinções entre os materiais Guarani e da Tradição Pantanal no sítio Córrego Lalima, ao menos em se tratando da forma das vasilhas e acabamentos de superfície, são evidentes.

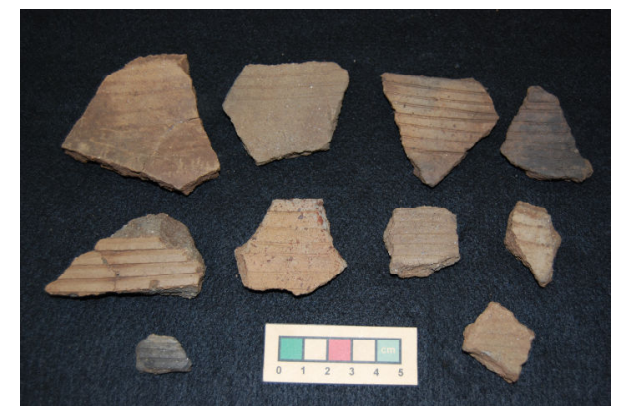

Foto 30: Fragmentos cerâmicos incisos e acanalados analisados no setor 2 do sítio Córrego Lalima

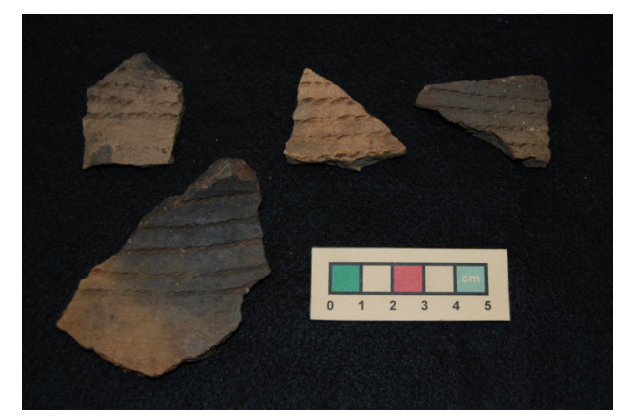

Foto 31: Fragmentos cerâmicos impressos com corda analisados no setor 2 do sítio Córrego Lalima

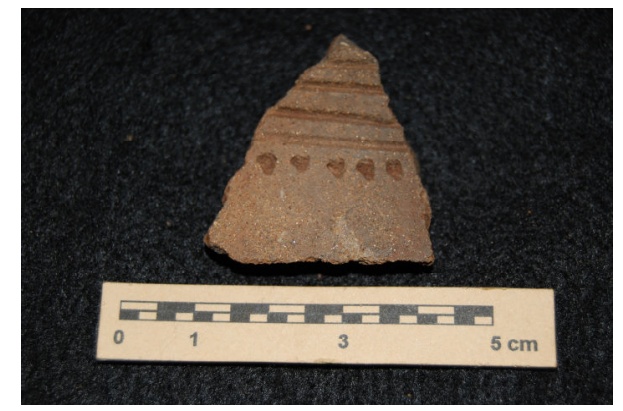

Foto 32: Fragmento cerâmico com incisões e ponteados analisados no setor 2 do sítio Córrego Lalima

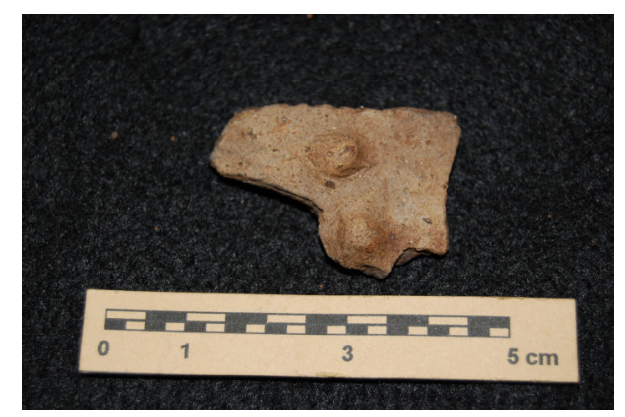

Foto 33: Fragmento cerâmico com apliquies mamilonares analisado no setor 2 do sítio Córrego Lalima 


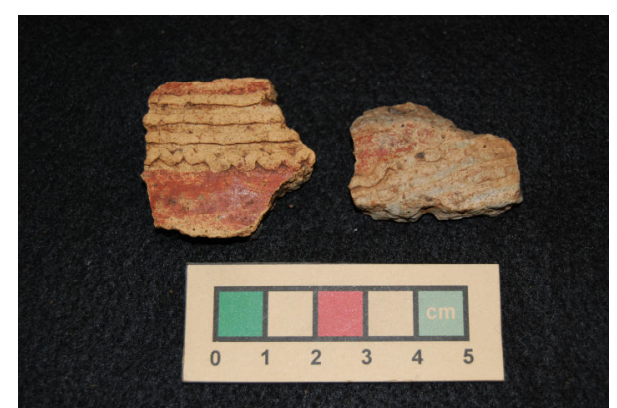

Foto 34: Fragmento cerâmico com pintura vermelha e apliques de filigranas de argila analisado no setor 2 do sítio Córrego Lalima

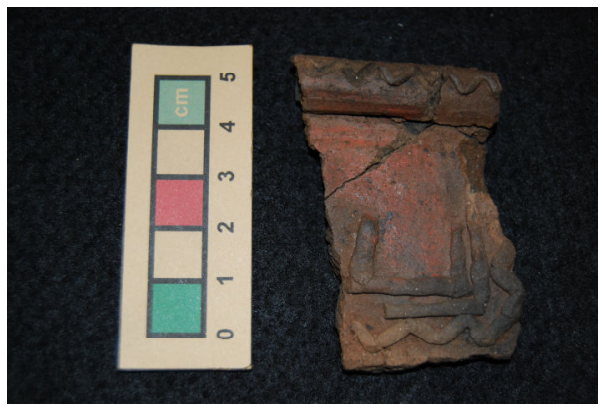

Foto 35: Fragmento cerâmico com pintura vermelha e apliques de filigranas analisado no setor 2 do sítio Córrego Lalima

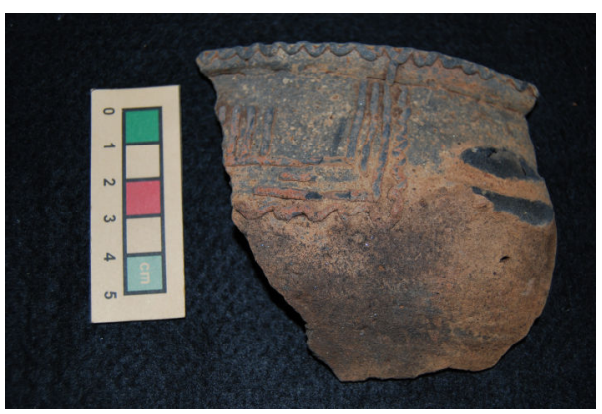

Foto 36: Fragmento cerâmico com apliques de filigrana analisado no setor 2 do sítio Córrego Lalima

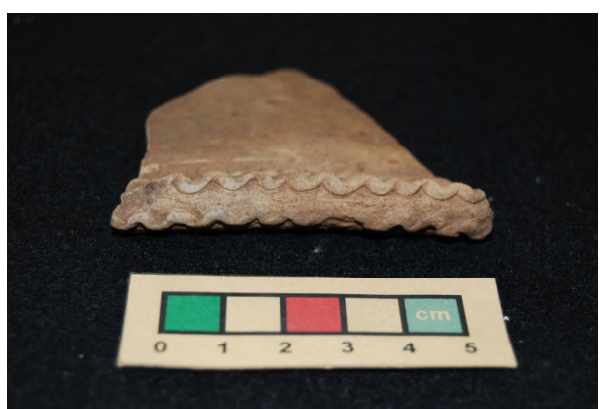

Foto 37: Fragmento de borda com apliques de filigranas no lábio analisado no setor 2 do sítio Córrego Lalima

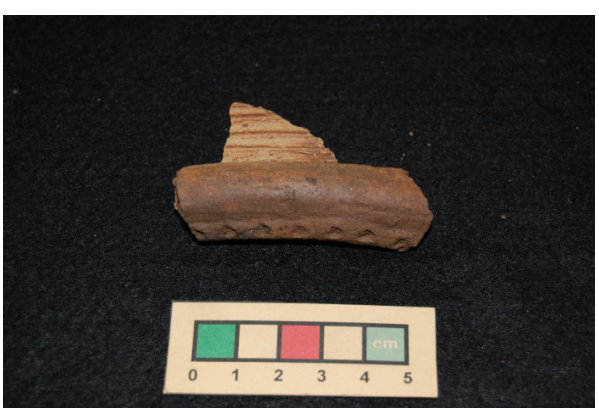

Foto 38: Fragmento de borda com lábio ponteado analisado no setor 2 do sítio Córrego Lalima

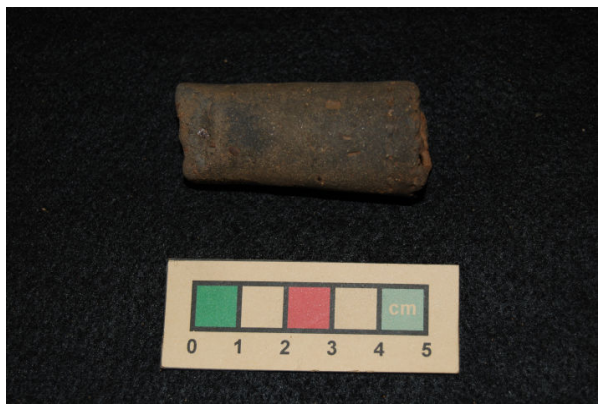

Foto 39: Cachimbo tubular coletado no setor 2 do sítio Córrego Lalima

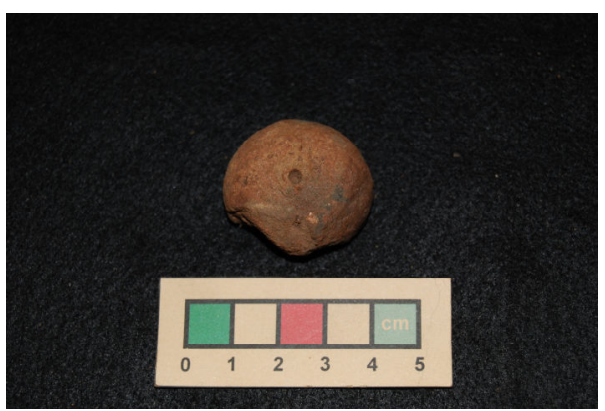

Foto 40: Rodela de fuso coletado no setor 2 do sítio Córrego Lalima

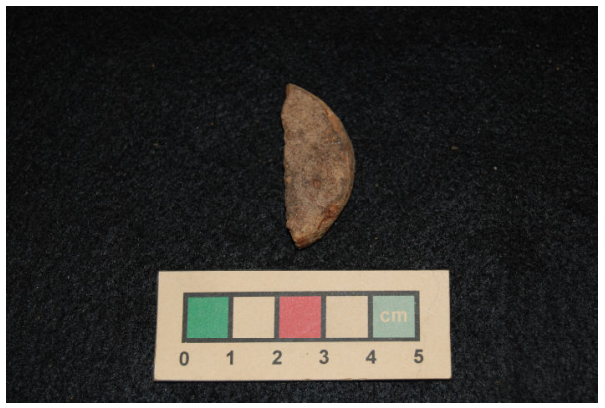

Foto 41: Ficha cerâmica coletado no setor 2 do sítio Córrego Lalima

Também foram achados outros artefatos cerâmicos no setor 2 do sítio Córrego Lalima, com um cachimbo tubular, uma rodela de fuso e uma ficha fragmentada (Fotos 
39 à 41). Os índios ainda nos disseram que a jazida de argila utilizada na confecção das vasilhas etnográficas situava-se em uma das nascentes do córrego do Lima, cuja margem esquerda localiza-se nas proximidades do setor 2 .

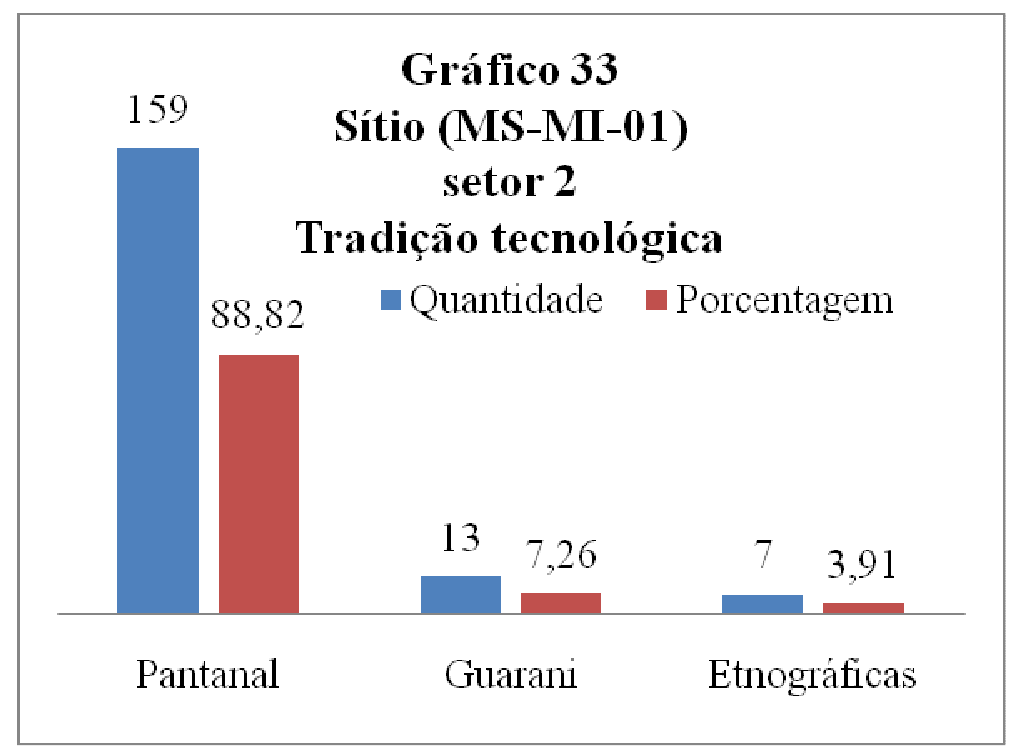

Assim como o setor 1, o setor 3 do MS-MI-01, situado no topo e nas encostas alta e média da porção oeste da colina, com cerca de $62.000 \mathrm{~m}^{2}$, foi delimitado sobre contexto arqueológico Guarani, onde foram coletados 664 materiais, sendo 627 fragmentos de vasilhas e 1 lítico coletados assistematicamente na superfície e $36 \mathrm{em}$ sub-superfície, dos quais 12 fragmentos cerâmicos em 6 das 16 sondagens escavadas (S1, S2, S5, S9, S12 e S16) e 26 materiais (22 cerâmicos, 3 líticos e 1 amostra de carvão) no poço-teste 5, o único empreendido no setor (Mapa 8 e foto 42). A coleta de superfície foi realizada em uma área de $12.500 \mathrm{~m}^{2}$, estabelecida entre os domicílios em torno de outro campo de futebol, situado no centro do setor, onde predominam sedimentos arenosos marrom-claros, tão perturbados pelo contexto etnográfico atual quanto os outros setores pesquisados (Foto 43). Tal paralelo também pode ser estendido à sub-superfície, constituída por sedimentos amarronzados sobre sedimentos mais avermelhados ou alaranjados, igualmente perturbados pela ocupação atual.

\begin{tabular}{|c|c|c|c|c|}
\hline Atividades de coleta & Cerâmicos & Líticos & Carvões & Totais \\
\hline Assistemática de superfície & 627 & 1 & & 628 \\
\hline Sub-superfície & 32 & 3 & 1 & 36 \\
\hline Totais & 659 & 3 & 1 & 663 \\
\hline
\end{tabular}

As sondagens foram escavadas em dois segmentos de reta intersectados no centro do setor, malha de $20 \mathrm{~m}$ e profundidade média de $40 \mathrm{~cm}$, sendo que 10 dos 16 


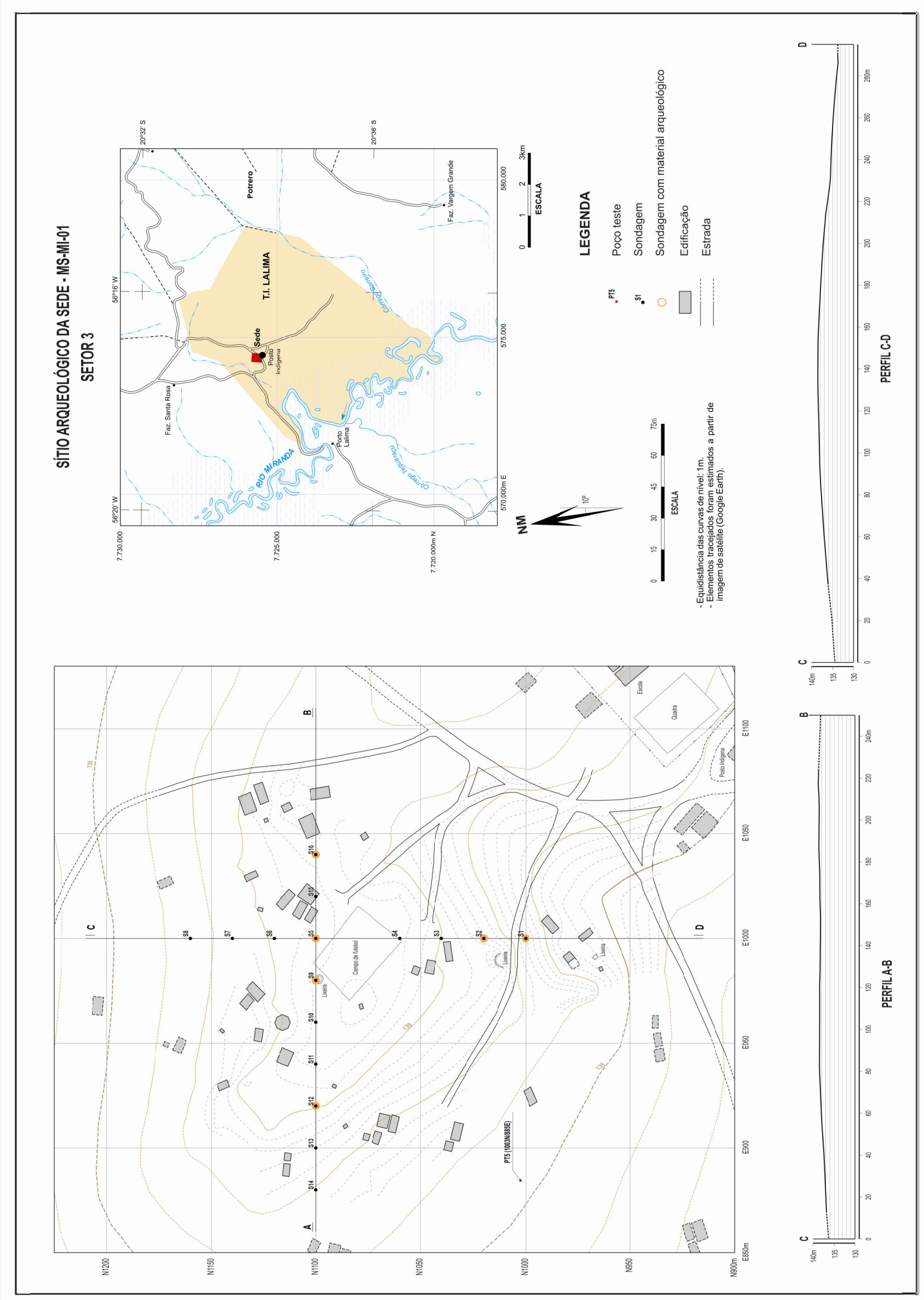


furos atingiram o embasamento quartzoso, evidenciado entre 20 e $50 \mathrm{~cm}$ (foto 44 ). Foram coletados materiais arqueológicos nas sondagens S1, S2, S5, S9, S12 e S16 (Tabela 15).

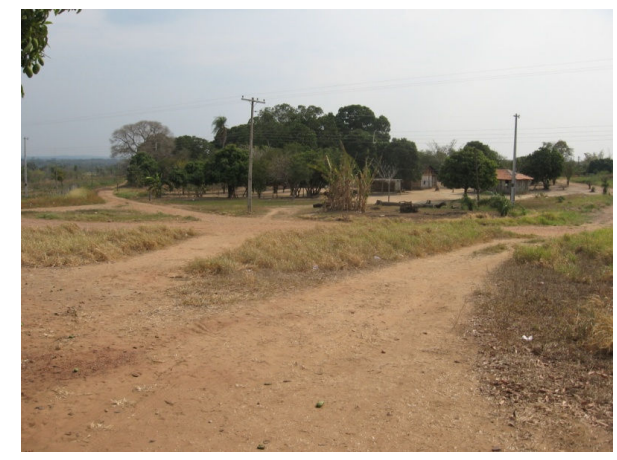

Foto 42: setor 3 do sítio Córrego Lalima

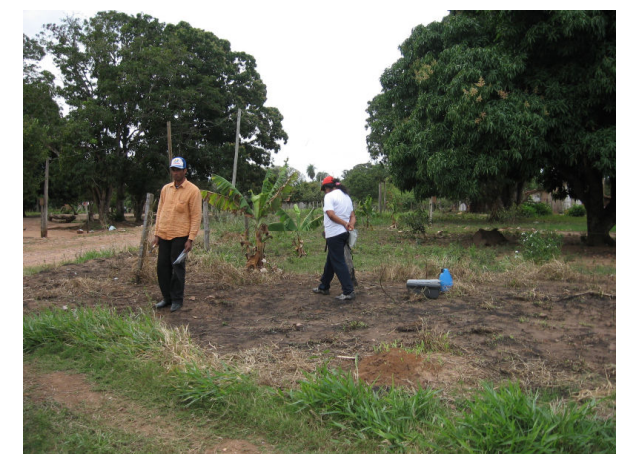

Foto 43: Coleta de superfície no setor 3 do sítio Córrego Lalima

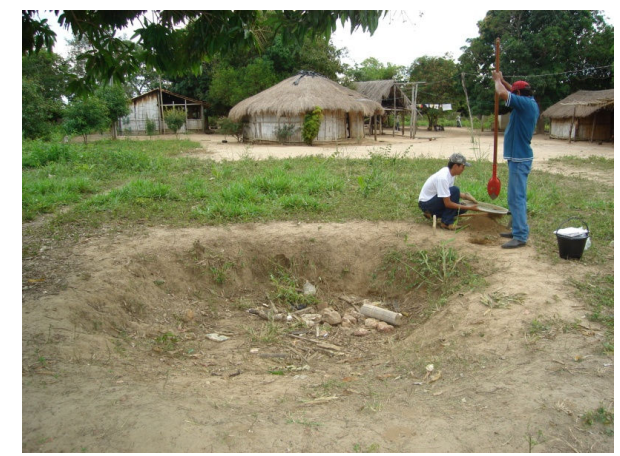

Foto 44: Escavação de sondagens no setor 3 do sítio Córrego Lalima

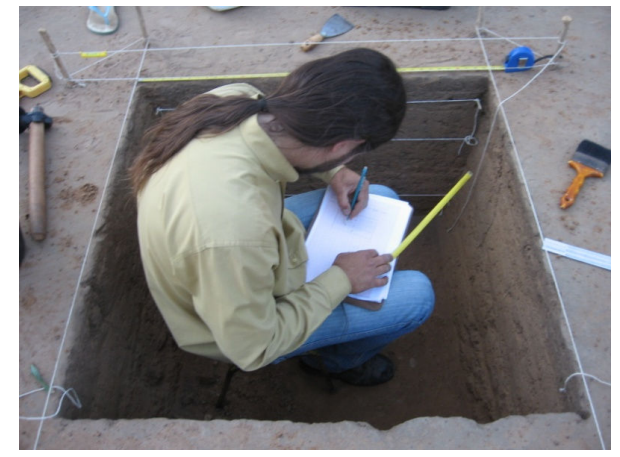

Foto 45: Escavação do poço-teste 5 no setor 3 do sítio Córrego Lalima

\begin{tabular}{|c|c|c|}
\hline \multicolumn{3}{|c|}{ Tabela 15: Materiais arqueológicos coletados nas sondagens escavadas no setor 3 do sítio Córrego Lalima (MS-MI-01) } \\
\hline Sondagens & Cerâmicos & Totais \\
\hline S1 & 2 & 2 \\
\hline S2 & 2 & 2 \\
\hline S5 & 1 & 1 \\
\hline S9 12 & 3 & 3 \\
\hline S16 & 3 & 1 \\
\hline Totais & 1 & 12 \\
\hline
\end{tabular}

O poço-teste 5 (1103N/885E), o único empreendido no setor 3, foi escavado nas proximidades da S14 (1100N/880E), em uma área que apresenta uma concentração de fragmentos de vasilhas cerâmicas Guarani, localizada em frente à casa de Sebastião Cabrocha (Mapa 8, Foto 45). O Sebastião, inclusive, doou um tembetá de pedra polida fragmentado, achado por ele mesmo durante a construção da sua casa (Foto 46). Foram escavados 6 níveis artificiais, os quais evidenciaram quatro camadas de sedimentos e o embasamento quartzoso. Assim, na superfície, formada por sedimento arenoso marromclaro (pale brown 10YR6/3), coletaram-se 9 fragmentos cerâmicos na quadrícula do 
poço-teste. Na camada A, evidenciada com a escavação do nível 1, formada por sedimento arenoso marrom-escuro, foram coletados 11 fragmentos de vasilhas. $\mathrm{Na}$ camada B, observada nos níveis 2,3 e 4, coletaram-se 6 materiais arqueológicos em meio aos sedimentos arenosos marrom-claros, sendo 2 cerâmicos, 3 lascas e 1 amostra de carvão muito pequenina. A camada $\mathrm{C}$, arqueologicamente estéril, constituída por sedimento arenoso marrom, foi verificada entre os níveis 3,4 e 5 , e a camada $D$, igualmente estéril, formada por sedimento arenoso marrom-alaranjado, foi identificada em parte do nível 5 e no nível 6 (Tabela 16). O substrato foi descoberto aos $60 \mathrm{~cm}$ de profundidade, aproximadamente (Ilustrações contidas no anexo 2). Muito possivelmente, as concentrações de materiais arqueológicos na superfície em torno da casa do Sr. Sebastião foram formadas por conta de fatores antrópicos associados ao contexto etnográfico da ocupação indígena atual, como a construção da casa e as atividades diárias de limpeza no quintal.

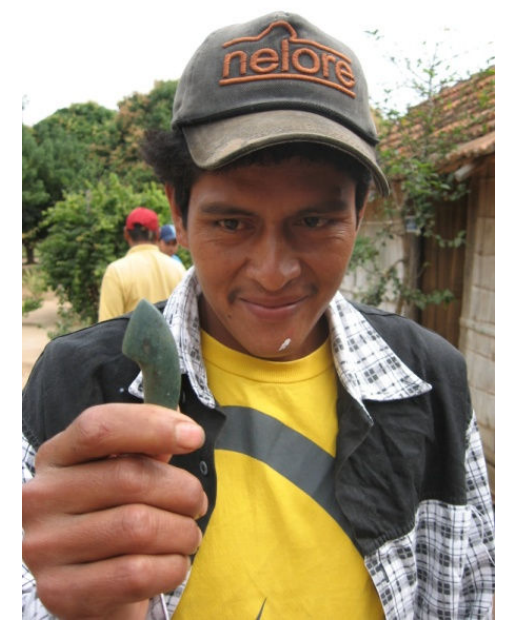

Foto 46: Tembetá achado por Sebastião no setor 3 do sítio Córrego Lalima

\begin{tabular}{|c|c|c|c|c|}
\hline \multicolumn{5}{|c|}{ Tabela 16: Materiais arqueológicos coletados no Poço-teste 5 no setor 3 do sítio Córrego Lalima (MS-MI-01) } \\
\hline Níveis/Camadas & Cerâmicos & Líticos & Carvões & Totais \\
\hline N0/Superficial & 9 & & & 9 \\
\hline N1/Camada A & 11 & & & 11 \\
\hline N2/Camada B & 1 & & & 1 \\
\hline N3/Camada B & 1 & & & 5 \\
\hline N4/Camadas B e C & & & & \\
\hline N5/Camada C & & & & \\
\hline N6/Camada C & 22 & 3 & 1 & 26 \\
\hline Totais & & & & \\
\hline
\end{tabular}

No setor 4, onde foram observados materiais Guarani e da Tradição Pantanal, situado no topo sudeste da colina, no localidade conhecida como Morrinho, onde também funciona a leiteria da Aldeia, não foram desenvolvidas atividades de coleta. No entanto, as observações preliminares efetuadas no momento em que o setor foi 
detectado sugerem que o mesmo pode caracterizar-se como o mais preservado do MSMI-01.

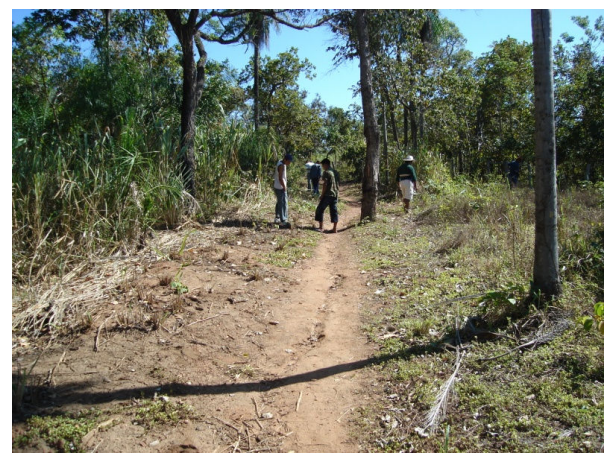

Foto 47: Setor 4 do sítio Córrego Lalima

\subsection{2 - José Rondon de Souza (MS-MI-02)}

O sítio José Rondon de Souza (MS-MI-02), plotado nas coordenadas UTM 21K 0573816/7726032, foi detectado no Baixadão, na Sede, próximo à planície de inundação da margem direita do rio Miranda (Mapa 4, Imagem 1). O sítio está implantado na baixa encosta de uma colina suave, constituída por sedimentos arenosos, situada na confluência da margem direita de uma pequena nascente com a margem direita do baixo curso do cór. do Lima. Atualmente, a área do sítio é ocupada pela família do Sr. José Rondon de Souza, irmão mais novo do Sr. Manuel de Souza Neto. Além da área residencial propriamente, formada por duas casas de bambu cobertas de sapé, e do quintal, onde se situa o pomar e as plantas de uso medicinal, a propriedade do Sr. José Rondon de Souza também apresenta roças de feijão, arroz, mandioca, abóbora e milho (foto 48).

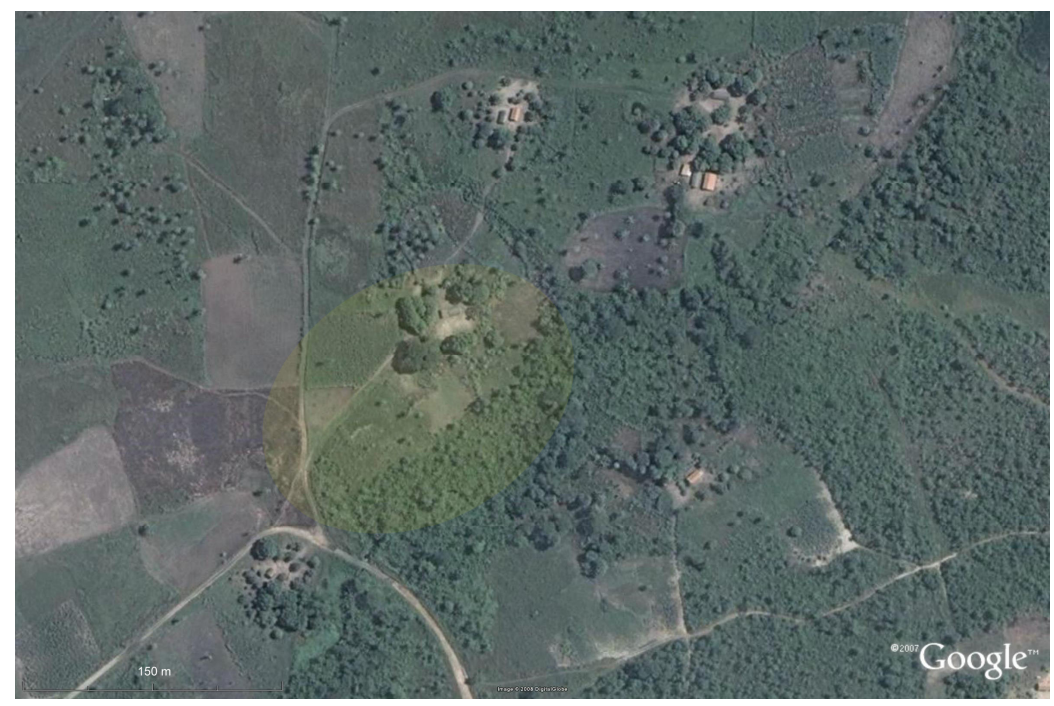


Imagem 1: Sítio José Rondon de Souza (MS-MI-02)

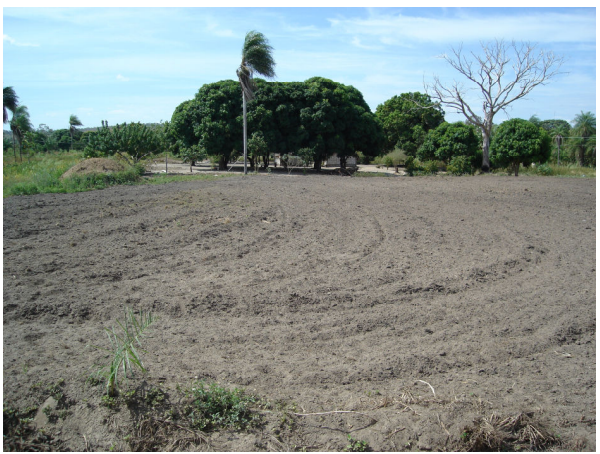

Foto 48: Sítio José Rondon de Souza

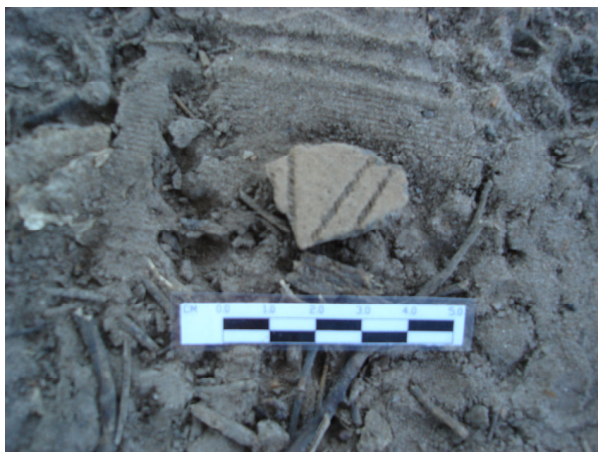

Foto 49: Fragmento cerâmico com impressões de corda no sítio José Rondon de Souza

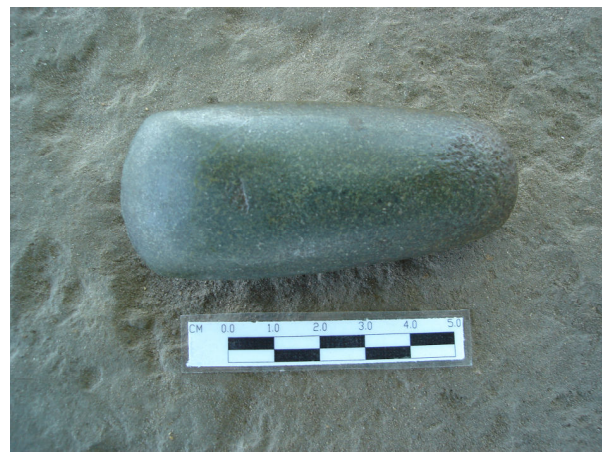

Foto 50: Lâmina de machado lítica polida achada pelo José Rondon no sítio José Rondon de Souza

Os materiais arqueológicos, constituídos principalmente por fragmentos de vasilhas cerâmicas em baixa densidade, estavam dispersos pela superfície, em torno das casas, no quintal, nas roças e na estrada, em uma área de aproximadamente $150 \mathrm{~m}$ de comprimento, no sentido leste-oeste, por 50m de largura (Foto 49). Foram coletados assistematicamente 57 fragmentos cerâmicos da Tradição Pantanal (Tabela 4), porém distintos, sobretudo em se tratando do acabamento de superfície, dos materiais recolhidos no setor 2 do sítio Córrego Lalima (MS-MI-01). O Sr. José Rondon também nos mostrou uma lâmina de machado lítica polida, achada no quintal da sua casa (Foto $50)$.

Apenas 19 fragmentos apresentavam atributos diagnósticos da forma e do acabamento de superfície das vasilhas cerâmicas, entre os quais 15 (78,94\%) foram categorizados como paredes, $3(15,78 \%)$ como bordas e 1 (5,6\%) como base (Gráfico 34). Entre as paredes, 3 fragmentos (20\%) foram classificados como paredes inflectidas, $1(6,66 \%)$ como segmento superior de vasilha fechada, restringida ou não restringida, e outro $1(6,66 \%)$ como parede carenada (Gráfico 35$)$. A base foi taxada como circularplana. 
Entre os fragmentos de bordas, apenas $2(66,6 \%)$ foram identificados, sendo taxados como direta vertical. Foram observados uma variante de lábio para cada uma das bordas, sendo 1 (33,33\%) reforçado externa, 1 (33,33\%) ondulado e 1 (33,33\%) rebarbado (Gráfico 36). Apenas foi possível aferir o diâmetro da boca em um dos fragmentos de borda, com $14 \mathrm{~cm}$.

Acerca da espessura, 16 fragmentos (84,21\%) foram classificados como finos, 2 $(10,52 \%)$ como médios e $1(5,26 \%)$ como grosso (Gráfico 37$)$. Sobre a relação da abertura da boca com o diâmetro do bojo, 5 fragmentos $(26,31 \%)$ foram associados com vasilhas fechadas e $2(10,52 \%)$ com vasilhas abertas (Gráfico 38). A respeito da classe simétrica e do contorno das vasilhas, apenas 2 fragmentos (10,52\%) foram associados com vasilhas não restringidas com contorno simples.
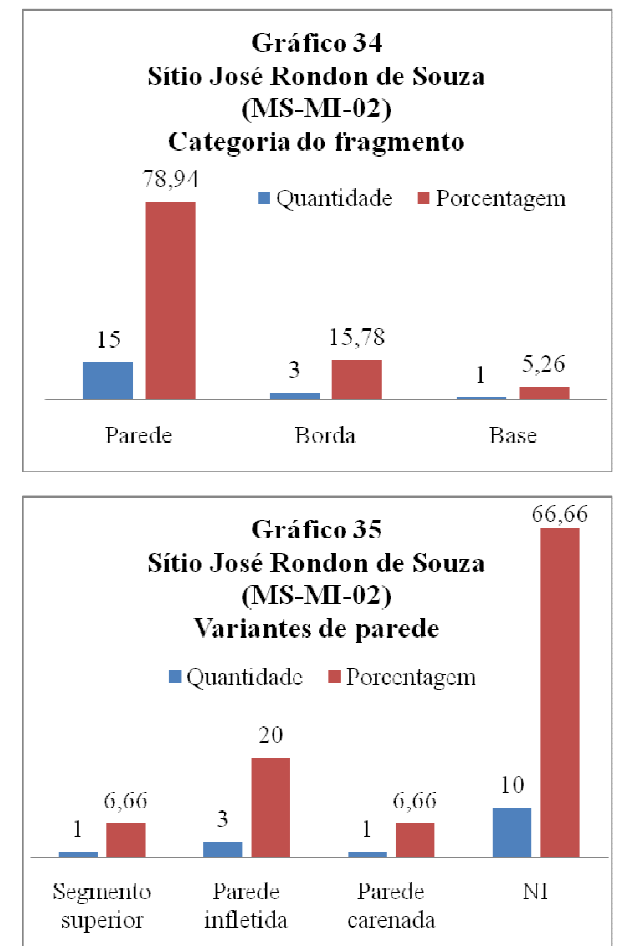
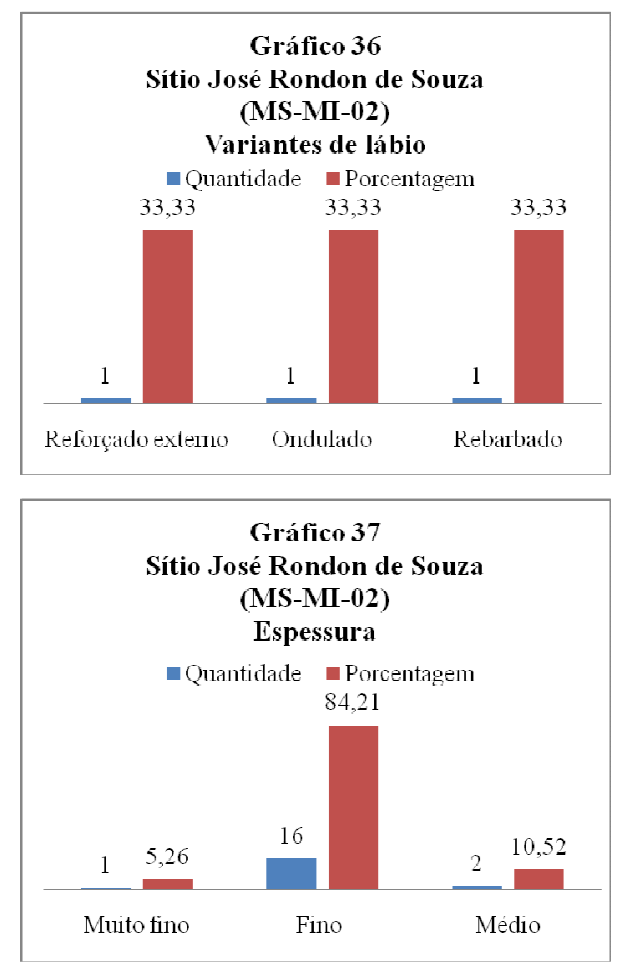

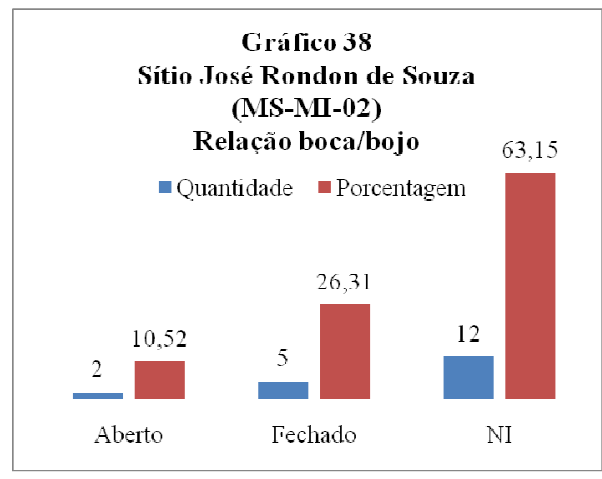


No tocante ao acabamento de superfície na face externa, foram observados 12 fragmentos $(63,15 \%)$ com tratamentos plásticos e 7 (36,84\%) com cromáticos (Gráfico 39). Entre os plásticos, foram registrados 4 fragmentos (21,05\%) polidos, outros 4 $(21,05 \%)$ impressos com cordas, 3 (15,78\%) alisados e 1 (5,26\%) aplicado. Cabe ressaltar que os tratamentos plásticos com impressões de corda formam motivos geometrizados, o que os torna distintos dos fragmentos impressos com corda detectados no setor 2 do sítio Córrego Lalima (MS-MI-01), onde não foram observados motivos geométricos balizados com impressões de corda. Entre os cromáticos, foram verificados 5 fragmentos (26,31\%) com banhos de engobo branco e 2 (10,52\%) com engobo vermelho. Na face interna, 13 fragmentos $(68,42 \%)$ apresentaram tratamentos plásticos e $6(31,57 \%)$ cromáticos (Gráfico 40$)$. Entre os plásticos, $6(31,57 \%)$ apresentaram alisamento e $6(31,57 \%)$ polimento, enquanto entre os cromáticos 4 (21,05\%) apresentaram engobo vermelho, 2 (10,52\%) engobo branco e $1(5,26 \%)$ apresentou enegrecimento. Foram observados um acabamento de superfície para cada uma das três bordas coletadas, sendo 1 alisado, 1 polido e 1 enegrecido (Gráfico 41, Fotos 51 à 54).
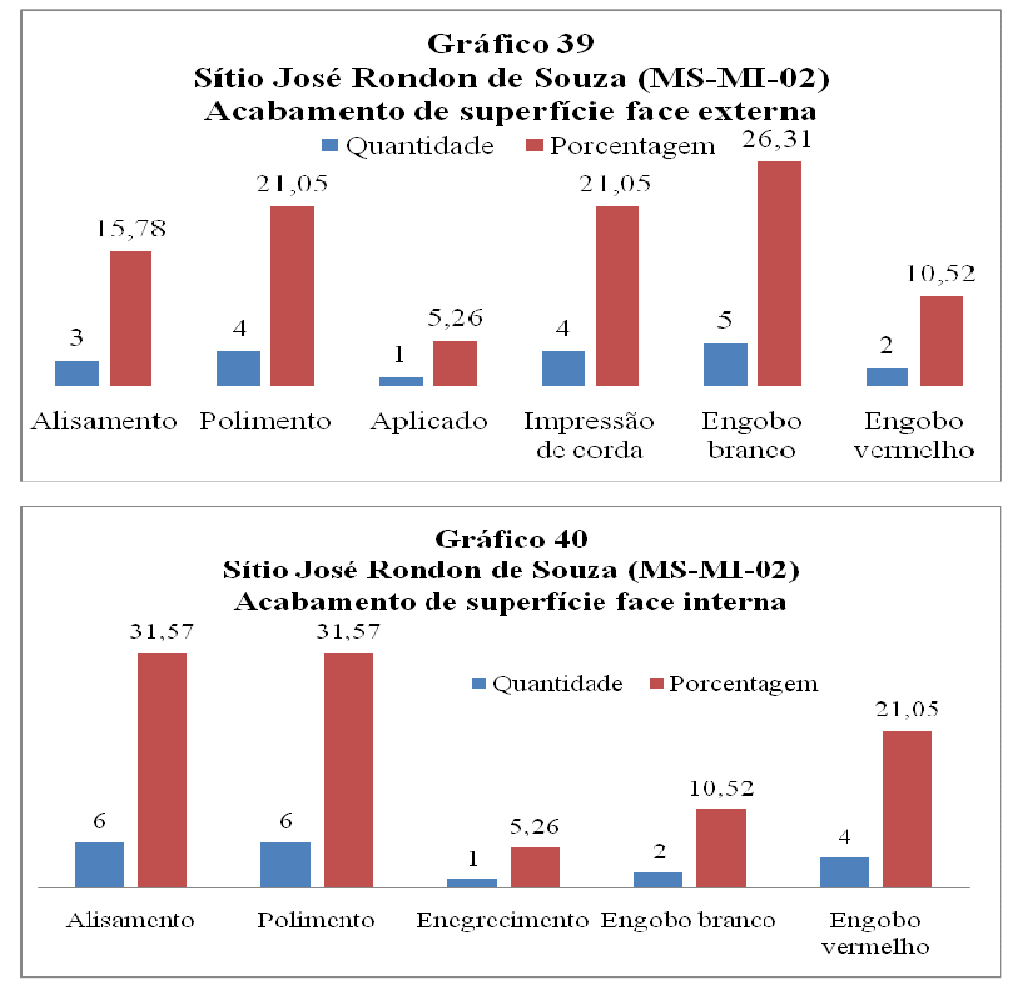


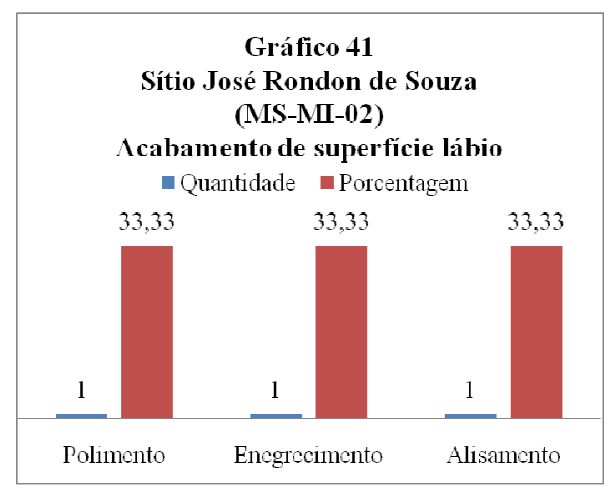

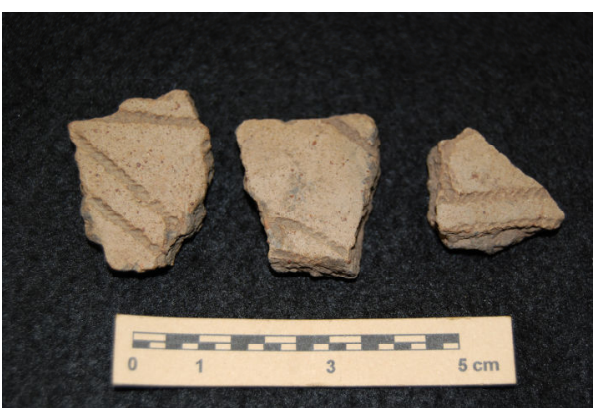

Foto 51: Fragmentos com impressões de corda analisados no sítio José Rondon de Souza

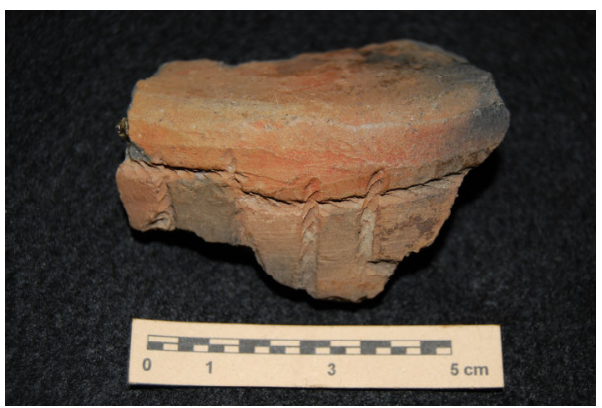

Foto 52: Fragmento de base com impressões de corda analisado no sítio José Rondon de Souza

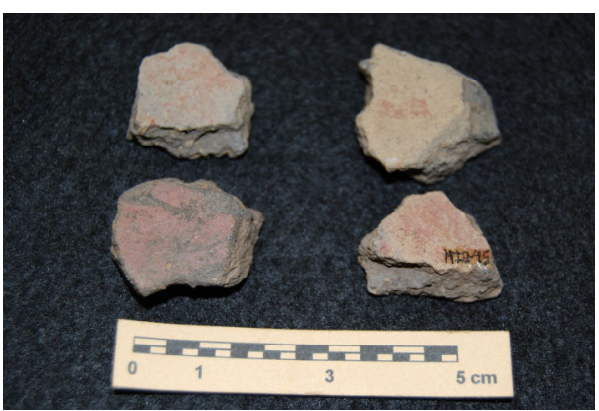

Foto 53: fragmentos com acabamento cromático analisados no sítio José Rondon de Souza

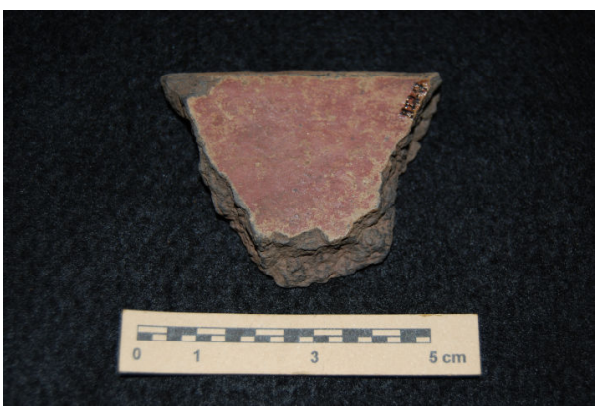

Foto 54: Fragmento de borda com engobo vermelho na face interna analisado no sítio José Rondon de Souza

No que se refere à tecnologia, todos os fragmentos foram associados à Tradição Pantanal, porém os atributos são mais semelhantes aos materiais coletados nos sítios MS-CP-25, detectado no planalto do Urucum-Amolar, em Corumbá/MS, e Cayman I, situado na margem esquerda do rio Paraguai, em Porto Murtinho/MS, que aos materiais da Fase Jacadigo, como no caso dos fragmentos analisados no setor 2 do sítio Córrego Lalima (Eremites de Oliveira 2004, Peixoto \& Bezerra 2004, Schmitz et al. 1998). Com efeito, o José Rondon de Souza (MS-MI-02) apresenta fragmentos cerâmicos análogos, algumas vezes até idênticos, aos materiais detectados no sítio MS-CP-25. Como visto anteriormente, o conjunto cerâmico do sítio MS-CP-25, destacado principalmente pela presença de decorações geometrizadas poli-cromáticas zoneadas por impressões de 
corda, também foi atribuída às populações Mbayá-Guaikurú por Schmitz et al. (ibidem). De fato, os materiais do MS-CP-25, assim como aqueles detectados em Lalima, apesar da amostra ínfima, são muito semelhantes ao vasilhame dos índios Kadiwéu, descrito, entre outros, por Ribeiro (1980: 287-95).

\subsection{3 - Tapera do Limpão (MS-MI-03)}

O sítio Tapera do Limpão (MS-MI-03) nos foi apresentado pelo Manuel de Souza Neto (Mapa 4, Imagem 2). Trata-se de uma antiga área de moradia conhecida por todos na Aldeia, talvez por estar localizada nas proximidades do porto, mas são poucos aqueles que detêm informações etnográficas sobre a origem do contexto arqueológico detectado no Limpão. Uma $\mathrm{Sr}^{\mathrm{a}}$. já idosa conhecida como Vovó Sila, parteira da Aldeia e esposa do tio mais velho do Manuel, nos informou que o avô do Manuel viveu no Limpão, mas essa foi a única referência direta sobre a ocupação do sítio. Muito provavelmente, o avô do Sr. Manuel, também chamado Manuel de Souza, irmão da nidjiena Maria Vicenza e igualmente nidjienigi, ou purungueiro, também manteve interlocução com Cardoso de Oliveira na década de 50 (cf. 1960, 1976, 2002).

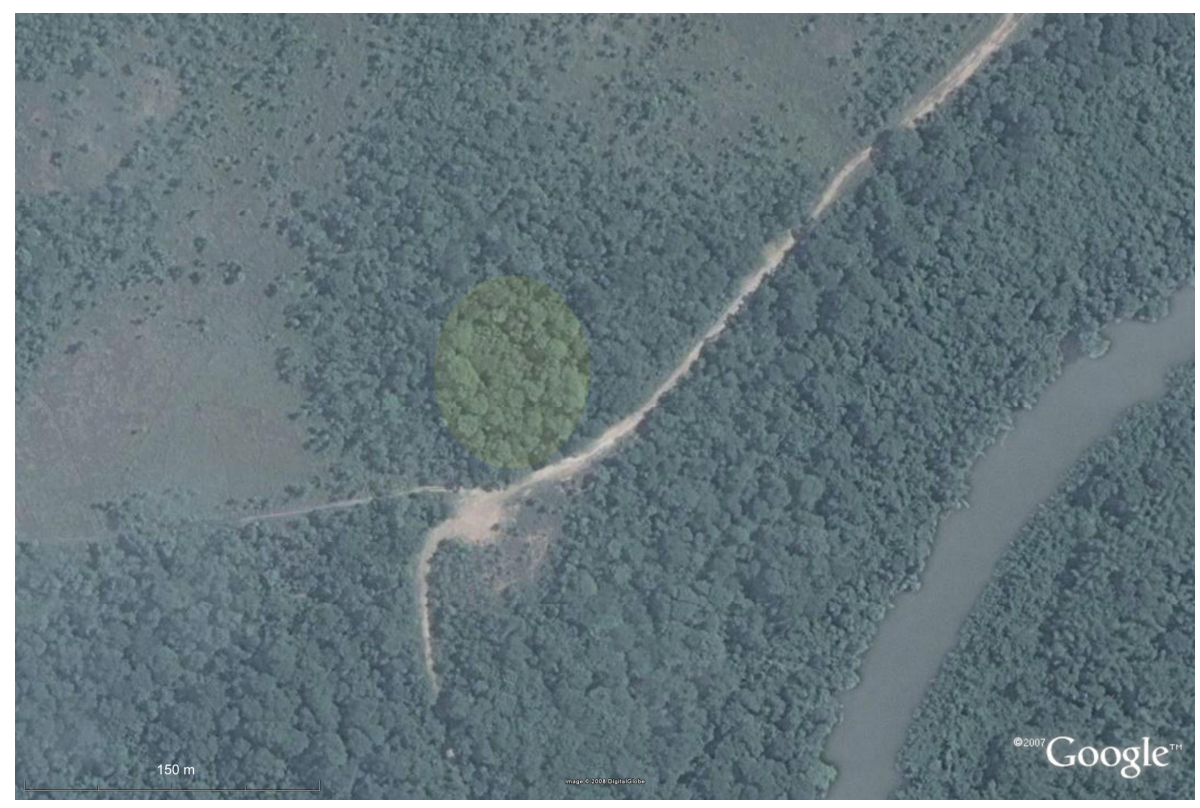

Imagem 2: Sítio Tapera do Limpão (MS-MI-03)

O MS-MI-03 está implantado em um topo de colina suave não inundável, localizado nas proximidades da planície de inundação do Miranda, ao lado da estrada de acesso ao porto, nas coordenadas UTM 21K 0572232/7724920 (Foto 55). A superfície apresenta sedimentos arenosos e litólicos. Ainda resta algo da mata ciliar e do cerrado, 
sobretudo em áreas que apresentam afloramentos de quartzo e quartzito, porém quase todo o entorno do sítio foi impactado pelo contexto etnográfico da ocupação indígena atual, sobretudo devido à construção da estrada, atividades de pecuária e mineração de cascalho.

O contexto arqueológico apresentou fragmentos de vasilhas cerâmicas da Tradição Pantanal semelhantes ao sítio José Rondon de Souza (MS-MI-02), fragmentos de louça, materiais líticos, esteios queimados e ecofatos. Entre os materiais líticos, foram coletados uma bigorna com depressão semi-esférica (quebra-coco), um batedor com marcas de uso e um núcleo em arenito silicificado, matéria-prima ausente na área (Foto 56). Os ecofatos são constituídos mormente por plantas frutíferas e medicinais, até hoje exploradas pelos índios, e por uma clareira circular em meio aos resquício de cerrado, com cerca de $50 \mathrm{~m}$ de diâmetro. Cabe frisar que o topônimo pelo qual o sítio é conhecido entre os índios, Tapera do Limpão, foi atribuído ao local justamente por conta da existência da clareira.

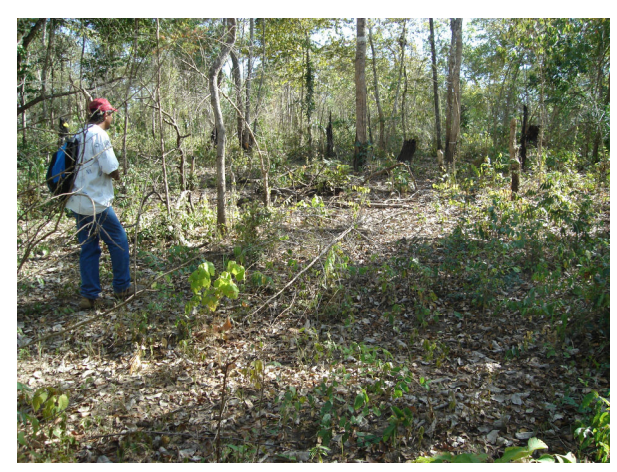

Foto 55: Sítio Tapera do Limpão

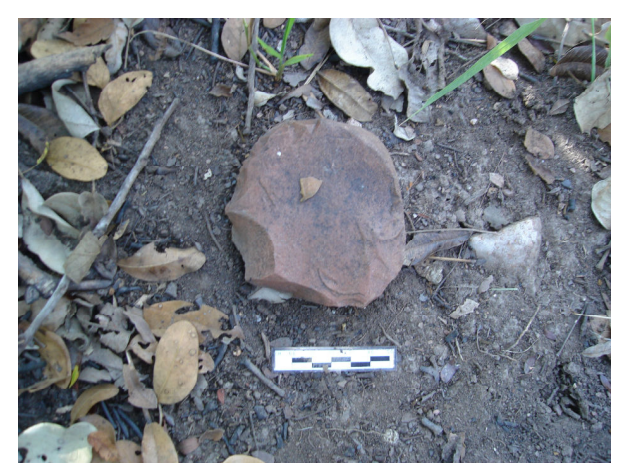

Foto 56: Núcleo em arenito silicificado coletado na Tapera do Limpão

Foram coletados assistematicamente 117 fragmentos de vasilhas cerâmicas e 4 materiais líticos na clareira (Tabela 4). Entre os materiais cerâmicos, apenas 16 fragmentos continham atributos diagnósticos da forma e do acabamento de superfície, os quais foram selecionados para a realização das análises preliminares. Dentre os fragmentos selecionados, $11(68,75 \%)$ foram categorizados como paredes e $5(31,25 \%)$ como bordas (ver Gráfico 42). Em se tratando das paredes, 1 fragmento $(9,09 \%)$ foi classificado como parede inflectida e 1 outro $(9,09 \%)$ como parede carenada (Gráfico $43)$.

No que se refere às bordas, apenas 3 fragmentos (60\%) foram identificados, sendo classificados como direta vertical. A respeito da forma do lábio, 2 fragmentos (40\%) foram especificados como ondulado (Foto 57 ), mais $2(40 \%)$ como rebarbado e 1 
(20\%) como aplanado (ver Gráfico 44). Não foi possível aferir o diâmetro da boca em nenhum dos fragmentos de borda coletados no Limpão.

Acerca da espessura, 13 dentre os fragmentos selecionados $(81,25 \%)$ foram categorizados como fino, 2 (12,5\%) como grossos e 1 (6,25\%) como fino (Gráfico 45). Sobre a relação entre a abertura da boca e o diâmetro do bojo, 3 fragmentos $(18,75 \%)$ foram taxados como abertos e 2 (12,5\%) como fechados (Gráfico 46).

Em se tratando das classes simétricas, 3 fragmentos (18,75\%) foram associados com vasilhas não restringidas. Não foi possível categorizar os contornos específicos, formas, alturas e funções das vasilhas a partir dos fragmentos selecionados.
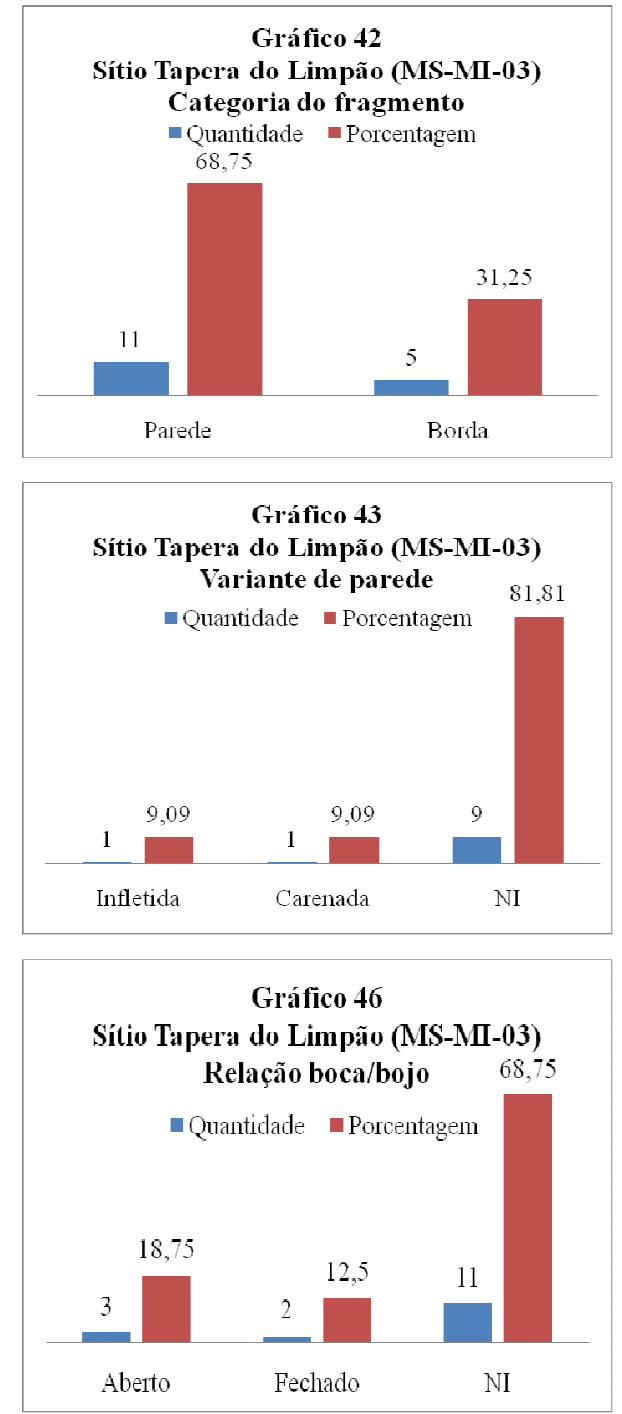
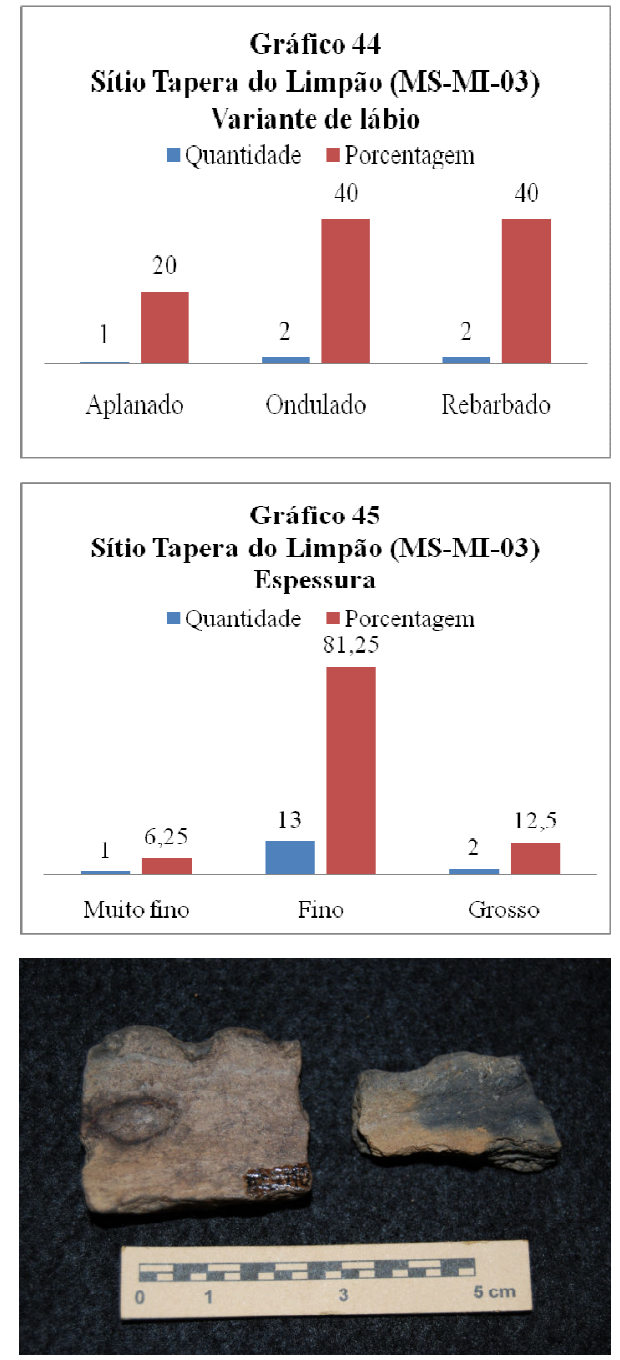

Foto 57: Fragmento de borda com lábio ondulado analisado na Tapera do Limpão

No tocante ao acabamento de superfície na face externa, 8 fragmentos (50\%) apresentaram tratamento plástico e outros 8 (50\%) tratamento cromático (Gráfico 47 ). Entre os tratamentos plásticos, 4 fragmentos (25\%) demonstraram alisamento, 3 $(18,75 \%)$ polimento e $1(6,25 \%)$ impressões de corda geometrizadas, e entre os 
cromáticos, 6 (37,5\%) apresentaram banho de engobo branco e $2(12,5 \%)$ engobo vermelho. Na face interna, 11 fragmentos $(68,75 \%)$ demonstraram tratamentos plásticos e $5(31,25 \%)$ cromáticos (Gráfico 48$)$. Dentre os plásticos, 6 fragmentos $(37,5 \%)$ apresentaram alisamento e $5(31,25 \%)$ polimento, enquanto entre os cromáticos, 3 fragmentos $(18,75 \%)$ demonstraram engobo branco, 1 (6,25\%) engobo vermelho e 1 $(6,25 \%)$ enegrecimento (Fotos 58 e 59). Acerca do acabamento de superfície no lábio das bordas, 4 fragmentos $(80 \%)$ apresentaram polimento e $1(20 \%)$ demonstrou enegrecimento.
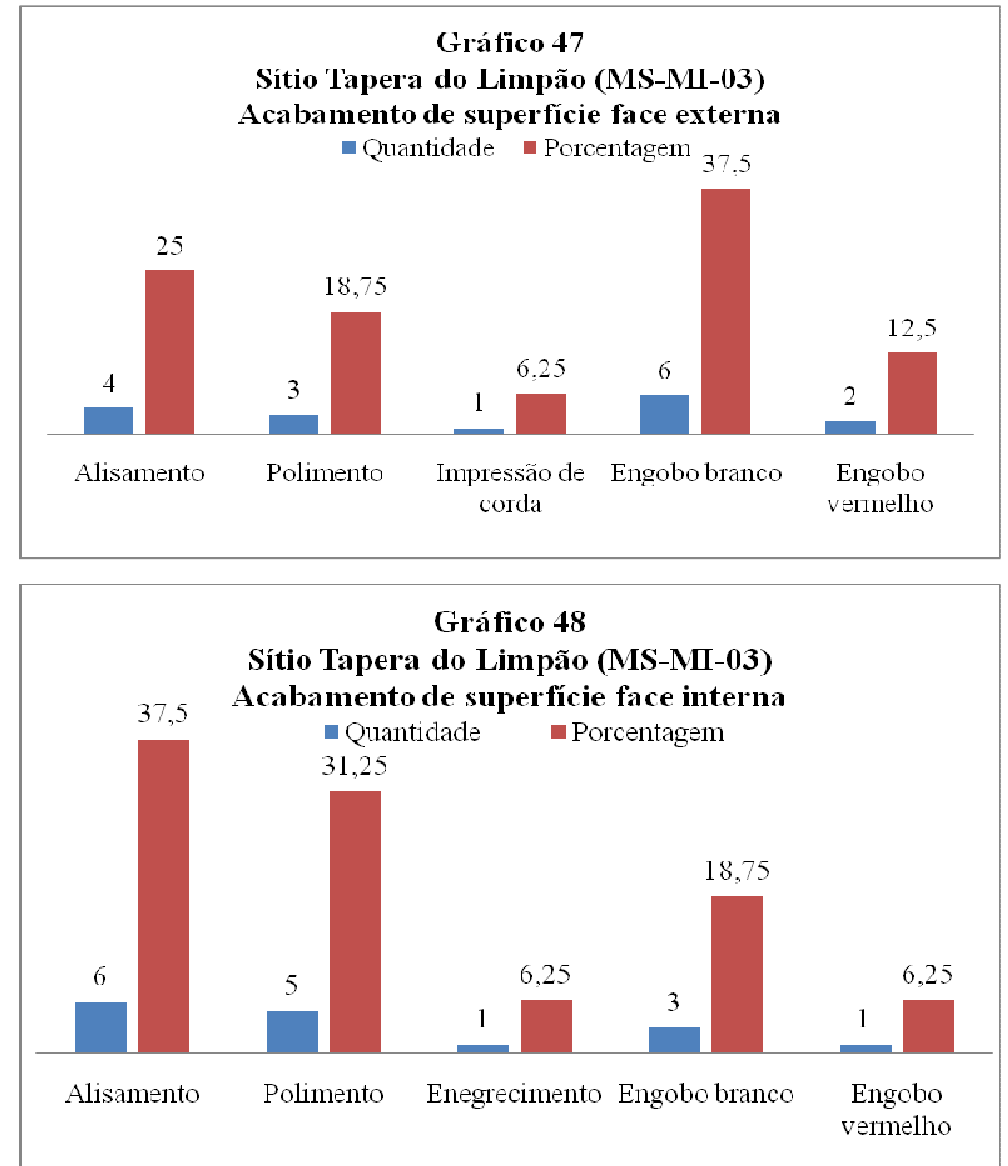

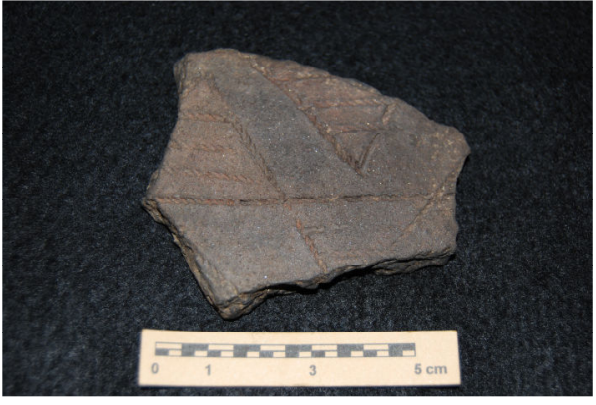

Foto 58: Fragmento cerâmico com impressões de corda analisado no sítio Tapera do Limpão

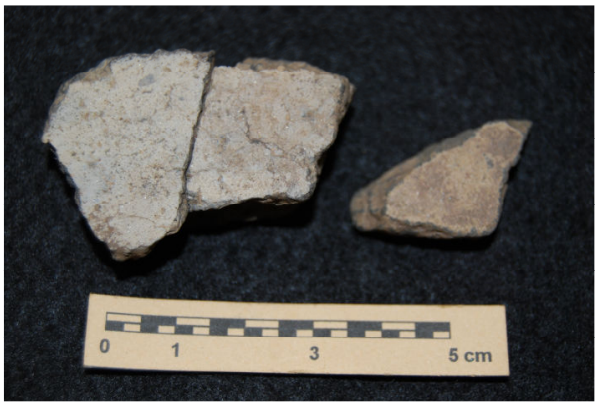

Foto 59: Fragmentos cerâmicos com acabamentos cromáticos analisados no Limpão 
Apesar da amostra ínfima, as análises realizadas permitem que o conjunto cerâmico analisado no Limpão seja inserido na Tradição Pantanal semelhante ao sítio José Rondon de Souza (MS-MI-03), pois além de apresentar 1 fragmento decorado com motivos geometrizados feitos com impressões de corda, também foram observados bordas onduladas e banhos de engobo branco e vermelho.

\subsection{4 - Tapera do Gino (MS-MI-04)}

Localizado a pouca distância do Limpão (MS-MI-03), na divisa entre a TI Lalima e a Faz. Santa Rosa, o sítio Tapera do Gino (MS-MI-04), implantado nas encostas de uma colina suave, constituída por sedimentos arenosos e litólicos, situada nas proximidades de uma nascente fluvial tributária do Miranda, nas coordenadas UTM 21K 0572877/7725744, também nos foi apresentado pelo Manuel de Souza Neto (Mapa 4, Imagem 3). Apesar dos contextos arqueológicos serem formados por materiais Guarani e da Tradição Pantanal semelhantes aos materiais cerâmicos coletados no José Rondon de Souza (MS-MI-02) e na Tapera do Limpão (MS-MI-03), a Tapera do Gino é conhecida na Aldeia por ser a antiga moradia do Gino, residente em Lalima até hoje.

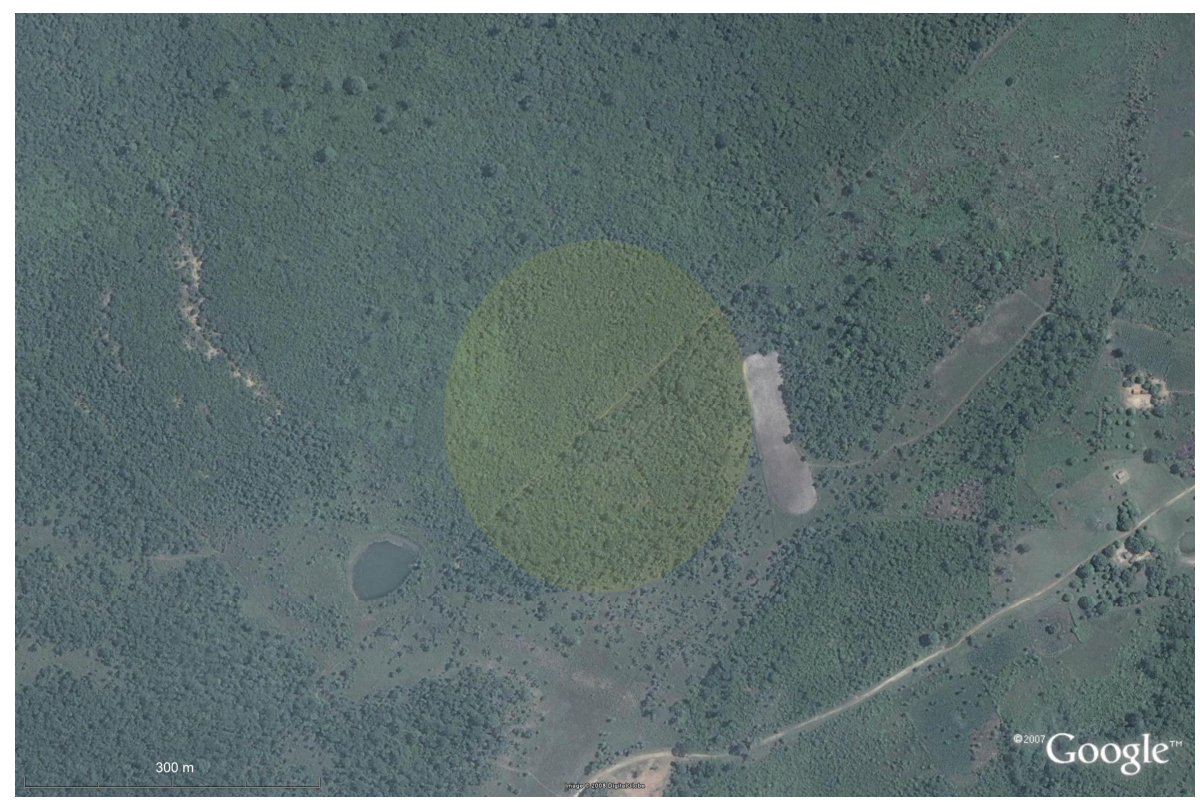

Imagem 3: Sítio Tapera do Gino (MS-MI-04)

Ao que as informações etnográficas indicam, o local foi abandonado pelo Gino e família a cerca de 20 anos. Apesar de ter permanecido no local por apenas 3 anos, a antiga casa do Gino apresentava as mesmas características espaciais que as moradias 
associados ao contexto etnográfico atual da ocupação indígena, ou seja, algumas casas de bambu, um quintal em torno das casas e as roças em torno do quintal. Os contextos materiais formados com o abandono da área pelo Gino são constituídos principalmente por restos de materiais industrializados, como plásticos, borrachas, vidros e metais, e ecofatos, sobretudo árvores frutíferas e plantas medicinais.

Os materiais cerâmicos detectados na Tapera do Gino estavam esparsos pela superfície, ao longo do acero e da cerca entre Lalima e a Faz. Santa Rosa, por aproximadamente $300 \mathrm{~m}$ em sentido sudoeste-noroeste (Foto 60). Também foi coletada uma conta azul em conjunto com os materiais cerâmicos. Provavelmente, os fragmentos cerâmicos afloraram à superfície por conta das escavações realizadas com a construção da cerca e do revolvimento dos sedimentos causados com o uso do trator na manutenção do acero, o que significa que pode haver materiais arqueológicos em sub-superfície. Cabe frisar que o acero da Santa Rosa é usado cotidianamente por muitos índios como via de acesso ao rio e à mata ciliar.

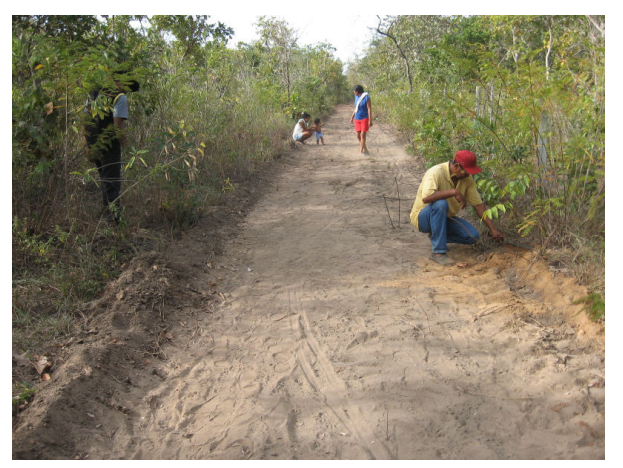

Foto 60: Coleta assistemática de superfície no sítio Tapera do Gino

Entre 121 fragmentos de vasilhas cerâmicas, coletados assistematicamente, foram selecionados 56 peças diagnósticas da forma e do acabamento de superfície para a realização das análises preliminares. Dentre os fragmentos selecionados, 44 (78,57\%) foram classificados com paredes e 11 (19,64\%) como bordas (Gráfico 49). Acerca das paredes, 7 fragmentos $(15,9 \%)$ foram categorizados como paredes carenadas, 2 (4,54\%) paredes inflectidas 1 (2,27\%) como ombro (Gráfico 50).

No que se refere às bordas, 5 fragmentos $(45,45 \%)$ foram classificados como direta vertical, $1(9,09 \%)$ como direta inclinada interna, 1 outro $(9,09 \%)$ como extrovertida e mais $1(9,09 \%)$ como côncava (Gráfico 51). No tocante às variantes do lábio, 3 dentre os fragmentos de borda $(27,27 \%)$ foram taxados como arredondados, 2 
$(18,18 \%)$ como aplanados, outros $2(18,18 \%)$ como expandidos, mais $2(18,18 \%)$ como rebarbado e 1 (9,09\%) como biselado (Gráfico 52). Em se tratando do diâmetro da boca, 2 fragmentos de borda (18,18\%) apresentaram $8 \mathrm{~cm}$ e 1 (9,09\%) 12cm (Gráfico 53).

A respeito da espessura, 35 fragmentos $(62,5 \%)$ foram taxados como finos, 9 $(16,7 \%)$ como médios, $8(14,28 \%)$ como muito finos e $4(7,14)$ como grossos (Gráfico 54). Sobre a relação entre a abertura da boca, 9 fragmentos $(16,7)$ foram associados com vasilhas fechadas e 5 (8,92\%) com abertas (Gráfico 55).

Em relação à classe de simetria das vasilhas, 4 fragmentos $(7,14 \%)$ foram associados com vasilhas não restringidas e 1 (1,78\%) com restringidas (Gráfico 56). A cerca do contorno específico e da forma, 1 fragmento $(1,78 \%)$ foi relacionado à uma vasilha com contorno simples e forma semi-esférica. Em termos funcionais, 1 fragmentos Guarani $(1,78 \%)$ foi associado com yapepó.
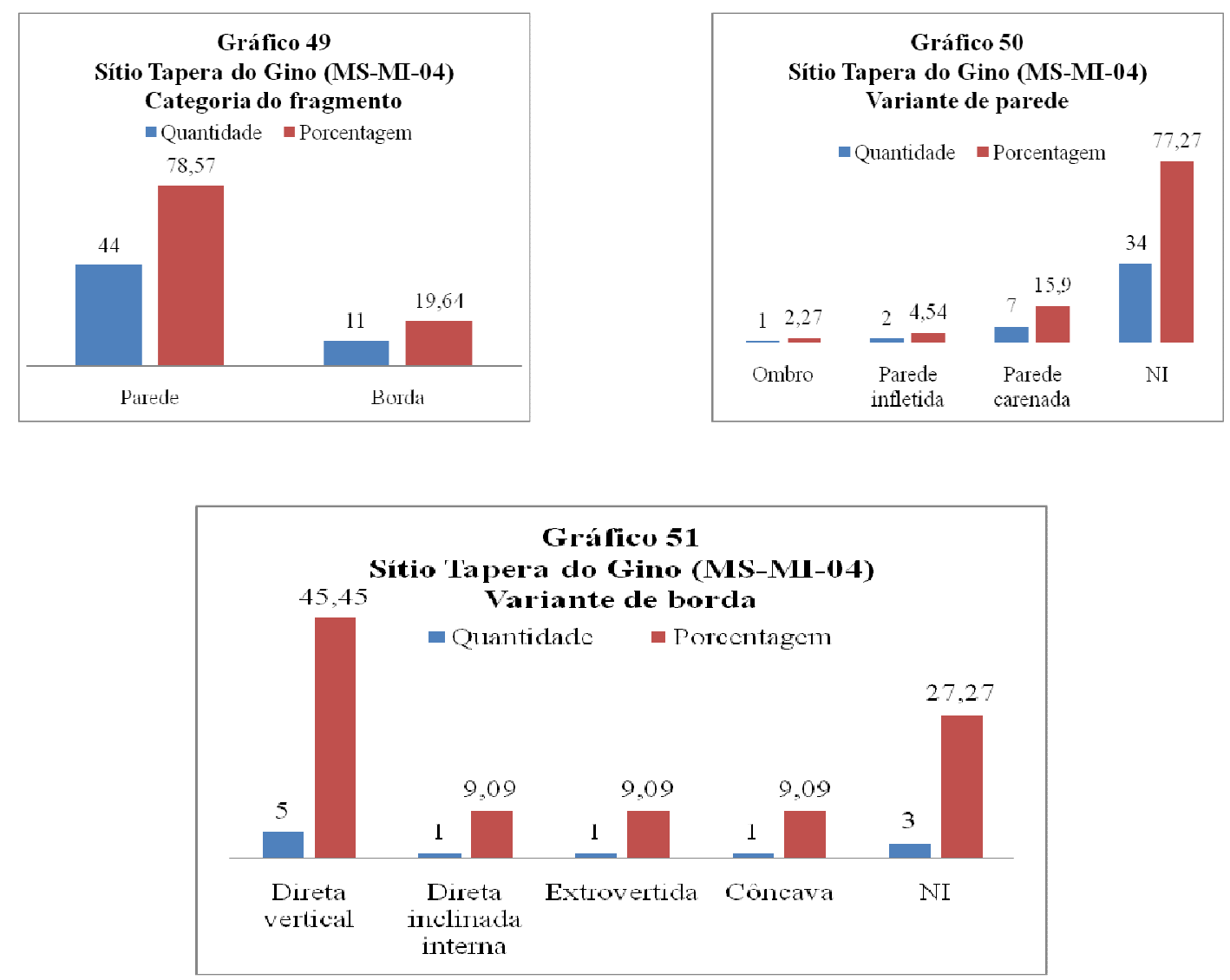

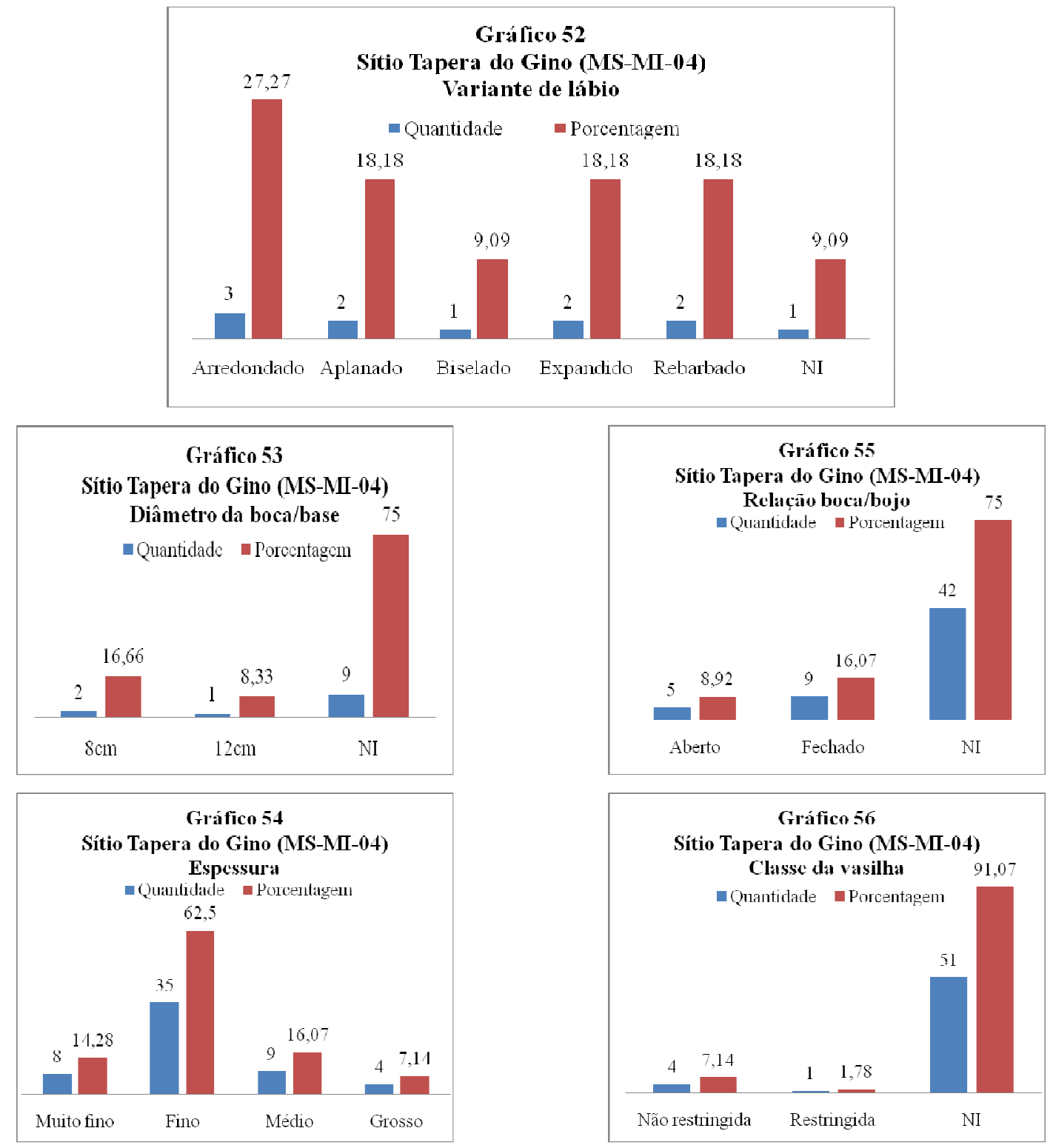

A cerca do acabamento de superfície na face externa, 40 fragmentos $(71,42 \%)$ apresentaram tratamentos plásticos e 16 (28,57\%) cromáticos (Gráfico 57). Entre os tratamentos plásticos, 19 fragmentos $(33,92 \%)$ foram corrugados, 7 (12,25\%) alisados, outros 7 (12,25\%) polidos, 3 (5,35\%) impressos geométricos com corda e policromia, 2 $(3,57 \%)$ roletados, $1(1,78 \%)$ escovado e 1 outro $(1,78 \%)$ perfurado. Dentre os fragmentos cromáticos, 13 (23,21\%) apresentaram engobo vermelho, 2 (3,57\%) engobo branco 1 outro $(1,78 \%)$ pintura policrômica. Na face interna, 45 fragmentos $(80,35 \%)$ demonstraram tratamentos plásticos e 11 (19,64\%) cromáticos (Gráfico 58). Entre os plásticos, 29 fragmentos (51,78\%) foram alisados, 15 (26,78\%) foram polidos e 1 $(1,78 \%)$ foi perfurado. Já dentre os cromáticos, 7 (12,5\%) receberam engobo vermelho, $2(3,57 \%)$ engobo branco e $2(3,57 \%)$ pintura vermelha. E se tratando do acabamento de 
superfície no lábio, 5 fragmentos de borda (45,45\%) apresentaram polimento, outros 5 $(45,45 \%)$ como alisamento e $1(9,09 \%)$ pintura vermelha (Gráfico 59).

No que se refere aos aspectos tecnológicos, 32 fragmentos $(57,14 \%)$ foram categorizados como Guarani e 21 (37,5\%) como Tradição Pantanal semelhante aos sítios José Rondon de Souza (MS-MI-02) e Limpão (MS-MI-03, Gráfico 60, Fotos 61 à 64).

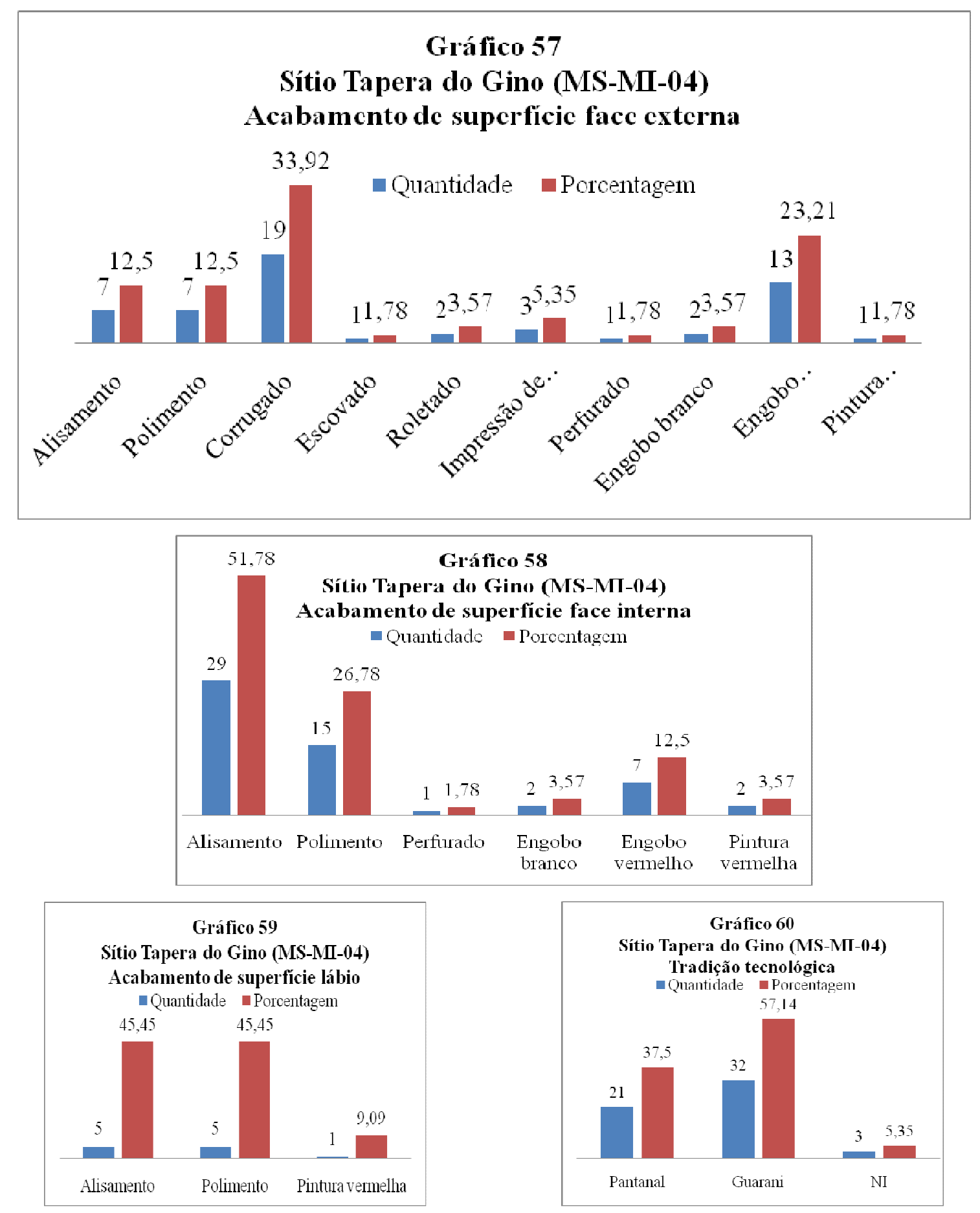




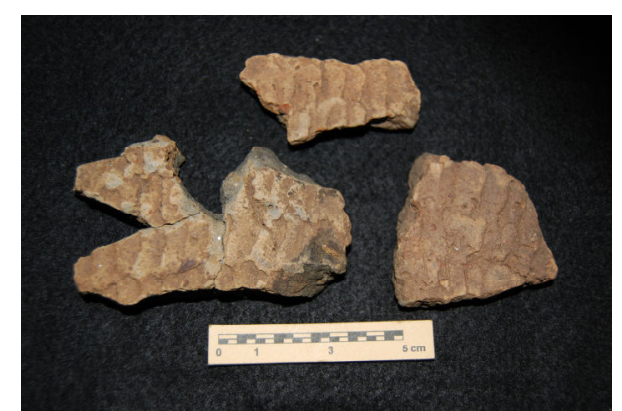

Foto 61: Fragmentos cerâmicos Guarani corrugados analisado no sítio Tapera do Gino

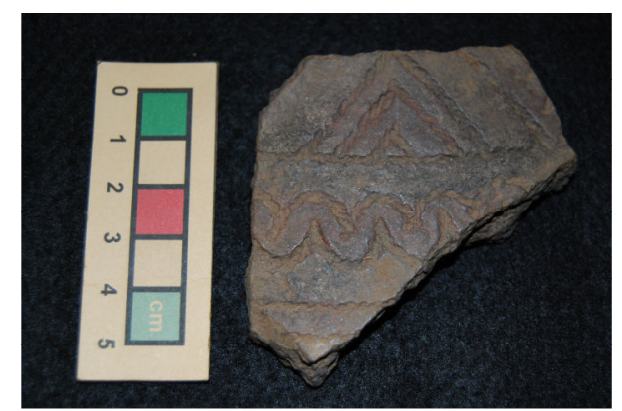

Foto 63: Fragmento cerâmico da Tradição Pantanal com impressões de corda analisado no sítio Tapera do Gino

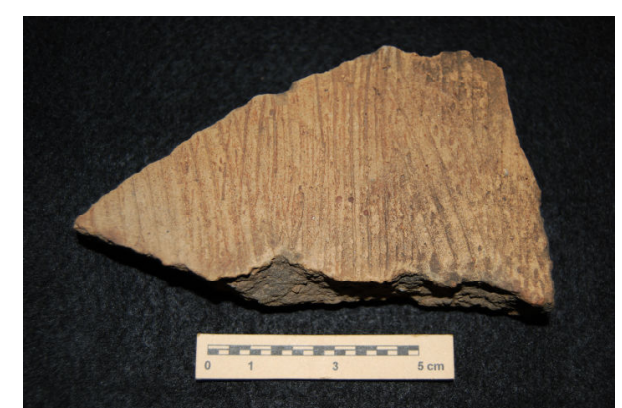

Foto 62: Fragmento cerâmico Guarani escovado analisado no sítio Tapera do Gino

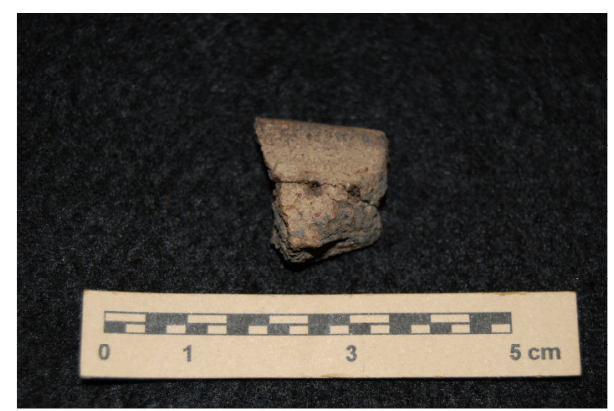

Foto 64: Fragmento cerâmico de borda da Tradição Pantanal com perfurações entre as faces analisado no sítio Tapera do Gino

\subsection{5 - Tapera da Mata do Urumbeva (MS-MI-05)}

A tapera da mata do Urumbeva (MS-MI-05), uma das mais conhecidas entre os Terena de Lalima, localizada nas coordenadas UTM 0574739/7724094 (Mapas 4 e 9), apresenta um contexto arqueológico diretamente conectado aos dados etnográficos de caráter etno-histórico associados à trajetória da ocupação indígena atual. Segundo as informações etnográficas, a Tapera do Urumbeva teria sido o local ocupado pela primeira família de índios Terena a se estabelecer em Lalima - até então ocupada somente pelos Guaikurú, na época assentados na tapera do Pirizal (MS-MI-09) - depois dos primeiros Boletins emitidos por Rondon, no início do séc. XX. Os descendentes destes Terena, os Cororó, estão até hoje em Lalima, porém vivendo em outros sítios. Um deles, inclusive, pode ser considerado como o último dos kouxomuneti Terena de Lalima. Ao que os dados orais indicam, o assentamento foi abandonado por que os Cororó resolveram acompanhar os outros índios que estavam se assentando em Lalima, os quais estavam se estabelecendo em torno do Posto Indígena do SPI, na Sede.

O sítio está implantado na baixa encosta de uma colina suave, nas proximidades de uma nascente fluvial tributária do Miranda. Predominam sedimentos areno-argilosos marrom, seguidos por arenosos, ambos dispostos sobre o embasamento quartzoso, 


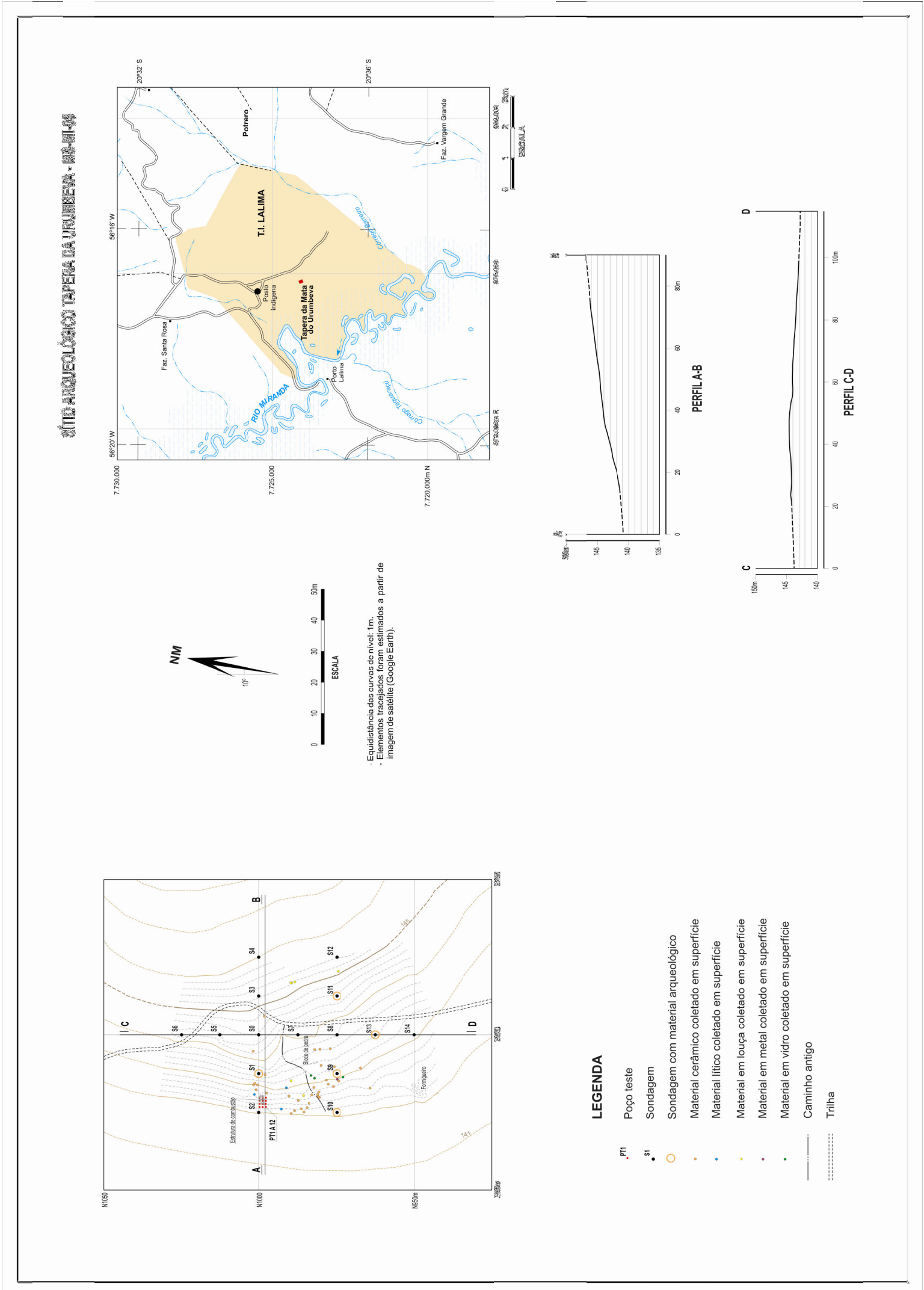


aflorante em inúmeras áreas em torno do sítio. A vegetação é formada por mata secundária de cerrado, com destaque para as palmáceas chamadas acurí, muito apreciadas pelos índios, e as gramíneas conhecidas por capim jaraguá, utilizadas como pastagem em todo o Pantanal. Embora não tenham sido encontrados mangais e laranjeiras na Tapera do Urumbeva, ecofatos típicos das taperas associadas à formação do contexto etnográfico atual, há uma clareira na área e mais uma série de outras plantas manejadas, frutíferas e medicinais.

O sítio possui cerca de $10.000 \mathrm{~m}^{2}$. As atividades de coleta sistemática de superfície e de sub-superfície resultaram na obtenção de 95 materiais arqueológicos, sendo 57 cerâmicos, 6 líticos, 23 orgânicos, 8 louças e 1 metal (Tabela 4). Em superfície, as atividades de coleta sistemática resultaram na coleta de 42 materiais, sendo 32 cerâmicos, 3 líticos, 6 louças e 1 metal. Em sub-superfície, foram coletados 53 materiais, sendo $23 \mathrm{com}$ as sondagens e $30 \mathrm{em}$ uma área de escavação (Mapa 9, Tabela 17 e Fotos 65 à 68).

\begin{tabular}{|c|c|c|c|c|c|c|}
\hline Atividade de coleta & Cerâmicos & Líticos & Orgânicos & Louças & Outros & Totais \\
\hline Sistemática de superfície & 32 & 3 & & 6 & 1 (Tampa de radiador) & 42 \\
\hline Sub-superfície & 25 & 3 & 23 & 2 & & 53 \\
\hline Totais & 57 & 6 & 23 & 8 & 1 & 95 \\
\hline
\end{tabular}

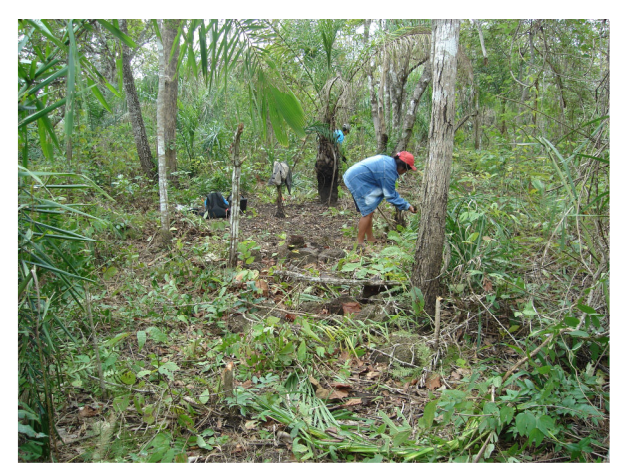

Foto 65: Limpeza da superfície na Tapera do Urumbeva

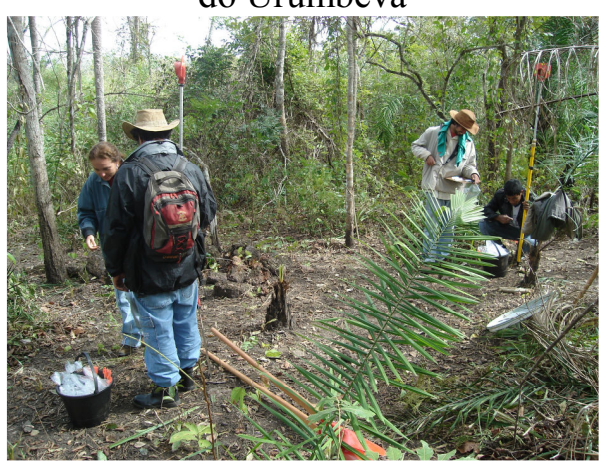

Foto 66: Coleta sistemática de superfície na Tapera do Urumbeva

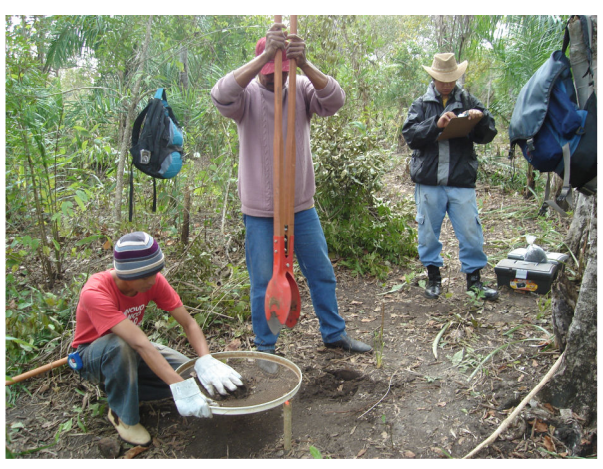

Foto 67: Escavação de sondagens na Tapera do Urumbeva

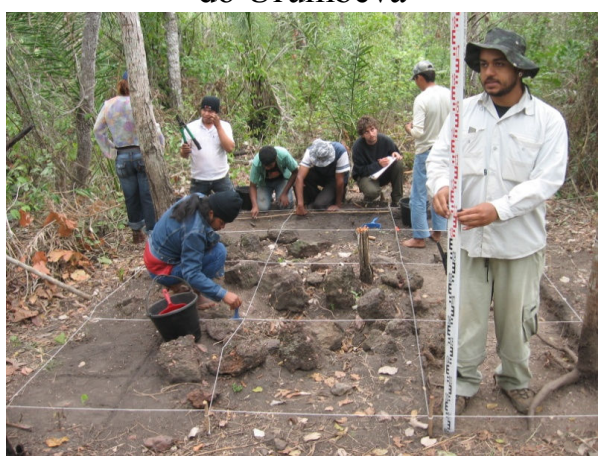

Foto 68: Área de escavação na Tapera do Urumbeva 
Foram escavadas 15 sondagens, em três segmentos de reta entrecruzados, malha de $12,5 \mathrm{~m}$ e profundidade média de $35 \mathrm{~cm}$. Observaram-se camadas arenosas e arenoargilosas marrons e marrom-escuras sobre camadas areno-argilosas marrom-alaranjadas e marrom-avermelhadas. $\mathrm{O}$ substrato foi atingido desde $5 \mathrm{~cm}$ de profundidade, porém alguns furos, escavados a até $64 \mathrm{~cm}$, não o alcançaram. Os materiais coletados, ou seja, 13 cerâmicos, 1 lítico, 8 orgânicos e 1 louça, foram descobertos em 5 das sondagens escavadas (S1, S9, S10, S11 e S13), entre os níveis 1 e 3, geralmente em contexto com sedimentos marrom e marrom-escuro (Tabela 18). O resultado mais interessante foi conquistado na sondagem $1(1000 \mathrm{~N} / 987,5 \mathrm{E})$, onde foram coletados 18 materiais (8 cerâmicos, 1 lítico, 8 orgânicos e 1 louça), localizada nas proximidades de uma estrutura de combustão circular formadas por blocos de laterita. Com efeito, tal estrutura é correlata dos fogões externos ainda utilizados no âmbito do contexto etnográfico atual nas atividades de preparação dos alimentos, sobretudo farinha de mandioca. Porém, hoje em dia os blocos lateríticos são preteridos em favor dos tijolos. Assim, tendo em vista a analogia com o contexto etnográfico atual e os resultados da $\mathrm{S} 1$, foi empreendida uma área de escavação em torno da estrutura, com o objetivo de obter os correlatos materiais das atividades de preparo e de consumo de alimentos (Mapa 9, Ilustrações contidas no anexo 2).

\begin{tabular}{|c|c|c|c|c|c|}
\hline Sondagens & Cerâmicos & Líticos & Orgânicos & Louças & Totais \\
\hline S1 & 8 & 1 & 8 & 1 & 18 \\
\hline S9 & 2 & & & & 2 \\
\hline S10 & 1 & & & & 1 \\
\hline S11 & 1 & & & & 1 \\
\hline S13 & 1 & & & & 1 \\
\hline Totais & 13 & 1 & 8 & 1 & 23 \\
\hline
\end{tabular}

A área de escavação foi executada com o quadriculamento retangular de $12 \mathrm{~m}^{2}$ (3x4) sobre a estrutura e a escavação das quadrículas situadas no seu entorno. Apenas foi escavado um nível artificial, por conta do alcance súbito do embasamento, sobre o qual o antigo fogão havia sido construído. Foram coletados 30 materiais, sendo 12 cerâmicos, 2 líticos, 15 orgânicos e 1 louça, descobertos nos poços-teste 1, 2, 3, 7, 8 e 9, em contexto com sedimentos arenosos marrom-acinzentados e cascalhentos (Tabela 19, Ilustrações no anexo 2).

É importante frisar que todos os materiais coletados, seja na superfície ou em sub-superfície, foram achados em contexto com muitos restos materiais de produtos industrializados, principalmente pedaços de metal, como arame e pregos, e fragmentos 
de recipientes vítreos, sobretudo cacos de garrafas. Entre baldes e bacias metálicas fragmentadas, provavelmente abandonadas no local por não atenderem mais às suas funções, destaca-se uma tampa amassada de radiador, aparentemente de um veículo antigo, onde se lê, em alto relevo, Ford, acima e mais destacado, e made in USA, abaixo, em letras um pouco menores.

\begin{tabular}{|c|c|c|c|c|c|}
\hline Poços-teste & Cerâmicos & Líticos & Orgânicos & Louças & Totais \\
\hline $1-1000 \mathrm{~N} / 980 \mathrm{E}$ & 3 & & & & 3 \\
\hline $2-1000 \mathrm{~N} / 979 \mathrm{E}$ & 1 & 1 & 3 & & 5 \\
\hline $3-1000 \mathrm{~N} / 978 \mathrm{E}$ & & & 1 & & 1 \\
\hline $7-999 \mathrm{~N} / 978 \mathrm{E}$ & 6 & & 8 & & 14 \\
\hline $8-999 \mathrm{~N} / 978 \mathrm{E}$ & 1 & 1 & 2 & 1 & 5 \\
\hline $9-998 \mathrm{~N} / 980 \mathrm{E}$ & 1 & & 1 & & 2 \\
\hline Totais & 12 & 2 & 15 & 1 & 30 \\
\hline
\end{tabular}

Entre os materiais cerâmicos coletados, apenas 14 fragmentos apresentavam atributo diagnósticos da forma e do acabamento de superfície das vasilhas cerâmicas, dentre os quais $13(92,85 \%)$ foram categorizados como bordas e $1(7,14 \%)$ como parede (Gráfico 61). No que se refere aos fragmentos de bordas, 6 (46,15\%) foram classificados como direta vertical e 2 (15,38\%) como extrovertida (Gráfico 62, Ilustração 8). A maioria das bordas (69,23\%), ou seja, 9 fragmentos, apresentaram lábio aplanado, porém também foram observados, nos 4 fragmentos restantes, sendo uma variante para cada fragmento $(7,69 \%)$, as seguinte formas de lábio: arredondado, apontado, biselado e expandido (Gráfico 63). Apenas foi possível identificar o diâmetro da abertura da boca em 1 fragmento de borda, aferido em $22 \mathrm{~cm}$.

Em se tratando da espessura, 13 fragmentos $(92,85 \%)$ foram classificados como fino e $1(7,14 \%)$ como médio (Gráfico 64). Acerca da relação entre a abertura da boca e o diâmetro do bojo, 8 fragmentos $(57,14 \%)$ foram associados com vasilhas abertas, não restringidas e com contorno simples. Dentre estes, 4 fragmentos $(28,57 \%)$ ainda foram relacionados com formas de vasilhas semi-esféricas. A borda com diâmetro da boca aferido foi reconstituída graficamente.
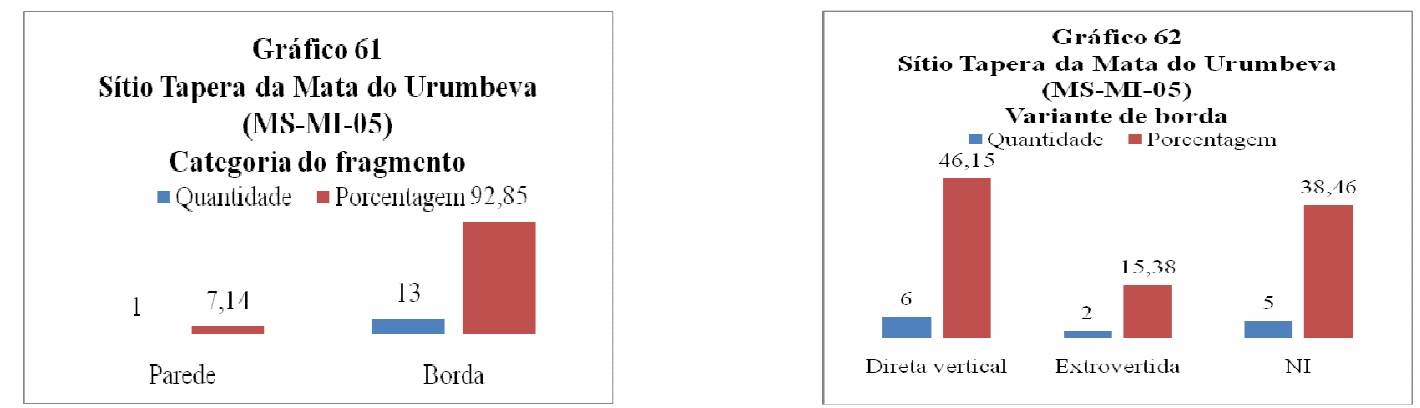


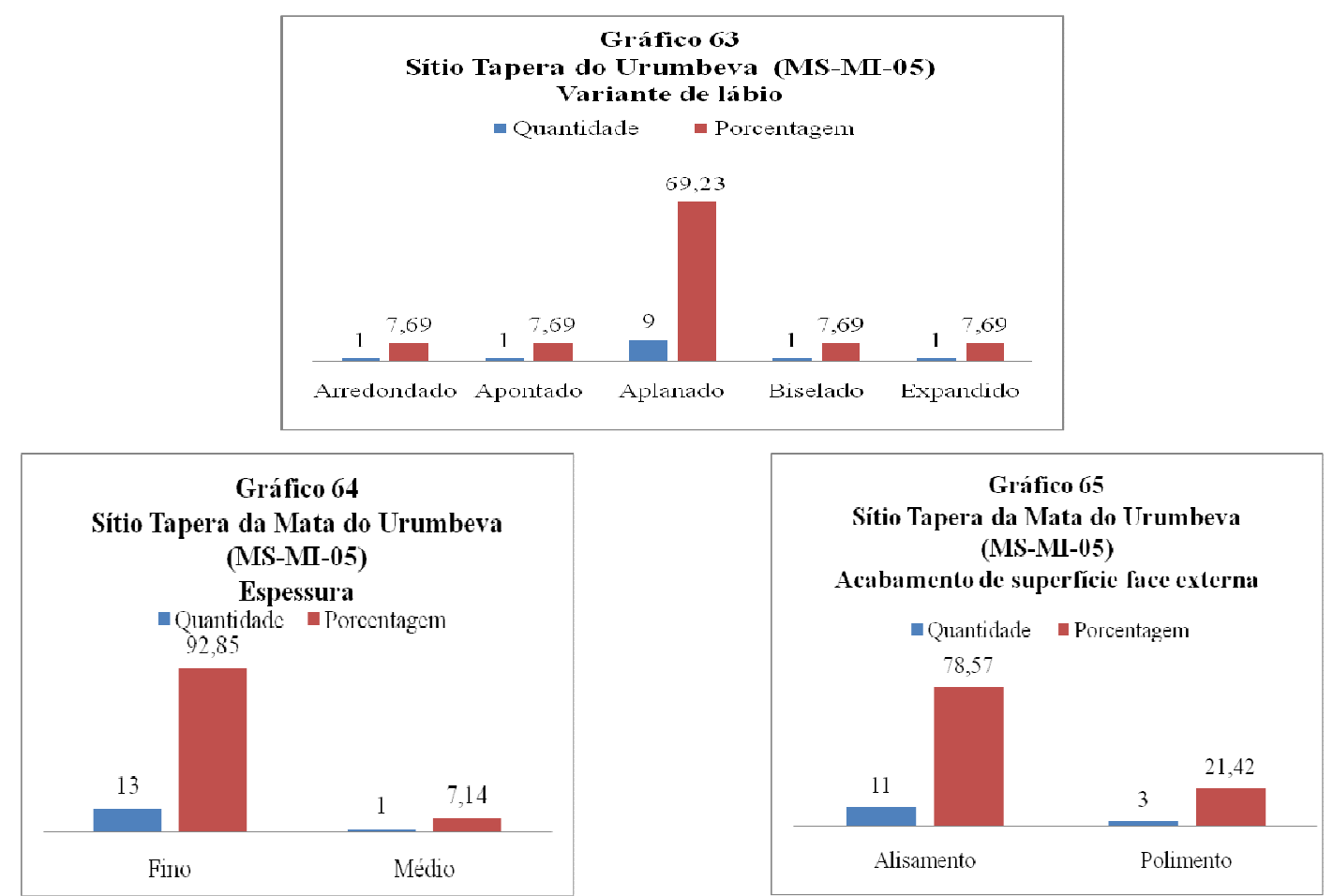

Sítio Tapera da Mata do Urumbeva (MS-MI-05) Bordas Direta Vertical

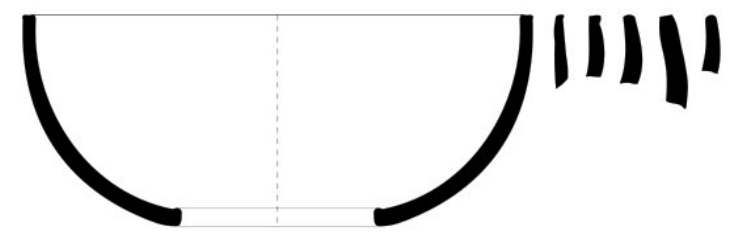

Sitio Tapera da Mata do Urumbeva (MS-MI-05) Bordas Extrovertida

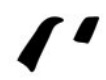

Ilustração 8: Bordas diretas e extrovertidas analisadas na Tapera da Mata do Urumbeva

No que se refere ao acabamento e superfície na face externa, todos os fragmentos apresentara tratamentos plásticos, sendo 11 (78,57\%) alisados e $3(21,42 \%)$ polidos (Gráfico 65, Fotos 69 e 70). Na face interna, 11 fragmentos (78,57) apresentaram tratamentos plásticos e $3(21,42 \%)$ cromáticos (Gráfico 66). Entre os 
plásticos, $6(42,85 \%)$ foram alisados e 5 (35,71\%) polidos, enquanto entre os cromáticos $2(14,28)$ receberam banho de engobo vermelho e $1(7,14 \%)$ foi pintado de vermelho. No lábio, 7 fragmentos de borda (53,84\%) apresentaram polimento, 5 $(38,56 \%)$ alisamento e 1 (7,69\%) pintura vermelha (Gráfico 67).

Em termos tecnológicos, todos os fragmentos analisados foram classificados como materiais etnográficos. Em termos amplos, os fragmentos cerâmicos do sítio Urumbeva são distintos de todos os outros conjuntos verificados até o presente na Aldeia Lalima, ao menos no que se refere à forma e ao acabamento de superfície das vasilhas. Com efeito, o vasilhame cerâmico ora analisado pode ser caracterizado, em termos amplos, como constituído por vasilhas não restringidas, com contornos simples, formas semi-esféricas, dimensões pequenas e médias, predominantemente alisadas ou polidas nas faces externa e interna, por vezes decoradas com engobo ou pintura vermelha. Não foram identificadas vasilhas restringidas e restringidas independentes com contornos inflectidos, compostos ou complexos, bem como com tratamentos plásticos decorativos, o que não significa que vasilhas com tais atributos não fossem usadas na Tapera do Urumbeva, haja vista que algumas pessoas ainda utilizam vasilhas com tais características na Aldeia, sobretudo para armazenar água.
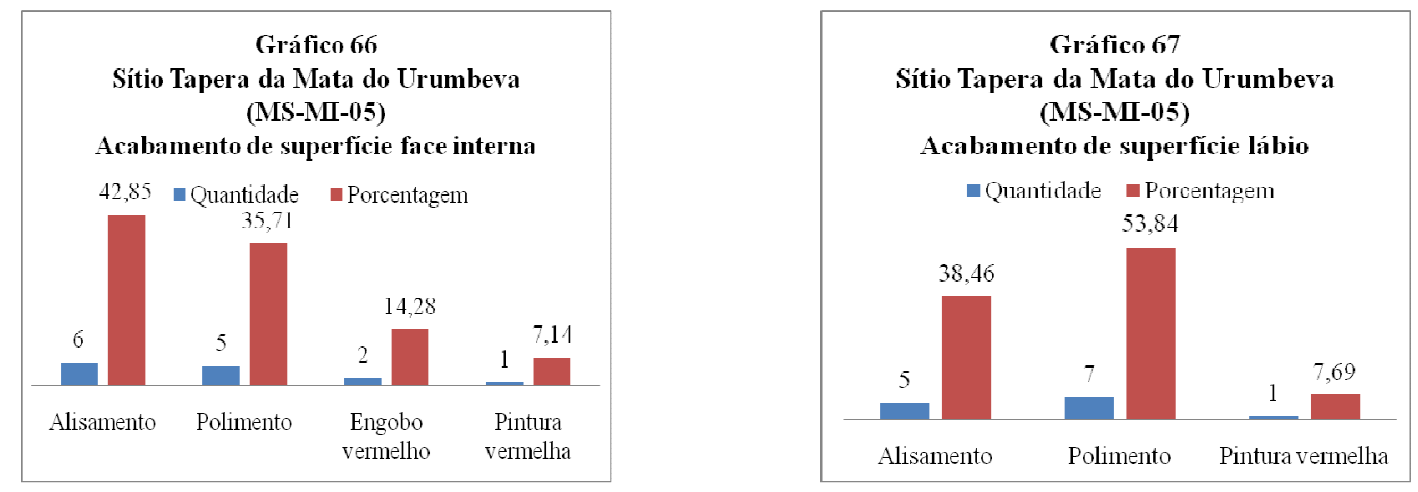

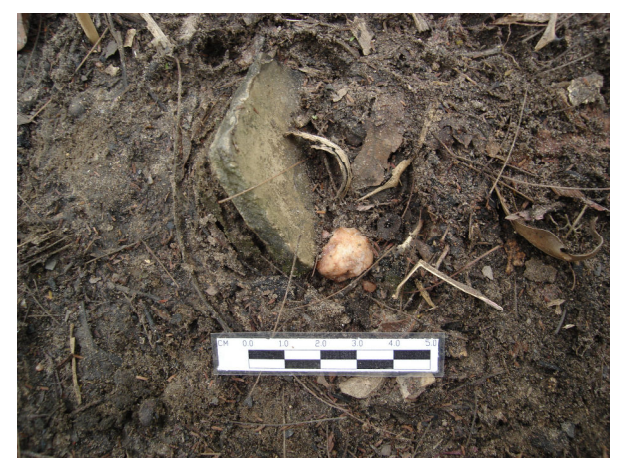

Foto 69: Fragmento cerâmico aflorando na Tapera do Urumbeva

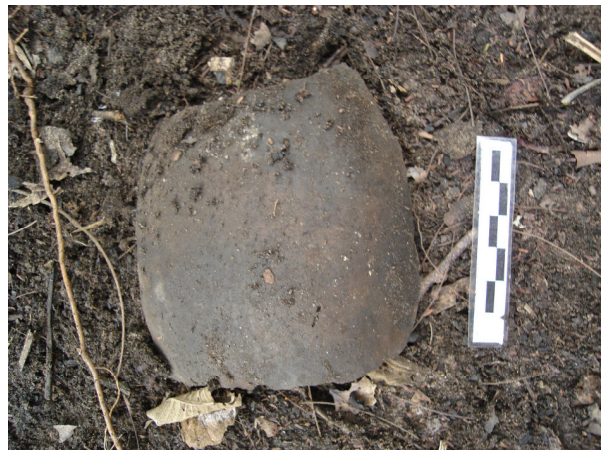

Foto 70: Fragmento cerâmico coletado na Tapera do Urumbeva 


\subsection{6 - Asa de Pote (MS-MI-06)}

O sítio Asa de Pote (MS-MI-06) está implantado logo na primeira colina depois da ponte de entrada na Aldeia, na Campina, o segundo local mais povoado de Lalima, nas coordenadas UTM 21K 0574450/7727296 (Mapas 4 e 10). A dita colina, dotada de encostas suaves, situa-se na confluência da margem direita de uma nascente fluvial, convertida em açude, com a margem direita do cór. Nascente do Guanandi, outrora perene, segundo os índios, porém atualmente sazonal, devido ao represamento das suas nascentes e ao empoçamento do seu curso, ocasionado com o destoque da mata ciliar e a construção da ponte sobre o seu leito, na entrada da Aldeia. Há resquícios de mata secundária apenas em uma curta faixa ao longo do leito do Nascente do Guanandi e em uma ou outra porção da colina, a qual apresenta-se, de fato, quase que completamente antropizada pelos domicílios, acesos, roçados, currais, pastos, estradas e açudes. A superfície é constituída por sedimentos arenosos marrons e areno-argilosos vermelhos, predominantes. O topo e as encostas alta e média possibilitam o amplo domínio visual nas direções noroeste, oeste e sudoeste, onde destacam-se, no horizonte, a calha do Miranda e a Serra da Bodoquena, bem como tudo o que se encontra entrementes.

Em superfície, os materiais estavam dispersos em concentrações esparsas por mais de $300.000 \mathrm{~m}^{2}$, sendo coletados, de maneira sistemática, 394 materiais arqueológicos, com 365 fragmentos de vasilhas cerâmicas, 14 líticos, 2 orgânicos, 9 amostras de carvão e uma suposta bolota de argila (Tabelas 4 e 20). As atividades de coleta foram desenvolvidas em duas áreas setorizadas, o setor 1, constituído por contexto Guarani, e o setor 2, formado por materiais da Tradição Pantanal análogos aos materiais analisados no setor 2 do sítio Córrego Lalima (MS-MI-01, Mapa 10).

\begin{tabular}{|c|c|c|c|c|c|c|}
\hline \multicolumn{7}{|c|}{ Tabela 20: Materiais arqueológicos coletados no sítio Asa de Pote (MS-MI-06) } \\
\hline Atividades de coleta & Cerâmicos & Líticos & Orgânicos & Carvões & Outros & Totais \\
\hline $\begin{array}{c}\text { Sistemática de superfície } \\
\text { Setor 1 }\end{array}$ & 176 & & & & & 176 \\
\hline $\begin{array}{c}\text { Sistemática de superfície } \\
\text { Setor 2 }\end{array}$ & 143 & 8 & & & & 151 \\
\hline $\begin{array}{c}\text { Sub-superfície } \\
\text { Setor 2 }\end{array}$ & 41 & 9 & 1 & 15 & 1 (suposta bolota de argila) & 67 \\
\hline Totais & 360 & 17 & 1 & 15 & 1 & 394 \\
\hline
\end{tabular}

No setor 1, foram coletados 176 fragmentos de vasilhas cerâmicas, os quais estavam concentrados em uma área de $10.000 \mathrm{~m}^{2}$ situados na média/baixa encosta da colina, sobre sedimentos areno-argilosos marrom, marrom-escuro e vermelho. A 


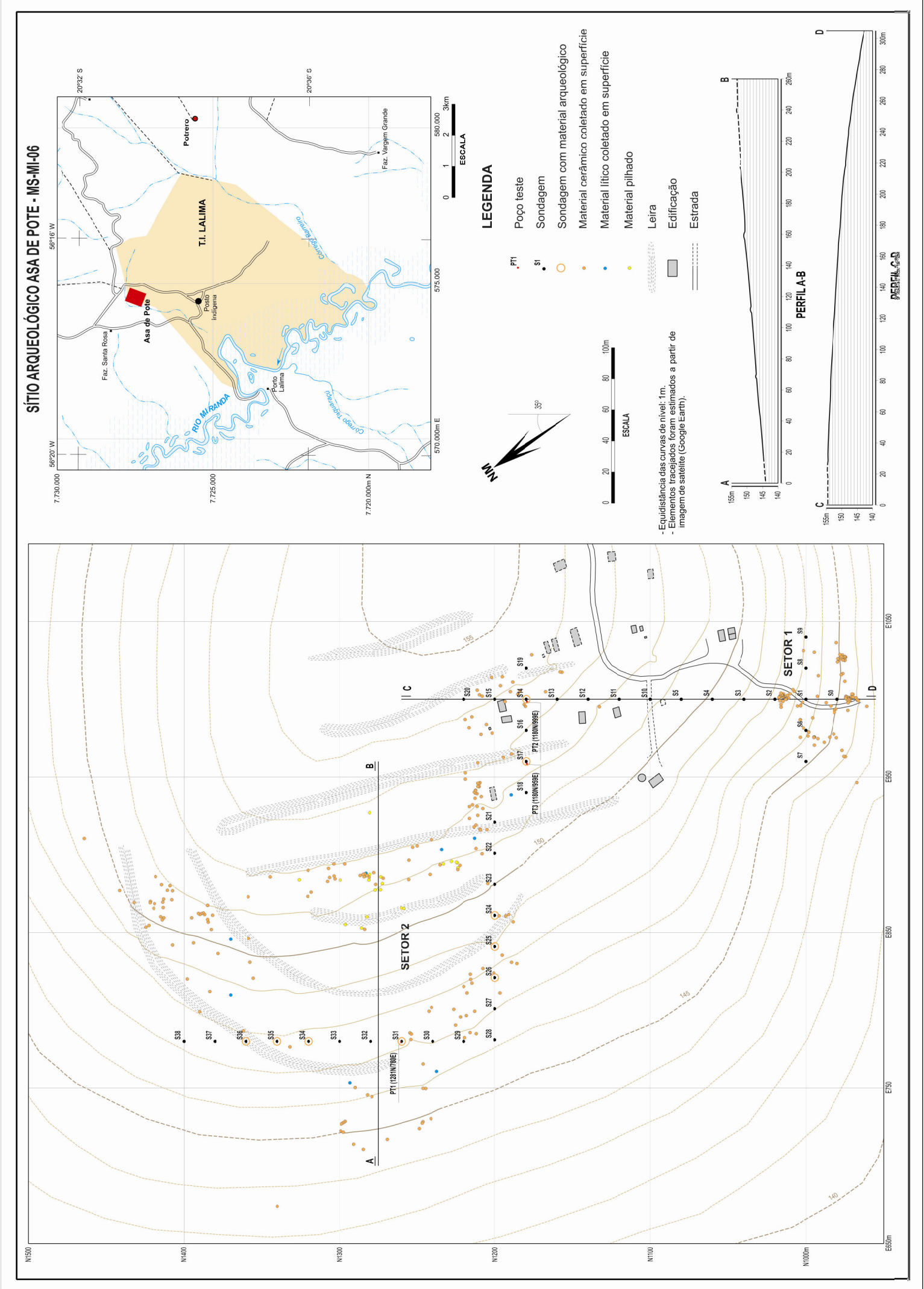


superfície do dito setor foi muito perturbada pelas atividades realizadas no âmbito do contexto etnográfico atual, sobretudo a construção de uma estrada e de uma roça de mandioca. Apesar da escavação de 11 sondagens dispostas em um cruzamento de dois segmentos, malha de $20 \mathrm{~m}$ e profundidade média de $42 \mathrm{~cm}$, não foram detectados materiais em sub-superfície, tanto que não foi empreendido nenhum poço-teste no setor (Mapa 10, Fotos 71 e 72)

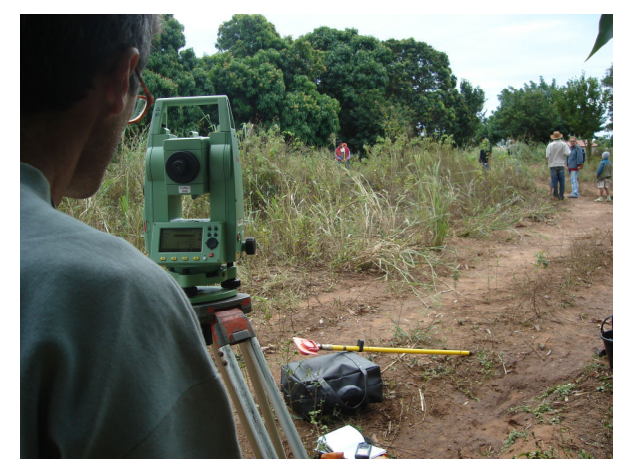

Foto 71: Topografia no setor 1 do sítio Asa de Pote

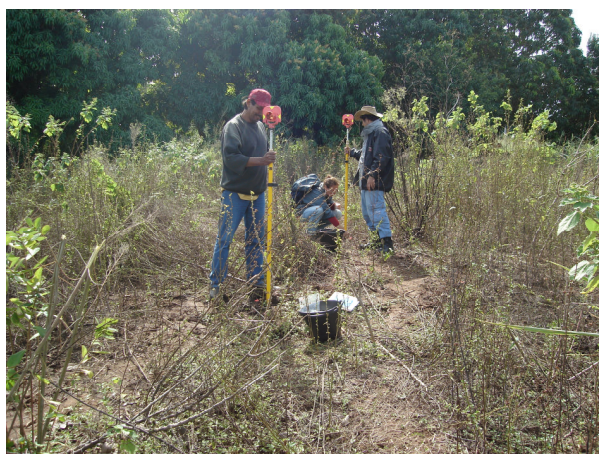

Foto 72: Coleta sistemática de superfície no setor 1 do sítio Asa de Pote

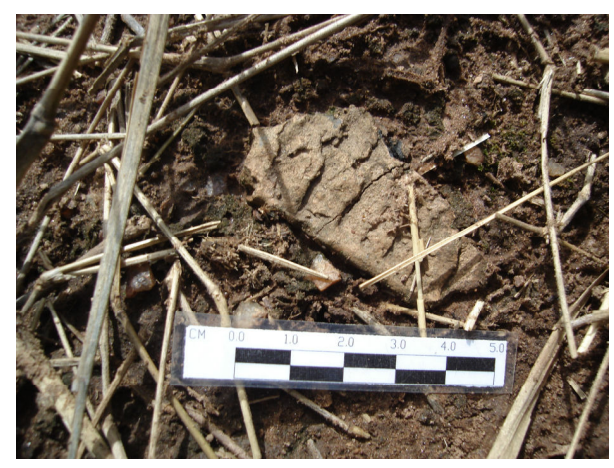

Foto 73: Fragmento cerâmico corrugado Guarani no setor 1 do sítio Asa de Pote

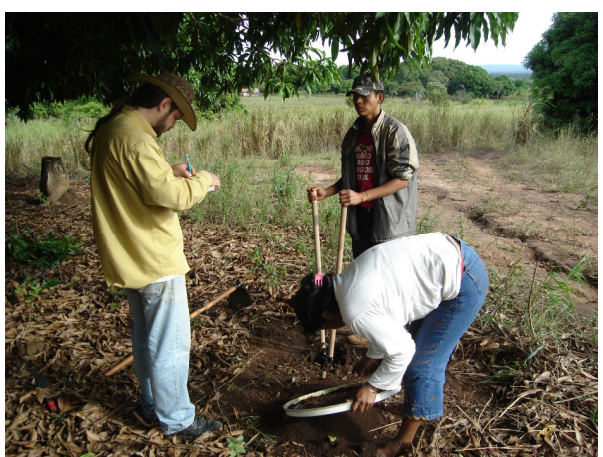

Foto 74: Escavação de sondagens no setor 1 do Asa de Pote

Levando-se em conta o resultado das sondagens, a estratigrafia apresenta, nas áreas menos impactadas, uma camada de sedimento areno-argiloso escuro sobre uma camada argilo-arenosa vermelha, com o substrato quartzoso localizado entre 30 e $50 \mathrm{~cm}$. É importante frisar que as sondagens que atingiram o substrato são as que menos apresentaram sedimentos escuros na superfície e nos primeiros níveis artificiais. Assim, tendo em vista que a maior quantidade de fragmentos estavam concentradas na mesma área em que foram escavadas as ditas sondagens, é possível que a camada escura, bem como os materiais arqueológicos, tenham sido carreados vertente abaixo pelas enxurradas vertidas na estrada. Além do mais, os materiais recolhidos na superfície pareciam aglutinados, talvez devido às atividades de limpeza desempenhadas no antigo 
domicílio do Sr. Ireno de Souza, pai da Sra . Aparecida de Souza Alves, Vice-cacique da Campina e uma das nossas auxiliares de pesquisa, outrora localizado na área setorizada, como ainda testemunham os ecofatos observados no local.

O setor 2 do Asa de pote (MS-MI-06), ao seu turno, possui cerca de $90.000 \mathrm{~m}^{2}$, os quais foram delimitados em contexto arqueológico da Tradição Pantanal, situado no topo e nas encostas alta e média da colina (Mapa 10). Atualmente, a área do setor é utilizada como roçado, no cultivo de abóbora, mandioca, melancia, milho e banana. Com a soma das coletas sistemáticas de superfície, as quais resultaram no recolhimento de 151 materiais (143 cerâmicas e 8 líticos) e de sub-superfície, onde foram coletados 66 materiais (15 nas sondagens e 52 nos poços-teste), coletaram-se, ao todo, 218 materiais (Tabela 20, Fotos 75 à 80). Em superfície, a obtenção dos materiais foi facilitada pelo arado das roças, constituídas por sedimentos areno-argilosos marromavermelhados, haja vista que as terras haviam sido preparadas para o cultivo pouco antes do desenvolvimento das atividades de coleta

As sondagens totalizaram 28 furos, dispostos em segmentos de reta estabelecidos sobre as concentrações de materiais em superfície, com malha de $20 \mathrm{~m}$ e média de profundidade de $76 \mathrm{~cm}$. Em termos gerais, as ditas sondagens evidenciaram duas camadas de sedimentos, uma areno-argilosa escura e outra argilo-arenosa vermelha. O substrato rochoso não foi alcançado no setor 2. Os materiais coletados, ou seja, 12 cerâmicas e 3 líticos, situados entre os níveis 2 e 5, portanto nas duas camadas observadas, foram descobertos em 9 dos furos escavados (S14, S17, S24, S25, S26, S31, S34, S35 e S36, Mapa 10, Foto 77, Tabela 21).

\begin{tabular}{|c|c|c|c|}
\hline Sondagens & Cerâmicos & Líticos & Totais \\
\hline S14 & 2 & 1 & 3 \\
\hline S17 & 1 & & 1 \\
\hline S24 & 1 & & 1 \\
\hline S25 & 1 & & 1 \\
\hline S26 & 1 & 1 & 2 \\
\hline S31 & 4 & & 4 \\
\hline S34 & & 1 & 1 \\
\hline S35 & 1 & & 1 \\
\hline S36 & 1 & & 1 \\
\hline Totais & 12 & 3 & 15 \\
\hline
\end{tabular}

Em função das sondagens e do grau de impacto avaliado na superfície, foram empreendidos 3 poços-teste no setor 2 , os quais resultaram na coleta de 52 materiais arqueológicos, sendo 29 fragmentos cerâmicos, 6 líticos, 1 orgânico, 1 suposta bolota de argila e 15 amostras de carvão. O poço-teste 1 (1281N/780E) foi escavado ao lado da sondagem 31 (1280N/780E), onde, por sua vez, haviam sido coletados 2 fragmentos 
cerâmicos e alguns grãos de carvão, descobertos entre os níveis 4 e 5 (Mapa 10, Foto 78). Foram escavados 7 níveis artificiais, os quais resultaram na evidenciação de 4 camadas de sedimentos, além da superfície, e na obtenção de 25 materiais arqueológicos, sendo 13 cerâmicos, 2 líticos, 1 suposta bolota de argila e 9 amostras de carvão (Tabela 22, Ilustrações contidas no anexo 2).

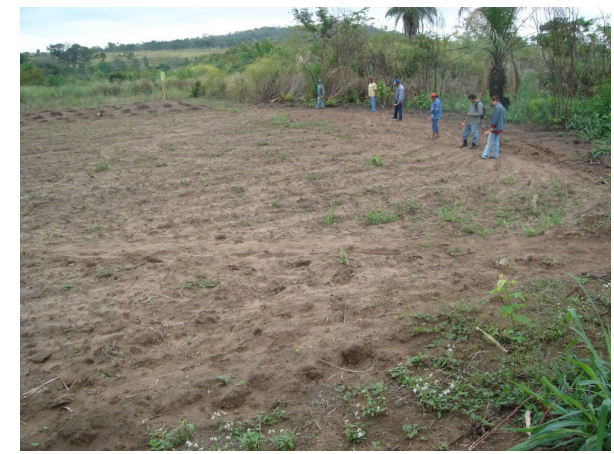

Foto: 75: Coleta sistemática de superfície no setor 2 do sítio Asa de Pote

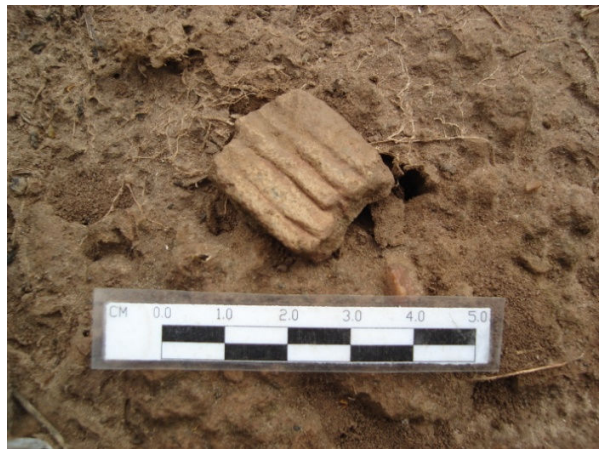

Foto 76: Fragmento cerâmico corrugado da Tradição Pantanal coletado no setor 2 do sítio Asa de Pote

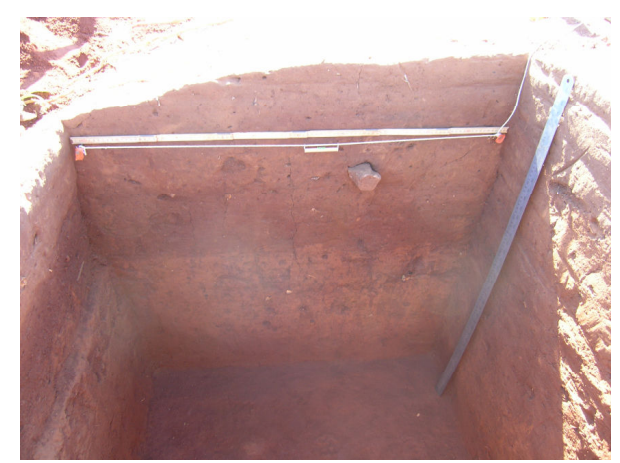

Foto 79: Escavação do poço-teste 2 no setor 2 do sítio Asas de Pote

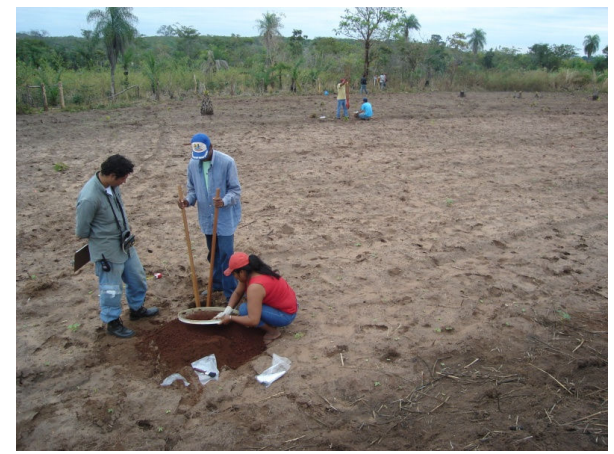

Foto 77: Escavação de sondagens no setor 2 do sítio Asa de Pote

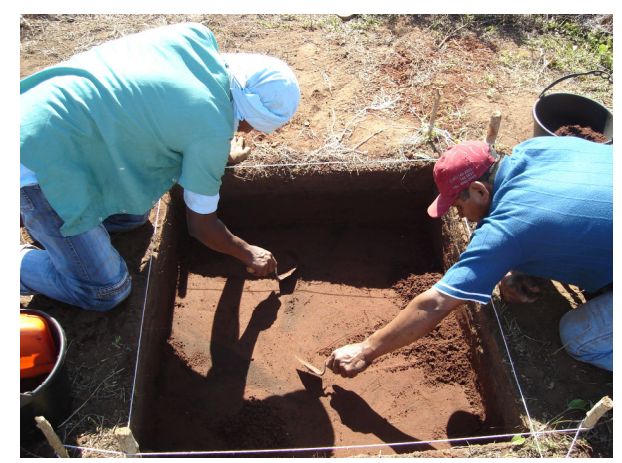

Foto 78: Escavação do poço-teste 1 no setor 2 do sítio Asa de Pote

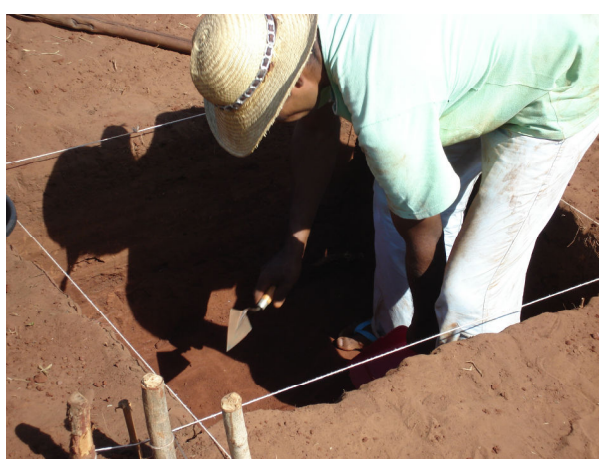

Foto 80: Escavação do poço-teste 3 no setor 2 do sítio Asa de Pote

Em função das sondagens e do grau de impacto avaliado na superfície, foram empreendidos 3 poços-teste no setor 2 , os quais resultaram na coleta de 52 materiais 
arqueológicos, sendo 29 fragmentos cerâmicos, 6 líticos, 1 orgânico, 1 suposta bolota de argila e 15 amostras de carvão. O poço-teste 1 (1281N/780E) foi escavado ao lado da sondagem 31 (1280N/780E), onde, por sua vez, haviam sido coletados 2 fragmentos cerâmicos e alguns grãos de carvão, descobertos entre os níveis 4 e 5 (Mapa 10, Foto 78). Foram escavados 7 níveis artificiais, os quais resultaram na evidenciação de 4 camadas de sedimentos, além da superfície, e na obtenção de 25 materiais arqueológicos, sendo 13 cerâmicos, 2 líticos, 1 suposta bolota de argila e 9 amostras de carvão (Tabela 22, Ilustrações contidas no anexo 2).

\begin{tabular}{|c|c|c|c|c|c|}
\hline Níveis/Camadas & Cerâmicos & Líticos & Carvões & Outros & Totais \\
\hline N0/Superficial & 2 & & & & 2 \\
\hline \multicolumn{6}{|l|}{ N1/Camadas A } \\
\hline N2/Camadas A e B & 5 & & & & 5 \\
\hline N3/Camada B e C & 5 & 1 & 3 & & 9 \\
\hline \multicolumn{6}{|l|}{ N4/Camadas C } \\
\hline N5/Camada C e D & 1 & 1 & 4 & & 6 \\
\hline N6/Camada D & & & 2 & 1 (suposta bolota de argila) & 3 \\
\hline \multicolumn{6}{|l|}{ N7/Camada D } \\
\hline Totais & 13 & 2 & 9 & 1 & 25 \\
\hline
\end{tabular}

$\mathrm{Na}$ superfície, constituída por sedimentos arenosos marrom-escuros (dark brown 10YR3/3), parcialmente recobertos por vegetação rasteira, foram coletadas 2 cerâmicas em volta da quadrícula. Na camada $\mathrm{A}$, formada pelos mesmos sedimentos observados na superfície, evidenciada com a escavação dos níveis 1 e 2, não foram achados materiais arqueológicos. Contudo, na camada B, observada nos níveis 2 e 3, composta por sedimentos argilo-arenosos marrom-escuro (very dark brown 7.5YR2.5/2), foram coletados 8 materiais arqueológicos, sendo 5 fragmentos cerâmicos no nível 2 e 1 e fragmentos e 2 amostras de carvão no nível 3. Já na camada C, vista nos níveis 3 e 4, formada por sedimento variegado argilo-arenoso marrom-avermelhado (dark-reddish brown 5YR3/3), foram coletados 6 materiais arqueológicos, todos no nível 3, sendo 4 cerâmicos, 1 lítico e 1 amostras de carvão. Na camada D, finalmente, constituída por sedimentos argilo-arenosos marrom-avermelhados (dark reddish brown 2.5YR3/3), observada a partir do nível 4, foram recolhidos 9 materiais nos níveis 5 e 6 , entre os quais 1 cerâmico, 1 lítico, 1 suposta bolota de argila e 6 amostras de carvão (Tabela 22, Ilustrações no anexo 2).

Com base na estratigrafia do poço-teste 1 , foi levantada a hipótese da ocorrência de três camadas distintas de ocupação no sítio Asa de Pote, sendo uma na superfície, outra entre as camadas B e C, nos níveis 2 e 3, e outra na camada D, entre os níveis 5 e 6. Apesar da perturbação da sub-superfície, causada pela utilização da área na 
agricultura, a hipótese sugerida com a escavação foi testada com o envio de duas amostras de carvão coletadas no poço-teste 1 para a realização de datações radiocarbônicas. Uma das amostras, coletada no nível 3, entre as camadas $\mathrm{B}$ e $\mathrm{C}$ $(\mathrm{PN}=348, \mathrm{X}=56 \mathrm{~cm}, \mathrm{Y}=62 \mathrm{~cm}$ e $\mathrm{Z}=27,5 \mathrm{~cm}$, Foto 81), foi datada em $1.070 \pm 60$ AP (Beta - 238768), enquanto a outra, recolhida no nível 6, na camada D (PN=362, $\mathrm{X}=86 \mathrm{~cm}$, $\mathrm{Y}=32 \mathrm{~cm}$ e $\mathrm{Z}=51,5 \mathrm{~cm}$, Foto 82 ), foi datada em $6.340 \pm 70$ AP (Beta -238767$)$.

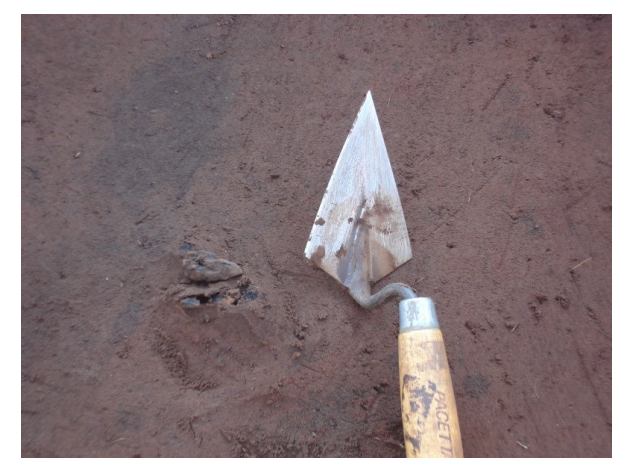

Foto 81: Amostra de carvão datada em $1.070 \pm$ 60 AP

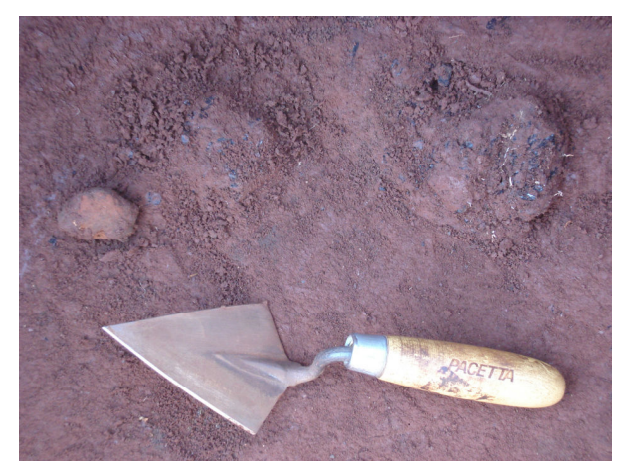

Foto 82: Amostra de carvão datada em $6.340 \pm$ 70 AP ao lado da suposta bolota de argila

Diante da antiguidade desta última data, cabe explicar que a maioria dos materiais arqueológicos, sobretudo cerâmicos, foram achados em contexto com a data proveniente da amostra de carvão coletada no nível 3, ou seja, entre 20 e $30 \mathrm{~cm}$ de profundidade. Entre os materiais recolhidos nos níveis 2 e 3, situados entre Z 16 e $28 \mathrm{~cm}$, e os materiais coletados nos níveis 5 e 6 , detectados entre $\mathrm{Z} 41$ e $53 \mathrm{~cm}$, foi observado um hiato em termos de materiais arqueológicos de ao menos $13 \mathrm{~cm}$, sendo que não foram encontrados materiais arqueológicos no nível 4, ou melhor, entre $30 \mathrm{e}$ $40 \mathrm{~cm}$ de profundidade. Além da amostra datada em 6 mil anos, descoberta no início do nível 6, ou seja, entre 50 e $60 \mathrm{~cm}$ de profundidade, ao lado de uma suposta bolota de argila e de outra amostra de carvão, a escavação do nível 5, situado entre 40 e $50 \mathrm{~cm}$, resultou apenas na coleta de uma lasca em quartzo ( $P N=356, X=72 \mathrm{~cm}, Y=34 \mathrm{~cm}$, $Z=41 \mathrm{~cm})$, um fragmento de vasilha cerâmica $(P N=355, X=48 \mathrm{~cm}, Y=63 \mathrm{~cm}$ e $Z=43 \mathrm{~cm})$ e mais 4 amostras de carvão, localizadas entre $Z 43$ e $48,5 \mathrm{~cm}$. Considerando que as amostras de carvão coletadas no nível 5 podem estar associadas às amostras de carvão provenientes do nível 6 , os últimos materiais arqueológicos detectados no poço-teste 1 foram respectivamente recolhidos à 10 e $8 \mathrm{~cm}$ acima da amostra datada e da suposta bolota de argila. Assim, ao mesmo tempo em que se julga que os carvões e a suposta bolota provenientes do nível 6 não estão associados com o contexto arqueológico 
descoberto no nível 3, avalia-se que a cerâmica e o lítico coletados no nível 5 foram deslocados do nível 3 por conta das atividades agrícolas.

Tendo em vista a consideração da data obtida no nível 3, acredita-se, com base no próprio contexto descoberto com a escavação do poço-teste 1 e nas demais escavações empreendidas no setor 2, apesar dos impactos causados no solo pelo contexto etnográfico atual, que apenas pode existir duas Camadas de ocupação no Asa de Pote, sendo uma em superfície e outra em sub-superfície. De qualquer modo, mesmo ciente de que ainda são necessárias mais datações arqueológicas para estabelecer a cronologia da Tradição Pantanal na Aldeia Lalima e para suprimir quaisquer dúvidas que podem ser levantadas por conta da datação obtida com a amostra de carvão recolhida no nível 6, fica registrada a sugestão de que a Tradição Pantanal semelhante à Fase Jacadigo também pode datar desde períodos pré-coloniais nas áreas não inundáveis.

O poço-teste $2(1180 \mathrm{~N} / 999 \mathrm{E})$ foi executado na roça de mandioca em frente à casa da $\mathrm{D}^{\mathrm{a}}$. Cida, nas proximidades da sondagem 14 (1180N/1000E), onde haviam sido detectados, entre os níveis 3 e 5, 2 fragmentos cerâmicos, 1 lítico e 1 amostra de carvão (Mapa 10, Foto 79). Escavaram-se 10 níveis artificiais, através dos quais foi possível observar 3 camadas de sedimentos, afora a superfície, e obter 17 materiais arqueológicos, sendo 9 cerâmicos, 2 lítico e 6 amostras de carvão (Tabela 23, Ilustrações contidas no anexo 2). A superfície, um tanto quanto revolvida pelo arado, apresentava sedimento areno-argiloso marrom, sem materiais arqueológicos na quadrícula, porém havia sido recolhidos 4 fragmentos cerâmicos nas proximidades durante as atividades de coleta sistemática. Na camada $\mathrm{A}$, visualizada com a escavação dos níveis 1, 2 e parte do 3, não foram coletados materiais arqueológicos nos sedimentos argilo-arenosos que a constituíam, assim como na camada B, composta por sedimento argilo-arenoso marrom-avermelhado e evidenciada nos níveis 3 e parte do 4 . A maioria dos materiais descobertos na quadrícula foram coletados no começo da camada $\mathrm{C}$, entre o fim do nível 3 e o início do 4, formada por sedimentos argiloarenosos vermelho, sendo 1 cerâmica, 1 lítico e 1 carvão no nível 3, e 8 cerâmicas e 1 lítico no nível 4. No nível 6, ainda foram recolhidas mais 5 amostras de carvão, porém sem contexto com materiais arqueológicos.

Os carvões coletados no fim do nível $3(\mathrm{PN}=364, \mathrm{X}=84 \mathrm{~cm}, \mathrm{Y}=22 \mathrm{~cm}$ e $\mathrm{Z}=$ $30 \mathrm{~cm}$ ), aparentemente não perturbado pela ação do arado, também foram enviados para a realização de datações radiocarbônicas, porém os mesmos não foram suficientes. Seja 
como for, assim como no poço-teste 1 , também foi observado um hiato no poço-teste 2 entre os materiais coletados em superfície, na sub-superfície, nos níveis 3 e 4, e entre concentrações de carvão sem contexto arqueológico descobertas no nível 6.

\begin{tabular}{|c|c|c|c|c|}
\hline \multicolumn{5}{|c|}{ Tabela 23: Materiais arqueológicos coletados no Poço-teste 2 no setor 1 do sítio Asa de Pote (MS-MI-05) } \\
\hline Níveis/Camadas & Cerâmicos & Líticos & Carvões & Totais \\
\hline N0/Superficial & & & & \\
\hline N1/Camada A & & & & \\
\hline N2/Camada A & 1 & 1 & 1 & 3 \\
\hline N3/Camadas A e B & 8 & 1 & & 9 \\
\hline N4/Camadas B e C & & & & 5 \\
\hline N5/Camada C & & & & \\
\hline N6/Camada C & & & & \\
\hline N7/Camada C & & & & \\
\hline N8/Camada C & & & & \\
\hline N9/Camada C & & 2 & 6 & 17 \\
\hline N10/Camada C & & & & \\
\hline Totais & 9 &
\end{tabular}

Devido ao fragmento cerâmico coletado no nível 3 do furo de sondagem 17 (1180N/960E), descoberto em contexto com uma concentração de carvão, o poço-teste 3 (1180N/959E) foi escavado ao lado do dito furo (Mapa 10, Foto 80). Assim, com a escavação de 6 níveis artificiais e a evidenciação de três camadas de sedimentos, foram coletados 10 materiais arqueológicos no poço-teste 3, sendo 7 cerâmicas, 2 líticos e 1 orgânico (Tabela 24, Ilustrações contidas no anexo 2). Os materiais arqueológicos, descobertos entre Z 29 e $37 \mathrm{~cm}$, quase que como da mesma forma que nos outros poçosteste escavados, foram coletados entre as camadas B, visualizada com a escavação de parte do nível 1, do nível 2 e parte do nível 3, e C, observados a partir do nível 3, as quais são constituídas, respectivamente, por sedimentos areno-argilosos marromavermelhados e argilo-arenosos vermelhos. A camada A, composta por sedimentos areno-argilosos marrom-avermelhados, observada nos níveis 1 e 2, não apresentou materiais arqueológicos, assim como a superfície, formada por sedimentos arenosos marrons. Apenas a superfície e a camada A foram perturbadas com o revolvimento dos sedimentos pelo arado, haja vista que o poço-teste 3 foi escavado na mesma roça que o poço-teste 2. Todavia, não foram descobertos carvões ou fragmentos grandes de vasilhas cerâmicas, os quais poderiam render datações radiocarbônicas ou termoluminescentes.

Entre os materiais cerâmicos coletados no setor 2 do sítio Asa de Pote, foram selecionados 42 fragmentos diagnósticos, sendo 35 (83,33\%) proveniente das atividades de coleta em superfície e $7(16,6 \%)$ de sub-superfície (Gráfico 68). No que se refere à categoria dos fragmentos, 22 (52,38\%) foram classificados como paredes, 18 (42,85\%) como bordas e 2 (4,76\%) como apêndices suspensão em forma de alças (Gráfico 69). 
Dentre os fragmentos de parede, $5(22,72 \%)$ foram associados ao segmento superior do bojo, $2(4,76 \%)$ foram taxados como ombros e outros $2(4,76 \%)$ como paredes inflectidas (Gráfico 70).

\begin{tabular}{|c|c|c|c|c|}
\hline Níveis/Camadas & Cerâmicos & Líticos & Orgânicos & Totais \\
\hline \multicolumn{5}{|l|}{ N0/Superficial } \\
\hline \multicolumn{5}{|l|}{ N1/Camada A e B } \\
\hline \multicolumn{5}{|l|}{ N2/Camada A e B } \\
\hline N3/Camada B e C & & 2 & & 2 \\
\hline N4/Camadas C & 7 & & 1 & 8 \\
\hline \multicolumn{5}{|l|}{ N5/Camada C } \\
\hline \multicolumn{5}{|l|}{ N6/Camada C } \\
\hline Totais & 7 & 2 & 1 & 10 \\
\hline
\end{tabular}

Em relação aos fragmentos de borda, 8 (44,4\%) foram categorizados como extrovertidos, $3(16,66 \%)$ como diretas inclinadas externa, outros $3(16,66 \%)$ como introvertidas e $2(11,11 \%)$ como diretas verticais (Gráfico 71). Em se tratando às formas do lábio, 8 fragmentos $(44,44 \%)$ foram classificados como reforçados externo, 4 $(22,22 \%)$ como rebarbado, $3(16,66 \%)$ como apontado, 2 (11,11\%) como roletado e 1 $(5,55 \%)$ como aplanado (Gráfico 72$)$. A respeito da abertura da boca, 2 fragmentos $(11,11 \%)$ apresentaram $10 \mathrm{~cm}$ de diâmetro e outros $2(11,11 \%)$ apresentaram $16 \mathrm{~cm}$, sendo que também foram aferidos os seguintes diâmetros de boca, com 1 ocorrência cada (5,55\%): $6 \mathrm{~cm}, 8 \mathrm{~cm}, 12 \mathrm{~cm}, 20 \mathrm{~cm}$ e $30 \mathrm{~cm}$ (Gráfico 73 ).

Acerca da espessura, 30 fragmentos $(71,42 \%)$ foram categorizados como finos, $10(23,8 \%)$ como muito finos, $1(2,38 \%)$ como médio e outro 1 (2,38\%) como grosso (Gráfico 74). No tocante à relação entre a abertura da boca e o diâmetro do bojo, 12 fragmentos $(28,57 \%)$ foram associados com vasilhas fechadas e 4 (9,52\%) com vasilhas abertas (Gráfico 75).

Em relação às classes simétricas, 4 fragmentos $(9,52 \%)$ foram relacionados com vasilhas não restringidas, $3(7,14 \%)$ com vasilhas restringidas e $1(2,38 \%)$ com vasilha restringida independente (Gráfico 76). Sobre o contorno específico, 6 fragmentos (14,28\%) foram taxados como simples. Já em se tratando da forma geométrica, 3 fragmentos $(7,14 \%)$ foram associados com vasilhas esféricas, 2 (4,76\%) com vasilhas semi-elípticas horizontais e 1 (2,38\%) vasilha semi-esférica (Gráfico 77). 


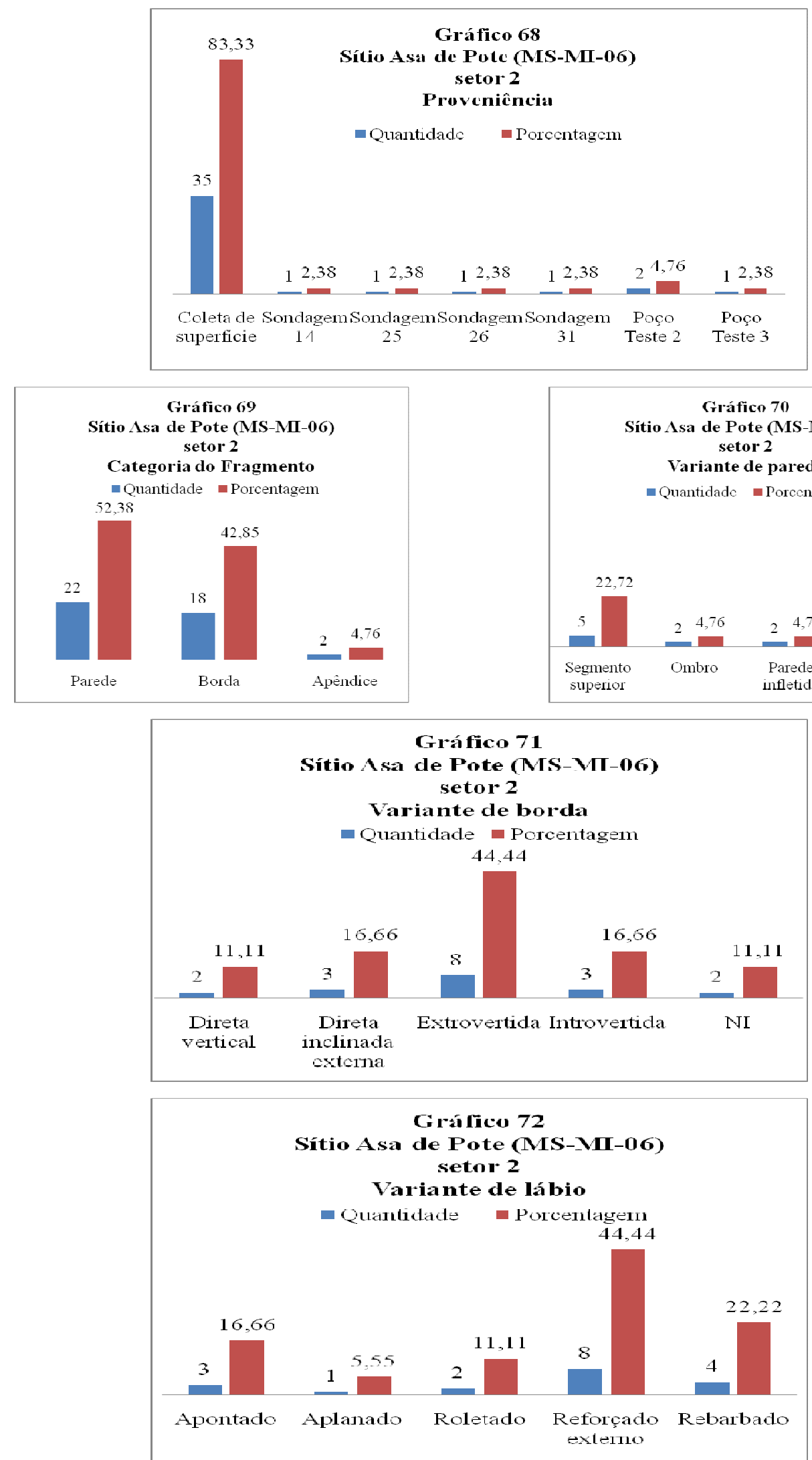




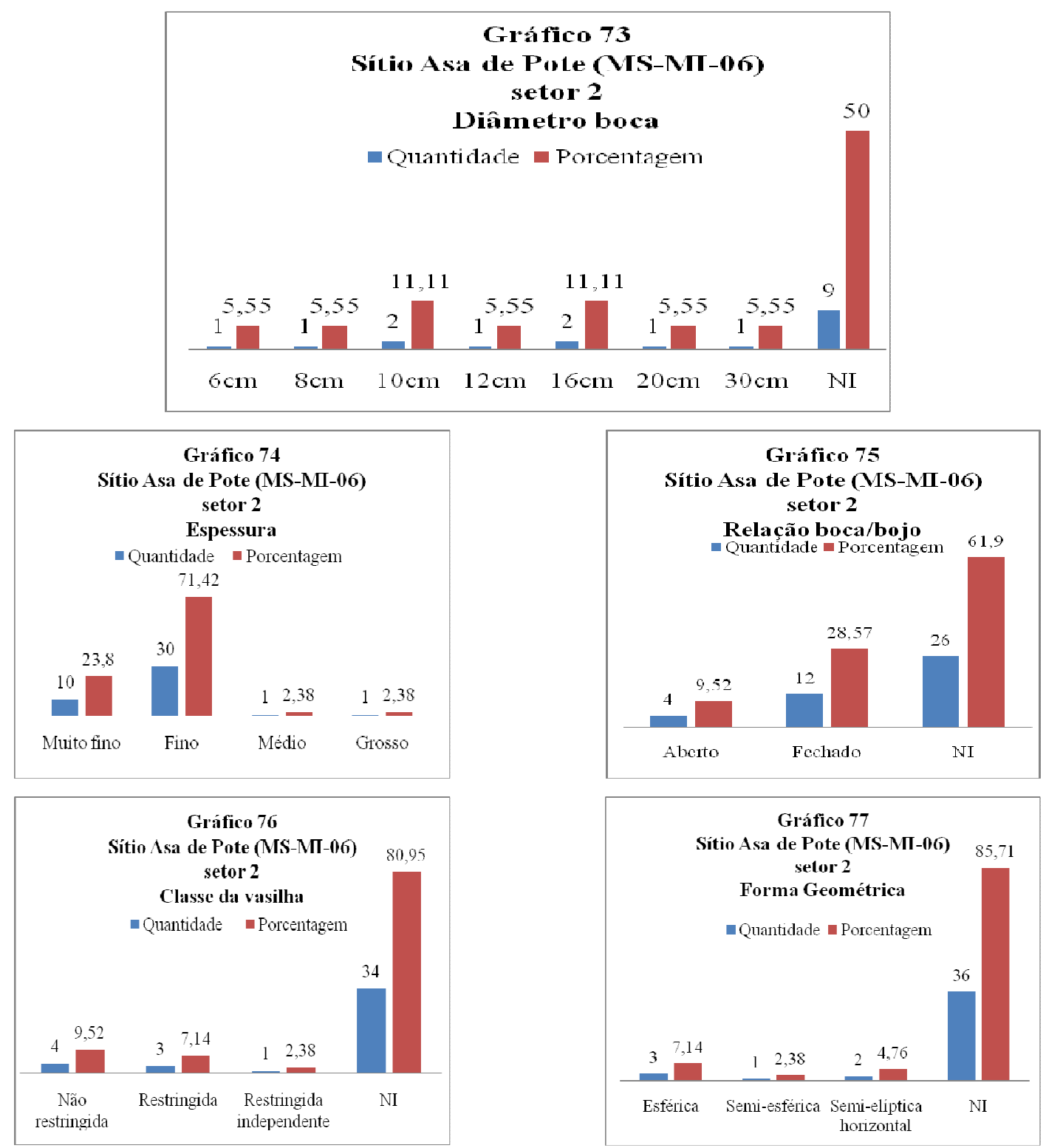

No que se refere ao acabamento de superfície na face externa, 40 fragmentos (95,23\%) apresentaram acabamentos plásticos e 4 (4,76\%) cromáticos (Gráfico 78). Entre os plásticos, 21 (50\%) foram alisados, 9 (26,19\%) corrugados, 4 (9,52\%) aplicados com filigranas de argila, $3(7,14 \%)$ roletados e $1(2,38 \%)$ foi polido. Já dentre os cromáticos, $1(2,38 \%)$ recebeu banho de engobo vermelho enquanto outro $1(2,38 \%)$ foi pintado com círculos vermelhos. Na face interna, 37 fragmentos $(88,09 \%)$ receberam tratamentos plásticos e $5(11,9 \%)$ cromáticos (Gráfico 79). Entre os plásticos, 32 (76,19\%) foram alisados, $4(9,52 \%)$ polidos e 1 (2,38\%) acanalado. Quanto aos cromáticos, $3(7,14 \%)$ foram pintados de vermelho e 2 (4,76\%) receberam engobo vermelho. Em se tratando das bordas, 13 fragmentos $(72,22 \%)$ apresentaram lábios 
alisados, 4 (22,22\%) aplicados com filigranas de argila e 1 (5,55\%) polido (Gráfico 80, Fotos 38 à 86).

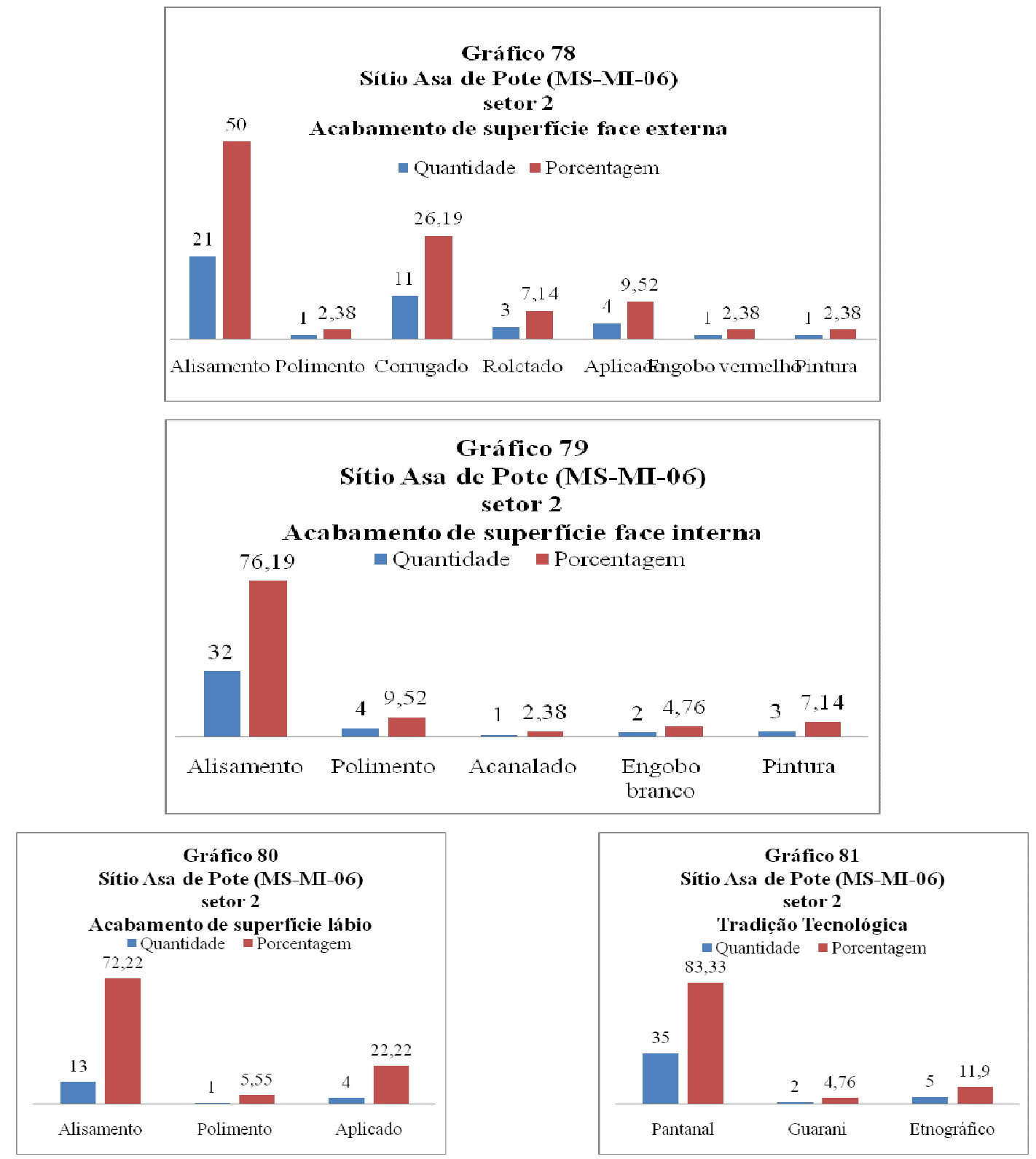

Em termo tecnológicos, 35 fragmentos $(83,33 \%)$ foram classificados como Tradição Pantanal, 5 (11,9\%) como etnográficos e 2 (4,76\%) como Guarani (Gráfico 81). Os materiais cerâmicos provenientes do setor 2 do sítio Asa de Pote apresentam atributos característicos semelhantes ao contexto arqueológico detectado no setor 2 do sítio Córrego Lalima (MS-MI-01), sobretudo a presença de decorações aplicadas com filigranas de argila nas faces externas e nos lábios reforçados das vasilhas. Todavia, o setor 2 do sítio Córrego Lalima apresenta maior densidade e variedade morfológica e no tratamento de superfície maior que o setor 2 do Asa de Pote (MS-MI-06). Talvez, o 
setor com materiais da Tradição Pantanal na Asa de Pote seja correlato de um assentamento menor ou de alguma área de atividade específica em relação àquele do setor 2 do sítio Córrego Lalima.

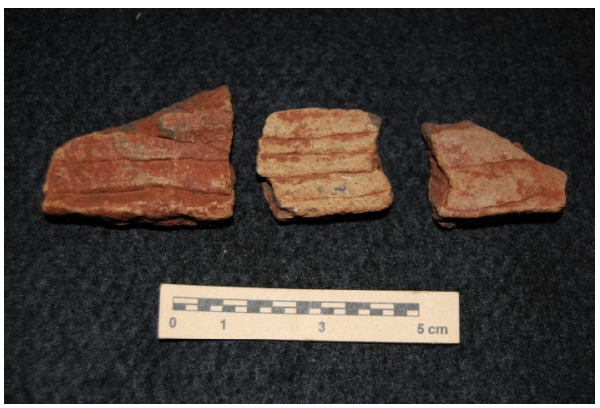

Foto 83: Fragmentos corrugados da Tradição Pantanal analisados no setor 2 do sítio Asa de Pote

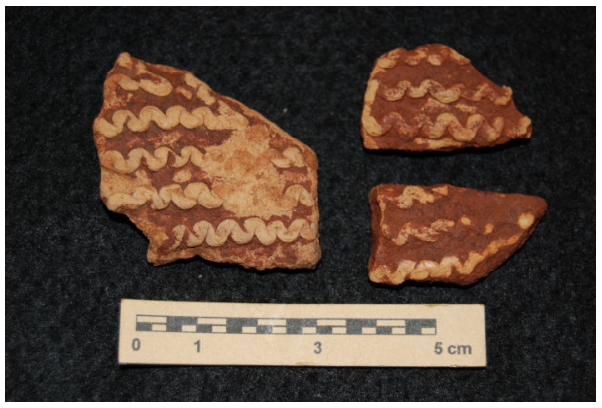

Foto 83: Fragmentos com apliques de filigranas de argila analisados no setor 2 do sítio Asa de Pote

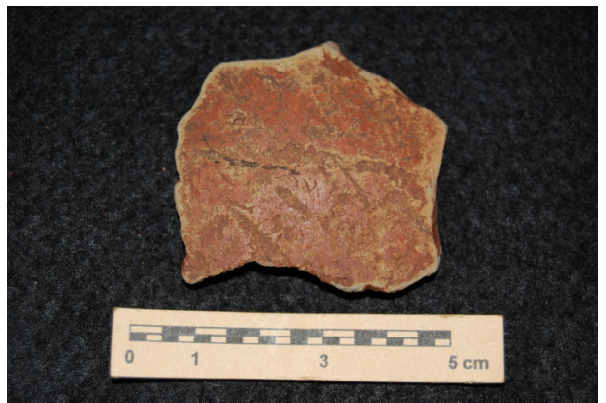

Foto 84: Fragmento com engobo vermelho da Tradição Pantanal analisados no setor 2 do sítio Asa de Pote

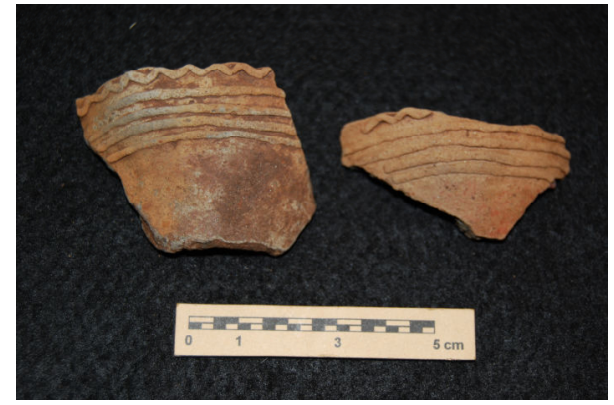

Foto 84: Fragmentos com apliques de filigranas da Tradição Pantanal analisados no setor 2 do Asa de Pote

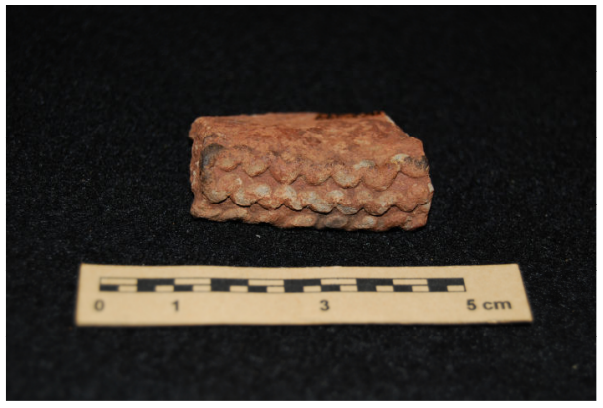

Foto 85: Fragmento de borda com apliques de filigranas da Tradição Pantanal analisados no setor 2 do sítio Asa de Pote

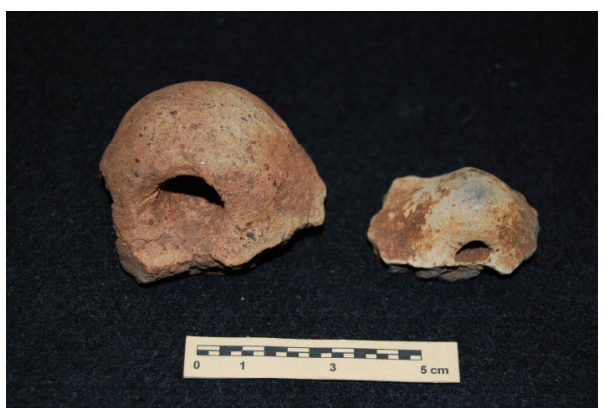

Foto 86: Apêndices de suspensão da Tradição Pantanal analisados no setor 2 do sítio Asa de Pote

\subsection{7 - Campina (MS-MI-07)}

O sítio Guarani Campina (MS-MI-07) foi detectado na área mais populosa da Campina, a segunda localidade mais povoada de Lalima, nas coordenadas UM $21 \mathrm{~K}$ 0574518/7726905 (Mapa 4). O sítio está implantado nas encostas de uma colina suave, situada entre a confluência da margem direita de uma nascente fluvial com o médio curso da margem esquerda do cór. Nascente do Guanandi (Foto 87). O setor 1 do sítio 
Asa de Pote (MS-MI-06), igualmente constituído por materiais arqueológicos Guarani, situa-se na outra margem da dita nascente fluvial, a cerca de 200m do sítio Campina.

Os materiais arqueológicos, formados principalmente por fragmentos de vasilhas cerâmicas Guarani, estão dispersos às centenas pela superfície, formada por sedimentos arenosos bastante perturbados e remexidos pela dinâmica da ocupação indígena do contexto etnográfico atual. Não foram desenvolvidas atividades de coleta, porém os caminhamentos realizados pela Campina indicam que o sítio pode apresentar dimensões semelhantes às apresentadas pelo sítio Córrego Lalima (MS-MI-01). Em um desses caminhamentos, inclusive, flagramos alguns índios descobrindo 2 fragmentos cerâmicos corrugados enquanto escavavam a fossa de um banheiro em uma residência construída recentemente, os quais acabaram sendo coletados (Foto 88).

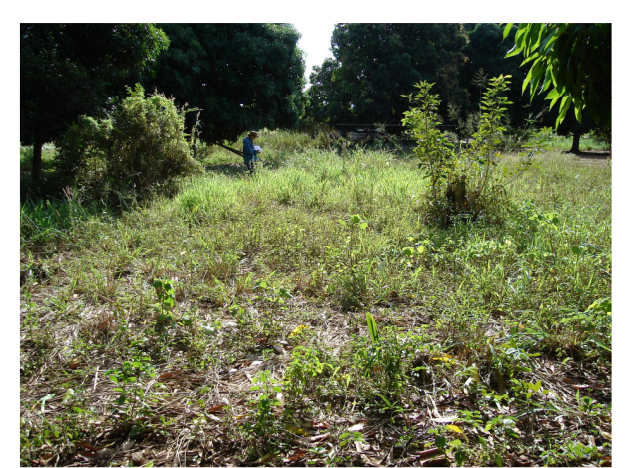

Foto 87: Local de implantação do sítio Campina

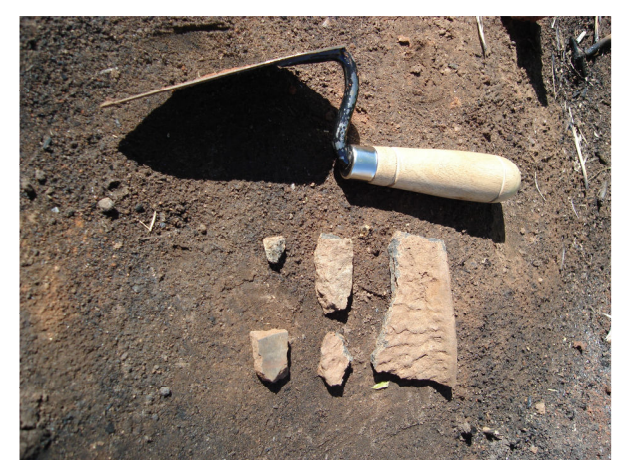

Foto 88: Fragmentos corrugados Guarani coletados no sítio Campina

\subsection{8 - Manuel de Souza Neto (MS-MI-08)}

O sítio Manuel de Souza Neto (MS-MI-08), localizado na casa e na roça do Manuel e vizinhos, está implantado na baixa encosta de duas colinas suaves, constituídas por sedimentos arenosos, situadas uma em cada margem da confluência de uma nascente flúvio-pluvial vinda da Sede, defronte ao PIN Lalima, com a margem esquerda do cór. do Lima, tributário da margem direita do Miranda, nas coordenadas UTM 21K 0573695/7725436 (Mapa 4, Imagem 4).

A maior parte dos materiais arqueológicos, constituídos por algumas dezenas de fragmentos de vasilhas cerâmicas da Tradição Pantanal, sendo alguns com impressões de corda geometrizadas, como nos sítios José Rondon de Souza (MS-MI-02), Limpão (MS-MI-03) e Gino (MS-MI-04), foi detectada na roça de feijão do Sr. Manuel e vizinhos, localizada na confluência da margem esquerda da nascente com a esquerda do 
cór. do Lima (Fotos 89 e 90). No quintal da casa do Sr. Manuel, situada na outra margem da boca da nascente, foram observados apenas alguns fragmentos cerâmicos desprovidos de atributos diagnósticos e duas lâminas de machado lítico polido, até então pertencentes uma à esposa do Sr. Manuel, Sra ${ }^{\mathrm{a}}$ Jandira Lipú, e outra ao seu tio, Sr. Luiz de Souza, sendo ambas doadas à coleção de materiais arqueológicos obtidos em Lalima.

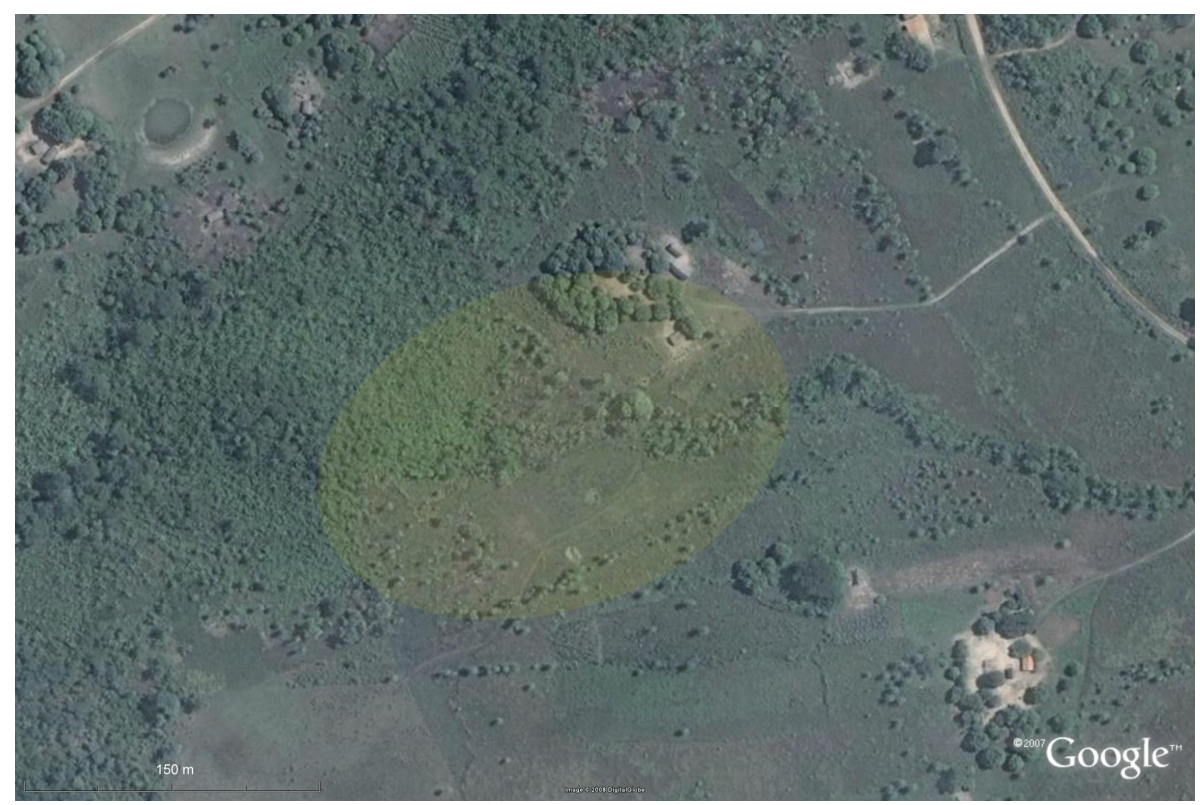

Imagem 4: Sítio Manuel de Souza Neto (MS-MI-08)

Não foram desenvolvidas atividades de coleta no sítio Manuel de Souza Neto, haja vista que uma das vizinhas não permitiu que entrássemos na sua propriedade, mesmo depois de muita negociação. Contudo, tudo indica que os fragmentos vieram à superfície com o uso da enxada, o que significa que pode haver materiais arqueológicos em sub-superfície. Nesse sentido, o MS-MI-04 pode ser entendido como um dos sítios mais promissores da Tradição Pantanal em se tratando dos contextos arqueológicos formados por fragmentos de vasilhas com motivos geométricos feitos com impressão de corda detectados em Lalima.

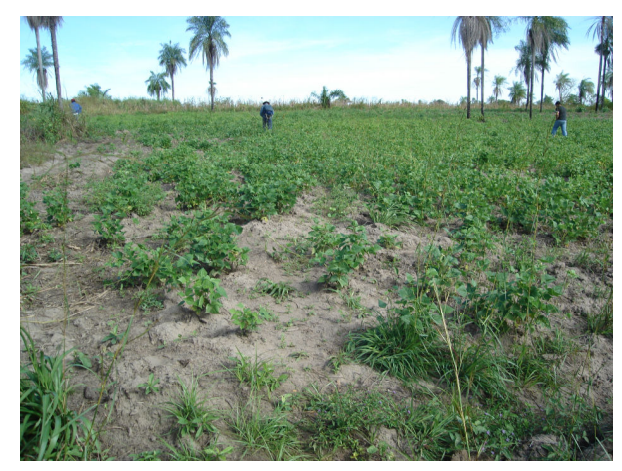

Foto 89: Local de implantação do sítio Manuel de Souza Neto

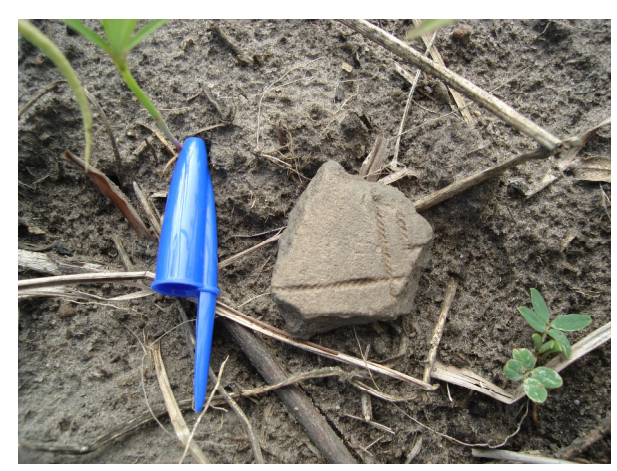

Foto 90: Fragmento cerâmico com impressões de corda achado no sítio Manuel de Souza Neto 


\subsection{9 - Tapera do Pirizal (MS-MI-09)}

De acordo com a maioria das informações etnográficas de caráter etno-histórico, o sítio Tapera do Pirizal seria o local onde os índios Guaikurú estariam assentados quando o Marechal Rondon passou por Lalima, em 1905. Plotado nas coordenadas UTM 21K 0573508/7725949, o sítio esta implantado em uma área plana, constituída por sedimentos arenosos, situada na beira da planície de inundação da margem direita do rio Miranda (Mapa 4, Imagem 5). O termo pirizal, inclusive, ou pirizeiro, se aplica a uma espécie de vegetação aquática que predomina nas áreas alagadas e charcosas ao longo das margens dos rios no Pantanal. Atualmente, a área do sítio é utilizada como pastagem.

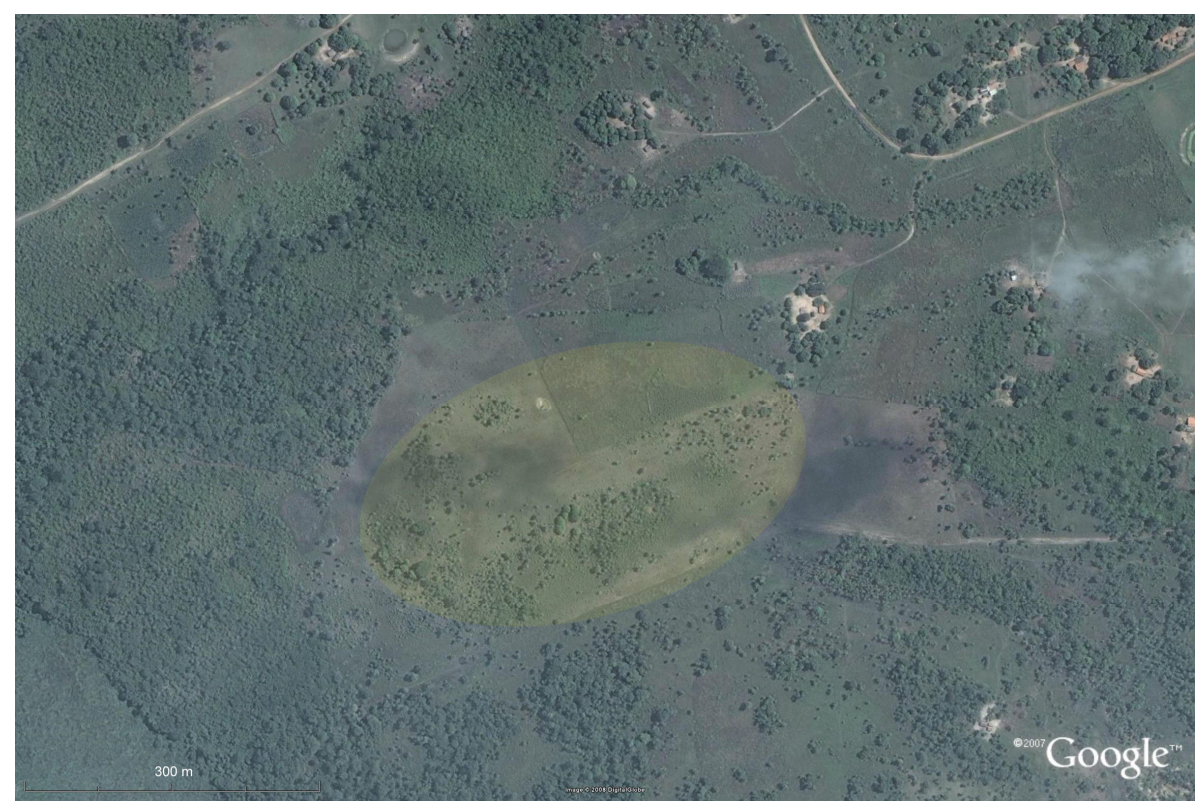

Imagem 5: Sítio Tapera do Pirizal (MS-MI-09)

$\mathrm{O}$ contexto arqueológico é semelhante àquele detectado na Tapera da Mata do Urumbeva (MS-MI-05), sendo constituído principalmente por vestígios de materiais industrializados, tais como plásticos, borrachas, vidros e metais, e ecofatos, sobretudo capoeiras, pomares e plantas medicinais. Na capoeira situada no limite leste da área do sítio, foi descoberta uma área formada por sedimento queimado e materiais arqueológicos. Os sedimentos queimados apresentavam textura arenosa, coloração alaranjada, consistência seca e compacta, e forma semi-elíptica, com cerca de $2 \mathrm{~m}$ de extensão, no sentido leste-oeste, por $1 \mathrm{~m}$ de largura. Entre os materiais arqueológicos detectados na área de sedimento queimado, foram coletados, de maneira assistemática, 
46 fragmentos de vasilhas cerâmicas e uma ponta de lança de ferro batido, provavelmente utilizada como fisga em atividades de pesca (Fotos 91 e 92). Entre os materiais cerâmicos coletados, caba destacar a presença de 4 fragmentos de borda associados com vasilhas não restringidas e restringidas com contornos simples, 1 base circular-côncava, relacionada $\mathrm{cm}$ vasilha de forma esférica, e 1 fragmento de parede decorado com banho de engobo vermelho.

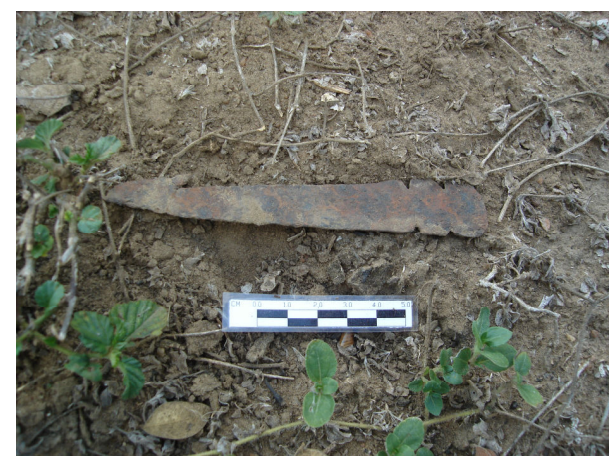

Foto 91: Ponta de ferro batido coletada na Tapera do Pirizal

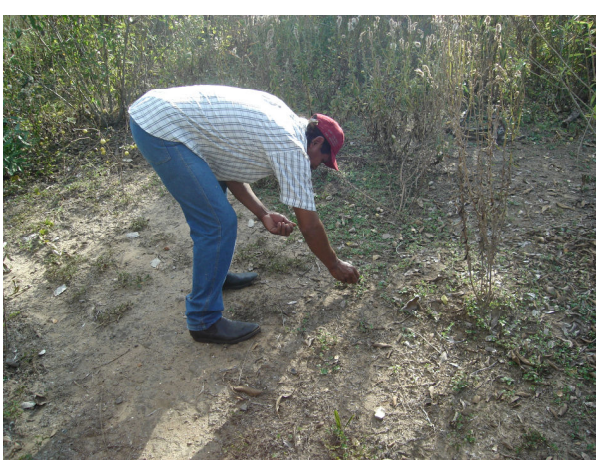

Foto 92: Coleta assistemática de materiais arqueológicos na Tapera do Pirizal

\subsubsection{0 - Potrero (MS-MI-10)}

Como sugerido pela própria denominação, o sítio Potrero (MS-MI-10) foi detectado no Potrero, a área da Fazenda Vargem Grande desapropriada pelo INCRA e retomada pelos Índios (Mapa 4). O sítio está implantado em uma colina suave, constituída por sedimentos argilosos e arenosos, situada entre o sopé do morro do Potrero e a margem esquerda do médio curso de um cór. sazonal tributário da margem direita do médio Miranda, nas coordenadas UTM 21K 0580296/7725567 (Foto 93).

Apesar de não terem sido realizadas análises preliminares nos fragmentos cerâmicos coletados no Potrero, o contexto arqueológico é constituído por materiais da Tradição Pantanal semelhantes àqueles detectados no setor 2 do sítio Córrego Lalima (MS-MI-01) e no setor 2 do sítio Asa de Pote (MS-MI-06), caracterizado sobretudo por fragmentos de vasilhas cerâmicas decoradas com apliques de filigranas nas faces externas e nos lábios reforçados, entre outros atributos. Foram assistematicamente coletados 54 fragmentos cerâmicos e 1 lâmina de machado lítico polido, detectados ao longo de aproximadamente $60 \mathrm{~m}$ no interior de uma voçoroca, por sua vez dotada de cerca de $150 \mathrm{~m}$ no sentido noroeste-sudeste, situada em meio à pastagem (Foto 94). 
Apesar dos impactos causados com o uso atual da área do sítio do Potrero, destinadas à pecuária, e da densidade relativamente baixa de materiais, ainda mais se comparado com o setor 2 do sítio Córrego Lalima (MS-MI-01), o contexto arqueológico do MS-MI-10 pode apresentar um grau de integridade maior que os sítios localizados nas áreas mais urbanizadas de Lalima. Da mesma forma, o contexto do Potrero também sugere que outros sítios, talvez em estados de conservação mais preservados e associados a outras populações, portadoras da Tradição Pantanal ou não, podem ser detectados nas margens do córrego onde o MS-MI-10 está implantado.

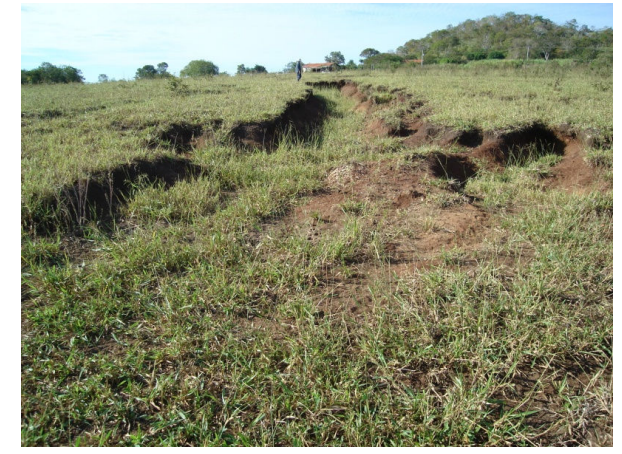

Foto 93: Local de implantação do sítio Potrero

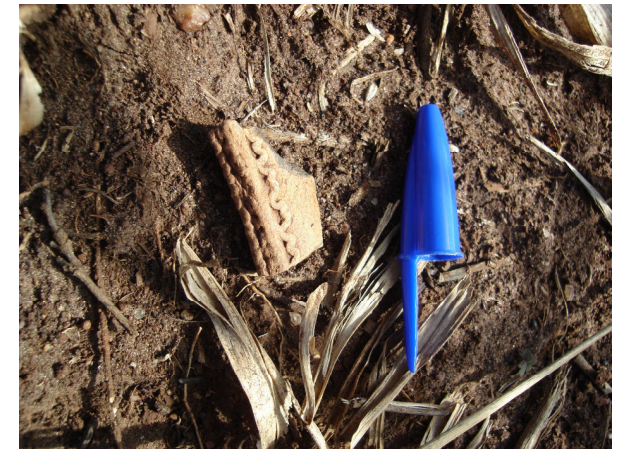

Foto 94: fragmento cerâmico de borda decorado com apliques de filigranas coletado no sítio do Potrero

\subsubsection{1 - Anita Vieira (MS-MI-11)}

O sítio Guarani Anita Vieira (MS-MI-11) foi detectado na propriedade da $\mathrm{Sr}^{\mathrm{a}}$. Anita Viera. O sítio está implantado em uma colina suave, constituída por sedimentos areno-argilosos vermelhos, situada nas nascentes do cór. do Lima, nas coordenadas $21 \mathrm{~K}$ 0575314/7726195 (Mapa 4, Foto 95). Os materiais arqueológicos, constituídos principalmente por fragmentos de vasilhas cerâmicas Guarani, estão dispersos pela superfície, aflorando nos quintais das casas e nas estradas de acesso à área, porém em densidades menores que nos sítios Córrego Lalima (MS-MI-01) e Campina (MS-MI07). Por outro lado, apesar da área ser utilizada atualmente na agricultura, pode haver setores do sítio mais preservados em sub-superfície, haja vista que a localidade não apresenta tantos impactos destrutivos causados com a dinâmica da ocupação indígena atual como na Sede e na Campina. Não foram realizadas atividades de coleta no sítio Anita Vieira, porém a irmã do auxiliar de pesquisa Mário Antônio Pereira, chamada Pereira, moradora na área, doou um cachimbo tubular decorado com incisões e ponteados, achado no quintal da sua casa. 


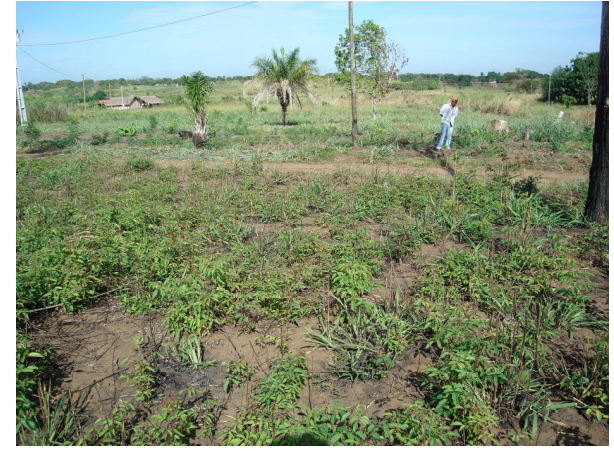

Foto 95: Local de implantação do sítio Anita Viera

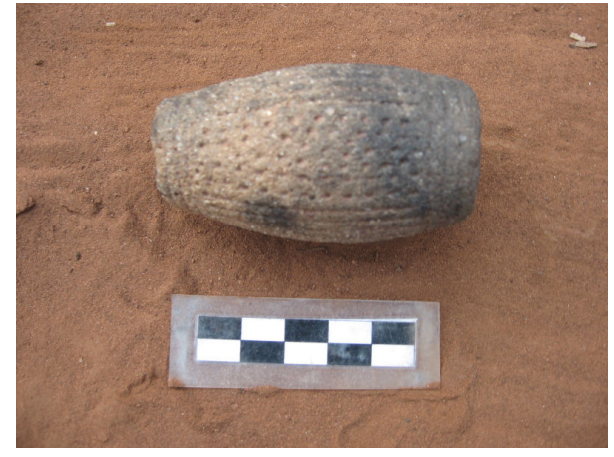

Foto 96: Cachimbo tubular achado no sítio Anita Vieira

\subsubsection{2 - Hélio Correia (MS-MI-12)}

O sítio Guarani Hélio Correia nos foi indicado por Hélio Correia, membro do Conselho Tribal do Cacique Gilmar Vieira e carpinteiro na Aldeia. O sítio está implantado em uma colina suave, constituída por sedimentos argilo-arenosos marromavermelhados, dotada de ampla visibilidade de entorno, situada entre o sopé do morro do Inocêncio, assim denominado por conta de um antigo Capitão Guaikurú de Lalima, chamada Inocêncio Xavier, que vivia nas proximidades, e a confluências das nascentes formadoras do cór. Nascente do Guanandi, tributário da margem direita do cór. do Lima, nas coordenadas UTM 21K 0575535/7727300 (Mapa 4, Foto 97).

Os materiais arqueológicos, constituídos principalmente por algumas centenas de fragmentos de vasilhas cerâmicas Guarani, estão densamente dispersos pela superfície da colina, atualmente utilizada como roça pelo Sr. Hélio Correia. Não foram realizadas atividades de coleta, porém tudo indica que o sítio figura como o contexto Guarani mais preservado de Lalima, ao menos em se tratando daqueles detectados até o presente.

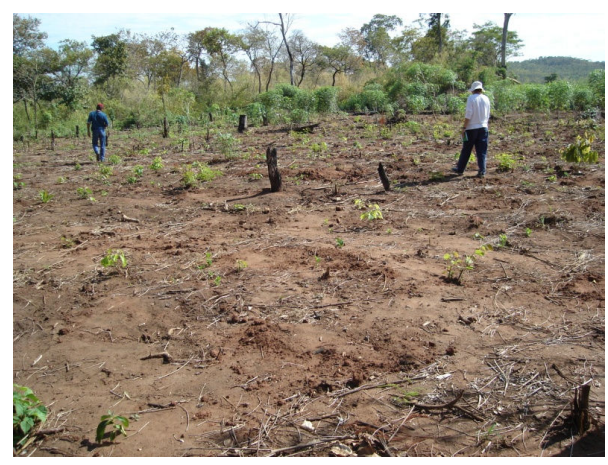

Foto 97: Local de implantação do sítio Hélio Correia 


\subsubsection{3 - Tapera do Agápto (MS-MI-13)}

O sítio Etno-histórico Tapera do Agápto (MS-MI-13) foi detectado na Faz. Santa Rosa, na baixa encosta de uma colina suave, constituída por solos arenos-argilosos marrom-avermelhados, situada na margem direita do médio curso do cór. Nascente do Guanandi, nas coordenadas UTM 21K 0574477/7727875 (Mapa 4, Foto 98). Assim como no Urumbeva (MS-MI-05) e no Pirizal (MS-MI-09), os materiais arqueológicos são constituídos por restos de materiais industrializadas e ecofatos, porém também foram achados e coletados, de maneira assistemática, 5 fragmentos de vasilhas cerâmicas, entre os quais caba destacar um fragmento de base arredondada com apêndices de fixação (tramp, Foto 99). De acordo com os dados etnográficos, a Tapera do Agápto foi ocupada por um índio chamado Agápto, empregado da Faz. Santa Rosa, sendo abandonada a mais de 50 anos.

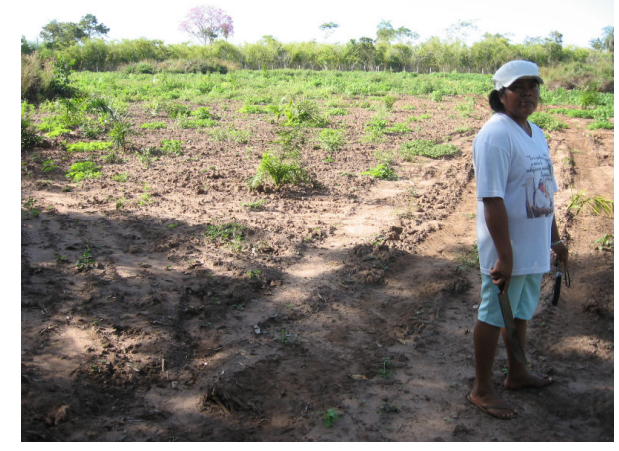

Foto 98: Local de implantação do sítio Tapera do Agápto

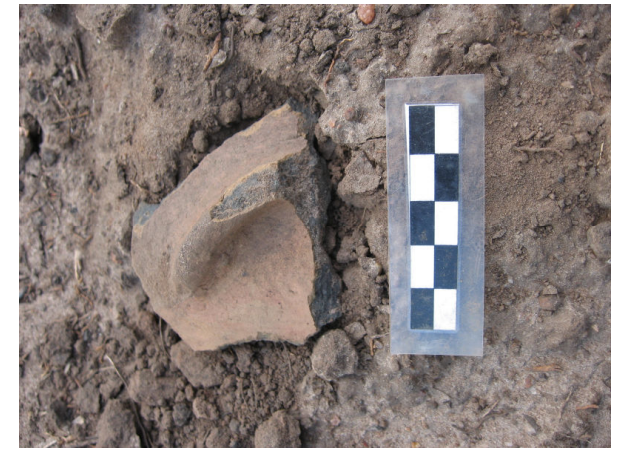

Foto 99: Fragmento cerâmico de base coletado na Tapera do Agápto

\section{2 - Áreas de ocorrências arqueológicas}

\subsection{1 - Ocorrência 1 (OC1)}

A área de ocorrência 1 (OC1) foi detectada em meio aos sedimentos arenosos carpidos em um roçado recém aberto pelo Manuel de Souza Neto, localizado a certa distância das áreas residenciais, nas proximidades da planície de inundação do rio Miranda, nas coordenadas UTM 21K 0574477/7723824, onde foram achados apenas 2 fragmentos de vasilhas cerâmicas lisos, desprovidos de quaisquer atributos diagnósticos, 
apesar dos sedimentos expostos e dos caminhamentos realizados (Mapa 4, Tabela 3, Foto 100). É possível que a área apresente materiais arqueológicos em sub-superfície.

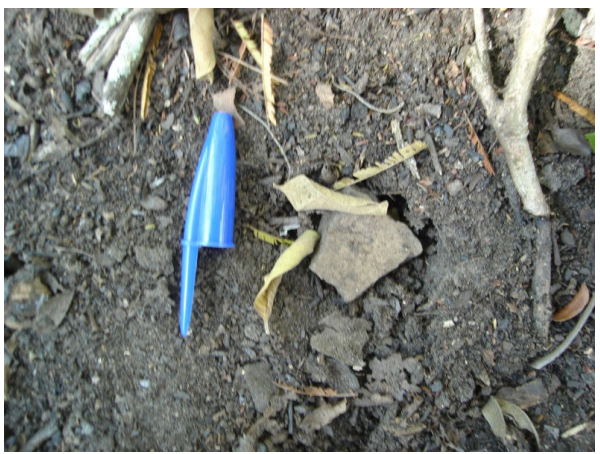

Foto 100: Fragmento cerâmico achado na Área de Ocorrência 1

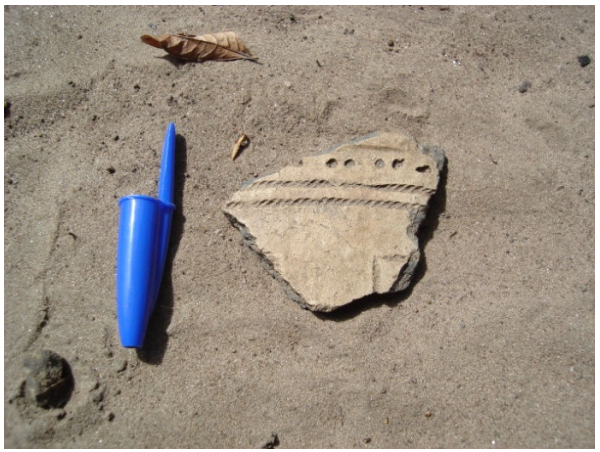

Foto 101: Fragmento cerâmico da Tradição Pantanal na Área de Ocorrência 2

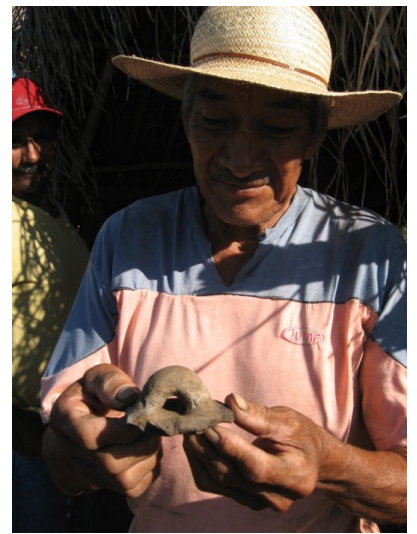

Foto 103: Fragmento cerâmico da Tradição Pantanal na Área de Ocorrência 4

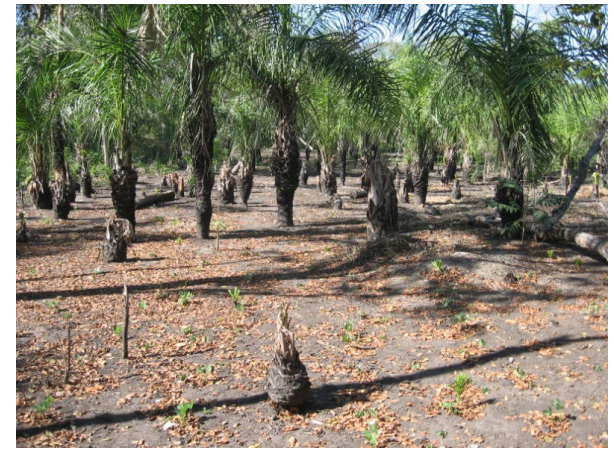

Foto 102: Área de Ocorrência 3

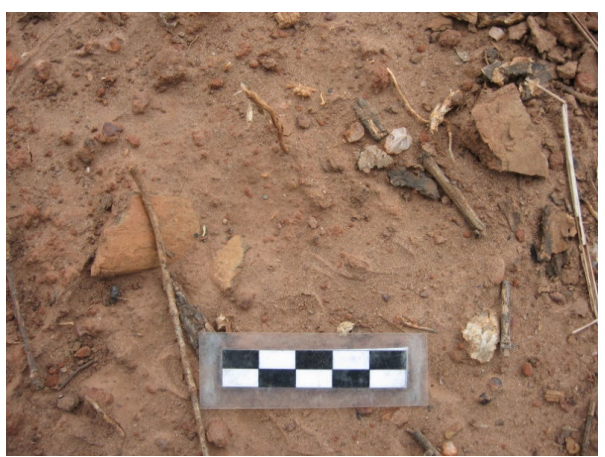

Foto 105: Fragmentos cerâmicos detectados na Área de Ocorrência 6

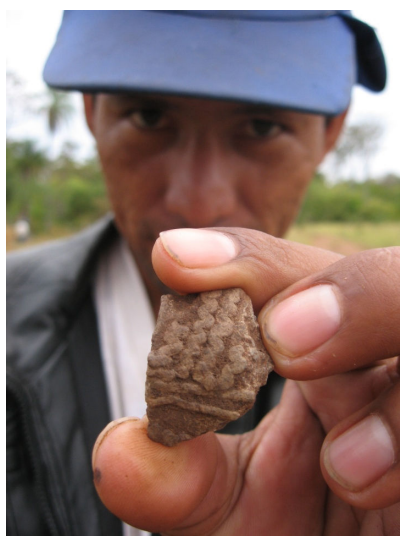

Foto 106: Fragmento cerâmico da Tradição Pantanal na Área de Ocorrência 7

\subsection{2 - Ocorrência 2 (OC2)}

Já a ocorrência 2 (OC2) foi registrada no domicílio de Martírio Vieira, localizada no topo de uma colina suave, formada por solos arenosos, igualmente 
expostos, situada na margem esquerda de uma calha pluvial, nas coordenadas UTM 21K 0575216/7725561, onde foram achados dois fragmentos de vasilhas cerâmicas da Tradição Pantanal, ambos decorados com motivos geométricos feitos com impressões de corda, sendo um uma borda com perfurações além das impressões (Mapa 4, Foto 101). Também há possibilidade da área conter materiais arqueológicos em subsuperfície.

\subsection{3 - Ocorrência $3(\mathrm{OC} 3)$}

A ocorrência 3 (OC3), ao seu turno, foi detectada na roça de Agripino Pires de Souza, localizada em uma área relativamente afastada das áreas residenciais, na baixa encosta de uma colina suave, formada por sedimentos arenosos marrom-escuros, situada na margem esquerda do cór. do Matinho, nas coordenadas UTM $21 \mathrm{~K}$ 0575196/7723975, onde foram achados 3 fragmentos de vasilhas cerâmicas desprovidos de atributos diagnósticos (Mapa 4, Foto 102). Também há possibilidade da área apresentar materiais arqueológicos em sub-superfície.

\subsection{4 - Ocorrência 4 (OC4)}

A ocorrência 4 (OC4), por sua vez, foi observada na roça de Estevão Cabrocha, localizada a certa distância das áreas residenciais, na baixa encosta de uma colina suave, formada por sedimentos arenosos marrom-escuros, situada na margem direita de uma calha pluvial com a margem esquerda do cór. do Matinho, nas coordenadas UTM 21K 0575998/7724418, onde foram detectados 2 fragmentos cerâmicos, provavelmente da Tradição Pantanal, haja vista que um deles trata-se de um apêndice de suspensão, semelhante aos encontrados no setor 2 do sítio Córrego Lalima (MS-MI-01) e no setor 2 do sítio Asa de Pote (MS-MI-06). A área também pode apresentar materiais arqueológicos em sub-superfície (Mapa 4, Foto 103).

\subsection{5 - Ocorrência 5 (OC5)}

A ocorrência 5 (OC5) foi registrada na área da Faz. Santa Rosa, em um dique marginal formado por sedimentos arenosos aluviais, situado na planície inundável da margem direita do rio Miranda, nas coordenadas UTM 21K 0569646/7727257, onde 
foram achadas algumas poucas dezenas de fragmentos de vasilhas cerâmicas Guarani. Trata-se do único contexto arqueológico detectado na área inundável durante a realização da pesquisa de levantamento na Aldeia Lalima (Mapa 4, Foto 104).

\subsection{6 - Ocorrência 6 (OC6)}

A ocorrência 6 (OC6) foi achada na divisa norte entre a Faz Santa Rosa e a Aldeia Lalima, no topo de uma colina suave, formada por sedimentos arenoso-argilosos marom-claros, com ampla visibilidade de entorno, situada nas imediações da margem direita das nascentes do cór. Guanandi, nas coordenadas UTM 21K 0576316/7727850, onde foram observados fragmentos de vasilhas cerâmicas em meio aos sedimentos escavados com a construção da cerca entre a área da Santa Rosa e o território de Lalima (Mapa 4, Foto 105). A ocorrência 6 pode estar relacionada com o sítio Guarani Hélio Correia (MS-MI-12).

\subsection{7 - Ocorrência 7 (OC7)}

Finalmente, a ocorrência 7 (OC7) foi detectada na Faz Santa Rosa, no topo de uma colina suave, formada por sedimentos areno-argilosos marrom-avermelhados, dotada de ampla visibilidade de entorno, rodeada por uma série de nascentes fluviais, nas coordenadas UTM 21K 0575715/7728224, onde foi achado um fragmento de vasilha cerâmica da Tradição Pantanal decorado com apliques de filigranas de argila, ao longo de uma estrada (Mapa 4, Foto 106). Cabe sublinhar que a área da ocorrência 7 apresenta todas as variáveis ambientais favoráveis à implantação de um assentamento indígena mais sedentário, como aquele correlato pelo setor 2 do sítio Córrego Lalima (MS-MI-01). 


\section{Capítulo 6 - Arqueologia na Aldeia Lalima e a História Indígena regional}

Apesar da perturbação causada pela dinâmica do contexto etnográfico atual, os resultados obtidos com a pesquisa arqueológica e etnoarqueológica realizada na TI Lalima justificam a compreensão da Aldeia enquanto palimpsesto da trajetória histórica da ocupação indígena regional. Com efeito, não só foram detectados contextos arqueológicos pré-coloniais da ocupação Guarani e, provavelmente, de populações portadoras da Tradição Pantanal, como ainda foram achados correlatos materiais possivelmente relacionados aos grupos Mbayá-Guaikurú, também associados à Tradição Pantanal, e à formação do contexto cultural atual da ocupação indígena, sendo que, neste caso, conta-se com as informações etnográficas de caráter etno-histórico.

A maioria dos sítios e das ocorrências foi localizada nas encostas e topos de colinas suaves, constituídas por solos relativamente férteis, ampla visibilidade de entorno e proximidade de nascentes e cursos d'água perenes e sazonais. Os distintos contextos arqueológicos foram detectados por toda a Aldeia, contudo as estruturas formadas por áreas de concentração de materiais cerâmicos observadas nos contextos Guarani e da Tradição Pantanal similar à Fase Jacadigo apresentam densidades, raios de dispersão e variações tecnológicas maiores que os sítios da Tradição Pantanal com materiais cerâmicos análogos ao MS-CP-25 e os sítios Etno-históricos. Contudo, tais variáveis são maiores no contexto Guarani que no da Tradição Pantanal semelhante à Fase Jacadigo, como demonstrado nas coletas de superfície assistemáticas realizadas nos setores 1 e 3 do sítio Córrego Lalima (MS-MI-01), constituídas por materiais Guarani, e sistemáticas no setor 2 do Córrego Lalima e no setor 2 do Asa de Pote (MSMI-06), formados por fragmentos da Tradição Pantanal. A exceção fica por conta do setor 1 do Asa de Pote, onde os fragmentos Guarani, embora mais densos e variáveis, possuem um raio de dispersão menor que os da Tradição Pantanal, por sua vez concentrados no Setor 2. De fato, tem-se a impressão de que os materiais Guarani do setor 1 do Asa de Pote foram aglutinados propositalmente e vertidos encosta abaixo pela ação pluvial.

Por outro lado, as atividades de coleta em sub-superfície demonstraram que os contextos arqueológicos da Tradição Pantanal similares à Fase Jacadigo apresentaram materiais mais profundos na estratigrafia que os contextos Guarani, sendo que os dois poços-teste escavados no setor 2 do sítio Córrego Lalima apresentaram maiores densidades, variações e profundidades que os poços-teste escavados nos setores 1 e 3 . 
Os poços-teste escavados no setor 2 do Asa de Pote, por sua vez, igualmente apresentaram materiais mais profundos que os poços-teste escavados em contextos Guarani, embora com densidades e variações menores, enquanto que as sondagens escavadas no setor Guarani do Asa de Pote, ou melhor, no setor 1, apresentaram-se totalmente estéreis em termos arqueológicos. Todavia, tudo leva a crer que os poçosteste no setor 2 do sítio Córrego Lalima, ou seja, justamente aqueles que apresentaram as maiores densidades e variações, foram escavados em lixeiras construídas no âmbito do contexto etnográfico atual, haja vista que, aparentemente, os materiais arqueológicos foram varridos da superfície e jogados em buracos juntamente com vestígios de materiais industrializados e restos recentes de alimentação.

Embora haja certa tendência em acreditar que os Guarani foram as primeiras populações agricultoras e ceramistas a se estabelecer nas terras altas do Pantanal, a soma dos dados arqueológicos preliminares obtidos em Lalima com aqueles fornecidos pelas demais pesquisas realizadas na região indicam que o mosaico cultural encontrado pelos europeus nos séculos XVI e XVII, caracterizado por várias populações culturalmente diversas - inclusive agricultores-ceramistas distintas dos Guarani - já devia existir no médio Miranda ao menos desde o ano mil depois de Cristo. Contudo, se por um lado os dados históricos e etnográficos apontam que os Guarani e os Gualacho desapareceram do Miranda no séc. XVII, por conta dos constrangimentos causados com o colonialismo - algo que por si só necessita de estudos arqueológicos mais aprofundados, haja vista que muitos dos sítios implantados na região podem ter sido abandonados por volta desta época - as pesquisas ainda são insuficientes para explicar as origens e os processos culturais associados à formação dos contextos arqueológicos Guarani e da Tradição Pantanal, seja em se tratando daqueles similares à Fase Jacadigo, datado entre o séc. IX e XI, ou então aos análogos ao sítio MS-CP-25, muito provavelmente relacionados às populações de índios cavaleiros Mbayá-Guaikurú vindos do Chaco entre os séculos XVII e XVIII.

Com efeito, ao mesmo tempo em que os contextos arqueológicos Guarani e da Tradição Pantanal similar à Fase Jacadigo parecem estar relacionados com populações agricultoras plenamente estabelecidas na região, as diferenças tecnológicas sugerem matrizes culturais distintas entre estas populações, não apenas no que se refere à cultura material, mas também em termos de assentamento, subsistência e, provavelmente, nos outros aspectos da cultura, inclusive língua e organização social. Ainda não se sabe se os Guarani ocuparam a área antes ou depois da chegada das populações portadoras de 
tecnologia cerâmica da Tradição Pantanal, haja vista que as datas obtidas em ambos os contextos são praticamente contemporâneas, porém se acredita que ambas mantiveram relações sociais diversas desde antes da chegada dos europeus e que, cedo ou tarde, os Guarani acabaram se impondo perante as outras populações no médio Miranda. Todavia, não só é provável que as populações por trás da Tradição Pantanal semelhante à Fase Jacadigo tenham se expandido, em período pré-colonial, a partir da outra banda do rio Paraguai, desde a Bolívia, passando pelos planaltos do Urucum-Amolar, na região de Corumbá, e alcançado os piemontes drenados pelo médio Miranda, entre os pantanais do Miranda-Aquidauana e as Serras da Bodoquena e de MaracajuAquidauana, como também é possível que estas populações tenham originado as sociedades agricultoras não Guarani encontradas na região de Miranda nos séc. XVI e XVII.

Além do mais, é preciso reconhecer que os contextos arqueológicos da Fase Jacadigo e similares apresentam alguns traços culturais compartilhados pelas sociedades Aruak, como certo sedentarismo, alguma densidade demográfica e agricultura, ainda mais se comparado com o modo de vida móvel das populações caçadoras-coletoraspescadoras do Chaco e das planícies inundáveis do Pantanal. Contudo, tais contextos não passam de meros acampamentos se comparados aos sítios monumentais da Tradição Descalvados, no alto Paraguai, da Fase Ipavu, no alto Xingú, e da Tradição Barrancóide, na Amazônia central e setentrional, relacionados com populações Aruak muito mais densas, sedentárias, hierarquizadas e agrícolas.

Os contextos arqueológicos formados por fragmentos de vasilhas cerâmicas da Tradição Pantanal análogos aos detectados no sítio MS-CP-25, similares ao vasilhame Kadiwéu, são constituídos por materiais cerâmicos em baixa densidade e, ao menos no caso da Tapera do Limpão (MS-MI-03) e da Tapera do Gino (MS-MI-04), por ecofatos. Contudo, se no último as capoeiras, pomares e plantas medicinais podem ser relacionadas ao contexto etnográfico atual, por tratar-se de um sítio multicomponencial cuja última ocupação foi protagonizada por uma família ainda presente em Lalima, no Limpão existem algumas informações etnográficas, um tanto quanto vagas, diga-se de passagem, que sugerem que o local teria sido ocupado pelos ancestrais do Manuel de Souza Neto, ou seja, pelos índios Guaikurú descendentes daqueles encontrados por Rondon, em 1905, na Tapera do Pirizal (MS-MI-09).

O Pirizal, apesar de ser constituído por materiais semelhantes aos da Tapera do Urumbeva (MS-MI-05), se localiza em uma área adjacente aos sítios Manuel de Souza 
Neto (MS-MI-08) e José Rondon de Souza (MS-MI-02), os quais, assim como os outros sítios associados à Tradição Pantanal similar ao MS-CP-25, ou seja, Limpão e Gino, estão todos implantados no contexto da confluência do cór. do Lima com a planície inundável do Miranda. Mesmo considerando que estes sítios foram sistematizados enquanto unidades distintas e que não foram realizadas atividades sistemáticas de coleta, sobretudo em sub-superfície, é possível, com base nas observações dos contextos arqueológicos, nas análises preliminares nos fragmentos cerâmicos coletados assistematicamente e nas parcas informações etnográficas, que todos correspondam a apenas um antigo assentamento, constituído por unidades residenciais distintas em termos espaciais e/ou cronológicos, relacionado aos índios cavaleiros Mbayá-Guaikurú que migraram para a região de Miranda entre os séculos XVII e XVIII. Assim, o assentamento no Pirizal pode ter se formado no final do séc. XIX pelos últimos descendentes das populações Guaikurú então assentadas na confluência do cór. do Lima com a margem direita do médio Miranda, depois dos processos de fragmentação territorial e cultural enfrentados durante os séculos XVIII e XIX.

De fato, não é improvável que, no passado, a cerâmica dos Guaikurú estabelecidos na região de Miranda fosse semelhante à dos Kadiwéu, haja vista que, assim como estes, aqueles vieram do Chaco e se estabeleceram inicialmente na região de Corumbá/MS. Porém, por outro lado, também é possível que estes materiais estejam associados aos próprios Kadiwéu, uma vez que eles também empreenderam correrias pelo Miranda. Com efeito, vários dos Guaikurú ainda presentes em Lalima não só vieram do Campo dos Índios, quer dizer, da Reserva Kadiwéu, como ainda tem parentes por lá. Análises comparativas sistemáticas entre os materiais da Tradição Pantanal coletados em Lalima e as dezenas de vasilhas Kadiwéu presentes na reserva técnica do MAE/USP, em curso, trarão novas questões relativas a esta discussão.

Como se sabe, os Guaná, populações Aruak encontradas pelos europeus na parte oriental do Chaco boliviano nos séculos XVI e XVII, migraram junto com os Mbayá, seus aliados, para as regiões de Corumbá e Miranda. Todavia, Tendo em vista que as evidências indicam que os materiais da Tradição Pantanal semelhantes à Fase Jacadigo são pré-coloniais, não foram detectados contextos arqueológicos que pudessem ser relacionados aos Guaná em Lalima, a não ser em se tratando dos materiais etnográficos achados nas Taperas relativas à formação do contexto cultural atual da ocupação indígena e das últimas vasilhas ainda usadas pelos índios na Aldeia (Fotos 107 e 108). 


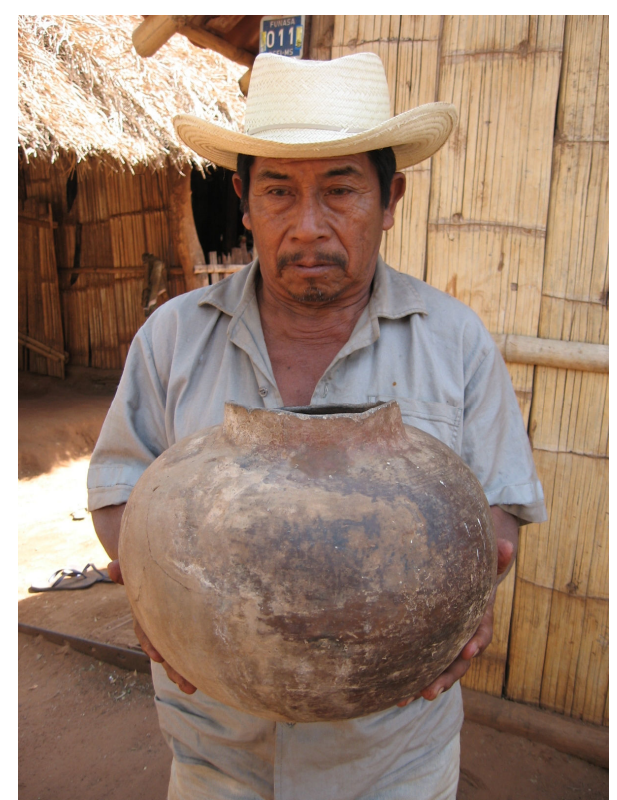

Foto 107: Vasilha cerâmica Terena da esposa de Pedro Sesé

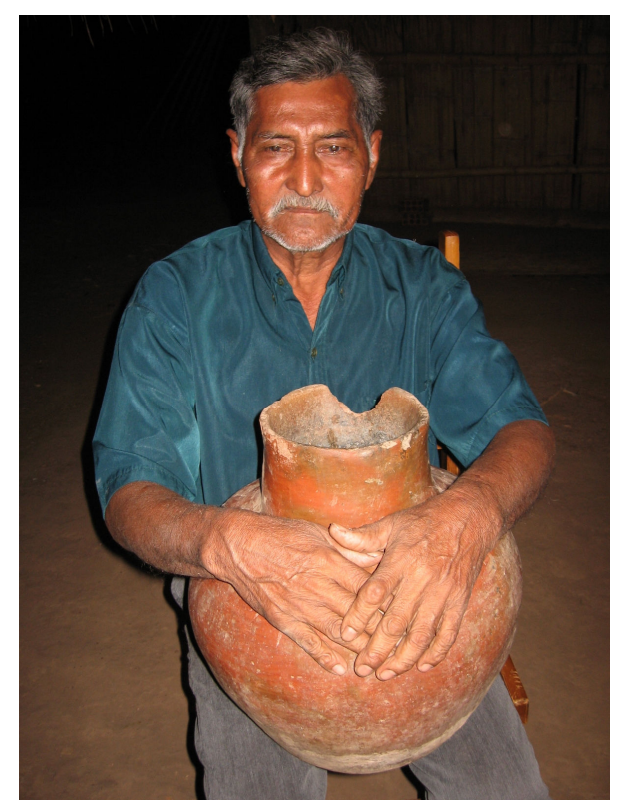

Foto 108: Vasilha cerâmica Terena de Martin Gomes

De fato, não são poucas as fontes que sustentam que os Mbayá e Guaná, embora aliados, mantiveram certa autonomia territorial e política entre si, de modo que, ao menos nos séculos XVIII e XIX, eles não deviam ocupar exatamente as mesmas áreas, mesmo levando em conta que muitos dos cativos Guaikurú eram Guaná. Assim, enquanto os Guaikurú galopavam por territórios relativamente extensos e assentamentos mais ou menos efêmeros e sazonais, em meio aos quais os campos de Lalima, os Guaná devem ter se assentado em certas áreas específicas, como aquelas onde atualmente se encontram os municípios de Miranda, em se tratando dos Laiana e Terena, e de Corumbá, no que se refere aos Kinikinao.

Com a exacerbação dos processos de fragmentação territorial e cultural desencadeados pelo colonialismo, sobretudo depois da Guerra do Paraguai, os territórios tradicionais dos Guaná foram usurpados e os remanentes escravizados nas colônias das fazendas recém implantadas. Destarte, tudo indica que os contingentes Guaná que contribuíram com a formação do contexto etnográfico atual em Lalima como confirmado, inclusive, por muitos relatos e histórias de vida contadas pelos anciões da Aldeia - vieram das fazendas da região depois da passagem de Rondon e com a atuação do SPI, no início do séc. XX, e não de alguma aldeia tradicional outrora existente na área, como parece ser o caso em se tratando dos Guaikurú.

Os sítios constituídos por materiais arqueológicos diretamente conectados com as informações etnográficas de caráter etno-histórico - correlatos dos processos 
históricos associados à formação do contexto cultural da ocupação indígena atual, protagonizado por remanescentes étnicos Guaikurú, Terna, Laiana e Kinikinao apresentam maior diversidade qualitativa de materiais em relação aos demais, sobretudo graças aos vestígios recentes de origem industrializada, tais como borrachas, metais, plásticos, porcelanas e vidros, além de ecofatos, restos faunísticos e fragmentos de vasilhas cerâmicas. Contudo, os fragmentos cerâmicos detectados nos sítios Etnohistóricos não só apresentaram densidades inferiores aos outros contextos arqueológicos identificados na Aldeia, como também foram observadas variações menores no que se refere à forma e ao acabamento de superfície das vasilhas. Da mesma forma, ainda é importante ressaltar que a Tapera da Mata do Urumbeva (MS-MI-05), a primeira área a ser ocupada por índios Terena em Lalima, apresentou estratigrafia rasa, com apenas $10 \mathrm{~cm}$.

No que se refere às áreas de ocorrência, algumas, como as ocorrências 6 e 7, por exemplo, ambas detectadas na Faz. Santa Rosa, podem vir a ser compreendidas, com a realização de pesquisas futuras, como correlatos de antigos assentamentos ou aldeias pré-coloniais, uma vez que ambas estão implantadas em locais que apresentam as mesmas variáveis dos sítios detectados. Por outro lado, a ocorrência 5, constituída por fragmentos Guarani, implantada na planície inundável do Miranda, também na Santa Rosa, pode vir a ser entendida, com a realização de mais pesquisas, enquanto sítio de atividade específica. Finalmente, vale lembrar que foram detectados alguns sítios que aparentemente apresentam estado de conservação maior que aqueles onde foram realizadas as atividades sistemáticas de coleta e topografia, e que ainda podem existir outros sítios na área, mesmo considerando a extensão mínima da Aldeia e o número de sítios e ocorrências já registrados.

Não foram achados sítios em aterros, lajedos ou abrigos sob-rocha. Contudo, por enquanto, tal fato deve ser atribuído mais à metodologia empregada que à realidade arqueológica, haja vista que a potencialidade regional, aferida através dos achados nas planícies e nos planaltos em torno da depressão, e a abundância arqueológica da Aldeia, atestada pelos sítios e pelas ocorrências detectadas, sugerem que a TI pode ter sido ocupada por grupos de caçadores-coletores antes do surgimento da cerâmica da Tradição Pantanal e da expansão das populações Guarani na região. De qualquer modo, é importante considerar que os índios desconhecem a existência de cavernas e ou abrigos na morraria em torno da Aldeia, mas não de arte rupestre, embora as informações sobre petróglifos sejam vagas, e que a planície do Miranda nas 
proximidades não se apresenta de maneira tão ampla quanto nos pantanais do MirandaAquidauana e do Abobral, onde os aterros são incontáveis.

No mais, também cabe registrar que foram observados inúmeros jabuticabais crescidos na planície inundável, os quais os índios garantem que sempre estiveram ali, bem como os acurizais, guarirobais, palmitais, laranjais, mangabeiras e outras variedades de plantas. Talvez, estes itens vegetais sejam correlatos de atividades de manejo ambiental desenvolvidas pelas populações indígenas em Lalima desde períodos pré-coloniais, assim como fizeram os índios canoeiros com o acurí no Pantanal. 


\section{Conclusão - A participação dos Terena na pesquisa arqueológica na Aldeia Lalima}

A experiência na Aldeia Lalima (ver mapa 3), vivida através de visitas esporádicas desde 2006 e de praticamente três meses de atividades de campo, entre maio e julho de 2007, pode ser vista como um exemplo de colaboração entre arqueólogos e populações indígenas em prol da construção do conhecimento arqueológico. Efetivamente, enquanto nós elaboramos o projeto e providenciamos os meios legais e financeiros (autorizações da FUNAI e do IPHAN e o fomento da FAPESP), necessários para a realização da pesquisa, a colaboração dos Terena nas pesquisas arqueológicas em Lalima se deu, principalmente, através do constante questionamento, controle e observação dos nossos procedimentos de pesquisa e na construção do conhecimento arqueológico e histórico sobre a trajetória de ocupação na aldeia.

O questionamento e controle dos nossos procedimentos de pesquisa ocorreram, principalmente: 1) nos momentos de negociações com as lideranças da comunidade, bem como com a comunidade em geral - sobretudo os chefes de família - para a obtenção da autorização para a realização da pesquisa na aldeia; 2) nas etapas de contratação dos interlocutores/auxiliares indígenas de pesquisa. A observação de nossos procedimentos de pesquisa e a participação dos Terena na construção do conhecimento arqueológico e histórico sobre a trajetória de ocupação na aldeia foi levada a cabo precisamente: 1) durante todo o trabalho de levantamento dos sítios; 2) de coletas de vestígios arqueológicos e históricos; 3) de tratamento inicial dos materiais coletados; 4) de busca das informações orais sobre a trajetória de ocupação de Lalima.

A obtenção da autorização indígena para a realização da pesquisa arqueológica na Aldeia Lalima foi uma experiência bastante ilustrativa daquilo que Zimmermann (2005: 301-306) apontou como "problemas para definir a comunidade" e "dificuldades com a aprovação de pesquisa". A autorização definitiva dos Terena para a realização da pesquisa foi obtida quando já nos encontrávamos em campo, após meses de negociações e preparativos, prontos para iniciar as atividades de levantamento.

Dado o caráter institucional do projeto de pesquisa, respaldado pelo MAE/USP e fomentado pela FAPESP (Processos $N^{\circ}$ 05/57404-0 e 06/60241-8), obviamente que dispúnhamos de toda a documentação legal necessária para a realização da pesquisa quando chegamos em Lalima - tanto da FUNAI, conforme a "Autorização para o Ingresso em TI N 24/CGEP/07”, obtida em 22 de fevereiro de 2007, quanto do IPHAN, 
através da Portaria No 039/07, publicada em 12 de fevereiro de 2007 no DOU, Seção I. Porém, mudanças políticas internas ocorridas às vésperas do início das atividades de campo, em maio de 2007, impuseram que a comunidade indígena fizesse uma nova avaliação e questionamentos de nossa pesquisa. O que aconteceu foi a eleição oficial de um novo Cacique, de um novo Conselho Tribal e o surgimento de um movimento de oposição a este cacique que gerou uma divisão política na aldeia e o surgimento de outro Cacique e outro Conselho Tribal.

Nas Terras Indígenas localizadas no Brasil, as pesquisas científicas são disciplinadas pela FUNAI, através da Instrução Normativa No 001/PRESI/1994. Em resumo, as Instruções prescrevem que as autorizações devem ser solicitadas junto à FUNAI/CGEP, localizada em Brasília, mediante envio do projeto de pesquisa e da documentação pessoal dos pesquisadores envolvidos, inclusive atestados médicos de saúde e carteiras de vacinação. Uma vez avaliadas e aprovadas, o que inclui consultoria científica do $\mathrm{CNPq}$, as solicitações são remetidas às delegacias regionais da FUNAI, para a realização de avaliações internas. Em seguida, toda a documentação deve ser encaminhada às Terras Indígenas envolvidas e os pesquisadores devem ir até as comunidades a fim de conquistar a aprovação das lideranças locais. Depois da resposta dos índios, a solicitação percorre o caminho inverso e o trâmite termina com a manifestação oficial da FUNAI/CGEP, através de correspondência enviada ao solicitante.

As negociações para a obtenção da autorização se iniciaram no primeiro semestre de 2006, na Delegacia Regional da FUNAI/MS, localizada em Campo Grande. Agendamos um encontro com o então coordenador do Setor de Educação da FUNAI/MS, Eliseu Lily, com o objetivo de apresentar o projeto de pesquisa e obter contatos na Aldeia Lalima, a fim de apresentar o projeto à comunidade antes mesmo de enviá-lo à FUNAI/CGEP. Em um golpe de sorte, encontramos o Chefe do PIN Lalima, Evair Borges, enquanto estávamos reunidos no Setor de Educação. Conversamos rapidamente sobre a pesquisa e o Chefe de Posto nos orientou a enviar a solicitação da autorização e aguardar pela chegada da documentação no PIN, para que fosse agendada uma reunião entre as lideranças e nós. Vale ressaltar que em Mato Grosso do Sul, um dos Estados com maior densidade demográfica indígena no país, parte considerável dos cargos públicos oferecidos pelos órgãos que atuam junto às populações indígenas, como a FUNAI, a Fundação Nacional de Saúde (FUNASA) e os governos estaduais e municipais, seja nas Terras Indígenas ou nos gabinetes nas cidades, são preenchidos 
pelos índios. Tanto que o então coordenador de Setor de Educação da FUNAI/MS e o chefe do PIN Lalima são índios Terena.

A solicitação da autorização chegou à Aldeia ainda no segundo semestre de 2006 e a reunião junto às lideranças locais foi agendada para o dia 17 de outubro. Assim como na maioria das Terras Indígenas localizadas em Mato Grosso do Sul, a representação política da comunidade é constituída pelo Cacique, também chamado de Capitão, pelo Vice-cacique, pelo Conselho Tribal e pelo Chefe de Posto. O cacique e o vice-cacique são eleitos pela comunidade e o conselho é nomeado por eles, não havendo um número pré-estabelecido de conselheiros. O Chefe de Posto também é escolhido através do voto e as eleições são convocadas em casos de desistência do cargo ou insatisfação popular generalizada. Geralmente, as posições políticas são ocupadas por indivíduos que possuem prestígio na comunidade, o qual é medido através das qualidades pessoais.

A reunião com as lideranças ocorreu nas dependências do Posto Indígena e contou com a presença do então cacique Celso Cabrocha, seis conselheiros e o chefe de posto. Nesta reunião explicamos o projeto às lideranças que, em seguida, nos questionaram e, por fim, manifestaram suas opiniões sobre a realização da pesquisa. Cabe ressaltar que os Terena são extremamente polidos enquanto discutem as questões da comunidade, tanto que eles não apenas nunca interrompem a fala de outrem, como incentivam a participação de todos nas discussões.

O projeto foi explicado através de uma espécie de aula expositiva, centrada em palavras-chave como Arqueologia, Antropologia, História Indígena, Pantanal e Aldeia Lalima. Além da problemática e dos objetivos da pesquisa, explicamos a metodologia, tornando claro não apenas que desenvolveríamos atividades de levantamento e coleta de dados arqueológicos e orais, mas também, que teríamos que permanecer por aproximadamente três meses na Aldeia e que precisaríamos recrutar auxiliares de pesquisa durante a realização do projeto, os quais seriam devidamente certificados e remunerados pelos seus serviços.

Foram muitos os questionamentos que tivemos de responder. Num primeiro momento, as lideranças manifestaram certo receio pela realização da pesquisa, pois se nós cadastrássemos os sítios e coletássemos os vestígios, não restaria mais nada para que eles próprios pesquisassem. Esta preocupação surgiu da parte dos professores integrantes do conselho tribal que têm como meta o aperfeiçoamento profissional, através de estudos científicos em cursos de pós-graduação. Respondemos que a nossa 
pesquisa possuía um caráter preliminar e que de forma alguma esgotaríamos o potencial arqueológico, histórico e antropológico da Aldeia. Além disso, esclarecemos que se eles tivessem a intenção de pesquisar Arqueologia, nossa presença na aldeia poderia ser uma oportunidade para isso, pois nossa intenção era continuar pesquisando em Lalima, sendo esta uma primeira etapa de atividades. Outra questão dizia respeito à classificação do material arqueológico. Eles estavam interessados em saber como faríamos, através dos vestígios arqueológicos, a identificação das diversas populações indígenas que teriam ocupado Lalima desde os tempos pré-coloniais. Respondemos que esta era uma das questões fundamentais da Arqueologia e que nosso objetivo com a pesquisa era tentar demonstrar como a diversidade cultural da ocupação indígena no Pantanal se manifesta nos vestígios arqueológicos. Também fomos questionados sobre o modo como a pesquisa poderia auxiliar os índios no processo de reclamação territorial, uma vez que eles afirmavam conhecer vários locais com "cacos de pote", "taperas" e outros vestígios associados à sua história nas terras das fazendas vizinhas à Aldeia Lalima. Nós afirmamos que a pesquisa arqueológica poderia servir de subsídio histórico nas reclamações dos indígenas por terra, especialmente se pudéssemos entender a correlação entre os vestígios materiais e os processos históricos que se desenrolaram ao longo da ocupação indígena na região.

Depois do cansaço gerado pelo jogo de perguntas e respostas, as lideranças manifestaram suas opiniões em relação à autorização da pesquisa. Afortunadamente, todos se mostraram favoráveis à realização do projeto, declarando que achavam importante que fosse realizado um estudo sobre a história dos índios em Lalima e que a pesquisa seria boa para a escola, bem como para as reivindicações por terra e por melhorias nas condições de existência. As lideranças ainda solicitaram, em contrapartida, que deixássemos cópias da pesquisa na Aldeia, depois que os estudos fossem concluídos. Comprometemo-nos não só em deixar as cópias, mas também em retornar o conhecimento produzido à comunidade, através de programas de educação patrimonial.

Voltamos à Lalima em Janeiro de 2007. Depois de nos apresentarmos ao Chefe de Posto e ao Cacique, passamos o dia andando pela Aldeia na companhia de João da Silva, um dos membros do Conselho Tribal que havia autorizado a realização da pesquisa na Aldeia, a fim de reconhecer a área, contatar com as pessoas e tentar detectar achados arqueológicos. Nesta ocasião percebemos que as negociações relativas à obtenção da autorização para a realização da pesquisa ainda não haviam sido 
concluídas, haja vista que o Vice-cacique nos procurou para tomar satisfações, pois o mesmo não havia participado da reunião em que negociamos a entrada na área. Além disso, percebemos que mesmo com a aprovação das lideranças ainda teríamos de negociar diretamente e, dia-a-dia, com os moradores da Aldeia a fim de termos acesso aos seus domicílios. Porém, não fazíamos idéia do que viria pela frente na tarde de sexta-feira, do dia 4 de maio de 2007, quando chegamos a Lalima com o intuito de iniciar as atividades de campo.

Assim que nos apresentamos no Posto Indígena da FUNAI, fomos informados da mudança política ocorrida na Aldeia, ou seja, a eleição de um novo cacique, Gilmar Vieira, e de um novo Conselho. Por causa deste evento, uma nova reunião de negociações foi marcada para explicarmos a estas novas lideranças o intento de nosso trabalho na Aldeia Lalima. Acordada a reunião, resolvemos visitar um dos integrantes do Conselho Tribal anterior, o professor de História Deli de Souza Alves, que reside na Campina, um dos bairros de Lalima. Nesta visita fomos informados da oposição deste setor da Aldeia às novas lideranças, bem como da existência de outro Cacique, Deir de Souza Alves, e de outro Conselho Tribal. Tendo em vista esta divisão política eles solicitaram outra reunião com a equipe a fim de explicarmos a eles os nossos procedimentos de pesquisa. Esta reunião ficou marcada para ocorrer logo após o término da reunião com as lideranças oficiais.

No dia das reuniões, nos dirigimos primeiro para a escola localizada no bairro da Sede. Chegamos na hora marcada e encontramos mais de 20 pessoas nos esperando para conversar conosco. Estavam reunidos o cacique Gilmar Vieira, membros do Conselho e algumas velhas lideranças da aldeia. A reunião teve o mesmo andamento da anterior com as discussões sendo coordenadas pelo Cacique. Assim, depois de nos apresentar, o cacique pediu que nós explicássemos a pesquisa que tínhamos vindo desenvolver a fim de que as lideranças pudessem aprovar ou não a realização da mesma. Sentimos como se as negociações articuladas anteriormente não valessem mais de nada. Começamos destacando que a nossa entrada na Aldeia estava dentro dos conformes da Lei e que, inclusive, possuíamos a autorização da FUNAI - no que fomos ratificados pelo Chefe de Posto - e prosseguimos explicando os objetivos e os métodos do projeto.

Apesar dos questionamentos terem se pautado em torno das mesmas questões proferidas pelas lideranças da gestão anterior, a reunião com o novo Conselho foi bem mais tensa, com as lideranças se mostrando muito mais receosas com a realização da pesquisa do que antes. Os momentos de maior tensão foram gerados quando os 
questionamentos se direcionaram para a questão da terra. Em termos traumáticos, as lideranças alegaram que outros estudos antropológicos e históricos já haviam sido realizados na Aldeia, sob encomenda da FUNAI e que, conforme havia sido prometido, tais estudos iriam garantir a posse da terra em disputa com os fazendeiros, porém muitos anos haviam se passado desde que os referidos estudos tinham sido efetuados e eles ainda estavam esperando pela demarcação das suas terras. Além disso, havia uma desconfiança de que os antropólogos contratados pela FUNAI haviam sido comprados pelos fazendeiros. A tensão aumentou quando um dos membros do Conselho declarou que eles não precisavam de projetos de Arqueologia e História na Aldeia, mas sim de projetos agropecuários e de desenvolvimento sustentável, com vistas ao combate da pobreza e à falta de recursos. Continuando com argumentos duros, outro membro do conselho, defendendo os interesses do diretor da escola da Aldeia - seu cunhado - que tinha o objetivo de realizar uma pesquisa sobre Lalima, nos pediu mais tempo para que eles pudessem pensar melhor sobre a viabilidade ou não da realização do projeto.

Complementando os termos que havíamos usado na reunião com a gestão anterior, respondemos que nós não estávamos ali com o objetivo de resolver os problemas fundiários da Aldeia, embora nos interessássemos por essas questões e nos julgássemos aptos para discuti-las antropologicamente. Ressaltamos que havíamos chegado em Lalima por vontade própria e que não éramos contratados de empresas, fazendeiros ou pela FUNAI. Devíamos satisfações apenas às Instituições que nos apoiavam na pesquisa com recursos e amparo legal, ou seja, ao MAE/USP, à FAPESP, à FUNAI e ao IPHAN. Da mesma forma, nos comprometemos a auxiliá-los, na medida do possível, com os projetos de sustentabilidade e de pesquisa na Aldeia. Contudo, o impasse criado com a declaração do conselheiro que pediu mais tempo para que as lideranças pensassem melhor a respeito da pesquisa, mesmo depois de já termos conquistado o aceite da maioria das lideranças presentes, apenas foi resolvido depois que apelamos para que a nova gestão honrasse as deliberações do conselho da gestão passada tendo em vista que, assim como este, aquele era reconhecido pela FUNAI e tinha nos concedido a autorização para realizarmos a pesquisa.

A reunião no bairro Campina, realizada no quintal do domicílio de Atanásio Alves, pai do cacique Deir de Souza Alves e do professor de História, foi bem mais tranqüila, talvez porque parte considerável das lideranças presentes, composto por cerca de dez pessoas, integrava o Conselho do ex-cacique Celso Cabrocha que se encontrava ausente da Aldeia. O único momento de tensão ocorreu enquanto explicávamos a 
estratégia metodológica do projeto, sobretudo depois que dissemos que o Conselho da Sede e o Chefe de Posto haviam se responsabilizado em encontrar os auxiliares de pesquisa que seriam contratados para nos ajudar na realização das atividades de campo. O Cacique Deir de Souza Alves foi enfático ao deliberar que um dos auxiliares deveria ser escolhido pelas suas lideranças, entre os moradores da Campina, ao que nós respondemos que da nossa parte não haveria problema, mas que gostaríamos que fosse feito um acordo entre ambos os Caciques e o Chefe de Posto, visto que a questão da contratação dos auxiliares de pesquisa havia sido travada na reunião na Sede. Assim, o Cacique Deir se comprometeu em procurar o Cacique Gilmar e o chefe de posto para resolver esta questão da contratação dos auxiliares de pesquisa. É importante ressaltar que o Cacique e o Conselho da Campina não são reconhecidos pela FUNAI, mas neste caso, nossa atuação na Aldeia acabou por legitimar esta facção política.

A questão da contratação dos auxiliares de pesquisa ficou resolvida da seguinte forma: visto que, inicialmente, durante as atividades de levantamento arqueológico, precisaríamos de duas pessoas para nos auxiliar, foi decidido que um dos interlocutores seria indicado pelo Conselho do Cacique Gilmar e o outro pelo Conselho do Cacique Deir. Depois do levantamento, nas atividades de coleta, quando necessitaríamos de mais três interlocutores, dois seriam indicados pelo Cacique Gilmar e um pelo Cacique Deir, já que a Sede é mais populosa que a Campina. Também é importante ressaltar que após explicarmos que os interlocutores teriam de nos auxiliar tanto no labor arqueológico de levantamento e coleta quanto na obtenção das informações orais sobre a trajetória de ocupação na aldeia, foi deliberado que um dos interlocutores seria mais velho, mas nem tanto, e o outro mais novo, selecionado entre os alunos do ensino médio - num primeiro momento as lideranças do cacique Gilmar e o Chefe de Posto haviam entendido que nós gostaríamos que os auxiliares fossem selecionados apenas dentre os jovens e adolescentes alunos na escola da aldeia. Esta solução foi bastante interessante, haja vista que o interlocutor mais novo poderia aprender não somente conosco, como pretendido pelas lideranças, mas também com o próprio interlocutor mais velho, tendo em vista que o conhecimento sobre a etno-história local e a região de Lalima foram tratados como pré-requisitos da contratação deste último. Esta situação vivenciada em Lalima se assemelha às situações relatas na bibliografia, com relação a outros contextos etnográficos. Nos relatos dos pesquisadores se percebe que a escolha dos auxiliares/interlocutores de pesquisa é sempre fruto de muita negociação e que precisa 
ser feita em concordância com as lideranças locais (cf. Jackson \& Smith 2005: 337-339; Wiynjorroc, Manabaru, Brown \& Warner 2005).

Assim, conhecemos os nossos primeiros interlocutores na segunda-feira, dia 8 de maio, quando iniciamos o trabalho de levantamento arqueológico. O mais velho, chamado Manoel de Souza Neto, foi designado pelo Conselho do Cacique Gilmar, do qual era membro e o mais novo, Ofnéias de Souza Alves - irmão do Cacique Deir - foi indicado pelo Conselho da Campina. Os outros três interlocutores foram conhecidos duas semanas depois, quando iniciamos as atividades de coleta. São eles: Mário Antônio Pereira e Claudinei da Silva, alunos do ensino médio na escola da aldeia, designados pelo Conselho do Cacique Gilmar Vieira, e Aparecida de Souza Pereira, dona de casa, agricultora e Vice-cacique do Cacique Deir, portanto obviamente indicada pelas lideranças da Campina. Contudo, não só tivemos fundos para contratar mais dois auxiliares durante um curto período nas atividades de coleta, como também houve um revezamento entre os auxiliares mobilizados, de modo que além dos interlocutores citados, ainda participaram Atair Góes de Oliveira e Gilmar de Souza, jovens pais de família, agricultores e residentes na Campina, bem como Edimara Pinheiro Paiva e Leonel da Silva, alunos do ensino médio, indicados pelo Conselho do Cacique Gilmar.

Sabemos que a utilização do trabalho e das informações nativas foi sempre uma prática dos arqueólogos em todo o mundo. Alguns autores, porém, salientam que nem sempre os arqueólogos deram o devido crédito e visibilidade a estes homens que ajudaram a construir o conhecimento sobre o passado (cf. Shepherd 2003). Nossa preocupação em registrar os nomes e as imagens de nossos interlocutores indígenas, bem como dar a eles voz em nosso trabalho - como se verá adiante - se constitui, em nossa opinião, num primeiro passo, ainda que tênue, em direção a pretendida multivocalidade e ao reconhecimento da importância e do valor destes modos de conhecer o mundo.

Todos os interlocutores/auxiliares de pesquisa contratados - cada um a sua maneira - participaram na construção do conhecimento nas pesquisas de campo, haja vista que detectamos 13 sítios arqueológicos nas atividades de levantamento e pesquisamos três destes sítios nas atividades de coleta. Efetivamente, a participação dos interlocutores foi realizada tanto através dos trabalhos de campo que exigem certo esforço físico, quanto por meio de trabalhos que necessitam de alguma especialização. No primeiro grupo, geralmente desenvolvidos com maior maestria pelos interlocutores mais velhos, podemos citar as caminhadas com mochilas, ferramentas e garrafas 
térmicas realizadas durante o levantamento, sendo que em muitas destas os interlocutores desempenharam o papel de guias; e ainda, as escavações de sondagens e coletas de sub-superfície, empreendidas tanto por intermédio de colheres de arqueólogo e trados articulados quanto por enxadas e enxadões. Já no outro grupo, os quais, por sua vez, eram realizados de maneira mais adequada pelos interlocutores mais novos, até porque muitos dos mais velhos são semi-analfabetos, podemos destacar o preenchimento de etiquetas e fichas nas atividades de coleta, seja em superfície ou em sub-superfície, bem como o manuseio de aparelhos como câmeras fotográficas digitais, gravadores, filmadoras, GPS e estação total. Os mais novos eram capazes, inclusive, de trabalhar com computadores, haja vista que existe um projeto desenvolvido pela Fundação Bradesco em Lalima que oferece cursos de informática básica aos alunos da escola, onde há uma sala com onze máquinas conectadas diretamente à internet.

Também contamos com a participação dos Terena de Lalima que cursam o magistério em Miranda, muitos dos quais, inclusive, já são professores na Aldeia. A participação destes alunos, da qual fez deles interlocutores/estagiários foi negociada depois que eles nos procuraram em busca de estágio certificado. A busca dos alunos pelos certificados tem relação com o curso de magistério, pois eles precisam comprovar que cumpriram cargas horárias em atividades relacionadas com projetos educacionais e científicos para se formarem. Contudo, os alunos não participaram das atividades de levantamento e coleta, assim como também não foram remunerados. Eles contribuíram com a lavagem e a triagem de parte do material coletado, porém não sem antes organizarmos alguns encontros para conversarmos sobre a pesquisa e o modo como eles procederiam.

Como se pode ver houve um controle local na escolha dos interlocutores/ auxiliares de pesquisa que foi ditado pelos interesses políticos, econômicos e pessoais dos indígenas e de acordo com a sua identidade social.

A colaboração das demais pessoas da comunidade que nos concederam informações orais sobre a história da ocupação histórica e atual da Aldeia foi tão importante quanto a contribuição dos interlocutores/auxiliares de pesquisa e dos interlocutores/estagiários. Os dados obtidos com a gravação das entrevistas podem revelar o contexto etno-histórico subjacente a alguns dos contextos arqueológicos detectados em Lalima. Assim, visto que nós temos o objetivo de estudar a Arqueologia na Aldeia Lalima no contexto da trajetória histórica da ocupação indígena regional, tentando demonstrar que a aldeia pode ser entendida enquanto palimpsesto da história 
dos índios na região - com base no pressuposto de que os contextos arqueológicos são os correlatos materiais dos processos históricos de ocupação - não podíamos desconsiderar o contexto etnográfico, pois os indígenas que o constituem, bem como a cultura que eles possuem, a história por trás dela e os testemunhos materiais formados pelos processos culturais engrenados nesta história estão indiscutivelmente conectados à trajetória que estamos estudando.

Todavia, sem prejuízo da participação dos demais, Manoel de Souza Neto se tornou nosso principal interlocutor em Lalima (Foto 109). Vice-cacique por duas vezes, ex-cabeçante das turmas de índios recrutadas para trabalhar em usinas sucroalcooleiras de Mato Grosso e Mato Grosso do Sul, arameiro, agricultor, caçador e pai de família, o Manuel, ou Maneco, no auge dos seus 50 anos de idade, possui experiência e história como interlocutor. Ele não somente participou na pesquisa antropológica encomendada pela FUNAI, como também é descendente direto de nidijienigi ou purungueiros (xamãs) Guaikurú tornados célebres enquanto interlocutores dos antropólogos Darcy Ribeiro e Roberto Cardoso de Oliveira, os quais estiveram em Lalima quando realizaram estudos entre os Kadiwéu e os Terena (Cardoso de Oliveira 1968, 1976, 2002: 200-205, Ribeiro 1980).

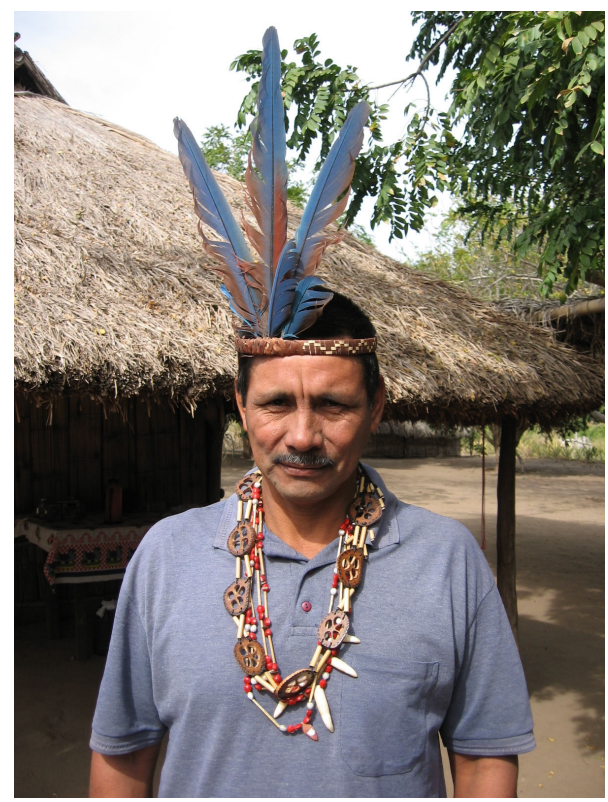

Foto 109: Manuel de Souza Neto, nosso principal interlocutor em Lalima

Com efeito, o Maneco, que se auto-identifica como Guaikurú, se mostrou um profundo conhecedor da etno-história e da região de Lalima, tanto que logo nos primeiros dias ele nos levou às taperas associadas com as histórias que ele havia ouvido 
dos mais velhos e a uma série de outros locais onde ele se lembrava de ter visto "cacos de pote". Impressionado com o fato de nós detectarmos fragmentos em sítios onde ninguém havia feito pote de barro e de não coletarmos de imediato os fragmentos que detectávamos, logo se tornou um entusiasta da Arqueologia, correlacionando-a com a história do seu povo e dos índios na região, e desenvolvendo um tino peculiar na tarefa de detectar sítios arqueológicos, diretamente relacionados com as informações orais que ele mantinha na memória ou não. Trabalhador exemplar, apenas reclamava, comicamente, quando não tinha nada pra fazer, o que ocorria geralmente quando nós nos desentendíamos em discussões teóricas e metodológicas. Além disso, o Manuel foi nosso anfitrião nos dias em que ficamos na aldeia, quando tivemos o prazer de conviver com a sua família, sobretudo com o seu pai, Antônio de Souza, 88 anos de idade, e com o seu tio, Luiz de Souza, 76 anos, alguns dos últimos conhecedores do idioma e da cultura dos Guaikurú de Lalima (Foto 110).

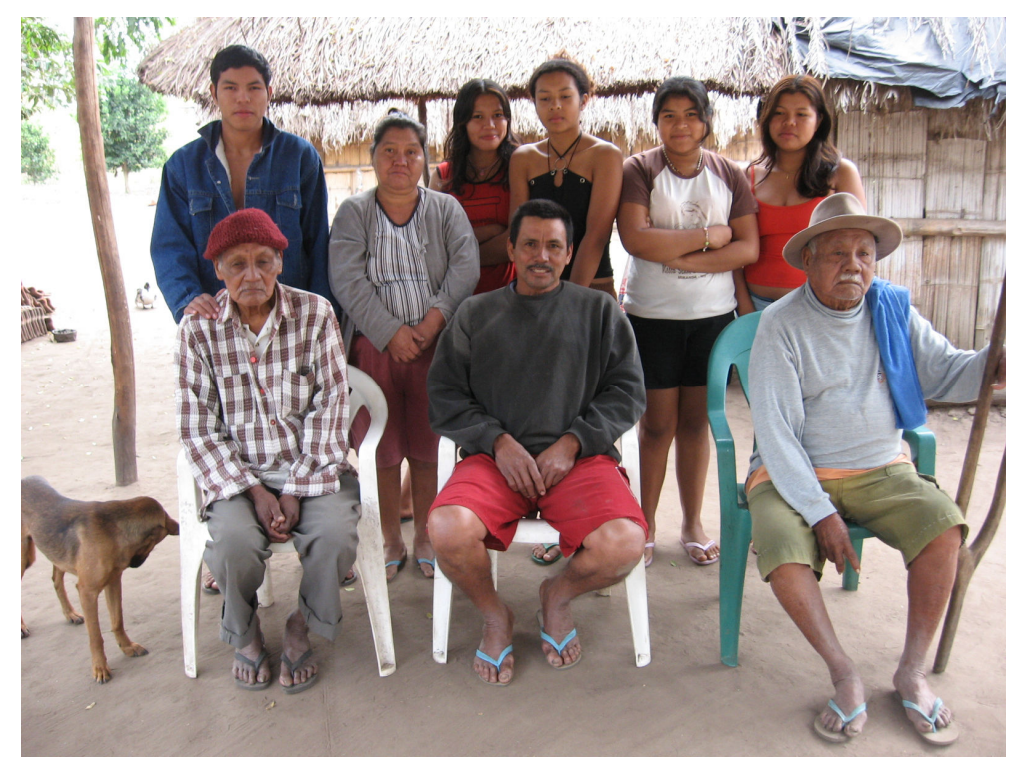

Foto 110: Família de Manuel de Souza Neto 


\section{Bibliografia}

ABREU, C.

2000 Capítulos de história colonial. Belo Horizonte: Itatiaia, São Paulo: Publifolha.

AB'SÁBER, A. N.

2006 O Pantanal Mato-Grossense e a Teoria dos Refúgios e Redutos. Brasil: paisagens de extensão (O Litoral e o Pantanal Mato-Grossense - Patrimônios Básicos). Cotia: Ateliê, p. 9-78.

AGUIRRE, J. F.

1948 Diário del capitan de fragata de la Real Armada, Juan Francisco Aguirre. Revista de la Biblioteca Nacional, 19 (1): 9-598. Buenos Aires: Imprensa de la Biblioteca Nacional.

ALMEIDA SERRA, R, F. de A.

1845 Parecer sobre os índios Uaicurús e Guanás, com a descrição de seus usos, religião, estabilidade e cultura. Revista do Instituto Histórico e Geográfico Brasileiro, VII. Rio de Janeiro.

ALTENFELDER SILVA, F.

1949 Mudança cultural dos Terena. Revista do Museu Paulista, III (Nova Série). São Paulo.

AMÍLCAR RODRIGUES, J. A.

1992 Aqueología del sudeste de Sudamérica. In: Meggers, B. J. (org.). Prehistoria Sudamericana: nuevas perspectivas. Santiago del Chile: Universitária, Washington: Taraxacum.

ANAWAK, J.

1994 Inuit perceptions of the past. In: Layton, R. (Ed.) Who needs the past? Indigenous values and archaeology. London, Routledge: 45-50.

ARAÚJO, A.

2001 Teoria e método em arqueologia regional: um estudo de caso no alto Paranapanema, Estado de São Paulo. São Paulo: Tese de doutorado Universidade de São Paulo.

ARAÚJO, H. J. T. et al.

1982 Geologia. In: BRASIL. Ministério das Minas e Energia. Secretaria Geral. Projeto RADAMBRASIL. 1982. Folha SF 21 Campo Grande; geologia, geomorfologia, pedologia, vegetação e uso potencial da terra. Rio de Janeiro, p. 17-184.

AZANHA, G.

2004 As terras indígenas Terena no Mato Grosso do Sul. São Paulo: CTI.

AZARA, F. de. 
1905 La geografia fisica y esférica del Paraguay y missiones guaranies. La Plata: Taller de Impressiones Oficiales.

BALDUS, $\mathrm{H}$.

1950 Lendas dos índios Terena. Revista do Museu Paulista, IV (Nova série). São Paulo.

BARRETO, C.

1999-2000 A construção de um passado pré-colonial: uma breve história da arqueologia no Brasil. Revista USP, 44: 32-51. São Paulo: USP.

BARTON, C. M. et al.

2004 Long term socioecology and contingent landscapes. Journal of archaeological method and theory, 11 (3): 253-296.

BASTOS, U. R. de A.

1972 Expansão territorial do Brasil colônia no vale do Paraguai. (Tese de Doutorado). São Paulo: FFLCH/USP;

BECKER, I. I. B.

1992 Lideranças indígenas no começa das reduções jesuíticas da Província do Paraguay. Pesquisas, 47 (Série Antropologia). São Leopoldo.

BERRA, J.C. \& DeBLASIS, P.

2006 A cerâmica de Ferraz Egreja. In: Vialou, A.V. Pré-história do Mato Grosso. São Paulo: EDUSP.

BINFORD, L.

1962 Archaeology as anthropology. American antiquity, 28 (2): 217-25.

1964 A consideration of archeological research design. American antiquity, 29 (4): 425-461.

1980 Willow smoke and dog's tails: hunter-gatherer settlement systems and archaeological site formation. American antiquity, 45: 4-15.

1981 Behavioral archaeology and the Pompeii premise. Journal of archaeological resources, 37: 195-208.

1983 Working at archaeology. New York: Academic Press.

BINFORD, L. R. \& BINFORD, S. R.

1972 New perspectives in archaeology. Chicago: Adline.

BITTENCOURT, C. M. \& LADEIRA, M. E.

2000 A história do povo Terena. Brasília: MEC.

BOGGIANI, G.

1975 Os Caduvéu. Belo Horizonte: Itatiaia/EDUSP. 
BORDES, F.

1968 Le paléolithic dans le monde. Paris: Hachete.

BRASIL. Ministério das Minas e Energia. Secretaria Geral. Projeto RADAMBRASIL.

1982 Folha SF 21 Campo Grande; geologia, geomorfologia, pedologia, vegetação e uso potencial da terra. Rio de Janeiro.

BROCHADO, J. P.

1973 Migraciones que difundieron la tradicion alfarera Tupiguarani. Relaciones, 7: 7-39.

1984 An ecological model of the spread of pottery and agriculture into Eastern South America. Ph. Thesis. Department of anthropology. University of Illinois at Urbana-Champaing.

1989 A expansão dos Tupi e da cerâmica policrômica amazônica. Dédalo, 27: $65-82$.

BROCHADO, J.P. \& MONTICELLI, G.

1994 Regras práticas na reconstrução gráfica das vasilhas de cerâmica Guarani a partir dos fragmentos. Estudos Ibero-Americanos, 2: 107-118. Porto Alegre: PUCRS.

BROCHADO, J. P., MONTICELLI, G. \& NEUMANN, E.S.

1990 Analogia etnográfica na reconstrução gráfica das vasilhas Guarani arqueológicas. Véritas, 35: 727-743. Porto Alegre.

BROOKS, R.L.

1993 Household abandonment among sedentary Plains society: behavioral sequences and consequences in the interpretation of archaeological record. In: Cameron, C. M. \& Tomka, S. A. Abandonment of settlements and regions: ethnoarchaeological and archaeological approaches. Cambridge, Cambridge University Press: 178-87.

BUENO, L. M. R

2007 Variabilidade tecnológica nos sítios líticos da região do Lageado, médio rio Tocantins. Revista do Museu de Arqueologia e Etnologia, Suplemento 4. São Paulo: MAE/USP

BYRNE, D.

2004 Archaeology in reverse: the flow of Aboriginal people and their remains through the spece of New South Wales. Public Archaeology: (240-254). London: Routledge.

CABEZA DE VACA, A. N.

1985 Naufragios y comentários. Madrid: Edción de Roberto Ferrero.

CAMERON, C. M. \& TOMKA, S. A.

1993 Abandonment of settlements and regions: ethnoarchaeological and archaeological approaches. Cambridge: Cambridge University Press. 
CARDOSO de OLIVEIRA, R.

1976 Do índio ao bugre: o processo de assimilação dos Terêna. 2. ed. Rio de Janeiro: Museu Nacional.

1968 Urbanização e tribalismo. Rio de Janeiro: Zahar.

2002 Os diários e suas margens. Brasília: UnB.

CARNEIRO da CUNHA, M.

1992 História dos índios no Brasil. São Paulo: Companhia das Letras.

CARVALHO, S. M. S.

1992 Chaco: encruzilhada de povos e "melting pot" cultural, suas relações com a bacia da Paraná e o sul mato-grossense. In: Carneiro da Cunha, M. História dos índios no Brasil. São Paulo, Companhia das Letras: 457-74.

CASTELNAU, F. de.

1949 Expedições às regiões Centrais da América do Sul. São Paulo: Nacional.

CHMYZ, I.

1974 Dados arqueológicos do baixo rio Paranapanema e alto rio Paraná. In: PRONAPA - Resultados preliminares do $5^{\circ}$ ano. Belém: Museu Goeldi.

1976 Arqueologia e história da vila espanhola de Ciudad Real del Guairá. Cadernos de arqueologia, 1: 7-105. Paranaguá: Museu de Arqueologia e Artes Populares/ UFPR.

1983 Sétimo relatório do Projeto Arqueológico Itaipu. Curitiba: Itaipu/IPHAN.

CONDORI, C.M.

1994 History and prehistory in Bolivia: what about the Indians? In: Layton, R. (Ed.) Conflict in the archaeology of living traditions. London, Routledge: 46-59.

CONKEY, M. \& HASTORF, C.

1998 The uses of style in archaeology. Cambridge: Cambridge University.

CORTESÃO, J. (org.).

1951 Manuscritos da Coleção de Angelis. Jesuitas e bandeirantes no Itatim (1596-1760). Rio de Janeiro: Biblioteca Nacional, Divisão de Obras Raras e Publicações.

COSTA, M. F.

1999 História de um país inexistente: o Pantanal entre os séculos XVI e XVIII. São Paulo: Kosmos.

DAVID, N. \& KRAMER, C.

2001 Ethnoarchaeology in action. Cambridge: Cambridge University Press. 
DIAS, A. S.

1994 Repensando a tradição Umbu através de um estudo de caso. Dissertação de mestrado. Porto Alegre, Pontifícia Universidade Católica do Rio Grande do Sul.

2003 Sistemas de assentamento e estilo tecnológico: uma proposta interpretativa para a ocupação pré-colonial do alto vale do rio dos Sinos, Rio Grande do Sul. São Paulo: Tese de doutorado Universidade de São Paulo.

DIAS, A. S. \& SILVA, F. A.

2001 Sistema tecnológico e estilo: as implicações desta interrelação no Estudo das indústrias líticas do Sul do Brasil. Revista do Museu de Arqueologia e Etnologia, 11: 95-108. São Paulo

DIAS Jr., o. \& CARVALHO, E.

1982 A fase Piumhy: seu reconhecimento arqueológico e suas relações culturais. Clio, 5: 5-43. Recife: UFPE.

EL-HAJ, N. A.

19-- Translating Truths: Nationalism, the Practice of Archaeology, and the Remaking of Past and Present in Contemporary Jerusalem. American Ethnologist, 25 (2): 166 -88

ELUYEMI, O.

1994 The archaeology of the Yoruba: problems and possibilities. In: Shennan,

S.J. (Org.) Archeological approaches to cultural identity. London, Routledge: 207-209.

ENDERE, M.L.

2005 Talking about others: archaeologists, indigenous peoples and heritage in Argentina. Public Archaeology, 4 (2/3): 155-162.

\section{EREMITES DE OLIVEIRA, J.}

1996 Guató - argonautas do Pantanal. Porto Alegre: Edipuc/RS.

1999 Ambiente e cultura no contexto da ocupação indígena da planície de inundação do Pantanal. Fronteiras, 3 (6) (jul/dez): 9-34. Campo Grande: UFMS.

2001 Acuri, a palmeira dos índios Guató. Suplemento antropológico, 36 (1): 355-386. Asunción.

2003 Da pré-história à história indígena: (Re) pensando a arqueologia e os povos canoeiros do Pantanal. Revista de arqueologia, 16: 71-86. São Paulo: SAB.

2004 Arqueologia das Sociedades Indígenas no Pantanal. Campo Grande: Oeste. 
2006 Cultura material e identidade étnica na arqueologia brasileira: um estudo sobre a discussão sobre a tradicionalidade da ocupação Kaiowá da terra indígena Sucuri'y. Revista de Arqueologia, 16: 29-49.

EREMITES DE OLIVEIRA, J. \& VIANA, S. A.

1999-2000 O Centro-Oeste antes de Cabral. Revista USP, 44: 142-89. São Paulo: USP.

ESSELIN, P.

2000 A gênese de Corumbá: confluência das frentes espanhola e portuguesa em Mato Grosso (1536-1778). Campo Grande: UFMS (Fontes Novas).

ETCHEVARNE, C.

1999-2000 A ocupação humana no Nordeste brasileiro antes da colonização portuguesa. Revista USP, 44: 12-41. São Paulo: USP.

FACCIO, N. B.

1998 Arqueologia do cenários das ocupações horticultoras da Capivara, baixo Paranapanema/SP. (Tese de Doutorado). São Paulo: MAE/USP.

FAUSTO, C.

2000 Os índios antes do Brasil. 3. ed. Rio de Janeiro: Jorge Zahar.

FELICÍSSIMO, M. P. et al.

2004 Estudos arqueométricos de cerâmicas indígenas pré-coloniais das lagoas do Castelo e Vermelha, localizadas no Pantanal sul-mato-grossense. Canindé, 4: 325-368.

FERREIRA, A. R.

1971 Carta dirigida ao governador e capitão-general João de Albuquerque de Melo Pereira e Cáceres (sobre o aldeamento dos índios Guaicurus e a escravização que estes fizeram com duas negras fugitivas numa fazenda dos arredores de Cuiabá).

FIGUTI, L.

2006 Os sítio a céu aberto na Fazenda Verde. In: Vialou, A.V. Pré-história do Mato Grosso. São Paulo: EDUSP.

FINNEGAN, R.

1992 Oral traditions and the verbal arts: a guide to research practices. London/New York: Routledge.

FERREIRA, J. A.

1905 Notícia sobre os Índios de Matto-Grosso dada em ofício de 2 de Dezembro de 1848 ao Ministro e Secretário d'Estado dos Negócios do Império, pelo Diretor Geral dos Índios da então Provincia. In: O Archivo 1 (2): 79-96. Cuiabá.

FLORENCE, H. 
1977 Viagem fluvial do Tietê ao Amazonas de 1825 a 1829. São Paulo: Cultrix-EDUSP.

FRANCHETO, B. \& HECKENBERGER, $M$.

2001 Os povos do alto Xingu: história e cultura. Rio de Janeiro: UFRJ.

GADELHA, R. M. A. F.

1980 As missões jesuíticas do Itatin: um estudo das estruturas sócioeconômicas coloniais, séc. XVI e XVII. Rio de Janeiro: Paz e Terra.

GANDIA, H. de.

1932 História de la conquista del Rio de La Plata e del Paraguay. Buenos Aires: Libreria de A. Garcia Santos.

1935 Las missiones jesuíticas y los bandeirantes paulistas. Buenos Aires: La Facultad.

GIESSO, M.

1998 Sobre a periferia: os arrabaldes das missões jesuítico-Guarani (trad. de Jorge Eremites de Oliveira). Fronteiras, 2 (4): 251-74. Campo Grande: UFMS.

GIRELLI, M.

1994 Lajedos com gravuras na região de Corumbá, MS. (Dissertação de Mestrado). São Leopoldo: UNISINOS.

GREEN, L.F.; GREEN,D.R. \& NEVES, E.G.

2003 Indigenous knowledge and archaeological science. Journal of Social Archaeology, 3 (3):366-398.

GUZMAN, R. D. de.

1835 Historia argentina de lo descobrimiento, poblacion e conquista do rio de la Plata. Buenos Aires: Imprenta del Estado.

HARRIS, $\mathrm{H}$.

2005 Indigenous worldviews and ways of knowing as theoretical and methodological foundations for archaeological resource. In: Smith, C. \& Wobst, M. W. Indigenous Archaeologies. London, Routledge.

HECKENBERGER, M. J.

1996 War and peace in the shadow of empire: sociopolitical change in the upper Xingu of Southeastern Amazonia, A.D. 1400-2000. PhD. Tesis. Ann Arbor. University of Pittesburgh.

2001 Estrutura, história e transformação: a cultura xinguana. In: FRANCHETO, B. \& HECKENBERGER, M. Os povos do alto Xingu: história e cultura. Rio de Janeiro: UFRJ.

2002 Rethinking the arawakan diaspora: hierarchy, regionality, and the Amazoniam formative. In: Hill, D. \& Santos-Granero, F. Comparative 
Arawakan history: rethinking language family and culture area in Amazonia. Urbana: University of Illinois.

2005 The ecology of power: culture, place, and personhood in the southern Amazon, AD 1000-2000. New York: Routledge.

HECKENBERGER, M., NEVES, E. \& PETERSEN, J.

1998 De onde vêm os modelos?: a arqueologia da origem dos Tupi e Guarani. Revista de antropologia. São Paulo: USP.

HENRIQUES, G., COSTA, F. \& KOOLE, E.

2004 O alto São Francisco e o mito dos Cataguá: contribuições para a história indígena em Minas Gerais. Revista do Museu de Arqueologia e Etnologia, 14: 195-208. São Paulo: MAE/USP.

HERBERTS, A. L.

1998 Os Mbayá-Guaicuru: área, assentamento, subsistência e cultura material. São Leopoldo (RS): Dissertação de Mestrado Universidade do Vale do Rio dos Sinos.

HODDER, I.

1987 Archaeology as Long-Term History. Cambridge: Cambridge University Press.

HOLANDA, S. B. de.

1960 História geral da civilização brasileira. Difusão Européia do Livro, 1 (1). São Paulo.

2000 Monções. São Paulo: Brasiliense.

ISAACSON, K. \& Ford, S.

2005 In: Smith, C. \& Wobst, M. W. Indigenous Archaeologies. London, Routledge.

INSTITUTO SÓCIO-AMBIENTAL

2001-2005 Povos indígenas no Brasil. São Paulo: ISA

JACKSON, G. \& SMITH, C.

2005 Living and learning on Aboriginal lands: decolonizing archaeology. In: Smith, C. \& Wobst, M. Indigenous Archaeologies. London, Routledge: 328-351.

JONES, S.

1997 The archeology of ethnicity. London: Routledge.

JOYCE, A. A. \& JOHANNESSEN, S.

1993 Abandonment and the production of archaeological variability at domestic sites. In: Cameron, C. M. \& Tomka, S. A. Abandonment of settlements and regions: ethnoarchaeological and archaeological approaches. Cambridge, Cambridge University Press: 138-153. 
KASHIMOTO, E. M.

1997 Variáveis ambientais e arqueologia no Alto Paraná. São Paulo: Tese doutorado (Arqueologia) Faculdade de Filosofia, Letras e Ciências Humanas da Universidade de São Paulo.

KASHIMOTO, E. M. \& MARTINS, G. R.

2000 Panorama arqueológico da margem direita do rio Paraná, MS: do povoamento por caçadores-coletores a índios Guarani coloniais. Cli, 14: 299-315. Recife: UFPE

2008 A problemática arqueológica da tradição cerâmica Tupiguarani em Mato Grosso do Sul. In: Prous, A. \& Lima, T. A. (org.). Os ceramistas Tupiguarani. Brasília: IPHAN

KOJAN, D. \& ANGELO, D.

2005 Dominant narratives, social violence and the practice of bolivian archaeology. Journal of Social Archaeology, 5 (3): 383-408.

LAMING, A., EMPERAIRE, J.

1959 A jazida José Vieira: Um sítio Guarani e pré-cerâmico no interior do Paraná. Arqueologia, 1: 1-142. Curitiba: C.P.U.P.

LAPONTE, D. \& ACOSTA, A.

2008 Estado actual y perspectivas de la arqueologia de la "tradicion Tupiguarani” em Argentina. In: Prous, A. \& Lima, T. A. Os ceramistas Tupiguarani. Brasília: IPHAN

LA SALVIA, F., BROCHADO, J. P.

1984 Cerâmica Guarani. Porto Alegre: Posenato arte e cultura.

LATHRAP, D. W.

1970 The upper amazon. London: Thames and Hudson.

LAYTON, R.

1985 The cultural context of hunther-gatherer rock art. Man, 20: 434-453.

1989 Who needs the past? (Indigenous values and archaeology). London: Routledge.

LEAVESLEY, M.G.; MINOL, B.; KOP, H. \& KEWIBU, V.H.

2005 Cross-cultural concepts of archaeology. Kastom, community, education and cultural heritage management in Papua New Guinea. Public Archaeology, 4: 3-13.

LECLAIR, J.

2005 Of grizzlies and landslides: the use of archaeological and anthropological evidence in Canadian aboriginal rights cases. Public Archaeology, 4 (2/3): 109-119. 
LEVI-STRAUSS, C.

1986 Tristes tópicos. Lisboa: 70.

MAEDER, E. J. A.

1996 Aproximación a las Missiones Guaraniticas. Buenos Aires: Universidad Católica Argentina.

MAGALHÃES, N. W.

1992 Conheça o Pantanal. São Paulo: Terragraph.

MARTINS, G. R.

1998 Relatório de registro de sítios arqueológicos em Rio Negro-MS. Fronteiras, 2 (4): 223-50.

2002a Santiago de Xerez: uma problemática para a arqueologia histórica. In: História Paraguaya. Assunción: Academia Paraguaya de la Historia.

2002b Breve painel etno-histórico de Mato Grosso do Sul. 2. ed. Campo Grande: UFMS/ ComPed/ INEP.

2001 Contribuições da etno-história para a arqueologia do nordeste de Mato Grosso do Sul, na área impactada pelo Gasoduto Bolívia-Brasil. Reista do Museu de Arqueologia, 11: 303-310. São Paulo: MAE/USP.

2003 Arqueologia do planalto Maracaju-Campo Grande. Campo Grande: UFMS.

2005 Resumo do conhecimento acumulado sobre o passado arqueológico do processo de povoamento humano no Centro-Oeste do Brasil. In: Vilhena-Vialou, A. Pré-história do Mato Grosso. vol. I. São Paulo: EDUSP.

MARTINS, G. R., KASHIMOTO, E. M.

1999a Arqueologia Guarani no Alto Paraná, Estado de Mato Grosso do Sul. Fronteiras, 3 (5): 51-64. Campo Grande: UFMS.

1999b Resgate arqueológico na área do gasoduto Bolívia/Brasil em Mato Grosso do Sul. Campo Grande: UFMS (Fontes Novas).

2000 Arqueologia do contexto do rio Jaurú (MT) impactado pelo gasoduto Bolívia-Mato Grosso. Revista do Museu de Arqueologia e Etnologia, 10. São Paulo.

MARTINS, G. R., KASHIMOTO, E. M. \& TATUMI, S. H.

1999 Datações arqueológicas em Mato Grosso do Sul. Revista do Museu de Arqueologia e Etnologia, 9. São Paulo.

MELIÁ, B., SAUL, M. V. A., MURARO, V. 
1987 O Guarani. Uma bibliografia etnológica. Santo Ângelo: Fundação PróMemória/ Fundames.

MENTZ RIBEIRO, P. A.

2008 A tradição ceramista Tupiguarani no sul do Brasil

METRAUX, A.

1928 La civilisation matérielle des tribus Tupi-Guarani. Paris: Orientalist Paul Genthner.

1946 Ethnography of the Chaco. In: Steward, J. H. Handbook of South American Indians. Washington, Smithsonian Institution: 197-370.

1974 Migraciones historicas de los Tupi-Guarani. Chaco: Universidade Nacional del Nordeste.

MIGLIACIO, M. C.

2000 A ocupação pré-colonial do Pantanal de Cáceres, Mato Grosso; uma leitura preliminar. (Dissertação de Mestrado). São Paulo: MAE/USP.

2000-2001 A ocupação indígena no Pantanal de Cáceres, Alto Paraguai - do período pré-colonial aos dias atuais. Revista do Museu Antropológico, $5 / 6(1)$.

2006 O doméstico e o ritual: cotidiano Xaray no Alto Paraguai até o século XVI. São Paulo: Tese de doutorado MAE/USP.

MILHEIRA, R. G.

2008 Território e estratégia de assentamento Guarani na planície sudoeste da Laguna dos Patos e Serra do Sudeste-RS. (Dissertação de Mestrado) São Paulo: MAE/USP

MILLER, E. T.

1983 História da cultura indígena do alto-médio Guaporé. Porto Alegre: Dissertação de mestrado PUC/RS.

MONTEIRO, J. M.

1992 Os Guarani e a história do Brasil meridional. In: Cunha, Manuela Carneiro da (org.). História dos índios no Brasil. São Paulo: Companhia das Letras.

1994 Negros da terra. São Paulo: Companhia das Letras.

MONTOYA, A. R. de.

1876 Arte de la lengua Guarani, ó mas bien Tupi. Vocabulário e tesoro. Viena-Paris.

MORAIS, J. L. de. 
1983 A utilização dos afloramentos litológicos pelo homem pré-histórico brasileiro: análise do tratamento da materia-prima. São Paulo: Fundo de Pesquisas do Museu Paulista (Coleção Museu Paulista).

1999-2000 Arqueologia da região Sudeste. Revista USP, 44 (dez/jan/fev): 194-217. São Paulo: USP

MOREIRA NETO, C. de.

2005 Os indio e a ordem imperial. Brasília: FUNAI

\section{NELSON, M.}

1997 Abandonment: conceptualization, representation, and social change. In:

Schiffer, M. Social theory in archaeology. Salt Lake City: University of Utah Press.

NEVES, E. G.

1999a Arqueologia, história indígena e o registro etnográfico. Revista do Museu de Arqueologia e Etnologia, Suplemento 3: 319-330

1999b Changing perspectives in Amazonian archaeology. In: Politis, G. \& Alberti, B. Archaeology in latin America. London, Routledge: 216-43.

2000 Paths in the dark waters: archaeology as indigenous history in the Upper Rio Negro Basin, northwest Amazon. Phd. Thesis. Indiana University, Bloomington.

2006 Tradição oral e Arqueologia na história indígena no alto rio Negro. In: Forline, L. C., Murieta, R. S. S. \& Vieira, I. C. G. Amazônia: além dos 500 anos. Belém: Museu Goeldi.

NIMUENDAJU, C.

1987 As lendas de criação e destruição do mundo como fundamento da religião dos Apapocúva-Guarani. São Paulo: Hucitec/EDUSP.

2002 Mapa etno-histórico de Curt Nimuendajú. Rio de Janeiro: IBGE.

\section{NOELLI, F. S.}

1993 Sem Tekohá não há Tekó: em busca de um modelo etnoarqueológico da subsistência e da aldeia Guarani aplicado a uma área de domínio no delta do Jacuí-RS. Porto Alegre: Dissertação mestrado (História) Pontifícia Universidade Católica do Rio Grande do Sul.

1996 As hipóteses sobre os centros de origem e as rotas de expansão dos Tupi, Revista de Antropologia, 39 (2): 7-53.

1998 The Tupi: explaining origin and expansion in terms of archaeology and historical linguistics. Antiquity, 72 (277): 648-63.

1999-2000 A ocupação humana na região Sul do Brasil: arqueologia, debate e perspectivas - 1872-2000. Revista USP, 44: 218-69. São Paulo: USP 
2004 La distibución geográfica de las evidencias aqueológicas Guaraní. Revista de Indias, LXIV (230).

NOELLI, F. S. \& BROCHADO, J. P.

1998 O cauim e as beberagens dos Guarani: equipamentos, técnica de preparação e consumo. Revista do Museu de Arqueologia e Etnologia, 8: 117-128. São Paulo: MAE/USP.

NOELLI, F. S., DIAS, A. S.

1995 Complementos históricos ao estudo funcional da indústria lítica Guarani. Revista do CEPA, 19 (22): 7-32.

NOELLI, F. S. \& FERREIRA, L. M.

(no prelo) A persistência da teoria da degeneração indígena e do colonialismo nos fundamentos da Arqueologia Brasileira. História, Ciências, Saúde-Manguinhos.

NORDENSKIOLD, E.

1917 The Guarani invasion of Inca Empire in the 16th century: an historical Indian migration. Geographical review. New York.

OBERG, K.

1948 Terena social organization and law. American anthropologist, L (2).

1949 The Terena and Caduveu of southern Mato Grosso. Washington: Smithsonian Institution.

ORTON, C., TYERS, P. \& VINCE, A.

1993 Pottery in archaeology. Cambridge: University Press.

\section{PALLESTRINI, L}

1984 Sítio arqueológico da lagoa São Paulo: Presidente Epitácio/SP. Revista do Museu Paulista, 25: 381-410. São Paulo: Museu Paulista.

PALLESTRINI, L. \& CHIARA, W.

1978 Indústria lítica de Camargo-76, Município de Pirajú, Estado de São Paulo. Revista do Museu Paulista, 2: 83-122. São Paulo: Museu Paulista (Série Ensaios, 2)

PANJA, S.

2003 Mobility strategies and site structure: a case study of Inamgaon. Journal of anthropological archaeology, 22 (2): 105-25.

PARKER, L.O.

2005 Indigenous people's rights to their cultural heritage. Public Archaeology, $4(2 / 3): 127-140$.

PÄRSSINEN, M. 
2005 Quando começou, realmente, a expansão Guarani em direção às Serras Andinas Orientais. Revista de Arqueologia, 18.

PEIXOTO, J. L. S.

1998 Populações indígenas de tradição Tupiguarani no Pantanal Sul-matogrossense. Revista do Museu de Arqueologia e Etnologia, 8: 71-86. São Paulo: USP.

2002 A ocupação dos povos indígenas pré-coloniais nos grandes lagos do Pantanal Sul-mato-grossense. Porto Alegre: Tese de doutorado PUC/RS.

PEIXOTO, J.L.S \& BEZERRA, M.A.O.

2004 Os povos ceramistas que ocuparam a planície aluvial antes da conquista européia. In: Anais do IV Simpósio sobre Recursos Naturais e Sócioeconômicos do Pantanal. Corumbá.

PERASSO, J. A. G.

1978 Estudios arqueológicos en el Paraguay; análisis interpretativo. Etnografia Paraguaya, 1(2): 1-32.

1992 Historia y arqueología Del pueblo de la Santíssima Trinidad Del Paraná. Assunción: Instituto Paraguayo de Prehistoria (fundación LeroiGourhan), Museo Guido Boggiani.

PIEDADE, S. C. \& SOARES, A. L.

2000 Considerações sobre um enterramento Guarani: alterações e hipóteses etno-históricas. Revista do Museu de Arqueologia e Etnologia, 10: 33168. São Paulo: MAE/USP

PÓVOA, M. B.

2007 Arqueologia dos Abrigos Cera, Aquidanana/MS: cultura material e inserção na paisagem. (Dissertação de Mestrado). São Paulo: MAE/USP

PRADO, F. R. do.

1839 História dos índios cavaleiros ou da nação Guaicuru. Revista do Instituto Histórico e Geográfico Brasileiro, I. Rio de Janeiro.

PROUS, A.

1992 Arqueologia brasileira. Belo Horizonte: UNB.

1999 As primeiras populações do Estado de Minas Gerais. In: Tenório, M.C. Pré-história da Terra Brasilis. Rio de Janeiro: UFRJ.

RICE, P. M.

1987 Pottery analysis. Chicago and London: The University of Chicago Press.

RIBEIRO, D.

1980 Kadiwéu. Rio de Janeiro: Vozes.

1982 Os índios e a civilização. 4. ed. Petrópolis: Vozes. 
ROBHRAN-GONZALEZ, E. M.

1996 Os grupos ceramistas pré-coloniais do Centro-Oeste brasileiro. Revista do Museu de Arqueologia e Etnologia, 6: 83-121. São Paulo.

RODRIGUES, A. D.

1964 A classificação do tronco lingüístico Tupi. Revista de Antropologia, 12: 99-104. São Paulo: FFLCH/USP

ROUSE, I.

1992 The Tainos: rise \& decline of the people who greeted Columbus. New Haven \& London: Yale University Press.

RUBERTONE, P.E.

1994 Archaeology, colonialism and 17th-century native America: towards an alternative interpretation. Conflict in the archaeology of living traditions. London, Routledge: 32- 45.

RYE, O. S.

1981 Technology: principles and reconstruction. Washington: Taraxacum

SCATAMACCHIA, M. C. M.

1990 A tradição policrômica no leste da América do Sul evidenciada pela ocupação Guarani e Tupinambá: fontes arqueológicas e etno-históricas. São Paulo: Tese de doutorado USP.

SANCHEZ-LABRADOR, J. S.

1910 El Paraguay Católico, con sus principales provincias convertidas a la Santa Fé y su vasallaje del Rey de España por Jesús, en gran parte arruinada por los mamelucos del Brasil e restablecidas por los mismos misioneros - año de 1770. Buenos Aires: Hermanos.

SCHADEN, E.

1974 Aspectos fundamentais da cultura Guarani. 3. ed. São Paulo: EPU/EDUSP.

SCHIAVETO, S. N. de O.

2003 A arqueologia guarani: construção e desconstrução da identidade indígena. São Paulo: FAPESP/AnnaBlume.

SCHIFFER, M. B.

1972 Archaeological context and sistemic context. American antiquity, 37 (2): 156-65.

1976 Behavioral archeology. New York: Academic Press.

1987 Formation process of the archaeological record. Albuquerque: University of New Mexico Press.

SCHMIDEL, U. 
1986 Relato de la conquista Del rio de la Plata y Paraguay: 1534-1555. Madrid: Alianza.

\section{SCHMIDT, M.}

1917 Die Aruaken. Ein beitrag zum problem der kulturverbreitung. Studien zur ethnologie und soziologie. (Tradução manuscrita existente no Museu Nacional).

1940a Hallazgos prehistóricos en Matto Grosso. Revista de la Sociedad Científica del Paraguay, 1(5): 27-62. Asunción.

1940b Nuevos hallazgos de grabados rupestres en Matto Grosso. Revista de la Sociedad Científica del Paraguay, 1(5): 63-71. Asunción.

1942 Ensaios de etnologia brasileira. São Paulo: Nacional.

1949 Los Payaguá. Revista do Museu Paulista, vol III: 128-269. São Paulo: USP.

SCHMITZ, P. I.

1967 Arqueologia da Rio Grande do Sul. Pesquisas. São Leopoldo: Unisinos.

1998 Arqueologia em Mato Grosso do Sul: dois projetos, dois resultados. Fronteiras, 2 (4): 203-221.

1999a Caçadores-coletores do Brasil Central. In: Tenório, M. C. (org.) Préhistória da Terra Brasilis. Rio de Janeiro, UFRJ: 75-88.

1999b Caçadores-coletores-pescadores do Pantanal de Mato Grosso do Sul. In: Tenório, M. C. (org.) Pré-história da Terra Brasilis. Rio de Janeiro, UFRJ: $149-57$.

1999c O Guarani: história e pré-história. In: Tenório, M. C. (org.) Pré-história da Terra Brasilis. Rio de Janeiro, UFRJ: 284-94.

SCHMITZ, P. I., BROCHADO, J. J. P.

1972 Datos para una secuencia cultural del Estado de Rio Grande do Sul, Brasil. Gabinete de Arqueologia, 2. Porto Alegre: UFRGS.

1981 Arqueologia do Rio Grande do Sul, Brasil. Estudos Leopoldenses. São Leopoldo: UNISINOS.

SCHMITZ, P. I. et al.

1998 Aterros indígenas no Pantanal de Mato Grosso do Sul. Pesquisas, 54 (Série Antropologia). São Leopoldo: UNISINOS.

SCHUCH, M. E. J.

1995 Xaray e Chané: índios frente à expansão espanhola e portuguesa no alto Paraguai. (Dissertação de Mestrado). São Leopoldo: UNISINOS. 
SEEGER, A.

1980 Os índios e nós: estudos sobre as sociedades tribais brasileiras. Rio de Janeiro: Campus.

SEPLAN/IBGE - Estado de Mato Grosso do Sul.

1990 Atlas Multirreferencial do Estado de Mato Grosso do Sul. Campo Grande.

SHEPARD, A. O.

1956 Ceramics for the archaeologist. Washington, D. C.: Carnegie Institution of Washington.

SHEPHERD, N.

2003 When the hand that holds the trowel is black...Disciplinary practices of self-representation and issue of 'native' labor in archaeology. Journal of Social Archaeology, 3 (3):334-352.

SIEGEL, P. E. \& ROE, P. G.

1986 Shipibo archaeo-ethnography: site formation process and archaeological interpretation. World archaeology, 18 (1): 96-115.

SILLIMAN, S.W.

2005 Culture contact or colonialism? Challenges in the archaeology of native north America. American Antiquity, 70 (1): 54-74.

SILVA, F. A.

1992. Manifestações artísticas pré-históricas: um estudo descritivo-classificatório e interpretativo da arte rupestre de Serranópolis-Goiás. Porto Alegre: Dissertação de mestrado UFRGS.

2000 As tecnologia e seus significados: um estudo da cerâmica dos Assurini do Xingu e da cestaria dos Kaiapó-Xikrin sob uma perspectiva etnoarqueológica. São Paulo: Tese de doutorado Universidade de São Paulo.

SILVA, F. A. et al.

2007 Arqueologia, Etnoarqueologia e História Indígena - um estudo sobre a trajetória de ocupação indígena em territórios do Mato Grosso e Mato Grosso do Sul: a Terra Indígena Kaiabi e a Aldeia Lalima. Revista do Museu de Arqueologia e Etnoarqueologia, 17: 509-514. São Paulo: MAE/USP.

SMITH, C. \& WOBST, M. (Eds).

2005 Indigenous Archaeologies. London, Routledge. 2006.

2006 Decolonizing archaeological theory and practice. In: Smith, C. \& Wobst, M. W. Indigenous Archaeologies. London, Routledge: 5-17.

SOARES, A. L. R. 
1998 Revisitando a organização sócio-política Guarani: pode-se fazer etnohistória e arqueologia? In: VII jornadas internacionales sobre las missiones jesuiticas, 1998, Chaco. Anais... Chaco, Instituto de Investigaciones Geohistoricas-CONICET/Faculdad de HumanidadesUNNE: 567-82.

1999 Os horticultores Guarani: problemáticas, perspectivas e modelos. In: Quevedo, J. (org.). Rio Grande do Sul: quatro séculos de história. Porto Alegre: Martins Livreiro.

2000 Os horticultores Guaranis: modelos, problemáticas e perspectivas. Revista do CEPA, 23: 103-41. Santa Cruz do Sul: EDUNISC.

2001-2002 Arqueologia, história e etnografia: o denominador Guarani. Revista de Arqueologia. São Paulo: Sociedade de Arqueologia Brasileira, vol. 14/15.

2004 Contribuição para a Arqueologia Guarani: o estudo do sítio Röpke. (Tese e Doutorado). São Paulo: MAE/USP.

SOUSA, N. M. de.

2002 A redução de Nuestra Señora de la Fe no Itatim: entre a cruz e a espada. Dourados: Dissertação de mestrado Universidade Federal de Mato Grosso do Sul.

STAPP, D.C. \& LONGENECKER, J.G.

2005 Reclaiming the Ancient One: addressing the conflicts between American Indians and archaeologists over protection of cultural places. In: Smith, C. \& Wobst, M. W. Indigenous Archaeologies. London, Routledge.

STARK, M.

1998 The archaeology of social boundaries. Washington: Smithsonian Institution.

STEINEN, K. Von Den

1940 Entre os Aborigenes do Brasil Central. Separata renumerada da Revista do Arquivo, XXXIV a LVIII. São Paulo: Departamento de Cultura.

STEWARD, J.

1948 Culture areas of the Tropical Forests. In: Steward, J. (Ed.) Handbook of South American Indians, vol.3. Washington D. C.: Boreal of American Ethnology, Smithsonian Institution, Bulletin 143: 883-903.

STEWART, A.M.; KEITH, D. SCOTTIE, J.

2004 Caribou crossings and cultural meanings: placing traditional knowledge and archaeology in context in an Inuit landscape. Journal of Archaeological Method and Theory, 11 (2): 183-212

SUSNIK, B. 
1959 Material arqueológico del área alto-paraguayense. Boletín de la Sociedad Científica del Paraguay y del Museo Andrés Barbero, 3. Asunción.

1978 Los aborigenes Del Paraguay - etnohistória de los guaranies (epoca colonial). Assunción: Museo Etnografico "Andres Barbero".

1984 Guía del Museo: Etnografia Paraguaya. Asunción: Museo Etnográfico Andrés Barbero.

1987 Las características etno-socio-culturales de los aborigenas del Paraguay en el siglo XVI. Historia Paraguaya, 24. Asunción.

SUTTON, P.

2005 Social scientists and native title cases in Australia. Public Archaeology, 4 (2/3): 121-126.

TAUNAY, A.

1981 Relatos monçoeiros. Belo Horizonte: Itatiaia/EDUSP.

1997 A retirada da Laguna. São Paulo: Companhia das Letras.

2000 Os índio do distrito de Miranda. In: Taunay, A. d'E. Ierecê a Guaná. São Paulo: Iluminuras.

TOMKA, S. A.

1993 Site abandonment behavior among transhumant agro-pastoralists: the effects of delayed curation on assemblage composition. . In: Cameron, C. M. \& Tomka, S. A. Abandonement of settlements and regions: ethnoarchaeological and archaeological approaches. Cambridge, Cambridge University Press: 11-24.

TRIGGER, B. G.

2004 História do pensamento arqueológico. São Paulo: Odysseus.

URBAN, G.

1992 A história da cultura brasileira Segundo as línguas nativas. In: Cunha, M.

C. História dos índios no Brasil. São Paulo: Companhia das Letras.

1996 On the geographical origins and dispersion of Tupian Languages. Revista de Antropologia, 39 (2): 61-104.

VIERTLER, R. B.

1990 A duras penas. Um histórico das relações entre indios Bororo e "civilizados" no Mato Grosso. São Paulo: FFLCH/USP

VILHENA-VIALOU, A.

1980 Tecno-tipologia das indústrias líticas do sítio Almeida em seu quadro natural, arqueo-etnológico e regional. São Paulo: Museu Paulista. 
2005 Pré-história do Mato Grosso. vol. I (Santa Elina). São Paulo: EDUSP.

2006 Pré-história do Mato Grosso. vol. II (Cidade de Pedras). São Paulo: EDUSP.

VILHENA-VIALOU, A. \& VIALOU, D.

1989 Abrigo pré-histórico Santa Elina, Mato Grosso: habitats e arte rupestre. Revista de pré-história, 7: 34-53. São Paulo.

VIVEIROS DE CASTRO. E

1996 Comentário ao artigo de Francisco Noelli. Revista de Antropologia, 39 (2): 55-60.

WATKINS, J.

2005 The politics of American archaeology: cultural resources, cultural affiliation and Kenniwic. In: Smith, C. \& Wobst, M. W. Indigenous Archaeologies. London: Routledge

WHARTON, G.

2005 Indigenous claims and heritage conservation: an opportunity for critical dialogue. Public Archaeology, 4: 199-204.

WEBER, A.

2002 Os Eyiguayegui-Mbayá-Guaicuru: encontros e desencontros com os luso-brasileiros na capitania do Mato Grosso. Dourados: Dissertação de mestrado Universidade Federal de Mato Grosso do Sul.

WILLEY, G. R.

1971 An introduction to American Archaeology. Englewood Cliffs, PrenticeHall.

WILLEY, G. R. \& SABLOF, J.

1980 A. A history of American archaeology. New York: W. H. Freeman and company.

WIYNJORROC, P., MANABURU, P., BROWN, N. \& WARNER, A.

2005 We just have to show you: research ethics blekbalawei. In: Smith, C. \& Wobst, M. W. Indigenous Archaeologies. London: Routledge.

WOBST, M.

2005 Power to the (Indigenous) past and present! Or: the theory and method behind archaeological theory and method. In: Smith, C. \& Wobst, M. W. Indigenous Archaeologies. London: Routledge.

WÜST, I.

1990 Continuidade e mudança: para interpretação dos grupos pré-coloniais na bacia do rio Vermelho, Mato Grosso. São Paulo: Tese doutorado (Antropologia) - Faculdade de Filosofia, Letras e Ciências Sociais da Universidade de São Paulo. 
1992 Contribuições arqueológicas, etnoarqueológicas e etno-históricas para o estudo dos grupos tribais do Brasil Central: o caso Bororo. Revista do Museu de Arqueologia e Etnologia, 2: 13-26. São Paulo: MAE/USP.

1999 Etnicidade e tradições ceramistas: algumas reflexões a partir das antigas aldeias Bororo do Mato Grosso. Revista do Museu de Arqueologia e Etnologia, Suplemento 3: 303-318. São Paulo: MAE/USP.

WÜST, I. \& VAZ, L. J.

1998 Grafismos de ação no alto São Francisco, sudeste do Mato Grosso. Revista do Museu Antropológico, 2 (1): 47-88. Goiânia.

ZEDEÑO, M. I.

1997 Landscapes, land use, and the history of territory formation: an example from pueblo in southwest. Journal of archaeological method and theory, 4 (1): 63-103.

\section{ZIMMERMAN, L.J.}

1994 Human bones as symbols of power: aboriginal American belief systems toward bonés and grave-robbing archaeologists. In: Layton, R. (Ed.) Conflict in the archaeology of living traditions. London, Routledge: 211216. 
ANEXOS 


\section{ANEXO 1}

A) Códigos das variantes das classes de atributos analisados nos fragmentos cerâmicos

B) Tabela de análise da variabilidade artefatual na cerâmica na Aldeia Lalima 
A) Códigos das variantes das classes de atributos analisados nos fragmentos cerâmicos

I - Identificação

1.1 - Nome do sítio

1.2 - Setor do Sítio

1.3 - Número do fragmento

1.4 - Proveniência

1.5 - Nível

II - Análise morfológica

2 - Análise dos atributos observáveis

2.1 - Categoria estrutural do

fragmento

$1=$ Parede

$2=$ Borda

$3=$ Base

$4=$ Pescoço

5 = Apêndice

99 = Não identificado

2.2 - Variantes da forma e da posição do fragmento de parede

$1=$ Segmento inferior

$2=$ Segmento superior

$3=$ Ombro (ponto de tangência vertical)

$4=$ Parede inflectida

5 = Parede carenada (ponto angular

saliente)

$6=$ Parede angular (ponto angular

reentrante)

$7=$ Parede complexa

99 = Não identificado
2.3 - Variantes da forma e da posição no fragmento de borda e de pescoço

$1=$ Direta vertical

$2=$ Direta inclinada externa

$3=$ Direta inclinada interna

$4=$ Extrovertida

$5=$ Extrovertida inclinada externa

$6=$ Introvertida

7 = Côncava

$8=$ Carenada

$9=$ Contraída

$10=$ Cambada

$11=$ Infletida

99 = Não identificado

\section{4 - Variantes da forma do lábio no}

fragmento de borda e pescoço

$0=$ Ausente

$1=$ Arredondado

$2=$ Apontado

$3=$ Aplanado

4 = Biselado

$5=$ Roletado

$6=$ Dobrado

$7=$ Expandido

$8=$ Reforçado externo

$9=$ Reforçado interno

$10=$ Ondulado

$11=$ Rebarbado

99 = Não identificado 
2.5 - Diâmetro da boca/base

$1=\leq 2 \mathrm{~cm}$

$2=\geq 2,1 \mathrm{~cm} \mathrm{e} \leq 4 \mathrm{~cm}$

$3=6 \mathrm{~cm}$

$4=8 \mathrm{~cm}$

$5=10 \mathrm{~cm}$

$6=12 \mathrm{~cm}$

$7=14 \mathrm{~cm}$

$8=16 \mathrm{~cm}$

$9=18 \mathrm{~cm}$

$10=20 \mathrm{~cm}$

$11=22 \mathrm{~cm}$

$12=24 \mathrm{~cm}$

$13=26 \mathrm{~cm}$

$14=28 \mathrm{~cm}$

$15=30 \mathrm{~cm}$

$16=32 \mathrm{~cm}$

$17=34 \mathrm{~cm}$

$18=36 \mathrm{~cm}$

$19=38 \mathrm{~cm}$

$20=40 \mathrm{~cm}$

$21=42 \mathrm{~cm}$

$22=44 \mathrm{~cm}$

$23=46 \mathrm{~cm}$

$24=48 \mathrm{~cm}$

$25=50 \mathrm{~cm}$

$26=52 \mathrm{~cm}$

$27=54 \mathrm{~cm}$

$28=56 \mathrm{~cm}$

$29=58 \mathrm{~cm}$

$30=60 \mathrm{~cm}$

$31=\geq 60,1 \mathrm{~cm}$

\section{6 - Variantes da forma no}

\section{fragmento de Base}

$1=$ Circular plana

$2=$ Circular côncava

3 = Circular convexa

$4=$ Circular cônica

5 = Sub-circular côncava

\section{7 - Variantes do fragmento de} apêndice

$1=$ Alça

$2=$ Pedestal

99 = Não identificado

\section{8 - Espessura do fragmento}

$1=$ Muito fino $(1 \mathrm{~mm}$ à $5 \mathrm{~mm})$

$2=$ Fino $(5 \mathrm{~mm}$ à $10 \mathrm{~mm})$

$3=$ Médio $(10 \mathrm{~mm}$ à $15 \mathrm{~mm})$

$4=$ Grosso (15mm à 20mm)

5 = Muito Grosso (maior que 20mm)

99 = Não identificado

\section{9 - Ângulo do fragmento}

$1=\operatorname{Vertical}\left(0\right.$ à $10^{\circ}$ positivos ou negativos)

$2=$ Ligeiramente aberto $\left(10\right.$ à $30^{\circ}$

positivos)

$3=$ Aberto (30 à $50^{\circ}$ positivos)

$4=$ Ligeiramente fechada $\left(10\right.$ à $30^{\circ}$

negativos)

$5=$ Fechada (30 à $50^{\circ}$ negativos)

$6=$ Muito fechada (50 à $75^{\circ}$ negativos)

$7=$ Horizontal $\left(75\right.$ à $95^{\circ}$ positivos ou negativos) 
$8=$ Muito aberto (50 à $75^{\circ}$ positivos)

$11=$ Cilíndrica

99 = Não identificado

12 = Cônica

13 = Hiperbólica

2.10 - Relação diâmetro da

99 = Não identificado

\section{boca/diâmetro do bojo}

$1=$ Aberto

3.4 $=$ Altura da vasilha

$2=$ Fechado

$1=\leq 10 \mathrm{~cm}$

$99=$ Não identificado

$2=$ maior que $10,1 \mathrm{~cm} \mathrm{e} \leq 20 \mathrm{~cm}$

$3=30 \mathrm{~cm}$

3 - Análise dos atributos deduzidos

$4=40 \mathrm{~cm}$

3.1 - Classe estrutural da vasilha

$5=50 \mathrm{~cm}$

$1=$ Não restringida

$6=60 \mathrm{~cm}$

$2=$ Restringida

$7=70 \mathrm{~cm}$

$3=$ Restringida independente

$8=80 \mathrm{~cm}$

99 = Não identificado

$9=90 \mathrm{~cm}$

$10=100 \mathrm{~cm}$

3.2 - Contorno específico

$11=\geq 100,1 \mathrm{~cm}$

$1=$ Simples

$99=$ Não identificado

$2=$ Infletido

3 = Composto

3.5 - Função

4 = Complexo

$1=$ Tostador

99 = Não identificado

$2=$ Panela

$3=$ Jarra

3.3 - Forma geométrica

$4=$ Prato

$1=$ Esférica

$5=$ Tigela aberta

$2=$ Semi-esférica

$6=$ Tigela fechada

$3=$ Elíptica vertical

7 = Ritual

$4=$ Semi-elíptica vertical

8 = Yapepó

$5=$ Elíptica horizontal

$9=$ Ñaetá

$6=$ Semi-elíptica horizontal

$10=\tilde{\text { Namopyu }}$

$7=$ Oval vertical

11 = Cambuchi

$8=$ Semi-oval vertical

12 = Cambuchi cabuâga

$9=$ Oval invertido

$13=\tilde{N a e}$

$10=$ Semi-oval invertido

$99=$ Não identificado 
III - Análise do Acabamento de superfície diagnóstico nas faces interna e externa dos fragmentos

4. - Acabamento de superfície

$4.1=$ Face externa

$4.2=$ Face interna

4.3 = Lábio

$1=$ Alisamento

$2=$ Polimento

$3=$ Enegrecimento

$4=$ Corrugado

$5=$ Corrugado-digitado

6 = Corrugado-ungulado

$7=$ Corrugado-imbricado

$8=$ Corrugado-espatulado

$9=$ Acanalado

$10=$ Ungulado

$11=$ Beliscado

$12=$ Serrungulado

$13=$ Ponteado

$14=$ Estampado

$15=$ Estocado

$16=$ Inciso

$17=$ Escovado

$18=$ Estriado

$19=$ Roletado

$20=$ Nódulado

21 = Impressão de corda e ponteado

$22=$ Exciso

$23=$ Aplicado

$24=$ Impressão de corda

$25=$ Inciso e aplicado
$26=$ Inciso e ponteado

$27=$ Perfurado

$28=$ Ungulado e inciso

$30=$ Engobo branco

$31=$ Engobo vermelho

32 = Engobo marrom

$33=$ Pintura vermelha

34 = Pintura de faixa vermelha

$35=$ Pintura de faixa vermelha sobre

engobo branco

36 = Pintura de faixa vermelha paralela

e linhas vermelhas paralelas e

perpendiculares sobre engobo branco

$37=$ Pintura de faixa vermelha paralela, linha preta paralela e linhas vermelhas paralelas e perpendiculares sobre engobo branco

$38=$ Pintura vermelha e aplicado

$39=$ Pintura vermelha sobre engobo

branco

$40=$ Pintura de faixa vermelha e linha preta sobre engobo branco

$41=$ Pintura de linhas vermelhas paralelas

42 = Corrugado Ungulado e engobo

branco

$43=$ Pintura de linhas vermelhas e pretas paralelas sobre engobo branco $44=$ Pintura vermelha e aplicado

$45=$ Entalhado

$46=$ Corrugado-roletado

$47=$ Engobo vermelho e perfurado

$48=$ Pintura policrômica e impressão de corda 
$49=$ Pintura de alinhamentos de

circulas vermelhos paralelos e

perpendiculares sobre engobo branco

$50=$ Ondulado

$99=$ Não identificado

\section{IV - Tradição tecnológica}

\section{1 - Tradição tecnológica}

$1=$ Tradição Pantanal

$2=$ Guarani

3 = Etnográfico

99 = Não identificado 


\section{ANEXO 2}

Ilustrações das escavações dos poços-teste na Aldeia Lalima 


\section{PROJETO KAIABI-LALIMA}

\section{Área Piloto Aldeia Lalima}

Sítio: Sítio da Sede Sigla: MS - MI - 01 Setor: 01 Poço Teste: 01 Coordenadas: 1005N/1000E

Responsáveis: Alexandre Heringer, Claudinei da Silva (Rim), Manoel

de Souza(Maneco), Mário Antônio (Tonho), Leonel da Silva (Leonel) e Fof's ～Nível: $0 \quad$ Data: 19/06/07
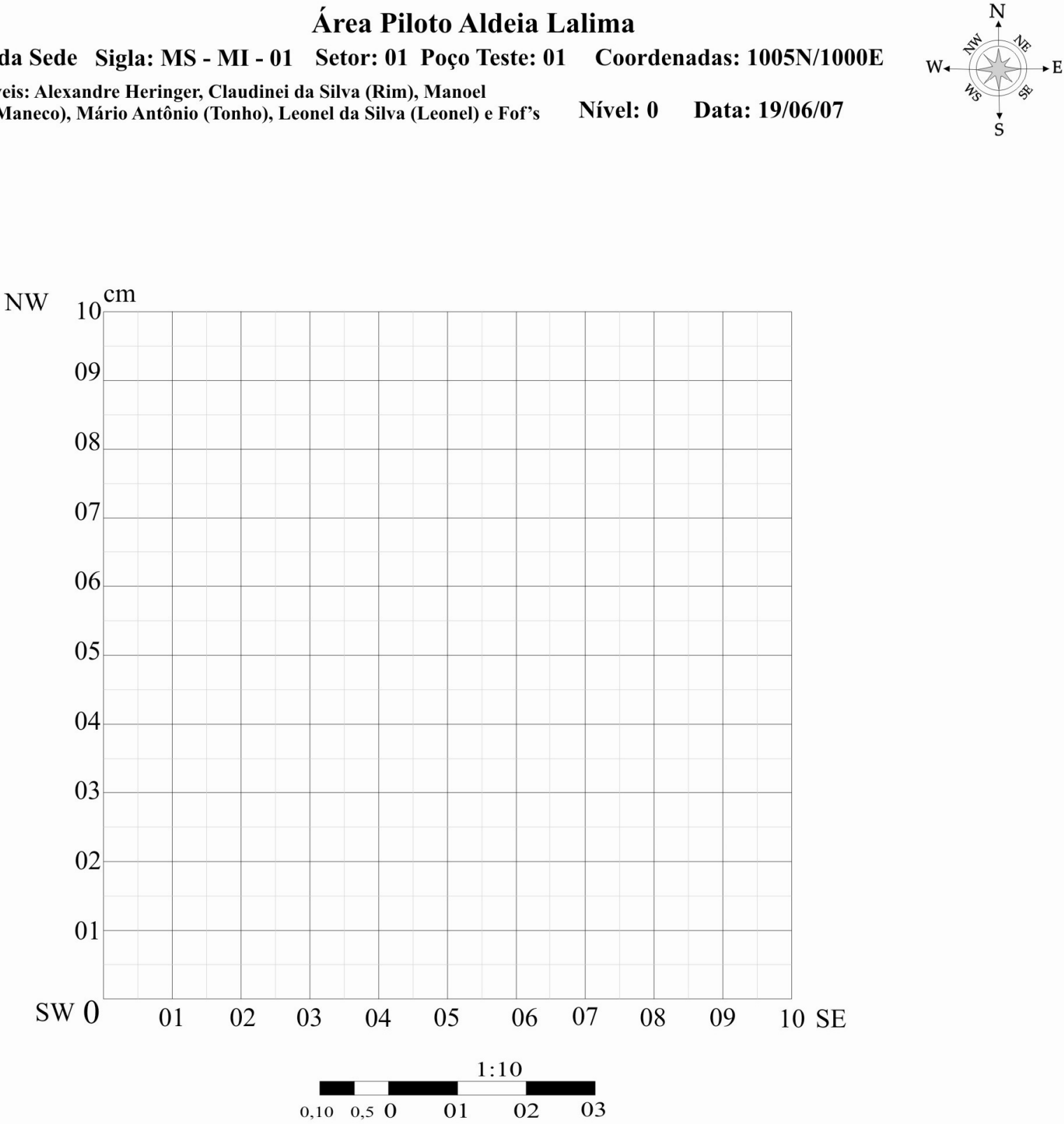

\section{LEGENDA}

\section{Objetos}

Lítico

Cerâmica

Telha

Louça

Vidro

Alumínio, ferro

Tecido

Plástico

Ladrilho

Cimento

Osso fauna

Concha

Carvão

Madeira
Seixo, rocha

0 Tijolo

Raíz

Radícula

Fogueira

Cinza

Solo queimado

Bolota de Argila

Buraco

- Cupinzeiro

Caminho de Cupim

Datum

*Material para datação
Solos

Marrom com preto de carvão

Marrom Escuro

Marrom

Marrom Claro

Marrom com vermelho

Marrom com vermelho claro

Vermelho- Tijolo

Vermelho

Vermelho Claro

Vermelho Alaranjado

VermelhoAmarelado

Solo Cinza Escuro 


\section{PROJETO KAIABI-LALIMA}

\section{Área Piloto Aldeia Lalima}

Sítio: Córrego Lalima Sigla: MS - MI - 01 Setor: 01 Poço Teste: 01 Coordenadas: 1005N/1000E Responsáveis: Alexandre Hering, Mário Antônio, Leonel da Silva e Ofnéias de Souza Alves
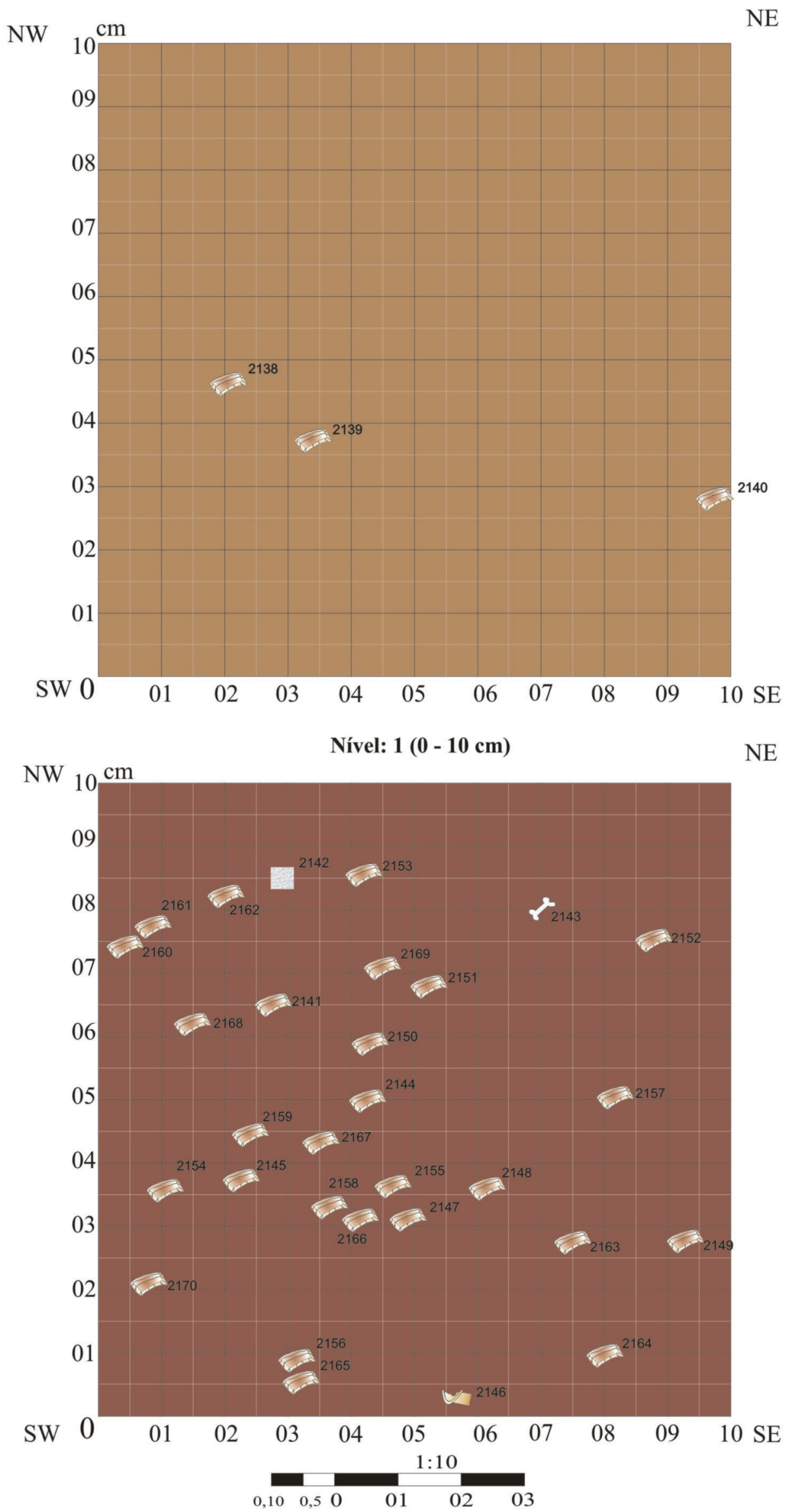


\section{PROJETO KAIABI-LALIMA}

\section{Área Piloto Aldeia Lalima}

Sítio: Córrego Lalima Sigla: MS - MI - 01 Setor: 01 Poço Teste: 01 Coordenadas: 1005N/1000E Responsáveis: Alexandre Hering, Mário Antônio, Leonel da Silva e Ofnéias de Souza Alves

Nível: 4 (30-40cm) Data: 19/06/07
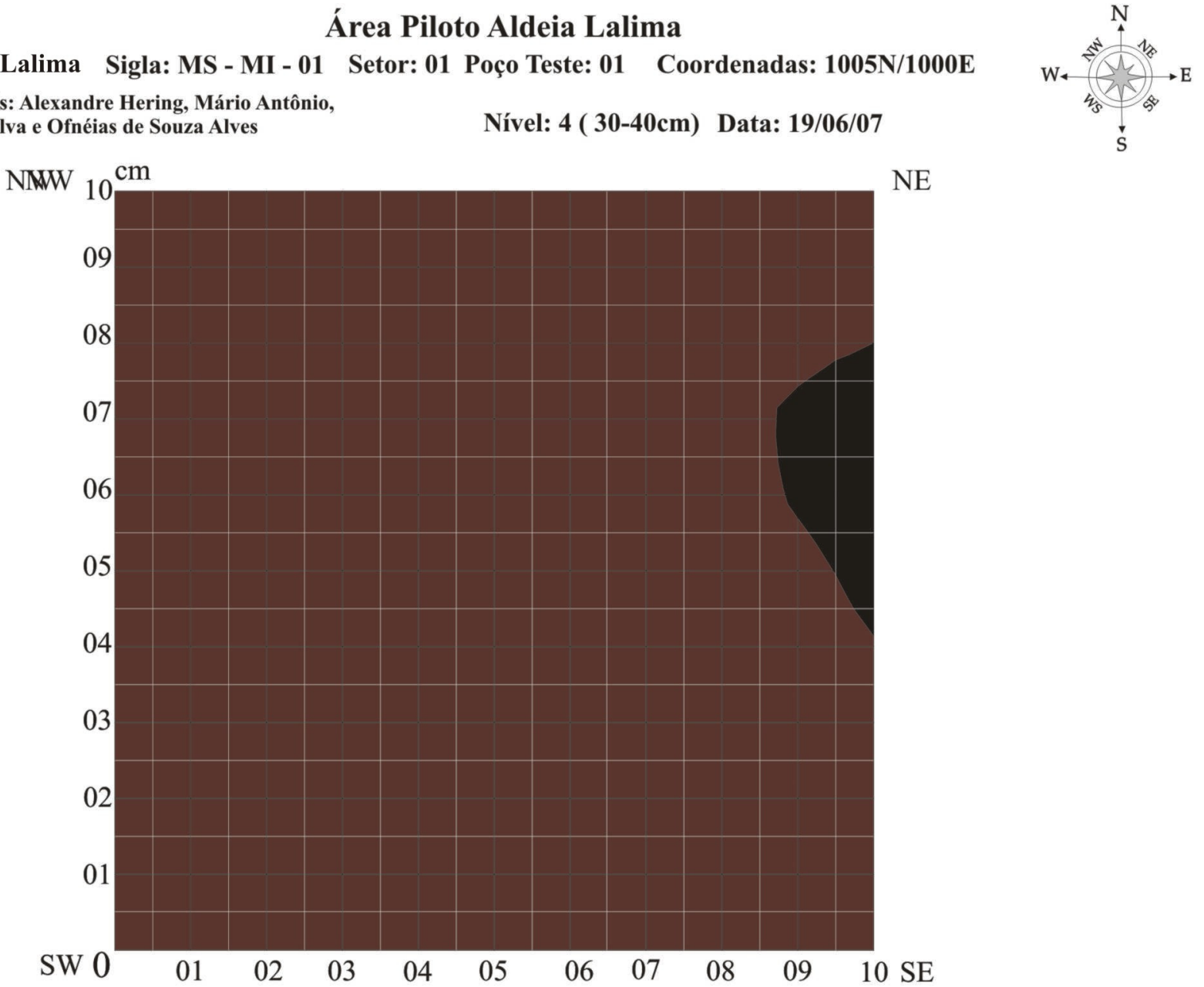

Nível: 5 (40 - 50cm) Data: 22/06/07

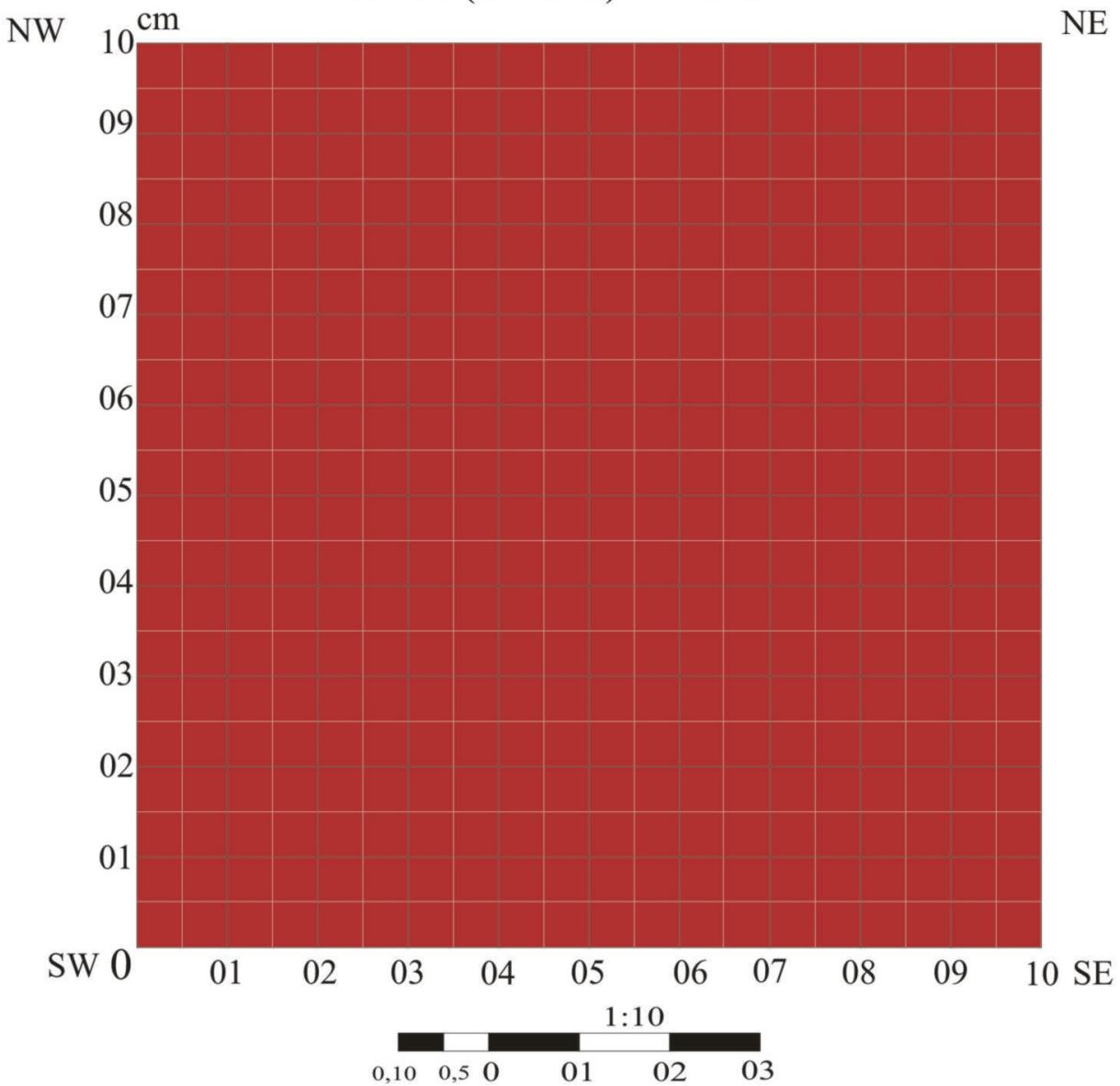




\section{PROJETO KAIABI-LALIMA}

\section{Área Piloto Aldeia Lalima}

Sítio: Córrego Lalima Sigla: MS - MI - 01 Setor: 01 Poço Teste: 01 Coordenadas: 1005N/1000E Responsáveis: Alexandre Hering, Mário Antônio, Leonel da Silva e Ofnéias de Souza Alves

Nível: 6 (50 - 60cm) Data: 22/06/07
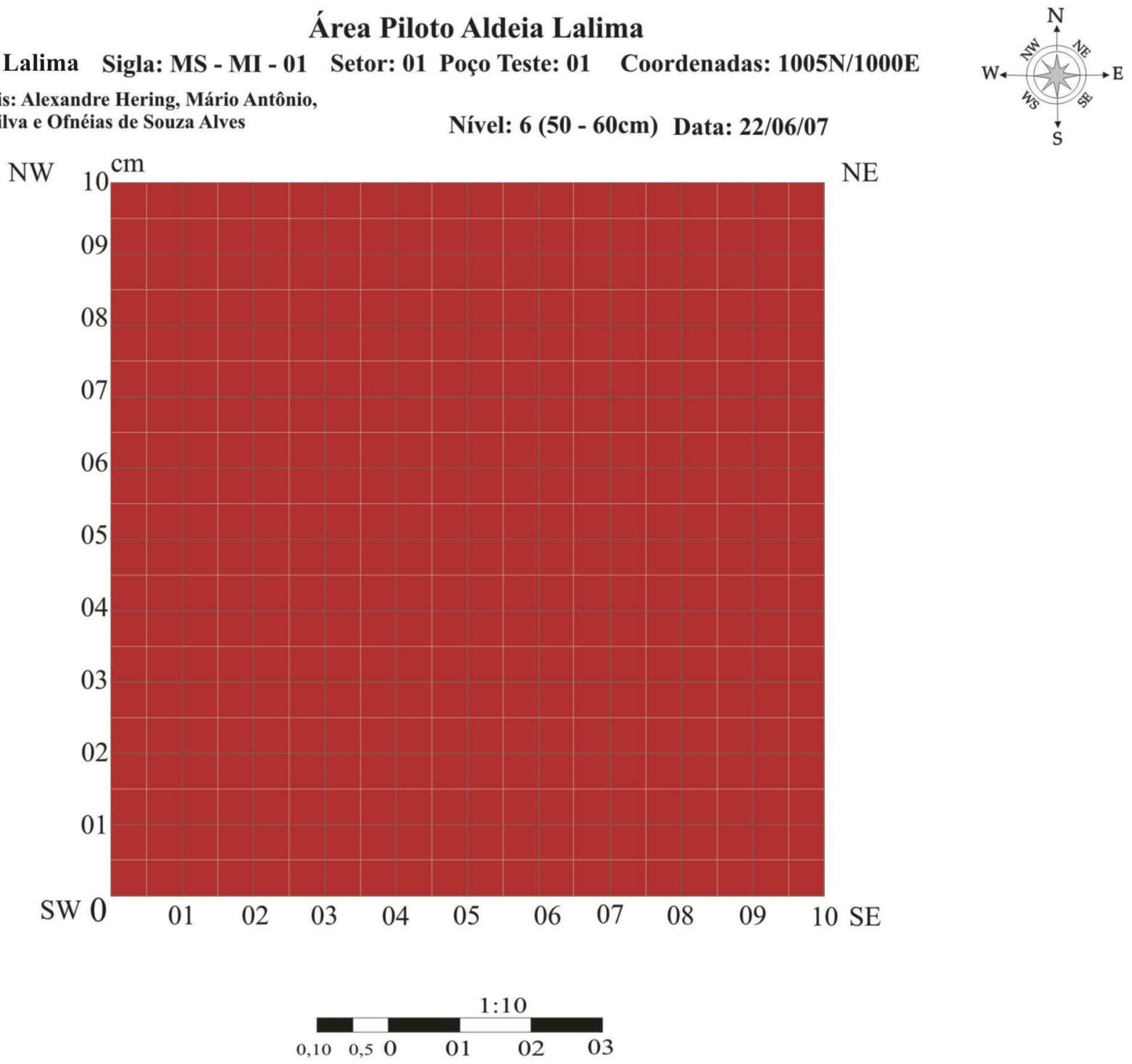


\section{PROJETO KAIABI-LALIMA \\ Área Piloto Aldeia Lalima}

Sítio: Córrego Lalima Sigla: MS - MI - 01 Setor: 01 Poço Teste: 01 Coordenadas: 1005N/1000E

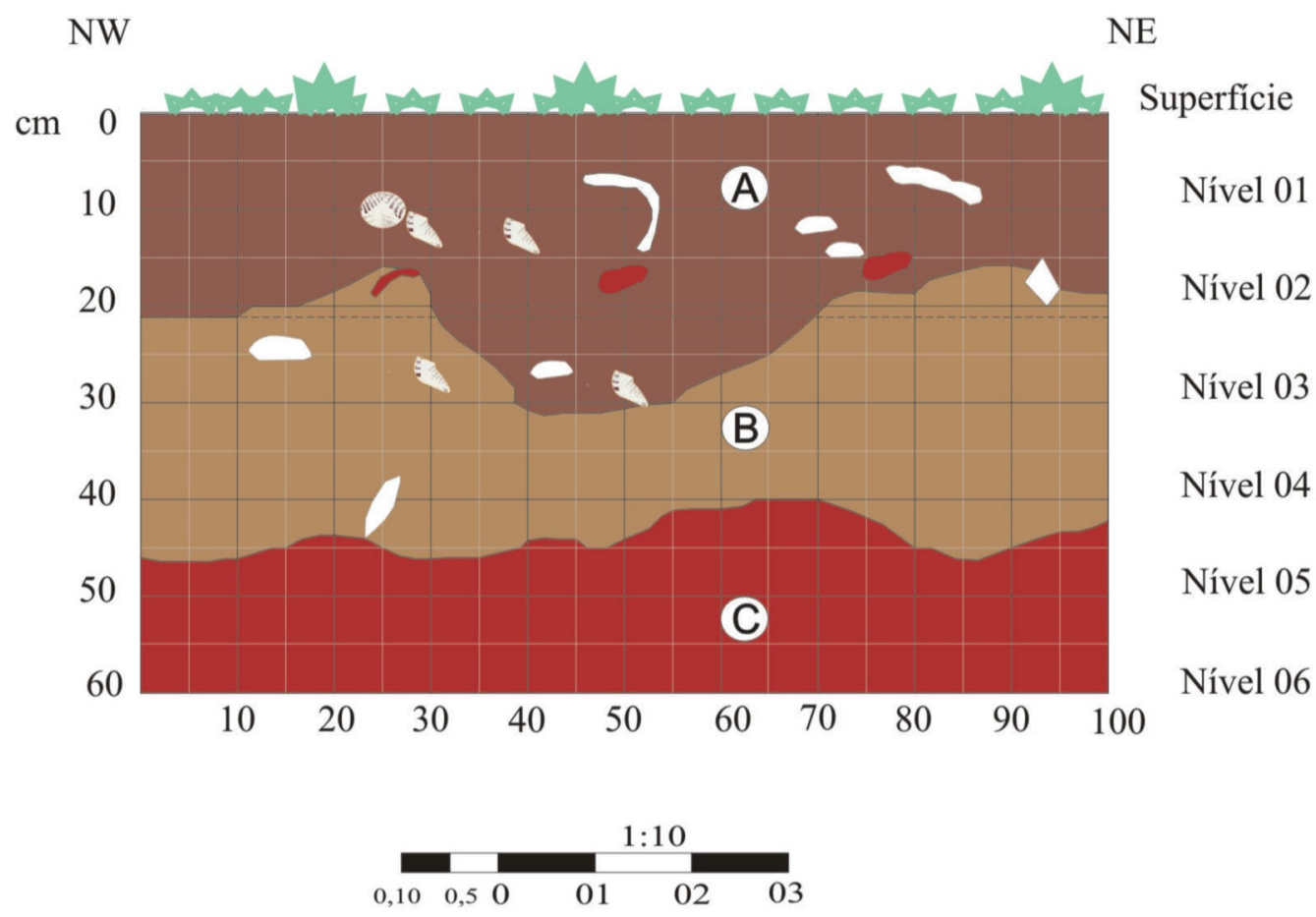

Superfície: Sedimento arenoso, marrom-claro, baixo grau de compactação, sem vegetação rasteira, com materiais arqueológicos.

A Sedimento arenoso, marrom-escuro (dark brown 10YR3/3), com alto grau de compactação, raízes, buracos de cupinzeiro e materiais arqueológicos.

B Sedimento areno-argiloso, marrom-escuro (dark brown 7.5YR 3/4), com altíssimo grau de compactação, com raízes pequenas e médias, buracos de cupinzeiros e manchas vermelhas concrecionadas, talvez relacionadas ao cupinzeiro.

C Sedimento areno-argiloso, vermelho (yellowish red 5YR4/6), com alto grau de compactação e pouca umidade, com presença de raízes de mangueira.

Raíz

Caminho de Cupim

Terra vermelha concrecionada do cupinzeiro. 


\section{PROJETO KAIABI-LALIMA}

\section{Área Piloto Aldeia Lalima}

Sítio: Córrego Lalima Sigla: MS - MI - 01 Setor: 01 Poço Teste: 02 Coordenadas: 1221N/1001E

Responsáveis: Alexandre Hering, Mário Antônio,

Leonel da Silva e Ofnéias de Souza Alves

Nível: 0 (superfície)

Data: 19/06/07
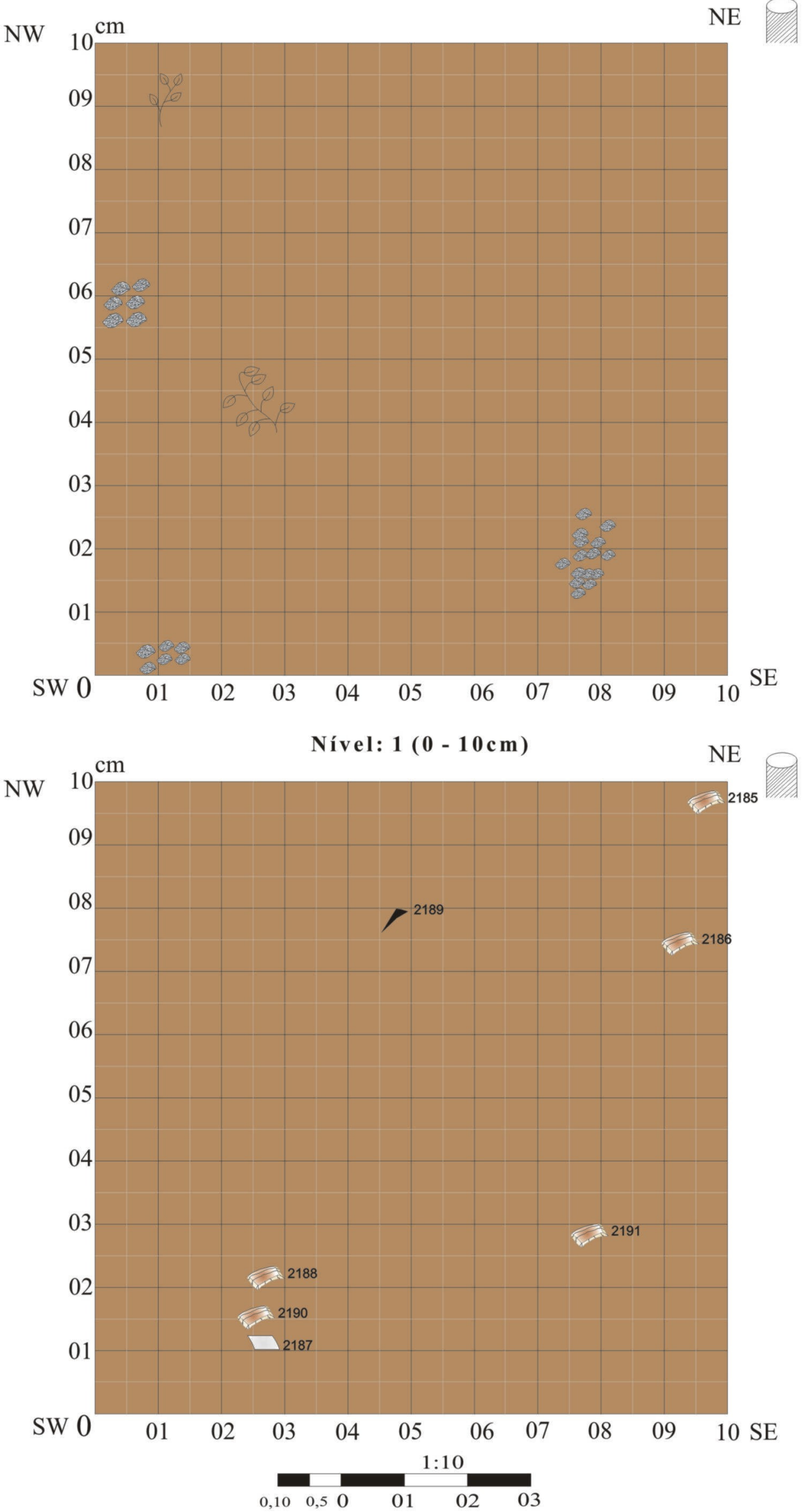


\section{PROJETO KAIABI-LALIMA}

\section{Área Piloto Aldeia Lalima}

Sítio: Córrego Lalima Sigla: MS - MI - 01 Setor: 01 Poço Teste: 02 Coordenadas: 1221N/1001E Responsáveis: Alexandre Hering, Mário Antônio, Leonel da Silva e Ofnéias de Souza Alves

Nível: 2 (10 - 20cm)

Data: 21/06/07
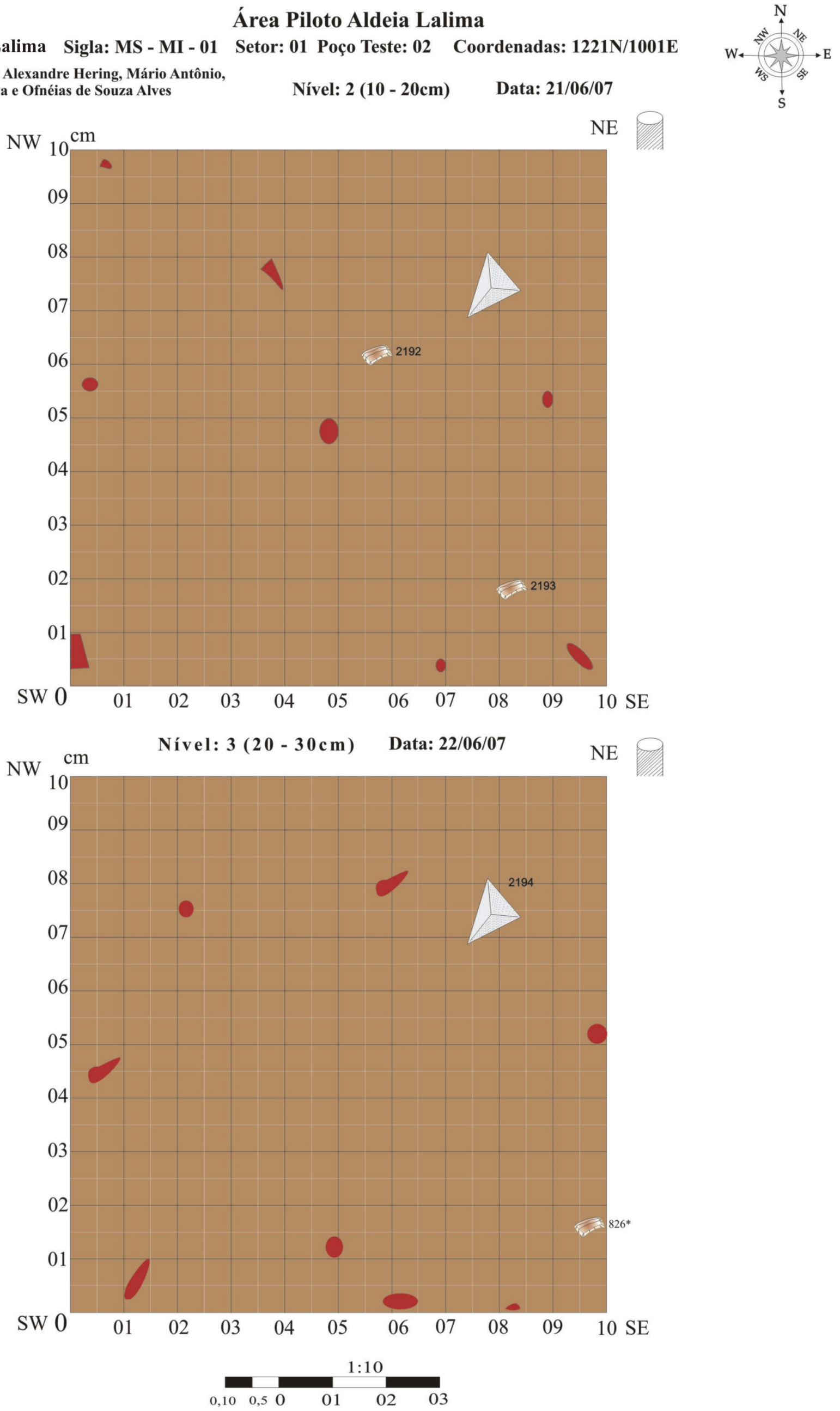


\section{PROJETO KAIABI-LALIMA \\ Área Piloto Aldeia Lalima}

Sítio: Córrego Lalima Sigla: MS - MI - 01 Setor: 01 Poço Teste: 02 Coordenadas: 1221N/1001E Responsáveis: Alexandre Hering, Mário Antônio, Leonel da Silva e Ofnéias de Souza Alves

Nível: $4(30-40 \mathrm{~cm})$

Data: 22/06/07
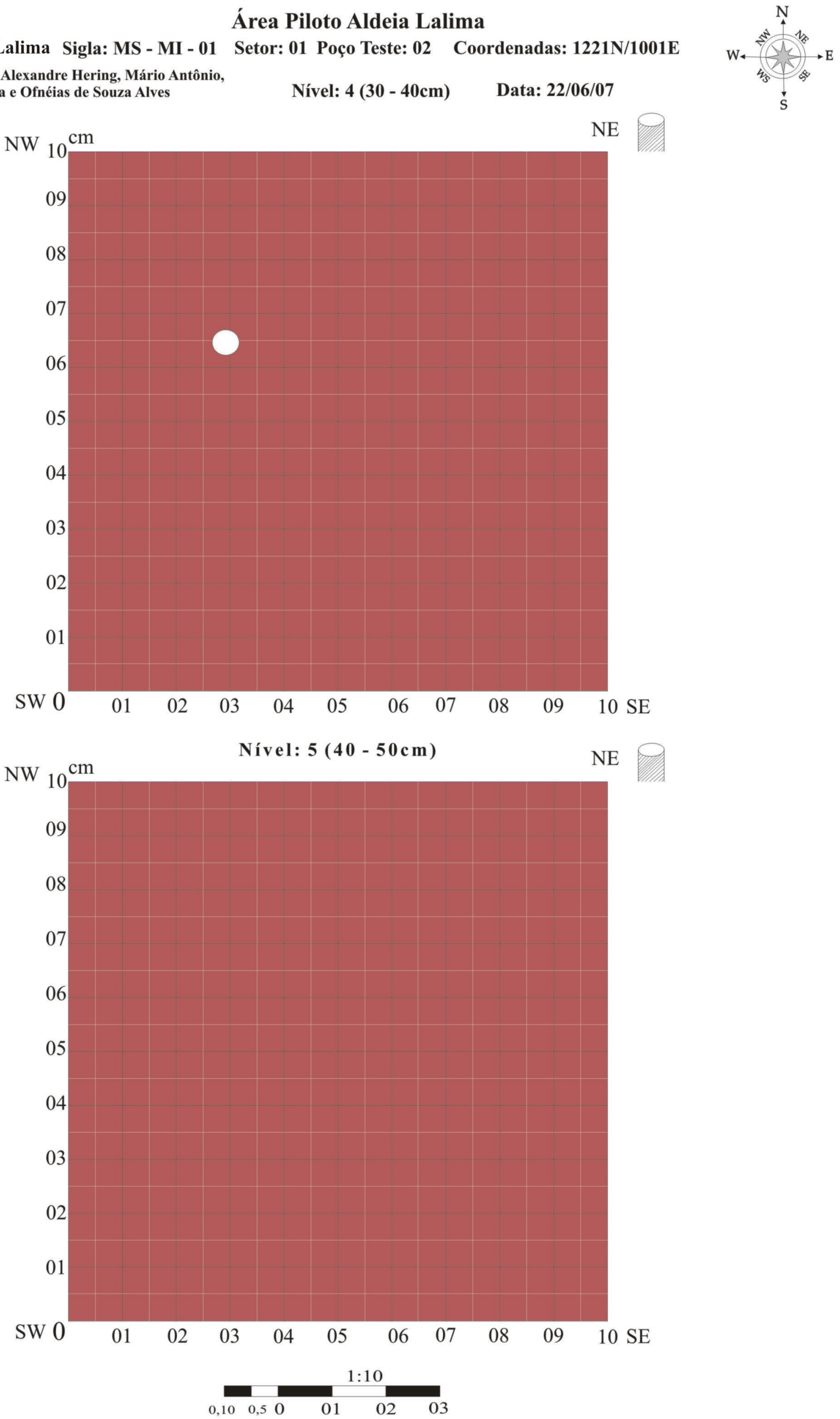


\section{PROJETO KAIABI-LALIMA \\ Área Piloto Aldeia Lalima}

Sítio: Córrego Lalima Sigla: MS - MI - 01 Setor: 01 Poço Teste: 02 Coordenadas: 1221N/1001E

Responsáveis: Alexandre Hering, Mário Antônio, Leonel da Silva e Ofnéias de Souza Alves

Perfil Norte Data: 25/06/07

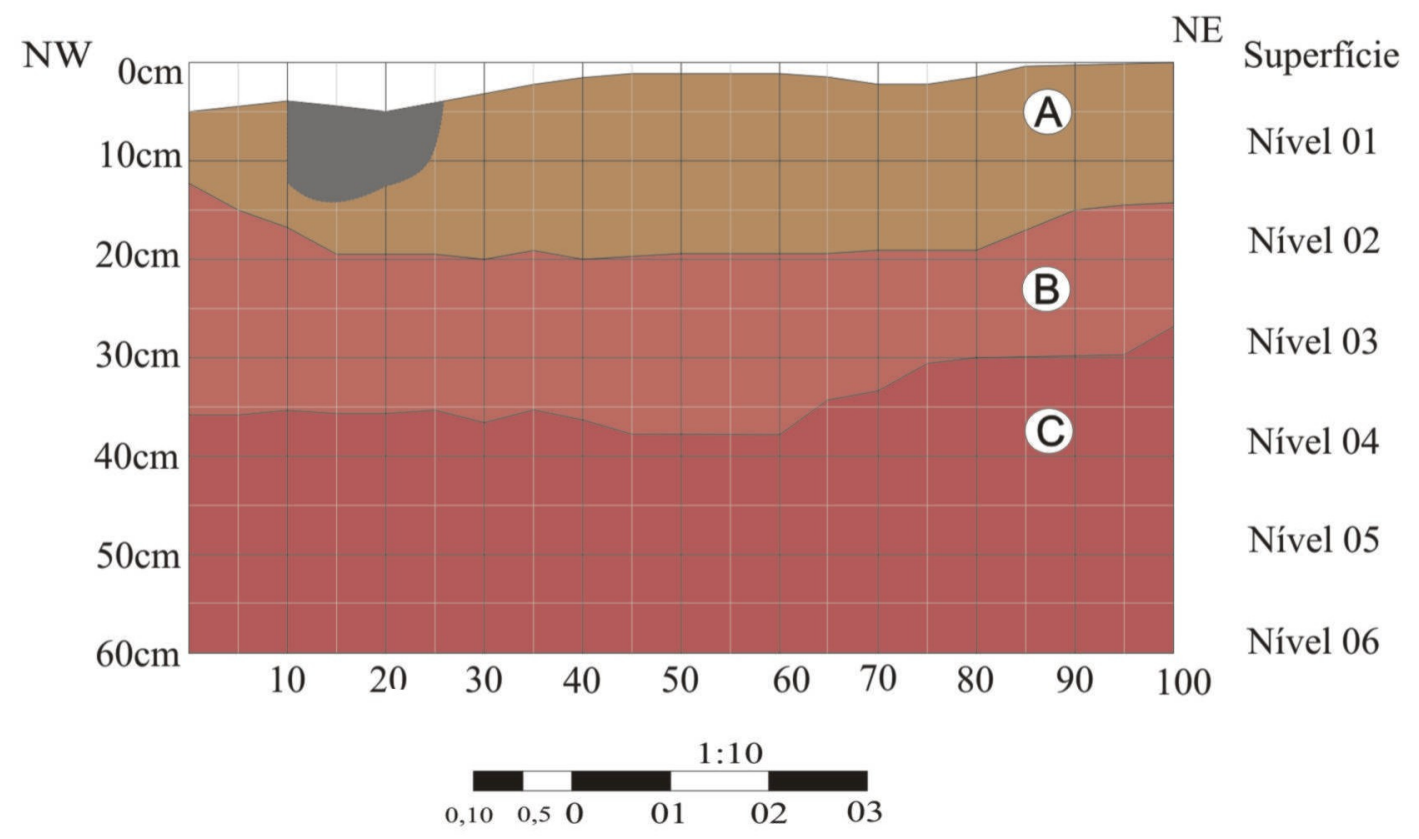

Superfície: Sedimento arenoso marrom-claro (dark yellowish brown 10YR4/4), baixo grau de compactação, seco, sem vegetação rasteira, com material arqueológico.

A Sedimento arenoso, marrom-claro (brown 7.5YR4/3), alto grau de compactação, seco, com material arqueológico.

B Sedimento areno-argiloso marrom (brown 7.5YR 4/3), compacto, seco, com material arqueológico.

C Sedimento areno-argiloso marrom-avermelhado (reddish brown 2.5YR4/4), compacto, seco, sem material arqueológico.

Desmoronamento. 


\section{PROJETO KAIABI-LALIMA}

\section{Área Piloto Aldeia Lalima}

Sítio: Córrego Lalima Sigla: MS - MI - 01 Setor: 02 Poço Teste: 03 Coordenadas: 1001N/983E Responsáveis: Alexandre Hering, Mário Antônio,

Leonel da Silva e Ofnéias de Souza Alves, Claudinei da Silva e Altair. Nível: 0 (0 - 10cm)

Data: 11/06/07
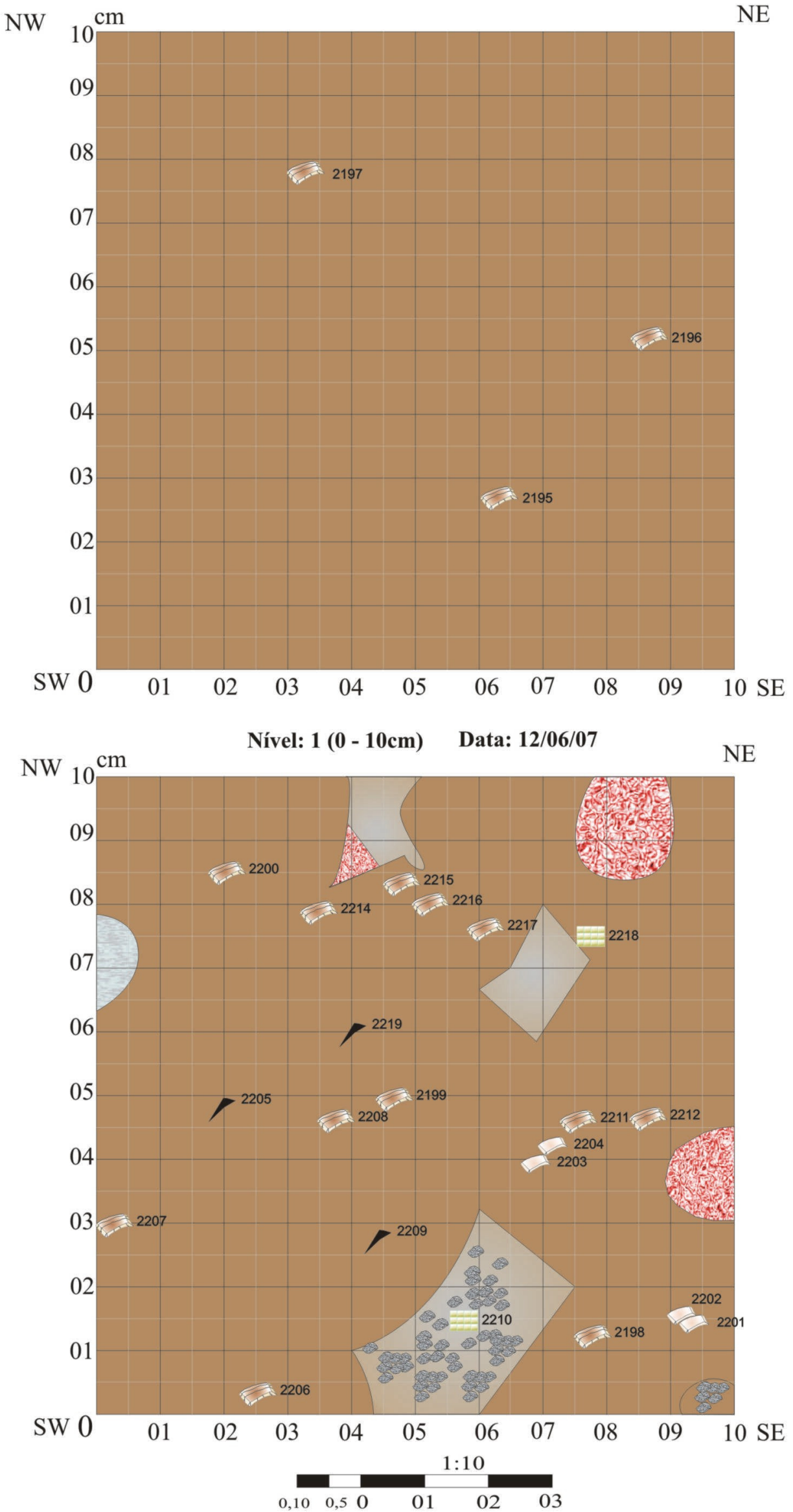


\section{PROJETO KAIABI-LALIMA \\ Área Piloto Aldeia Lalima}

Sítio: Córrego Lalima Sigla: MS - MI - 01 Setor: 02 Poço Teste: 03 Coordenadas: 1001N/983E

Responsáveis: Alexandre Hering, Mário Antônio,

Leonel da Silva e Ofnéias de Souza Alves, Claudinei da Silva e Altair. Nível: $2(10-20 \mathrm{~cm}) \quad$ Data: 12/06/07
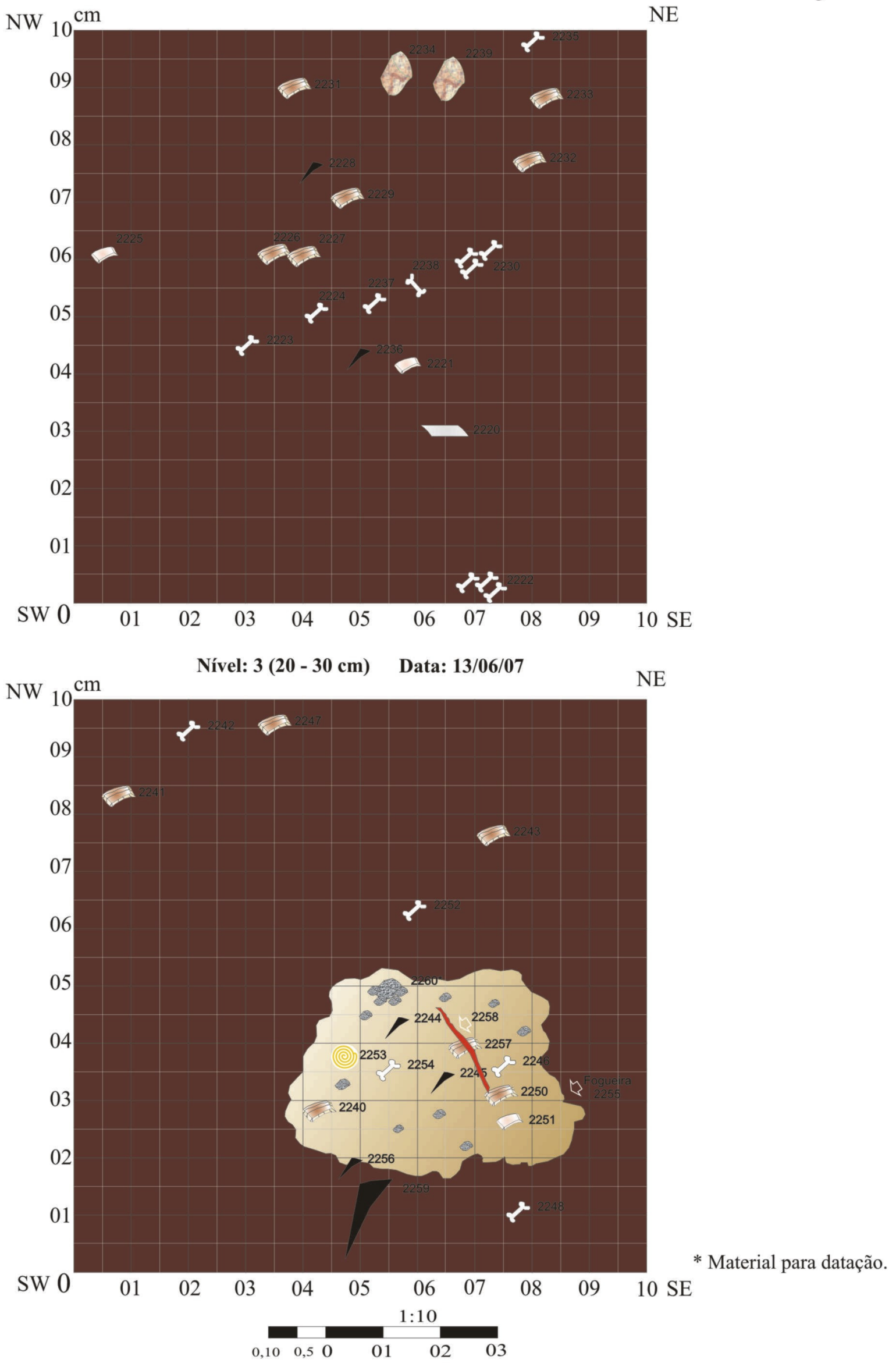


\section{PROJETO KAIABI-LALIMA}

\section{Área Piloto Aldeia Lalima}

Sítio: Córrego Lalima Sigla: MS - MI - 01 Setor: 02 Poço Teste: 03 Coordenadas: 1001N/983E Responsáveis: Alexandre Hering, Mário Antônio,

Leonel da Silva e Ofnéias de Souza Alves, Claudinei da Silva e Altair. $\quad$ Nível: 4 (30 - 40cm) Data: 13/06/07
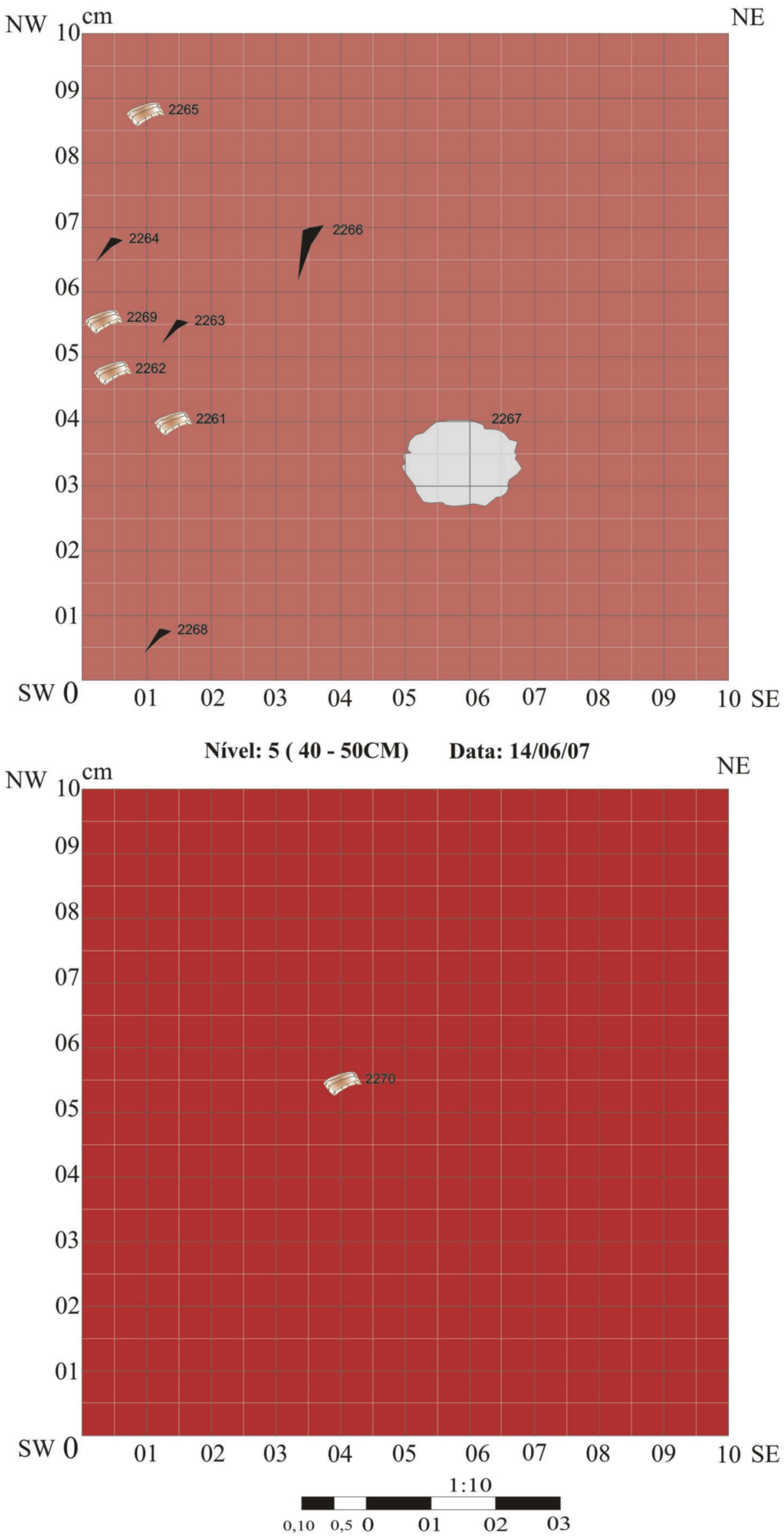


\section{PROJETO KAIABI-LALIMA}

\section{Área Piloto Aldeia Lalima}

Sítio: Córrego Lalima Sigla: MS - MI - 01 Setor: 02 Poço Teste: 03 Coordenadas: 1001N/983E Responsáveis: Alexandre Hering, Mário Antônio,

Leonel da Silva e Ofnéias de Souza Alves, Claudinei da Silva e Altair. $\quad$ Nível: 6 (50 - 60cm) Data: 14/06/07
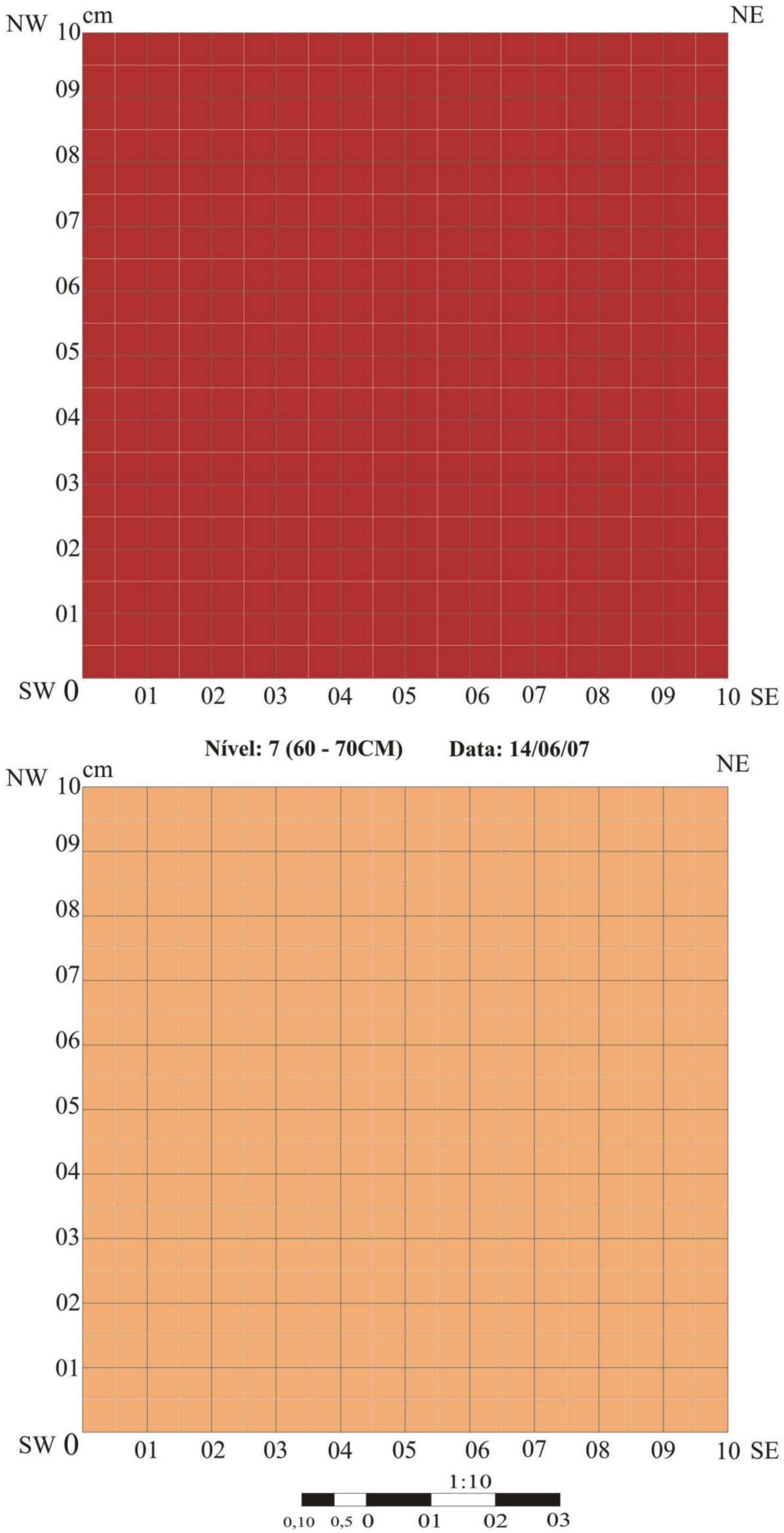


\section{PROJETO KAIABI-LALIMA}

\section{Área Piloto Aldeia Lalima}

Sítio: Córrego Lalima Sigla: MS - MI - 01 Setor: 02 Poço Teste: 03 Coordenadas: 1001N/983E Responsáveis: Alexandre Hering, Mário Antônio,
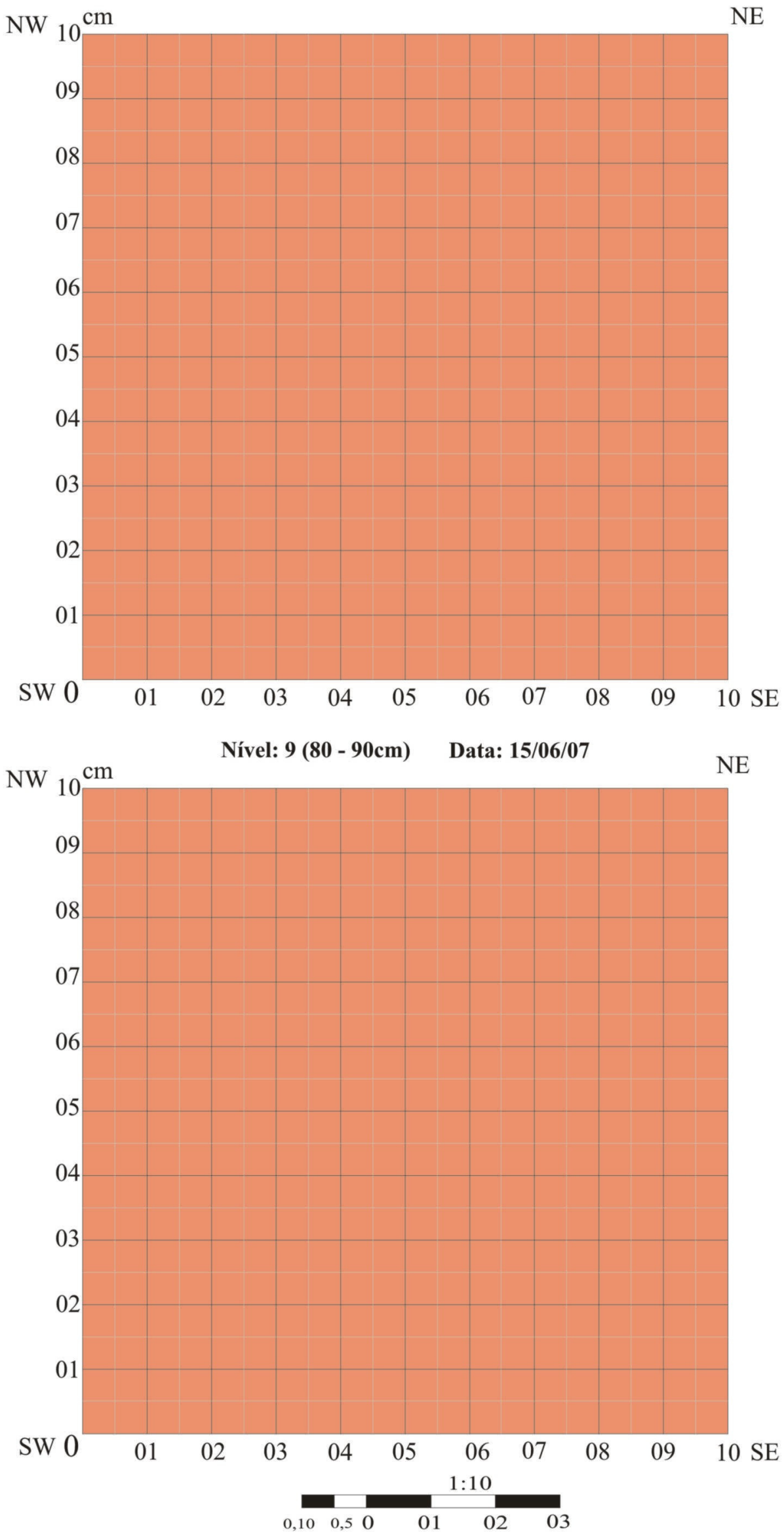


\section{PROJETO KAIABI-LALIMA}

\section{Área Piloto Aldeia Lalima}

Sítio: Córrego Lalima Sigla: MS - MI - 01 Setor: 02 Poço Teste: 03 Coordenadas: 1001N/983E Responsáveis: Alexandre Hering, Mário Antônio, Leonel da Silva e Ofnéias de Souza Alves, Claudinei da Silva e Altair.

Nível: 10 (90 - 100cm) Data: 15/06/07

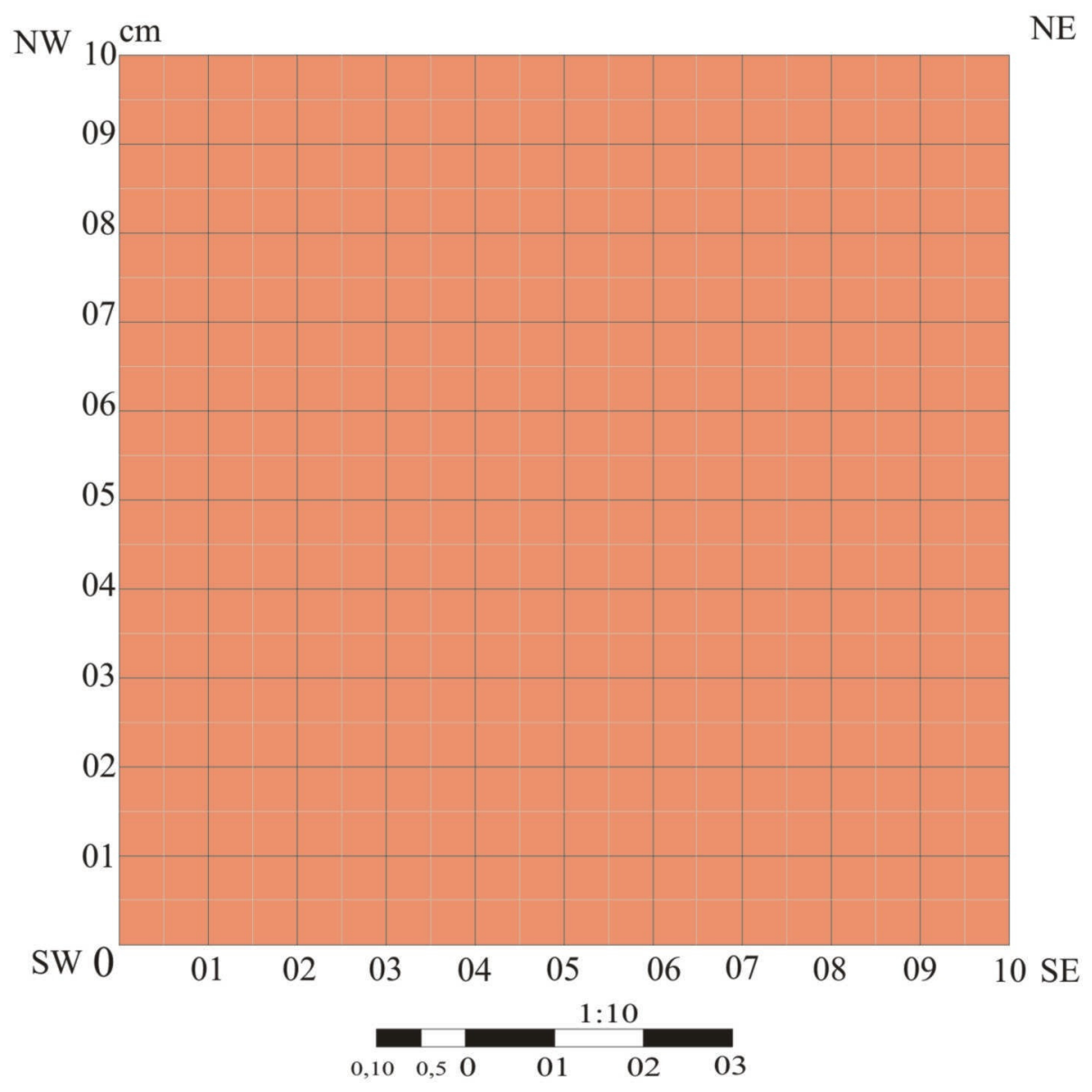




\section{PROJETO KAIABI-LALIMA \\ Área Piloto Aldeia Lalima}

Sítio: Córrego Lalima Sigla: MS - MI - 01 Setor: 02 Poço Teste: 03

Responsáveis: Alexandre Hering, Mário Antônio,

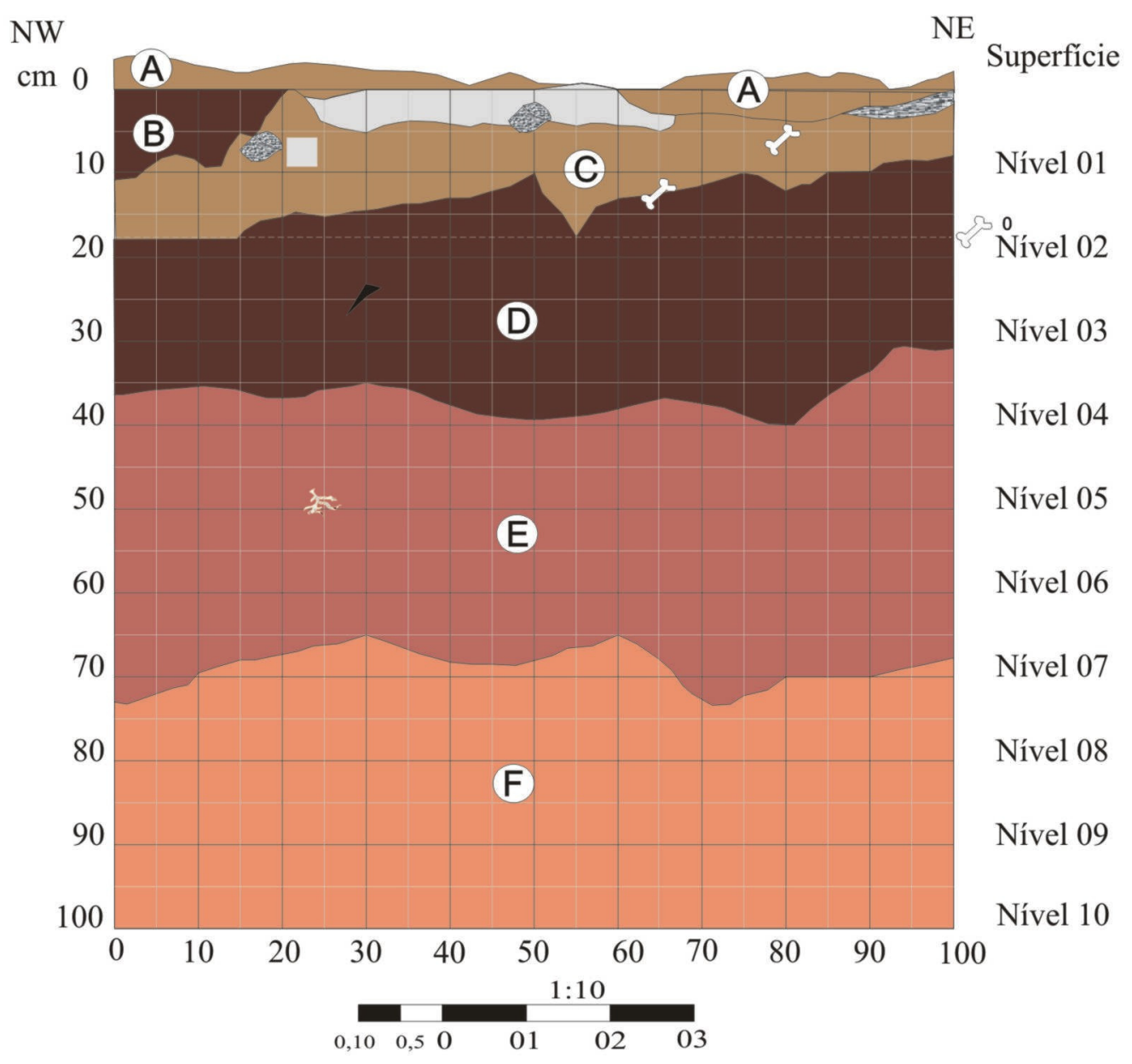

Superfície: Sedimento areno-argiloso, marrom-claro, desprovido de vegetação, com presença de material arqueológico e restos de materiais industrializados, descartados pelo contexto etnográfico atual.

A Areia fina, marrom-claro (dark brown 10YR3/3).

B Areia fina, marrom (dark grayish brown 10YR3/2), com carvões.

C Sedimento areno-argiloso, marrom-claro (dark brown 7.5YR3/2), graus baixo e médio de compactação, com raízes, materiais arqueológicos e muitos vestígios de materiais industrializados, associados ao contexto etnográfico atual.

D Sedimento areno-argiloso, marrom-escuro (very dark brown 10YR2/2), grau médio de compactação, nível médio de umidade, com presença de material arqueológico e material industrializado recente.

E Sedimento compacto em transição de areno-argiloso marrom-escuro para argilo-arenoso vermelho (dark reddish brown 5YR3/4), sem vestígios de materiais industrializados, porém com menor quantidade de material arqueológico.

(F) Sedimento argiloso, vermelho-alaranjado (dark red 2.5YR3/6), compacto, com porções de areia, estéril arqueologicamente.

\section{LEGENDA}

Carvão
Osso fauna $\quad>$ Lítico
Cinza




\section{PROJETO KAIABI-LALIMA}

\section{Área Piloto Aldeia Lalima}

Sítio: Córrego Lalima Sigla: MS - MI - 01 Setor: 02 Poço Teste: 04 Coordenadas: 906N/1001E Responsáveis: Alexandre Hering, Mário Antônio,

Leonel da Silva e Ofnéias de Souza Alves, Claudinei da Silva e Altair. Nível: 0 (Superfície) Data: 25/06/07

$\mathrm{NE}$
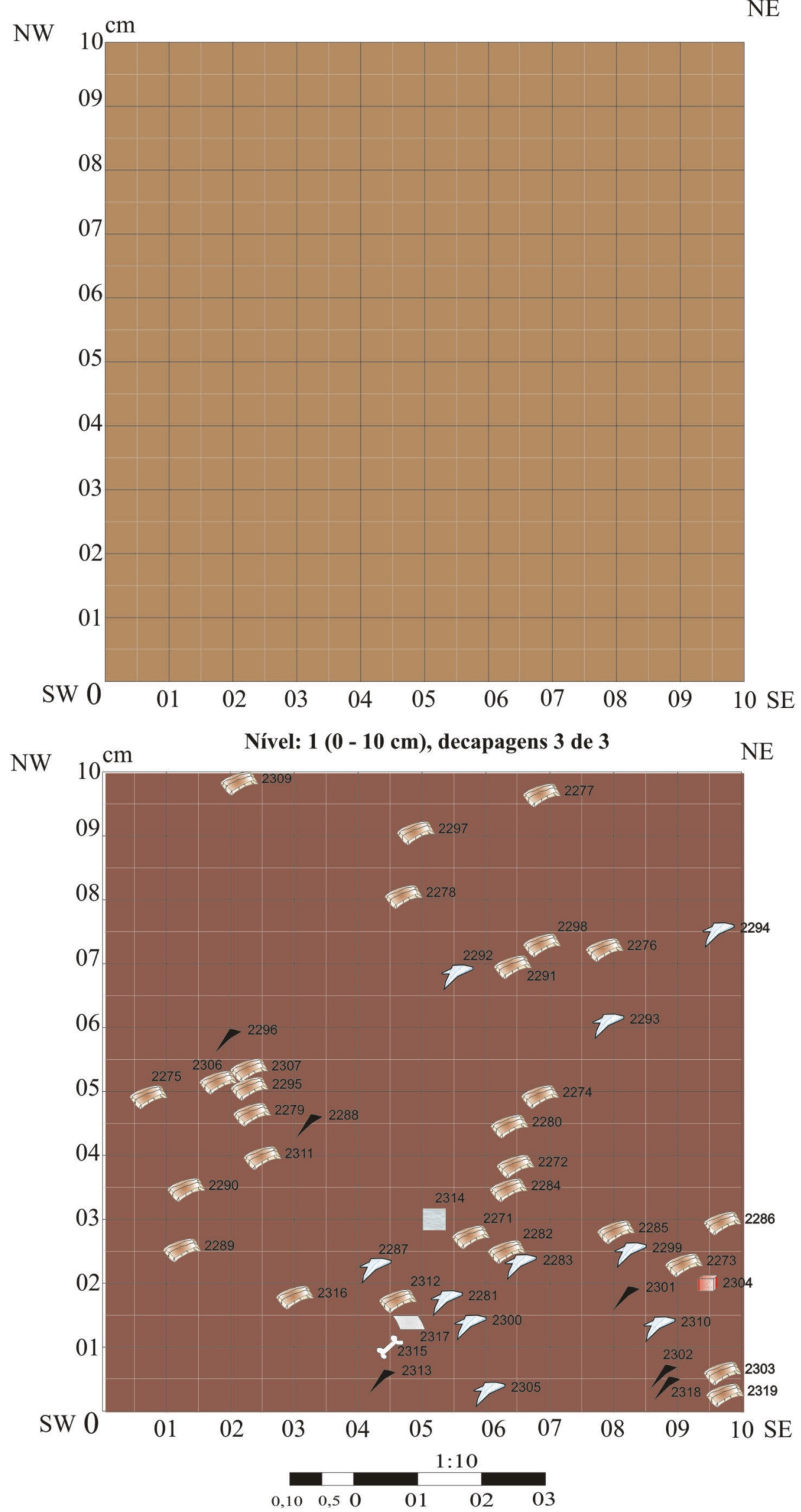


\section{PROJETO KAIABI-LALIMA}

\section{Área Piloto Aldeia Lalima}

Sítio: Córrego Lalima Sigla: MS - MI - 01 Setor: 02 Poço Teste: 04 Coordenadas: 906N/1001E Responsáveis: Alexandre Hering, Mário Antônio,

Leonel da Silva e Ofnéias de Souza Alves, Claudinei da Silva e Altair. Nível: 2 (10 - 20cm) Data: 26/06/07
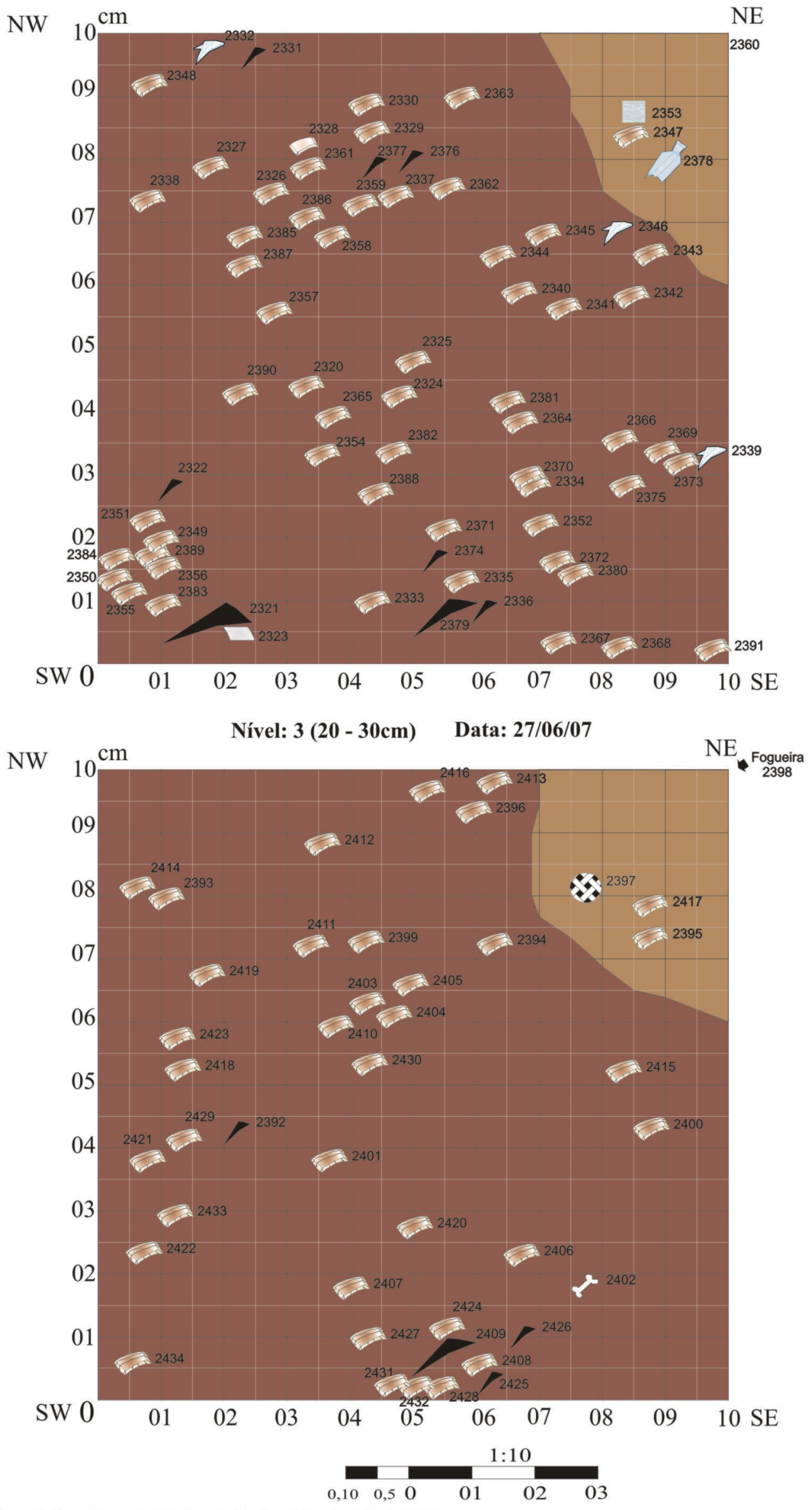


\section{PROJETO KAIABI-LALIMA}

\section{Área Piloto Aldeia Lalima}

Sítio: Córrego Lalima Sigla: MS - MI - 01 Setor: 02 Poço Teste: 04 Coordenadas: 906N/1001E

Responsáveis: Alexandre Hering, Mário Antônio,

Leonel da Silva e Ofnéias de Souza Alves, Claudinei da Silva e Altair. Nível: 4 (30 - 40cm) Data: 28/06/07
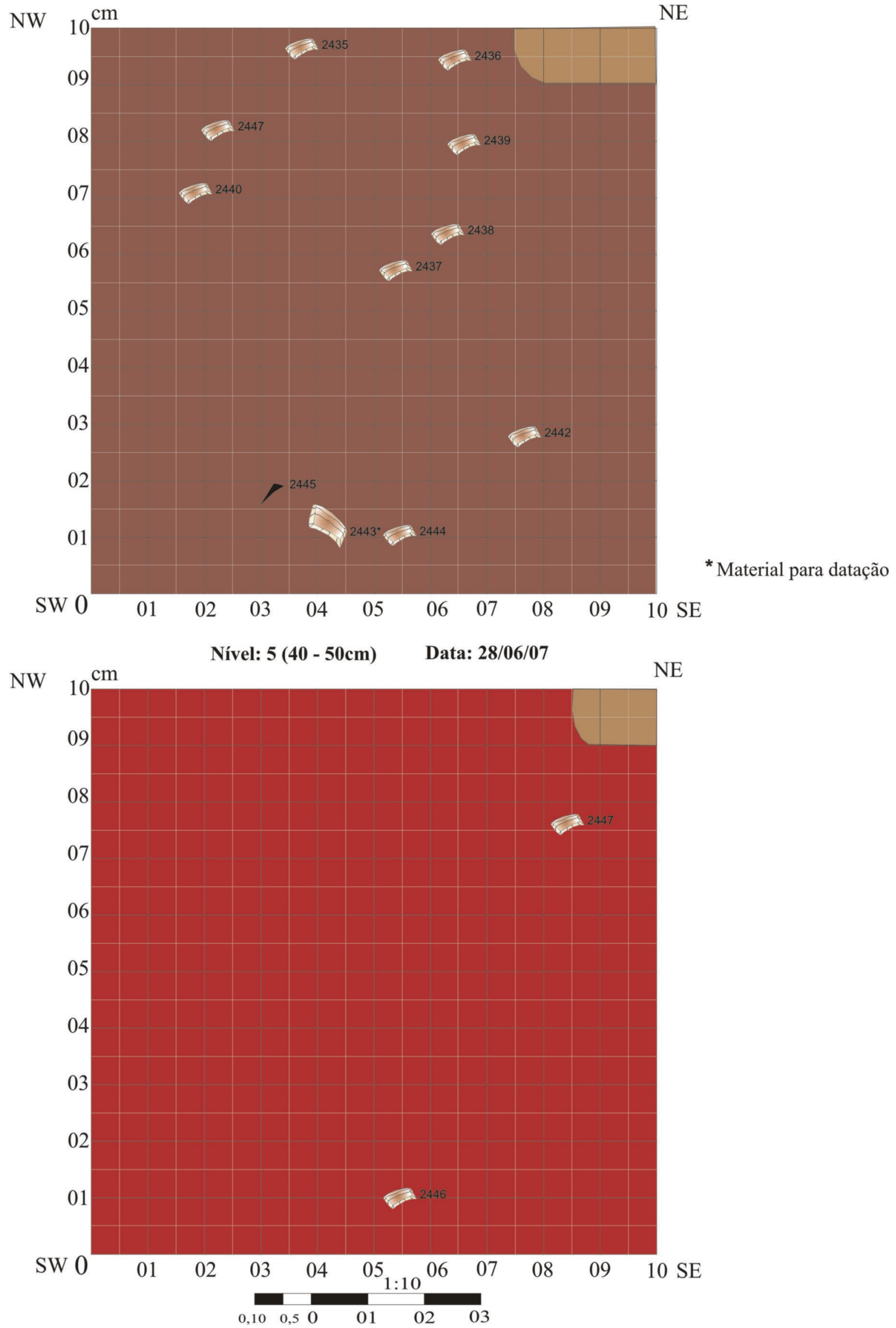


\section{PROJETO KAIABI-LALIMA}

\section{Área Piloto Aldeia Lalima}

Sítio: Córrego Lalima Sigla: MS - MI - 01 Setor: 02 Poço Teste: 04 Coordenadas: 906N/1001E Responsáveis: Alexandre Hering, Mário Antônio, Eduardo e Maneco Leonel da Silva e Ofnéias de Souza Alves, Claudinei da Silva e Altair. Nível: 6 (50 - $60 \mathrm{~cm})$ Data: 06/07/07

$\mathrm{NE}$
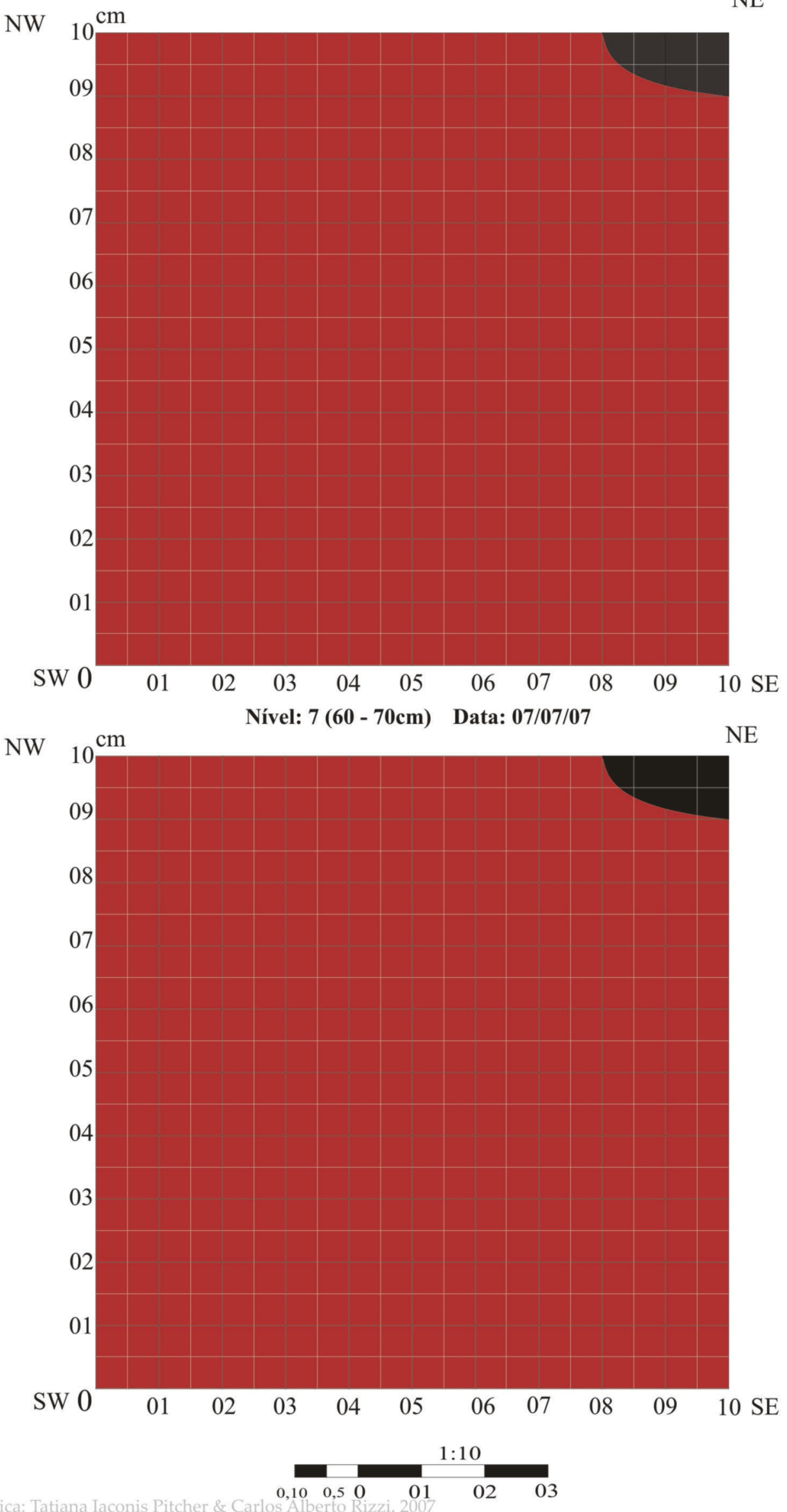


\section{PROJETO KAIABI-LALIMA \\ Área Piloto Aldeia Lalima}

Sítio: Córrego Lalima Sigla: MS - MI - 01 Setor: 02 Poço Teste: 04 Coordenadas: 906N/1001E Responsáveis: Alexandre Hering, Mário Antônio,

Leonel da Silva e Ofnéias de Souza Alves, Claudinei da Silva e Altair. Nível: 8 (70 - 80 cm) Data: 07/07/07
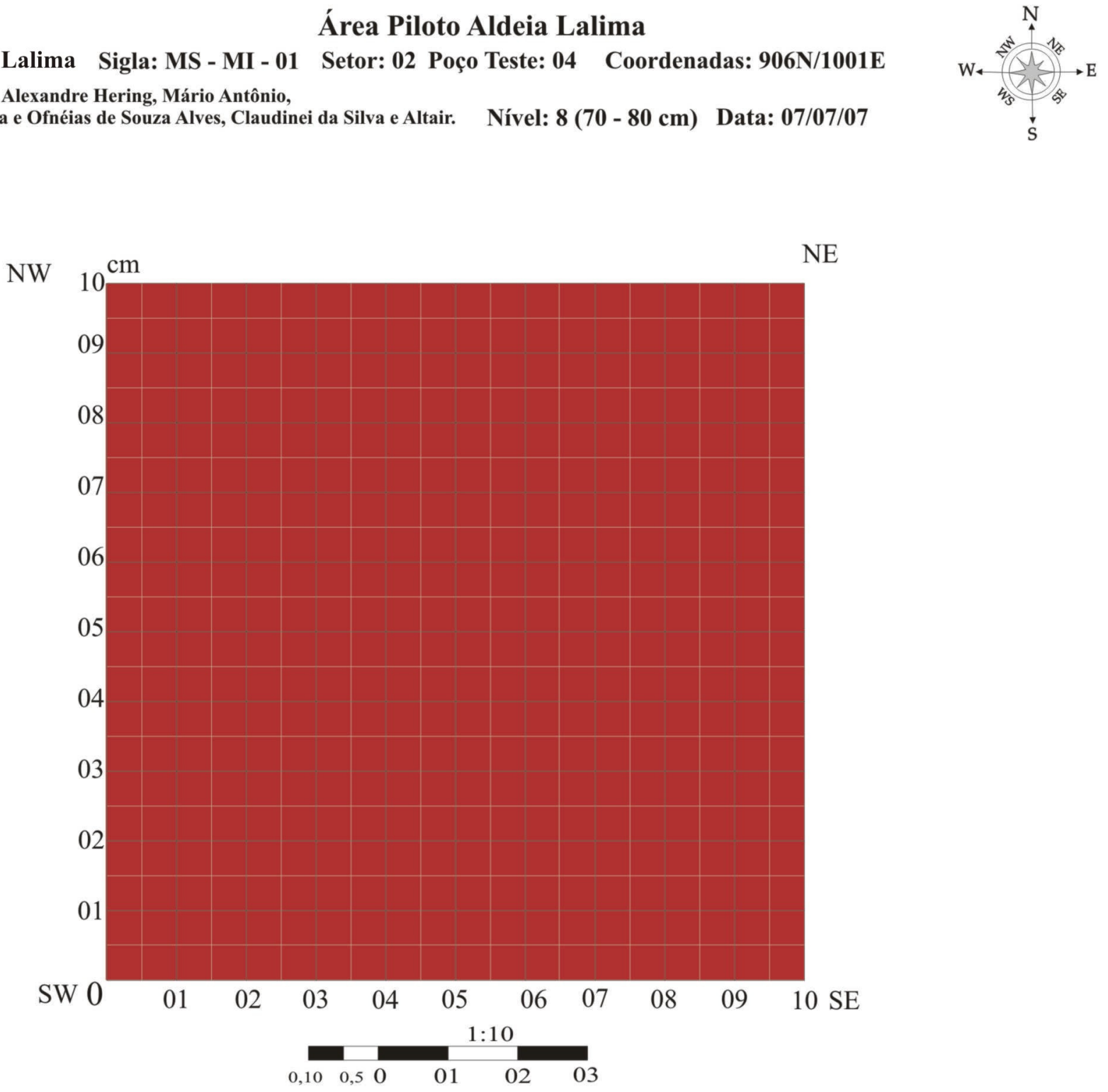


\section{PROJETO KAIABI-LALIMA \\ Área Piloto Aldeia Lalima}

Sítio: Córrego Lalima Sigla: MS - MI - 01 Setor: 02 Poço Teste: 04 Coordenadas: 906N/1001E

Responsáveis: Alexandre Hering, Mário Antônio,

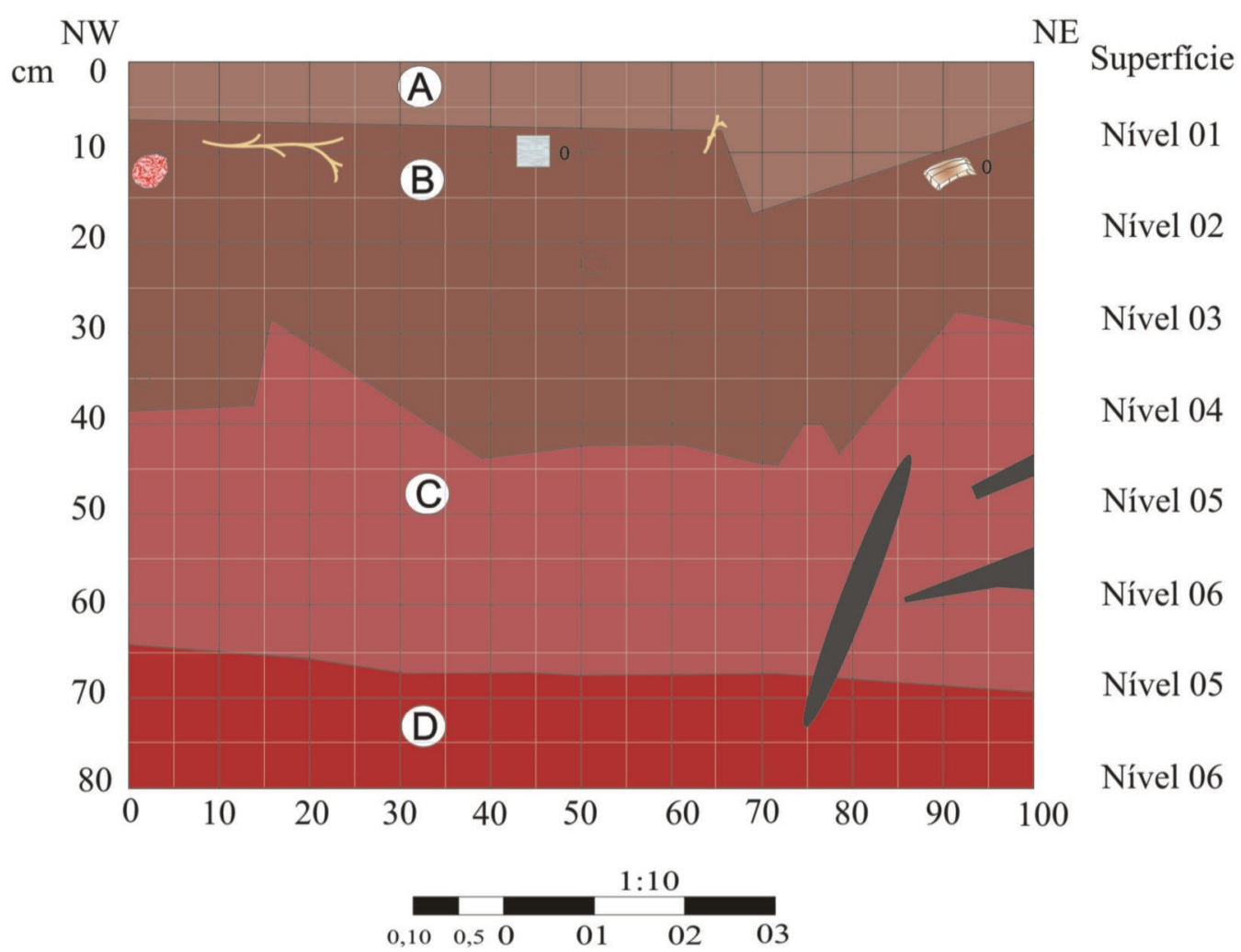

Superfície: Sedimento arenoso marrom-claro, compacto, seco, desprovido de vegetação (chão de terra batida), com presença de materiais arqueológicos.

A Sedimento arenoso, marrom (brown 7.5YR4/4), baixo grau de compactação, seco, com cascalhinhos de quartzo, grãos de carvão, raízes, radículas, material arqueológico e vestígios de materiais industrializados associados ao contexto cultural atual.

B Sedimento arenoso, marrom-escuro (dark brown 7.5YR 3/3), compacto, seco, com cascalhinhos, grãos de carvão, porções de solo queimado, material arqueológico e refugos de materiais industrializados associados ao contexto cultural atual.

C Sedimento areno-argiloso, marrom-avermelhado (strong brown 7.5YR4/6), muito compacto, seco, com cascalhinhos, manchas escuras, raízes, radículas e material arqueológico em pouca densidade.

D Sedimento argilo-arenoso, vermelho (dark red 2.5YR3/6), muito compacto, úmido, com cascalhos e radículas.

\section{LEGENDA}

Solo queimado

Raíz
Cerâmica

Plástico 


\section{PROJETO KAIABI-LALIMA}

\section{Área Piloto Aldeia Lalima}

Sítio: Córrego Lalima Sigla: MS - MI - 01 Setor: 03 Poço Teste: 05 Coordenadas: 1103N/885E

Responsáveis: Alexandre Hering, Mário Antônio,

Leonel da Silva e Ofnéias de Souza Alves, Claudinei da Silva e Altair. Nível: 0 Superfície

Data: 17/06/07 $\mathrm{NE}$
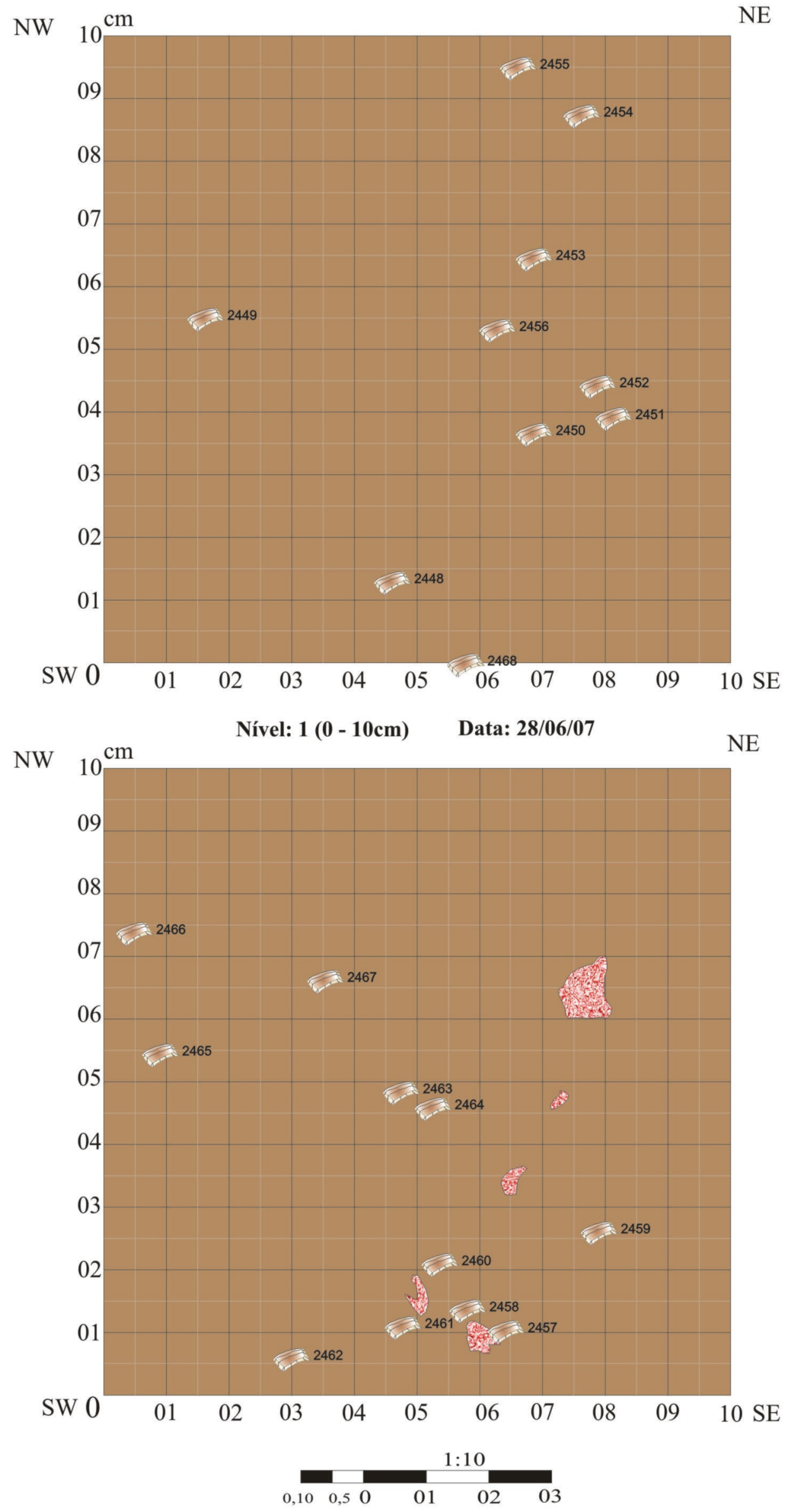


\section{PROJETO KAIABI-LALIMA}

\section{Área Piloto Aldeia Lalima}

Sítio: Córrego Lalima Sigla: MS - MI - 01 Setor: 03 Poço Teste: 05 Coordenadas: 1103N/885E

Responsáveis: Alexandre Hering, Mário Antônio,

Leonel da Silva e Ofnéias de Souza Alves, Claudinei da Silva e Altair. Nível: 2 (10 - 20cm)

Data: $28 / 06 / 07$

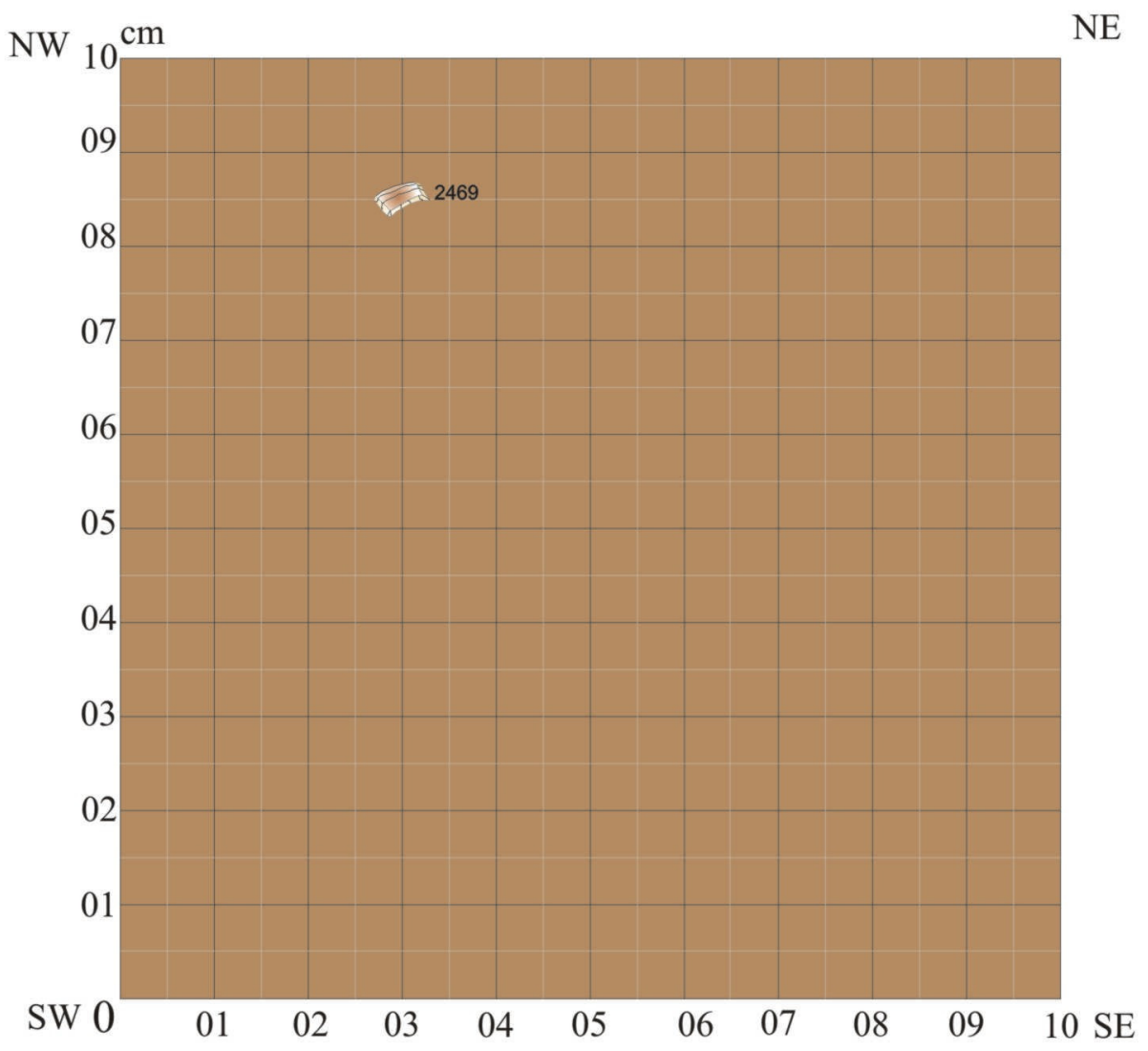

Nível: 3 (20 - 30cm) Data: 28/06/07

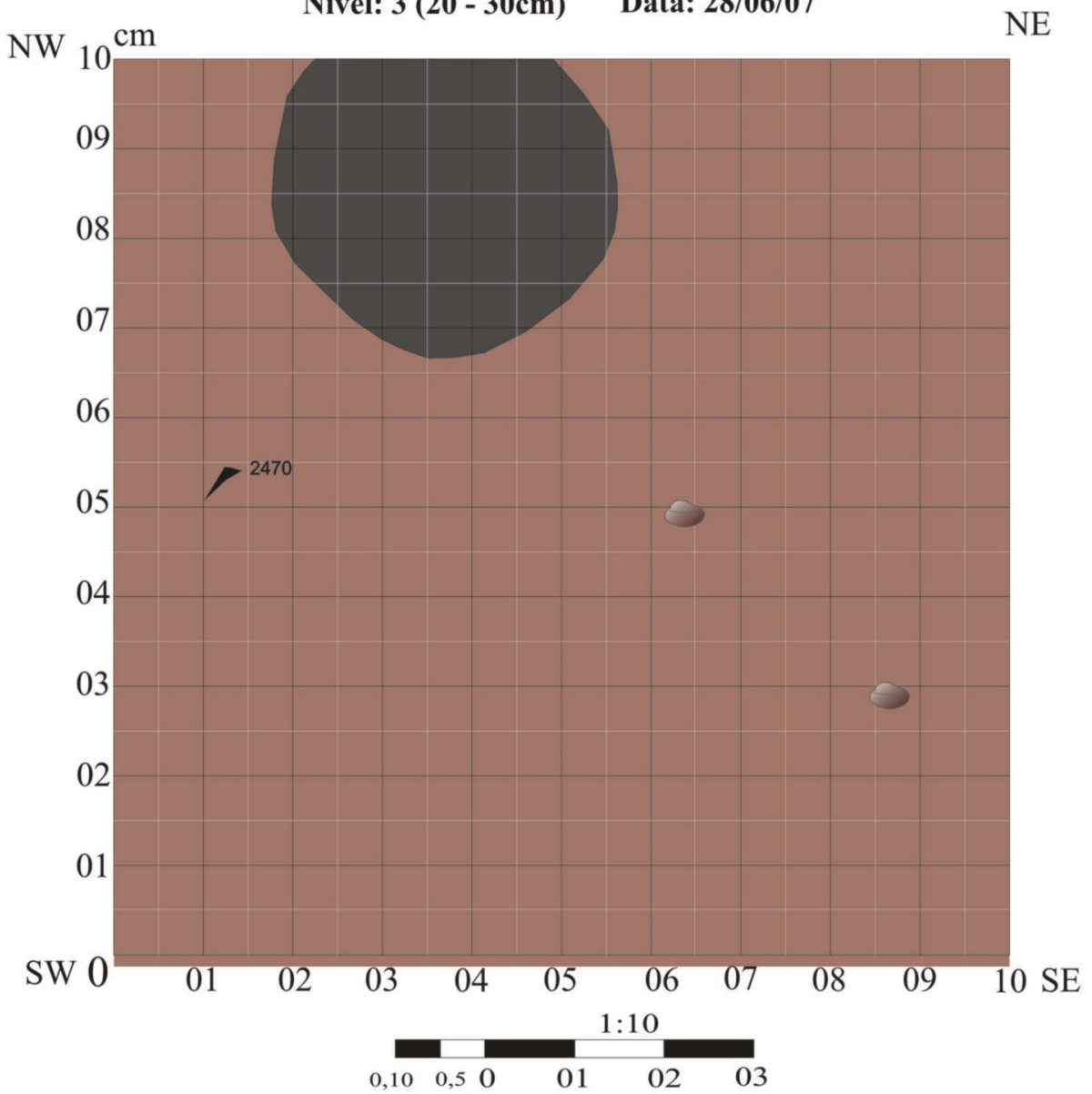




\section{PROJETO KAIABI-LALIMA}

\section{Área Piloto Aldeia Lalima}

Sítio: Córrego Lalima Sigla: MS - MI - 01 Setor: 03 Poço Teste: 05 Coordenadas: 1103N/885E

Responsáveis: Alexandre Hering, Mário Antônio,

Leonel da Silva e Ofnéias de Souza Alves, Claudinei da Silva e Altair. $\quad$ Nível: 04 (30-40cm) Data: 06/07/07
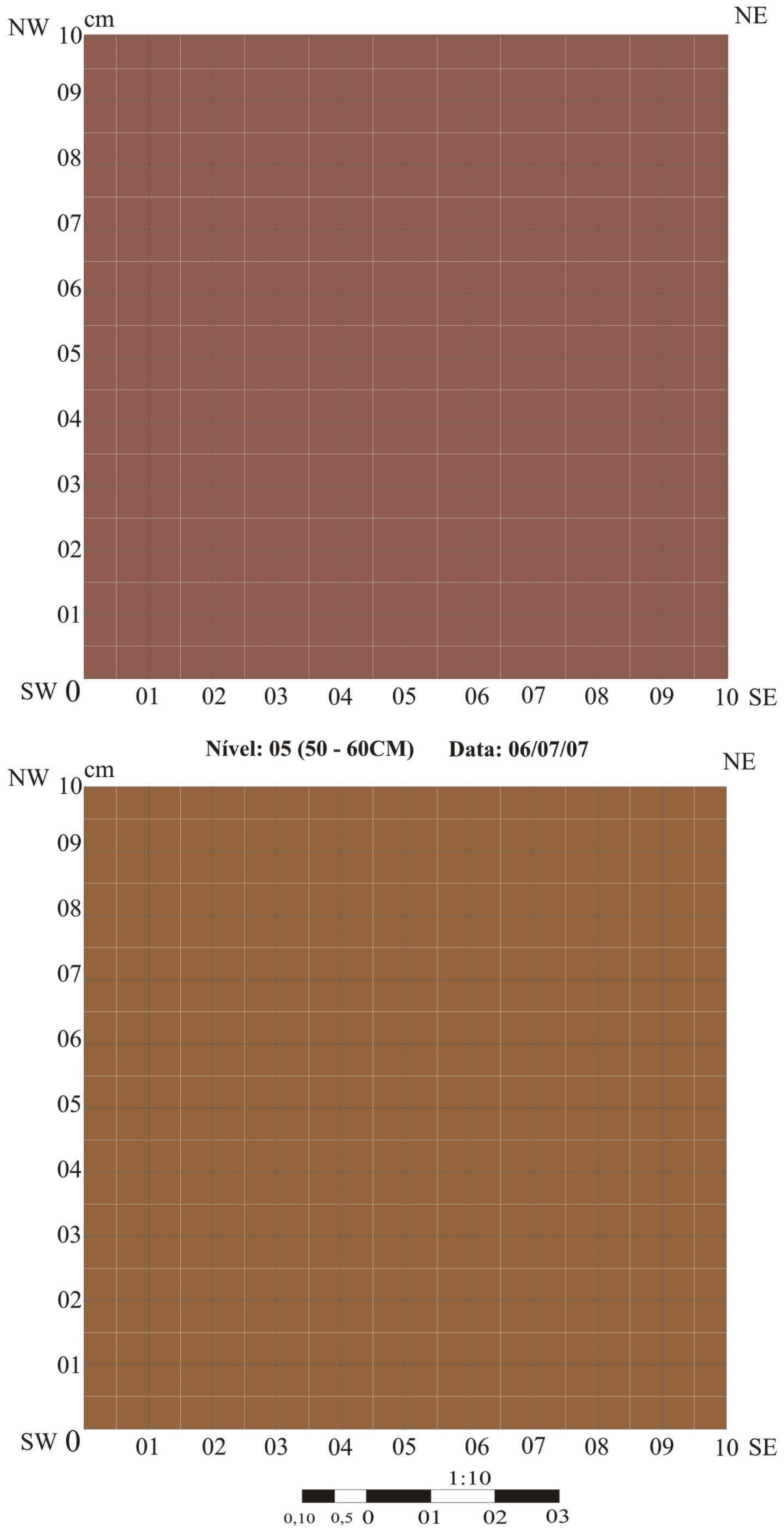


\section{PROJETO KAIABI-LALIMA}

\section{Área Piloto Aldeia Lalima}

Sítio: Córrego Lalima Sigla: MS - MI - 01 Setor: 03 Poço Teste: 05 Coordenadas: 1103N/885E Responsáveis: Alexandre Hering, Mário Antônio,

Leonel da Silva e Ofnéias de Souza Alves, Claudinei da Silva e Altair. Nível: 06 (50-60cm) Data: 06/07/07

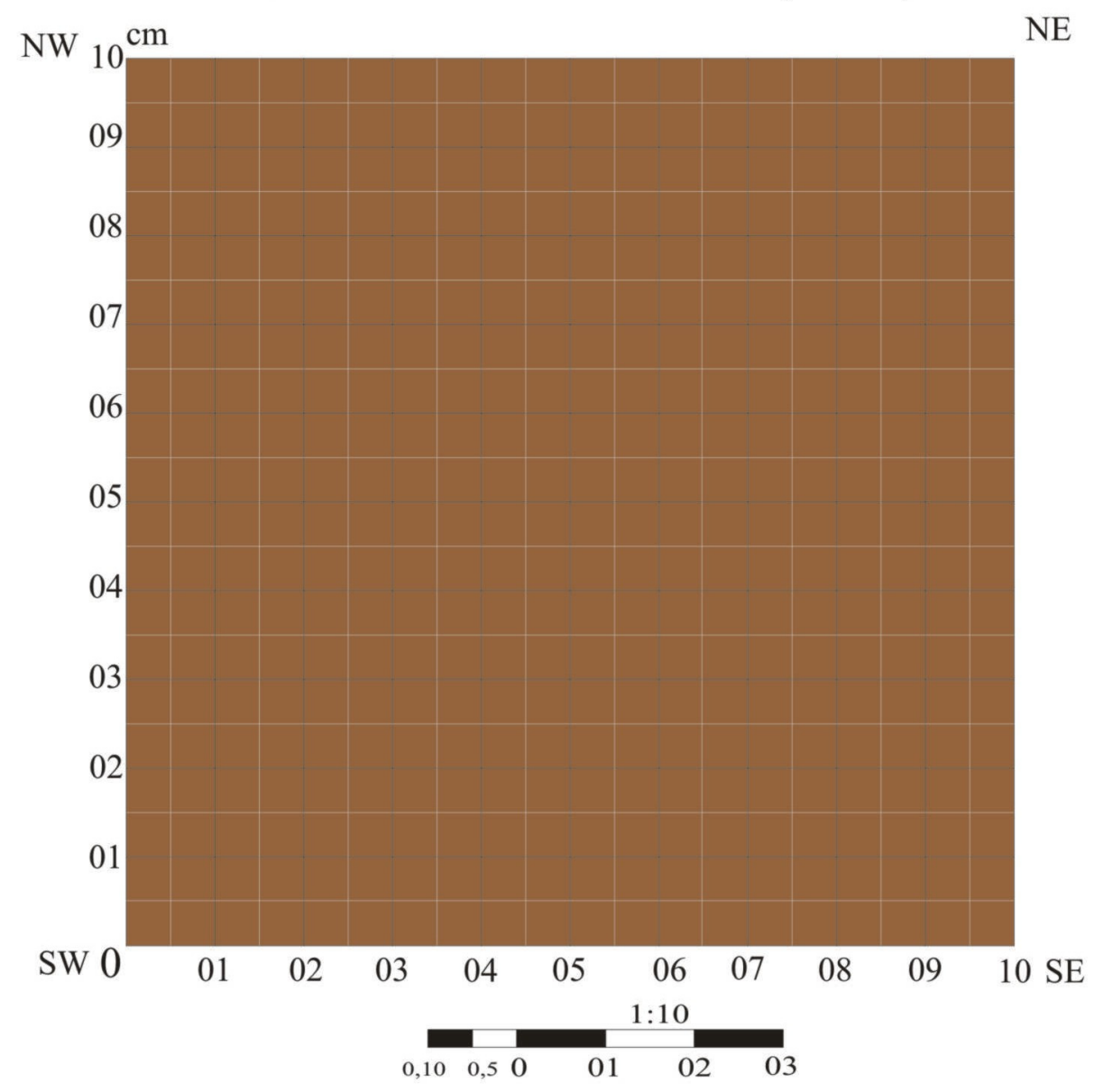




\section{PROJETO KAIABI-LALIMA \\ Área Piloto Aldeia Lalima}

Sítio: Córrego Lalima Sigla: MS - MI - 01 Setor: 03 Poço Teste: 05 Coordenadas: 1103N/885E

Responsáveis: Mário Antônio,

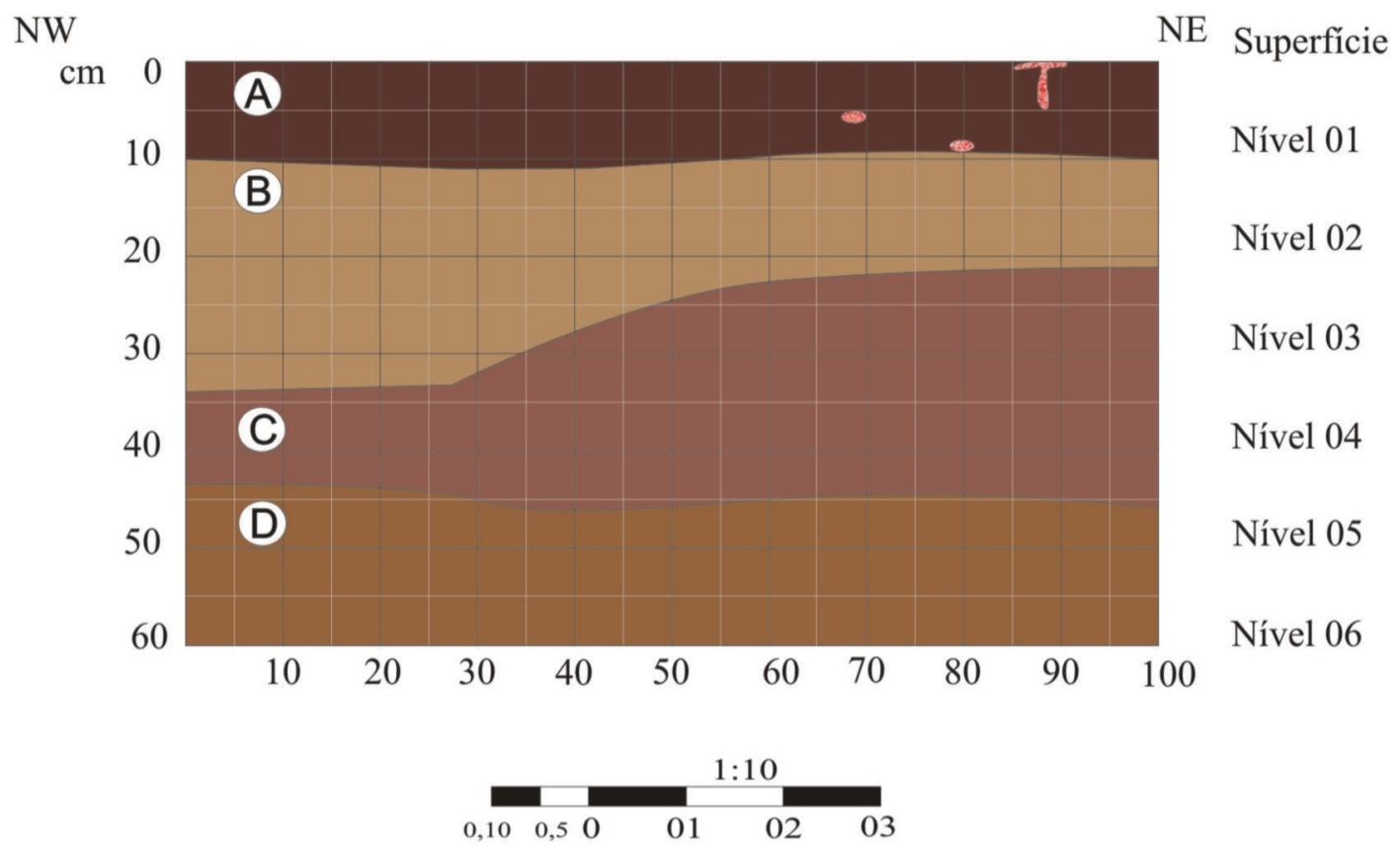

Superfície: Sedimento arenoso, marrom-claro (pale brown 10YR6/3), seco, pouco compacto, com presença de materiais arqueológicos.

A Sedimento arenoso, marrom-escuro, seco, pouco compacto, com cascalhos, grãos de carvão, manchas de sedimento queimado, raízes secas, buracos de cupim e materiais arqueológicos.

B Sedimento arenoso, marrom-claro, seco, pouco compacto, com grãos de carvão, cascalhos, raízes secas, cupins e materiais arqueológicos em pouca densidade.

C Sedimento arenoso, marrom, seco, compacto, com cascalhos, estéril arqueologicamente.

D Sedimento arenoso, marrom-alaranjado (strong brown 7.5YR5/6), seco, compacto, com presença de muitos cascalhos, substrato rochoso em quartzo no fim da camada, sem materiais arqueológicos.

Raíz

Caminho de Cupim

Terra vermelha concrecionada do cupinzeiro. 


\section{PROJETO KAIABI-LALIMA}

\section{Área Piloto Aldeia Lalima}

Sítio: Asa de Pote Sigla: MS - MI - 06 Setor: 02 Poço Teste: 01 Coordenadas: 1260N/780E Responsável: Rafael dos Santos.

Nível: 0 (Superfície) Data: 07/06/07

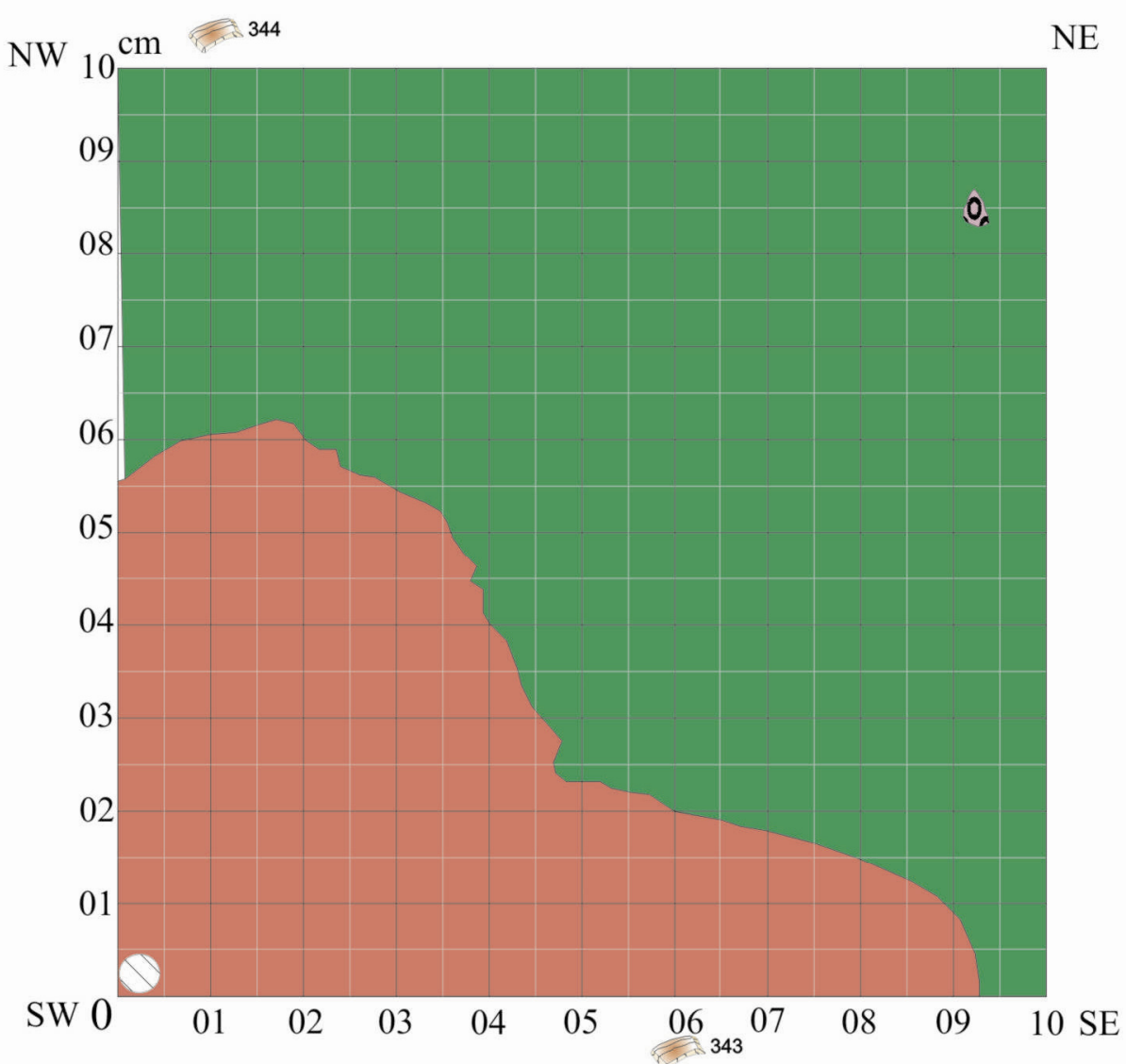

Nível: $01(0-10 \mathrm{~cm})$

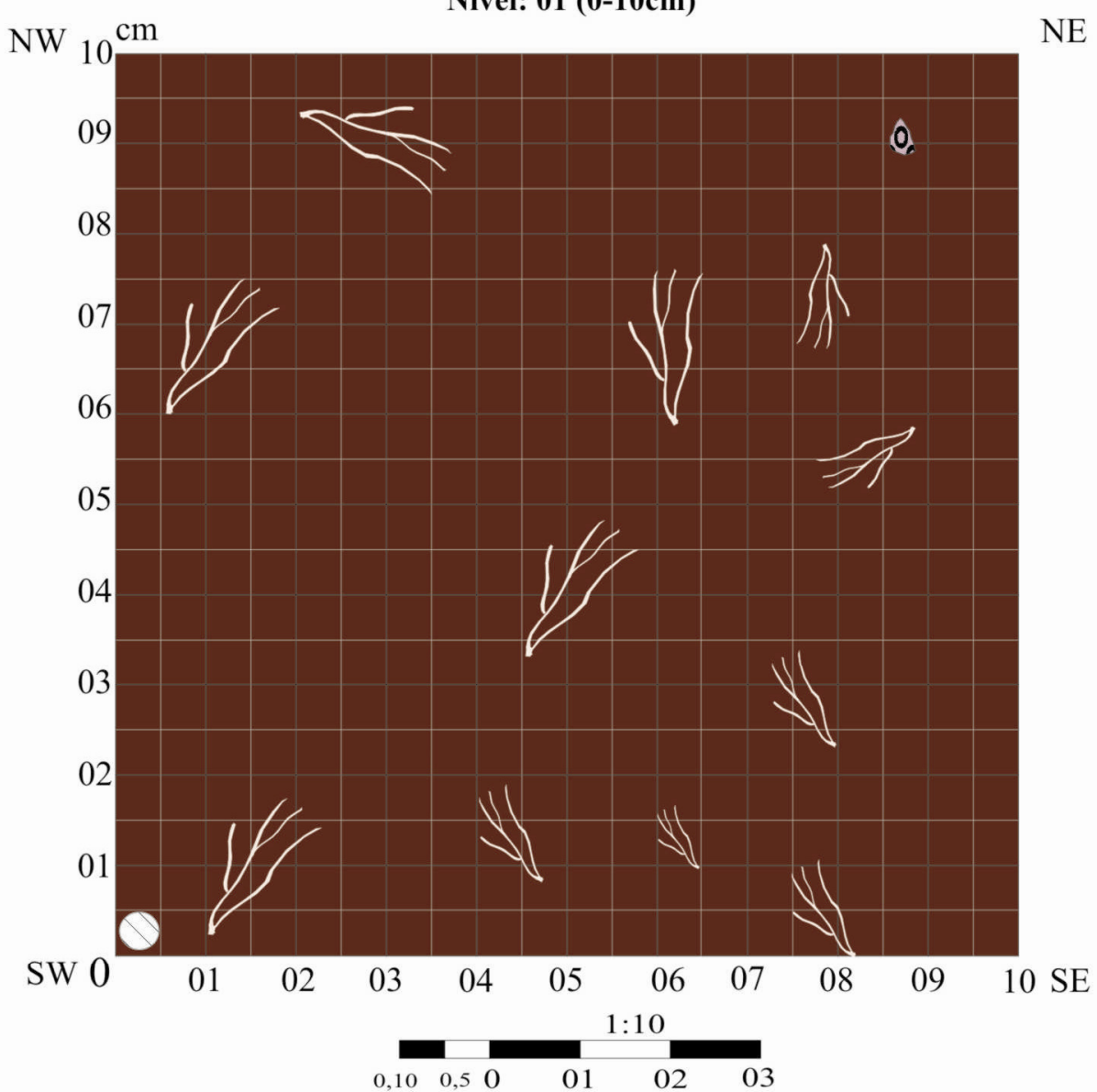




\section{PROJETO KAIABI-LALIMA}

\section{Área Piloto Aldeia Lalima}

Sítio: Asa de Pote Sigla: MS - MI - 06 Setor: 02 Poço Teste: 01 Coordenadas: 1260N/780E

Responsável: Rafael dos Santos.

Nível: 02 (10 - 20cm) Data: 07/06/07

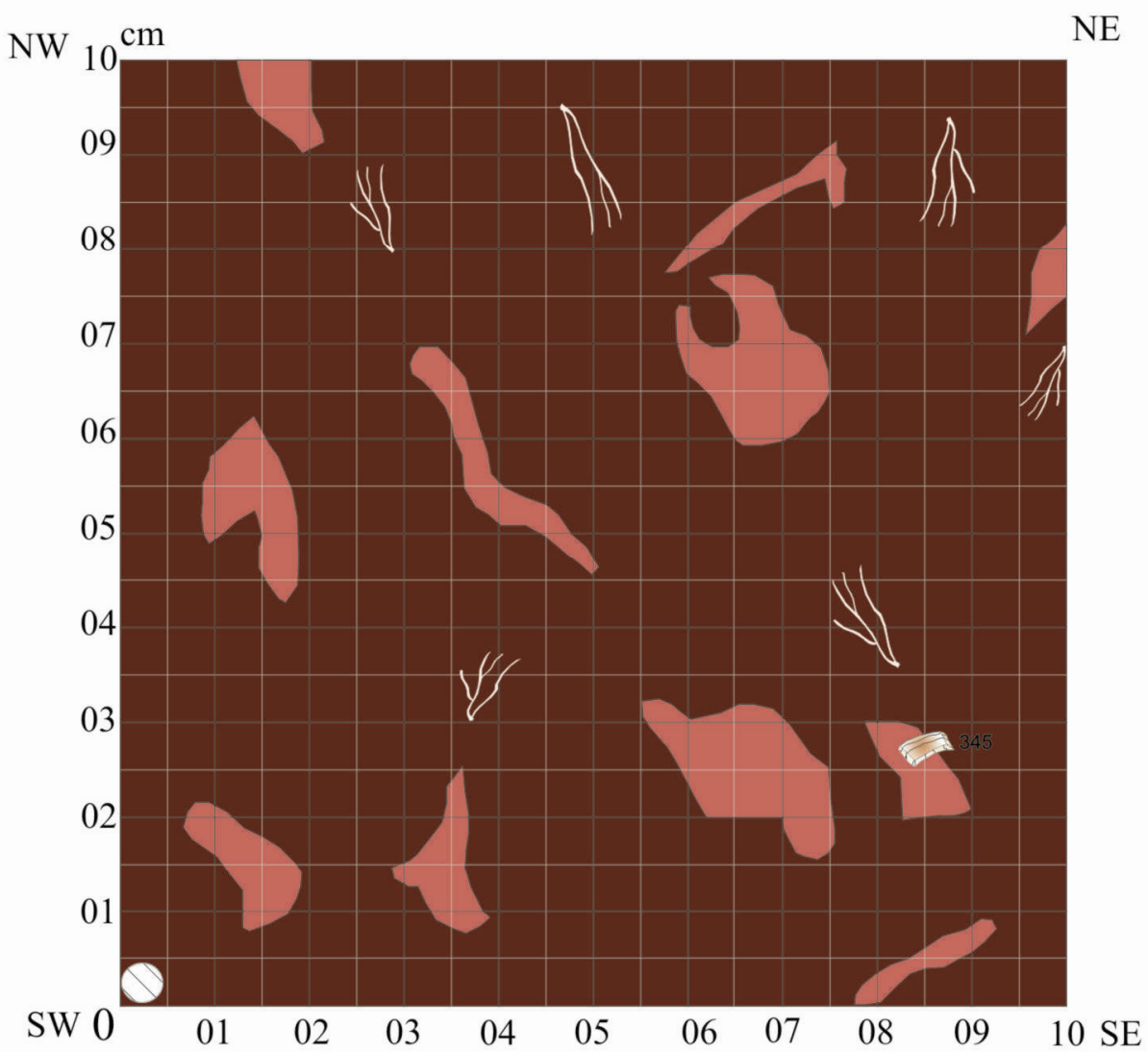

Nível: 03 (20 - 30cm) Data: 08/06/07

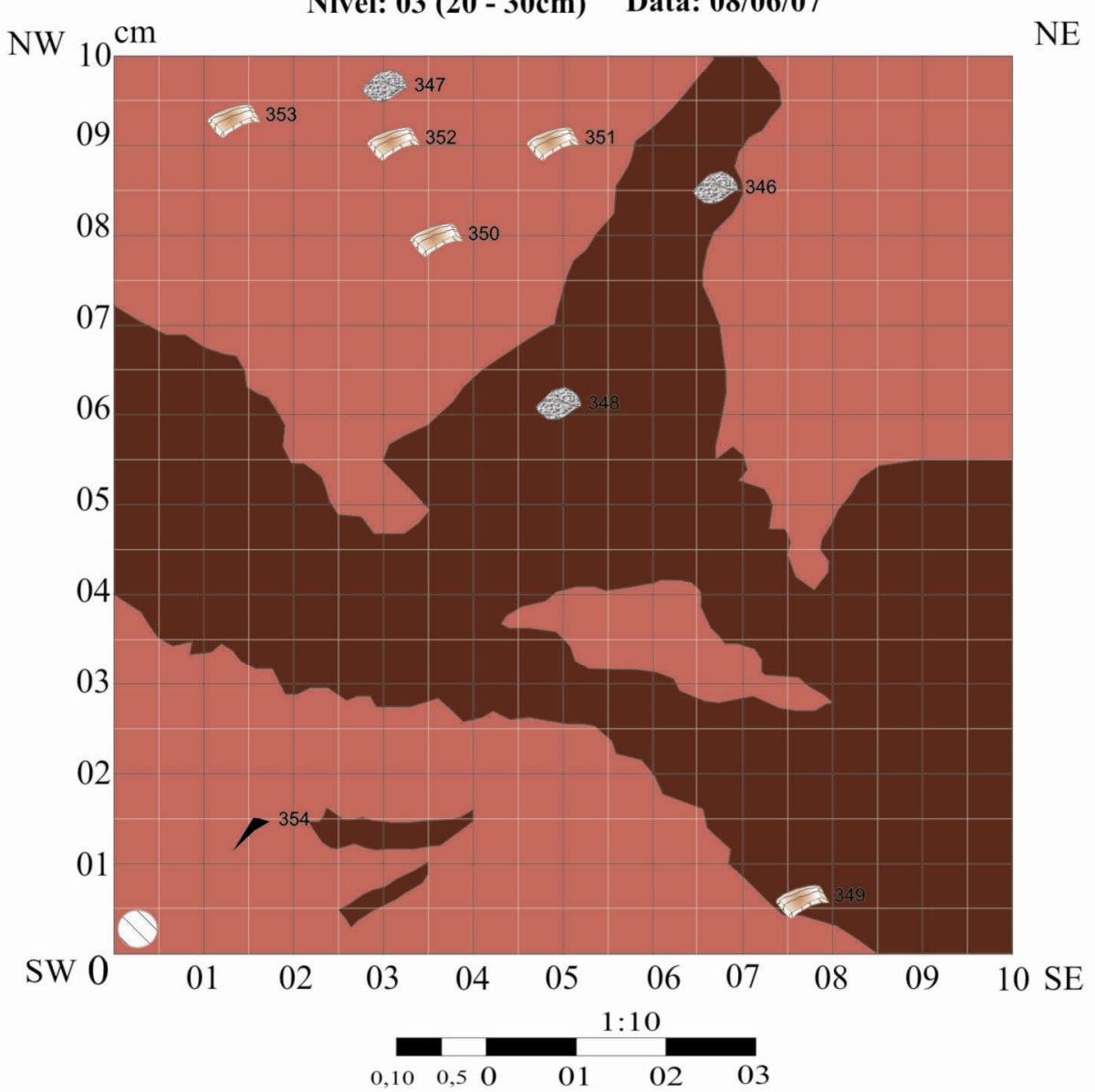




\section{PROJETO KAIABI-LALIMA}

\section{Área Piloto Aldeia Lalima}

Sítio: Asa de Pote Sigla: MS - MI - 06 Setor: 02 Poço Teste: 01 Coordenadas: 1260N/780E

Responsável: Rafael dos Santos.

Nível: 04 (30 - 40cm) Data: 11/06/07
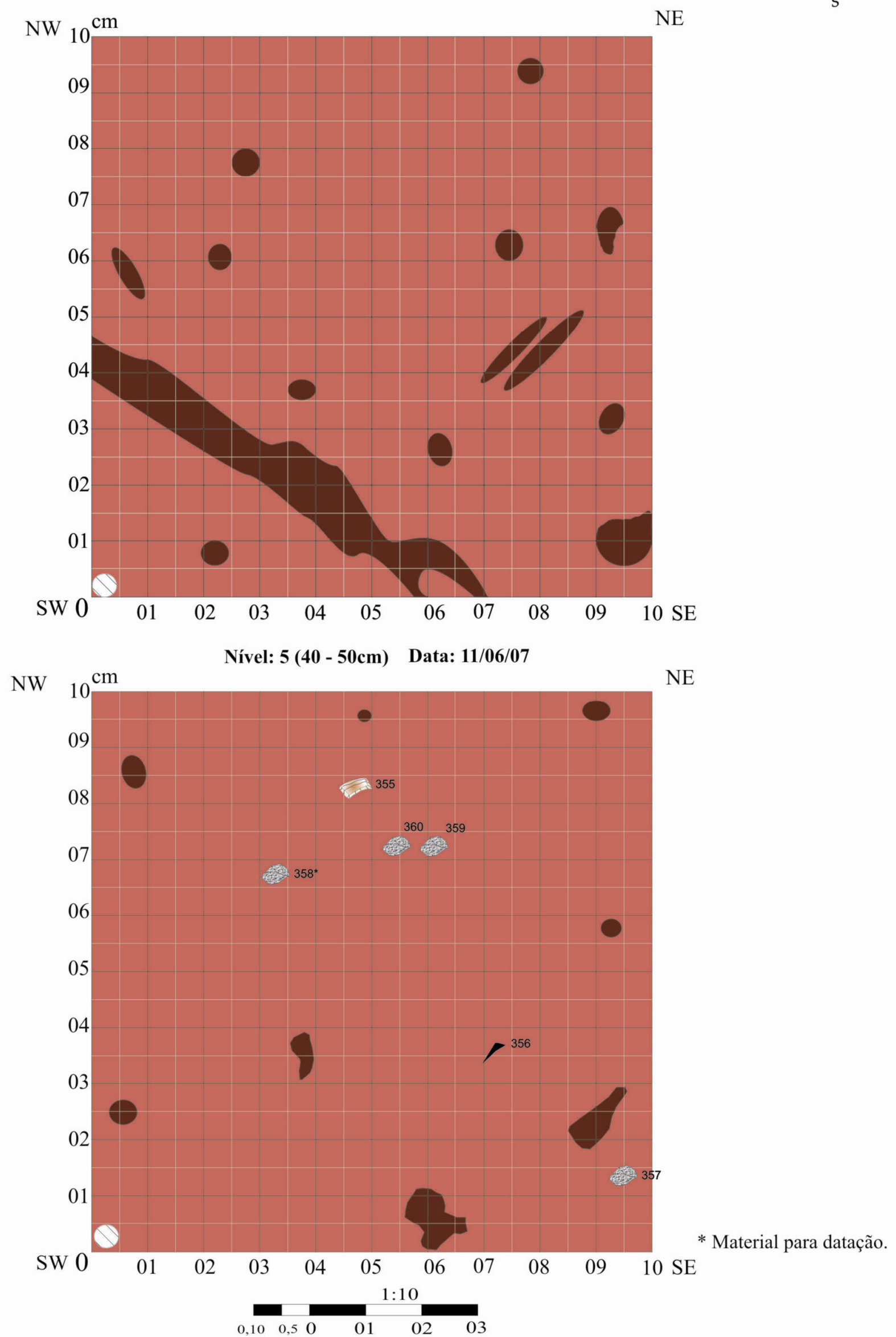


\section{PROJETO KAIABI-LALIMA}

\section{Área Piloto Aldeia Lalima}

Sítio: Asa de Pote Sigla: MS - MI - 06 Setor: 02 Poço Teste: 01 Coordenadas: 1260N/780E

Responsável: Rafael dos Santos.

Nível: $06(50-60 \mathrm{~cm}) \quad$ Data: 12/06/07

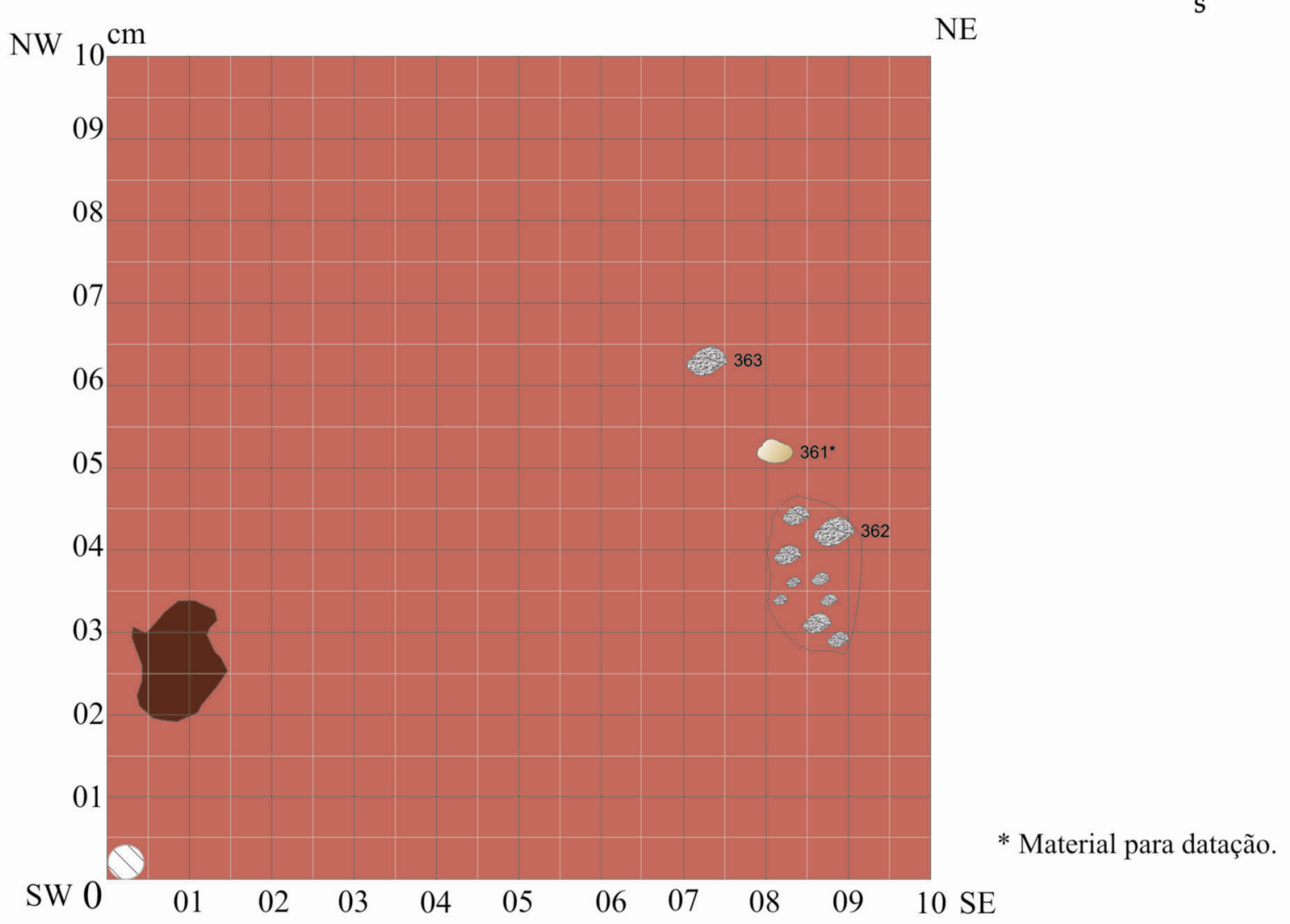

Nível: $07(60-70 \mathrm{~cm})$

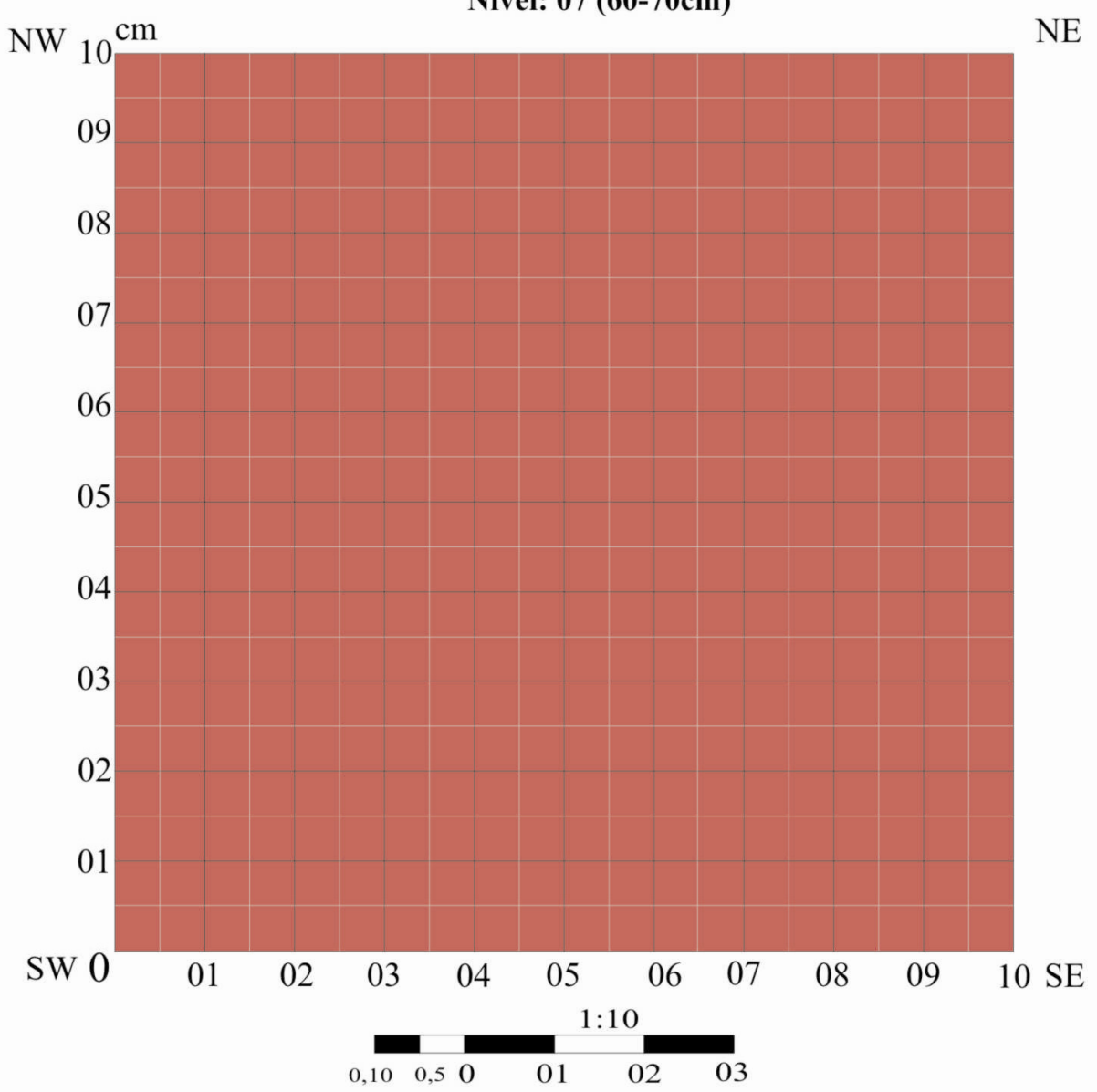




\section{PROJETO KAIABI-LALIMA \\ Área Piloto Aldeia Lalima}

Sítio: Asa de Pote Sigla: MS - MI - 06 Setor: 02 Poço Teste: 01 Coordenadas: 1260N/780E

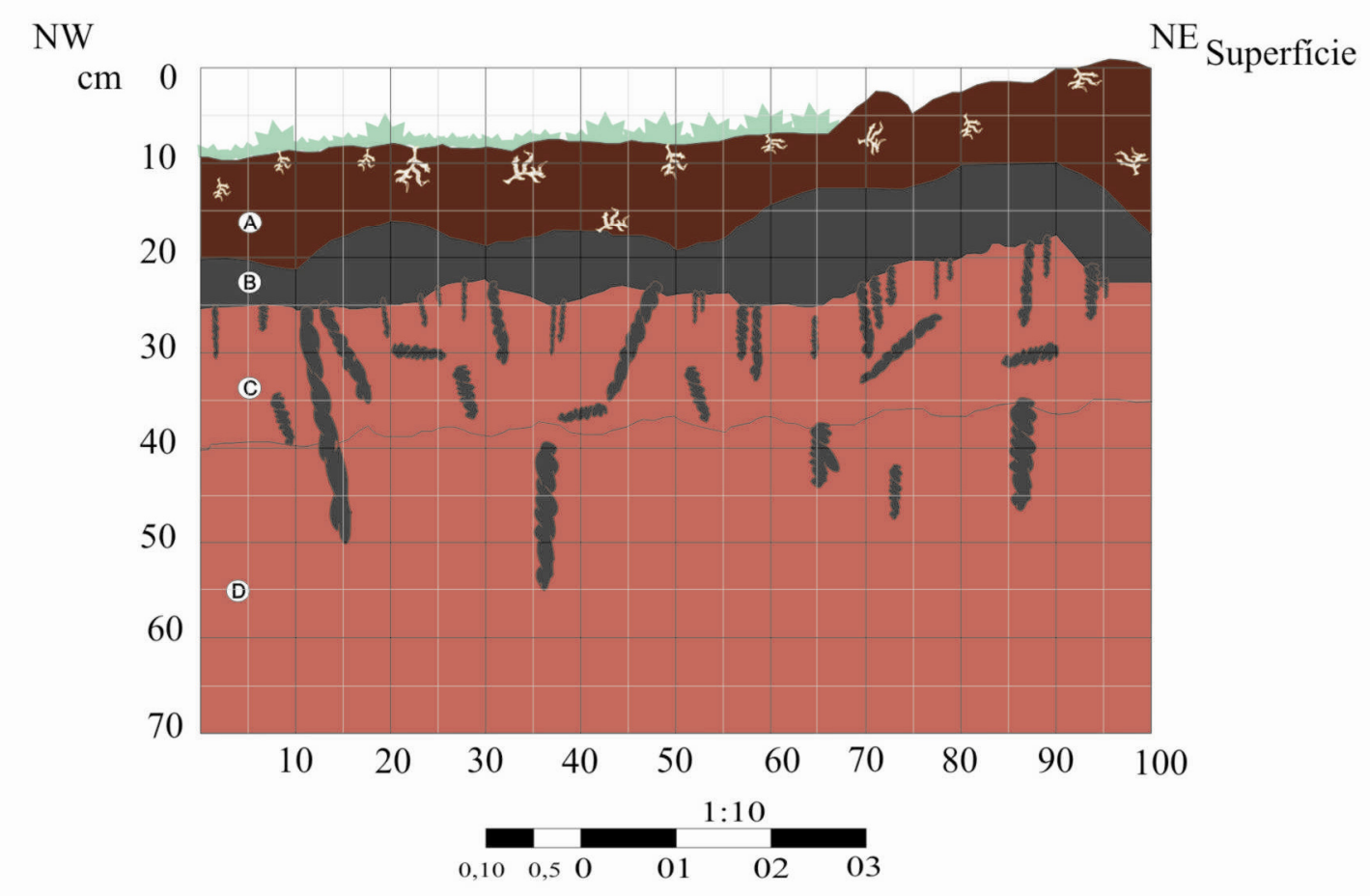
A Camada superficial de solo marrom-escuro com presença de radículas.
B Camada de solo escuro com presença de radículas.
C Camada de solo argilo-arenoso marrom avermelhado com percolações de solo escuro.
D Camada de sedimento argilo-arenoso marrom avermelhado estéril. 


\section{PROJETO KAIABI-LALIMA}

\section{Área Piloto Aldeia Lalima}

Sítio: Sítio da Sede Sigla: MS - MI - 07 Setor: 02 Poço Teste: 02 Coordenadas: 11180N/999E

Responsáveis: Alexandre Hering, Atair e Cida.

Nível: 0 (superfície) Data: 06/06/07
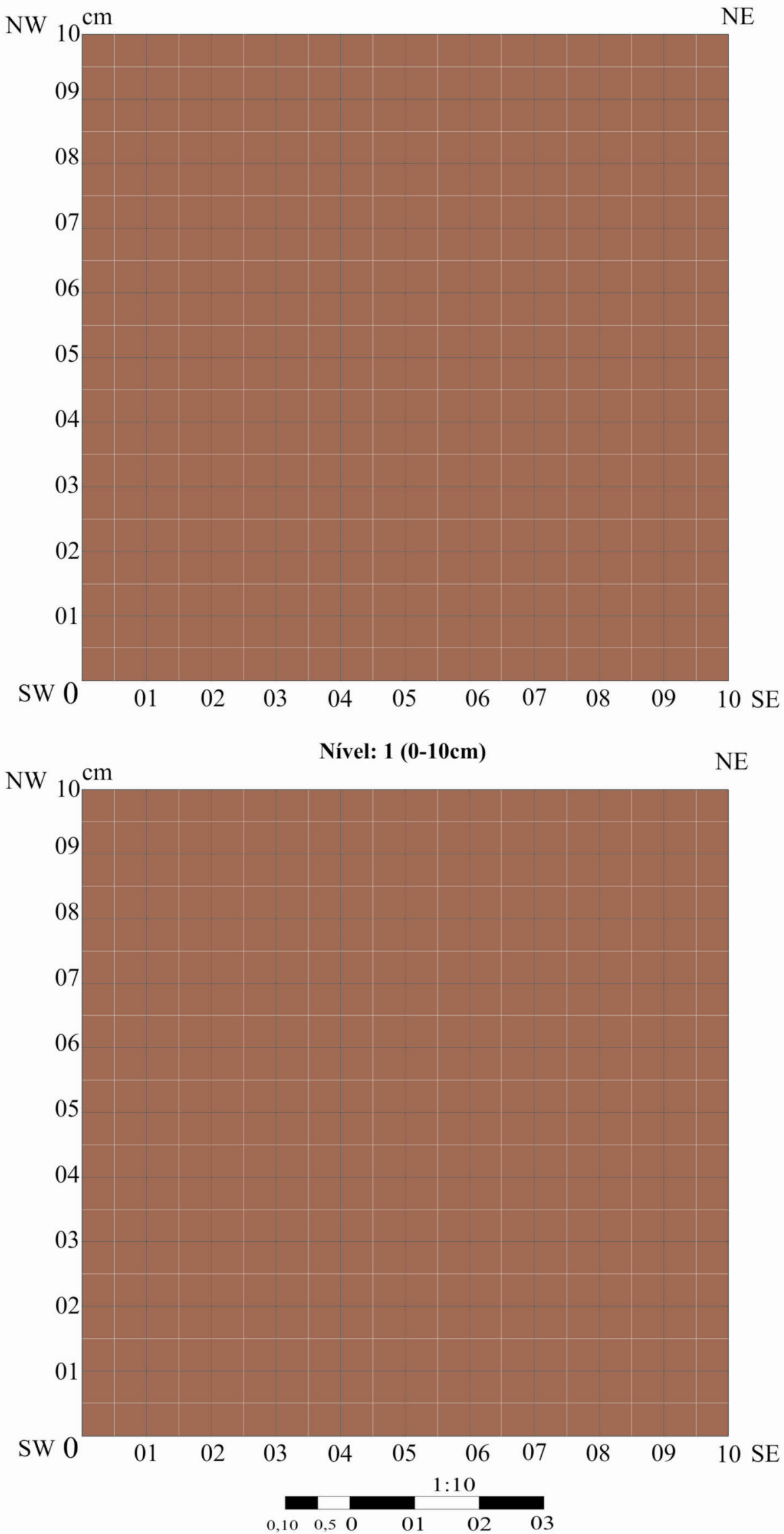


\section{PROJETO KAIABI-LALIMA}

\section{Área Piloto Aldeia Lalima}

Sítio: Sítio da Sede Sigla: MS - MI - 07 Setor: 02 Poço Teste: 02 Coordenadas: 11180N/999E

Responsáveis: Alexandre Hering, Atair e Cida.

Nível: 2 (10 - 20cm) Data: 06/06/07
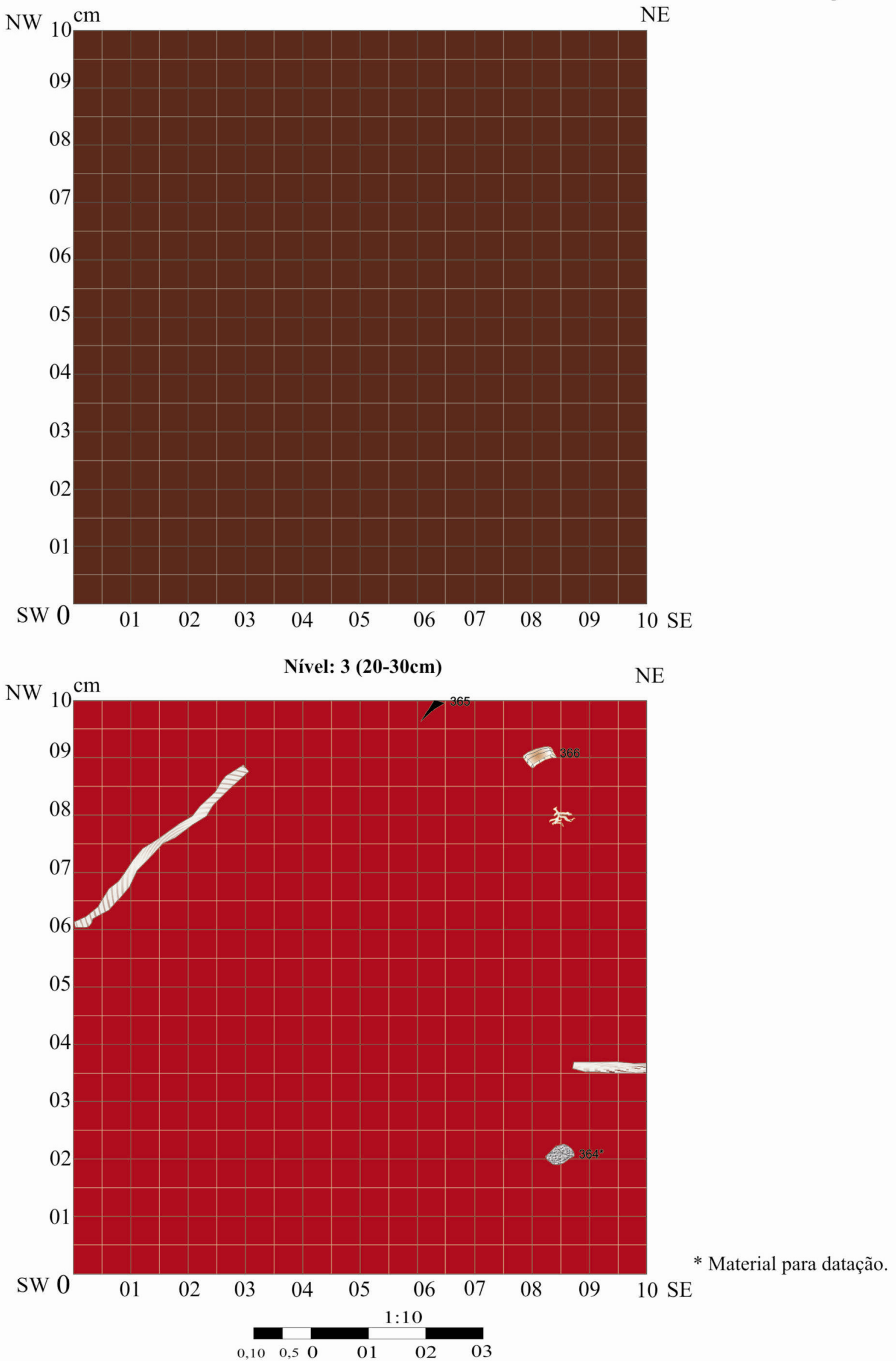


\section{PROJETO KAIABI-LALIMA}

\section{Área Piloto Aldeia Lalima}

Sítio: Sítio da Sede Sigla: MS - MI - 07 Setor: 02 Poço Teste: 02 Coordenadas: 11180N/999E
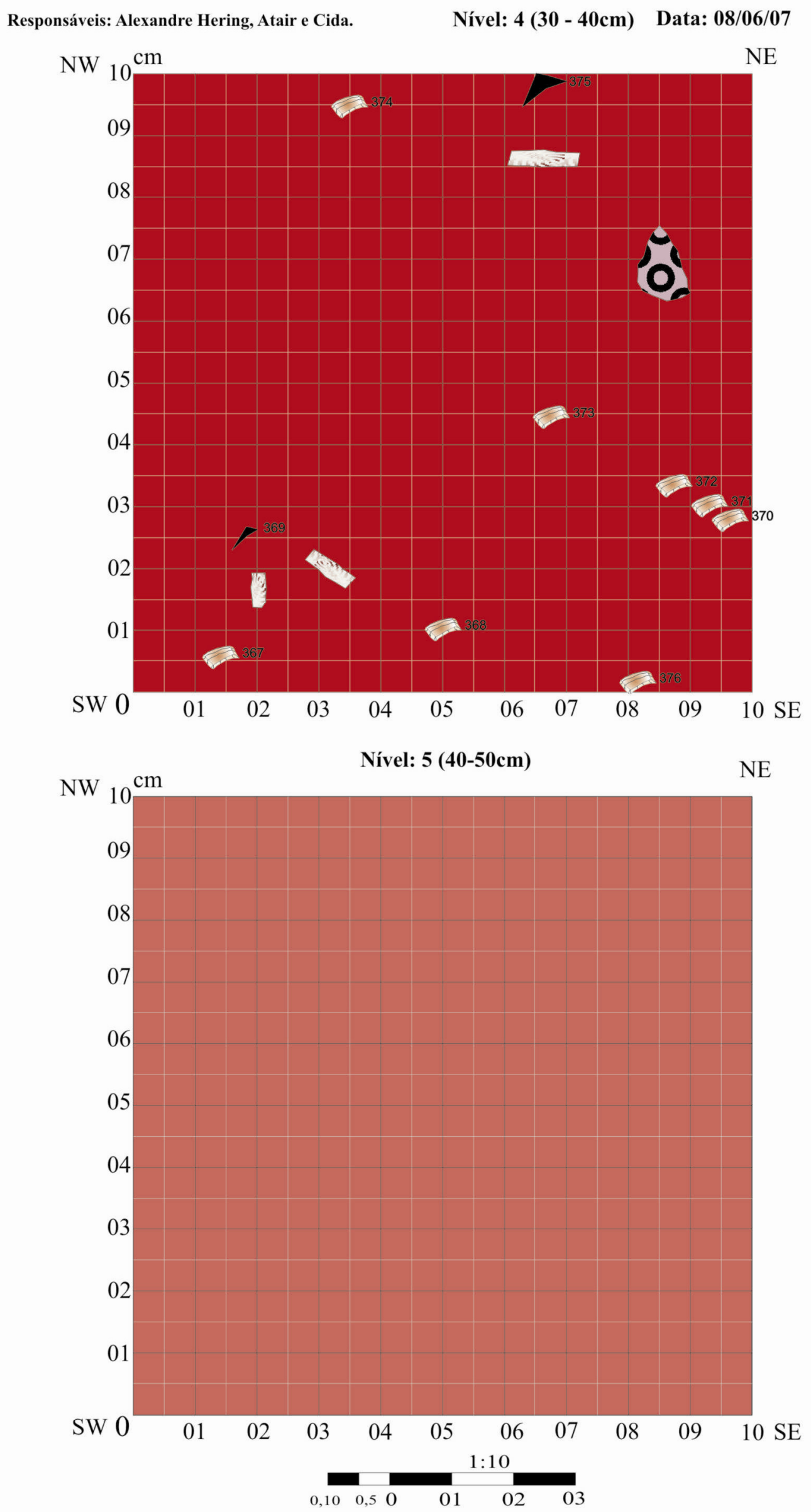


\section{PROJETO KAIABI-LALIMA}

\section{Área Piloto Aldeia Lalima}

Sítio: Sítio da Sede Sigla: MS - MI - 07 Setor: 02 Poço Teste: 02 Coordenadas: 11180N/999E

Responsáveis: Alexandre Hering, Atair e Cida.

Nível: 6 (50 - 60cm) Data: 08/06/07
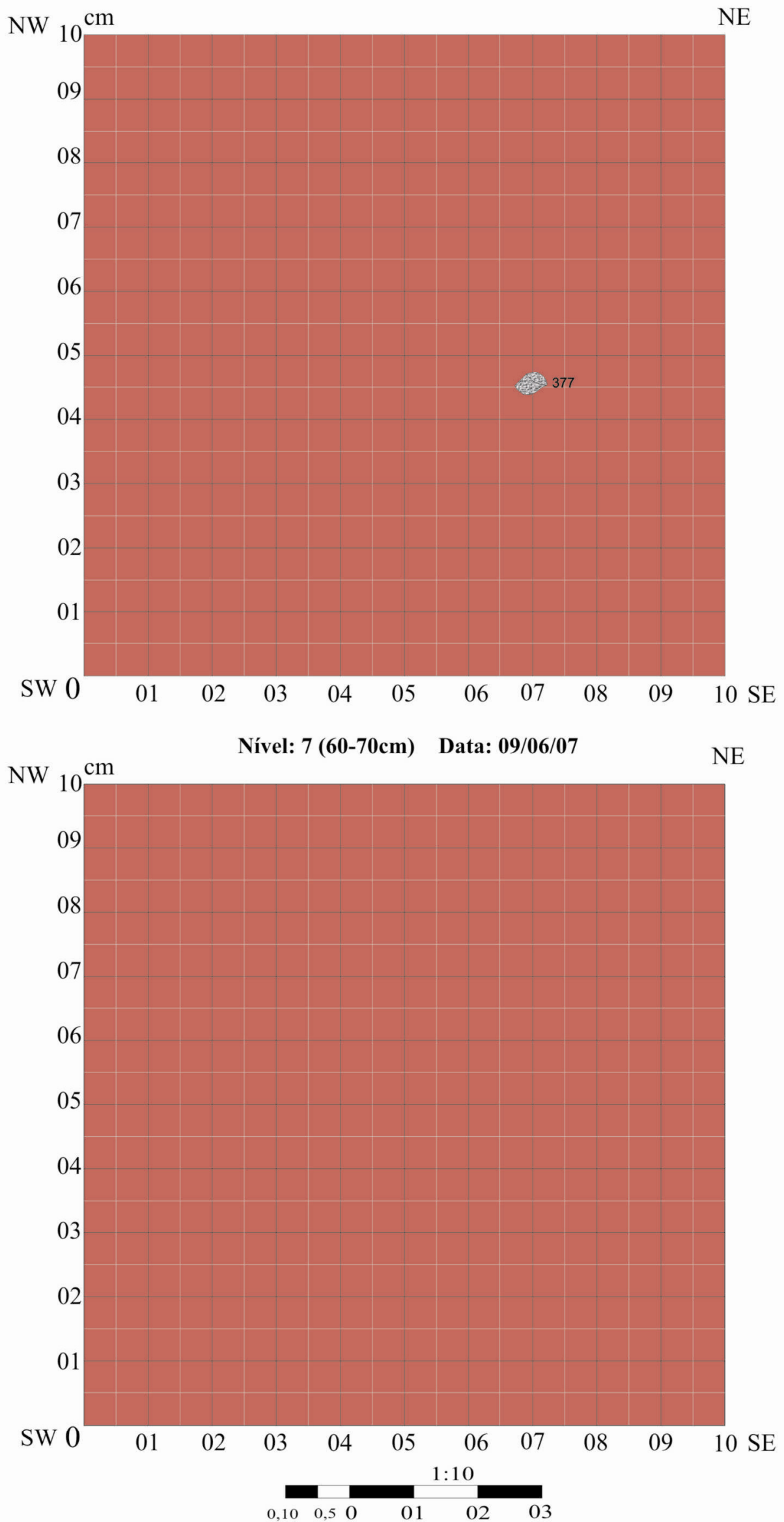


\section{PROJETO KAIABI-LALIMA}

\section{Área Piloto Aldeia Lalima}

Sítio: Sítio da Sede Sigla: MS - MI - 07 Setor: 02 Poço Teste: 02 Coordenadas: 11180N/999E

Responsáveis: Alexandre Hering, Atair e Cida.

Nível: 8 (70 - 80cm) Data: 09/06/07
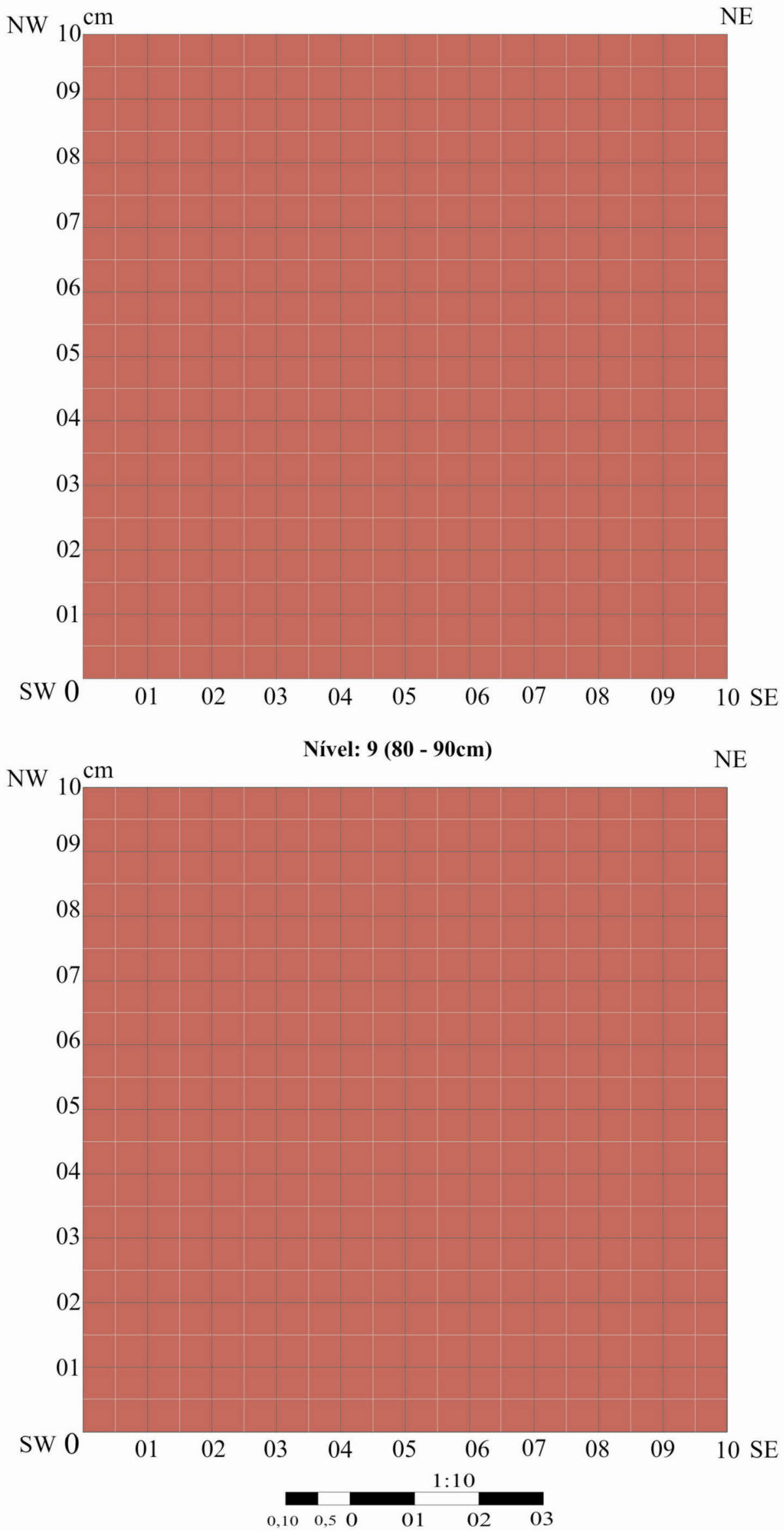


\section{PROJETO KAIABI-LALIMA}

Área Piloto Aldeia Lalima

Sítio: Sítio da Sede Sigla: MS - MI - 07 Setor: 02 Poço Teste: 02 Coordenadas: 11180N/999E

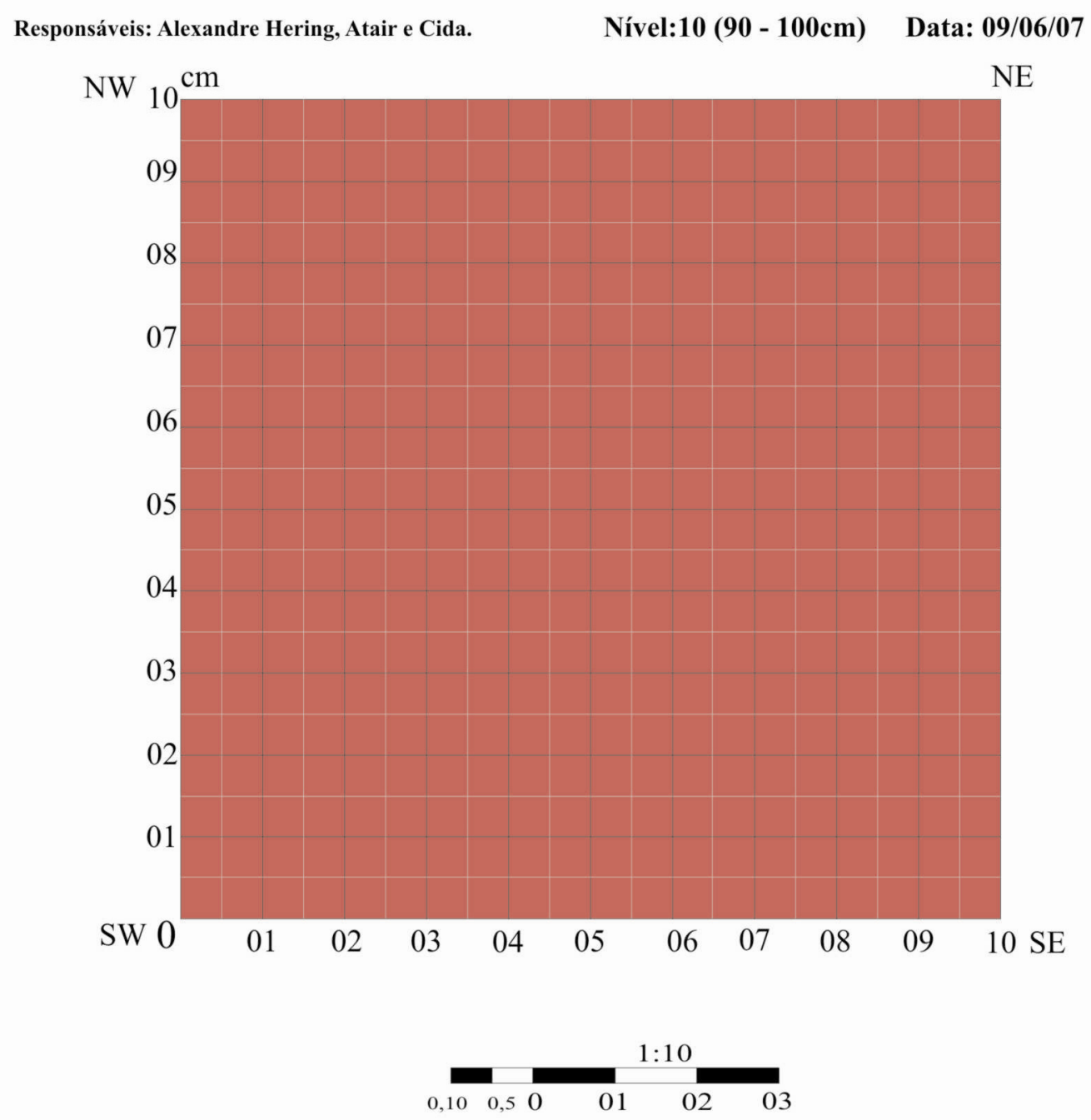




\section{PROJETO KAIABI-LALIMA \\ Área Piloto Aldeia Lalima}

Sítio: Sítio da Sede Sigla: MS - MI - 07 Setor: 02 Poço Teste: 02 Coordenadas: 11180N/999E

Responsáveis: Alexandre Hering, Atair e Cida. Perfil: Norte Data: 19/06/07

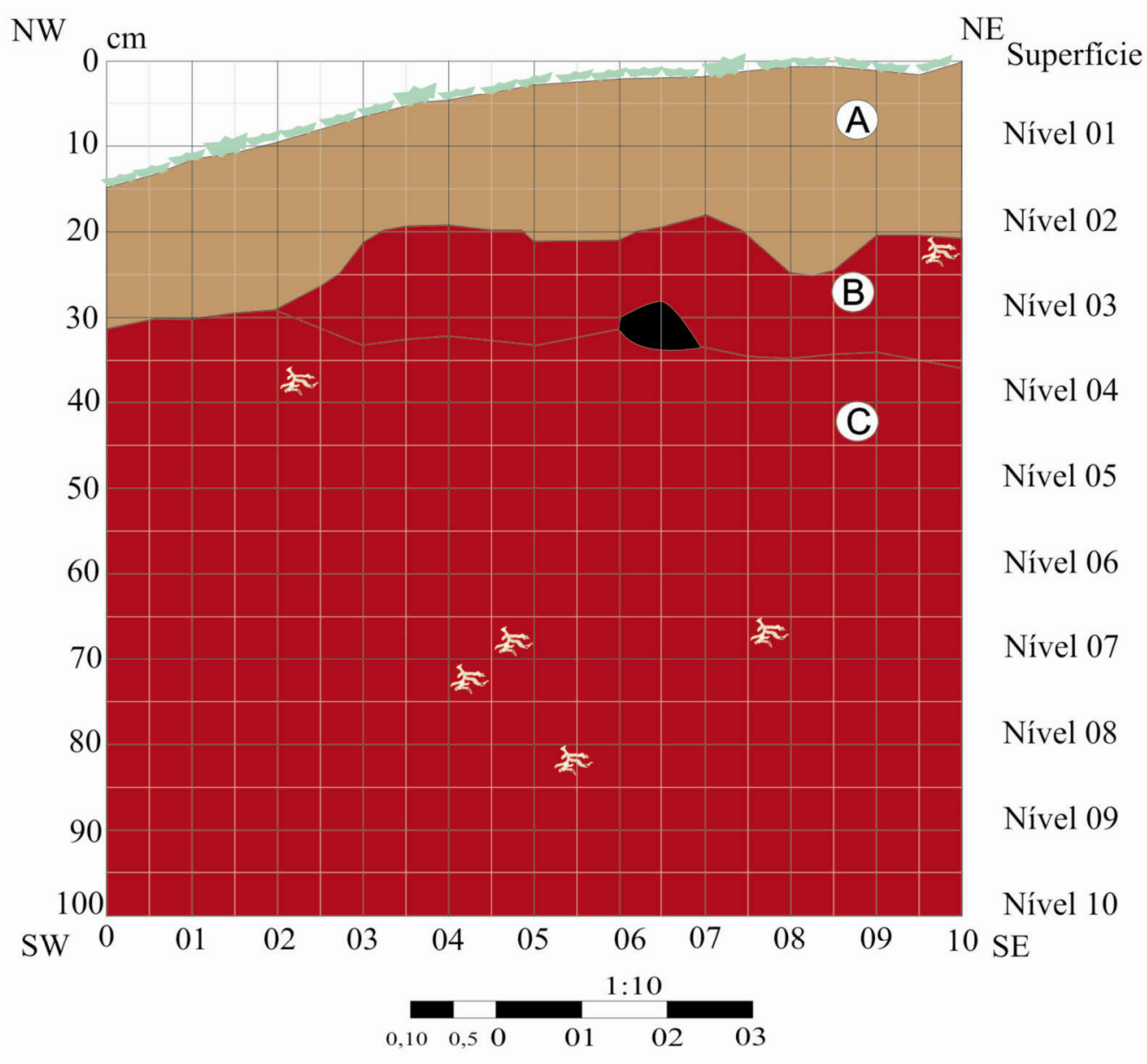

Raíz

Lítico

A Camada de sedimento argilo-arenoso, marrom-claro.

B Camada de sedimento argilo-arenoso, vermelho.

C Camada de sedimento argilo-arenoso, vermelho. 


\section{PROJETO KAIABI-LALIMA}

\section{Área Piloto Aldeia Lalima}

Sítio: Sítio da Sede Sigla: MS - MI - 07 Setor: 02 Poço Teste: 03 Coordenadas: 1180N/959E Responsáveis: Eduardo Bespalez, Alexandre Hering, Mário Antônio, Leonel da Silva e Ofnéias de Souza Alves

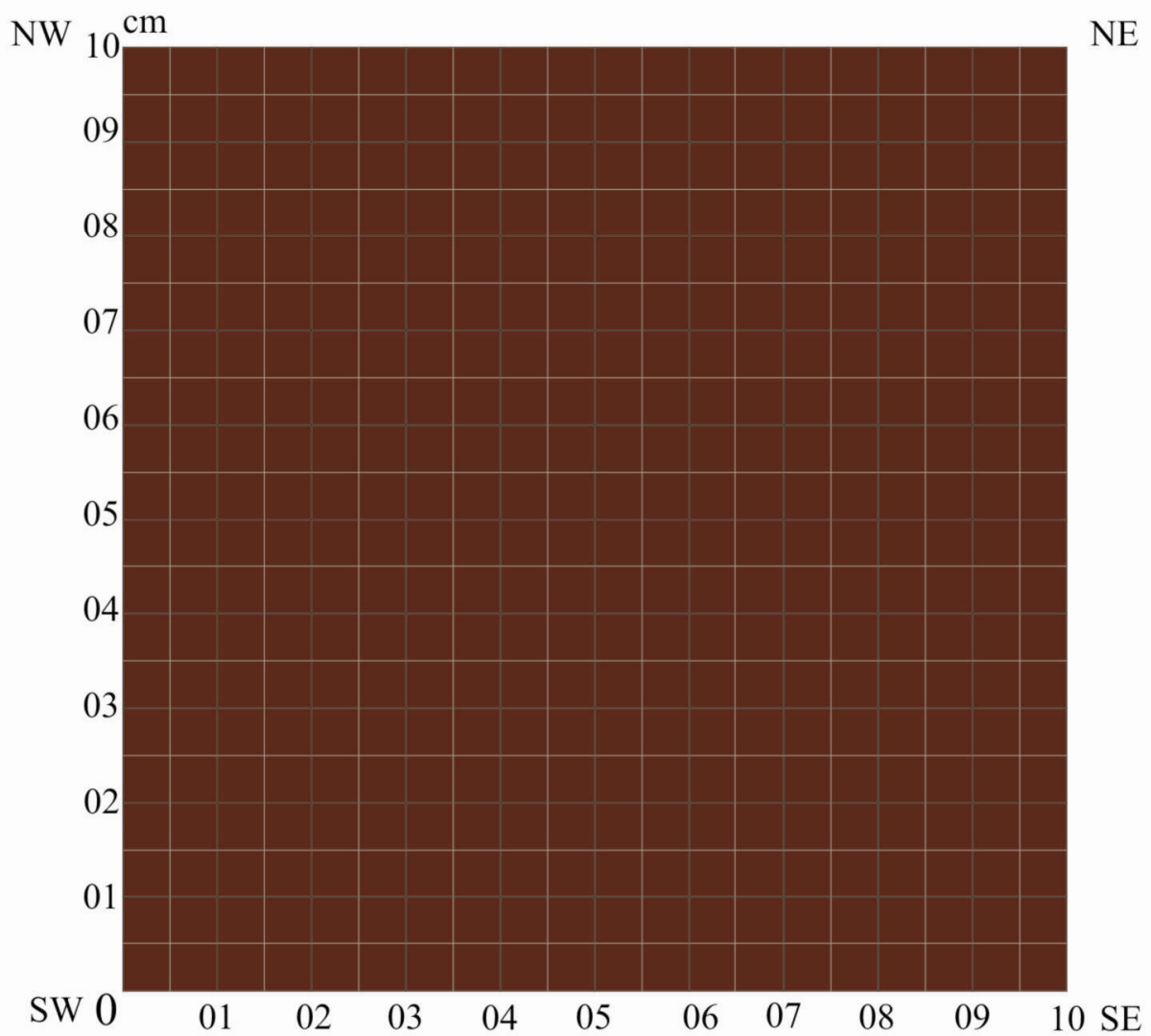

Nível: $1(0-10 \mathrm{~cm})$

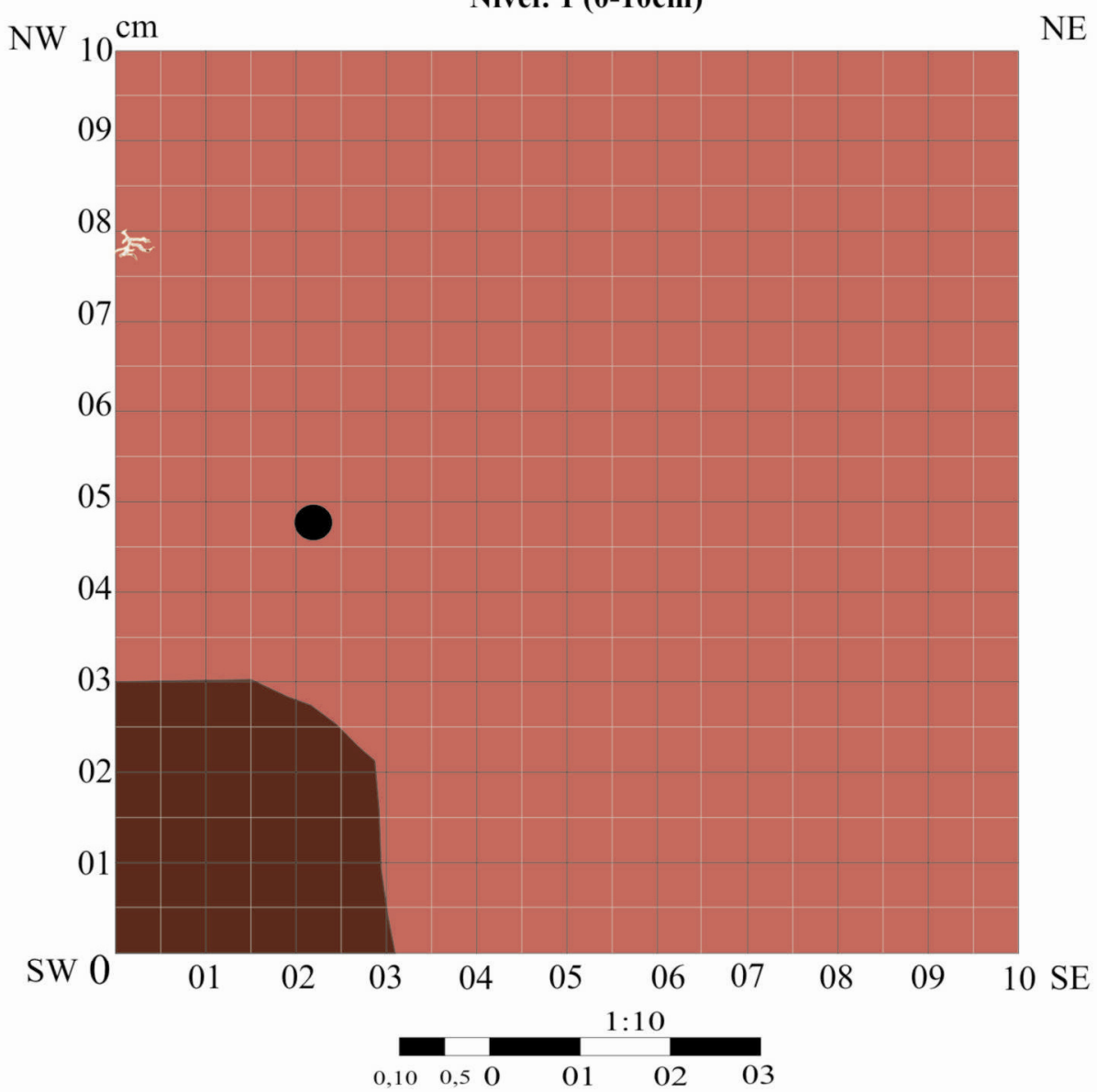




\section{PROJETO KAIABI-LALIMA}

\section{Área Piloto Aldeia Lalima}

Sítio: Sítio da Sede Sigla: MS - MI - 07 Setor: 02 Poço Teste: 03 Coordenadas: 1180N/959E Responsáveis: Eduardo Bespalez, Alexandre Hering, Mário Antônio, Leonel da Silva e Ofnéias de Souza Alves

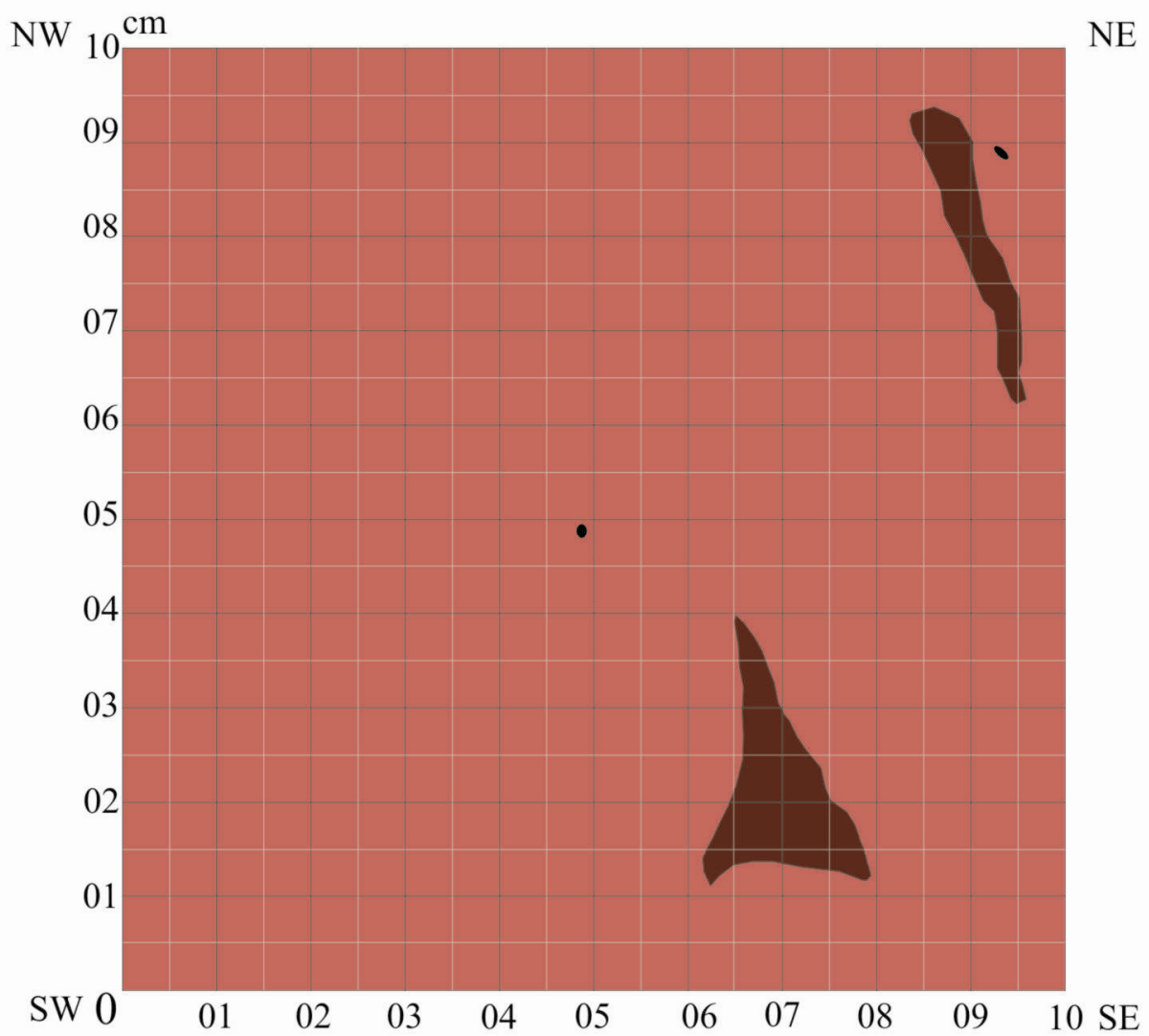

Nível: 3 (20-30cm)

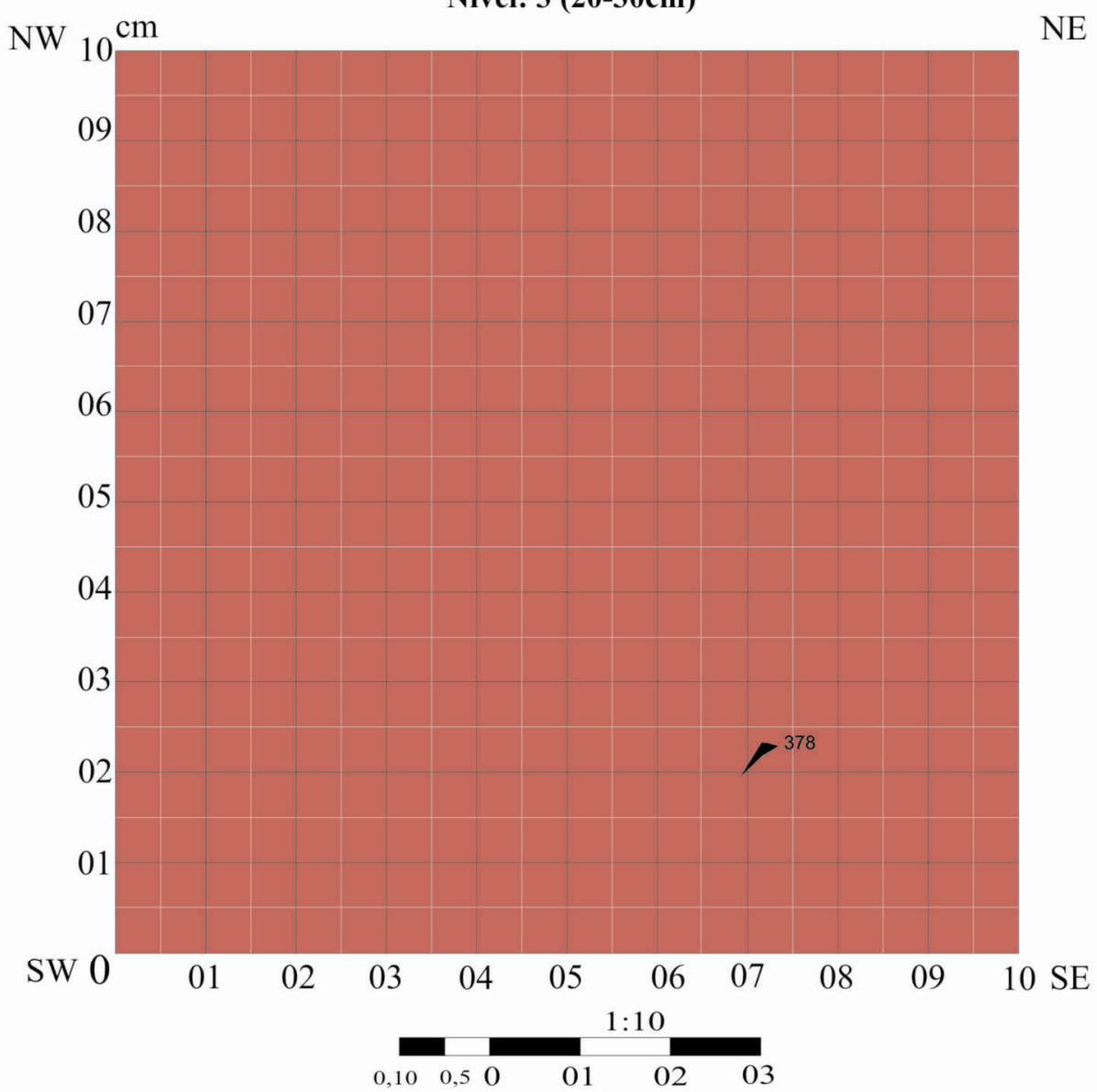




\section{PROJETO KAIABI-LALIMA}

\section{Área Piloto Aldeia Lalima}

Sítio: Sítio da Sede Sigla: MS - MI - 07 Setor: 02 Poço Teste: 03 Coordenadas: 1180N/959E Responsáveis: Eduardo Bespalez, Alexandre Hering, Mário Antônio, Leonel da Silva e Ofnéias de Souza Alves

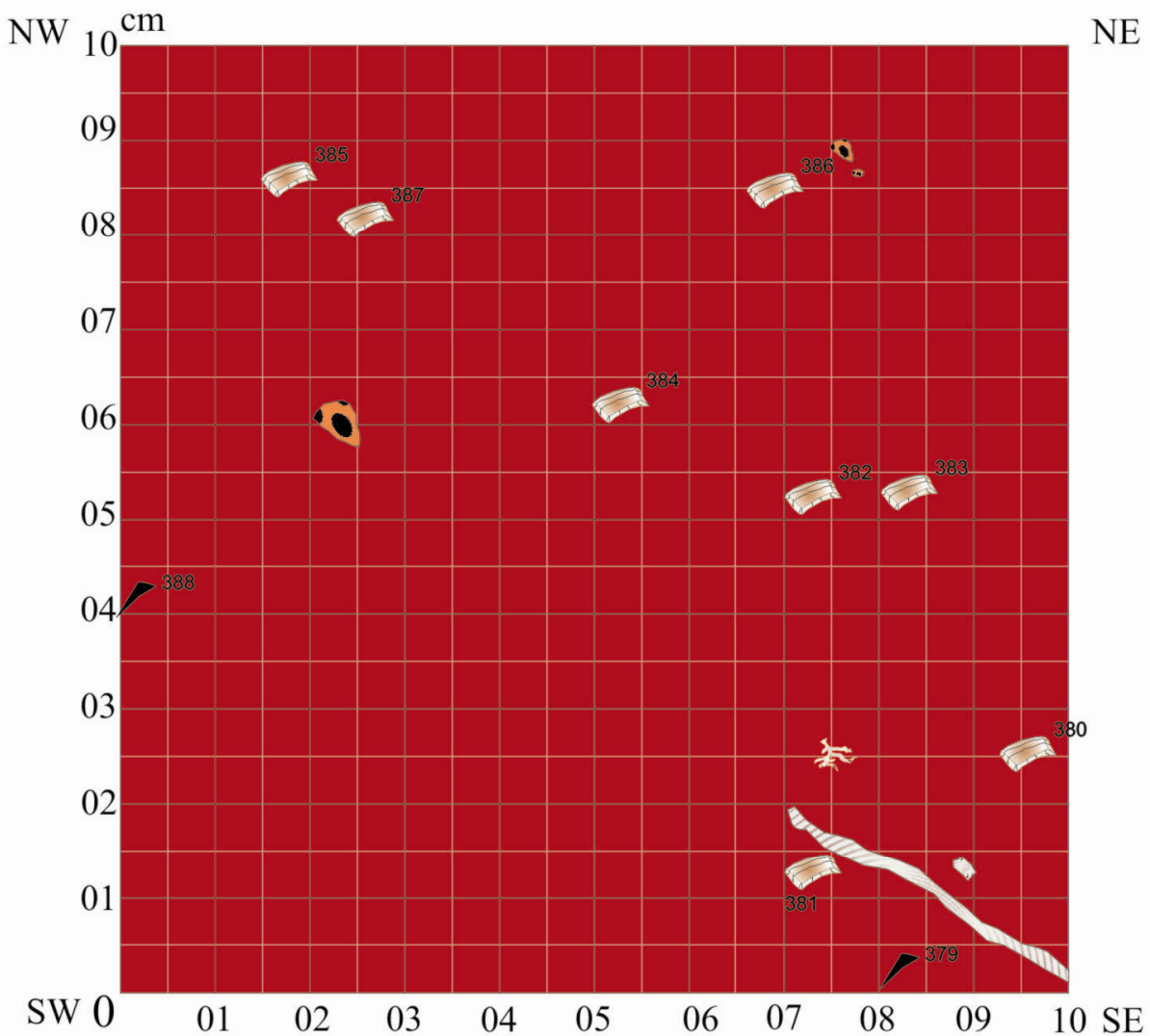

Nível: 5 (40-50cm)

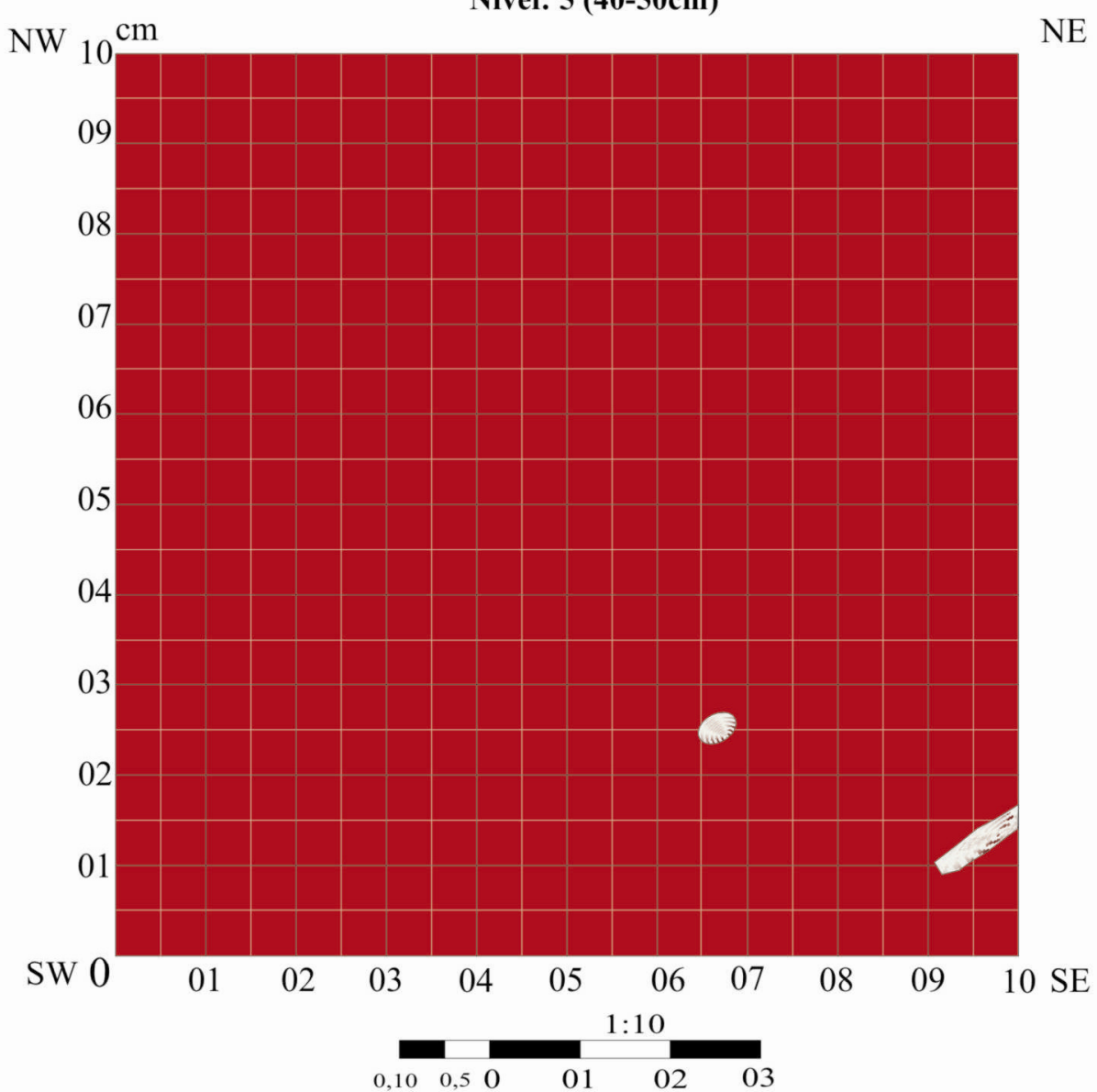




\section{PROJETO KAIABI-LALIMA}

\section{Área Piloto Aldeia Lalima}

Sítio: Sítio da Sede Sigla: MS - MI - 07 Setor: 01 Poço Teste: 3 Coordenadas: 1180N/959E

Responsáveis: Eduardo Bespalez, Alexandre Hering, Mário Antônio,

Leonel da Silva e Ofnéias de Souza Alves

Nível: $6(50$ - 60cm) Data: 13/06/07
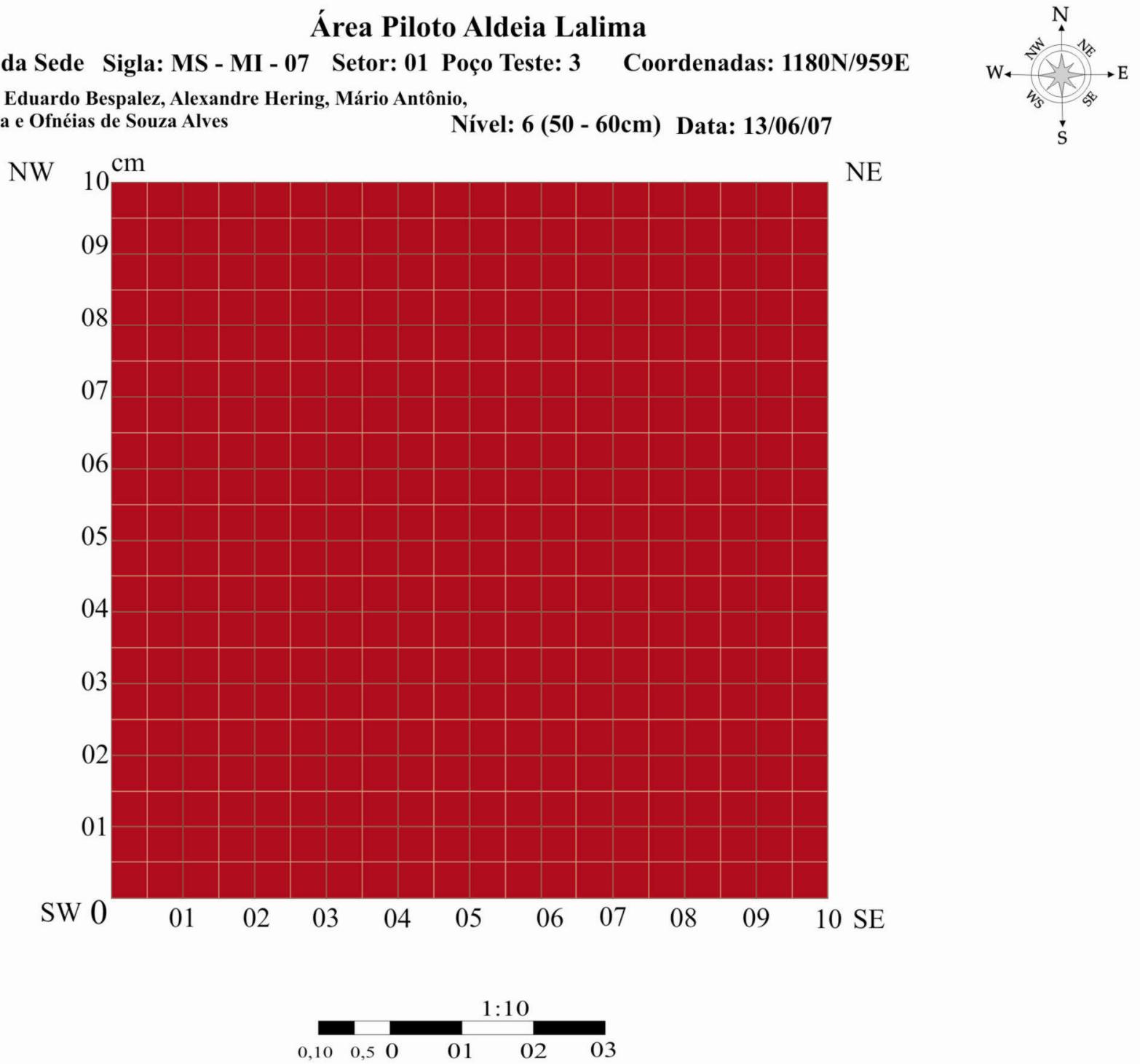


\section{PROJETO KAIABI-LALIMA \\ Área Piloto Aldeia Lalima}

Sítio: Sítio da Sede Sigla: MS - MI - 07 Setor: 01 Poço Teste: 03 Coordenadas: 1180N/959E Responsáveis: Eduardo Bespalez, Alexandre Hering, Mário Antônio,

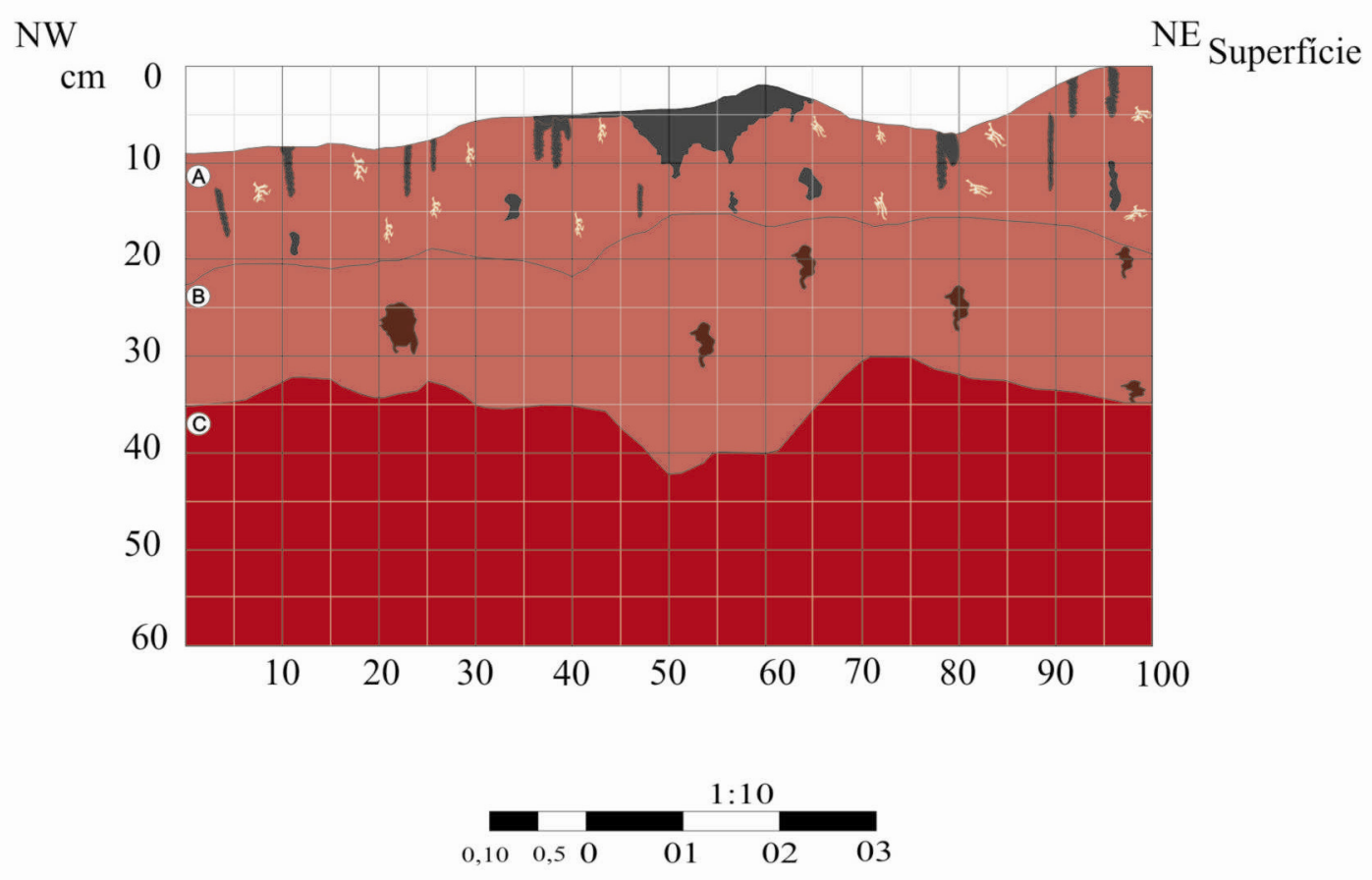

Raíz

A Camada de solo arenoso marrom-claro com manchas de sedimento areno-argiloso marrom-escuro. e com presença de material arqueológico.

B Camada de sedimento marrom-avermelhado com manchas de sedimento areno-argiloso marrom-escuro.

C Camada de sedimento areno-argiloso vermelho e estéril. 


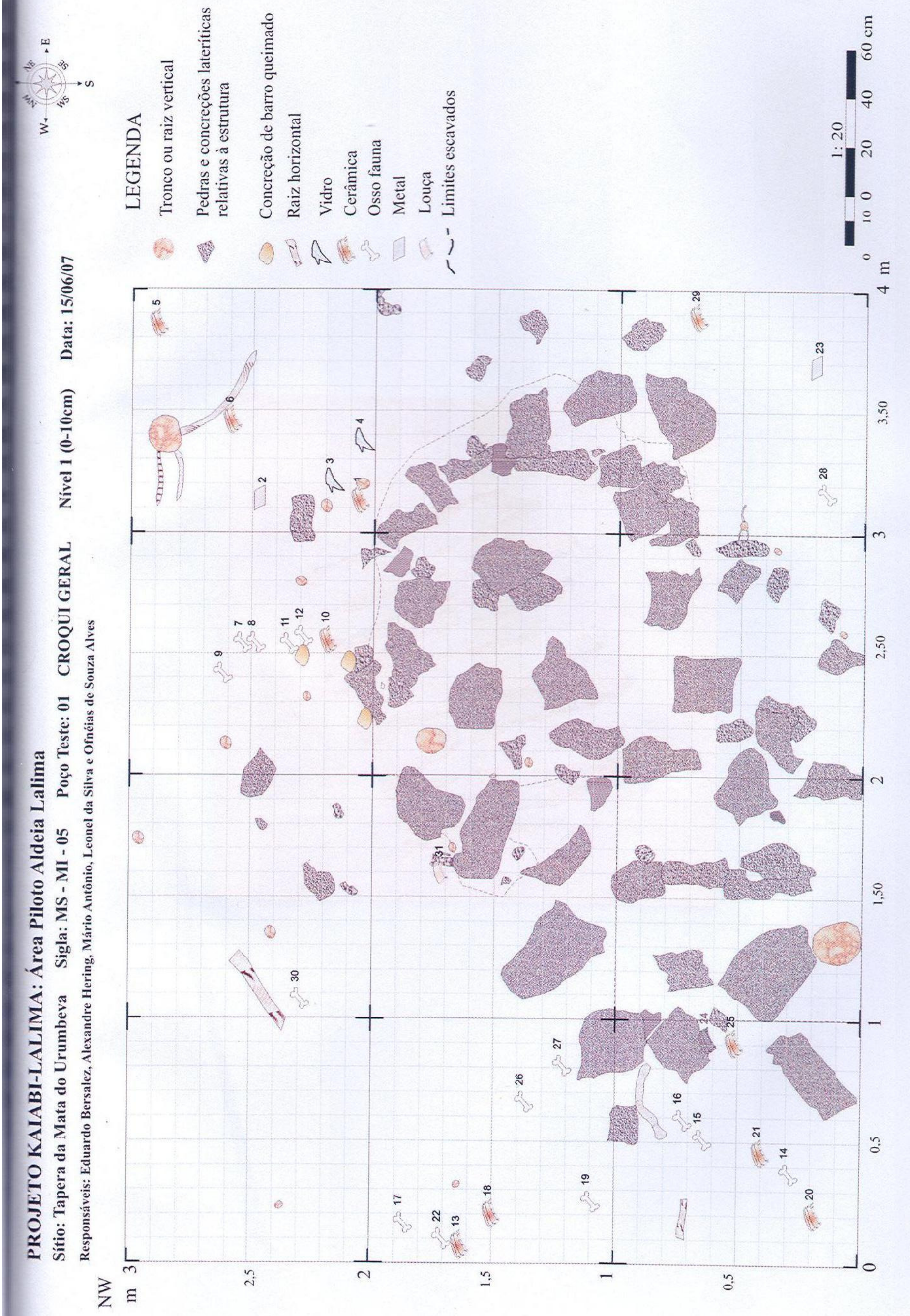




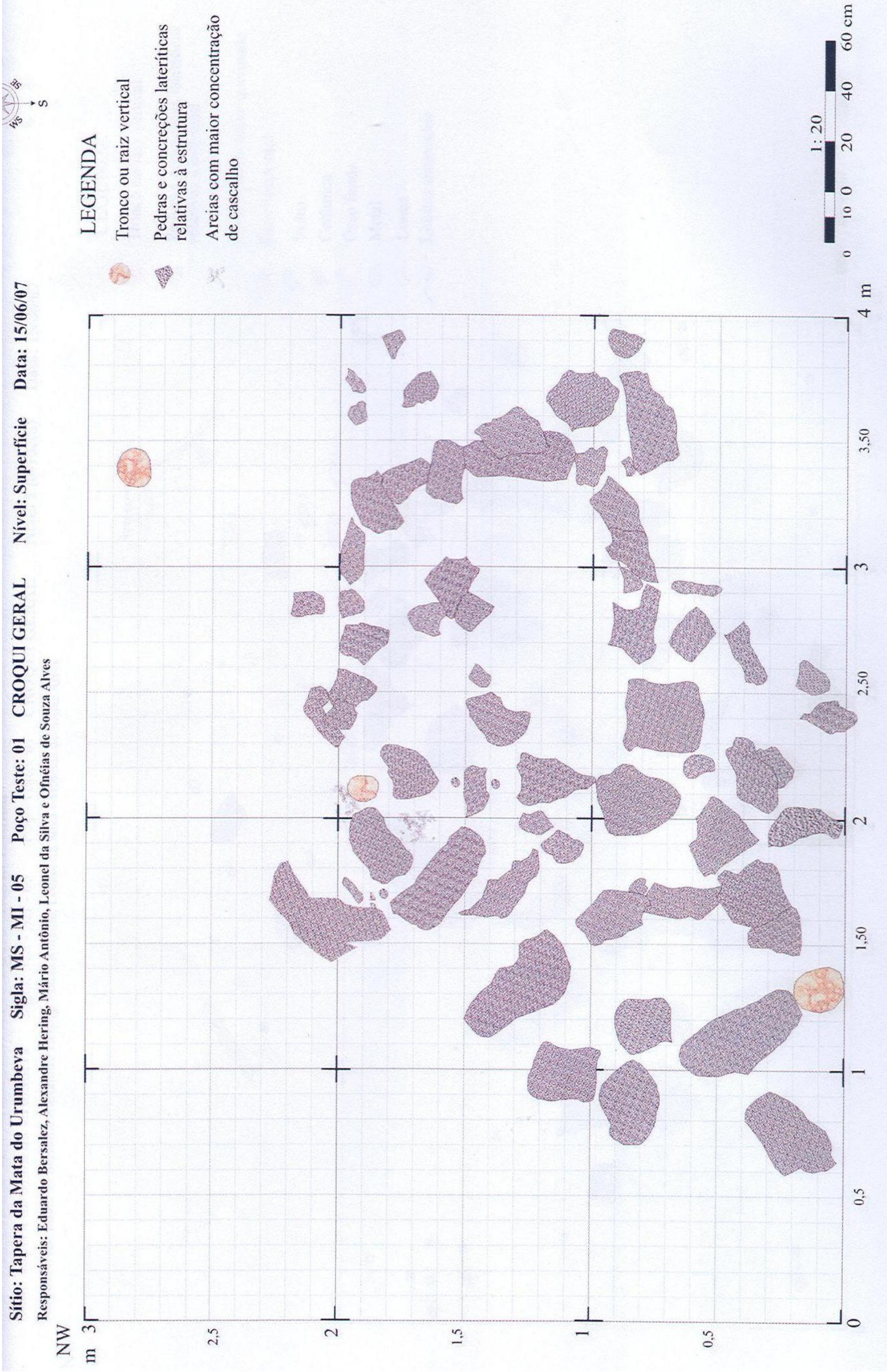




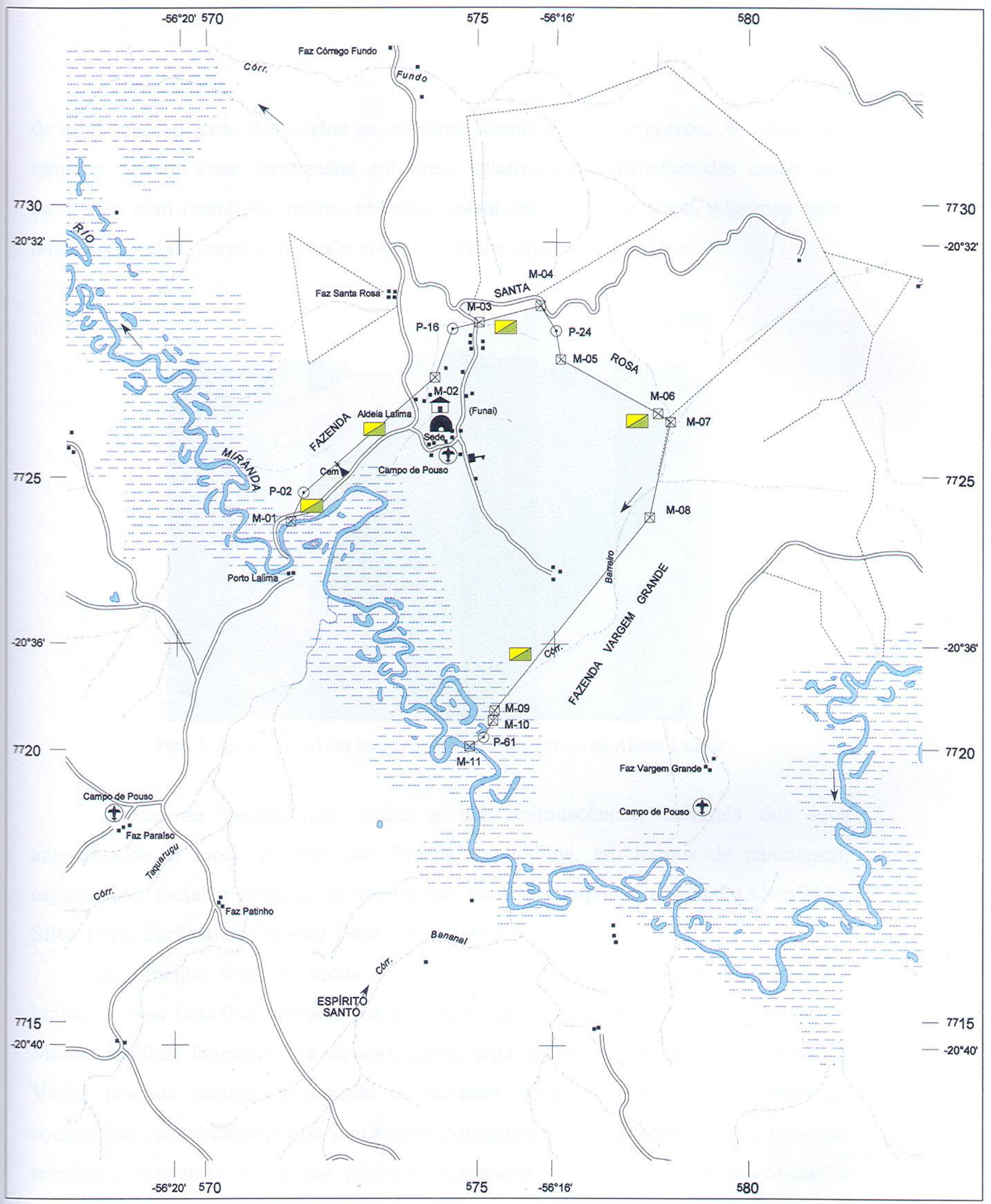

SINAIS CONVENCIONAIS

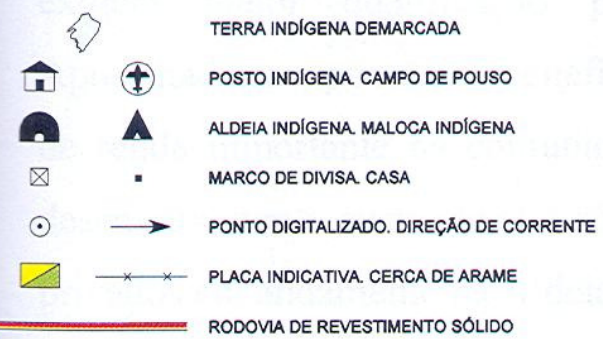

RODOVIA TRANSITAVEL O ANO TODO

RODOVIA TRANSITÁVEL EM TEMPO BOM. CAMINHO RIO PERMANENTE, RIO INTERMITENTE LAGO OU LAGOA. TERRENO SUJEITO A INUNDAÇAOO LIMITE ESTADUAL. LIMITE MUNICIPAL

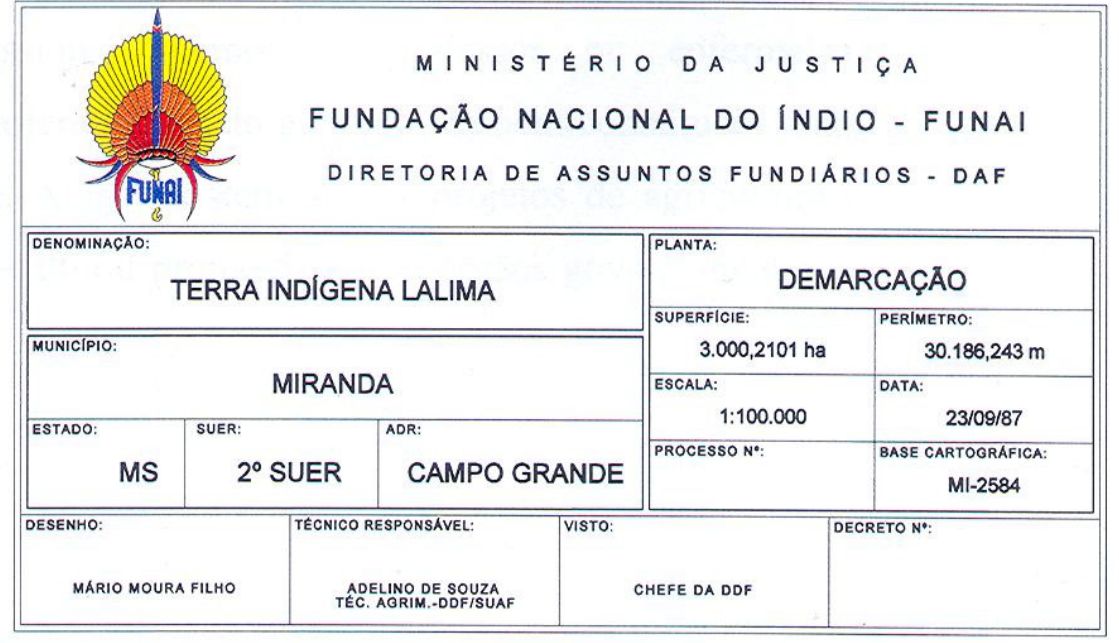


Análise preliminar da variabilidade artefatual na cerâmica na Aldeia Lalima

\begin{tabular}{|c|c|c|c|c|c|c|c|c|c|c|c|c|c|c|c|c|c|c|c|c|c|c|c|}
\hline \multicolumn{24}{|c|}{ Análise preliminar da variabilidade artefatual na cerâmica na Aldeia Lalima } \\
\hline \multicolumn{5}{|c|}{ I Identificação } & \multicolumn{15}{|c|}{ II Análise morfológica } & \multirow{2}{*}{\multicolumn{3}{|c|}{$\begin{array}{l}\begin{array}{c}\text { III Análise do acabamento } \\
\text { de superfície }\end{array} \\
4 \text { Acabamento de superfície }\end{array}$}} & \multirow{3}{*}{$\begin{array}{c}\begin{array}{c}\text { IV } \\
\text { Tradição } \\
\text { tecnológica }\end{array} \\
5 \text { Tradição } \\
\text { Tecnológica } \\
5.1 \\
\text { Tradição } \\
\text { tecnológica }\end{array}$} \\
\hline \multicolumn{5}{|c|}{1 Identificação } & \multicolumn{10}{|c|}{2 Atributos observáveis } & \multicolumn{5}{|c|}{3 Atributos deduzidos } & & & & \\
\hline $\begin{array}{c}1.1 \\
\text { Sítio }\end{array}$ & $\begin{array}{c}1.2 \\
\text { Setor }\end{array}$ & $\begin{array}{c}1.3 \\
\text { Número }\end{array}$ & $\begin{array}{c}1.4 \\
\text { Prove- } \\
\text { niência }\end{array}$ & $\begin{array}{c}1.5 \\
\text { Nível }\end{array}$ & $\begin{array}{c}2.1 \\
\text { Categoria } \\
\text { do } \\
\text { fragmento } \\
\end{array}$ & $\begin{array}{c}2.2 \\
\text { Varian- } \\
\text { tes da } \\
\text { parede } \\
\end{array}$ & $\begin{array}{c}2.3 \\
\text { Varian- } \\
\text { tes da } \\
\text { borda } \\
\end{array}$ & $\begin{array}{c}2.4 \\
\text { Variantes } \\
\text { do lábio }\end{array}$ & $\begin{array}{c}2.5 \\
\text { Diâmetro } \\
\text { da } \\
\text { boca/base } \\
\end{array}$ & $\begin{array}{c}2.6 \\
\text { Variantes } \\
\text { da base }\end{array}$ & $\begin{array}{c}2.7 \\
\text { Variantes } \\
\text { do } \\
\text { apêndice } \\
\end{array}$ & $\begin{array}{c}2.8 \\
\text { Espessu- } \\
\text { ra }\end{array}$ & $\begin{array}{c}2.9 \\
\text { Ãngulo }\end{array}$ & $\begin{array}{c}2.10 \\
\text { Relação } \\
\text { boca/ } \\
\text { bojo } \\
\end{array}$ & $\begin{array}{c}3.1 \\
\text { Classe } \\
\text { da } \\
\text { vasilha } \\
\end{array}$ & $\begin{array}{c}3.2 \\
\text { Con- } \\
\text { torno }\end{array}$ & $\begin{array}{c}3.3 \\
\text { Forma }\end{array}$ & $\begin{array}{c}3.4 \\
\text { Altu- } \\
\text { ra }\end{array}$ & $\begin{array}{c}3.5 \\
\text { Função }\end{array}$ & $\begin{array}{c}4.1 \\
\text { Face } \\
\text { externa }\end{array}$ & $\begin{array}{c}4.2 \\
\text { Face } \\
\text { interna }\end{array}$ & $\begin{array}{c}4.3 \\
\text { Lábio }\end{array}$ & \\
\hline & & & & & & & & & & & & & & & & & & & & & & & \\
\hline & & & & & & & & & & & & & & & & & & & & & & & \\
\hline & & & & & & & & & & & & & & & & & & & & & & & \\
\hline & & & & & & & & & & & & & & & & & & & & & & & \\
\hline & & & & & & & & & & & & & & & & & & & & & & & \\
\hline & & & & & & & & & & & & & & & & & & & & & & & \\
\hline & & & & & & & & & & & & & & & & & & & & & & & \\
\hline & & & & & & & & & & & & & & & & & & & & & & & \\
\hline & & & & & & & & & & & & & & & & & & & & & & & \\
\hline & & & & & & & & & & & & & & & & & & & & & & & \\
\hline & & & & & & & & & & & & & & & & & & & & & & & \\
\hline & & & & & & & & & & & & & & & & & & & & & & & \\
\hline & & & & & & & & & & & & & & & & & & & & & & & \\
\hline & & & & & & & & & & & & & & & & & & & & & & & \\
\hline & & & & & & & & & & & & & & & & & & & & & & & \\
\hline & & & & & & & & & & & & & & & & & & & & & & & \\
\hline & & & & & & & & & & & & & & & & & & & & & & & \\
\hline & & & & & & & & & & & & & & & & & & & & & & & \\
\hline & & & & & & & & & & & & & & & & & & & & & & & \\
\hline & & & & & & & & & & & & & & & & & & & & & & & \\
\hline & & & & & & & & & & & & & & & & & & & & & & & \\
\hline & & & & & & & & & & & & & & & & & & & & & & & \\
\hline & & & & & & & & & & & & & & & & & & & & & & & \\
\hline & & & & & & & & & & & & & & & & & & & & & & & \\
\hline & & & & & & & & & & & & & & & & & & & & & & & \\
\hline
\end{tabular}

